\title{
Reis door de hel der onschuldigen : de expressieve politiek van de Nederlandse anti-vivisectionisten, 1890-1940
}

Citation for published version (APA):

Kluveld-Reijerse, A. A. (1999). Reis door de hel der onschuldigen : de expressieve politiek van de Nederlandse anti-vivisectionisten, 1890-1940. [Doctoral Thesis, Maastricht University]. Universiteit Maastricht. https://doi.org/10.26481/dis.19991015ak

Document status and date:

Published: 01/01/1999

DOI:

10.26481/dis.19991015ak

Document Version:

Publisher's PDF, also known as Version of record

Please check the document version of this publication:

- A submitted manuscript is the version of the article upon submission and before peer-review. There can be important differences between the submitted version and the official published version of record. People interested in the research are advised to contact the author for the final version of the publication, or visit the DOI to the publisher's website.

- The final author version and the galley proof are versions of the publication after peer review.

- The final published version features the final layout of the paper including the volume, issue and page numbers.

Link to publication

\footnotetext{
General rights rights.

- You may freely distribute the URL identifying the publication in the public portal. please follow below link for the End User Agreement:

www.umlib.nl/taverne-license

Take down policy

If you believe that this document breaches copyright please contact us at:

repository@maastrichtuniversity.nl

providing details and we will investigate your claim.
}

Copyright and moral rights for the publications made accessible in the public portal are retained by the authors and/or other copyright owners and it is a condition of accessing publications that users recognise and abide by the legal requirements associated with these

- Users may download and print one copy of any publication from the public portal for the purpose of private study or research.

- You may not further distribute the material or use it for any profit-making activity or commercial gain

If the publication is distributed under the terms of Article $25 \mathrm{fa}$ of the Dutch Copyright Act, indicated by the "Taverne" license above, 


\section{Reis door de hel der onschuldigen}

\section{De expressieve politiek van de Nederlandse Anti-vivisectionisten,}

1890-1940

\section{PROEFSCHRIFT}

ter verkrijging van de graad van doctor aan de Universiteit Maastricht,

op gezag van de Rector Magnificus, Prof.dr. A.C. Nieuwenhuijzen Kruseman, volgens het besluit van het College van Dekanen,

in het openbaar te verdedigen

op vrijdag 15 oktober 1999 om 14.00 uur

door

Amanda Alwien Kluveld-Reijerse 


\section{Promotores:}

Prof.dr. M.J. Schwegman

Prof.dr. A. Labrie

\section{Beoordelingscommissie:}

Prof.dr. J.H.W. Kusters (voorzitter)

Dr. J. van Dijck

Prof.dr. M.F. Gijswijt-Hofstra (Universiteit van Amsterdam)

Prof.dr. M.A. Meijer

Prof.dr. P. de Rooy (Universiteit van Amsterdam)

- 1999. Amanda Kluveld-Reijerse, Maastricht

Alle rechten voorbehouden. Niets uit deze uitgave mag worden verveelvoudigd, opgeslagen in een geautomatiseerd gegevensbestand of openbaar gemaakt, in enige vorm of op enige wijze, hetzij elektronisch, mechanisch, door fotokopieën, opnamen, of enige andere manier, zonder voorafgaande schriftelijke toestemming van de auteur.

In het voorjaar van het jaar 2000 verschijnt bij de Amsterdam University Press een handelseditie (met illustraties) van dit proefschrift. 
I got grace in times of $t_{\text {riction }}$

I got truth in times of Fiction

Henry Rollins 


\section{Woord vooraf}

Was het schrijven van dit boek een reis door de hel of een heldhaftige reis? Op sommige momenten had het van allebei wel iets weg. Hoe het ook zij, ik heb ondervonden dat het schrijven van een proefschrift zeker geen eenzaam avontuur is. Allerlei mensen hebben mij tijdens mijn tocht begeleid.

Zo was daar Prof. dr. Marjan Schwegman. Aanvankelijk als mijn co-promotor, later als promotor heeft zij mij vanaf het begin op alle mogelijke manieren gesteund. Op de momenten dat ik dacht dat ik nooit in staat zou zijn om een proefschrift te schrijven, bleef zij vertrouwen tonen. Ze meende dat het me uiteindelijk zou lukken als ik maar mijn eigen koers zou varen, niet zou proberen te worden als enkele door mij zeer bewonderde anderen en niet aan de verleiding zou toegeven om al te veilige paden in te slaan. Marjan Schwegman was ook altijd bereid om naar aanleiding van mijn project met de nodige humor en levenswijsheid van gedachten te wisselen over wat ik als 'de complexiteit van het leven in het algemeen' zou willen aanduiden. Dat laatste is mijn proefschrift evenzeer ten goede gekomen als haar aanstekelijke enthousiasme voor het vak en haar intelligente, opbouwende en uitdagende kritiek. Ik had me voor het wonderlijk avontuur van het schrijven van een boek geen betere gids kunnen wensen.

Prof. dr. Arnold Labrie, mijn andere promotor, wist mij vanaf het begin tot doorzetten aan te moedigen en bracht het op om vele van mijn teksten met onduidelijk status van zinnig commentaar te voorzien. Hij was kritisch en niet gemakkelijk te overtuigen. Steeds wees hij op het belang van 'scherp te zijn'. Het was voor mij dus zaak om mijn visie vanaf het begin -toen ik naar mijn idee nauwelijks was toegerust om de klus te klaren- zo helder mogelijk te formuleren. Die constante oefening heeft er zeker toe bijgedragen dat ik uiteindelijk niets liever wilde dan onbevreesd mijn eigen boek schrijven en het resultaat aan Arnold Labrie voorleggen.

Behalve van mijn promotores kreeg ik steun van Dr. Jo Wachelder. Hem wil ik danken voor alle tijd die hij vanaf het begin aan mij heeft besteed. Hij was bereid om ieder stuk tekst dat ik schreef grondig, dat wil zeggen woord voor woord, met mij door te nemen en was nooit te beroerd zijn vertrouwen in de goede afloop van mijn project uit te spreken. Ik zal niet snel vergeten hoe hij op onverwachte momenten de meest fantastische literatuurverwijzingen tussen de enorme stapels papier op zijn bureau te voorschijn trok.

Zonder de gastvrijheid en hulp van de medewerkers van de Nederlandse Bond tot Bestrijding der Vivisectie, de Anti-Vivisectie Stichting en de Nederlandse Dierenbescherming had ik vast veel meer moeite gehad om het materiaal voor mijn onderzoek bij elkaar te krijgen. De samenwerking met de medewerkers van de UB (Bonnefanten) van de Universiteit Maastricht was niet alleen gezellig maar ook onmisbaar. Dr. Derk Jansen was zo genereus om zijn materiaal over S.F.W. Roorda van Eysinga, een van de helden uit dit boek, met mij te delen. Ook belde hij mij menigmaal op uit Oenkerk omdat hij 'weer iets over Felix Ortt' te vertellen had.

Dankbaar ben ik ook Dr. Willem Melching. Door hem en de ronduit gezellige weekeinden in Barchem die hij organiseerde, heb ik van mijn AlO-opleiding genoten. Prof. dr. Marijke GijswijtHofstra heeft mij met haar enthousiasme en vertrouwen over heel wat drempels heen getrokken. Dit geldt ook voor mijn collega's van de Faculteit der Cultuurwetenschappen. Mijn dank gaat in het bijzonder uit naar de mensen die mijn teksten hebben becommentarieerd: Drs. Pieter Caljé, Dr. Jos Perry, Dr. Rein de Wilde, Prof. dr. Wiel Kusters, Dr. Joke Spruyt, Dr. José van Dijck, Dr. Mieke Aerts, de leden van het op initiatief van Arnold Labrie gevormde promovendi-clubje en de leden van het deelproject 'moderniteit, grenzen en transgressies'. Mijn onderwijskundige collega's Dr. Marjan Pollemans en Drs. Annette Schade dank ik voor hun geduld. Ook de studenten Cultuur -en Wetenschapsstudies, te veel om op te noemen, ben ik dankbaar. Zij zijn een bron van inspiratie geweest. Systeembeheerder Bert Kerkhofs dank ik voor al zijn hulp bij problemen met de computer.

De Universiteit voor Humanistiek stelde mij tot mijn vreugde nog voor mijn promotie aan als Universitair Docent cultuurgeschiedenis van zingeving en humanitaire vraagstukken in de 
twintigste eeuw. Ik ben erkentelijk voor dit vertrouwen. De studenten humanistiek toonden een bemoedigende belangstelling voor mijn proefschrift.

De volgende mensen mogen in dit dankwoord niet ontbreken. Henry Rollins, van jou mocht ik de regels uit je gedicht Shine als motto voor mijn boek gebruiken. Dr. Dick van Lente, mijn vroegere scriptiebegeleider tijdens mijn studie Maatschappijgeschiedenis aan de Erasmus Universiteit, jij gaf mij 'support op afstand'. Drs. Marja Roholl, toen ik nog student was, gaf jij mij het advies om hoe dan ook 'voor het hoogste te gaan'. Drs. Godelieve van Heteren, ik wil je graag bedanken voor je 'mentorachtige' steun en voor je enthousiasme voor medische geschiedenis. Bedankt, Titia Eggen voor de vele gesprekjes in de supermarkt en bij de brievenbus. Prof. dr. Frits Boterman, bedankt voor allerlei wijze raad. Prof. dr. Wouter Hanegraaff, ik voelde me altijd zeer gesteund door je interesse voor mijn onderzoeksonderwerp en de manier waarop je meeleefde met de spanning die de laatste fase van het schrijven met zich meebracht. Drs. Micha Wertheim, ik dank je voor alle aanmoediging en betrokkenheid per email en voicemail. Drs. Willeke Los, bedankt voor je belangstelling voor mijn vorderingen en je aanmoedigende aanwezigheid tijdens lezingen. Bedankt, bewoners van het Giordano Bruno Huis (mijn tweede thuis), voor jullie onmisbare gastvrijheid, vriendschap en hulp. Christel Grimbergen, jou dank ik voor je inspirerende aanwezigheid, je bemoedigende emails en socratische vragen. Dank je wel, Prof. dr. Henri Beunders. Door jou ben ik mezelf uiteindelijk niet voorbij gerend en mijn doel niet voorbij geschoten. Ik dank je voor het vakkundig becommentariëren van een aantal hoofdstukken maar bovenal voor je vriendschap.

Dr. Jaap Talsma, zonder jou had dit boek er nog lang niet gelegen. Op het moment dat ik het helemaal niet meer zag zitten bood jij aan om mijn proefschrift te redigeren. Dat heb je, ondanks drukte op je werk en in de politiek, in je kerstvakantie gedaan. Nauwgezet corrigeerde jij mijn werk en daarbij probeerde je steeds 'vanuit mij' te denken. Met dit arbeidsintensieve werk heb je mij bijna letterlijk naar en over de eindstreep gesleurd. En alsof dat nog niet genoeg was, hielp je me ook nog met het maken van de lay-out en de index. De herinnering aan de lange dagen en avonden dat wij samen achter de computer doorbrachten, gespannen maar zonder elkaar in de haren te vliegen, zal ik altijd blijven koesteren. Het schrijven van dit boek was voor mij alleen al om die ervaring de moeite waard. Ik dank je voor je vriendschap, je kalme aanwezigheid, je rebelsheid waar ik mijn hart aan kon ophalen en niet te vergeten je gastvrijheid.

Tot slot: Jan Kluveld, aan jou draag ik dit boek op.

Amanda Kluveld

Maastricht, zomer 1999 


\section{Inhoudsopgave}

Woord vooraf

1 Reis door de hel

Inleiding

Vivisectie vanaf de Oudheid

De heldenreis als expressieve politiek

2 Een weg geplaveid met winnaars en verliezers

Geschiedschrijving over anti-vivisectionisme

Kanttekeningen bij het winnaars en verliezersperspectief 28

3 De vrouw als gids

1898: De Nationale Tentoonstelling van Vrouwenarbeid $\quad 32$

$\begin{array}{ll}\text { Een strijd voor vrouwen } & 34\end{array}$

De NBBV: oprichting en opbouw $\quad 39$

Romanheldinnen $\quad 45$

Gemma (46); Anna en De familie van Westvoorne (48)

Slachtoffers en wraakgodinnen $\quad 50$

'Wetend' worden $\quad 52$

Het vrouwelijke voorbeeld: eenheid en offervaardigheid 58

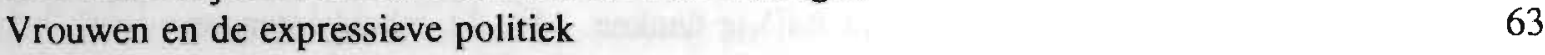

4 Fantasie als voertuig en obstakel

1903: Cursus over Vivisectie $\quad 64$

De verbeelding als brug $\quad 65$

$\begin{array}{ll}\text { Pijn en verbeelding } & 72\end{array}$

$\begin{array}{ll}\text { Menselijke dieren } & 75\end{array}$

$\begin{array}{ll}\text { Het beest in de mens } & 78\end{array}$

$\begin{array}{ll}\text { Van voertuig tot obstakel } & 83\end{array}$

5 De man van het licht als reisgezel

1908: Optreden voor de hoorzitting van de Commissie inzake Vivisectie 85

Het offer en de kruisiging $\quad 86$

$\begin{array}{ll}\text { De ziel der wijze } & 88\end{array}$

De navolging van Christus 93

Onze lieve Heiland van de doornen kroon (94); Zielereizen (95); Ortt en het tolstojanisme (96)

Anti-vivisectionisme en christen-anarchisme

De navolging van Christus en de politieke stijl van de NBBV $\quad 105$

De overwinning van het christen-anarchisme

Ontwikkeling van de expressieve politiek: religie

6 Wetenschap als wegwijzer

1917 : Inleiding tot het pneumat-energetisch monisme

De 'twijfel-chaos'

De waarheidszoeker

Evenwichtige mannen, gefragmenteerde vrouwen

Besluit 
7 De hel in kaart gebracht

Anti-vivisectionisten, hun tegenstanders en het parlement $\quad 130$

$\begin{array}{ll}\text { Die Folterkammern der Wissenschaft } & 130\end{array}$

Vivisectie en de soevereine wetenschap $\quad 134$

De Commissie inzake vivisectie $\quad 137$

Pro en contra vivisectie 1900-1906 (138); Het Comité (141); De leden van de commissie (144); De hoorzitting (145); Het rapport (151)

Besluit

8 Besluit en aankomst in een nieuwe tijd

1928: Een nieuw begin

De anti-vivisectie-beweging gedurende het Interbellum

De splitsing en de oprichting van de SAVB

De expressieve politiek: aandachtspunten en ontwikkeling 1890-1940

De Tweede Wereldoorlog

Beschavingsoffensief en individuele hervorming

Epiloog

Lijst van geraadpleegd materiaal

Summary

Personenregister 


\section{Reis door de hel}

\section{Inleiding}

In de lente van 1897 constateerde M.A. Roorda van Eysinga-Romijn dat het ondanks het naderen van de twintigste eeuw nog lang zou duren eer de beschaving met een 'hart vol vreugde en gejuich' kon worden begroet. Zeker, de materiële welvaart was met 'reuzenstappen' vooruitgegaan en op vrijwel ieder ander terrein viel een onmiskenbare groei van de beschaving waar te nemen. Dit alles zou stellig reden tot blijdschap geven, ware het niet dat de vivisectie, een 'met de dag tot een heillozer werk' verheven praktijk, al deze verworvenheden met een 'krijschende wanklank' overstemde. ${ }^{1}$

Vivisectie, een verzamelnaam ${ }^{2}$ voor medisch-wetenschappelijke experimenten op levende dieren, was volgens Roorda de 'gruwel der gruwelen'3, een praktijk die zonder enige terughoudendheid de kop moest worden ingedrukt. Roorda was beslist niet de eerste die een dergelijke mening was toegedaan. Al sinds de Oudheid stond 'de vivisector' - zoals de uitvoerder van het experiment op dieren in de negentiende eeuw zou worden aangeduid - als een min of meer verdacht figuur te boek. Zijn bloedige zoektocht naar de verborgen werking van het leven maakte hem voor velen tot een huiveringwekkende figuur aan wiens morele kwaliteiten openlijk getwijfeld werd. Celsus en later Augustinus beschuldigden hem van experimenten op mensen. Tertullianus betitelde hem zonder aarzelen als een barbaar. Dit negatieve beeld kreeg in de loop der eeuwen steeds verder gestalte. Zo betwistte men gedurende de zestiende en zeventiende eeuw vooral de wetenschappelijke waarde van experimenten op dieren. In de achttiende eeuw werd steeds vaker benadrukt dat het lijden van het proefdier een uitermate afschrikwekkend en daarom te verwerpen kenmerk van de vivisectie was. ${ }^{4}$

In geen periode van de geschiedenis hebben het werk en de persoon van de vivisector evenwel tot zoveel commotie geleid ${ }^{5}$ en zoveel actie tot gevolg gehad als aan het einde van de negentiende en het begin van de twintigste eeuw. ${ }^{6}$ Waar de tegenstanders van medisch-wetenschappelijke proeven op levende dieren voorheen slechts incidenteel en individueel hun mening over het onderwerp naar voren brachten, verenigden zij zich, onder meer ook als reactie op de groei van de experimentele fysiologie ${ }^{7}$, rond 1900 in speciaal op de bestrijding van vivisectie gerichte

1. M.A.Roorda van Eysinga-Romijn, Kort verslag over 1896 (Scheveningen 1897) 16.

2. Latijn, samengesteld uit de woorden vivus (levend) en sectio (het snijden). Een voorloper van deze term is het in de Romeinse Oudheid gebezigde Vivi Animantis Sectio (het snijden in een levend wezen). Gedurende de Renaissance werd de term Vivi Sectio (levend snijden) gebruikt.

3. Roorda van Eysinga-Romijn, 1896, 16.

4. Zie over de receptie van vivisectie in de genoemde eeuwen: A.H. Maehle en U. Tröhler, 'Animal experiments from antiquily to the end of the eighteenth century: attitudes and arguments' in: N.A. Rupke ed., Vivisection ir. historical perspective (Londen, New York 1987). Zie ook: Keith Thomas, Man and the nalural world. Changing attiludes in England 1500-1800 (Londen, New York 1983). Cock Smit, Dierproeven honderd jaar discussie (Kampen 1989) 16-20. H. Verhoog. 'Het dier als meetlat. Dierproeven en proefdieren' in: M.B.H. Visser en F.J. Grommers ed. Dier of ding Objectivering van dieren (Wageningen 1988) 76-83. A. Reijerse. Standpunten over vivisectie en ani-vivisectie in Nederland 1870-1917. Ongepubliceerde doctoraalscriptie Maatschappijgeschiedenis Erasmus Universiteit Rotterdam (Rotterdam 1992).

5. Zic hierover: Coral Lansbury. The Old Brown Dog: Women, workers and vivisection in Edwardian England (Wisconsin 1985). Lansbury analyseen de rellen die ontstonden naar aanleiding van de plistsing van een bronzen beeld van een hond. Het was een initiatief van de anti-vivisectionisten die met het beeld de aan vivisectie onderworpen dieren wilden herdenken. Studenten probeerden het beeld te ontvoeren en te vernietigen. Zij raakten slaags met de antivivisectionistische vrouwen en arbeiders.

6. Zie over de tot dan toe ongekend heftige emoties bijvoorbeeld: Aniela Jaffé. Anna Kingsford. Religiöser Wahn und Magie (Bonn 1980). In deze jungiaanse studie wordt beschreven hoe de Engelse arts en anti-vivisectioniste Anna Kingsford pogingen ondernam om experimenteel fysiologen als Claude Bernard door middel van magische krachten up afstand te vermoorden.

7. Zie over Engeland: June Goodfield-Toulmin. 'Some aspects of English physiology: 1780-1840', Journal of the Histon of Biology 2 (1969) 283-320. 
associaties. Zo werd door de feministe Frances Power Cobbe en de gepensioneerde marineofficier George Hoggan in 1876 in Engeland 's werelds eerste anti-vivisectie organisatie, The Victoria Street Society ${ }^{8}$ (VSS), opgericht. ${ }^{9}$ Dit voorbeeld vond al spoedig ook in andere landen navolging. Duitse anti-vivisectionisten verenigden zich in 1881 in de Internationale Gesellschaft zur Bekämpfung der wissenschaftlichen Tierfolter, in Scandinavië werd een jaar later de Nordika Samfundet till Bekämpande av dat Vetenschapliga Djur plägeriets Arrsberättelse gesticht. De Zwitsers volgden in 1883 met de Schweizerische Antivivisektions Gesellschaft. ${ }^{10}$ Nederland kent sinds 1890 de Nederlandsche Bond tot Bestrijding der Vivisectie (NBBV). "Een van de oprichters van deze laatstgenoemde organisatie was dominee S.F.W. Roorda van Eysinga, de echtgenoot van Roorda van Eysinga-Romijn.

Onder de mensen die zich bij de anti-vivisectie-verenigingen aansloten waren, in vergelijking met andere protest- of hervormingsbewegingen uit die tijd, relatief veel vrouwen. ${ }^{12}$ Ook Roorda van Eysinga-Romijn wijst daarop. In het jaarverslag van de NBBV over 1896 zegt zij expliciet dat het in de afgelopen jaren vooral 'kloeke medewerksters' waren die een belangrijke bijdrage aan de strijd tegen het kwaad hadden geleverd. Eén vrouw, Marie Jungius, had de 'roem der Nederlandsche vrouw in den vivisectiestrijd'13 volgens Roorda wel op een zeer bijzondere wijze vertegenwoordigd. Zij had, door het bestuderen van medisch-wetenschappelijke jaarverslagen, de beweging voorzien van belangrijke gegevens over in Nederland verrichte vivisecties. Deze waren vervolgens in woord en geschrift wereldkundig gemaakt. ${ }^{14}$ Dit alles was volgens Roorda essentieel, omdat de te voeren strijd ten zeerste werd bemoeilijkt door de onwetendheid over de aard en omvang van medisch-wetenschappelijke proeven op levende dieren. Vrijwel niemand wist wat het woord vivisectie betekende; er was nauwelijks iemand die, zoals Roorda het uitdrukte, de 'verborgen zonden der vivisectoren' kende. ${ }^{15}$ Het was om die reden een belangrijke taak voor de

8. De volledige naam van deze organisatie was: Society for the Prolection of Animals Liable 10 Vivisection. De vereniging werd Victoria Street Society genoemd naar de straat waar zij was opgericht.

9. In Engeland werden meerdere anti-vivisectie organisaties opgericht. Bijvoorbeeld de British Union for the Abolition of Vivisection (BUAV) in 1898.

10. Zie over de Scandinavische anti-vivisectie-beweging: L.Bromader, 'Vivisecktionsdebatten I Sverige under 1880talet', Lychnos (1969-1970) 249-9I. En van dezelfde auteur: 'The Vivisection debate in Sweden in the 1880's' in: Rupke, Vivisection, 214-235. De Zwitserse beweging wordt beschreven in de dissertatie van R. Neff. Der Streit um der wissentschaflichen Tierversuch in der Schweiz des 19. Jahrhundert (Basel 1989). Het Duitse verzet tegen vivisectie wordt beschreven door Maehle en Tröhler, 'Antivivisection in Nineteenth Century Germany' in: Rupke. Vivisection in hislorical perspective, 149-187.

11. Nederland kende voor de Tweede Wereldoorlog nog andere anti-vıvisectie-organisaties: hel Comité ter Beperking der Vivisectie (1906), de Stichting Anti-Vivisectie Bond (SAVB) die in 1931 werd opgericht als afsplitsing van de NBBV. De SAVB wijzigde onder druk van de NBBV in 1934 haar naam in Anti Vivisectie Stichting (AVS). Zowel de NBBV als de AVS bestaan tegenwoordig nog steeds. Beide organisaties zijn gevestigd in Den Haag. In 1927 werd te Bandoeng de Nederlandsch-Indische Bond tot Bestrijding der Vivisectie (NIBBV) opgericht. Een beknopt historisch overzicht van de geschiedenis van de Nederlandse anti-vivisectie-beweging wordt gegeven in Smit, Dierproeven, en in: A.H.H.M. Mathijsen, 'De oefenoperaties aan de Rijks veeartsenijschool als doelwit van de anti-vivisectie-beweging 1870-1880', Argos, Speciale Uitgave (1991) 65-84. C.A. Davids noemt de anti-vivisectie-beweging in zijn studies naar de Nederlandse dierenbescherming. Zie: C.A. Davids, 'Aristocraten en juristen, financiers en feministen. Het beschavingsoffensief van de dierenbeschermers in Nederland voor de Eerste Wereldoorlog', Volkskundig Bulletin 13 (1987) 157-195. Van dezelfde historicus: Karel Davids, Dieren en Nederlanders. Zeven eeuwen lief en leed (Utrech 1989). Zie vok: J.J. Kouwenhove. 'De NBBV 85 jaar Aktueel', Herkomst onbekend, overdruk aanwezig in het archief van de NBBV te 's-Gravenhage.

12. Zie hierover Mary-Anne Elston. 'Women and anti-vivisection in Victorian England, 1870-1890' in: Rupke. Viviseclion, 259-294.

13. Roorda van Eysinga-Romijn, 1896, 17

14. Zie uver de strijdwijze van Maric Jungius behalve dit procfschrift ook: Amanda Kluveld, 'Anti-vivisectionisme en feminisme. De strijd van Marie Jungius tegen een kwaad dat uit de samenleving moet verdwijnen' in: Rineke van Daalen en Marijke Gijswijt-Hofstra ed. Gezond en wel. Vrouwen en de zorg voor gezondheid in de twintigste eeuw (Amsterdam 1998) 141-154.

15. Roorda, 1896, 17. 
NBBV om "de menschen de oogen te openen' ${ }^{16}$ en, zoals een andere anti-vivisectionist het enkele jaren later zou omschrijven, het kwaad van de vivisectie als kwaad 'tentoon te stellen" ${ }^{17}$. Met dat oogmerk publiceerden de anti-vivisectionisten een stroom aan geschriften, romans, essays, artikelen en een enkel gedicht. Het was de bedoeling op deze wijze de waarheid over vivisectie, deze 'hel der onschuldigen' ${ }^{18}$, aan de in onwetendheid verkerende samenleving te onthullen.

Het Nederlandse verzet tegen vivisectie in de periode 1890 tot 1940 is het onderwerp van dit proefschrift. Centraal staat de wijze waarop de anti-vivisectie-beweging de vivisectie als maatschappelijk kwaad zichtbaar probeerde te maken en de manier waarop de verbeelding van medisch-wetenschappelijke proeven op levende dieren de discussies over dit onderwerp aanwakkerde en beïnvloedde. De titel van dit boek, 'Reis door de hel der onschuldigen', verwijst naar de vele gestalten die de vivisectie in de anti-vivisectionistische publicaties aannam. Die zullen in dit boek in de verschillende hoofdstukken de revue passeren. De reis verwijst bovendien naar de wijze waarop veel tegenstanders van vivisectie hun taak, de vivisectie te hestrijden door de waarheid voor het voetlicht te brengen, beschreven. Voor hen was het alsof zij, door op zoek te gaan naar de waarheid over vivisectie, als reizigers een onbekend en geheimzinnig gebied betraden.

\section{Vivisectie vanaf de Oudheid}

Hoewel er voor het ontstaan van de anti-vivisectie-beweging al eeuwen vivisecties waren verricht, was die praktijk nooit breed bekend geworden. Op zichzelf is dat niet verwonderlijk als wordt bedacht dat het gebruik van dierproeven eeuwenlang beperkt bleef tot de incidentele activiteiten van enkele individuen. ${ }^{19}$ Voorbeelden zijn de Griek Alkmaion van Kroton (6e eeuw voor Chr.) en de Romein Galenus van Pergamon (129-199 na Chr.). De eerste beschreef in 450 voor Christus hoe hij inzicht had verkregen in de functie van de optische zenuw door deze bij een dier door te snijden. De tweede schreef een handleiding voor het verrichten van vivisecties en formuleerde op basis van de door hem verrichte proeven zijn leer van de lichaamssappen.

Gedurende de Middeleeuwen verdween het gebruik van dierproeven bijna geheel om tijdens de Renaissance weer toe te nemen. Vivisecties werden in de laatstgenoemde periode voornamelijk verricht om de werking van de organen van levende wezens te observeren en stonden als experimenten in dienst van de anatomie. ${ }^{20}$ Illustratief voor de toenmalige verstrengeling van fysiologie en anatomie is De Motu Cordis (1628), de studie waarin William Harvey zijn ontdekking van de bloedsomloop beschreef.

De Motu Cordis en de moeizame acceptatie van Harveys inzichten door de wetenschappelijke wereld $^{21}$, gaven onbedoeld een krachtige impuls aan het gebruik van dieren voor fysiologische

16. Roorda, $1896,17$.

17. Felix Ort, 'Eerste Cursus: inleiding' in: Cursus over vivisectie ('s-Gravenhage 1903) 1-9, aldaar 9

18. 'De hel der onschuldigen' is ontleend aan een bekend anti-vivisectionistisch geschrift The Nine Circles of the Hell of the Innocent uit 1892 vervaardigd door Frances Power Cobbe. Dit werk. waarvan de titel naar Dante's Inferno verwees. was een zeer belangrijke inspiratiebron voor de Nederlandse anti-vivisectionisten. Zie over Cobbe's geschrift: Richard D. French. Anti-vivisection and Medical Science in Victorian Socierv (Londen 1975)

19. Voorbeelden: De auteur van de Hippocratische tekst 'Over het har' (rond 300 vour Christus) gaf aan hoe hij de borst van een levend dier opensneed om op deze wijze te ontdekken dat de hartboezem en de harkamer beurtelings na elkaar klopten. Tevens kreeg hij door middel van vivisectie inzicht in de werking van het slikken. Hij liet een varken gekleurd water drinken en sneed het vervolgens de keel door. In Alexandrie lukte het Erasistratos (305-240 v Chr.) om door middel van anatomische en fysiologische waamemingen onderscheid te maken tussen gevoels en bewegingszenu-
wen.

20. De verstrengeling van anatomie en fysiologie blijkt ook uit het feit dat anatomische lessen niet zelden aanschouwelijk werden gemakkt en afgesloten door middel van demonstratie van vivisectie. 21. De wetenschappers hingen toen vooral Galenus' leer van de lichaamssappen aan. Harveys leer was in hun ogen
ketters. 
experimenten. Aanvankelijk gold dit vooral voor de Republiek der Verenigde Nederlanden"2, een land waar het experimenteel wetenschappelijk onderzoek in 1628 nog nauwelijks was doorgedrongen. Dat dit zo'n tien jaar later veranderde is voor een belangrijk deel op het conto te schrijven van René Descartes die zich in zijn Discours de la Méthode (1637) als eerste toonaangevende figuur uitsprak ten gunste van de opvattingen van Harvey. Geprikkeld door de stelling van de invloedrijke Descartes, voerden wetenschappers als Jan de Wale en Franciscus Sylvius de in $D e$ Motu Cordis beschreven proeven uit. Dat Descartes zijn werk in de Republiek had geschreven en gepubliceerd was daarbij wellicht een extra stimulans. Ook zij concludeerden dat Harvey het bij het rechte eind had. De Leidse academische wereld was al spoedig dezelfde mening toegedaan. ${ }^{23}$ Dit terwijl wetenschappers elders in de wereld nog altijd fel van leer trokken tegen Harveys theorie.

Hoewel de uiteindelijke aanvaarding van de theorie en methoden van Harvey tot gevolg had dat het aantal experimenten op dieren in Europa sterk toenam, werden in Nederland nog altijd niet bijzonder veel dierproeven verricht. Het aantal vivisecties in de zeventiende eeuw liep eerder in de tientallen dan in de honderdtallen. In de achttiende eeuw nam het aantal experimenten up dieren in Nederland zelfs af. Elders in Europa was dit niet het geval. Daar kreeg de vivisectie in deze periode juist een nieuwe impuls, mede doordat men vanaf het einde van de achttiende eeuw naar ziekteverwekkers zocht. Met de opkomst van de bacteriologie kwam tegen het einde van de negentiende eeuw ook het op experimenten op dieren gebaseerde serum- en vaccinatieonderzoek op gang. Anders dan bij de anatomie en fysiologie ging het bij dit soort onderzoek niet zozeer om de werking van organen die door het snijden in het dier kon worden waargenomen, maar om de werking van micro-organismen die in het lichaam van het dier werden gebracht.

Dit neemt niet weg dat tegelijkertijd ook het daadwerkelijke 'snijden in het levende', zoals de letterlijke vertaling van vivisectie luidt, in de negentiende eeuw sterk opkwam. Dit gebeurde aanvankelijk in Frankrijk waar aan de universiteiten en de veeartsenijscholen in Alfort en Toulouse, een grote belangstelling ontstond voor empirisch en experimenteel onderzoek op dieren. ${ }^{24}$ De fysioloog François Magendie (1783-1855) en diens leerling Claude Bernard (18131878) waren belangrijke dragers van deze ontwikkelingen. Eerstgenoemde werd vooral bekend door zijn onderzoeken naar de werking van de ruggemergzenuwen bij levende honden. Magendie sneed dieren open om te kijken wat er gebeurde. Bernard streefde naar een fysiologie en een geneeskunde die werkten volgens de principes van de experimentele methode die hij in zijn beroemde Introduction a l'étude de la médicine expérimentale ${ }^{25}(1860)$ beschreef. Gesteld wordt wel dat sinds Bernards Introduction dieren in Frankrijk systematisch en veelvuldig als onderzoeksinstrumenten werden gebruikt.

Voor het negentiende-eeuwse Engeland ging dit in mindere mate op. Daar stond de wetensciappelijke wereld aanvankelijk wantrouwend tegenover de experimentele fysiologie en lag het snijden in het levende van meet af aan gevoelig. Illustratief is de beslissing van Charles Bell om na de proeven van Magendie te hebben uitgevoerd over te stappen op de anatomische onderzoeks-

22. Het gedeelte over de opkomst van vivisectic in Nederland is gebaseerd op: G. A. Lindeboum, Geschiedenis van de medische wetenschap in Nederland (Bussum 1972). Van dezelfde auteur: 'Dog and frog. Physiological experiments at Leiden during the seventeenth century' in: Th. H. Lunsingh Scheurleer en G. H. M. Posthumus Meyjes ed.. Leiden Universiry in the seventeenth century. An exchange of learning (Leiden 1975) 279-293. F. Sassen. Descartes (Den Haag 1963).

23. De Leidse universiteit (opgenicht 1575) stond vanal het begin van de zeventiende eeuw open voor vivisecties. De universiteit had in he anatomisch laboratorium in de oude Begijnenkerk een speciule ruimte ingericht voor het verrichten van dierproeven. Ook in Nederland was er dus sprake van een verstrengeling van anatomie en fysiologie.

24. Zie hierover: Paul Elliol, Vivisection and the Emergence of Experimental Physiology in Nineteenth Century France' in: Rupke. Vivisection, 48-77. Zie ook: Michael Gross, 'A lessened locus of reelings ? A transformation of French Physiology in the Early Nineteenth Century'. Journal of the History of Biology 12 (1979) $231-271$.

25. Zie over Bernards opvattingen over de experimentele fysiologie: Nils Roll-Hansen. 'Critical theology: Immanuel Kant and Claude Bernard on the limitations of experimental physiology'. Journal of the History of Biology 9 (1976) 51 . 91. William Colem. 'The cognitive basis of the discipline: Claude Bernard on physiology', ISIS 76 (1985) 49-70. 
methode. Hij verklaarde dat de proeven op honden voor hem persoonlijk te afschuwelijk waren om uit te voeren omdat de dieren te erg leden. Bells relaas neemt niet weg dat er wel degelijk Britse fysiologen waren die zich met vivisectie bezighielden en dat ook in Engeland de experimentele medische wetenschap gedurende de negentiende eeuw sterk opkwam. ${ }^{26}$ In Nederland gebeurde dit nog wat later. Van het enthousiasme van de zeventiende-eeuwse wetenschappers was niet veel overgebleven. Pas aan het einde van de negentiende eeuw werden ook in dit land proeven op dieren steeds belangrijker. ${ }^{27}$

\section{De heldenreis als expressieve politiek}

In het negentiende-eeuwse Nederland bleef de vivisectie een onzichtbaar en ontoegankelijk gebeuren. De analogie tussen het anti-vivisectionisme en een reis naar een onbekend gebied, een heldenreis of een heldhaftige reis door de hel, wordt alleen al daardoor versterkt. Toch is dit alles niet de enige aanleiding om in dit boek het begrip reis centraal te stellen. De titel 'reis door de hel der onschuldigen' is ook gekozen omdat de anti-vivisectionisten zelf hun streven niet zelden beschreven volgens het patroon van de 'heldenreis'. ${ }^{28}$ Het betrof een tocht - in de woorden van sommige anti-vivisectionisten zelfs een 'kruistocht'- door een duister gebied, een reis waarvan de afloop onzeker was en tijdens welke de betreffende anti-vivisectionistische held of heldin afstand moest doen van materieel gewin en maatschappelijke erkenning. De ideale strijder tegen vivisectie was in deze voorstelling een man of een vrouw die bereid was om zich vol overgave en tegen alle kritiek en spot in, te beijveren voor de bestrijding van vivisectie. Dit alles in het besef dat hij, alle offers ten spijt, tijdens zijn leven geen of nawwelijks tastbare resultaten van zijn streven zou zien.

In dit zelfbeeld van de anti-vivisectionisten, in deze kenschetsing van de anti-vivisectionistische strijd, valt een ambivalentie aan te wijzen. Enerzijds beschreven de anti-vivisectionisten zichzelf als helden, als de winnaars van de geschiedenis, als grote geesten en morele krachtpatsers die uiteindelijk het gelijk aan hun kant zouden krijgen. Anderzijds beklemtoonden zij dat de bijzondere kwaliteiten van de anti-vivisectionistische held in zijn eigen tijd door de meeste mensen nog niet op waarde konden worden geschat. De anti-vivisectionist werd, nog altijd volgens het zelfbeeld, bespot, verguisd en buitengesloten donr zijn tijdgenoten. In deze voorstelling was hij tegelijkertijd winnaar en verliezer of, beter gezegd, het verlies dat hij in de ogen van zijn tijdgenoten leed, was voor veel anti-vivisectionisten een essentieel deel van de ervaringen die een persoon tot held en winnaar maakten.

Wat verstonden de Nederlandse anti-vivisectionisten onder winnen en verliezen of, wanneer deze vraag met andere woorden wordt gesteld, wat wilden zij bereiken en op welke wijze streefden zij hun doel na? In de historiografie wordt dit probleem nogal eens verward met de vraag wat de anti-vivisectionisten daadwerkelijk hebben bereikt, een vraag die ogenschijnlijk eenvoudig te beantwoorden is. Het is de anti-vivisectionisten nameiijk in de verste verte niet gelukt om door het zichtbaar maken van het vivisectie-vraagstuk een wettelijke regulering van vivisectie, laat staan een verbodswet af te dwingen. Daarbij komt nog dat de omvang van de Nederlandse anti-vivisectie-beweging en de discussies die zij wist te ontketenen, zeer magertjes afsteken bij de grootte en de invloed van haar Britse 'moeder'. Laatstgenoemde ontketende ware rellen tussen de anti's en medicijnenstudenten, die slechts door hardhandig ingrijpen van de politie konden worden bedwongen. De Engelse anti-vivisectie-beweging stond bovendien aan de wieg van

26. Zie bijvoorbeeld: Diana Manuel, Marshall Hall (1790-1857): Vivisection and the Development of Experimental Physiology' in: Rupke, Vivisection, 78-104 en S. Richards. 'Vicarious suffering, necessary pain: Physiological Method
in late Nineteenth-century Britain" in: Rupke, Vivisection. 125-148.

27. Zic over de opkomst van laboratoria waar vivisecties werden verricht: H. Beukers, 'Een nieuwe werkplaats in de genceskunde: de opkomst van laboratoria in de geneeskundige faculteiten'. Tijdschrift voor de Geschiedenis der
Geneeskunde. Natuumetenschappen, Wiskunde en Techniek 9 (1986) 266-278. Ook: Smit, Dierproeven.

28. Joseph Campbell, A Hero with a Thousand Faces (Princeton 1949). Kathleen Turner. The History of Hell (New
York 1993). 
een regulerende wetgeving en twee spectaculaire parlementaire enquêtes. ${ }^{29} \mathrm{Zij}$ ontlokte reacties aan beroemde tijdgenoten als koningin Victoria, Charles Darwin en T.H. Huxley, en dwong de medische wetenschappers tot het vormen van een Research Defence Society. Dit alles gebeurde in Nederland op bescheidener schaal of helemaal niet. ${ }^{30}$ Zeker is dat in de loop van de twintigste eeuw het aantal verrichte vivisecties in Nederland van nog geen duizend per jaar is gestegen tot meer dan een miljoen. ${ }^{31}$ Ook de Engelse anti-vivisectionisten hebben een dergelijke toename van het aantal dierproeven niet kunnen tegenhouden.

Daarmee is de vraag wat de anti-vivisectionisten bereikt hebben in ieder geval voorlopig beantwoord. In de historiografie wordt althans doorgaans niet onder stoelen of banken gestoken dat de tegenstanders van vivisectie hun strijd hebben verloren. Is dat ook zo? Wordt hier niet ten onrechte verondersteld dat het zonder meer duidelijk is wat de anti-vivisectionisten wilden bereiken, wat het doel van hun anti-vivisectionisme was? Waren de anti-vivisectionisten er wel op uit om een wettelijk verbod van vivisectie tot stand te laten komen? Dat zonder meer aan te nemen is wellicht een anachronisme.

Immers, wat door de anti-vivisectionisten rond de eeuwwisseling onder winst en verlies, politiek slagen en falen, doel en middelen werd verstaan hoeft niet hetzelfde te zijn als wat daar vandaag onder wordt verstaan. Alleen al het gegeven dat de anti-vivisectie-beweging vooral werd aangehangen en vormgegeven door vrouwen, een groep die lange tijd van de parlementaire politiek was uitgesloten en zich in deze periode op allerlei manieren politiek trachtte te manifesteren, doet vermoeden dat de kwestie aanzienlijk gecompliceerder ligt. Het is niet ondenkbaar dat binnen een dergelijke beweging werd uitgegaan van een heel andere opvatting over slagen en falen, winnen en verliezen, over het bereiken van een doel dan toen, maar vooral ook tegenwoordig gangbaar is.

Een andere dan de gangbare visie op winnen en verliezen wordt ook voorgesteld door Ido de Haan en Henk te Velde in 'Vormen van politiek'. ${ }^{32}$ De Haan en Te Velde pleiten voor een bezinning op de vraag wat politiek in de negentiende eeuw inhield. Politiek is in hun visie meer dan 'een vanzelfsprekende overlegpraktijk in formele organen'. Ook door vrouwenhistorici wordt al minstens een decennium een ruimere opvatting van politiek bepleit. Uit een aantal studies ${ }^{33}$ is inmiddels duidelijk geworden dat door een bredere opvatting over politiek - waarin bijvoorbeeld aandacht wordt besteed aan de verhouding tussen privé en openbaar en aan verschillende opvattingen over macht en strijd- meer zichtbaar wordt van de beweegredenen en handelwijzen van personen en groepen die, indien een beperktere of klassieke visie op politiek wordt gebezigd, niet of slechts marginaal in de geschiedschrijving zouden voorkomen.

29. Zie: The National Anti-Vivisection Socicty. The Royal Commission on vivisection. Evidence by the Honble. Stephen Coleridge (Londen 1907). Zie ook: E.M. Tansey. 'Protection against dog distemper and dogs protection bills: The medical rescarch council and the anti-vivisection protest 1911-1933., Medical History 38 (1994) 1-26.

30. Pas in 1977 zou vivisectie in Nederland wettelijk gereguleerd worden (Wet op de dierproeven 1977). Zie hierover Boon, Nederlands Dierenrecht (Arnhem 1983). Judith Hampson vergelijkt in haar studie: 'Legislation: A practical solution to the vivisection dilemma ?' in: Rupke, Vivisection, 314-339 deze Nederlandse wetgeving mel dic van Oostenrijk, Cyprus, België, Denemarken, Ierland, Duitsland, Griekenland, Frankrijk, Italië, Luxemburg, Lichtenstein. Malta en Noorwegen.

31. W.I.I. van der Gulden, Dierprot'ven, geen vivisectie (oratie Nijmegen 1988). Zie ook: Henk Smit ed., Dierproeven in de modeme samenleving (Deventer 1978).

32. Ido de Haan en Henk te Velde, 'Vormen van politiek'. BMGN 111 (1996) 167-200. Zic ook: Henk te Velde 'De vanzelfsprekendheden van de negentiende ecuw'. De negentiende eeuw: documentalieblad Werkgroep $19 e$ eeuw 2 ? (1998) 1-3, aldaar 3.

33. Zie bijvoorbeeld: Marjan Schwegman ed. O Op hel strijdtoneel van de politiek. Twaalfde Jaarboek voor Vrouwengeschiedenis (1993) 421-434. Marianne Braun. De prijs van de liefde. De eerste feministische golf, het hinwelijksrechl en de vaderlandse geschiedenis (Amsterdam 1992). Vergl. Piet de Rooy, Een ideaal dat ons toelacht (Amsterdam 1994). Francisca de Haan en Romke van der Heide, 'Vrouwen-Vereenigingen. Dames-Comité's en leministen. De zorg van vrouwen voor vrouwelijke gevangenen in de negentiende ecuw'. Tijdschrift voor sociale geschiedenis 23 (1997) 278311. 
Een bredere opvatting van politiek geeft de mogelijkheid een nieuw licht te werpen op de geschiedenis van het anti-vivisectionisme. Zij stelt dus in staat te zien dat het zichtbaar maken van het vivisectie-vraagstuk voor de Nederlandse anti-vivisectionisten veel belangrijker was dan het sluiten van een politiek compromis of het afdwingen van een wettelijk verbod op dierproeven. Dat het bovendien belangrijker was te tonen hoe men zich als individu en beweging tot deze kwestie verhield, dan door het verwerven en uitoefenen van macht, de vivisectie daadwerkelijk te doen verdwijnen.

Illustratief is in dit verband het optreden van Felix Ortt, de belangrijkste voorman van het Nederlandse anti-vivisectionisme, voor de hoorzitting van de Commissie inzake Vivisectie. De commissie was in 1907 door de ministers van Binnenlandse Zaken, en Landbouw, Nijverheid en Handel ingesteld. Onder voorzitterschap van het antirevolutionaire kamerlid J.W.H.M. van Idsinga, legde zij zich toe op de beantwoording van de vraag of medisch-wetenschappelijke proefnemingen op levende dieren in Nederland door wetten beperkt of verboden dienden te worden en zo ja, op welke wijze dat dan moest. In de periode van 20 mei tot en met 26 oktuher 1908 vroeg de commissie een veertiental voor- en tegenstanders van vivisectie tijdens een hoorzitting naar hun mening over deze kwestie. ${ }^{34}$ Op deze wijze vernamen zij ook de opvattingen van Ortt. De anti-vivisectionist gaf voor de commissie te kennen dat hij geen heil zag in een verbod van vivisectie. Daarvoor was hij naar zijn zeggen te veel anarchist. Hij liet zich, zo stelde hij, niet door de wet maar door zijn eigen geweten leiden en meende dat een ander daarin ook vrij gelaten diende te worden. Indien een medicus 'uit gewetensdrang' een proef nam om een mensenleven te redden diende dit gerespecteerd te worden:

'Wanneer het geweten van een ander anders spreekt dan het mijne, wil ik hem niet dwingen; daarom zie ik geen heil in een verbodswet $[\ldots \mid]^{3.35}$

Ortt etaleerde tijdens de hoorzitting onder meer met deze uitspraak zijn hoge morele levenshouding. Dit schijnt op dat moment zijn voornaamste doel te zijn geweest. Hetzelfde geldt voor de anti-vivisectionist Jacob van Rees met wie Ortt samen een anti-vivisectionistische brochure publiceerde. ${ }^{36}$ Ook Van Rees werd door de Commissie inzake Vivisectie gehoord. Op de vraag 'Welke proefnemingen moeten Uw inziens geheel verboden worden', antwoordde hij:

'Ten deze sta ik op een eigenaardig standpunt. Ik ben [...] absoluut tegen elk met menschelijk gezag dwingend verbod; zulks in verband met mijne levensbeschouwing als religieus anarchist, aanhanger van de opvattingen van Tolstoi aangaande de zuivere christelijke leer. ${ }^{.37}$

34. De commissie werd ingesteld bij beschikking van 23 februari 1907. No. 1916 Afdeeling 0 en No. 1810 afdeling VD. (Directie van Landbouw). De commissie bestond behalve uit voorzitter Idsinga uit: $\mathrm{Dr}$. M. A. Brants, burgemeester der gemeente Schiedam, R.P. van Calcar, hoogleraar aan de Rijksuniversiteit Leiden, Dr. J. Poels, directeur van de Rijksseruminrichting te Rotterdam. Dr. C.L. Rümke, arts te 's-Gravenhage, Dr. H.C.C. Spronck, hoogleraar aan de Rijksuniversiteit Utrecht en Mr. A.G. Vreede. Commies-redacteur van de gemeente secretarie van Hilversum. Zie: Rapport der Commissie inzake Vivisectie, aan de H. Ex. De Ministers van Binnenlandsch Zaken, Landbouw, Nijverheid en Handel. Met Bijlagen 1-IX (1909). Zie ook C.A. Pekelharing. 'Wettelijke regeling der vivisectie', De Gids: Nieuwe Vaderlandsche Lefteroefeningen 27 (1909) 328-335. De Commissic inzake Vivisectie ondervroeg de anti-vivisectionisten Felix Ortt en Jacobus van Rees. Verder hoorde zij: Dr. G.W. van Zadelhof, arts te Utrecht, Dr. J.T. Wouters, homeopathisch arts te Arnhem, C. Schimmel, leraar heelkunde, operatie en verbandleer en kliniek aan de Rijksveeartsenijschool te Utrecht, prof. Dr. H. Zwaardemaker, hoogleraar fysiologie te Utrecht. Dr. A. Aletrino, arts en literator te Amsterdam. Prof. Dr. C. Winkler, hoogleraar in de psychiatrie en neuropathologie te Amsterdam. W. A. Stark, officier van gezondheid te Nieuwediep. Dr. A.K.W. Arntzenus, arts te 's-Gravenhage. Prof. Dr. L. Bouman, directeur van he gemeentelijk abattoir te Amsterdam. Dr. Ph. Van Lissa, ans te 's-Gravenhage. Jhr. Mr. W.F. van Rochussen, oudminister van Buitenlandse Zaken, oud-lid van de Raad van State, ondervoorzitter van het Comité tot Beperking van
Vivisectie.

35. 'Verslag van de verhooren der voor de Commissie verschenen personen' in: Rapport der Commissie inzake Vivisectie met Bijlagen I-IX, bijlage II vraag 363, 1-52, aldaar 44

36. NBBV, Is de vivisectie in het belang der menschheid? Een beroep op alle medici van Nederland door den Nederlandschen Bond tot Bestrijding der Vivisectie met voonwoord van Prof. Dr. J. Van Rees, Buitengewoon Hoogleraar (8)

Vivisectie mel Bijlagen I-IX, bijlage II vraag 182, 1-52, aldaar 23 
Evenals Ortt lijkt het Van Rees tijdens zijn optreden voor de Commissie inzake Vivisectie vooral te zijn gegaan om het uitdragen van een hoge morele levenshouding en niet om een wettelijk verbod van vivisectie. De anti-vivisectionisten voerden eerder een expressieve dan een instrumentele politiek. Dit onderscheid is ontleend aan de politicologische studie Middle Class Radicalism ${ }^{33}$ van Frank Parkin waarin met het begrip expressive politics gedoeld wordt op de activiteiten en beweegredenen van sociale en politieke bewegingen die niet of niet zozeer gericht zijn op het bereiken van specifieke, concrete economische of materiële doelen. Bij expressieve politiek draait het volgens Parkin veel eerder om het tot uitdrukking brengen van bepaalde morele standpunten en veel minder of helemaal niet om het verwerven van macht:

'Expressive activity [...] is that which is less concerned with specific achievements than with the benefits and satisfactions which the activity itself affords. The rewards are as much in the action itself as in the ends it is directed to. [...] Expressive politics is that which is mainly concerned with the defence of principles, even if this means relinquishing power. ${ }^{39}$

Instrumentele politiek omschrijft Parkin als volgt:

'Instrumental activity may be thought of as that which is directly geared to the attainment of concrete and specific goals, generally of a material kind. Emphasis is placed on the ends to be achieved rather than on the means employed in attaining them. [...] Instrumental politics is that primarily concerned with the attainment of power to bring about desired ends, even if this means some compromise of principle. ${ }^{40}$

'Reis door de hel der onschuldigen' biedt de lezer een tocht langs de expressieve politieke stijl van de Nederlandse anti-vivisectie-beweging, een stijl die floreerde in de periode waarin zich volgens De Haan en Te Velde in Nederland een nieuwe vorm van openbaarheid ontwikkelde. In die openbaarheid zouden sentiment en groepsbelang expliciet worden aangesproken met behulp van een mobiliserende retoriek.

De anti-vivisectionisten brachten door het zichtbaar maken van de vivisectie als politiekmaatschappelijk vraagstuk een morele en religieuze levenshouding tot uitdrukking. Om wat voor wereldheschouwing ging het? Wat verstonden de anti-vivisectionisten onder vivisectie, welke gestalte namen proeven op levende dieren in hun propaganda-materiaal aan? Op welke wijze maakten zij het vraagstuk zichtbaar? Op welke wijze verhield de expressieve politieke stijl zich tot andere politieke stijlen? Het zijn deze vragen die in dit boek aan de hand van een aantal aan het anti-vivisectionisme gerelateerde thema's aan de orde komen.

Daar tot nu toe nauwelijks enig historisch onderzoek naar de Nederlandse anti-vivisectiebeweging is verricht ${ }^{41}$, zijn die thema's gekozen op basis van de historiografie van het Engelse anti-vivisectionisme. Deze geschiedschrijving maakt duidelijk dat het verzet tegen vivisectie geplaatst kan worden tegen de achtergrond van bepaalde opvattingen over religiositeit, wetenschap en moderniteit. Bovendien blijkt uit die geschiedschrijving dat denkbeelden over mannelijkheid en vrouwelijkheid, emotionaliteit en verbeelding binnen de beweging belangrijk waren. Door deze thema's in afzonderlijke hoofdstukken centraal te stellen zal duidelijk worden in hoeverre dit alles tevens opgaat voor het Nederlandse anti-vivisectionisme. Om te voorkomen dat een dergelijke thematische behandeling resulteert in een statische weergave van de anti-vivisectionistische politieke stijl, wordt tegelijkertijd een chronologie aangebracht. Per hoofdstuk wordt telkens een vorm van 'expressieve politiek in actie' als ijkpunt in de tijd genomen: gebeurtenissen (bijvoor-

38. Frank Parkin, Middle Class Radicalism. The social hases of the British campaign for nuclear disarmamen (New York/Washington 1968).

39. Parkin, Middle Class, 34. Vergl. Hilda Kean, 'The feminist en socialist response to Vivisection', History workshop journal 40 (1995) 16-38. Met name de paragraaf: 'Contradictions: Politics and Moral Opposition'.

40. Parkin. Middle Class, 34.

41. Alleen Mathijsen, 'Oefenoperaties'. Davids 'Aristocraten', Davids, Dieren, Smit, Dierproeven, Boon, Dierenrecht $\mathrm{en} \mathrm{L.} \mathrm{Bergkamp.} \mathrm{Het} \mathrm{proefdier} \mathrm{mens.} \mathrm{De} \mathrm{normering} \mathrm{en} \mathrm{regutering} \mathrm{van} \mathrm{medische} \mathrm{experimenten} \mathrm{op} \mathrm{mensen} \mathrm{(Alphen} \mathrm{aan}$ de Rijn 1988) hebben in hun studies kort iets over de geschiedenis van het Nederlandse anti-vivisectionisme gezegd. 
beeld het hierboven aangehaalde optreden voor de Commissie inzake Vivisectie), geschriften (van allerlei vorm, van fictie tot essays) of lezingen. Het gaat daarbij steeds om vormen van expressieve politiek die ik kenmerkend acht voor het Nederlandse anti-vivisectionisme in het debetreffende jaar. Tezamen bestrijken de hoofdstukken zo de periode 1870-1940. Daarbij ligt het zwaartepunt rond 1900, grofweg de periode 1890-1920, de tijd waarin de beweging opkwam, bloeide en ten onder dreigde te gaan. De ontwikkeling van de politieke stijl van de anti-vivisectionisten in die tijdspanne zal vergeleken worden met het verzet tegen vivisectie in de jaren dertig, de periode waarin het anti-vivisectionisme in Nederland opnieuw en deels op een andere manier dan voorheen opkwam.

Op deze manier is het mogelijk om ook ontwikkelingen en spanningsvelden weer te geven en kunnen de eventuele veranderingen in de politieke stijl en de daarmee samenhangende gedaantewisselingen van de vivisectie worden besproken en begrepen. Tegelijkertijd zal zo duidelijk worden op welke wijze de anti-vivisectionistische verbeelding van het vivisectie-vraagstuk verschilde van of overeen kwam met het beeld dat elders in de samenleving, dat wil zeggen in de parlementaire politiek, bij de voorstanders van vivisectie en de publieke opinie bestond. Zo worden niet alleen de eigenheid van de politieke stijl van de anti-vivisectionisten, maar ook de overeenkomsten met de strijdwijze en het referentiekader van andere bij het debat betrokken politieke bewegingen in kaart gebracht.

Met dit alles verhoudt deze 'reis door de hel der onschuldigen' zich op een specifieke wijze tot de historiografie van het anti-vivisectionisme waarin de politieke stijl van de beweging aan de orde wordt gesteld. Dat zal duidelijk worden uit het volgende hoofdstuk waarin deze historiografie kritisch besproken wordt. Daarbij zal blijken dat de historiografie van het verzet tegen dierproeven doordrongen is van bepaalde klassieke opvattingen over mannelijkheid en vrouwelijkheid, winnen en verliezen, politiek slagen en falen. De geschiedenis van het anti-vivisectionisme is met andere woorden geschreven vanuit een impliciete waardering voor instrumentaliteit en een afwijzing van expressiviteit. ${ }^{42}$ Dit alles maakt, zoals uit het volgende overzicht mag blijken, dat de antivivisectionisten op een specifieke manier als verliezers in het geschiedverhaal terecht zijn gekomen.

42. Parkin is van mening dat in het politicologisch onderzoek van zijn tijd, de jaren zestig, te weinig oog is voor het gegeven dat individuen soms louter tot een politieke beweging toetreden omdat ze zich aangetrokken voelen tot het zij volgens Parkin te veel gericht zijn op machtsgerelateerde the possibility that groups and individuals may be as deeply economische motieven: 'Less attention has been paid to moral values which are quite unrelated to material and economic interes' instrumentaliteit en de wardering voor beide: Ineke van den Wetering. Zie over die tegenstelling expressiviteit en Surinaamse vrouwen in Nederland' in: Van Daalen en Gijswijt-Hofstra ed. Gerond 


\section{Een weg geplaveid met winnaars en verliezers Geschiedschrijving over anti-vivisectionisme}

In $O p$ het breukvlak van twee eeuwen ${ }^{1}$ benadert Jan Romein het anti-vivisectionisme als deel van een tegen het einde van de negentiende eeuw opgekomen verzameling humanitair-idealistische stromingen. In Romeins visie belichaamden deze door hem als petites religions ${ }^{2}$ aangeduide bewegingen, waartoe hij onder meer het vegetarisme, het spiritisme en de natuurgeneeswijze rekent, de onzekerheid van de tijd waarin zij ontstonden. ${ }^{3}$ De kleine geloven fungeerden als houvast voor de vele, doorgaans uit de bourgeoisie afkomstige 'zoekende zielen' die het vertrouwen in de officiële religies vaak definitief verloren hadden. Uit een soort schuldgevoel, uit angst voor het opkomende proletariaat en voortgedreven door een volgens Romein 'ongrijpbaar maar toch overal voelbaar idealisme [...]' zochten en vonden zij in de humanitaire beweging een oplossing voor de sociale problemen van hun tijd. Om die reden waren de petites religions, zoals de historicus Piet de Rooy heeft aangetoond, geduchte concurrenten van socialisten die hun aanhang eveneens uit de hogere middenklasse rekruteerden en zich bovendien op de sociale kwestie richtten. ${ }^{4}$

De spanning en rivaliteit tussen socialisme en kleine geloven ontging Romein niet, of beter gezegd, hij werd er beslist door geraakt. Dit blijkt onder meer uit de onverbloemde irritatie die doorklinkt in zijn beschrijving van de petites religions. In Op het breukvlak van twee eeuwen worden de kleine geloven in niet mis te verstane termen aangeduid als 'bourgeois', 'eenzijdig', 'onwerkelijk', 'verwend', 'ziekelijk' en 'onmenselijk door een bloedeloze humorloosheid'. De voorlieden van de bewegingen, waaronder Van Rees en Ortt, komen er nog slechter vanaf. Romein refereert aan hen met benamingen als 'honderd en één profeten', 'edele gluiperds', 'eenogen in het land der blinden' en 'kwakzalvers in luilekkerland."

Dat het bezigen van dergelijke kwalificaties zeer verleidelijk is, blijkt wel uit de strekking van andere Nederlandse publicaties die aan de petites religions zijn gewijd. Uit deze historiografie wordt duidelijk dat veel onderzoekers in de loop van hun (deel)studies of andersoortige publicaties aan een 'romeiniaanse' ergernis ten prooi vallen. Een en ander wordt beschreven door Hugo Röling in zijn studie over het negentiende- en vroeg-twintigste-eeuwse vegetarisme. ${ }^{6}$ Hoewel deze historicus van mening is dat Romein in zijn analyse van de kleine geloven een iets te gemakkelijke verbinding legde tussen belachelijkheid en verwerpelijkheid, geeft hij toe tijdens zijn onderzoek in de verleiding te zijn gekomen om de absurde consequenties van de leerstellingen van de kleine geloven bloot te leggen en te beoordelen aan de hand van de soms pathologische individuen die er door aangetrokken werden. ${ }^{7}$ Waar Röling zich van die neiging bewust is, geven anderen zich zonder enige terughoudendheid over aan de verlokkingen van de spot. Zo vraagt lleen Montijn ${ }^{x}$ zich af wie toch 'die Felix Ortt' was om vervolgens zelf, zonder enige studie vooraf, vast het antwoord te geven. Het kon niet anders of hij was een charlatan. Een recensie van Huub Wijfjes

\footnotetext{
1. Jan Romein, Op het breukvlak van twee eelowen (2 din. Leiden/Amsterdam 1967).

2. Romein ontleende de term petites religions aan Jules Bois, Les petites religions de Paris (Parijs 1894).

3. Romein noemt: spiritisten. theosofen, geheelonthouders, vegetariërs, magnetiseurs, 'blont-voeters', reinlevers, aardstralers, Christian scientists, anti-kunstmesters, homeopaten, antroposofen. Zie voor kritick op deze reeks: Marijke Gijswijt-Hofstra, Vragen bij een onlloverde wereld (Oratie Amsterdam 1997). Vergl. E.H. Kossmann. 'Romeins Breukvlak en de Nederlandse geschiedenis', BMGN 100 (1991) 652-658
}

4. Piet de Rooy. 'Een hevig gewarrel. Humanitair idealisme en socialisme in Nederland rond de ecuwwisseling'. $B M G N$ 104 (1991) 625-640

5. De tot nu toe gebezigde citaten van Romein zijn te vinden in Romein, Breukvlak, 643, 644, 646

6. H.Q. Röling. De God'lijke stem van het medelijden. Vegetarisme in Nederland 18941914 (Werkschrili Amsterdam 1972).

7. Röling, God'lijke stem, 1.

8. lleen Montijn, 'Een beetje heilig. Vegetarisme als levenshouding' NRC 22 mei 1993. 
heeft eenzelfde tendens. ${ }^{9}$ Daarin wordt een ieder die rond 1900 een oplossing aandroeg voor 'schrijnende maatschappelijke problemen' als profeet gekenschetst. ${ }^{10}$ Hier klinkt een duidelijke echo van Romein.

Waarom zijn de kleine geloven zo ergerniswekkend? De Rooy geeft een plausibele verklaring. Romeins visie op de petites religions zou gekleurd zijn door een whig-interpretation die als volgt kan worden samengevat. De kleine geloven kwamen voort uit dezelfde motieven als het socialisme, maar waren 'van begin af gedoemd ten onder te gaan tegenover deze zoveel hoger staande theorie en een zoveel praktischer uitgevoerde belangenstrijd'. "Met andere woorden: in Romeins analyse van de kleine geloven is een denken in termen van politieke winnaars en verliezers te bespeuren. Dit geldt ook voor het werk van andere publicisten en historici die eveneens de uiteindelijke ondergang van de kleine geloven als maatstaf gebruiken. Zij lijken er vanuit te gaan dat dergelijke bewegingen niets wezenlijks hebben bijgedragen aan de maatschappelijke discussie over actuele problemen en vinden het daarom kennelijk des te ergerniswekkender dat de "honderd en een profeten' er zelf zo onbeschaamd op vertrouwden dat hun idealen uiteindelijk verwezenlijkt zouden worden: 'zo niet morgen, dan toch overmorgen' sneerde Romein in dit verband. En dat terwijl ieder redelijk mens toch kon begrijpen dat daarvan geen sprake kon zijn. Lien Heyting stelt ongeduldig vast dat idealisten als Felix Ortt werkelijk meenden:

'door de oprichting van een eigen alternatief maatschappijtje in een klap te kunnen afrekenen met alle onrechtvaardigheden uit de samenleving die zij de rug toekeerden." ${ }^{2}$

Het waren 'dromers', zo constateren Frans Becker en Johan Frieswijk hoofdschuddend ${ }^{13}$ :

'Dichterlijke naturen [...] dwepers, mensen die hun dromen voor grotere werkelijkheid hielden dan de werkelijkheid zelf. Dat geldt in sterke mate voor de leiders van de beweging: Felix Ortt, Lodewijk van Mierop, Prof. J. van Rees en Louis Baehler. ${ }^{14}$

Dergelijke lieden waren 'gespeend van alle nuchtere werkelijkheidszin'. '5 Hun ideeën waren, zo vat Maria Boersen het nog eens kernachtig samen, vooral 'zweverig'. 10

Resumerend kan gesteld worden dat veel hedendaagse Nederlandse historici de opvattingen van Romein delen. Zij schenken, althans die indruk wordt gewekt, zo weinig mogelijk aandacht aan de kleine geloven. ${ }^{17}$ Waar zij toch iets over dergelijke bewegingen opmerken, doen zij dit vooral ironisch. Hun boodschap luidt dat de idealisten van de kleine geloven, en dus ook de antivivisectionisten de verliezers van de geschiedenis zijn.

Ook in de Engelse historiografie wordt de anti-vivisectie-beweging als zodanig afgeschilderd. Illustratief is Richard French' Anti-vivisection and medical science in Victorian society, het in 1975 gepubliceerde standaardwerk over de geschiedenis van het negentiende-eeuwse verzet tegen vivisectie in Engeland. Deze studie is min of meer representatief voor de wijze waarop historici die in de Angelsaksische traditie staan het verzet tegen dierproeven hebben benaderd. Het antivivisectionisme wordt erin omschreven als de strijd van een terrein verliezunde, maar tot het einde

9. Huub Wijfjes. 'Niet drinken, niet roken en op tijd naar bed' een recensie van het boek: Lief, links en lastig- zeventig jaar Volksontwikkeling en natuurvriendenwerk (Amsterdam 1994) van G. Leenders cn J. Palm, De Volkskrant 25 februari 1995

10. Vergl. Jan Meyers, Domela, een hemel op aarde (Amsterdam 1993) 7.

11. De Rooy. 'Een hevig gewarrel', 626.

12. Lien Heyting, De wereld in een dorp. Schilders, schrijvers en wereldverheteraars in Laren en Blaricum $1880-1920$ (Amsterdam 1994) 62.

13. Frans Becker en Johan Frieswijk, Bedrijven in eigen heheer. Kolonies en productieve associaties in Nederland 19011958. Met bijdragen van J.M. Welcker en F.J.M. van Puijenbroek (Nijmegen 1976).

14. Becker, Bedrijven. 38 .

15. Becker. Bedrijven, 38. Vergl. Rudolf Jans, Tolstoi in Nedertand (Bussum 1952) en Annemiek de Groot, 'De lust tot last. De rein leven beweging als pionier in de strijd om de nieuwe mens' Einde van een utopie? Groniek, historisch
tijdschrift (1993) 55-64.

16. Maria W.J.L.M. Boersen, De kolonie' der Intemationale Broederschap te Blaricum (Blaricum 1987) 15

17. Vergl: Herman Noordegraaf, Niet met de wapenen der harharen. Het christen-socialisme van Bart de Ligt (Baarn 1994). Noordegraaf geeft aan dat ook het christen-socialisme natuelijks bestudeerd is. 
van de negentiende eeuw dominante literaire en theologische elite die zich tezamen met een opkomende beweging van vrouwen verzette tegen de aan macht winnende en zich gestaag specialiserende en professionaliserende medische wetenschap. ${ }^{18}$ French laat zien dat de strijd tegen dierproeven voor velen fungeerde als een 'drager' om uitdrukking te geven aan argwanende en zelfs vijandige gevoelens tegen de toenemende sociale, politieke en culturele invloed van de wetenschap op de samenleving.

Het anti-vivisectionisme was evenwel meer dan een reactie op een dreigend afnemen van sociaal aanzien. Mensen met zeer verschillende achtergronden, niet alleen zij die aan macht moesten inboeten, werden tot de beweging aangetrokken. De individuele motieven die daarbij een rol speelden, kunnen alle, hoe verschillend ook, in verband worden gebracht met een cultureel klimaat dat door French als volgt wordt aangeduid: 'a sense of malaise signified by a sense of duty and morality in certain of the educated classes'..$^{19}$

Anti-vivisectionisme bood volgens French een mogelijkheid om gestalte te geven aan een political counteroffensive ${ }^{20}$ tegen de modernisering van de samenleving. Een dergelijke strijd, zo stelt French, kon door niemand gewonnen worden. De anti-vivisectionisten konden het gezicht van de twintigste eeuw die voor hen lag eenvoudigweg niet veranderen. Zij vochten tegen het niet te stuiten proces van modernisering en dit maakte dat hun verlies inherent was aan hun strijd. Daarbij kwam nog dat de anti-vivisectionisten er volgens French een weinig krachtige strijdwijze of politieke stijl op na hielden. Zij zouden, en hier verwijst French expliciet naar Parkin, vooral een expressieve politiek hebben bedreven. " Speciaal de voorvrouwen van de anti-vivisectiebeweging gaven volgens French vorm aan deze bijzondere strijdwijze. Zij bedienden zich van compromisloze, emotionele statements en zaaiden, onverzoenlijk als zij waren, tweedracht in eigen gelederen. Hun wetenschappelijke tegenstanders pakten de zaak naar het oordeel van French aanzienlijk beter, dat wil zeggen instrumenteler, aan. Zij beijverden zich voor het tot stand brengen en in stand houden van goede relaties met de politieke elite. De wetenschappers verbonden de wetenschappelijke vrijheid van de medicus op overtuigende wijze met de alom gevoelde noodzaak om de internationale positie van Engeland te versterken.

Het door French gemaakte onderscheid tussen twee soorten politiek, die van wetenschappers en die van anti-vivisectionisten, maakt de laatstgenoemden zelfs tot dubbele verliezers. Niet alleen waren zij gedoemd ten onder te gaan in het moderniseringsproces, zoals de kleine geloven volgens Romein gedoemd waren om ten onder te gaan door het opkomen van het socialisme, zij bedienden zich ook van een verkeerde politiek. Bij hem lijkt dit denken in termen van winnaars en verliezers verbonden te zijn met een vrij rigide en anachronistisch beeld van de negentiende-eeuwse politieke stijl, een beeld dat bovendien doortrokken is van geseksueerde voorstellingen. Ook French denkt dus dat er twee lijnrecht tegenover elkaar staande politieke stijlen zijn aan te wijzen. Enerzijds een ú:; vrouwen gedominecide, emotionele, compromisloze, op het eigen ego gerichte en nict zetden hysterische, irrationele, anti-moderne, anti-technologische, religieuze, tegen de modernisering strijdende en daarom tot mislukken gedoemde politieke stijl van de anti-vivisectionisten. Anderzijds een door mannen gedomineerde, op compromissen en het algemeen belang gerichte, succesvolle, redelijke, rationele en bij het proces van modernisering aansluitende politieke stijl van wetenschappers.

Het dichotomisch denken van French, zijn scherpe onderscheid tussen een mannelijke en vrouwelijke manier om politiek te bedrijven is een belangrijke inspiratiebron geweest vuor een

\footnotetext{
18. Dit is ook de mening van Nicolaas Rupke. Zie Rupke. 'Introduction', 1-13

19. French, Antivivisection, 410

20. Ibidem, 408 .

21. Ibidem, 407 .
} 
aantal vrouwenhistorici. Susan Hamilton, Coral Lansbury en Mary-Ann Elston 22 interesseren zich voor de vraag welke specifieke rol vrouwen in het Victoriaanse en Edwardiaanse anti-vivisectionisme hebben gespeeld. In hun zeer van elkaar verschillende studies komen zij ieder tot de conclusie dat vrouwen uitermate veel invloed hebben gehad op de strijdwijze van de antivivisectie-beweging. Voor de aan de beweging deelnemende vrouwen zou de strijd tegen vivisectie gelijk hebben gestaan aan een protest tegen hun eigen maatschappelijke onderdrukking. Daar het voor vrouwen niet gebruikelijk was om in de openbaarheid op te treden, zij geen stemrecht hadden, en op alle mogelijke manieren vanuit een positie van achterstand opereerden, zochten zij volgens deze onderzoeksters, hun toevlucht tot het schrijven van romans, novellen en korte verhalen. Daarin zouden zij via de beschrijving van onderdrukte en gepijnigde proefdieren in feite hebben getracht hun eigen treurige situatie aan het licht te brengen. Op deze wijze zou de strijd tegen vivisectie mede vorm hebben gekregen door aan het gevoel van vrouwen ontsproten fantasieën, verhalen en fictie. Deze opvatting over de vrouwelijke politieke stijl van de antivivisectionisten werpt wel meer licht op de relatie tussen vrouwen en de strijd tegen vivisectie, maar is geen breuk met French' dichotomie. De anti-vivisectionistische vrouwen krijgen hooguit een duidelijker en wellicht meer heroïsch gezicht, maar worden in deze studies nog altijd in het perspectief van winnaars en verliezers geplaatst. $\mathrm{Zij}$ zijn hooguit sympathiekere verliezers geworden. ${ }^{23}$

Met zijn dichotomie sluit French, zij het indirect, aan bij historici die een beweging als het anti-vivisectionisme vrijwel uitsluitend associëren met het romantische, irrationele, oncontroleerbare, donkere, ja zelfs proto-nazistische gezicht van de negentiende- en twintigste-eeuwse geschiedenis. Illustratief is de studie Panorama oder Ansichten vom Neunzehnten Jahrhundert (1938) van de Duitse historicus Dolf Sternberger. ${ }^{24}$ Sternberger benadert anti-vivisectionistische romans en schilderijen als gevaarlijke pogingen om de werkelijkheid op verraderlijke wijze te verdraaien. Hij zag hierin de voorbode van een wereld waarin ervaringen gekleurd worden door ongenuanceerde voorstellingen, door een misplaatst beroep op esthetiek, gevoel, mystiek en een denken in absolute tegenstellingen. In dit verband mag niet onvermeld blijven dat Sternberger de belangrijkste reden voor deze scherpe veroordeling van het anti-vivisectionisme vond in zijn eigen tijd. Zijn panorama van de negentiende eeuw is geschreven als kritiek en reactie op de verontrustende actualiteit van het Duitsland van de jaren dertig. Het was bedoeld om de donkere laag in het bewustzijn van zijn tijugenoten bloot te leggen. ${ }^{25}$

Van dit denken in pendanten dat overigens weer past bij het denken van de late negentiende eeuw, wordt, hoe begrijpelijk en zinvol dit in Sternbergers tijd ook is geweest, in mijn studie naar het Nederlandse anti-vivisectionisme afstand genomen. Dat wil zeggen dat er in dit boek niet bij voorbaat vanuit wordt gegaan dat de anti-vivisectie-beweging een gevaarlijke beweging was. Een dergelijke vooronderstelling voegt uiteindelijk niets toe aan Sternbeigers karakterisering. In deze studie wordt bovendien afstand genomen van de eerder besproken historiografie waarin het denken in termen van winnaars en verliezers zo $n$ overheersende rol speelt.

Zo roept het scherpe onderscheid tussen vrouwelijke, expressieve en met religiositeit doorspekte politiek en mannelijke, rationele en moderne politiek, een aantal vragen op. Één darvan is of de onderscheiden soorten politiek, die in de geschiedschrijving van het anti-

22. Lanshury, Broun dog, Elston 'Women' en Susan Hamilton, 'Pets and scientific subjects: Constructions of the Ammal Body in Victorian Anti-Vivisection Periodicals' in: Anthony Purdy cd. Literature and the hody (Atlanta 1993) 77.94.

23. Vergl.: George L. Mosse. 'Fin de siècle. Challenge and response', BMGN 104 (1991) 573-580.

24. Dolf Sternberger. Panorama oder Anvichten vom 19. Jarhhundert (eerste druk Hamburg 1938, 1981)

25. Zie hierover: Ernst Bloch. 'Dolf Sternbergers Panorama' in: C. J. Friedrich en Benno Reilenberg ed., Sprache und Politik (Heidelberg 1968). Zie ook de woorden van Stemherger zelf: 'Und doch kam in und mil ihr (Sternbergers tijdgenuten) wie bei einer Eruption Gestein und Geröll, Grund und Schlamm zutage und zur Wirkung. welches alles gerade in jenem bürgerlichen neunzehnten Jahrhundert angelager war |... ebendiese Wahmemung war es, die mich in den ersten Jahres des Dritten Reiches darauf gebracht hat, die Epoche [...] zu studieren'. Sternberger, Panorana, 7. 
vivisectionisme staan voor de verliezers en winnaars in de moderne wereld, werkelijk zo scherp van elkaar te onderscheiden zijn. Zou de scheidslijn niet minder groot en in ieder geval minder karikaturaal kunnen zijn dan de zojuist besproken historici ons willen doen geloven? De analyses van French en Romein verschillen nauwelijks van de manier waarop de socialistische en liberale tegenstanders van het anti-vivisectionisme, de strijd tegen vivisectie beschreven en veroordeelden. Met andere woorden: de wijze waarop historici doorgaans een beeld geven van de tot mislukken gedoemde anti-vivisectionistische politiek versus de succesvolle rationele politiek van wetenschappers is soms een volledige reproduktie van die contemporaine commentaren. Ook dezen maakten, zoals uit het volgende mag blijken, een scherp onderscheid tussen een slappe, zweverige, door vrouwen en verwijfde mannen gevoerde strijd van de tegenstanders van vivisectie en een redelijke, door echte mannen gevoerde strijd voor wetenschappelijke vrijheid.

\section{De contemporaine kritiek}

De meeste critici van de tegenstanders van vivisectie karakteriseerden het verzet tegen medischwetenschappelijke experimenten op levende dieren als ziekelijk, sentimenteel en als onmannelijk of als typisch vrouwelijk. Vóór de oprichting van de NBBV was dat al zo. De strijd tegen dierproeven werd toen in Nederland gevoerd door een aantal dierenbeschermers dat aangesloten was bij de in 1864 opgerichte 's-Gravenhaagsche Vereeniging tot Bescherming van Dieren, de eerste dierenbeschermingsorganisatie van Nederland. ${ }^{26}$ Een van die anti-vivisectionistische dierenbeschermers was Maria van Manen-Thesing, redactrice van Androcles, maandschrift aan de belangen van dieren gewijd. ${ }^{27}$ In zijn autobiografie schetst de fysioloog Pieter Harting ${ }^{28}$ hoe hij eind 1873 als Utrechts hoogleraar en hoofdredacteur van het populair-wetenschappelijke tijdschrift Album der natuur ${ }^{29}$ bezoek kreeg van de redactrice van Androcles. Deze verzocht hem een artikel voor haar tijdschrift te schrijven. Een jaar eerder had Harting een dergelijk verzoek van haar echtgenoot, mr. C. van Manen, bestuurslid van de Haagsche Vereeniging al eens beleefd geweigerd:

'Ik kende dit tijdschrift alleen bij naam en gevoelde geen roeping om aan diens wens te voldoen, wel bevroedende dat mijne opvattingen over onzer plichten ten opzichte van dieren niet geheel zouden overeenstemmen met die der Haagsche Vereeniging. Ik weigerde dus, voornamelijk op grond mijner drukke werkzaamheden, er bijvoegende dat ik mijn populaire opstellen alleen voor het Album der Natuur mocht bestemmen. ${ }^{30}$

26. De 's-Gravenhaagse Vereeniging tot Bescherming van Dieren, de eerste Nederlandse dierenbeschermings-organisatie werd in 1865 opgericht. Al spoedig werd in andere steden dit voorbeeld gevolgd. In Rotterdam en Utrechl nog datzelfde jaar, de Amsterdamse Sophia Vereeniging werd in 1867 opgericht, Leiden kreeg haar dierenbescherming in 1871. Haarlem in 1872 en Arnhem en Dordrecht in 1875. In dat laatstgenoemde jaar werd een poging ondernomen om de verschillende stedelijke organisaties een gezamendijke Algemeene Nederlandschen Bond tegen het Mishandelen van Dieren te laten vormen. De Haagsche Vereeniging had daar echter geen behoefte aan. Zij beschouwde zichzelf als een landelijke organisatie daar veertig procent van haar leden buiten Den Haag woonde. In 1877 doopte de GVBD zichzelf $\mathrm{nm}$ in de Nederlandsche Vereeniging tot Bescherming van Dieren. De Algemeene Bond werd opgeheven. De meeste stedelijke dierenbeschermings-organisaties gingen op in de NVBD of verdwenen. Zie over de oprichting van de NVBD en de geschiedenis van de Nederlandse dierenbescherming: Davids 'aristocraten', Davids, Dieren. Zie ook: A.R. de Rijck, I25 jaar dierenbescherming (Den Haag 1989).

27. Androcles was de spreekbuis van de dierenbeschermingsbeweging. Het blad werd in 1869 opgericht. Van 1890 tot $1905 \mathrm{kreeg}$ het tijdschrift de toevoeging: Orgaan van de NBBV. In de praktijk betekende dit niet dat het tijdschrift geheel met anti-vivisectionistische artikelen was gevuld. De NBBV stond slechts een paar pagina's ter beschikking.

28. Zie over hem: Bert Theunissen, 'Een warm har en een koel hoofd. Pieler Harting over wetenschap. De natie en de vooruitgang', Bijdragen en Mededelingen betreffende de Geschiedenis der Nederlanden 110 (1995) 473-498, aldaar 482. Zie ook: A.A.W. Hubrecht. 'Pieter Harting herdacht' in: Jaarboek van de Koninklijke Akademie van Welenschappen (1888) 1-35, C.H.D. Buys Ballot, Levensbericht van Pieter Harting' in: Levensberichten van de Maatschappij der Nederlandsche Lelterkunde te Leiden (1886-1887) 149-175 en H.F. Jonkman, 'Pieter Harting' in: Mannen van Beteekenis in onze dagen (Haarlem 1886) 319-366.

29. Zie hierover: Liesbeth Coffeng. 'Het Album der Natuur. Popularisering van de naturwetenschap in een tijdschrift uit de eerste helft van de negentiende eeuw:, Groniek: onafhankelijk Gronings historisch studentenblad 27 (1994) $52-66$.

30. Pieter Harting, Mijne Herinneringen (Amsterdam 1961) 117 
In de periode tussen het bezoek van de twee echtelieden was Harting steeds meer overtuigd geraakt van de juistheid van zijn beslissing. Hij had inmiddels kennis genumen van de inhoud van Androcles, kon zich weliswaar met veel ervan 'volgaarne vereenigen', maar meende dat de rest van het tijdschrift toch vooral getuigde van een 'overdreven sentimentaliteit'. Deze laatste kwalificatie was volgens hem in het bijzonder van toepassing op een opstel over vivisectie ${ }^{31}$ dat volgens Harting 'meer voor het goede hart dan voor het verstand der schrijver getuigde'. Verontwaardigd stelde Harting dat 'door sentimenten gedreven leken' zich een oordeel aanmatigden over zaken die aan rationeel denkende en ervaren mannen van de wetenschap overgelaten moesten worden. Men diende naar zijn mening 'eenvoudig vertrouwen te hebben in hun plichtsbesef en verantwoordelijkheid'. Gezien dit standpunt is het niet verwonderlijk dat Harting niet van zins was om het verzoek van mevrouw Van Manen in te willigen. Aanvankelijk vertelde hij haar niet de werkelijke reden voor deze weigering. Hij vermeed het onderwerp vivisectie daar het naar zijn oordeel vanzelf sprak 'dat eene vrouw anders denkt dan een professor'. Toen zij echter, welbespraakt als zij was, 'aanhield en telkens weder aandrong', stelde Harting dat hij onmogelijk zijn opstellen kon publiceren in een tijdschrift waarin artikelen over vivisectie werden gepubliceerd waar hij ernstig bezwaar tegen had. Dit alles kon volgens Mijne Herinneringen niet voorkomen dat 'de vloed harer welsprekendheid ter bestrijding der vivisectie zich weldra [over hem] uitstortte' en dat het 'door haar aangevoerde' bij hem al spoedig het vermoeden deed rijzen dat mevrouw Van Manen zelf de schrijfster van het door hem 'geïncrimineerde' artikel was. Nadat hij de redactrice 'hoffelijk maar standvastig' nul op het rekest had gegeven was Harting er volledig van overtuigd geraakt dat de anti-vivisectionistische overgevoeligheid voor het lot van proefdieren als onmannelijk kon worden gekwalificeerd. ${ }^{33}$ In een aantal artikelen in Album der Natuur die hij in de jaren zeventig en in het begin van de jaren tachtig publiceerde, stak hij deze mening niet onder stoelen of banken. In deze opstellen schreef hij dat gevoel en sentimentaliteit typisch vrouwelijke eigenschappen waren die bij tijd en wijle behoorlijk overdreven konden worden en bovendien ronduit belachelijk waren wanneer deze in een man werden aangetroffen. ${ }^{34}$

Harting was niet de enige die er zo over dacht. Twee jaar na de oprichting van de NBBV (en zeven jaar na het overlijden van Harting) kwam de liberale publicist Dirk Beerends met een open brief in het geweer tegen de anti-vivisectionisten. ${ }^{35}$ Aanleiding was een aantal anti-vivisectionistische artikelen in Androcles. Ook in Beerends kritiek spelen opvattingen over mannelijkheid en vrouwelijkheid een belangrijke rol. Beerends diagnostiseerde de anti-vivisectionisten als lijders aan 'spleen', een ziekte die bij uitstek geassocieerd werd met slappe mannen en verwende vrouwen. Daaraan voegde hij toe dat het lichamelijk en geestelijk gestel van de anti-vivisectionisten ongetwijfeld slap zou zijn, zoals dat van de meeste vrouwen. Zo zouden zij noch in staat zijn om een operatie te aanschouwen zonder flauw te vallen, noch enige opoffering kunnen opbrengen. Het

\footnotetext{
31. Dit is waarschijnlijk het anonieme artikel 'Vivisectie' geweest. Androcles, maandschrift aan de belangen van dieren gewijd (1872) 95-113.

32. Citaten afkomstig uit Harting. Herinneringen. 117.

33. Ibidem. 117

34. Zie: Pieter Harting, 'Vivisectiẻn'. Album der Naluur (1874) 65-70. 'Philotherie of philantropie', Album der Naluur (1881) 131-142 'Eene psychologische studie naar aanleiding van een hangend vraagstuk', Album der Natuur (1884) 161184. Zie tevens de ingezonden brief van Harting in: Dagblad van Zuid-Holland en 's-Gravenhage 14 februari i 874 . In deze brief reageen Haring op een arikel uit dezelfde krant (in het bijvoegsel van het dagblad van 8 en 9 februari) Over een rekest van de dierenbeschermers tegen vivisectie. Zie ook: Een paar bedenkingen naar aanleiding van het conflict ontstaan tusschen Prof. Harting en de Vereeniging tot Bescherming van Dieren te 's-Gravenhage betrekkelijk vivisectie, opgedragen aan de abonnee's van het Album der Natuur ('s-Gravenhage 874).
}

35. Dirk Beerends, Is de vivisectie onzedelijk ? Open brief aan Androcles, met aanteekeningen door Dirk Beerends (Amsterdam 1892). Zie over de polemiek van Beerends met de anti-vivisectionisten: A.J.J. Ebeling. Bewijst elkander schuldige eer. Open brief aan den heer Dirk Beerends (Amsterdam 1893). 
enige waar zij goed in waren was het ziekelijk verwennen van hun bovenmatig geprikkelde en luie 'favorietpoes' en het beschimpen van grote Nederlandse medici. ${ }^{36}$

Tegenover de slappe en voor niets deugende anti-vivisectionist stelde Beerends de medische wetenschapper die in staat was om zijn menselijk gevoel in toom en zijn zenuwen in bedwang te houden De medicus was kalm en toonde zelfbeheersing. Door veel oefening had hij een vaste hand gekregen en was hij 'meester over het mes' geworden. Terwijl de anti-vivisectionisten hem bespotten, offerde hij zich op om zich volledig in te zetten voor de genezing van anderen. Het kon niet anders of ook in de door hem verrichte vivisecties lag 'iets edels, iets opofferends'. De medisch-wetenschappelijke proeven op levende dieren werden verricht uit altruïsme en waren daarom, aldus Beerends, ten nutte van de mensheid. ${ }^{37}$

Zo werd de onmannelijkheid van de strijders tegen vivisectie benadrukt door daar een bepaald idee over mannelijkheid tegenover te stellen. Interessant in dit verband is de constatering van Henk te Velde dat in de periode van 1870 tot aan de Eerste Wereldoorlog drie connotaties van mannelijkheid in de levensbeschouwelijk-politieke publicistiek kunnen worden aangetroffen:

'Het woord kon ten eerste volwassen betekenen opgevat als het evenwicht van een overtuigd wilskrachtig karakter; het kon ten tweede zelfstandig en onafhankelijk inhouden; en ten derde viriel in de zin van strijdbaar, maar ook offervaardig. ${ }^{.38}$

Te Velde laat zien dat mannelijkheid rond 1870 vooral gebruikt werd in de eerste en tweede betekenis van het woord. Het stond voor bedwinging van emoties, voor daadkracht en zelfstandigheid en kende onvolwassenheid als tegenpool. Tegen het einde van de negentiende eeuw, bij het ten einde lopen van het klassiek-liberale tijdperk, zou er een verschuiving van het mannelijkheidsideaal zijn opgetreden. Nieuwe politici als Abraham Kuyper en Ferdinand Domela Nieuwenhuis zetten in hun politieke strijd juist emoties in en beriepen zich op hun mannelijke opofferingsgezindheid. In deze periode was het tegendeel van mannelijkheid niet langer sentimentaliteit en onvolwassenheid maar slappe verwijfdheid. Dit laatste was, zo stelt Te Velde:

' $[\ldots$.$] iets anders dan vrouwelijkheid, maar nu emoties uitdrukkelijker werden toegelaten op het$

politieke terrein, ontstond de behoefte aan een nieuwe bepaling tussen mannelijke en vrouwelijke emotionaliteit. ${ }^{39}$

Uit de opvattingen van de klassiek-liberale Harting en andere critici van het Nederlandse antivivisectionisme blijkt dat het schema van Te Velde wellicht te strikt is. Immers, wat de medici en hun sympathisanten onder mannelijkheid verstonden, lijkt op een combinatie van de door hem onderscheiden betekenissen, namelijk zowel bedwinging van emoties als opofferingsgezindheid. ${ }^{\text {s0 }}$ Een verschil met de betekenissen van het woord mannelijk die hij schetst is dat de critici de 'onmannelijke sentimentaliteit' en 'slappe verwijfdheid' van de anti-vivisectionist wel degelijk reduceerden tot vrouwelijkheid. Mannelijke anti-vivisectionisten werden met vrouwen vergeleken. Bovendien meenden de meeste commentatoren van doen te hebben met een beweging die zich speciaal tot vrouwen richtte.

36. Beerends, Is de viviseclie, 24. In 1909 zou de Amerikaanse neuroloog Charles Loomis Dana het anti-vivisectionisme aanduiden als Zoophil-Psychosis, evenals Beerends ging het volgens hem dus om een soor ziekte. Zie hierover: Craig Buettinger. 'Antivivisection and the charge of zoophil-psychosis in the early twenticth century', The historian 55 (1993) 277-288.

37. Beerends. Is de vivisectie, 17

38. Henk te Velde, 'Viriliteit en opoffering. Mannelijkheid in het Nederlandse politieke debat van het fin de siècle'. Tijdschrift voor Vrouwenstudies 56 (1993) 421-434, aldaar 422.

39. Te Velde, 'Viriliteil'. 428.

40. Zie ook de kritiek van Dr. W. Koster in De Tijdpiegel van januari 1891: 'Hoe de vivisectie bestreden word', en de reactie daarop van J.B. Th. Hugenholtz: Open brief aan Dr. W. Kosler ('s-Gravenhage 1891). Theunissen 'Warm hart' Beerends huldigt Harting als liberaal door te verwijzen naar het door Opzoomer gemaakte grafschrift voor de man. Zie ook: Henk te Velde. Gemeenschapszin en plichtsbesef: liberalisme en nationalisme in Nederland 1870-1918 (Groningen 1992). Vergl.: Hans Righar, Politieke Cultuur. Een omgevingsverkenning (Amsterdam 1989) 24. Zie voor de wijze warop de opofferingsgezindheid van De Savomin Lohman werd benadrukt: H. Van Malsen, Alexander Frederik de Savormin Lohman. Ontwikkelingsgang van zijn denken en handelen (Haarlem 1931). 
Te Velde brengt de preoccupatie met mannelijkheid onder meer in verband met een angst voor verschillende opkomende emancipatiebewegingen, waaronder die van vrouwen. Dit is interessant te meer omdat ook bij Beerends die verontrusting een rol lijkt te spelen. Een nadere beschouwing van zijn betoog brengt aan het licht dat de publicist zich er niet eens zozeer druk over maakte dat er tegen vivisectie werd geprotesteerd. Het ging hem eerder om de wijze waarop de antivivisectionisten te werk gingen en vooral om wie zij met hun geschriften wilden aanspreken. Beerends was van mening dat de vivisectie-bestrijders zich niet aan de regels van het spel hielden omdat zij met 'van vreemden bodem overgenomen' en 'opzettelijk absurde' teksten inspeelden op de sentimenten van vrouwen. Zij waren er op uit om met hun 'vals', 'apodictisch' beeld van de professoren 'teerhartige dames' aan het 'rillen' te brengen. Beerends achtte het laakbaar dat de anti-vivisectionisten juist deze zwakke vaten van hun natuurlijke bestemming, het moederschap, afhielden door hen voor de strijd tegen vivisectie te winnen. Het kon niet anders dan dat mannen die zich tot zoiets verlaagden, zelf veel kenmerken bezaten van de groep waar zij zich toe richtten. ${ }^{41}$

Er was in Beerends' visie evenwel hoop op een oplossing voor dit ergerniswekkend verschijnsel. Echte vrouwen, dat wil zeggen de vrouwen die hun bestemming niet verloochenden, zouden opstaan. Zowel de arme moeder uit het proletariaat 'wier borsten zo verdroogd waren' dat zij haar kind niet kon voeden, als Florence Nightingale, die een ware moeder voor soldaten was geweest, zouden uiteindelijk de anti-vivisectie-moralisten 'de keel dichtknijpen'. Zij zouden hen straffen omdat zij hun aandacht aan het vivisectie-vraagstuk en niet aan het belang van de mensheid hadden gewijd. De overwinning was uiteindelijk aan de echte vrouw die haar natuur, haar moederschap niet verloochende. ${ }^{42}$ De latere Nobelprijswinnaar Willem Einthoven dacht er in 1906 precies zo over. In zijn afscheidsrede als rector magnificus van de Leidse universiteit memoreerde hij dat vooral de vrouwelijke medicijnen-studenten fanatieke tegenstanders van vivisectie waren. Hoe afschrikwekkend was het volgens de hoogleraar om te zien hoe jonge vrouwen serieus het leven van een kind en dat van een paar konijnen tegen elkaar afwogen. Troost had hij gevonden in de wetenschap dat dergelijke opvattingen wel zouden verdwijnen wanneer de dames een eigen gezin, dus gewichtiger zaken, hadden om zich mee bezig te houden. ${ }^{43}$

Voordat de overwinning van het moederschap op het anti-vivisectionisme zou plaatsvinden kon de beweging, daarover waren zowel Harting, Beerends en Einthoven het eens, veel schade aanrichten. Gevreesd werd dat politici gevoelig zouden zijn voor de anti-vivisectionistische propaganda. Het was inmiddels gebleken dat zoiets in het geheel niet ondenkbaar was. In 1883 had de minister van Binnenlandse Zaken het, naar aanleiding van een door dierenbeschermers ingediend rekest, al nodig geacht om bij de Koninklijke Nederlandsche Academie der Wetenschappen (KNAW) advies in te winnen over de wenselijkheid om medisch-wetenschappelijke proeven op levende dieren wettelijk te regelen. De KNAW had geantwoord dat een dergelijke wet zowel onnodig als onwenselijk was. ${ }^{44}$ Deze opvattingen hadden de minister er evenwel niet van weerhouden om in 1888 een aantal voorschriften op te stellen voor het uitvoeren van oefenopera-

41. De in deze alinea gebezigde citaten zijn te vinden in Beerends. Onzedelijk, 22, 26.

42. Ihidem.

43. Willem Einthoven, 'Rectoraatsrede Leiden, 17 september 1906' in: A. De Waan, Hel levenswerk van Willem Eimhoven 1860-1927. Uitgegeven ter gelegenheid van het honderdjarig bestaan der vereeniging Nederlandsch Tijdschrif voor Geneeskunde (Haarlem 1957) 231-235, aldaar 234. Zie ook het verslag van deze rede in de Nieuwe. Ronterdamsche Courant van 18 september 1906. Zie ook F. Ort, Ons Standpunt verdedigd door Felix Ortt (Haarlem 1927) 331

44. De afdeling natuurkunde van de KNAW benoemde een commissic bestaande uit drie medisch hoogleraren.: $A$ Heynsius uit Leiden, W. Koster uit Utrecht en B.J. Stokvis uit Amsterdam. Het advies van deze commissie werd op 24 februari uitgebracht. Zie: Mathijsen 'Oefenoperaties'. 79. Zie over het advies van de KNAW: 'Verslag van hel antwoord aan de Minister van Binnenlandsche Zaken te geven op vier vragen betrekkelijk de vivisectie (uitgebracht in vergadering 24 februari 1883)' in: Verslagen en mededeelingen der Koninklijke Academie van Wetenschappen. Afdeeling Natuurkunde, tweede reeks deel XVIII (Amsterdam 1883) 415-423. 
ties door leerlingen van de Rijks Veeartsenijschool. ${ }^{45}$ Deze voorschriften waren weliswaar geen wetgeving in formele zin maar het was toch een teken aan de wand: 'Engelse toestanden' dreigden.

Engeland kende sinds 1876 mede door de niet aflatende ijver van de anti-vivisectionisten de Cruelty to Animals Act waarin was bepaald dat iedere onderzoeker een vergunning diende aan te vragen wanneer hij dierproeven wilde verrichten. ${ }^{46}$ De consequentie van dit alles was, volgens de in 1898 overduidelijk pro-vivisectionistische redactie van het gerenommeerde Nederlandsch Tijdschrift voor Geneeskunde, dat:

'[...] de medisch hoogleraar met een officiële vergunning tot het verrichten van vivisecties

[wordt behandeld] als een pas uit de gevangenis ontslagen misdadiger [...] die moet worden gewantrouwd en gecontroleerd. ${ }^{37}$

Einthoven ondervond zelf in 1900 de werking van de Engelse wet tijdens een congres voor fysiologen. Blijkens zijn verslag in het Nederlandsch Tijdschrift was hij er niet bepaald over te spreken:

'Er was slechts een bezwaar dat echter als lood op de overigens zo aangename herinnering drukt; het was de moeilijkheid die den vreemdeling ondervindt. Wanneer hij een vivisectie wenschte te verrichten. De weerzinwekkende schijnheiligheid van het Engelsche volk [...] komt m.i. niet duidelijker aan het licht dan door de eensdeels ziekelijk, anderdeels echter gehuichelde teerhartigheid voor honden, konijnen en kikvorschen. ${ }^{48}$

Zowel de redactie van het Nederlandsch Tijdschrift als Einthoven reageerden met hun opmerkingen over de Engelse wet op het bericht dat de histoloog Jacob van Rees, als hoogleraar verbonden aan de Gemeentelijke Universiteit te Amsterdam, tot de anti-vivisectie-beweging was toegetreden. Dit werd in medische kringen als een zware slag ervaren. Waar het tot dan toe mogelijk was geweest om de anti-vivisectionistische propaganda af te doen als 'lekenpraat' was er nu iemand uit het eigen midden die zich achter de beweging schaarde. Een ernstiger vorm van verraad - Van Rees was nota bene een promovendus van de (inmiddels overleden) Harting - was nauwelijks denkbaar. ${ }^{49}$ Ontstemd verklaarde de redactie van het Nederlandsch Tijdschrift:

'Het doet ons oprecht leed dat de hoogleraar Van Rees zich schaart aan de zijde van hen, die van onze medische experimentatoren spreken als van 'verachtelijke, eerlooze sujetten'. Van Rees zelf schrijft hun 'een zekere verstomping van het gemoed toe' waarmede dus ook hij breekt met den vorm van een bezadigd betoog en niet schroomt, vele zijner collega's een beleediging toe te werpen. ${ }^{50}$

Naarmate de jaren verstreken en in Nederland geen regulerende wetgeving tot stand kwam, veranderde de tendens van de kritiek op de anti-vivisectionisten. Dat wil zeggen: het gebruik van geseksueerde argumenten verdween niet, maar de toon werd veel meer dan voorheen die van een winnaar tegenover een wat zielige verliezer. ${ }^{51}$ Nu de angit voor de gevolgen van het verzet tegen

45. Vourschriften betreffende het verrichten van heelkundige operatiën door leerlingen van 's Rijksveeartsenijschwol. Vustgesteld ingevolge machliging van de Minister van Binnenlandsche Zaken d.d. 17 oksober 1888. Zic ook: Rapport der Commissie inzake Vivisectie. 13

46. Zie over deze wet: 'Appendix A: The Cruelty to Animals Act 1867' in: R.D. Ryder, Victims of science. The use "!f animals in research (Londen 1975) 166-169. E. Westacott, A century of vivisection and antivivisection. A study of their effect upon science, medicine and human life during the past hundered y'ars (Essex 1956) 103-110.

47. 'Redactionecl commentaar: Prof. Van Rees en de vivisectie'. Weekhlud van het Nederlandsch Tijdschrift voor Geneeskunde, tevens orgaan van de Nederlandsche Maatschappij tol Be'vordering der Geneeskunst, no. 19. tweede deel (5 november 1898$) 753$.

48. Ook geciteerd in Androcles, maandschrifi aan de belangen van dieren ge'wijd 33 (1902) 20)

49. Van Rees promoveerde in 1878 bij Haring. De titel van zijn dissenatie luidde: Over de luchademing van Curicus Moenas (Uirecht 1878). Het proefschrift handelde aver de ademhaling van een krabbensoort. Zie hieruver: J. James, 'Jacobus van Rees (1854-1928), een vreemde eend in de universitaire bijt', 140 NTVG 2554-2559.

50. NTVG 19 (5 nov. 1898) 753-754, aldaar 754.

51. Een uitzondering hierop vormt het commentaar van fysioloug Cornelis Pekelharing in het artikel 'wetlelijke regeling der viviscctie' De Gids 27 (1909) 328-335, aldaar 328. 
vivisectie was verdwenen, namen de commentatoren bovendien meer ruimte om een verklaring te geven voor het ontstaan van de beweging. De Amsterdamse hoogleraar G. van Rijnberk, een collega van Van Rees, deed dit alles het fanatiekst en duidelijk niet zonder genoegen. Typerend zijn de vele aan de aard en oorsprong van de anti-vivisectie beweging gewijde opstellen van zijn hand in het Nederlandsch Tijdschrift voor Geneeskunde. ${ }^{52}$

In zijn artikelen karakteriseerde Van Rijnberk het verzet tegen dierproeven als 'een uitwas van [...] gevoel' en de anti-vivisectionistische idealen als 'gemoedsweekheden' en 'weeigheden'.s. Evenals Harting. Beerends en Einthoven dit voor hem hadden gedaan, associeerde hij dergelijke kenmerken met vrouwelijkheid. Van Rijnberk vergeleek de anti-vivisectionisten met moeders die zich er maar niet toe konden brengen om op de eerste schooldag haar door en door vertroetelde zoontje de confrontatie met de harde buitenwereld te laten aangaan. Hij stelde haar bovendien gelijk aan 'een vrouwtje' dat er door overgevoeligheid naar smacht om zich uitsluitend met steentjes in plaats van met planten of dieren te voeden. ${ }^{54}$

Van Rijnberk noemde de naam van zijn 'afvallige' collega Van Rees niet, maar vrijwel iedere beweging waarin Van Rees actief was of waaraan diens naam verbonden werd, werd door hem in zijn opstellen gehekeld. Dit lot trof de geheelonthouding, het spiritisme, het vegetarisme, de natuurgeneeswijze en het 'rein leven'. ${ }^{55}$ Volgens Van Rijnberk ging het hier bij uitstek om een verzameling stromingen en levenswijzen die naast het anti-vivisectionisme tot de 'gemoedsbeweging' gerekend dienden te worden. Zij waren volgens de hoogleraar ontstaan uit de angst van het gewone publiek dat niet meer in staat was om de ontwikkelingen in de wetenschap te begrijpen. Beroepsbestrijders als Felix Ortt, eveneens onwetend maar daarbij kwaadwillend, speelden op deze vrees in en maakten de beweging zo tot "een ware muizeval voor zwakke geesten en onevenwichtige gemoederen'. ${ }^{56}$

Zo werd Van Rees in Van Rijnberks artikelen dus toch, zij het via een omweg, bekritiseerd en gekarakteriseerd als overgevoelig, onmannelijk, zwak en week; als een tegenpool dus van de schrijver zelf. Dit idee van antipoden spreekt tot de verbeelding wanneer men bedenkt dat beide hoogleraren aan dezelfde universiteit (de Gemeentelijke Universiteit te Amsterdam) en zelfs onder één dak werkzaam waren. Beiden maakten gebruik van dezelfde lokaliteit en hun laboratoria waren tegenover elkaar gesitueerd. ${ }^{57}$ Het principieel vivisectie-vrije laboratorium ${ }^{58}$ van de antivivisectionist Van Rees was slechts door een binnenplaatsje gescheiden van de ruimte waar onder supervisie van Van Rijnberk proeven op dieren werden verricht.

De anti- en de pro-vivisectionist, de onmannelijke en de mannelijke hoogleraar, de gevoelsmens en de man van het verstand tezamen onder een dak. Dat dit op z'n minst een zekere spanning gaf, blijkt wel uit de wijze waarop beide hoogleraren met belangstelling werden gadegeslagen door de medicijnen-student Simon Vestdijk die bij beiden colleges volgde. Vestdijk,

52. Deze opstellen werden gebundeld in: G. Van Rijnberk. Voor en tegen proeven op levende dieren (Haarlem 1917) 53. Van Rijnberk, Voor en tegen, 30. Zie ook: Lize Deutmann. Mystiek en officieele wetenschap. Tevens critiek op Van Rijnherk's Hedendaagsch Mirakelgeloof in het Ned. Tijdschrif voor Geneeskunde ('s-Gravenhage 1915).

54. Van Rijnberk, Voor en tegen, 30.

55. Zie voor een overzicht van de bewegingen waarin Van Rees actief was; A. Arriëns, J. Henri Ledehoer en P. V.d Meulen. Prof. Dr. J. Van Rees dankbaar herdacht (Assen 1929). Van Rees baarde als Amsterdams hoogleraar ook opzien omdat hij op straat geheelonthouderskrantjes verkocht op de Brink in Hilversum. Zie hierover: Beslevaer Prof. Dr. J Van Rees herdacht. Uitgave ten bate van hel Van Rees Comité lot stichting van de Van Rees-aula en áe geheelonthouding. Z.j./Z.p. Zie ook Ger Harmsen. Blauwe en rode jeugd. Een bijdrage tot de geschiedenis van de jongelieden geheelonthoudersbond van oprichting tot opheffing (1912-1950) eerste druk 1961 (Nijmegen 1975)

56. Van Rijnberk, Voor en tegen, 22.

57. Aan het Daniël Jonas Meijer plein.

58. Zie over het vivisectie-vrije laboratorium van Rees: Arriëns, Van Rees. Heyting, De wereld, 59 
die in 1917 ging studeren, beschouwde de beide hoogleraren als tegenpolen. ${ }^{59} \mathrm{Hij}$ dacht, evenals Van Rijnberk en de eerdere critici van de anti-vivisectionisten, in termen van onmannelijkmannelijk, gevoel-verstand. Dit blijkt uit de wijze waarop hij de herinnering aan Van Rees en Van Rijnberk verwerkte in De vrije vogel en zijn kooien. ${ }^{60}$ In deze zesde roman uit de doorgaans als autobiografisch aangemerkte Anton Wachter-cyclus worden de hoogleraren Reetra (Van Rees) en Reinders (Van Rijnberk) ten tonele gevoerd. ${ }^{61} \mathrm{Zij}$ maken beiden indruk op de voor zijn kandidaatsexamen studerende Anton Wachter, zij het op geheel verschillende wijze.

Reinders, de 'zwaargebouwde baardman' met 'zachte rekelachtige ogen' die tijdens zijn college 'theorieën verwekt als onechte kinderen' makt indruk op hem omdat hij een 'onvervalste libertijn', een 'cynische hond', een 'aartsverachter der zeden' en daarbij een 'vrouwenman' is. Behalve dat hij er om bekend staat dat hij zo suggestief college over voortplanting geeft dat de dames op de voorste rij van de zaal ervan gaan blozen, gaat het verhaal dat de hoogleraar een relatie heeft met zijn vroegere huishoudster. Nadat mevrouw Reinders haar om die reden had ontslagen, had hij de vrouw prompt een betrekking als bibliothecaresse aangeboden. De assistent van professor Reetra ontdekt dat Reinders in zijn laboratorium zijn bibliothecaresse in de borsten knijpt, in plaats van experimenten op een vogeltje te verrichten.

Professor Reetra fascineert Anton Wachter vanwege zijn 'expressieve profetenkop', zijn 'baardig hoofd met fraaie ramsogen' waardoor hij aan een 'Indische Yogi' doet denken. Wetenschappelijk stelt Reetra niets voor, weet Anton. Vroeger, voordat het idealisme zijn denkkracht had aangetast, moest hij een zeer goede wetenschapper zijn geweest. Nu was hij een 'groot man in de drankbestrijding en 'aanverwante branches', 'pacifisme, socialisme tot reinleven toe'. Waar Reinders een echte verleider is, verdenkt Anton Wachter Reetra ervan dat hij werkelijk slechts eerzame bedoelingen heeft wanneer hij zich het lot van ongehuwde moeders aantrekt. Zo'n idealist zal het, zo besluit Anton, altijd verliezen van een man als Reinders. Dat gebeurt ook voor Antons ogen. Een paar minuten voordat hij examen moet afleggen wordt de zachtmoedige Reetra in zijn nabijheid door Reinders uit het examenlokaal 'verjaagd'. Dat Anton getuige is van de vernedering van de oude man beloont Reinders met een 'schelmengrijns'. Hierna is de jonge student ervan overtuigd dat er een verband bestaat tussen reputatie en prestatie: 'de lichten der wetenschap zijn rabauwen, sluwe verleiders, de idealist kan niets'. ${ }^{62}$

Het zal zeker niet de bedoeling van Harting, Van Rijnberk en de andere contempuraine critici van de vivisectie-bestrijding zijn geweest om hun publiek tot dezelfde gevolgtrekkingen te laten komen als de hoofdpersoon uit Vestdijks roman. Zij wilden met hun onderscheid tussen mannelijke wetenschappers en onmannelijke anti-vivisectionisten juist aannemelijk maken dat men op het verantwoordelijkheidsgevoel en de zedelijke opvattingen van eerstgenoemden blindelings kon vertrouwen. ${ }^{63} \mathrm{Na} 1909$ werd daarbij steeds onverbloemder benadrukt dat de wetenschappers aan d: winnende hand war:n en dat de anti-vivisectionisten gedoemd waren om wetenschappelijk,

59. Zie over Vestdijks studentenjaren en zijn relatic met Van Rijnberk en Van Rees: Hans Visser, Simon Vestdijk. Een
schrijversteven (Utrecht 1987). H. Visser, Brieven rond de Vestdijk-biografie (Amsterdam 1987). Zie i.v.m. Van Rees
en Vestdijk ook James 'Vreemde eend' en Rob Schouten, de student Vestdijk'. AMC magazine. Special: 325 jaar
Academische Geneeskunde in Amsterdan 9 (1994) 106-111. Voor een beschrijving van de proeven die in hel
laboratorium van Van Rijnberk werden verricht door de studenten hel verslag 'Juffrouw Keizer' in L.F. C. Mees, Eén
voor éen. Korte geschiedenissen uit
een lang leven (Driebergen/Rijsenburg 1988) 23-25. Zie ook: G. van Rijnberk, Leidraad voor het physiologisch
practicum. Bloed, hart, bloedsomloop, ademhaling, spijsvertering, centraal zenuwstelsel, zintuigen (tweede deel
Haarlem 1917). 60. Simon Vestdijk. De vrije vogel en zijn kooien. De geschiedenis van een domicilie. Anton Wachter romans 6 (Rotterdam 1982). De roman werd geschreven in 1857 en de eerste druk verscheen in 1958.

61. Visser, Schrijversleven, James 'Vreemde eend'. Zie ook: Marja Pruis, Wie is wie in Anton Wachter. Een kennismaking met de personages uit de romancyclus van Simon Vestdijk (Amsterdam 1994).

62. De in de laatste twee alinea's aangehaalde citaten zijn te vinden in: Vestdijk, Vrije vogel, $50 \mathrm{ev}$.

63. Vergl. Remieg Aerts, 'Bevoegde autoriteiten. Burgerlijke intellectuelen in de negentiende eeuw', De negentiende' eeuw: documentatieblad Werkgroep $19 e$ eeuw 22 (1998) 72-95, aldaar $86 \mathrm{ev}$. 
cultureel en politiek te verliezen. Van dit denken in termen van slagen en falen, mannelijkheid en vrouwelijkheid, is de hedendaagse historiografie van het anti-vivisectionisme nooit geheel losgekomen. Vooral waar het gaat om beschouwingen over de politieke betekenis van de antivivisectie-beweging klinkt de echo van de contemporaine kritiek zo luid dat het soms zelfs om een reproduktie ervan lijkt te gaan.

\section{Kanttekeningen bij het winnaars en verliezersperspectief}

Het winnaars- en verliezersperspectief heeft tot gevolg dat de politieke stijl van de anti-vivisectiebeweging wordt beschreven als een statische entiteit. Deze zou rond de eeuwwisseling zijn ontstaan en vervolgens zijn verdwenen doordat het humanitair-idealisme in stukken brak door de aanraking van de harde realiteit van de Eerste Wereldoorlog (Romein) ofwel, zoals de Duitse historicus Wolfgang Krabbe meent, doordat het geruisloos en probleemloos overging in het nationaal-socialisme. Dat de anti-vivisectie-beweging ook tijdens het Interbellum, in de jaren veertig en vijftig, en zelfs tot op heden is blijven bestaan, wordt daarbij buiten beschouwing gelaten. ${ }^{64}$

Hoe moeilijk het is om het perspectief van winnaars en verliezers los te laten, blijkt uit de beschouwingen die De Rooy aan het onderwerp wijdde. Ook deze hedendaagse historicus, die toch op overtuigende wijze aantoont dat Romeins visie op de kleine geloven in feite niet verschilt van de opvattingen van de socialisten rond de eeuwwisseling, staat, althans met één been, in de whigtraditie. Hij reduceert het belang van de petites religions als sociale beweging tot hun betekenis voor datzelfde socialisme. De Rooy is van mening dat de kleine geloven deel uitmaakten van een bredere humanitaire beweging (door Romein samengevat onder het begrip kleine geloven) waaruit de SDAP haar aanhang rekruteerde en die aantrekkingskracht uitoefende op een deel van de heterogene middenklasse. De leden van deze sociale laag waren weliswaar trots op de geweldige vooruitgang in macht, moraal en zeden die zich aan het eind van de negentiende eeuw manifesteerde, maar tegelijkertijd angstig voor 'het kwade' dat met deze verworvenheden zou zijn gegroeid. In deze omstandigheden zouden zij zich de vraag hebben gesteld hoe het kwade kon worden bestreden en het goede behouden. Daar politici,

'niet langer [konden] rekenen op een deferential society die met aandacht en ontzag haar verrichtingen volgde en het christelijk geloof haar vanzelfsprekendheid had verloren, zochten velen de oplossing voor dit vraagstuk in de groei van een nieuw gemeenschapsgevoel.'

Over de wijze waarop deze saamhorigheid zou moeten worden bereikt verschilde men evenwel van mening. Hij onderscheidt een politieke en een ethische tak.

'De politieke tak (...) was vooral geneigd als een soort makelaar te opereren. Zij bracht de verschillende conflicterende belangen bij elkaar, nam voortdurend het initiatief tot kleine en grote, maar altijd zeer practische voorstellen tot vermindering van de maatschappelijke problemen, waarbij de staat meestal de rol kreeg toebedeeld om de bereikte compromissen te bewaken en te betalen. ${ }^{\text {'s }}$

De ethische tak was volgens De Rooy veelvormiger. Deze zou hebben bestaan uit de traditionele 'forces of organized virtue' en de kleine geloven. De eerste soort hewegingen, waartoe door hem bijvoorbeeld de dierenbescherming wordt gerekend, was uit op een collectieve verbetering van het moreel niveau. De petites religions zouden daarentegen juist streven naar de verbetering van de samenleving door middel van de hervorming van het individu waardoor zij de sociale kwestie in

64. W.R. Krabbe, Gesellschafisveränderung durch Lebensreform. Struklumerkmale einer sozialreformerischen Bewegung in Deutschland der Industrialisienungsperiode (Götingen 1974). Zie over deze kwestic in hel bijzonder: Krabbe, 'Die Weltanschauung der Deutsche Lebensreformbewegung ist der Nationalsozialismus. Zur Gleichschaltung einiger Alternativströmung im Dritten Reich: Archiv für Kulturgeschichte 7. Band 413-461 (Ketlen/Wenen 1989). Vergl: Janos Frecot. 'Die Lebensreformbewegung' in: Klaus Vondung ed., Das Wilhelminische Bildungsbürgerium Zur So-ialgeschichte seiner ldeeen (Göttingen 1976) 138-152.

65. Dit citat en het voorgaande zijn te vinden in Piet de Rooy. Op zoek naar volmaaktheid. H.M. Bemelot Moens en het mysterie wan afkomst en toekomst (Houten 1991) 191. 
feite tot grote verontwaardiging van de socialisten, 'privatiseerden'. Wat hij niet lijkt te zien is dat juist in dit onderscheid tussen 'politiek' en 'ethisch' de toch wel karikaturale categorieën 'praktische politici' enerzijds en 'onpraktische idealisten' anderzijds besloten liggen.

Kortom, de contemporaine kritiek op de kleine geloven wordt in zekere zin gereproduceerd in de hedendaagse historiografie. Daarbij komt nog dat De Rooy uitgaat van een vrij strikte scheiding van verschillende vormen van politiek, een scheiding waarvan De Haan en Te Velde juist afstand nemen. In ieder geval is duidelijk dat een meer open benadering van de politieke stijl die door bewegingen gericht op morele hervorming werd gehanteerd, noodzakelijk is wanneer wij bijvoorbeeld willen begrijpen waarom het beeld van de 'onpraktische', idealistische wereldhervormer juist een essentieel onderdeel van de expressieve politiek vormde.

Hier komt Felix Ortt weer ten tonele. Hij droeg dergelijke beledigende predikaten als geuzennamen. De 'spot der menigte' die de humanitair-idealisten ten deel viel, kon hem op sommige momenten zelfs niet groot genoeg zijn. Hij benadrukte de exclusiviteit en zeker ook de heldhaftig opofferingsgezinde, Don Quichote-achtige zijde van zijn anti-vivisectionistische en religieus-anarchistische levenshouding mee.

Een andere kanttekening bij het denken in termen van falen en slagen, van praktisch en onpraktisch is dat dit perspectief uitsluitend uitgaat van de verschillen tussen de onderscheiden soorten politiek. Aan de overeenkomsten wordt weinig aandacht besteed, terwijl deze er wel degelijk waren. Zowel de medische wetenschappers, als de parlementaire politici en de antivivisectionisten maakten het vivisectie-vraagstuk zichtbaar door het te verbinden met of te verbeelden aan de hand van begrippen als liefde voor de mensheid, opoffering, zonde, deugd, kwaad en het hogere. $\mathrm{Zij}$ deelden een zelfde soort referentiekader en voor een deel dezelfde preoccupaties en dezelfde opvattingen over mannelijkheid en vrouwelijkheid. En mogelijk waren er nog andere overeenkomsten. De betekenis van individuele hervorming ook voor de onderscheiden confessionele, op compromissen mikkende politici en de op collectieve verbetering gerichte ethici zou wel eens belangrijker kunnen zijn geweest dan de schematische indeling van De Rooy suggereert. Wellicht ook hadden de kleine geloven, en de anti-vivisectionisten in het bijzonder, meer affiniteit met de strevingen die vooral werden toegeschreven aan de meer traditionele forces of organized virtue. Aandacht voor deze punten van mogelijke overeenstemming zou kunnen bijdragen aan een beter begrip van bovengenoemde bewegingen en de tijd waarin zij floreerden. ${ }^{60}$

Het is evenwel niet de bedoeling te ontkennen dat er verschillen bestonden tussen de hierboven genoemde bewegingen en politieke stijlen, zoals Davids doet wanneer hij de dierenbescherming en de anti-vivisectie-beweging met elkaar vergelijkt. Davids is van mening dat de NBBV evenals bijvoorbeeld de Bond ter Bestrijding van Vogelmoord, de Nederlandsche Vegetariërs Bond en de Anti-trekhonden Bond louter een van de vele vertakkingen of specialisaties van de dierenbescherming was. Met die stelling sluit hij aan bij een historiografie die dierenbescherming en vivisectiebestrijding aan elkaar gelijk stelt omdat beide bewegingen hun oorsprong zouden vinden in het toenemen van de gevoeligheid ten opzichte van dierenleed. Dat die gevoeligheid in de zeventiende en achttiende eeuw steeg, staat hier overigens niet ter discussie. ${ }^{67}$ Ontdekkingsreizen, astronomische, natuurkundige en geologische ontdekkingen brachten het heersende antropocentrisme in die

66. Vergl: B. Kruithof en P. de Rooy, 'Liefde en plichtbesef. De kinderbescherming in Nederland rond 1900'. Sociologisch Tijdschrift 13-4 (1987) 637-668.

67. Dit gedecite over de ontwikkeling van mens-dier relaties is gebaseerde op: Thomas, Natural world, James Turner, Reckoning with the Beast. Animals, pain and humanity in the Victorian Mind (Baltimore 1990), Harriet Ritvo. The Animal Estate. The English and other crealures in the Victorian age (Londen 1987), John Passmore. 'The treatment of Animals', Journal of the History of Ideas 36 (1975) 195-218. Dix Harwood, Love for Animals and How it Developed in Greal Briltain (New York 1928). Brian Harrison. Peacable Kingdom: Stahility and Change in Modem Brilain (Oxford 1982). Thomas L. Haskell, 'Capitalism and the Origins of the Humanitarian Sensibility'. American Historical Review 90 (1985) 339-361, 547-566. Davids, Dieren, centreer zijn verhaal over de relatie tussen mens en dier in Nederland eveneens rond de begrippen afstand en nabijheid. Zie ook: Maarten Pieterson ed.. Hel technisch labyrint. Een maatschappijgeschiedenis van drie industriële revoluties (Amsterdam 1981). 
periode een serieuze klap toe. De afstand tussen mens en dier werd daardoor kleiner dan tevoren. Gedurende de negentiende eeuw leek de kloof tussen mens en dier aanvankelijk weer toe te nemen, zij het op een andere manier dan voorheen. Ditmaal ging het niet uitsluitend om een in een wereldbeschouwing beleefde afstand, maar letterlijk om een minder duidelijke nabijheid van mens en dier. In de historiografie wordt in dit verband gewezen op de situatie in Engeland waar de Industriële Revolutie met zich meebracht dat mensen die van het platteland kwamen en dus in de nabijheid van dieren leefden, in steden gingen werken en wonen.

Het dier verdween evenwel niet geheel uit het leven van de negentiende-eeuwse stedelingen. Het kwam op een andere manier terug, bijvoorbeeld als onderdeel van de aloude volkssporten waarmee de arbeiders in de snelgroeiende fabriekssteden zich vermakten. Voorbeelden daarvan zijn hanengevechten, katknuppelen, palingtrekken en het zogenaamde bullbaiting, evenementen waarbij doorgaans gegokt en gedronken werd. Vooral dit laatste aspect van de 'bloedsporten' was een doorn in het oog van de fabriekseigenaren die hun arbeiders met moeite en vaak tevergeefs de voor de fabriek gewenste arbeidsdiscipline probeerden bij te brengen. Het waren deze belanghebbenden, die een wetsvoorstel tegen het bullbaiting indienden. $\mathrm{Zij}$ werden gesteund door methodisten en andere religieuze groepen die tegen de bloedsporten ageerden omdat zij vreesden dat het gokken en drinken de geloofsbeleving van de arbeiders niet ten goede kwam. De tegenstanders van bullbaiting stuitten evenwel op fel protest van een groep standgenoten die van mening waren dat fabrieksarbeiders recht hadden op ontspanning. Een goed oud Engels gebruik diende naar het oordeel van deze groep behouden te blijven.

De discussies over het bullbaiting, en opmerkelijk genoeg voural het standpunt van de voorstanders, vormen een cruciaal onderdeel van de door historici gegeven verklaring voor de negentiende-eeuwse gevoeligheid ten opzichte van dieren. De verdedigers van bullbaiting zouden bevreesd zijn geweest voor het verdwijnen van de oude manier van leven, een vrees die door velen werd gedeeld. De strijd voor het behoud van de volkssporten was in feite een uiting van het verlangen naar het herstel van de relatie met de natuur, van de bijzondere verbintenis met het natuurlijke leven die de mens voor de komst van de fabrieken zou hebben gekend. De voorstanders van de volkssporten deelden de gevoelens van romantische dichters en schilders die dit verlangen in hun werk tot uitdrukking brachten. Zij koesterden tevens dezelfde gevoelens als de adel en de burgerij die, al even romantisch, hun huisdieren tot voorwerp van affectie maakten. Dit alles, gecombineerd met het steeds duidelijker zichtbaar worden van de sociale gevolgen van de industrialisering en urbanisatie, zou bij grote delen van de elite bovendien specifieke sentimentele en humane gevoelens hebben losgemaakt. Uiteindelijk viel deze toenemende gevoeligheid voor alles wat leed, via kunst en literatuur, de huisdierencultus, de discussies over de volkssporten en pogingen om arbeiders te disciplineren, ook het dier ten deel. Zo wordt doorgaans verklaard dat in 1824, ironisch genoeg in het Londense Old Slaughter's Cofjeehouse, de Society for the Prevention of Cruelty to Animals werd opgericht. Later zou een vertakking van anti-vivisectionistische organisaties hebben plaatsgevonden. Beide bewegingen zijn volgens de hierboven geresumeerde geschiedschrijving een en dezelfde. Er wordt daarbij geen velschil naar politieke stijl of strijdwijze gemaakt.

Davids is, zoals gezegd, eenzelfde mening toegedaan en stelt het anti-vivisectionisme gelijk aan de door De Rooy onderscheiden forces of organized virtue. Juist door dit ontkennen van enig onderscheid tussen de strijd tegen vivisectie en de dierenbescherming verdwijnt een zeer kenmerkend deel van het anti-vivisectionisme geheel uit het zicht, het deel namelijk waarmee deze stroming van de dierenbescherming te onderscheiden is: de religiositeit. Die religiositeit krijgt wel aandacht in French' studie van de expressive politics van de tegenstanders van dierproeven. Maar in het door hem gemaakte (en het hierboven reeds bekritiseerde) onderscheid tussen deze vorm van politiek en de politieke stijl van wetenschappers, gaat hij uit van een strijd tussen deze antimoderne religiositeit en de moderne wetenschap. Ook deze dichotomie zal in dit proefschrift niet worden gehanteerd. French' associatie van het door vrouwen gedımineerde verzet tegen vivisectie 
met religiositeit en met anti-moderniteit is te eenvoudig. ${ }^{6 x}$ Daarmee wordt over het hoofd gezien dat religie in een zeer nauwe relatie kon staan met de wijze waarop de nieuwe vrouw rond de eeuwwisseling in de openbaarheid trad om zich uit te spreken over politiek-maatschappelijke vraagstukken en met de manier waarop zij zich verhield tot moderniteit. ${ }^{69}$

$\mathrm{Er}$ is nog een andere reden om de idee van een strijd tussen een geheel op zichzelf staande, niet-religieuze wetenschap en een religieuze tegenbeweging te verwerpen; het is immers niet vol te houden dat de afstand tussen beide zo groot was. Wetenschappers legitimeerden zichzelf niet zelden met verwijzingen naar 'het hogere' terwijl diep religieuze anti-vivisectionisten hun geloof graag wetenschappelijk, ja zelfs positivistisch trachtten te onderbouwen. Romein wees er terecht op dat de voorlieden van de kleine geloven hun 'geloven' in 'weten' wilden omzetten. ${ }^{70}$ Ook Stuart Hughes constateerde een dergelijke complexiteit in de door hem rond 1900 gesitueerde revolt against positivism." $\mathrm{Zo}$ blijkt ook hier dat het winnaars- en verliezers-perspectief niet voldoende mogelijkheden biedt om aan een dergelijke veelvormigheid recht te doen en tot een beter begrip te komen van de politieke stijl van het Nederlandse verzet tegen vivisectie.

68. Vergl. J. William Frost, 'Marginal religion. marginal women', Reviews in American History 25 (1997) 213-219. Zie ook de recensie van Fransica de Haan over het proefschrift van Marijke Mossink, De levenshrengsters. Over vrouwen, vrede, feminisme en politiek in Nederland (Amsterdam 1995). Fransica de Haan, 'Kiesrecht het einde van het reminisme: Tijdschrift voor vrouwenstudies 18 (1997) 74-76, aldaar 76.

69. Lange tijd is deze lacune niet opgevuld. In vrouwenhistorische studies werd wel een belangrijke tol toegekend aan de Nieuwe Vrouw maar nauwelijks aandacht besteed aan haar religiositeit. Wellicht speelde daarbij ook de angst mee dat zij op die manier als anti-modern naar voren zou komen. Dit alles is binnen vrouwengeschiedenis aan het veranderen.

70. Vergl.: Derk Jansen, Op zoek naar nieuwe zekerheid. Negentiende-eeuwse protestanten en het spiritisme (Groningen 1994).

71. H. Stuar Hughes, Consciousness and the sociery. The reorientation of European social though 1890-1930 (New York 1961). 


\section{De vrouw als gids \\ 1898: De Nationale Tentoonstelling van Vrouwenarbeid}

Het is 1898. Ter gelegenheid van de Nationale Tentoonstelling van Vrouwenarbeid spreekt de feministe en schrijfster Marie Jungius een rede uit getiteld: 'de vivisectie is een kwaad en moet uit de samenleving verdwijnen'.' Suze Groshans, vriendin van de spreekster en presidente van de NBBV, zal het zich in 1928 nog goed herinneren: 'Hoe geestdrittig, hoe aandoenlijk jong, maar onwankelbaar in haar overtuiging"2 had Jungius daar gestaan toen zij verklaarde over een 'hachelijke zaak' te zullen spreken en voorspelde dat zij haar publiek 'eenige pijnlijke oogenblikken' zou bezorgen. ${ }^{3}$ Aan het einde van haar voordracht had de spreekster alle aanwezigen dringend opgeroepen om samen met haar tegen medisch-wetenschappelijke proeven op levende dieren te strijden. Tevergeefs. Hoewel de vele toehoorders de lezing met interesse hadden gevolgd $^{4}$, reageerde niemand. Het debat waar Jungius en dag-vourzitter Felix Ortt op hoopten, bleef uit. ${ }^{5}$

$\mathrm{Na}$ de pauze werd deze teleurstelling ruimschoots goedgemaakt. Alvorens het programma werd hervat, betrad iemand uit het publiek het spreekgestoelte. De man, die Jungius complimenteerde met haar 'wonderschone rede', bleek niemand minder dan Jacobus van Rees, de bekende Amsterdamse hoogleraar histologie. ${ }^{6} \mathrm{Hij}$ schaarde zich aan de zijde van de anti-vivisectionisten en gaf te kennen evenals de spreekster van mening te zijn dat niet wetenschappers, maar leken uiteindelijk het kwaad van de vivisectie zouden bestrijden. Het publiek was onder de indruk. Vooral de aanwezige leden van de NBBV, waarvan Marie Jungius bestuurslid ${ }^{7}$ was, waren enthousiast omdat het één van hen gelukt was een gerenommeerd medicus openlijk zijn steun te laten betuigen. Zij zouden de herinnering aan deze triomf nog tıt Jang na de lezing en zelfs tot jaren na het overlijden van Jungius blijven koesteren en beschrijven als een cruciaal moment in de geschiedenis van hun beweging. Zo duidde Felix Ortt Jungius' rede trots aan als 'ons eerste openlijk optreden' ${ }^{8} \mathrm{Mr}$. S. Rink, die in 1911 voor het Congres voor dierenbescherming en tegen vivisectie te Kopenhagen een overzicht gaf van de geschiedenis van de Nederlandse vivisectiebestrijding, sprak van een 'aangrijpende' lezing die 'het uitgangspunt van de inleiding van dit onderwerp bij het groote publiek' had gevormd. 'Suze Groshans zou de gebeurtenis in de loop der jaren zelfs als een soort 'opwekking' beschrijven. In haar versie zou Van Rees meteen na de

1. Marie Jungius, De vivisectie is een kwaad en moel daarom wit de samenleving vercivilincn ('s-Gravenhage 1898)

2. S.(uze) G.(roshans). 'Lectuur', Uitkomst, driemaandelijksch tijdschrift. Orgaan van den Ned. Bond tol Bestrijding der Vivisectie en van den Ned. Vereeniging voor Natuurgeneeswijze 1 (1928) 1.

3. De laatste twee citaten zijn afkomstig uit Jungius, De vivisectie, 1.

4. Zo wordt onder meer vermeld in : Rapporten van aangesloten Vereenigingen uitgebracht in de zittingen van den Nationale Vrouwenraad van 10 en 11 april $10.00 \mathrm{u}$ in Eensgezindheid' in: Tweede Algemeene Vergadering van den Nationale Vrouwenraad van Nederland te Amsterdam (z.p. Amsterdam) 46-53, aldaar 47.

5. Dat zij daar op hoopten blijkt uit: Felix Ort, Verslag van de eerste jaarvergadering NBBV (z.p. 1897 ) 9

6. Weefselleer. Van Rees prefereerde zelf de term histologie of histiologie. Zie over Van Rees: James 'Vreernde eend' Arriēns. Van Rees en Van Rees Comité, Bestevaer prof. Dr. J. Van Rees herdacht. Uitgave ten hate van hel Van ReesComité tot stichting van de Van Rees-Aula aan de school voor Internationale Broederschap (humanitaire school) Laren N.H. (2.j. 1929). Zie ook: H. Henkels ed.. Ono en Adya van Rees. leven en werk tot 1934) (Utrecht/Den Haag 1975).

7. Het bestuur van de NBBV was in 1898 als volgt samengesteld: Jhr. Ir. F.L. Ort, voorzitter. Mej. M. Jungius. Mevr. M.J. Roorda van Eysinga-Romijn, penningmeester. S.B. Criellaer. Mej. S. Groshans. Mevr. C. Van der HuchlKerkhoven.

8. F. Ort. Verslag betreffende de verrichtingen van den Ned. Bond tot Bestrijding der Vivisectie over het 2 de vereenigingsjaar 1898-1899\%, Verslag van de tweede Jaarvergadering van den Nederlandschen Bond lol Besirijding der
Vivisectie (Z.p. 1898) 3-7. aldaar 3 . 9. S. Rink. 'Het Internationaal Congres te Kopenhagen. De bestrijding der Vivisectie in Nederland', Orgaan van den
Ned. Bond tot bestrijding der Vivisectie 8 (december 1911) 12-17, aldaar 14 . 
opruep van Jungius letterlijk naast de spreekster en daarmee achter de strijd tegen vivisectie zijn gaan staan. ${ }^{10}$

Dit voor de geschiedenis van het Nederlandse anti-vivisectionisme zo belangrijke moment valt dus samen met een bepalende gebeurtenis uit de historie van het feminisme (de Nationale Tentoonstelling van Vrouwenarbeid) als ook met een belangrijke gebeurtenis uit het openbare leven van de feministe en anti-vivisectioniste Marie Jungius. Deze verbinding is niet vanzelfsprekend. Immers, wat heeft een lezing over vivisectie te maken met vrouwenarbeid en feminisme? Of, om de vraag ruimer te formuleren, wat is het verband tussen vrouwen, vrouwelijkheid en het verzet tegen vivisectie in Nederland? Deze vraag, die in dit hoofdstuk centraal staat, wordt door Jungius zelf niet beantwoord. Dat is vreemd wanneer men bedenkt dat zij, de spil van de organisatie van de Nationale Tentoonstelling van Vrouwenarbeid ${ }^{11}$, volgens critici te veel haar stempel op het evenement drukte door ruimte te geven aan allerlei humanitair-idealistische stromingen ${ }^{12}$ die niets met de positie van de vrouw in de samenleving te maken hadden. ${ }^{13}$ Ongetwijfeld was Jungius van deze bezwaren op de hoogte. $\mathrm{Zij}$ deed evenwel geen moeite om tijdens haar lezing te verduidelijken waarom het vraagstuk volgens haar wel op de tentoonstelling thuishoorde. Geen enkele keer refereerde zij aan sekse, zij nam het woord 'vrouw' niet in de mond en sprak in plaats daarvan over 'menschen'. ${ }^{14}$

Niet alleen Jungius, ook de historiografie van het Nederlandse verzet tegen dierproeven verduidelijkt niets over de relatie tussen vrouwen en anti-vivisectionisme. Historici hebben tot op heden geen aandacht geschonken aan de relatie tussen de strijd tegen vivisectie en het feminisme. Ook de geschiedschrijving van de eerste feministische golf vult deze leemte niet op: slechts sporadisch is aandacht besteed aan vrouwen die zowel een rol speelden in het feminisme als in het anti-vivisectionisme of humanitair-idealisme. De reden daarvoor is niet dat de combinatie van beide idealen weinig voor de hand ligt. De lacune is daarentegen, zoals uit een verhelderende studie van Myriam Everard kan worden opgemaakt, ontstaan uit een gebrek aan belangstelling voor en een veroordeling van vrouwen die, zoals Jungius en Groshans, zowel door contemporaine critici als door latere socialistisch georiënteerde vrouwenhistorici tot het zogenaamde burgerlijk feminisme zijn gerekend. ${ }^{15}$ Zo zijn humanitair-idealistische feministen en het anti-vivisectionisme ook op het niveau van de geschiedschrijving met elkaar verbonden. Beide zijn als een burgerlijk verschijnsel veroordeeld en terzijde geschoven. ${ }^{16}$

Dat het hier om een specifiek kenmerk van de Nederlandse geschiedschrijving gaat, bleek in het vorige hoofdstuk waarin werd vermeld dat de relatie tussen vrouwen en het verzet tegen vivisectie in de historiografie van het Engelse anti-vivisectionisme wel de nodige aandacht heeft gekregen. Richard French heeft hiertoe de aanzet gegeven door zich af te vragen waarom het antivivisectionisme voor vrouwen aantrekkelijk was en of de aanwezigheid van vrouwen van invloed

10. Groshans, 'lectuur', 34.

11. Jungius was vice-presidente van de Commissie van Voorbereiding van de Nationale Tentoonstelling van Vrouwenarbeid.

12. Gesproken wordt over anti-vivisectionisme, vegetarisme en theosolic.

13. Zie hicrover: Ulla Jansz, Denken over sekse in de eerste feministische golf (Amsterdam 1990) 84

14. Jungius, De vivisectie, passim

15. Myriam Everard, 'Het burgerlijk feminisme van de eerste golf: Annette Versluys Poelman en haar kring' in: Jeske Reys ed. De eerste feministische golf. Zesde jaarhoek voor vrouwengeschiedenis (Amsterdam 1985) 106-137. In hel boek van Maria Grever en Berteke Waaldijk. Feministische openhaarheid. De Nationale Tentoonstelling van Vrouwenarbeid in 1898 (Amsterdam 1998) wordt wel uitgebreid aandacht besteed aan Marie Jungius en haar ideeën.

16. Een van de weinige historici die aandacht heeft besteed aan Suze Groshans is Carin Schnitger. C. Schnitger 'Idelheid hoeft geen ondeugd te zijn. De Vereeniging voor verbetering van Vrouwenkleding' in: Reys, Feministische golf, 163-185. Zie over Groshans ook: A.G.M. Liernur. 'Suze Groshans. In dankbare berinnering' in: Leven en laten leven 1894-1944. Uitgave van de Nederlandsche Vegetariërs Bond ter gelegenheid van hel vijftig-jarig bestaan. Opgedragen aan Suze Groshans en Ir. Felix Ortl. (z.p. 1944). De eerder genoemde Myriam Everard verrichue naarstig speurwerk naar Jungius. Zie over Jungius ook: A. Kluveld, 'Anti-vivisectionisme'. 
was op de door de anti-vivisectionisten gevoerde politiek. Die vragen zijn ook voor deze dissertatie over de politieke stijl van de anti-vivisectionisten van belang.

\section{Een strijd voor vrouwen}

In Antivivisection and Medical Science in Victorian Society verklaart French de aantrekkingskracht die het Victoriaanse anti-vivisectionisme op vrouwen zou hebben gehad hoofdzakelijk door te verwijzen naar wat hij aanduidt als Cobbe's 'pluralistic conception of the potential roles of women'. ${ }^{7}$ Cobbe's ideeën over de maatschappelijke rol van vrouwen zouden voor vele Victorians aantrekkelijk zijn geweest, omdat zij niet ingingen tegen de Victoriaanse stereotypering ${ }^{18}$ van $^{-}$ de vrouw als moreel superieur aan, minder intelligent en emotioneler dan de man. De oprichtster van de Victoria Street Society legitimeerde haar anti-vivisectionisme en het feit dat zij als vrouw aan een openbaar debat deelnam, met behulp van algemeen aanvaarde opvattingen over vrouwen en vrouwelijkheid. Op deze wijze wist zij zowel feministen als anti-feministen in dezelfde beweging onder te brengen.

De belangstelling van vrouwen voor de strijd tegen vivisectie wordt door French dus teruggebracht tot de capaciteiten van één persoon, een leidersfiguur. Hij heeft daarin gedeeltelijk gelijk. Het kan althans niet ontkend worden dat Cobbe in meer dan één opzicht haar stempel op de Engelse anti-vivisectie-beweging heeft gedrukt. Het gaat evenwel te ver wanneer de suggestie wordt gewekt dat Cobbe's opvattingen uniek of nieuw waren. Dat zij dat niet waren, is de stelling van literatuurwetenschapster Hamilton. Zij geeft aan dat Cobbe's denkbeelden deel uitmaakten van het zogenaamde woman's mission feminism. Het zou gaan om een feministische stroming die aansloot bij de laat-Victoriaanse opvattingen over vrouwen en vrouwelijkheid, maar op één punt van deze heersende gender-ideologie afweek. De woman's mission feminists meenden, evenals Cobbe, dat de typisch vrouwelijke deugden en kwaliteiten niet uitsluitend waardevol waren in de 'natuurlijke omgeving' van de vrouw, het huis, de familie, de privésfeer. ${ }^{19}$ Vrouwen konden juist door hun kwaliteiten een belangrijk aandeel leveren aan openbare debatten en het openbare leven. Dit zou, zo meenden de woman's mission feminists, zowel de maatschappelijke positie van de vrouw, als het morele peil van de samenleving ten goede komen.

Onder meer verwijzend naar de studie van F.K. Prochaska ${ }^{20}$ vergelijkt Hamilton de Engelse anti-vivisectie-beweging met de meeste andere Victoriaanse filantropische en reformorganisaties. Ook deze kwamen volgens haar voort uit het gedachtengoed van de woman's mission feminists. Een belangrijk verschil tussen deze hervormingsbewegingen en het anti-vivisectionisme was volgens Hamilton dat de eerstgenoemde bewegingen tegen het einde van de negentiende eeuw de uitgangspunten van het woman's mission feminism steeds vaker ter discussie stelden. Zij ervoeren de (traditionele) omschrijving van de vrouwelijke deugden in toenemende mate als ' $\mathrm{klasse}$ specifiek' en daardoor als problematisch. Al spoedig zouden zij pogingen hebben ondernomen om de betekenis en kwaliteiten van de vrouw te herdefiniëren. Het denken in termen van een strikt verschil tussen mannen en vrouwen maakte, aldus Hamilton, al spoedig plaats voor een denken in termen van gelijkheid. Zo'n verschuiving of omslag zou binnen de door Hamilton om die reden

\section{French, Antivivisection, 242.}

18. Vergl. Nancy Armstrong. Desire and domestic fiction. A political history of the novel (New York 1987). Historici typeren het nu als een stereotypering maar gaan er wellicht aan voorbij dat de eigenschappen die aan vrouwen werden toegekend ook voor vrouwen zelf betekenis hadden. Get is duidelijk dat het éen hel ander niet uitsluit. Vergl. Gerrie Gijsbertsen, Hermine. Discoursanalyse van de Domestieke roman. Ongepubliceerde docloraalscriptie (Amsterdam
1998).

19. Vergl. Sheila Jeffreys, The spinster and her enemies. Feminisin and sexuality 1880-1930 (Londen 1985).

20. F. Prochaska, Women and philanthropy in 19th century England (Oxford 1980) 233, 251. Zie ook: Harrison. 'State intervention and moral reform' in: Patricia Hollis ed. Pressure from without in early Viciorian England (Londen 1974)
289-322. 
als 'conservatief' veroordeelde anti-vivisectie-beweging, niet plaats hebben gevonden." De negentiende-eeuwse Engelse anti-vivisectionisten onttrokken zich aan de problematisering van de traditionele gender-ideologie. Zij bleven vasthouden aan het verschildenken en het daarmee verbonden beeld van de vrouw als een aan de moeder analoge beschermster van zedelijkheid en moraliteit.

Elston komt tot eenzelfde conclusie en stelt bovendien dat het rigide denken in termen van verschillen binnen de anti-vivisectie-beweging gepaard ging met een extreme beduchtheid voor de teloorgang van de vrouwelijke deugden in het openbare leven. Hamilton is het daar mee eens en wijst op Cobbe. Deze anti-vivisectioniste was van mening dat de vrouw bij uitstek geschikt was om de samenleving zuiver en vrij van zedeloosheid te maken. Tegelijkertijd liet zij niet na om waarschuwend op te merken dat indien zou blijken dat vrouwen hun deugden zouden verliezen en 'less dutifull [...] less conscientious, less unselfish, less temperate, less chaste' zouden worden, zij 'for heaven's sake' maar moesten blijven waar zij waren. ${ }^{22}$ Een sprekend voorbeeld van 'verschildenken', zo kan met Hamilton worden aangenomen. Niettemin is het denken in termen van een omslag van verschildenken naar gelijkheidsdenken problematisch. Dat blijkt uit andere studies over het negentiende-eeuwse feminisme waarin er sterk aan wordt getwijfeld of er wel zo'n kentering heeft plaatsgevonden. ${ }^{23}$ De meeste (vrouwen-)historici gaan er tegenwoordig vanuit dat het verschil- en gelijkheidsdenken binnen één en dezelfde feministische stroming verenigd konden zijn.

Dit alles neemt niet weg dat Hamilton en Elston er terecht op wijzen dat de persoon van Cobbe en de anti-vivisectie-beweging niet los kunnen worden gezien van de geschiedenis van het negentiende-eeuwse feminisme. Anders dan French beperken zij zich bovendien niet tot de opmerking dat de anti-vivisectionisten zich op een bepaalde manier tot het probleem van het openbare optreden van vrouwen verhielden. Zij laten zien op welke wijze dit probleem de strijdwijze en politiek van de vrouwelijke vivisectie-bestrijders beïnvloedde en proberen te verklaren waarom het anti-vivisectionisme ook los van Cobbe's opvattingen voor veel vrouwen aantrekkelijk was.

Het antwoord op deze vraag luidt volgens Hamilton dat het anti-vivisectionisme aan vrouwen de mogelijkheid bood om zich tegen hun eigen maatschappelijke onderdrukking uit te spreken en te verzetten, zonder dat zij als radicale feministen te boek kwamen te staan. Met Lansbury stelt zij dat het dierlijk slachtoffer dat in de anti-vivisectionistische geschriften werd beschreven, naar het slachtofferschap van vrouwen verwijst. De gelijkstelling van vrouwen en proefdieren in het antivivisectionistisch propaganda-materiaal kwam volgens Hamilton tot stand met behulp van een hijzondere vertelwijze die door haar wordt aangeduid als domestic narrative. Het proefdier werd in de domestic narrative als huisdier (domestic animal) beschreven, als deel van het gezin en daarmee als deel van de 'natuurlijke' omgeving van de vrouw. Bovendien werden in dit soort teksten bepaalde, als vrouwelijk aangemerkte en rond 1900 met de huiselijke, privésfeer

\footnotetext{
21. Vergl.: Olive Banks, Faces of feminism. A study of feminism as a social movement (Oxford 1981) dic, rouls Ulla Jansz in Denken over... stelt, de door haar onderscheiden evangelische traditie binnen hel negenticnde-eeuwse reminisme als conservatief veroordeelt umdat deze stroming zich op het verschildenken zou hebben gebascerd. Zie over het misleidende van het predikaat conservatier: Mieke Aerts, 'Gewoon hetzelfde of gewoon anders ? Een reministisch dilemma'. Te Elfder Ure. Dilemma's van het ferminisme 39 (Nijmegen 1986) 4-13.

22. Hamilton 'Pets', 86-87. Zie vok: Theodor Stanton ed. The woman question in Europe. A series of original essays with an introduction by Frances Power Cohbe (Londen 1884).

23. Zie: Jansz, Denken over, 23. In dit verband wijst Jansz op : Nancy F. Cott, 'Feminist theory and feminist movement: The past before us' in: 23. Julliet Mitchell and Ann Oakley ed., What's feminism? (New York 1986) 4962. Joan Wallach Scott. 'Deconstruction equality-versus-difference: or, the uses of poststructualist theory for feminism', Feminist studies 14 (1988) 33-50. Selma Sevenhuijsen. De orde van het vaderschap (Amsterdam 1987). Schwegman, Feminisme als... Zie ook: Ulla Jansz. 'Suciale kwestie en sckse in de politieke geschiedenis. De arbeidswet van 1889' in: Marjan Scbwegman et al. ed., Op het strijdtoneel van de pulitiek. Twaalfde Jaarboek voor Vrouwengeschiedenis (Nijmugen 1992) 70-91.
} 
geassocieerde kenmerken en kwaliteiten ${ }^{24}$, aan het dier toegeschreven. De dieren werden beschreven als trouw en liefdevol. $\mathrm{Zij}$ toonden genegenheid aan hun meester, waren vergevingsgezind en begripvol. Hamilton stelt dat de domestic narrative geschreven werd als reactie op medisch-wetenschappelijke verhandelingen waarin over het proefdier werd geschreven als over een lichaam dat zich in de openbaarheid, de met mannen geassocieerde publieke sfeer, bevond. Het door de anti-vivisectionisten met het vrouwelijke in verband gebrachte proefdier werd in deze fysiologische teksten gereduceerd tot een object, een fysiek exterieur zonder innerlijk. De wetenschappelijke uiteenzettingen zouden op deze wijze de mannelijke onderdrukking van de vrouw representeren. De geschriften van de vivisectie-hestrijders waren volgens Hamilton bedoeld als 'vrouwelijke tegenconstructie' van deze mannelijke constructie van het proefdier.

Lansbury is eveneens van mening dat vivisectie-bestrijders vrouwen en proefdieren aan elkaar koppelden. Dit gebeurde, zo meent zij, vooral in anti-vivisectionistische romans. Anders dan Hamilton is zij er evenwel niet van overtuigd dat aan het verband tussen vrouwen en dieren bewuste strategische overwegingen ten grondslag lagen. De koppeling zou in haar visie eerder zijn voortgekomen uit de invloed van fictie (romans, gedichten, korte verhalen, schilderijen) op de belevingswereld van individuen en groepen. Deze wordt door haar vergeleken met de werking van een ondergrondse rivier die onzichtbaar vanuit het binnenste van de aarde vormgeeft aan het daarboven gelegen landschap. Waar in de marxistische geschiedschrijving de produktieverhoudingen als basis bepalend zijn voor de ontwikkelingen in de hovenbouw, zijn voor Lansbury de voorstellingen over sociale groepen en individuen in romans en andere vormen van fictie, bepalend voor de wijze waarop mensen de wereld ervaren. Dorn haar wordt fictie beschreven als een autonome kracht in de geschiedenis, onmisbaar voor de verklaring van sociale en politieke verhoudingen. Uitgaande van deze werking van fictie zijn romans, afbeeldingen en korte verhalen voor Lansbury niet alleen de neerslag van de wijze waarop mensen de wereld ervaren. Fictie heeft in haar visie bovendien zelf het vermogen om ervaringen vorm te geven en te scheppen en heeft vervolgens weer invloed op de verbeelding van de werkelijkheid.

Vanuit deze visie benadert Lansbury het genre van de anti-vivisectie-romans dat, zo stelt zij, niet los kan worden gezien van een brede traditie van fictionele voorstellingen van vrouwen en dieren. Lansbury denkt onder meer aan het achttiende-eeuwse moralistische beeldverhaal The four stages of cruelty van de Engelse kunstenaar William Hogarth, en het genre van de Victoriaanse pornografische roman. ${ }^{25}$ Deze werken, hoe verschillend ook wat betreft vorm, inhoud en auteursintentie, hebben met elkaar gemeen dat zij het slachtofferschap van vrouwen en dieren op de een of andere wijze met elkaar verbinden.

In het werk van Hogarth wordt aan de hand van vier houtgravures het levensverhaal van Tom Nero verteld. Achtereenvolgens is te zien hoe de hoofdpersoon in zijn kinderjaren zijn hond mishandelt, op latere leeftijd een uitgeput paard afranselt, hoe hij daarna zijn zwangere vriendin vermoordt en tenslotte hoe hij tot de strop wordt veronrdeeld en als lijk ter dissectie aan de anatomen wordt overgedragen. Het verband dat in Tom Nero wordt gelegd tussen het maltraiteren van dieren en het mishandelen en vermoorden van vrouwen -door Lansbury aangeduid als het 'Hogarthiaanse thema'- wordt in de Victoriaanse pornogratische roman op een andere wijze uitgewerkt. In dit soort fictie werden vrouwen niet zelden aangeduid als, vergeleken met of gelijkgesteld aan dieren. Dit geldt met name voor een specifiek subgenre hinnen de Victoriaanse

24. Zie hierover: Peter Gay. The Bourgeois Experience Victoria to Freud. The Cultivation of Hatered (New York/ Londen 1993). Met name hoofdstuk vier 'The powerful weaker sex'. Over dit onderwerp in verband met hervormingsbewegingen: Harrison, Peacable Zie ook: Elaine Showalter. Sexual anarchy. Gender, Culture al the Fin the Siècle (Londen 1992).

25. Zie over Hogarths beeldverhalen: Bernard S. Meyer en T. Copplestone ed., The history of an (Londen/ New York 1985) 698. Volgens Kitson ontleende Hogarth zijn werkwijze aan eigentijdse roman-en toneelfiguren. Op deze wijze ontwikkelde hij een nieuwe vorm van het beeldverhaal waarvan hij zowel de verteller als de schilder was. Doorgaans bracht Hogarth zes of meer episoden uit het leven van een persoon samen. Hij toonde meestal de lotgevallen van een persoon die zich (zoals Tom Nero) door een karakterfout of dwaasheid onvermijdelijk tot een rampzalig einde voert. 
pornografie de zugenaamde Jack the Riding Master verhalen. Deze draaiden om de inventieve inspanningen van de mannelijke hoofdpersoon, doorgaans de verteller, om met behulp van geweld (meestal slaan en groepsverkrachtingen) de wil van als Young Mare beschreven jonge vrouwen te breken, hen te onderdrukken en tot slachtoffer te maken.

Zo werden vrouwen en dieren in twee zeer verschillende soorten fictie aan elkaar geklonken. Lanshury is er van overtuigd dat dit niet zonder gevolgen bleef. De vergelijking tussen vrouwen en dieren zou mede door het wijdverspreide, voor iedereen toegankelijke werk van Hogarth, langzaam maar zeker deel zijn geworden van de werkelijkheid en van de manier waarop de werkelijkheid ervaren werd. De pornografische romans hadden een zelfde werking. Ook al waren deze boeken slechts voor een select gezelschap beschikbaar, toch oefenden zij volgens Lansbury als de eerder beschreven ondergrondse rivier invloed uit op het zelfbeeld van vrouwen en op de beeldvorming over vrouwen en dieren.

Ook de auteurs van anti-vivisectie-literatuur ontkwamen volgens Lansbury niet aan dit onbewuste effect van de 'kracht van fictie'. Mannelijke en vrouwelijke auteurs ondergingen die invloed evenwel op verschillende wijze. De mannelijke auteur zou volgens Lansbury heen en weer worden geslingerd tussen zijn:

"compassion for the vivisected dog and his obvious desire to see a woman flogged, between his passion for authority and his concern voor suffering animals. ${ }^{26}$

Vrouwelijke auteurs zouden daarentegen juist de (onbewuste) behoefte voelen om zich tegen het 'Hogarthiaanse thema' te verzetten door het drastisch om te keren. ${ }^{27}$

Dit alles verklaart, zo stelt Lansbury, dat Beatrice Grant, de vrouwelijke hoofdpersoon van de door Leonard Graham geschreven anti-vivisectie-roman The professors wife, op een zeer ellendige manier aan haar einde komt. Grant is tevreden gehuwd met een beroemde chirurg en vivisector die haar voornamelijk als een pretty plaything beschouwt. Haar geluk wordt ruw verstoord als iemand haar op een dag vertelt wat vour soort onderzoek haar echtgenoot verricht. Verontrust over het afschuwelijke verhaal betreedt de jonge vrouw voor het eerst het laboratorium van haar man. Wat zij daar ziet -een aan vivisectie onderworpen dier- schokt haar op zodanige wijze dat ze een acute aanval van brain fever krijgt en met krankzinnigheid wordt geslagen. Haar echtgenoot stelt haar onder behandeling van een collega die Beatrice Grant drogeert, hypnotiseert en langzaam als een proefdier laat sterven. Haar weduwnaar keurt dit zeker niet af, zoals blijkt uit hetgeen hij zijn collega toevoegt:

'Yes we made use of our opportunities; the phenomena were most instructive. After all, the

lower animals are unsatisfactory; you learn more by the human subject' ${ }^{28}$

Beth Caldwell, de hoofdpersoon van The Beth Book, een roman van de feministe Sarah Grand, overwint juist de vivisector. Wanneer zij evenals de onfortuinlijke Beatrice Grant het laboratorium van haar echtgenoot betreedt en daar een lijdend proefdier aanschouwt, wordt zij niet ziek of gek. Zij helpt het dier daarentegen koelbloedig uit zijn lijden.

Volgens Lansbury is de belangrijkste overeenkomst tussen beide romans dat de vrouwelijke hoofdpersonen door het aanschouwen van het lijdende dier een treffende gelijkenis zien tussen de eigen seksuele en maatschappelijke onderworpenheid en het slachtofferschap van het proefdier. ${ }^{29}$

26. Lansbury, Brown dog, 132.

27. Volgens Lansbury is het verschil tussen de plot geschreven door mannelijke en door vrouwelijke auteurs ook terug te vinden in de andere anti-vivisectie-romans die zij analyseerde. Ze verwijst daarbij naar: George Macdonalds, Paul Faher, surgeon (z.p. 1871). Wilkie Collins, Heart and Science (z.p. 1883). Edward Berdoe, St. Bernard. The Romance of a medical student (Londen 1877). Aesculapius Scalpel (pseudoniem voor E. Berdoe), Dying scientifically: A key to St. Bernards (Londen 1988). Barry Pain, The Octave of Claudius (z.p. 1897).

28. Geciteerd door Lansbury. Brown dog, 234.

29. Het is opvallend dat in hedendaagse romans waarin het vivisectie-vraagstuk ter sprake komt nog altijd op de een of andere wijze een verband wordt gelegd tussen het proefdier en de vrouw als slachtoffer. Neem bijvoorbeeld: Elisabeth George. Playing for the Ashes (Toronto 1994). In deze roman wordt Olivia Whitelaw, een ernstig zieke en aan lager wal geraakte jonge vrouw 'gered' door de anti-vivisectionist en dierenbevrijder Chris Faraday. In Patrick White, The Vivisector (Londen 1970) zijn het voornamelijk vrouwen die het slachtoffer worden van Hurtle Duffields' geestelijke 
Beatrice Grant kan deze wetenschap niet aan en gaat er onmiddellijk aan onderdoor. Beth Caldwell wordt door het nieuw verworven inzicht juist gestimuleerd om de strijd met haar onderdrukker aan te gaan en voor zichzelf op te komen. Beide romans gaan uit van het 'Hogarthiaanse thema', zij het dat de vrouwelijke auteur er een andere draai aan geeft. Hierin meent Lansbury een verzet tegen de onderdrukking van de vrouw te zien.

Resumerend kan gesteld worden dat Lansbury, Hamilton en Elston het verzet tegen vivisectie uitsluitend in het licht van de strijd van vrouwen tegen maatschappelijke en seksuele onderdrukking zien. ${ }^{30}$ Volgens hen was het anti-vivisectionisme voor vrouwen aantrekkelijk omdat zij, met gebruikmaking van fictie en de domestic narrative, op onopvallende wijze hun slachtofferschap aan de orde konden stellen en bestrijden. De vrouwen beïnvloedden de anti-vivisectionistische politieke stijl doordat zij een speciaal soort teksten schreven waarin via de beschrijving van het proefdier de situatie van de vrouw werd besproken.

Alvorens aan te geven wat een dergelijke benadering van het anti-vivisectionisme voor waarde kan hebben voor de studie naar het Nederlandse anti-vivisectionisme, dient eerst een aantal kanttekeningen te worden geplaatst. De eerste is dat Hamilton in haar analyse van de domestic narrative wellicht een te hedendaagse manier van denken aan de anti-vivisectionistische auteurs toeschrijft: het denken in termen van constructies. Daar staat tegenover dat Lansbury met haar specifieke opvattingen over de kracht van fictie, mogelijk juist niet voldoende recht doet aan de bewuste politieke overwegingen achter de door haar geanalyseerde anti-vivisectie-romans. Een ander probleem is dat deze benadering niet geheel verklaart waarom vrouwen nu juist voor het anti-vivisectionisme kozen om de strijd tegen hun onderdrukking te voeren. Waarom zou het antivivisectionisme meer of betere mogelijkheden hebben geboden om de strijd tegen maatschappelijke onderdrukking te voeren? Ook is niet geheel duidelijk geworden wat voor rol vrouwen en de opvattingen over vrouwen en vrouwelijkheid nu precies binnen de anti-vivisectie-beweging speelden.

Deze kanttekeningen ten spijt is de waarde van de hierboven beschreven benadering duidelijk. Zonder twijfel is de aandacht voor de anti-vivisectie-fictie als strijdmiddel belangrijk. Immers, door de relatie tussen vrouwen en het anti-vivisectionisme vanuit dit perspectief te benaderen wordt niet alleen de aandacht gevestigd op een mogelijk verband tussen anti-vivisectionisme en het vrouwenvraagstuk. Ook wordt zo gewezen op de mogelijkheid dat het protest tegen vivisectie met gender-voorstellingen was doortrokken, een aspect dat in French' studie mede door de wat eenzijdige focus op Cobbe's opvattingen niet aan de orde komt. De vraag is nu of, en zo ja op welke wijze, gender-voorstellingen een belangrijke rol speelden in de politieke stijl van het Nederlandse anti-vivisectionisme. Na een korte schets van de voorgeschiedenis en oprichting van de NBBV wordt in de rest van dit hoofdstuk dan ook de rol van vrouwen en het denken over vrouwelijkheid in de Nederlandse strijd tegen vivisectie aan de orde gesteld.

vivisecties. Ook in non-fictie wordt in deze helf van de twintigste eeuw de vergelijking tussen vrouwen en proefdieren nog altijd gemaakt. Zie daarvoor de brief die in Kathleen Sasz. Petishism. Pel cults of the Western world (Londen 1968) wordt geciteerd. De brief ondertekend met 'een hartstochtelijk strijd tegen vivisectie' werd in de jaren zestig ontvangen door een Amerikaanse vivisector en eindigt met: "Het zal njet lang meer duren voor we uw lelijke, domme, trouweloze vrouw, vergeleken bij wie de lelijkste hond een volmaakte: schoonheid is, op de operatietafel vastbinden, en als ze daar ligt te krijsen. overdekt met bloed en uitwerpselen, zullen wij u uitnodigen om u te tonen welk een zegen voor de mensheid uw smerige, sadistische seksuele uitspattingen (bedoeld wordt de vivisectie A.K.) betekenen. Vertaling afkomstig uit de Nederlandse uitgave van Petishism: De troeteltrend of het petisjisme (Amsterdam 1971)

30. Deze manier van denken is ook terig te vinden in : Judith R. Walkowitz. City of dreadfull delight, Narratives of sexual danger in Late-Victorian Londen (Londen 1992). Volgens Walkowitz verwezen de anti-vivisectie posters van de Londense anti-vivisectionisten naar de seksuele onderdrukking van de vrouw en niet zozeer naar het vivisectie-
vraagstuk. 


\section{De NBBV: oprichting en opbouw}

Een in een Duits tijdschrift gepubliceerd artikel van de Dresdener Internationale Gescllschaft zur Bekämpfung der wissenschafilichen Thierfolter wekte in 1889 de belangstelling van de Axelse predikant Ds. J.B.Th. Hugenholtz. ${ }^{31}$ Het stuk handelde over de wijze waarop voor wetenschappelijk onderzoek op 'gruwelijke wijze' dieren werden 'gemarteld' en werd besloten met een dringende oproep aan de lezer om zich als lid aan te melden. Hugenholtz besefte meteen 'hoezeer de vivisectie zich aan alle zedelijkheid vergreep' en aarzelde, naar eigen zeggen, geen moment om aan de oproep gehoor te geven. Niet lang daarna ontving de predikant als dank voor zijn aanmelding een brochure getiteld Verborgene Gräuel. ${ }^{32}$ Het werkje bevatte een door Hermann Stenz geschreven dialoog tussen een voorstander van vivisectie, 'Philo' genaamd, en zijn tegenstander 'Anti'. Laatstgenoemde kwam telkens als winnaar uit de woordenstrijd naar voren. Het geheel werd vergezeld door het verzoek om het werkje onder de aandacht van zoveel mogelijk mensen te brengen.

Hugenholtz die inmiddels had geconstateerd dat zijn landgenoten nauwelijks iets van het vivisectie-vraagstuk afwisten, besloot daarop om Verborgene Gräuel te vertalen en aan zoveel mogelijk onwetenden uit te delen:

'Wilde ik de gruwelen der vivisectie die letterlijk alle beschrijvingen te boven gaan bekend maken, ik moest dan zoveel mogelijk exemplaren van verborgen gruwelen onder 't volk verspreiden ${ }^{63}$

Tenminste tweeduizend exemplaren meende Hugenholtz nodig te hebben om in dien nacht licht te ontsteken'.34 Een dergelijke onderneming zou hoge kosten met zich meebrengen. De predikant schatte het benodigde kapitaal op honderdvijftig gulden en liet de Nederlandsche Vereeniging tot Bescherming van Dieren (NVBD) weten dat een financiële tegemoetkoming voor zijn strijd tegen het 'toppunt van alle denkbare dierenmishandeling' hem niet onwelkom zou zijn. Kennelijk was Hugenholtz er niet van op de hoogte dat de NVBD het vivisectie-vraagstuk al sinds jaar en dag als een gevoelige kwestie beschouwde. Sinds de oprichting van de Haagsche Vereeniging was er onder leden en bestuurders verdeeldheid over de vraag of de vivisectie bestreden diende te worden en/of door wetten beperkt. Ook in het in Mijne herinneringen beschreven gesprek tussen Harting en mevrouw Van Manen kwam deze spanning naar voren. Tijdens zijn onderhoud met de redactrice van Androcles maakte Harting duidelijk dat hij niet te spreken was over het adres dat de Haagsche Vereeniging aan de Minister van Binnenlandse Zaken had gericht, en waarin gevraagd werd om:

'de H.H. professoren der medische faculteit en veeartsen uit te nodigen om de vivisectiën tot de volstrekt noodzakelijke te beperken en gebruik te maken van de bestaande middelen ter verzachting van dusdanige kunstbewerkingen'. ${ }^{35}$

Harting kon, zo stelde hij, onmogelijk zijn artikelen over vivisectie in Androcles publiceren, daar de Haagsche Vereeniging hem en zijn ambtgenoten 'onder een soort curateele' 36 wilde stellen. Volgens Mijne herinneringen zou mevrouw Van Manen daarcp hebben geantwoord -'ter eere van het gezond verstand' van zijn bezoekster wilde Harting dit erkennen- dat 'zij zelve de door het bestuur der vereeniging bij den Minister aangewende poging ontijdig en onvoorzichtig vond'. Een upmerkelijke uitspraak. Van Manen was tegen vivisectie, schreef anti-vivisectionistische opstellen

31. J.B.Th. Hugenholtz, Het vivisectie-vraagstuk. Rede gehouden in Patrimonium te Amsterdam en Utrecht (Utrecht 1892) 5 .

32. Hermann Sicnz, Verborgene Gräuel. Talsachen und Vernunftgründe gegen die Vivisektion, gesammelt von Hermann Stenz. Internat. Verein. Zur Bekämpfung der Wisselschafl. Thierfolter (Dresden 1889).

33. Hugenholtz, Vivisectie-vraagstuk, 5.

34. Ibidem.

35. Dit adres van de HVBD is tot op heden onvindhatr. Daarover klaagt W. Wijnaendts Francken-Dyserinck al in hair brochure: Het vivisectie-vraagsiuk in hel Nederlandsche purle'me't ('s-Graventage 1903). De in dit hoofdstuk geciteerde tekst uit het adres van 1873 is ontleend aan de brochure van de HVBD : Een parar bedenkingen ...(1874) 4.

36. Harting. Herinneringen, 117. 
in Androcles maar was, als Harting het zich juist herinnert, tegelijkertijd van mening dat het adres van de Haagsche Vereeniging beter (nog) niet geschreven had kunnen worden.

Dat die voorzichtige houding door meer vooraanstaande leden van de HVBD werd gedeeld, bleek toen Harting het anti-vivisectionisme van de dierenbeschermers aanviel in Album der Natuur en het Dagblad van Zuid-Holland en 's-Gravenhage. De Haagsche Vereeniging antwoordde hem weliswaar met een geheel aan dit conflict gewijde brochure, maar besteedde na deze polemiek jarenlang nauwelijks enige aandacht aan het onderwerp. Er werden geen adressen meer aan de regering verzonden en alleen in Androcles dat, anders dan Harting vermoedde formeel onafhankelijk van de dierenbescherming opereerde, werd sporadisch een artikel aan het onderwerp gewijd.

Bij de Engelse dierenbeschermers was het niet anders verlopen. Sinds haar oprichting in 1824 verzette de R.S.P.C.A. zich voornamelijk tegen dierenmishandeling door het volk. Onderwerpen als de jacht en de vivisectie, handelingen van de eigen sociale klasse, lagen binnen de beweging gevoelig. ${ }^{37}$ Discussies over deze kwesties zorgden al spoedig voor interne conflicten en verdwenen na verloop van jaren van de agenda. Een aantal dierenbeschermers, waaronder Frances Cobbe, wilde daar niet mee akkoord gaan, maar kon aanvankelijk niet veel beginnen. Zij waren te zeer afhankelijk van de contacten van de machtige en rijke dierenbescherming. Voor deze kleine groep anti-vivisectionisten was het dan ook een geschenk uit de hemel toen de secretaris van de R.S.P.C.A. in 1874 een brief ontving van de secretaris van koningin Victoria. Het schrijven bevatte een donatie en de mededeling dat de vorstin zeer geinteresseerd was in anti-vivisectionistische denkbeelden. Om deze mededeling kon de R.S.P.C.A. niet zomaar heen. Victoria was zeer geliefd en gerespecteerd onder de aanhang van de dierenbescherming. De R.S.P.C.A. wilde alleen al daarom maar al te graag tonen hoezeer de beweging met het onderwerp begaan was.

Een paar maanden na de ontvangst van de brief kreeg de beweging haar kans. Aanleiding was een schandaal dat zich tijdens de jaarlijkse bijeenkomst van de British Medical Association had voorgedaan. De Franse fysioloog Magnan had tijdens dit congres een lezing gehouden over de fysiologische effecten van alcohol en daarbij ter demonstratie experimenten op honden uitgevoerd. Een aantal aanwezigen was hierdoor geschokt geraakt en was er toe overgegaan een van de proefdieren uit zijn lijden te helpen. Het incident werd in de kranten breed uitgemeten en door de R.S.P.C.A. aangegrepen om zich in de discussie over vivisectie te mengen. John Colam, de president van de beweging, daagde Magnan en zijn assistenten voor de rechter. De Fransman was echter al naar huis teruggekeerd en zijn helpers werden wegens gebrek aan bewijs niet veroordeeld.

Naar aanleiding van de affaire-Magnan stelde de R.S.P.C.A. met veel ophef een commissie in die zich speciaal op het onderwerp vivisectie zou richten. Cobbe, die al jaren trachtte om het onderwerp op de agenda te krijgen en er om bekend stond dat zij de beroemde vivisector Moritz Schiff met anti-vivisectionistische geschriften had bestookt, werd gevraagd om in de commissie zitting te nemen. Voor de aanvankelijk enthousiaste Cobbe liep het initiatief op een teleurstelling uit. De R.s.P.C.A. toonde zich naar haar oordeel tijdens de bijeenkomsten van de commissie weinig daadkrachtig. Toen de commissie bovendien tegenover de pers verklaarde dat zij niets van doen had met Cobbe's vroegere anti-vivisectionistische praktijken, verliet zij de R.S.P.C.A. De dierenbeschermers hielden zich vanaf die tijd nauwelijks meer met het onderwerp bezig. Gesteund door de inmiddels in de kranten losgebroken discussies, richtte Cobbe in 1876 de Victoria Stre't Society op.

De daarop volgende vloed van anti-vivisectionistische geschriften en discussies had ook zijn invloed in Nederland. Vanaf 1879 zou het anti-vivisectionisme binnen de dierenbescherming zelts

37. De Engelse dierenbeschermers verzetten zich wel tegen vivisectie in Frankrijk. Zo was een delegatie van de R.S.P.C.A. naar Frankrijk afgereisd om een adres aan Napoleon III aan te bieden. Daarin werd verzocht om 'de cruautées monstrueuses' en "de brutalités infernales" die aan de Alfortse veeartsenijschool werden verricht, onmiddellijk te verbieden. Het rekwest had niet het gewenste resultaat. In Alfort werd het curriculum in het geheel niet gewijzigd. French sociely for animal welfare', History today 28 (1978) 105-122 
enkele jaren een sterke opleving kennen. Directe aanleiding was de verbeten anti-vivisectionistische campagne die de Engelse veearts James Cowie op 'het continent' voerde. Over de persoon van Cowie is slechts weinig bekend. Het verhaal gaat dat een essay over de heelkundige oefeningen die aan de veeartsenijschool van het Franse Alfort werden verricht, hem diep had geraakt en tot actie aangespoord. ${ }^{38}$ Hoe het ook zij, eind jaren zeventig toog Cowie naar het vasteland van Europa om daar zijn mening over het vivisectie-vraagstuk te verkondigen. In 1879 deed hij ook Nederland aan. Het ging de Engelse veearts hier aanvankelijk naar wens. Hij werd met open armen ontvangen door de Nederlandse dierenbeschermers en kon al spoedig op audiëntie bij de Minister van Binnenlandse Zaken. De bewindsman gaf te kennen dat hij Cowies streven waardeerde. Hetzelfde gold naar zijn zeggen voor A.H.W. Wirtz, de directeur van de Utrechtse veeartsenijschool. Dat nam niet weg dat Cowies bezorgdheid naar het oordeel van de minister geheel overbodig was, aangezien

' [...] aan de Nederlandsche veeartsenijscholen [...]voor oefeningen in operatieve heelkunde gebezigde paarden niet noodeloos [...] gekweld [werden]. ${ }^{39}$

Alleen de noodzakelijke vivisecties werden verricht. Problemen ontstonden toen Cowie met deze verklaring geen genoegen wilde nemen en er bij Wirtz meer malen op aandrong nadere informatie te verschaffen. De Engelsman kreeg nooit antwoord. Toen hij vervolgens met behulp van het bestuur van de NVBD zijn toevlucht tot de pers nam, bleek hij niet op veel sympathie te kunnen rekenen. De minister beschouwde de zaak als afgedaan en Cowies open brief aan de kranten werd in de Nieuwe Rotterdamsche Courant door 'het Utrechtse' hooghartig beantwoord. In het Utrechts provinciaal en Stedelijk Dagblad werd zijn persoon zelfs belachelijk gemaakt door hem aan te duiden als 'de oude heer Cowie, een landbouwer die naar 't schijnt in veeartsenijkunde liefhebbert'. Na zoveel onwil en onbegrip gaf de Engelse veearts het teleurgesteld op. Vier maanden later concludeerde hij ten overstaan van zijn collega's op het National Congress of Veterinary Surgeons:

'So the Dutch must be allowed to rest in their inglorious position with immunity to any outside call on their humanity and kindness to animal creation. ${ }^{40}$

Deze 'buitenlandse blamage' moet voor de Nederlandse dierenbeschermers niet te verteren zijn geweest. Dat lijkt tenminste evident indien met Davids wordt aangenomen dat de oprichting van de Nederlandse dierenbeschermingsbeweging verklaard kan worden als een acculturatie van de elite'. Davids meent dat de dierenbeschermers zich met de verspreiding van de gedachte dat dieren in georganiseerd verband beschermd dienden te worden, aanpasten aan een internationale norm. Zonder dierenbeschermingsbeweging 'dreigde Nederland af te zakken tot het onbeschaafd gezelschap’ van Spanje, Turkije en Portugal, landen waár vóór 1865 eveneens geen organisatorisch kader voor dierenbescherming bestond. Een dergelijk decurumverlies tegenover de elite in beschaafde landen zoals Engeland en Duitsland zou, zo vreesde men, voor de internationale handelsbetrekkingen wel eens ongunstig kunnen uitvallen. ${ }^{41}$

In deze context bezien moet de affaire-Cowie voor de Nederlandse dierenbeschermers buitengewoon pijnlijk zijn geweest. Mogelijk heeft de discussie die de Engelse veearts ontketende er dan ook toe bijgedragen dat de bemoeienis van dierenbeschermers met het vivisectie-vraagstuk nieuw leven werd ingeblazen. Illustratief voor deze hernieuwde belangstelling zijn de vier rekesten voor "wettelijke bepalingen [...] ter beperking van vivisectie's2 die door de NVBD aan de Koning werden gericht. Ook in Androcles werd in deze periode een toenemend aantal artikelen nver het onderwerp gepubliceerd. Evenals in Engeland zou het verband tussen anti-vivisectionisme en

\footnotetext{
38. Vrijwel alle informatie over Cowie in dit hoofdstuk is ontleend aan de studie van Mathijsen 'oefenoperaties'

39. Geciteerd door Mathijsen 'oefenoperaties', 77

40. Ibidem, 78

41. Davids, 'aristocraten'. 193-194.

42. Zoals blijkt uil de disseratie van Hendrik M. Witsen, Rechtskundige beschouningen over vivisectie, (Amsterdam 1880).
} 
dierenbescherming evenwel niet lang stand houden. Nieuwe pijnlijke gebeurtenissen die het vivisectie-vraagstuk nogmaals tot een gevoelige kwestie zouden maken, konden niet uitblijven. De vivisectie werd zelfs een 'twistappel in den boezem der vereeniging'.

Het begon allemaal toen de NVBD in 1881 een nieuwe voorzitter in de persoon van H.L.V.E. Salomon kreeg. Deze luitenant van de Grenadiers en Jagers te Maastricht had, als oprichter van de eerste Limburgse afdeling van de NVBD, zijn sporen op het gebied van de georganiseerde dierenbescherming al ruimschoots verdiend. Ondanks deze verdienste was de militair vanaf het begin een vreemde eend in de bijt van het deftige Haagse dierenbeschermingswereldje. Zowel met zijn opvatting dat het beschermen van dieren een 'totale oorlog'43 was, als met zijn lijfspreuk 'leg de leugen af en spreek de waarheid'44 baarde hij nogal wat opzien. Daarbij kwam dat de toon waarop de waarheid naar zijn mening gesproken diende te worden aanzienlijk verschilde van de manier waarop het bestuur van de NVBD dit gewend was te doen. Salomons uitlatingen over medici en vivisectoren, die naar zijn mening 'niet zoveel beschaving hadden als waar zij zich op grond van [...] opleiding en maatschappelijke status op voorstonden', en zijn definitie van vivisectie als 'eene verfijnde wreedheid door mannen die zich ondanks dat, op hun hoog standpunt van beschaving' durfden beroemen, werden met toenemende verontrusting en ergernis aangehoord.

Waarschijnlijk zouden Salomons ruwe taal en spot minder problemen hebben opgeleverd als hij deze uitsluitend had gebruikt om kritiek te leveren op meer volkse vormen van dierenmishandeling zoals palingtrekken en katknuppelen. Juist zijn bemoeienis met vivisectie en daarmee met het beschavingspeil van de elite maakte zijn optreden problematisch. Een deel van het bestuur en een aantal leden van de NVBD hadden er, wellicht met de affaires Harting en Cowie nog in het geheugen, geen behoefte aan om op slechte voet te raken met de medische wetenschappers die hun standsgenoten waren. Toen in de periode van Salomons voorzitterschap het ledental van de Nederlandsche Vereeniging gestaag afnam, werd dit door het bestuur dan ook al spoedig in verband gebracht met het optreden van de luitenant. Een conflict tussen de voorzitter en de zojuist tot het hoofdbestuur toegetreden jonkheer De Klerck, die een meer gematigder koers voorstond, kon niet uitblijven. In 1884 trad Salomon af.

Met de afsluiting van de 'episode Salomon' was het duidelijk geworden dat de vivisectie voor de dierenbeschermers een netelige kwestie was. De NVBD erkende dit openlijk in 1886 toen het hoofdbestuur, toch eens zo ijverig in het schrijven van anti-vivisectionistische adressen, weigerde een rekwest van de Societé Antivivisectioniste de Belgique te ondertekenen:

'Mijne heeren het is bij zoveel verschil van mening voor hot bestuur niet gemakkelijk ten opzichte van dit gewichtig vraagstuk eene stelling te nemen. Terwijl in Androcles de heer van der Hucht, wiens ijverige bemoeiingen ten bate van de veıceniging alle hulde en lof verdienen, de vivisectie op wetenschappelijke gronden met hand en tand bestrijdt, zijn er wederom vele anderen, waaronder zelfs eene dame, die hun lidmaatschap hebben opgezegd wegens ons dwaze ijveren tegen de wetenschappelijke dierenontleding $[\ldots] .^{4.5}$

Zo verdween in de hierop volgende jaren de vivisectie van de dierenbeschermingsagenda. Het ledental van de Nederlandsche Vereeniging steeg weer onder de veel gematigder koers van haar gloednieuwe voorzitter De Klerck.

Van alle commotie rond vivisectie in de dierenbescherming was Hugenholtz zoals gezegd niet op de hoogte toen hij vijf jaar na het aftreden van Salomon om geld vroeg voor de vertaling van Verborgene Gräuel. Het verbaasde hem dan ook dat de NVBD zijn initiatief slechts met vijfentwintig gulden wilde steunen. 'Uit liefde en ijver door de goede zaak' besloot hij toen maar om de

43. De affaire Salomon wordt beschreven in Davids, Dieren, 169-173. Zie ook Davids, 'aristocraten'

44. H.I.V.E. Salomon. Open brief aan den minisier van Justitie (z.p 1886) 45. Zie: Jaarverslag der Algemeene Vergadering der Nederlandsche Vereeniging lol Bescherming van Dieren. (z.p.
1886) 7. 
rest van de kosten zelf te betalen. Hugenholtz bleek er evenwel niet zo alleen voor te staan als hij aanvankelijk gedacht moet hebben. Zijn plannen waren bij de redactie van Androcles, die los van de NVBD door was gegaan met het publiceren van anti-vivisectionistische artikelen, niet onopgemerkt gebleven. Spoedig na het antwoord van de NVBD ontving Hugenholtz een brief van één van de redacteuren, Ds. S.F.W. Roorda van Eysinga. Deze gaf daarin uiting aan 'zijne blijdschap' over het feit dat er weer een 'nieuwe stem tegen de gruwelen der vivisectie [...]' was opgegaan. ${ }^{46}$ De mededeling werd vergezeld door de toezegging van de redactie van Androcles om honderd gulden bij te dragen aan de verwezenlijking van Hugenholtz' project. Gesterkt door deze welwillende steun stelde Hugenholtz in de loop van de daaropvolgende correspondentie voor om het niet bij de vertaling van Verborgene Gräuel te laten. Hij wilde een bond oprichten 'ten einde de vivisectie krachtig te kunnen bestrijden'. ${ }^{47}$

Met dit plan wist hij niet alleen Roorda van Eysinga maar ook de toenmalige hoofdredactrice van Androcles, de schrijfster Marie Daal (pseudoniem voor mevrouw C.C.A. Van der HuchtKerkhoven) te winnen. Zij bleek de gulle geefster van de honderd gulden te zijn en toonde zich ook later in allerlei opzichten genereus. Zo mobiliseerde zij haar contacten in de nationale en internationale dierenbeschermingswereld. En niet zonder resultaat. De Duitse anti-vivisectioniste en schrijfster Marie-Espérance von Schwartz, een vriendin van de Italiaanse held Guiseppe Garibaldi, leverde een financiële bijdrage. ${ }^{48}$ Hetzelfde gold voor de bekende Engelse strijder tegen dierproeven Edward Maitland. Het aldus ontvangen bedrag, aangevuld met geld dat Van der Hucht-Kerkhoven zelf ter beschikking stelde, vormde al snel een aanzienlijk startkapitaal. Tot aan haar overlijden zou mevrouw Van der Hucht de reserves van de NBBV meerdere malen aanvullen. ${ }^{49}$

Hiermee wordt iets duidelijk van het aandeel van vrouwen bij de oprichting van de NBBV. Vrouwen waren belangrijke financiers van het Nederlandse anti-vivisectionisme. De meeste donaties die de NBBV in de eerste twee decennia van haar bestaan ontving, waren van vrouwen afkomstig. Het ging om bedragen van één tot honderd gulden. De beroemde feministe Cécile Goekoop-de Jong van Beek en Donk, later de schrijfster van de roman Hilda van Suylenburg, schonk tweehonderdvijftig gulden en werd lid van de nieuwe organisatie. ${ }^{\text {so }}$ Een waar kapitaal verwierf de bond in 1905 door de nalatenschap van mevrouw M.J.J. Coster van Voorhout-Hamm. De erfenis bedroeg tussen de vijfenzestig- en zesentachtigduizend gulden. ${ }^{51}$

Hiermee is zeker niet alles gezegd over het aandeel van vrouwen in het georganiseerd verzet tegen dierproeven in Nederland. Vrouwen waren behalve als financiers op allerlei niveaus in de beweging actief. Zo zou de NBBV vanaf 1910 meer dan twintig jaar lang door Suze Groshans worden geleid. Ook de in 1931 door de arts Pieter Pijl opgerichte Stichting Anti-Vivisectie Bond kende vanaf het einde van de jaren dertig tot in de jaren vijftig een vrouwelijke president: Mary

46. Hugenholtz, Vivisectie-vraagstuk, 6.

47. Ibidem.

48. Deze Duitse anti-vivisectioniste schreef onder het pseudoniem Elpis Melena (een letterlijke nieuw-Griekse vertaling van Espérance (hoop) en Schwanz (zwar), de succesvolle anti-vivisectie-roman Gemma, oder Tugend und Laster (München 1877). In 1891 werd door de NBBV een Nederlandse vertaling van Gemma gepubliceerd: Gemma, naar hel Duitsch van Elpis Melena ('s-Gravenhage 1891).

49. Van der Hucht-Kerkhoven was zeer gefortuneerd. Ze was erfgenaam van het Indische fortuin van de Kerkhovens over wie Hella Haasse schrijft in Heren van de Thee (Amsterdam 1992), Zie hierover: P.A. J. Caljé. 'De jongens van weleer' in: Hel Corps als Koninkrijk (Delft 1998) 84-314.

50. Cécile Goekoop-de Jong van Beek en Donk, Hilda van Suylenburg (Amsterdam 1984). De roman werd voor hel eerst gepubliceerd in 1897 .

51. Zie hierover: Hugo Nolthenius, 'Verslag van de achtste jaarvergadering van den NBBV' in: Orgaan van den Nederlandschen Bond to Bestrijding der Vivisectie (mei 1905) 118-132, 122. De NBBV werd voor de helft tot erfgenaam benoemd. Het bedrag was belast met het vruchtgebruik van haar weduwnaar. Bovendien waren er in het testament allerlei regelingen opgenomen die verband hielden met het leven van enkele personen en dat van een pard. De NBBV betreurde het dat de identiteit van het betreffende paard vooralsnog onbekend was. Gestreefd werd naar een oplossing van het vraagstuk door bemiddeling van de paardenarts J.H.B. Moubis. 
Stuart. Lager in de hiërarchie van de organisaties waren vrouwen net zo goled vertegenwoordigd. Als bestuurslid, penningmeester, secretaris, vertaler van buitenlands propagandamateriaal en natuurlijk als lid. Hoewel minder opzienbarend dan in Engeland, waar het aantal vrouwelijke leden in sommige anti-vivisectie-organisaties kon oplopen tot zeventig procent, was bij de NBBV rond de eeuwwisseling en bij de SAVB in de jaren dertig, een groot aantal vrouwen aangesloten. Uit de incomplete ledenlijsten kan worden opgemaakt dat iets meer dan de helft van de ongeveer duizend leden/donateurs van deze organisaties vrouw was.

Of de door de anti-vivisectionisten georganiseerde bijeenkomsten en lezingen, zoals dit in Engeland het geval was, ook in Nederland vooral door vrouwen werden bezocht is niet bekend. Wel kan uit een verslag in de Nieuwe Rotterdamsche Courant van een in 1907 gehouden antivivisectie-tentoonstelling en van een lezing van de Franse anti-vivisectionist Dr. Marchéal, worden opgemaakt dat zich onder het publiek 'vele dames' bevonden. ${ }^{52}$ Zeven jaar eerder constateerde de medisch hoogleraar Willem Einthoven, zoals gezegd, dat het met name vrouwelijke studenten waren die tijdens zijn colleges anti-vivisectionistische standpunten naar voren brachten. ${ }^{53}$ Zeker is dat zowel in Engeland als in Nederland vrouwen belangstelling toonden voor de strijd tegen vivisectie. In een tijd waarin dit voor een vrouw niet vanzelfsprekend was, traden deze antivivisectionistes in de openbaarheid of werden zij in ieder geval lid van een organisatie waarbinnen een dergelijke handelwijze niet ongewoon werd gevonden. Toch is er ook een belangrijk verschil aan te wijzen tussen de manieren waarop dit rond 1900 in Nederland en in het Victoriaanse Engeland gebeurde. Zo benoemden de Nederlandse anti-vivisectionisten hun strijd zelf niet, zoals de Engelse strijders tegen dierproeven dit deden, als een woman's cause. Eerder bleek al dat Marie Jungius zich in haar lezing voor de Nationale Tentoonstelling van Vrouwenarbeid niet expliciet tot vrouwen richtte.

Daar staat tegenover dat de NBBV zich aansloot bij de Nationale Vrouwenraad. Jaarlijks kozen de anti-vivisectionisten een vrouw uit hun midden om zich door haar in die raad te laten vertegenwoordigen. In de ogen van de anti-vivisectionisten hadden vrouwen en de strijd tegen vivisectie kennelijk wel iets met elkaar te maken. Maar de vraag welk verband zij zagen tussen die twee is niet eenvoudig te beantwoorden. Zowel uit de notulen van de vergaderingen van de NBBV, als uit de verslagen van de bijeenkomsten van de Nationale Vrouwenraad blijkt dat noch de leden van het hoofdbestuur van de NBBV, noch hun vertegenwoordigster het nodig achtten om het lidmaatschap van de raad op de een of andere wijze te legitimeren of te motiveren. ${ }^{54}$ In de Engelse anti-vivisectie-geschriften werd wel aangegeven waarom het anti-vivisectionisme een strijd voor vrouwen was. French vond in dit materiaal aan vrouwen gerichte oproepen en op vrouwen gerichte tactieken:

'The $[\ldots]$ columns of the movements periodicals rang with appeals to the united strength of women and to the benign influence of their tender sympathies. In particular women were expected to exercise social sanctions against medical men who refused to commit themselves against vivisection. Some women suggested that their sex could do without doctors entirely. $\left\lceil\ldots \mid\right.$ In any case, women were to stand forth publicly on behalf of the cause. ${ }^{.55}$

De Nederlandse anti-vivisectionisten plaatsten dergelijke oproepen dus niet. Kijkt men evenwel naar een ander soort bronnen, te weten de Nederlandse anti-vivisectie-romans (waarvan de Engelse equivalenten door French nauwelijks van belang werden geacht voor het onderzoek naar de anti-vivisectie-beweging), dan blijkt dat daarin veel explicieter een verband wordt gelegd tussen

52. De lezing was georganiseerd door het Comité tot Beperking der Vivisectie. De spreker, Dr. Maréchal, was evenwel geen voorstander van de beperking van vivisectie, hij stond de totale bestrijding van dierproeven voor. Dit onderscheid tussen bestrijders en beperkers komt later aan de orde. Het verslag van de lezing werd gedaan in de Nieuwe Rotterdansche Courant 14 mei 1907. Zie ook 'Lezing van Dr. Maréchal', Orgaan 3 (1907) 188-193, aldaar 188.

53. Einthoven, 'Rectoraatsrede', 134.

54. Zie bijvoorbeeld: 'Rapporten van aangesloten vereenigingen' in: Tweede Algemeene Vergadering van den Nulisnale Vrouwenraad (z.p. 1902) 46-53.

55. French, Antivivisection, 240. 
het vivisectie-vraagstuk en het 'vrouwen-vraagstuk'. Beide thema's zijn althans nadrukkelijk verwerkt in de romans die de NBBV in 1891, één jaar na haar oprichting, publiceerde: De familie van Westwoorne en Gemma. De eerste was een tweedelige roman, onder het pseudoniem Marie Daal geschreven door Van der Hucht-Kerkhoven. Gemma was de Nederlandse vertaling van een oorspronkelijk in 1877 gepubliceerde Duitse roman, onder het pseudoniem Elpis Melena geschreven door de eerder genoemde Marie-Espérance von Schwartz. ${ }^{57}$

\section{Romanheldinnen}

Wat is anti-vivisectie-fictie, wat is een anti-vivisectie-roman? In de historiografie van het antivivisectionisme lopen de opvattingen daarover uiteen. Hamilton, een literatuurwetenschapster, is van mening dat er geen duidelijke grens bestaat tussen fictionele en niet-fictionele teksten. Voor Lansbury bestaat dit onderscheid juist wel. Zij combineert deze opvatting met een vrij breed begrip van hetgeen onder anti-vivisectie-romans zou moeten worden verstaan. Waar Hamilton zich uitsluitend richt op teksten die door de anti-vivisectie-beweging werden gepubliceerd, gaat Lansbury uit van alle romans waarin het vivisectie-vraagstuk op de een of andere wijze aan de orde komt, ongeacht of de auteur actief was in de anti-vivisectie-beweging. De door de NBBV uitgegeven romans die in deze paragraaf worden besproken werden door anti-vivisectionisten geschreven met als doel een bijdrage te leveren aan het anti-vivisectionisme. Zo was Gemma, oder Tugend und Laster door de schrijfster Elpis Melena uitdrukkelijk bedoeld als wapen in de strijd tegen vivisectie.

Gemma is geheel geschreven in de geest van Harriet Beecher Stowe's Uncle Tom's Cabin (1852). In haar voorrede toont Elpis Melena grote bewondering voor de Amerikaanse auteur die met de publicatie van haar roman een 'alles omverwerpende aardbeving' ontketende en zo het 'schandelijk misbruik der slavernij' op zijn grondvesten deed schudden. De herinnering aan het succes van Uncle Tom's Cabin ${ }^{58}$ had Elpis Melena doen beseffen dat van romans een bezielende werking uit kon gaan. ${ }^{59}$ Deze 'kracht van de verbeelding' wilde zij maar al te graag inzetten voor de strijd tegen vivisectie. Daarom werd Gemma in het leven geroepen. Zij had tot taak om het publiek als het ware te bekeren. De lezers moesten er door haar toe worden aangespoord zich op te werpen als 'apostel der humaniteit', opdat zij voortaan met 'loffelijken ijver in (hun) kring' werkzaam zouden zijn als strijder tegen de vivisectoren die tijdens hun 'verschrikkelijk beulswerk' in 'gewetenloosheid alle duivelen, welke de onsterfelijke Alighieri [...] in zijn Commedia Divina afschildert' verre achter zich hadden gelaten' ${ }^{\text {. }}$

Vóór de publicatie van Gemma had Elpis Melena haar manuscript in de lente van 1877 voorgelegd aan een oude familievriend, Ernst Grysanovski. Deze Duitse anti-vivisectionist had zich meteen enthousiast getoond: 'jouw Gemma spreekt recht tot het hart' ${ }^{\text {61 }}$ zo oordeelde hij. Het boek was naar zijn mening bij uitstek geschikt om invloed uit te oefenen in de hoogste kringen, in

\footnotetext{
56. Marie Daal, De familie van Westvoorne ('s-Gravenhage 1891).

57. Elpis Melena. Gemma oder Tugend und Laster (München 1877). De roman werd in verschillende Lalen vertaal waaronder in het Engels en Italiaans. In 1891 werd de NBBV de Nederlandse vertaling gepubliceerd: Gemma, naar het Duitsch van Elpis Melena ('s-Gravenhage 1891).

58. Harriet Beecher Stowe. Uncle Tom's Cabin, or life among the lowly (Boston 1952). In Nederland werd de roman voor het eerst in 1984 gepubliceerd als De Negerhut (Haarlem 1854). In deze disseratie is gebruik gemaakt van De hut van oom Tom, een verhaal uil hel slavenleven in Noord-Amerika (Amsterdam 1991).

59. Als het ware als een voorloopster van de hedendaagse hlosoof Richard Rorty. Zie voor de opvattingen van Rorty: Contingency, Irony and Solidarily (Cambridge 1989) over de morele werking die van Uncle Tom's Cabin en andere logenaamde sentimentele verhalen uit zou gaan. Zie ook de kritiek daarop van Patricia de Martelaere, "Wie goed doet, goed ontmoet: ironische bemerkingen bij Rorty's idyllisch liberalisme' in: Sorin Alexandrescu ed., Richard Rorty (Kampen 1995) 115-127 Zie ook: Gerard de Vries, 'De gevoelens van ironici' in : idem. 128 142. Zie ook: R.Rorty, 'Rechten van de mens, rationaliteit en sentimentaliteit' in : G. Hottois, M. Van den Bossche en M. Weyemberg ed., Richard Rorty. Ironie, politiek en posimodernisme (Antwerpen/Baam 1994).
}

60. Elpis Melena, Gemma, voorrede (geen blz. Nr)

61. Citaat is vrij vertaald en ontleend aan Tröhler en Maehle, 'Anti-vivisection...', 157. 
het bijzonder via de daar tegenwoordige dames. Deze vrouwen zouden door lezing van de roman gestimuleerd worden om het anti-vivisectionistische gedachtengoed in hun directe omgeving te propageren. In combinatie met een door Grysanovski te schrijven essay ${ }^{62}$, dat niet zozeer 'het hart' van deze dames maar juist 'het hoofd' van academische, medisch geschoolde mannen moest aanspreken, kon de roman een belangrijke bijdrage leveren aan de 'kruistocht tegen de meest gewelddadige wreedheid van onze eeuw'. ${ }^{63}$

Met hetzelfde doel voor ogen werd de tweede roman geschreven die de NBBV in 1891 liet uitgeven. Evenals Elpis Melena hoopte Van der Hucht-Kerkhoven haar lezers door fictie aan te zetten tot een betere manier van leven. Bescheiden, maar niet zonder de overtuiging dat haar werk een dergelijke invloed zou kunnen uitoefenen, vatte zij deze pretentie als volgt samen:

'Mochten slechts enkelen mijner lezers door de kennismaking met de familie van Westvoorne zich geroepen voelen om zich krachtiger en ernstiger dan voorheen aan te gorden tot den strijd tegen begrippen en toestanden, welke eener beschaafde maatschappij onwaardig zijn, dan reeds zou ik mij gelukkig achten. ${ }^{64}$

Het was niet de eerste keer dat Van der Hucht-Kerkhoven met deze bedoeling een boek schreef. Op de titelpagina van De familie van Westvoorne duidt de auteur zichzelf aan als Marie Daal, de schrijfster van Anna. Zij verwees daarmee naar de roman die zij in 1883 publiceerde. Dit boek handelde volgens een bewonderende tijdgenoot niet alleen over het beschermen van dieren en de bestrijding van vivisectie. Het was tevens een aanbeveling voor de emancipatie van de vrouw. ${ }^{65}$ Deze omschrijving geldt voor alle drie de romans die hier worden besproken. In Gemma, Anna en De familie van Westvoorne wordt het vivisectie-vraagstuk op de een of andere wijze gekoppeld aan de problematiek waarmee vrouwen te maken krijgen wanneer zij zelfstandig in de openbaarheid treden om de samenleving te hervormen.

\section{Gemma}

De roman Gemma, oder Tugend und Laster handelt over de lieve, intelligente zeventien-jarige Gemma Farnham die samen met haar vader, de fysioloog Dr. Farnham, haar hondje Roy en een huishoudster, een groot, somber landhuis in Engeland bewoont. Dagelijks rijdt zij op haar pony Stornello, trouw verzorgt zij het graf van haar jong gestorven moeder en zij verricht liefdewerk onder de armen en gebrekkigen. Op een dag verandert dit rustige leventje voor goed. Gemma vindt in de huisbibliotheek van haar vader een boek, geschreven door de Franse fysioluog Dr. Béclard. ${ }^{66}$ Leergierig als ze is, slaat ze het boek open. Al lezende wordt zij geconfronteerd met een wereld die zij niet kent. Zij leest over honden die met stompe spijkers met poten en oren op een tafel worden vastgenageld en voor de meest uiteenlopende onderzoeken opengesneden en gepijnigd. Onmiddellijk valt zij ten prooi aan wanhoop en verdriet.

Nadat haar vader met een blik op haar roodbehuilde ogen korzelig heeft gevraagd wat er in vredesnaam aan de hand is, toont Gemma hem het boek. Zij hoopt troost te vinden en van haar vader te vernemen dat het beschrevene niet aan de werkelijkheid is ontleend, dat het in plaats daarvan slechts de neerslag betreft van de duistere en huiveringwekkende fantasie van de auteur.

62. Iatros ( pseudoniem voor E. Grysanovski). Die Vivisektion, Ihr wissenschaflichen Wert und ihre ethische Berechtigung (Leipzig 1877). Van dit essay werden 423 exemplaren verkocht waarvan 200 aan Elpis Melena. Gemina werd daarentegen een doorslaand succes al is helaas de oplage niet bekend.

63. Tröhler en Maehle. 'Germany' in: Rupke. Vivisection, 157. Grysanovski (1824-1888) studeerde wiskunde, astronomie en oosterse talen te Königsberg. Toen een carrière in de diplomatie mislukte werd hij huisleraar van eén Italiaanse prins. Door de familie Von Schwartz werd hij vervolgens in de gelegenheid gesteld om medicijnen te studeren. Na voltooiing van deze studie opende hij een praktijk in Pisa en later in Florence. Zie ook: Elpis Melena, Dr. E.F.G. Gnsanovski. Milleilungen aus seinem Lehen und seinen Briefen (Hannover 1890).

64. Marie Daal, Westvoome, voorwoord (geen blz. nrs.).

65. Dr. E. Laurillard, 'Een goed boek' in: Androcles, maandschrift aan de belangen van dieren gewijd (1884) 3 Tevens ter gelegenheid van het overlijden van Van der Huchl-Kerkhoven gepubliceerd in: Orgaan van den Nederlandschen Bond tot Bestrijding der Vivisectie 12 (1916) 63-64.

66. Deze fysioloog heeft in werkelijkheid bestaan. Zie over hem A. Westacot, Century, 159 en Elliot, 'France'. 48-77. 
Die hoop wordt door Dr. Farnham vrijwel meteen de grond in geboord. In plaats van haar gerust te stellen, gaat hij er toe over om het werk van zijn Franse collega met nadrukkelijke instemming te citeren. Als Gemma haar vader smeekt om zijn enthousiaste voordracht te staken voldoet hij aan haar verzoek. Wat hij haar vervolgens onthult doet haar echter nog veel meer verdriet. Trots vertelt hij dat hij al jaren zelf een vivisector is.

Zo wordt Gemma voor het eerst van haar leven met het bestaan van het kwaad geconfronteerd. Het is voor haar een grote schok dat het kwade zich in haar eigen veilige familie bevindt. Waar zij tot dan toe haar vaders tekortkomingen met de mantel der liefde bedekte, kan zij nu zijn 'verdorvenheid en verdoemenis' niet langer ontkennen. Voortaan moet Gemma het kwaad onderkennen als deel van haar bestaan. Met de blik in de hel der onschuldigen verdwijnt voorgoed het paradijs van haar kinderjaren. Zelfs haar ongevoelige vader beseft dit. Wanneer hij ziet dat het boek dat zijn dochter heeft gelezen de studie van Béclard is, spreekt hij 'toornig':

'Ik gaf je sinds lang verlof de boeken die ge begrijpen kunt, uit mijn bibliotheek te nemen maar nimmer heb ik je vergund je zonder mijn raad daarbij in te winnen, van mijn wetenschappelijke werk te bedienen'

De analogie met Gods gramschap over Adam en Eva die zich van hun naaktheid bewust bleken te zijn is duidelijk. Het boek dat Gemma in haar onschuld ter hand nam, is een verboden vrucht of in vergelijking met een ander verhaal over ongeoorloofde kennis, de sleutel van de kamer die Blauwbaards jonge bruid, in tegenstelling tot alle andere vertrekken in het grote kasteel van haar echtgenoot, niet mocht openen. ${ }^{67} \mathrm{Dr}$. Béclards werk is, zoals uit het vervolg van Gemma blijkt, een aansporing om de wereld van het kwaad nader te verkennen. Het boek is één van de vele gedaanten van de slechts schijnbaar toevallige ongelukjes en voorvallen die, zoals door Joseph Campbell wordt beschreven, in verhalen 'een onvermoede wereld onthullen en het individu in relatie brengen met krachten die hij niet goed begrijpt'. ${ }^{68}$

Gemma's confrontatie met het kwaad, verandert van een 'giftige dolk die een bloedende wond toebrengt' in een louterend inzicht dat de eerste stap vormt naar een hogere levensvervulling. Want nadat zij haar tranen heeft gedroogd kiest zij ervoor haar gehele leven aan de bestrijding van vivisectie, aan de strijd tegen het kwaad te wijden. Zo volgt zij het patroon van de heldenreis, de avontuurlijke zoektocht die Campbell universeel acht voor mythen en vertellingen. ${ }^{69}$ Evenals de helden in deze verhalen moest de heldin van Elpis Melena zich, zoals Kathleen Turner het samenvat in The History of Hell: 'in de buik van het beest wagen', alvorens zij 'de weg der beproevingen naar verheerlijking' kon inslaan'. ${ }^{70}$

Dat Gemma die weg inderdaad inslaat, dat zij ingaat op de uitdaging van het avontuur, maakte haar bijzonder. Daarover laat Elpis Melena geen misverstand bestaan. Terwijl de herinnering aan het kwaad bij velen door 'de tijd en eenige nietswaardige verstrooiingen' uit het geheugen wordt gewist, trekt Gemma juist vastberaden ten strijde. Haar bijzondere karaktereigenschappen maken dat zowel het 'erbarmen voor het lijden van anderen', als de 'ijver om een lofwaardig doel te bereiken' onverminderd voort blijven bestaan. Wat maakt haar tot zo'n vasthoudend strijdster?

Wanneer de vraag wie bij uitstek over de juiste kwaliteiten om de vivisectie te bestrijden beschikte aan Gemma zou kunnen worden gesteld, zou zij zonder aarzelen geantwoord hebben: 'de vrouw'. Dit blijkt uit het aan koningin Victoria gerichte adres voor het wettelijk verbod van de vivisectie dat Dr. Farnham's dochter na haar eerste confrontatie met het kwaad schreef. Gemma stelde in dit geschrift dat mannen, omdat zij nu eenmaal over een fysieke en verstandelijke macht beschikten, in de strijd tegen de vivisectie van grote betekenis waren. Desondanks was het naar

67. Zie hierover: Clarissa Pinkola Estés. Women who run with the wolves. Myths and stories of the Wild Woman archelype (New York 1992).

68. Camphell, Held, 51 .

69. In haar oratie wijst Marjan Schwegman erop dat Campbell uitsluitend aandacht besteed aan mannelijke helden. Schwegman, Prima donna.

70. Kathleen Tumer, Hell, 11 
haar oordeel de vrouw die de belangrijkste rol binnen de anti-vivisectie-beweging te vervullen had. Vrouwen waren volgens Gemma geroepen om een 'meedogende beschermengel' te zijn, niet alleen voor echtgenoot en kinderen, maar voor alle lijdende schepsels. Dat was haar natuurlijke missie.

Dat betekende voor Gemma niet een strikte scheiding tussen een vooral in de huiselijke sfeer opererende vrouw en de in de openbaarheid strijdende man. Evenals Cobbe benadrukte zij dat de kwaliteiten van de vrouw juist in het volle maatschappelijke leven tot hun recht zouden komen, en veel goed zouden kunnen doen. Precies voor deze opvatting meende zij bij koningin Victoria gehoor te vinden. De vorstin verenigde in zich, als geen ander, de tot het terrein van de mannen behorende politieke macht en de zo belangrijke vrouwelijke deugden. Gemma's hoop was dan ook op deze sterke vrouw gericht.

Die hoop was ijdel. Gemma's adres, haar smeekbede zoals ze het zelf omschreef, zou de vorstin nooit bereiken. Dr. Farnham gooide het met zoveel zorg vervaardigde geschrift ongelezen in een donkere hoek van de boekenkast. Zo lukt het Gemma niet om in de openbaarheid te treden en haar idealen na te streven. Iedere stap die zij buiten de deur zet, iedere poging die zij onderneemt om uit de privésfeer te treden, wordt genadeloos afgestraft. Als zij niet bijna verdrinkt tijdens een van haar wandelingen dan wordt zij wel gadegeslagen door een rijk, oud lid van het Hogerhuis. Deze maakt haar het hof en wendt sympathie voor haar anti-vivisectionisme voor, terwijl hij er slechts naar verlangt haar 'schoone vesting stormenderhand' te nemen.

Het komt er op neer dat Gemma zich uitsluitend met een trouwe mannelijke begeleider, haar pony Stornello, de hond Roy, of haar in de loop van het verhaal hervonden broer Oswaldo, veilig buitenshuis kan begeven. Het isolement waarin zij leeft - zoals in veel negentiende-eeuwse romans gesymboliseerd door het gekooide vogeltje bij haar hed maakt dat zij niet bij machte is om haar boodschap wereldkundig te maken. Alleen een huwelijk met de door haar vader zeer gewaardeerde politicus Mawworm biedt uiteindelijk nog uitzicht op een audiëntie bij koningin Victoria. Zich van haar machteloosheid bewust verklaart Gemma zich verdrietig maar dapper bereid om te trouwen, erop vertrouwend dat haar echtgenoot zijn invloed zal aanwenden om haar in de strijd tegen de vivisectie terzijde te staan. Het lot behoedt haar voor deze vergissing. Onverwachte familieomstandigheden noodzaken de trouwlustige oude man om het huwelijk uit te stellen. Nog voor er een nieuwe datum wordt vastgesteld is Gemma gestorven.

Gemma sterft als maagd. Zij blijft, daarnaar verwijst ook haar naam, een knop of een edelsteen, onaangetast door de buitenwereld. Dit plot kan worden opgevat, daar zou althans een interpretatie in de lijn van Hamilton en Lansbury op uitkomen, als een protest tegen de machteloosheid van de aan de privésfeer gekluisterde vrouw. Tegelijkertijd spreekt uit de wijze waarop de schrijfster zelf haar hoofdpersoon beschermt en gevangen houdt, de door Cobbe onder woorden gebrachte bezorgdheid dat de vrouwelijke deugden uiteindelijk aangetast zouden worden wanneer zij onbeschermo werden ingezet ter verbetering van de maatschappij. Uit de romans van Marie Daal spreekt een geheel andere visie op de mogelijkheden van vrouwen. Zij slingert hen juist meedogenloos in het volle leven. Anders dan Gemma weten zij zich bovendien uitstekend te redden.

\section{Anna en De familie van Westvoorne}

In Daals eerste roman wordt de jonge Anna beroofd van allen die haar lief zijn en beschermen. Haar verloofde Herman van Weerde verlaat haar omdat zij ervoor kiest om bij haar zieke hondje Skye te blijven in plaats van met hem naar een bal te gaan. Skye sterft, evenals haar vader, de weduwnaar professor Van Bergen. Vervolgens moet de gevoelige, intelligente Anna -door haar nichtjes wordt zij laatdunkend aangeduid als 'savante'- zich maar zien te redden in een wereld die haar met onbegrip en vijandigheid gadeslaat.

Hetzelfde geldt voor de burgemeestersdochter Eliegonda van Westvoorne, één van de hoofdpersonen uit Daals roman De familie van Westvoorne. Hoewel deze jonge vrouw, in tegenstelling tot Anna en evenals Gemma, nog de steun heeft van haar broer, wordt ook zij 
plotseling en onzachtzinnig met de harde werkelijkheid van het bestaan geconfronteerd. Haar vader sterft en na een leven van luxe moet zij zich zien te redden. Al spoedig blijkt dat de gezusters Van Westvoorne nauwelijks zijn toegerust om in hun eigen onderhoud te voorzien. Frits van Westvoorne, hun idealistische antimilitaristische broer, maakt zich dan ook bezorgd. Vooral wanneer Eliegonda kiest voor een carrière als zangeres in Duitsland. Hij beseft maar al te goed dat het leven voor de kunst voor een jonge, onervaren vrouw niet zonder risico's is. Een van die gevaren dient zich vrijwel meteen na het eerste succesvolle optreden van Eliegonda aan, in de persoon van Dr. Oldenburg, een van de meeste begeerde vrijgezellen van de stad. De jongeman wordt verliefd op de zangeres en doet alles om haar hart en de vriendschap van haar broer te winnen. Hij is hierin succesvol totdat beiden ontdekken dat Dr. Oldenburg in zijn laboratorium vivisecties op jonge straatkatjes pleegt. Ondanks haar onervarenheid weet Eliegonda deze moeilijkheden glansrijk te overwinnen. Nadat zij hem als vivisector heeft geïdentificeerd, wijst zij het huwelijksaanzoek van de dokter vriendelijk maar beslist af. De enige schade die zij daardoor ondervindt, is een vluchtig gevoel van treurnis omdat zij haar aanbidder niet van haar antivivisectionistische standpunt heeft kunnen overtuigen. Van Gemma's wanhoop toen zij haar vader als vivisector identificeerde, is bij Eliegonda geen sprake.

Ook Anna doorstaat alle rampen met verve, hoewel zij aanvankelijk in een 'zelfzuchtig medelijden' dreigt te blijven zwelgen wanneer zij, evenals Gemma, wordt geconfronteerd met de aanblik van het kwaad. Op een dag kruist zij het pad van een katje met afgesneden oren dat haar angstig, gejaagd, kermend en bloedend tegemoet komt rennen. Deze gebeurtenis schokt haar zozeer dat zij wekenlang ijlend op bed ligt en dat het, zoals Daal schrijft, 'nacht wordt in haar ziel'. Na deze zware crisis komt zij onder de hoede van Meta van Warnsveldt. Deze vrouw verzorgt de doodzieke Anna en als de jonge vrouw uiteindelijk herstelt, vertelt Meta haar levensverhaal aan haar. Het blijkt dat Meta op Anna's leeftijd verloofd was met een lieve jongeman. Tot een huwelijk tussen beiden was het evenwel niet gekomen. Vlak voor de grote dag was de aanstaande tussen het raderwerk van een fabrieksmachine vermorzeld. Sinds het moment waarop Meta in de kille fabriekshal het dode, met bloed besmeurde lichaam van haar geliefde had aanschouwd, was er nooit een klacht over haar lippen gekomen. In plaats daarvan was zij een lieve en wijze pleegmoeder geweest voor de kinderen van haar broer, de weduwnaar Willem Warnsveldt.

Door het verhaal van haar vriendin herinnert Anna zich dat haar vader vóór zijn sterven de uitdrukkelijke wens had geuit dat zijn dochter haar uiterste best zou doen om iets voor de samenleving te betekenen. Wanneer Meta het plan opvat om een vereniging op te richten met als doel jonge vrouwen die zelfstandig willen werken of een opleiding volgen, een goed, beschermend huis te geven, zet zij zich dan ook met volle overgave in als secretaris. Haar doorzettingsvermogen en durf om, ondanks de kritiek van haar tante, oom en onbenullige rijke nichtjes, als jonge vrouw een dergelijke openbare functie te bekleden worden beloond. De verdwenen verloofde keert op zijn schreden terug en blijkt inmiddels in te zien hoe verkeerd hij haar liefde voor honden heeft beoordeeld. Het huwelijk dat volgt, wordt bekroond door de geboorte van een zoon. Door het moederschap verandert Anna's schoonheid -die in de loop van de roman telkens wordt vergeleken met die van een nog niet geheel ontloken roosje- in de adembenemende pracht van de Madonna Sixtina. ${ }^{71}$ Anna heeft haar bestemming in het leven gevonden. Ze is volwassen geworden en daarmee is de Nieuwe Vrouw geboren. ${ }^{2}$

71. De Madonna is in de loop der eeuwen niet alleen met moederschap geassocieerd maar ook met wijsheid. Zie hierover: Marina Warner, Alone of all her sex. The Myth and Cult of the Virgin Mary (Londen 1976).

72. Anna werd in Engeland gepubliceerd als Anna the professors daughter. Volgens Lansbury is hel de eerste in Engeland uitgegeven roman waarin het 'Hogarthiaanse thema' radicaal wordt omgedraaid. De vrouwelijke hoofdpersoon overwint de 'brute verloofde' en sluit een huwelijk op haar termen. $\mathrm{Zij}$ wordt geen slachtoffer van mannelijke onderdrukking. maar groeit uit tot een sterke New Woman. 
De romans Anna, De familie van Westwoorne en Gemma werden door vrouwen geschreven. Op grond daarvan zou, onder verwijzing naar Lansbury's stelling, verwacht kunnen worden dat de vrouwelijke hoofdpersoon uiteindelijk de vivisector overwint. Voor Anna en Eliegonda lijkt dat op te gaan. Over Gemma kan dit niet zo makkelijk gezegd worden. Het hoofdstuk getiteld 'het slachtoffer', waarin Gemma's dood wordt beschreven, lijkt er in eerste instantie op te wijzen dat de hoofdpersoon uit Elpis Melena's roman het onderspit delft. Er is evenwel een verschil tussen Gemma en de vrouwen uit de andere romans. Anders dan de laatstgenoemden is Gemma geen gewoon menselijk wezen, een vrouw van vlees en bloed met kwaliteiten en gebreken. Zij bezit daarentegen een allegorische natuur. Gemma is geen wezen van deze wereld. Het meisje is, zoals Sternberger het omschrijft, een engel of een vrouwelijke Christusfiguur. Zij kan vergeleken worden met Evangeline, één van de hoofdfiguren uit Uncle Tom's Cabin, het boek waarnaar Elpis Melena's roman gemodelleerd was. Evangeline en Gemma zijn de tegenstandsters van het kwaad dat in de roman van Beecher Stowe wordt gerepresenteerd door de slavenhouder Simon Legree en in Gemma door de vivisector Dr. Farnham.

De meisjes die in godvruchtigheid en weerloze schoonheid niet voor elkaar onderdoen, gaan ten onder aan louter goedheid. Beiden sterven aan een niet duidelijk omschreven aandoening. Bij Evangeline openbaart de ziekte zich door een hoestbui, bij Gemma door hoge koorts die opkomt nadat zij door haar dronken vader tegen de borst wordt gestoten en van de trap gegooid. Het was in de negentiende-eeuwse literatuur niet ongebruikelijk om, zoals hier gebeurt, door ziekte of lichamelijke zwakheid, onschuld en zuiverheid met vrouwelijkheid te verbinden. Susan Sontag laat zien dat met de aandoening tuberculose (denk aan de hoest van Evangeline) in romans niet zelden werd verwezen naar de overwinning van de onschuld op lagere, seksuele gevoelens. ${ }^{73}$ Elisabeth Bronfen die onder meer sterfbed-scènes in achttiende-eeuwse en Victoriaanse romans analyseert, is van mening dat de dood van Evangeline een middel was om bepaalde morele waarden over te dragen en de lezer als het ware te bekeren:

'Eve's passage from here to the beyond [...] illustrates the way the deathbed scene serves to pass on a moral responsability to others. [...] Eve stages the death of innocence, and the Christ-like sacrifice is meant to convert its spectators to Christianity and to correct the antislavery movement. ${ }^{74}$

Wat voor Evangeline geldt, gaat ook op voor Gemma. Zij overlijdt bovendien niet om wat haar persoonlijk is aangedaan, maar om het kwaad dat anderen is berokkend.

Die anderen zijn in Uncle Tom's Cabin en Gemma respectievelijk de vrome slaaf Tom (naar wiens schamele onderkomen de titel van het boek verwijst) en het hondje Roy. De eerstgenoemde wordt op instigatie van Legree zodanig afgeranseld dar hij uiteindelijk aan zijn verwondingen sterft. Zijn niet aflatende trouw, de kalme wijze waarop hij zijn boosdoeners vergeeft, en de manier waarop hij, terwijl hij zijn laatste adem uitblaast, de ogen ten hemel slaat en het "christen zijn' prijst, zijn de tekens van zijn welhaast bovenmenselijke berusting in de rol van slachtoffer. Roy is even lijdzaam als Tom en nog weerlozer. Dit dier heeft zowel zijn bazin als haar vader van de verdrinkingsdood gered, maar wordt desondanks, zonder pardon, door Dr. Farnham op de vivisectie-tafel genageld. Nadat er wekenlang op hem is geëxperimenteerd, sterft Roy uiteindelijk, ver weg van Gemma's troostende armen, en zonder de mogelijkheid om, zoals Tom, nog een laatste statement af te leggen.

De beulen van Tom en Roy worden in hun aardse hestaan gestraft door twee mannelijke vertegenwoordigers van de rechtvaardigheid. In Uncle Tom's Cabin is het de jonge master George die uiteindelijk de satanische Legree tegen de grond slaat. Even afdoende handelt Gemma's broer. Oswaldo doet afstand van zijn rechten op de erfenis van zijn vader en schenkt hem, geheel 73. Susan Sontag. Illness as Methaphor (New York 1979), Zie ook: Marjan Schwegman, Feminisme als boeledoening
(Amsterdam 1989).

74. Elisabeth Bronfen, Over her dead body. Death, femininity and the aesthetic (Manchester 1992) 90 
conform de wens van zijn geliefde zuster, vergeving. Een en ander heeft tot gevolg dat Dr. Farnham door krankzinnigheid wordt geslagen. Toch -en dit ziet Sternberger in zijn analyse van beide romans over het hoofd- zou het kwaad nok zonder het ingrijpen van de jongemannen zijn gestraft. Beecher Stowe beschrijft hoe voor de komst van de wrekende planter, het leven van Legree in toenemende mate wordt beheerst door een onbekende kracht. Hij vreest de straf waarvan hij voelt dat hij die niet kan ontlopen. Ook Gemma's vader had zichzelf al lang voor de komst van zijn verloren gewaande zoon door 'zijne misdaden en ondeugden'75 veroordeeld tot een lichamelijk en zedelijk lijden. In het laatste hoofdstuk van Gemma wordt beschreven hoe de fysioloog uiteindelijk wordt geteisterd door waandenkbeelden:

'Bloed ! Bloed! Altijd en overal bloed ! .... en terwijl hij deze woorden huiverend en door een innerlijken angst aangegrepen uitstootte, bezag hij zijne handen aan alle zijden en wischte ze dan zijn kleederen af, als wilde hij ze van vlekken reinigen [...] dat vervloekte tuig! $\mathrm{Zij}$ alleen hebben mij met bloed bedekt [...] Ik wil van de verwenschte bloedvlekken bevrijd worden! [...] Zo huil je nog altijd oude Roy! Wil je wel eens uitscheiden met bloed op mijn handen te schreien, ellendig beest ... een causticum dokter! Ach neen, in de geheele wereld is niets te vinden, dat die vlekken zou kunnen wegnemen. ${ }^{76}$

Tijdens het delirium ziet Dr. Farnham zijn overleden dochter voor zich gezeten op haar pony Stornello, temidden van alle dieren die Dr. Farnham tijdens zijn loopbaan heeft gepijnigd en met Roy aan haar zijde. En juist uit wat hij aan zich voorbij ziet trekken, wordt duidelijk dat Gemma meerdere gezichten heeft. $\mathrm{Zij}$ is een proefdier, zoals blijkt uit de manier waarop zij als het ware samensmelt met de dierlijke slachtoffers die zij eens beschreven zag in het werk van Dr. Béclard. Tegelijkertijd is het Gemma die trots te paard zit en alleen al door haar aanwezigheid de riding master laat schreeuwen. Daarnaast is het meisje zowel de Christus die vergeving schenkt, als de personificatie van de wrekende rechtvaardigheid. Gemma is de wraakgodin waar de negentiendeeeuwse lezer volgens Sternberger gedurende het gehele verhaal op hoopte. Niet voor niets is 'De Nemesis' de titel van het hoofdstuk waarin Dr. Farnhams krankzinnigheid wordt beschreven. Dat Gemma vele gezichten heeft past bij haar symbolische natuur. ${ }^{77}$

Toch is het niet alleen aan de symbolische hoedanigheid van Gemma toe te schrijven dat zij zoveel kanten heeft. Ook Anna, die zoals gezegd, veel meer een vrouw van deze wereld is, heeft meer dan één gezicht. Behalve een reine, zedelijk hoogstaande jonge vrouw en een Nieuwe Vrouw in wording, is zij een vertoornde Walküre, een Engel der Wrake. ${ }^{78} \mathrm{Zij}$ wordt zelfs regelrecht boos bij ieder onrecht dat zij ziet en trekt ten strijde tegen iedere belager van onschuldigen en weerlozen. Dit maakte Anna, zo geeft Marie Daal ruiteriijk toe, zelfs minder perfect dan men volgens haar van een romanheldin verwachten kon. Duidelijk mag zijn dat de vrouwen in de antivivisectie-romans niet uitsluitend werden beschreven als slachtotfers of als personen die pogingen ondernemen om, al dan niet met succes, aan het slachtofferschap te ontsnappen en een overwinning op de man te behalen. Voor deze diversiteit aan betekenissen en associaties die in de antivivisectie-romans met het vrouwelijke verbonden worden, hebben Lansbury en Hamilton geen oog.

Hoewel de verwijzingen naar de vrouwenkwestie in de hierboven genoemde romans duidelijk zijn en het feminisme voor veel anti-vivisectionisten een belangrijk en zelts een aan de strijd tegen vivisectie verwant thema was, zijn anti-vivisectionisme en feminisme zeker niet uitwisselbaar. De opvattingen over vrouwen en vrouwelijkheid die in de anti-vivisectionistische geschriften -of dit nu romans of periodieken waren- werden verwoord, stonden niet ten dienste van een alles overkuepe-

75. Elpis Melena, Gemma, 154

76. Elpis Melena, Gemma, 152

77. Zie over de allegorische en symbolische vrouwenfiguur: Marina Warner, Monuments \& MaiderLs. The allegory of the female form (Londen 1985)

78. Daal, Anna, 21 
lende vrijheidsstrijd van de onderdrukte vrouw. Zij maakten daarentegen deel uit van een scala van geseksueerde voorstellingen door middel waarvan het vivisectie-vraagstuk en het daarmee nauw verbonden profiel van de ideale strijder tegen het kwaad, zichtbaar werden gemaakt. Zonder af te doen aan het bestaan van een band tussen feminisme en anti-vivisectionisme verschuift de aandacht in de volgende paragraaf naar de manier waarop ook andere prominente thema's door geseksueerde voorstellingen in de anti-vivisectie-fictie zichtbaar werden gemaakt.

\section{'Wetend' worden}

De Nederlandse anti-vivisectionisten maakten in vrijwel al hun geschriften onderscheid tussen 'toegestane' en 'verboden' manieren om 'wetend' te worden. De discussie over vivisectie draaide, zoals Felix Ortt het in 1906 formuleerde, niet om de 'vraag van 't nut' maar om de 'vraag naar de geoorloofdheid ${ }^{79}$ van de kennis die door vivisectie werd verworven. De meeste anti-vivisectionisten waren het daarmee eens. $\mathrm{Zij}$ beschreven vivisectie als een ongeoorloofde bron van kennis. Niet zelden deden zij dat door deze onderzoeksmethode gelijk te stellen aan het uitleven van mannelijke hartstocht en begeerte. Zo zou vivisectie volgens een in 1895 gepubliceerde brochure van de anti-vivisectionist C.S. 'wellust, onbehoorlijken wellust' ${ }^{80}$ kweken. Andere anti-vivisectionisten associeerden medisch-wetenschappelijke experimenten op levende dieren eveneens met vaak als mannelijk aangeduide ondeugden, zoals mateloze eerzucht, gebrek aan respect en vooral gevoelloosheid.

Door dergelijke kwalificaties uitdrukkelijk te koppelen aan mannen en mannelijkheid werden de positivistische uitgangspunten verworpen. Dat wil zeggen, dat de anti-vivisectionisten ingingen tegen de opvatting dat de relatie van de wetenschapper tot het onderzoeksobject onpersoonlijk moest zijn. Ook de notie dat vooral gestreefd diende te worden naar de uitschakeling van iedere vorm van een gevoelsmatige relatie met het onderzochte en de, eveneens positivistische, afkerigheid van iedere identificatie met het voorwerp van studie, werden afgewezen. ${ }^{81}$ De antivivisectionisten beschreven de vivisector als iemand die zonder gevoel voor het onderzoeksobject, de natuur op wrede wijze dwong haar geheimen prijs te geven. Vaak werd daarbij, zoals in de Engelse anti-vivisectie-romans, op de een of andere wijze een parallel getrokken met verkrachting. De anti-vivisectionist en medicijnen-student Pieter Pijl stelde in 1916 in zijn op rijm geschreven mystieke gedicht Het Tweede Leven ${ }^{82}$ over een heldenreis naar en door een onstoffelijke wereld:

'Dat heel het snijden, pluizen, treffen der stof in menschen, plant en dier [...] dat al die arbeid helpt geen zier, als hij gedreven wordt door 's menschen grootste feil: VOL BEGEERT’ HET WEZEN DAARIN TRACHTEN UIT TE HALEN

[...]

O Drang naar 't Wezen van de dingen

Ach- diep bedroefd moet ik hier zingen

als ik bedenk der Wetenschappen pad,

[...]

Slechts nacht,

gesmacht in diepsten nacht

79. Pro en contra betreffende vraagstukken van Algemeen helang. Serie I. No. 7: Vivisectie: Pro: Prof. Dr. H.J.L. Siruijken, arts te Breda. Contra: Felix Ortt te Soest (Baarn 1906) 14.

80. C.S. (pseudoniem voor C. Stams), Tegen vivisectie. Vermeerderd mel een gedicht van J. Blankenaar (Rotterdam 1895).

81. Vergl. Marjan Schwegman, Healing the gap between science and love. The religious experience of Maria Montessori. Paper presented at the project Varieties of Religious Experiences (New Brunswick 1997). Zic ook: Marjan Schwegman, Maria Montessori: 1870-1952. Kind van haar tijd, Vrouw van de wereld (Amsterdam 1999). Marjan Schwegman. 'leder ding op zijn eigen plaats'. Kennis en Methode: lijdschrift voor wetenschapsfilosofie en methodol(sgit' 17 (1993) 12-29. Stuar Hughes, Consciousness. Vergl. Remieg Aerts" bevoegde autoriteiten"

82. Piel Pyl (pseudoniem voor Pieter Pijl), Het Tweede Leven (Amsterdam 1916). 
Elf jaar later stelde de anti-vivisectionistische huisarts Lize Deutmann in het toenmalige orgaan van de NBBV, de Geillustreerde Dierenvriend: ' $\mathrm{Zij}$ [de vivisectoren] bestuderen het leven niet maar verkrachten het [... ${ }^{883}$ In 1937 stelde Deutmann in hetzelfde tijdschrift dat de vivisectie 'een verkrachting van de heilige wetten der liefde was'. ${ }^{\text {s }}$

Tegenover de materialistische, mannelijke wijze van kennis verwerven, stelden de antivivisectionisten vervolgens andere, geoorloofde manieren om 'wetend te worden'. Vaak werden deze juist met behulp van vrouwenfiguren uitgebeeld. Een voorbeeld is het verhaal over de Engelse anti-vivisectioniste Anna Kingsford, levensgezel van de eerder genoemde Edward Maitland die de oprichting van de NBBV op verzoek van Van der Hucht-Kerkhoven financieel ondersteunde. Kingsford, zo gaat het verhaal, was in haar jonge jaren een groot liefhebster van de jacht totdat zij op een dag bij de aanblik van een angstige vos voelde dat zij in wezen zelf het bedreigde dier was. ${ }^{85}$ Een en ander had tot gevolg dat Kingsford een geheel ander leven zou gaan leiden. Zij werd dierenbeschermster, vegetariër en anti-vivisectioniste. Znals Anna Kingsford zich inleefde in de gevoelens van de vos, zo identificeerde de romanheldin Anna van Bergen zich met de gevoelens van het mishandelde katje en later met het levensverhaal van haar vriendin Meta. Ook zij verkrijgt door identificatie een bepaald soort kennis. Zij wordt wetend en is daardoor in staat om op een andere, betere manier te leven. Haar 'weten' is wijsheid, een deugd die, zoals Warner laat zien, door de eeuwen heen met vrouwelijkheid is geassocieerd. ${ }^{86}$

In de anti-vivisectionistische geschriften werden vrouwen behalve als 'wijs', voorgesteld als personen die, meer dan mannen, de weg wisten naar een geoorloofde wijze om kennis te verwerven. Vrouwen zouden in staat zijn om de waarheid te vinden achter de door de positivisten als uitgangspunt genomen fysieke, zichtbare wereld. Beter dan wie ook waren zij in staat om de beperkingen van de liefdeloze en afstandelijke positivistische wereldbeschouwing aan te tonen. $\mathrm{Zo}$ is het de feeënkoningin Queen Mab die Frits van Westvoorne leert dat er meer bestaat dan alleen de zintuiglijk waarneembare wereld. De vrouw uit het gelijknamige gedicht van Shelley fungeerde Frits' hele leven als een gids. Hij droeg de bundel van Shelley ${ }^{87}$ altijd bij zich en was, zo vertelde hij een ieder die het horen wilde, om deze fee antimilitarist geworden. Om haar had hij tegen de wens van zijn vader het leger verlaten. Op het moment dat de jonge idealist meent dat dit alles voor niets is geweest en zijn bestaan 'verloren en onvruchtbaar voor de menschheid' is, verschijnt de fee. Zij die bezielde en geroepen had tot de strijd stond plotseling voor hem 'zoo schoon, zoo lieflijk, zoo etherisch ${ }^{\text {} 88}$.

De tovervrouw neemt Frits bij de hand en zet hem aan haar zijde in haar feeënwagen. Ze wijst hem erop dat de ontwikkeling van de mensheid een zeer langdurig en langzaam proces is. maar dat hij zijn aandeel daarin niet mag onderschatten. Om dit duidelijk te maken toont zij hem de genius der beschaving, een fakkeldragende vrouwenfiguur met een schoon en edel gelaat. Zij wijst Frits van Westvoorne en Queen Mab de weg door de duisternis en toont hun de barbaren der negentiende eeuw:

'Het waren allen afschuwelijke wezens, mannen en vrouwen, en hij [Frits] herinnerde zich dat

hij verscheidene van die wezens meer had aanschouwd, er vertrouwelijk mee had omgegaan.

83. Lize Deutmann, 'Vivisectie'. Geillustreerde Dierenvriend 5 (1937) 205

84. Geillustreerde Dierenvriend 5 (1937) 189.

85. Zie hierover: Janet Barkas. The vegetable passion. A history of the vegetarian state of mind (Londen 1975$) 84 \mathrm{c.v}$

86. Warner, Monuments, 223.

87. Zic: G. Dekker. Die invloed van Keals en Shelley in Nederland gedurende de negentiende eeuw (Groningen/Den Haag 1926).

88. Daal, Westvoorne. 232 
Vroeger had hij slechts den uiterlijke vorm gezien, waarin ze zich aan de wereld vertoonden, maar nu zag hij ze in hun gemoed. ${ }^{89}$

Frits ziet steeds afzichtelijker wezens, zielen en geesten, aan zich voorbij trekken. Allen dragen ze een naam op het voorhoofd: Geldzucht, Tyrannie, Aristocratie, Fanatisme, Macht der gewoonte, Materialisme, Conventionalisme, Traagheid, Bekrompenheid, Modezucht: 'booze geesten die met hun onreinen adem de maatschappij verpesten'. Het afschuwelijkste gedrocht dat Frits aanschouwt lijkt meer op een monster dan op een menselijk wezen. Het draagt de naam vivisectie:

'Hij was juist bezig een onschuldig dier levend te ontleden en de vreeselijkste folteringen te doen ondergaan. Daar trad de genius op hem toe en liet den vollen schijn van zijn fakkel op den arbeid des vivisectors vallen. Deze schrikte want zijn werk schuwde het licht, en eenige omstanders wendden zich ontzet van hem af en volgden den Genius. Eenige maar niet alle want Onrechtvaardigheid, Harteloosheid en Nieuwsgierigheid schaarden zich aan de zijde van den vivisector, die met een grijnslach den Genius aanzag en zijn werk voortzette',

Frits ziet hoe, terwijl de genius der beschaving op haar weg voortschrijdt, Domheid, Onwetendheid en Huichelarij, gekleed als priesters en luid biddend, haar de weg proberen te versperren totdat een andere vrouwengestalte met fakkel te hulp snelt. Tot opluchting van Frits draagt deze figuur de naam 'godsdienst' op het voorhoofd. Met vereende krachten vervolgen beschaving en godsdienst hun weg door de negentiende eeuw, telkens stuitend op onbegrip, onwil en angst voor de tiran, publieke opinie, geheten. Bij het zien van zoveel troosteloosheid meent Frits dat het kwaad voor altijd de overhand zal hebben.

Queen Mab troost hem. Zij wijst erop dat het aantal zwarte zielen gestaag afneemt. Steeds meer volgen beschaving en godsdienst. Frits ziet echter dat met de toename van het aantal lichtgestalten de strijd van de boze steeds hardnekkiger wordt. Op zeker moment meent hij zelfs te kunnen waarnemen dat beschaving en godsdienst terrein prijsgeven. Dan schiet een derde vrouwengestalte te hulp. Haar naam is de genius der rechtvaardigheid. Met de samenkomst van de drie vrouwen blijkt de strijd gestreden. De overwinning van het goede is een feit en voor Frits' ogen ontluikt een heerlijke wereld waarin oorlog en vivisectie verdwenen zijn. Frits meent dat dit alles op z'n minst een eeuw in beslag heett genomen maar de fairy queen corrigeert hem vriendelijk: 'niet honderd maar vele honderden jaren waren zij onderweg'.

Evenals Frits van Westvoorne wordt ook Pieter Pijl in Het Tweede Leven door een aan Queen Mab en de lichtgestalten verwante vrouwenfiguur, naar een betere, hogere en de materie overstijgende wereld begeleid:

'Zoo sprak een lichtend gestalte tot mij, in deze ure, die mij hemelsch werd,

Toen zij daar -ongezien door gewonen-

naast mij, zo zij aan zij

daar was gekomen

Toen kwam 't lichtend wezen nog meer naderbij,

en raakte me aan .....

En dan ..... doortrilde mij een Hemelsch Vuur,

want in ditzelfde zaal'ge uur

voeld' ik in mij het laatste van me gaan,

dat mij aan 'even van deez' wereld nog kon kluist'ren....

Een groote kracht steeg binnen in me op.

Een grooter macht dan alles wat ik kon

89. Daal, Westvoorne, 190.

90. Ibidem.

91. Ibidem. 
vervulde mij, .....

En verder door, steeds verder door ........

Steeg ik ter Hemelzon

[...]

En immer ijler schreed ik heen,

En liet alleen

geheel beneen

de wereld........dezen strik.'

Hoe verschrikkelijk het was om zelf in de materiële wereld gevangen te zijn had Pijl eerder geleerd en wel, door een aan Evangeline en Gemma verwant meisje. Als zij sterft, laat zij de held eenzaam en wanhopig achter in de 'waarnemingswereld':

'Nu is het donk're nacht

voor mij -die achterbleef.....

$\mathrm{Nu}$ is zij heen.....

Voor goed..... voor immer heen !

En ik -O, God ! -ik blijf......

Hier heel alleen beneên.'

De dood van het meisje roept bij de held het verlangen op om zelf op reis te gaan. Als hij inderdaad vertrekt, is het dit meisje dat hem later in de vorm van drie 'lichtgestalten' tot gids dient. Met een verwijzing naar Dante's Divina Conımedia heet dit meisje Beatrice.

In de Nederlandse anti-vivisectie-fictie is het stervende meisje als gids een bekend thema. Zo is het eerste hoofdstuk van de roman Naar het groote licht ${ }^{92}$ (1898) van Felix Ortt, eveneens aan het sterfbed van een meisje gewijd. De hoofdpersonen van de roman zijn een lichtzinnige student en zijn zusje 'zoo zacht, zoo zwak, met teere handjes en lichtblauwe oogen' ${ }^{93}$ Evenals Evangeline en Gemma is het zusje geen lang leven gegund. De jongeman beseft dit maar al te goed wanneer bekend wordt dat zij aan tering lijdt. Zijn hopeloosheid, verdriet en de wens om iets voor haar te betekenen, verliezen het evenwel van zijn verlangen naar zinnelijk genot. De jongeman kan het eenvoudigweg niet opbrengen om dagen lang bij het meisje te waken en verlaat haar voor een weekeinde om zich met zijn vrienden aan een 'kroegjool' over te geven. Terwijl hij zich overgeeft aan de roes sterft het zusje. Thuisgekomen had zijn familie hem met het dode meisje alleen gelaten.

'In het reine jongemeisjeskamertje, met zijn eenig zusje bewegingloos wit in de witte bloemen.

Hij had ineens een woeste lust gekregen de oogen nog eens open te doen, even maar, om eens

nog ze te zien zooals ze hem altijd hadden aangekeken, half lachend, half verwijtend in zijn pretmaken. Maar hij had niet gedurfd; hij had gevoeld de ontwijding van zijn kleverige wijnvingers aan het heilige donde gezichtje. ${ }^{94}$

De jongeman bekeert zich en gaat verder als een orthodox-protestant het leven door. Als hij als oude man sterft, komt zijn ziel tot bewustzijn: 'Zij zweefde naar deze en naar gene zijde, zonder gids, zonder doel'." Hoe aangenaam het zweven ook was toch vroeg de ziel zich af waar zij terechtgekomen was en waar Christus en de ziel van het zusje waren. Dit was de hemel niet zo realiseerde zij zich:

92. Felix Ort, Naar hel groote licht (eerste druk 1897. Almelo 1918)

93. Ort, Groole licht, 3.

94. Ihidem, 4.

95. Ibijem, 8. 
'O zusje, zusje... ik was niet waard je te zien. En in wanhoop voelde de Ziel branden het Licht buiten en branden het Licht binnen; overal helle glans, alles hel, hel...dat was niet de hemel..'t was de $\mathrm{Hel}^{\prime \prime 6}$

De jongeman had tijdens zijn leven de raad van zijn geestelijke leidsvrouw in de wind geslagen en werd gestraft. ${ }^{97}$ Hetzelfde overkomt de jonge zwarte vrouw Eidechse wier lotgevallen in 1932 in het verhaal Fatum ${ }^{98}$ door G. Buss, de Duitse hofdichter van de Nederlandsch Indische Bond tot Bestrijding der Vivisectie, werden beschreven. Eidechse is door haar stam voorbestemd om met het dorpshoofd te trouwen. Op een kwade dag ontmoet zij een paar blanke jagers in het oerwoud. Eén van hen geeft haar een kralenketting. Als het meisje verheugd naar het dorp terugkeert wordt zij ontboden door een wijze oude vrouw, de tovenares van de gemeenschap. Deze waarschuwt het meisje ernstig. Ga niet meer naar die blanke man. Hij zal jou alleen laten. De stam zal je verstoten als ze erachter komen. Je zult vluchten, de krokodillen zullen je onder water trekken en aan stukken scheuren, de maraboe zal zich verzadigen aan je ontwijde borsten. Hoewel geschrokken door de woorden van de ouwe vrouw, luistert Eidechse niet. Ze is ijdel, verlangt naar meer kado's en gaat op zoek naar de jager. Spoedig daarna eindigt haar leven op dezelfde gruwelijke wijze als de tovenares haar voorschilderde.

Anders dan de onfortuinlijke heldin uit Buss' verhaal krijgt de man uit Naar het groote licht een nieuwe kans. Op het toppunt van zijn wanhoop wordt zijn ziel gered door de aanraking van de ziel van het zusje. Zij tempert het brandende licht. Gelouterd door deze beroering reïncarneren zij. De ziel van de man keert terug op aarde als telg van een verarmde adellijke orthodox protestantse familie. Zijn leven raakt al spoedig nauw verbonden met de lotgevallen van twee jonge mensen die hij al sinds zijn jeugd kent: de feministe Marie Loving (de wedergeboren ziel van het zusje) en de arts Willem Dam waarmee zij getrouwd is. De eenzame, hardwerkende Frits brengt het echtpaar na zijn werk graag een bezoekje. Tijdens een van die avonden bemerkt hij tot zijn schrik dat zijn vrienden ruzie hebben. Niet snel daarna vertellen zij hem wat er aan de hand is. Willem wil zijn praktijk opzeggen en als vivisector in dienst treden van het Instituut Pasteur in Nederlandsch-Indië. Marie is het daar als anti-vivisectioniste niet mee eens. Ook al verdient haar man met zijn praktijk nauwelijks genoeg geld, zij is nog liever arm, dan dat zij haar echtgenoot naar Indië volgt in de wetenschap dat hij daar dagelijks dieren zal martelen. Frits begrijpt dat maar al te goed. Ook hij is tegen vivisectie. In een poging om Marie te hulp te schieten raakt hij met Willem over het onderwerp in discussie. Het gaat hem niet goed af. De medisch geschoolde Willem die zich als een enthousiaste 'gomelastieke bal' in het debat werpt, troeft hem telkens af. Hij legt Frits uit dat het lijden van proefdieren noodzakelijk is om het lijden van mensen uit de wereld te helpen. Frits kan daar naar zijn gevoel niets tegenin brengen. Dan spreekt Marie hem aan:

'Maar Frits, hoe is het mogelijk dat jij, die godsdienstig bent en je een christen noemt, dat jij kunt zeggen dat je in beginsel niet tegen vivisectie bent [...]. Stel je voor dat je bezig waart in een levend dier te snijden, dat je opkeek en Christus naast je stond; zou je hem in de oogen durven zien? Zou je werkelijk denken, dat hij, die zich de goede herder noemt, die zijn leven stelt voor zijn schapen, de daad zou goedkeuren? O, ik weet zeker dat je je diep schamen zoudt, en ik weet dat Christus zou zeggen: ben je een volgeling van mij? Durf je je noemen

96. Ort, Groote licht, 11.

97. Zie ook het sprookje van Anna Kingsford, Het land aan gene zijde van de zon ('s-Gravenhage 1895). Daarin wordt verhaald over drie jongemannen die het har van een prinses willen winnen. Daarvoor mocten zij een 'heldenreis' voltooien, ze moeten de wereld in. De prinses geeft hen een gids mee, een vogeltje, dat hen raad zal geven. Twee jongemannen slaan de raad in de lucht en eindigen jammerlijk. Een daarvan als vivisector. De jongeman die wel luister trouwt uiteindelijk met de prinses: 'wie dit leven leeft, geeft wijding aan zijn genje en aan de hoogste volkomenheid I...I paar hij de Goddelijkheid van den held'. Kingsford, Gene zijde, 20. Het werk werd vertaald door C.J. van der Hucht-Kerkhoven

98. G. Buss, 'Fatum'. Anti-Vivisectie. Driemaandelijksch lijdschrift van den Nederl-Ind. Bond lot Bestrijding der
Vivisectie 4 (1932) 148.150. 
naar mijn naam? Heb ik je dit geleerd? En dat hij je zou wegzenden, en 't dier zou opnemen in zijn armen en 't genezen met zijn wonder-macht. Hiermee is immers de vivisectie voor een Christen veroordeeld. Ik ben geen geleerde en weet niets van al die argumenten voor en tegen vivisectie [...] maar ik voel, ik weet even zeker, dat vivisectie verkeerd is [...]. ${ }^{99}$

Duidelijk is dat ook in Naar het groote licht het 'geoorloofde weten' aan een vrouwenfiguur wordt gekoppeld. Meer nog dan in Anna staat dit vrouwelijke voor een kennis die nauw samenhangt met, zo niet gelijkgesteld wordt aan, een geloof in het hogere. Marie's weten staat gelijk aan voelen, intuïtie en, zoals Ortt het aanduidt met haar achternaam (Loving), het vertrouwen in een allesomvattende liefde. Door dit geloof wordt Frits van Beers als het ware bevrijd uit de materiële wereld waarin de discussie met Willem over de vraag naar het nut hem gevangen houdt. Zo blijken Gemma, haar voorbeeld koningin Victoria, Meta, Marie Loving, Queen Mab, de tovenares uit het verhaal over Eidechse, en de vrouwenfiguren uit Het Tweede Leven allen aan elkaar verwant. $\mathrm{Zij}$ fungeren als gids naar het hogere en het goede, naar de geoorloofde en superieure kennis.

Behalve de hierboven beschreven allegorische vrouwenfiguren (Gemma, de stervende zusjes), etherische vrouwenfiguren (Queen $\mathrm{Mab}$ en de lichtgestalten), de Nieuwe Vrouwen (Anna, Eliegonda, Meta) en de vorstinnen (Victoria en nogmaals Queen Mab) was er nog een vrouwenfiguur die in de anti-vivisectionistische geschriften als gids naar het hogere werd beschreven. Het gaat om de figuur van de moeder die, zoals volgens Marianne Hirsch gebruikelijk was in veel door vrouwen geschreven negentiende-eeuwse romans, in het leven van de anti-vivisectionistische romanheldinnen juist de grote afwezige is. ${ }^{100}$

Aan het moederschap werden niet zelden de kwaliteiten heelheid, eenheid en onbegrensdheid toegeschreven:

'Ben ik jou of ben jij mij'? Alles is één, en één is alles. Je hart is het wereldhart en het rythme van het wereldgebeuren slaat in je polsen. Laten we gaan [...]. De Ruimte is ons en wij zijn de ruimte.' ${ }^{101}$

Dit zegt de figuur Moeder Bona. Zij is de gids of geestelijke leidsvrouw van Eli die, evenals Frits, symbool staat voor de vele malen gestorven en wedergeboren mens. Zijn lotgevallen staan centraal in de door Ortt zeer geprezen anti-vivisectie-roman Eli, waar zijt Gij? van Jo ZeegersClaessen. Het moederschap van Moeder Bona staat voor de eenheid van alles en fungeert als bemiddelaar tussen het individu en de Almachtige.

Buss zag eveneens een relatie tussen moederschap, goddelijkheid en onbegrensdheid:

'[moederschap is] een begrip van God zelf. [...] Wel spreken de menschen van een vaderland als een hoog doel .... als een deel van deze aarde, aan elke natie eigen, toch met menschelijke grenzen... maar een moeder is een zoo hoog iets, dat niet meer aan aardsche dingen doet denken.... daarvoor is het te heilig. Moederliefde is goddelijk in het heelal en onbegrensd. ${ }^{102}$

Ter illustratie van de materie overstijgende kracht van de moederliefde publiceerde Buss in 1932 het verhaal 'Mutterliebe' 103 waarin de lotgevallen van een jonge Javaanse marktvrouw centraal staan. De vrouw draagt dagelijks haar zuigeling in een selendang mee naar haar werk. Om zo snel mogelijk op de markt te zijn steekt zij, hoewel dit eigenlijk verboden is, zoals vele anderen dagelijks een spoorbrug over. Op een kwade dag gaat het mis. Geheel onverwacht ziet de vrouw

99. Ort, Groole licht, 150.

100. Zie: Marianne Hirsch. The mother/daughter plot. Narrative, psychoanalysis, feminism. (Indianapolis 1989). Zie ook: Schwegman, Prima donna. Vergl. Marina Warner. The absent mother, or Women against Women in the 'old wives ' rail (Hilversum 1991)

101. Jo Zeegers-Claessen, Eli, Waar zijt Gij ? De mensch, de maalschappij en haar loekomsl (Deventer 1937) 171

102. G. Buss, 'Feuilleton'. Anti-Vivisectie, Driemaandelijks tijdschrift van den Nederl. Ind. Bond lot Bestrijding de'r Vivisectie. 5 (1932) 74-76.

103. G. Buss, "Muterliebe', Anti-Vivisectie 5 (1932) 73-75, aldaar 74. Hei verhal is alkomstig uil Buss" bunulel Aus Heissen Zonen. 
de trein in volle snelheid op zich afkomen. Er is geen weg terug, naar geen enkele kant is ontsnapping mogelijk. De machinist hoort het afschuwelijke geluid van verbrijzelende botten en een schreeuw die slechts door Mutterschmerz kan worden voortgebracht. Als de trein eindelijk tot stilstand is gekomen ziet het treinpersoneel dat het onderlichaam van de vrouw volledig is verminkt. De lijdende moeder houdt desondanks ferm de selendang met haar kind vast. Zij heeft zich opgeofferd. Door zich languit voor de trein te werpen had zij een ultieme poging gedaan om haar kind te redden door het in een bundeltje buiten de spoorbrug te laten bungelen. Met wijd opengesperde ogen kijkt de vrouw de te hulp geschoten mannen aan. Haar blik is nog slechts met de wilskracht van een moeder bezield. Pas op het moment dat haar springlevende kindje wordt gered, verslapt haar greep en breken de ogen. Als verloste moeder stort zij in de diepte.

Niet alleen in romans maar ook in andersoortige anti-vivisectionistische geschriften waarvan vele door vrouwen werden geschreven, werd mede aan de hand van dit soort verwijzingen naar vrouwen en vrouwelijkheid, de eenheid van al het levende en niet-levende benadrukt. Ook werd op deze wijze een allesomvattende liefde, een bestendige relatie met het hogere en de bereidheid om offers te brengen gepropageerd. In Engeland was het Anna Kingsford die aanbood om in plaats van de door de fysiologen gebruikte dieren op de vivisectie-tafel te sterven. Zij wilde als een vrouwelijke Christus hun plaats innemen en de verlosser der dieren zijn. De NBBV stelde Kingsford in een welhaast hagiografische schets ten vourbeeld als ideale strijder tegen het kwaad. $^{104}$ Ook binnen de Nederlandse anti-vivisectie-beweging waren er vrouwen die zich binnen de eigen gelederen opwierpen als pleitbezorgsters van offervaardigheid. Eén van hen was Marie Jungius.

\section{Het vrouwelijke voorbeeld: eenheid en offervaardigheid}

In de jaren na haar opzienbarende optreden voor de Nationale Tentoonstelling van Vrouwenarbeid hield Marie Jungius vele lezingen in het land. Eén daarvan, getiteld 'Over de onbegrensdheid van ons meegevoel", hield zij in 1900 te Nijmegen, Rotterdam en Den Haag. De christen-anarchistische uitgeverij Chreestarchia, waarmee Felix Ortt zeer nauwe banden had, publiceerde de rede datzelfde jaar nog in een brochure. ${ }^{105}$ De NBBV zou menigmaal naar dit geschrift verwijzen daar de bond zich volledig met de inhoud kon verenigen.

In haar rede stelt Jungius dat mensen, dieren, planten en mineralen alle een onvernietigbaar deel, een ziel in zich droegen. $\mathrm{Zij}$ waren met andere woorden als zielsverwant aan te merken en daarom slechts in graad en niet in wezen verschillend. De aanvaarding van het bestaan van deze zielsverwantschap had als consequentie, zo meende Jungius, dat men niet langer kon uitgaan van het bestaan van grenzen tussen verschillende levensvormen. Zelfs de scheidingslijn tussen de organische en anorganische natuur vervaagde. Alles was één in oorsprong en ontwikkelingsgang. Het meegevoel met al het verwante kon daarom niet anders dan onbegrensd zijn.

Jungius was, als vele kunstenaars, schrijvers en humanitair-idealisten in haar tijd, geïnspireerd geraakt door oosterse, of met het Oosten geassocieerde, mystiek en religiositeit. Zij vertolkte naar haar zeggen slechts een lied dat eeuwen geleden was ontstaan uit de woorden van Boeddha: 'alle leven is verwant'. Het klonk, alsof het door 'een duizendstemmig koor' werd vertolkt. De aanvankelijk uit de intuïtie ontsproten wijsheid werd in de moderne tijd door verstand en wetenschap bevestigd. Het evolutionisme, dat volgens Jungius zo'n duidelijk stempel op haar tijd drukte, was immers bij uitstek een 'ontwikkelings- en eenheidstheorie':

104. Zie bijvoorbeeld: Suze Groshans. 'Pioniers in de strijd tegen vivisectie (bij de plaat): Anna Kingsford', Orgaan 13 (1916) 95-98.

105. Marie Jungius. Over de onhegrensdheid van ons meegevoel. Rede uitgesproken le Rollerdam, 's-Gravenhage en Nijmegen (Soest 1900). 
"iets is daar losstaand alles, alles in den innigsten samenhang, in een onophoudelijke huwing, vervloeiing, versmelting, vervorming. 'ins

De theosofie waarin de vereniging van wetenschappelijke inzichten, mystiek en oosterse wijsheid alsmede de eenheid en broederschap van al het levende centraal stonden, vormde voor Jungius ongetwijfeld een inspiratiebron. Verwonderlijk is dat niet. De theosofie en het antivivisectionisme waren lange tijd nauw met elkaar verbonden. Felix Ortt en Roorda van Eysinga hadden zich in het theosofisch gedachtengoed verdiept, Pijls Het Tweede Leven werd uitgegeven door de Theosofische Uitgeverij en op de ledenlijst van de NBBV stond de Nederlandse theosofische loge, Post Nubila Lux ${ }^{107}$, vermeld. De eerder genoemde Anna Kingsford was behalve een bekend anti-vivisectioniste ook een vooraanstaand lid van de theosofische beweging in Engeland. ${ }^{108}$

De theosofie was overigens ook in Nederland in veel bredere dan alleen de anti-vivisectionistische kring bekend. Jungius' rede past dan ook in het culturele klimaat van Nederland rond 1900 dat, zoals Remieg Aerts laat zien, gekenmerkt werd door een grote belangstelling voor begrippen als eenheid, heelheid en verzoening. Menig literator, kunstenaar, architect of denker voelde zich aangetrokken tot de theusofische wereldbeschouwing. ${ }^{109}$ Een goed voorbeeld is Frederik van Eeden die in 1890 te Londen de eerder genoemde Edward Maitland ontmoette. Van hem hoorde hij over de in 1888 overleden Kingsford. Van Eeden was, zoals Jan Fontijn schrijft, diep onder de indruk van deze vrouw die hij 'vrouwelijk geniaal'110 achtte. Niet voor niets schreef hij in 1895 een inleiding bij de vertaling van Kingsford's dissertatie over de voordelen van een vleesloze voeding. ${ }^{11}$ Daarin stelde Van Eeden dat het erom ging dat de mens toegaf aan zijn diepste gevoel van deernis. Medelijden werd naar zijn oordeel te vaak ondergeschikt gemaakt aan de zucht naar kennis, terwijl het zich juist diende uit te strekken tot aan de dieren toe. Van Eeden verwees in verband met dit laatste aspect naar de evolutietheorie van Darwin en Wallace. Had deze niet deze duidelijk gemaakt 'hoe verglijdend de grens tussen mens en dier was?' "'? De strekking van Jungius' rede was niet anders.

Geïnspireerd door het evolutionair denken stelde ook Jungius dat het gevoel van deernis voor al het levende uiteindelijk tot een ieder zou doordringen. Zij was ervan overtuigd dat de mensheid een morele of zedelijke evolutie doormaakte. Het zou gaan om een onomkeerbaar proces dat zich volgens een vooropgezet plan voltrok. Dat nam niet weg dat het individu in de morele evolutie een belangrijke rol speelde. Als deel van de maatschappij was hij verantwoordelijk voor alles wat er gebeurde. Gehoor gevend aan een innerlijke drang -die een ieder in meer of mindere mate in zich droeg- diende hij niets anders te doen dan te streven naar zelfverbetering, naar eenheid en heelheid. Evenals in haar toespraak over vivisectie voor de Nationale Tentoonstelling van Vrouwenarbeid wijdde Jungius in Over de onbegrensdheid van ons meegevoel geen woord aan de specifieke kwaliteiten van vrouwen in dit proces van zedelijke vervolmaking. Uit een aan haar denkbeelden gewijd artikel van Suze Groshans blijkt evenwel dat zij deze wel degelijk aan de vrouw toeschreef. ${ }^{113}$ Vrouwen hadden volgens haar een grote verbeeldingskracht en een sterk ontwikkeld gevoelsleven. Zij zouden daarom, beter dan mannen, in staat zijn om zich in anderen

106. Jungius, Onbegrensheid, 13

107. Zie: J.J. Poorman, 'De loge Post Nubila Lux'. Theosofia (mei 1937) 155-169. J.H. Dubbink. 'Een eeuw Theosofische organisaties in Nederland of een vrijwel vergeten stuk geschiedenis' Theosophia (juni 1981) 64-74.

108. Jaffe, Kingsiord, $58-64$

109. Romein, Breukvlak, 851. Remieg Acrts, 'Op zock naar een Nederlands fin de siècle', De Gids (1993) 91-102. Zie ook: Simone Godschalckx. De invloed van de theosofie op de Nederlandse letterkunde iussen 1880 en 1930 (Leuven 1982).

110. Fontipn, Tw'e'spult 1901, 292

111. Anna Kingsfords dissertatie was getiteld: The perfect way: A treatise advocating the return to the natural and ancien foud of our race. Werd in 1894 Nederlands vertald als De perfecte voeding

112. Fontijn. Tweespall 1901, 293.

i i? Suze Groshans. De lack van de vrouw bij de gemoedsontwikkeling ('s-Gravenhage 1914) 
te verplaatsen en offers te brengen. In die kwaliteiten was volgens Jungius tegelijkertijd hun zwakheid gelegen.

Het gevoel en de offervaardigheid van de vrouw konden al snel uitgroeien tot een ondeugd. Zo waren moeders niet zelden overdreven gericht op hun kinderen. Erger was het evenwel wanneer de vrouw met al haar deugden geen uitweg voor haar energie kon vinden en haar kwaliteiten niet kon inzetten voor serieuze werkzaamheden voor de samenleving. Daar energie en arbeidslust nooit verloren gingen, moest de vrouw deze dan wel aanwenden voor 'deze goede gave onwaardige arbeid'. Een dergelijke situatie die, zo schrijft Jungius, vaak voorkwam bij vrouwen uit gegoede kringen, kon fataal zijn. De energie kon zich omzetten in de vrouw zelf waardoor haar persoonlijkheid zich al naar gelang de omstandigheden ten kwade kon wijzigen.

De door Groshans beschreven denkbeelden van Jungius over het gevaar van ledigheid en gedwongen passiviteit dat vrouwen bedreigde, pasten in het debat over hysterie en krankzinnigheid onder vrouwen dat door medici, feministes en romanschrijvers werd gevoerd. ${ }^{1 / 4}$ Medici als $G$. Jelgersma en $C$. Winkler waren van mening dat krankzinnigheid en hysterie bij vrouwen veroorzaakt werden doordat $\mathrm{zij}$ in het openbaar optraden. 115 Feministes als Catharina van Tusschenbroek en Cécile Goekoop-de Jong van Beek en Donk meenden juist dat de oorzaak gezocht moest worden in de beperkingen die aan vrouwen werden opgelegd. Juist wanneer de vrouw zich kon ontwikkelen en arbeid kon verrichten zou zij, zo meenden de laatstgenoemden, gezond blijven. ${ }^{116}$

Jungius was het daar dus mee eens. Zij dacht echter niet uitsluitend aan arbeid in de zin van betaald werk. Jungius meende dat vooral werkzaamheden ten behoeve van de humanitairidealistische beweging, activiteiten voor de strijd tegen het kwaad, heilzaam waren voor vrouw en samenleving. De Nieuwe Vrouw diende geen andere macht te zoeken dan één die ten goede gebruikt kon worden, te streven naar zelfverwezenlijking, niet langs 'de platgetreden sombere wegen van zelfzucht, doch langs het steile maar uitzichtrijke pad van onderlinge verantwoordelijkheid". Vrouwen dienden elkaars leidsvrouw te zijn. ${ }^{117}$

Voor Marie Jungius vervulde Jeanne d'Arc de functie van gids. In haar werkkamer omringde zij zich met afbeeldingen die vooral naar de spirituele zijde van deze Franse heldin verwezen. Hoewel zij nergens in haar geschriften een direct verband legt tussen de Maagd van Orléans en haar eigen persoon, is het aannemelijk dat Jungius zichzelf naar deze historische en legendarische vrouw heeft gemodelleerd. Zeker is dat haar bewonderaars overeenkomsten zagen tussen de Franse 'strijdster voor God' en de anti-vivisectioniste. Zowel feministen (de jonge Ida Heijermans) ${ }^{118}$ als anti-vivisectionisten (Suze Groshans) beschreven haar als een jong meisje met blauwe kinderogen dat, bezield door een standvastig gelouf, naar voren trad en de strijd aanging. Suze Groshans vergeleek haar indirect met Jeanne d'Arc door Van Rees' reactie op Jungius' rede op de Nationale Tentoonstelling van Vrouwenarbeid als een bekering te beschrijven. Het jonge, tengere meisje had de grote belangrijke professor door haar bezielend geloof weten te kerstenen, evenals Jeanne d'Arc dit met een hele schare mannen had gedaan. Ook toen Jungius geestelijk en

114. Zie : Maarten van Buuren, 'Een barst waardoor het kwaad de ziel binnendringl. Hysterie en literatuur in de 190 eeuw'. De Revisor 6 (1991) 30-48. Te Velde. 'Tijd'. Ruth Weber, 'De medische wereld en de vrouw', De Negentiende Eeuw 6 (1982) 2-20. Elaine Showalter. The female malady. Women, madness, and English cullure, 1830-1980 (New York 1985).

115. Hector Treub en C. Winkler, De vroww en studie. Voordrachlen en dehalten gehouden in de vergaderingen win 3 maarl en 10 november 1898 voor de 'Vereeniging ler heharliging van de helangen der Vrouw' te Rolterdam (Haarlem 1898) 40-42. Zie ook: G. Jeigersma, Leerhoek der functionele neurosen (Amsterdam 1897) 34 116. Catharine van Tussenbroek. Over het tekort aan levensenergie bij onze jonge vrouwen en meisjes. Ride
uitgesproken op de Nationale Tentoonstelling van Vrouwenarheid (1898) 6.

117. Groshans, De Vrouw. 105. 118. Ida Heijermans. 'Marie Jungius 1 april 1864-22 december 1908' in: Verzen en sprookjes van Marie Jungius mel
voomword van Ida Heijernans (Huis ter Heide 1928) 5-10. 
lichamelijk instortte en jong stierf, werd dit door velen heschreven alsof zij haar leven had opgeofferd aan de strijd die zij voerde.

De beschrijvingen van Jungius' heldendom maakten deel uit van een veel bredere literaire traditie. Warner laat zien hoe schrijvers en kunstenaars rond 1900 Jeanne d'Arc als vrouwelijke heldin en verzinnebeelding van deugdzaamheid afschilderden. ${ }^{119} \mathrm{Zij}$ maakten van haar een onschuldig kind dat in nauw contact stond met de natuur. Juist die onschuld van een kind zou, zo stelt Warner, de Franse heldin een 'philosphical position of immense strength'120 en een spirituele kracht hebben geven. Als dit ergens duidelijk wordt dan is het wel in het werk van de beroemde Amerikaanse auteur en fervent anti-vivisectionist Mark Twain ${ }^{121}$ die haar beschreef als spiritueel strijdster in een door God verlaten wereld. ${ }^{122}$ Het is niet uitgesloten dat Jungius zich aan deze Jeanne d'Arc heeft gespiegeld.

Zeker is dat het beeld van Jeanne d'Arc als kind, als diep gelovige en deugdzame jonge vrouw en als maagd die, gezeten op een paard, tegen de gevestigde orde ingaat, grote overeenkomsten vertoont met het profiel van de Nieuwe Vrouw als ideale strijdster tegen vivisectie zoals dat Jungius voor ogen stond. Van vrouwen en anti-vivisectionisten verwachtte zij een standvastig geloof en offervaardigheid. Daarbij merkte zij op dat vrouwen nooit mochten zwichten voor mannelijke verstandsargumenten. Vrouwen moesten zich hoeden voor de mannelijke, positivistische vrees om belachelijk te schijnen wanneer men gevoel toont of iets nieuws wil proberen dat nog niet als wetenschappelijk gangbaar is geafficheerd. De vrouw moest een geheel mens worden, moest in voelen en handelen één zijn. Boven alles moest zij haar moederlijke eigenschappen inzetten ter bescherming van al het zwakkere en zich profileren als opvoedster van het toekomstig geslacht. Ook vrouwen die geen moeder waren konden hun moederlijke kwaliteiten inzetten. Jungius deed dat als onderwijzeres en dus als opvoedster van kinderen. Ook Anna Kingsford verwees naar het moederschap. In een van haar dromen, die nauwgezet door Maitland werden opgetekend, zag ze in een donker onderaards vivisectie-laboratorium dat de dieren waarvoor zij zich inzette plotseling in kinderen veranderden. ${ }^{123}$

De moeder als gids was niet alleen in fictie en dromen belangrijk. Dat kan onder meer uit de relatie tussen Van der Hucht-Kerkhoven en Jungius kan worden opgemaakt. ${ }^{124}$ Eerstgenoemde vertoonde volgens haar tijdgenoten een sterke overeenkomst met Meta uit De familie van Westvoorne en werd door velen als de moeder van de humanitair-idealistische beweging gezien. In Den Haag onderhield zij contacten met een grote groep idealisten waaronder antimilitaristen, spiritisten, vegetariërs en christen-anarchisten. Jungius kende zij door haar activiteiten in de Nederlandsche Kinderbond, een door Van der Hucht-Kerkhoven opgerichte organisatie die zich tot doel stelde om kinderen zachtheid, liefde en respect voor al het levende bij te brengen. ${ }^{125}$

119. Marina Warner, Joan of Arc. The image of female heroism (Londen 1991). Vergl.: Hedwig Röckelein, Charlotte Schoell-Glass en Marie E. Müller, Jeanne d'Arc, oder wie Geschichte eine Figur konstruien (Bazel/Wenen 1996). Zie over offervaardigheid als vrouwelijke kwaliteit: Jolande Withuis' 'de dubbele bodems van vrouwelijke opoffering', De Gids 158 (1995) 340-353. Zie ook: Annemieke Drenth, 'Over dienende liefde en zorgende macht. Sekse en sekseverhoudingen in historisch perspectief. Tijdschrift voor Vrouwenstudies 18 (1997) 322-336.

120. Wamer, Joan, 248.

121. Het anti-vivisectionisme van Mark Twain is terug te vinden in: Mark Twain. The horse's tale and the dog's tale (New York 1906). Deze verhalen werden in het Nederlands uitgegeven: De geschiedenis van een paard, gevolgd door de geschiedenis van een hond ("s-Gravenhage 1915).

122. Warner, Joan, 251.

123. Jaffé, Kingsford, 17-18

124. Zie over de wijze waarop het moederschap door Amerikaanse anti-vivisectionistes werd ingezet: Craig Buettinger, 'Women and antivivisection in late Nineteenth-Century America', Joumal of social history 30 (1997) 857-872.

12.5. De Nederlandsche Kinderbond stelde zich tot doel om bij ' de kinderen het volk der toekomst, rechtvaardiging en meegevoel aan te kweeken jegens al wat leeft, en ruwheid en baldadigheid tegen te gaan' (artikel 1 statuten van der Nederlandsche Kinderbond). Zie: Marie Jungius, De Nederlandsche Kinderbond en de eenheid van alle humanilaire stre'v'n. Toespraak op hel congres voor mautschappelijk werd van de Nationale Tentoonstelling van Vrouwenarbeid (Amsterdam 1899). De Nederlandsche Kinderbund. Gedenkboekje 1891-1931 ('s-Gravenhage 1931) en : M.J.A. Margadant-Van Arcken. Dierenjuf. Natuureducatie en de relatie tussen jonge kinderen en dieren (Utrecht 1990). 
In 1895 bood Van der Hucht-Kerkhoven Jungius een betrekking aan als particulier secretaresse. Dit stelde Jungius in staat om haar betrekking als onderwijzeres op te geven en zich volledig in te zetten voor feminisme, anti-vivisectionisme en de verbreiding en ontwikkeling van humanitaire opvattingen. De schrijfster van Anna en De familie van Westvoorne maakte Jungius, met andere woorden, vrij om zich geheel aan het uitdragen van haar idealen te kunnen wijden. Jungius kon voortaan zonder restricties haar expressieve politiek bedrijven en zelf het lichtend voorbeeld voor anderen zijn. Nadat Jungius in 1900 -volgens sommigen door deze zware taken- lichamelijk en geestelijk volledig was ingestort, koos Van der Hucht-Kerkhoven Felix Ortt om de fakkel over te nemen. Evenals Jungius werd hij aangesteld als secretaris. Hierdoor kon hij ontslag nemen als ingenieur bij Rijkswaterstaat, een betrekking die hij naar eigen zeggen niet langer kon verenigen met zijn christen-anarchistische idealen. Na haar overlijden in 1915 liet Van der Hucht-Kerkhoven aan Ortt een lijfrente na waarmee hij voor de rest van zijn leven in zijn levensonderhoud (en dat van zijn vriendin en drie kinderen) kon voorzien. Zijn werkzaamheden voor de NBBV en andere humanitair-idealistische organisaties kon hij op deze wijze ongestoord voortzetten. Ortt was toen al uitgegroeid tot de belangrijkste figuur binnen de Nederlandse anti-vivisectie-beweging.

Felix Ortt overkwam hetzelfde als Frits, de hoofdpersoon uit Van der Huchts De familie van Westvoorne. Deze idealistische jongeman gaf, gestimuleerd door Shelley's Queen Mab, zijn carrière in het leger op omdat hij zich niet langer met een dergelijk oorlogszuchtig beroep kon verenigen. Na enige tijd in armoede te hebben geleefd, werd hij geholpen door een oude, blinde, gefortuneerde man die met zijn idealen sympathiseert. Het lijkt niet toevallig dat de hoofdpersoon van Ortts deels autobiografische roman Naar het groote licht, eveneens een betrekking als ingenieur heeft opgegeven. Wellicht is het zelfs nog veelzeggender dat hij hem, evenals de hoofdpersoon uit Van der Huchts roman 'Frits', heeft genoemd.

De idee van een 'geestelijke leidsvrouw' werd zowel in de 'werkelijkheid' als in fictie vormgegeven en ingezet voor de strijd tegen vivisectie. De kinderlijke, maagdelijke, stralende en strijdvaardige Jungius (gemodelleerd naar Jeanne d'Arc, maar ook een onderwijzeres en daarmee een moederlijke opvoedster), de moederlijke wijze, oude weduwe Van der Hucht-Kerkhoven (die zoveel op de figuur van Meta zou hebben geleken), de jonge idealistische ingenieur Felix Ortt (die zoveel overeenkomsten vertoont met de uitverkorenen van Queen Mab) en de wijze, zusterlijke Suze Groshans (die de denkbeelden en handelingen van haar vriendin Jungius steeds in herinnering bracht), alle vier droegen zij de boodschap uit dat de ideale anti-vivisectionist bereid moet zijn om zijn gehele leven voor de strijd in te zetten en zelfs te sterven indien dit noodzakelijk was.

De strekking van Jungius' rede tijdens de Nationale Tentoonstelling van Vrouwenarbeid was dat men bereid moest zijn om op vivisectie gebaseerde geneesmiddelen af te slaan. De weigering van een genezing met behulp van zulke middelen bleek ook voor latere anti-vivisectionisten van belang. Bij het overlijden van Pieter Pijl in 1938 werd bijvoorbeeld nadrukkelijk vermeld dat deze arts een op vivisectie gebaseerd medicijn had geweigerd. ${ }^{126}$ Evenals Jungius zou hij van mening zijn geweest dat gezondheid en genot niet vergaard dienden te worden ten koste van het lijden van duizenden 'doorpriemde en doorregen' dieren. Koos men daar wel voor dan getuigde dit van eigendunk, de 'verachtelijkste menselijke neiging'. De enige juiste weg was het persoonlijke offer dat door het desbetreffende individu werd gebracht vanuit het besef van de eenheid van al het levende en een diep doorvoeld medelijden. Dit gold volgens Jungius zowel voor vrouwen als voor mannen:

'Zijn er onder ons geen vader zoowel als moedernaturen. In de ware liefde, het blijde offer is geslacht noch tijd, zij kent geen andere eenheid meer dan die van het goddelijke, de tegenstellingen zijn opgelost. ${ }^{127}$

126. 'Pieter Pijl', Meededeelingen 7 (1938) 3.

127. Groshans, Vrouw, 105. 
Vrouwen en de expressieve politiek

Het Nederlandse anti-vivisectionisme was nauw verstrengeld met een feminisme dat het denken in termen van verschillen en het denken in termen van gelijkheid tussen mannen en vrouwen in zich verenigde. Voor Jungius en Groshans was het onderscheid tussen de seksen zowel complementair als overbrugbaar en aan verandering onderhevig. Bovendien was de NBBV door de veelzijdige activiteiten van haar leiders Van der Hucht-Kerkhoven, Felix Ortt, Marie Jungius en Suze Groshans, verbonden met andere humanitair-idealistische organisaties die uiteindelijk eerder de 'Nieuwe Mensch' en veel minder de Nieuwe Vrouw centraal stelden.

Dit wil niet zeggen dat vrouwen en de opvattingen over vrouwelijkheid voor het Nederlandse protest tegen vivisectie onbelangrijk waren. Deze denkbeelden en voorstellingen slechts te beschouwen als onderdeel van een conservatief feminisme of een al dan niet bewust gevoerde strijd tegen de onderdrukking van de vrouw zou onjuist zijn. Een bredere benadering is noodzakelijk om de diversiteit aan ideeën over vrouwen en vrouwelijkheid die binnen het protest tegen vivisectie van betekenis waren, tot haar recht te laten komen. Zo is de analyse van fictie onontbeerlijk om inzicht te krijgen in de wijze waarop een rol speelden vrouwen en vrouwelijkheid in de werkelijkheid van de NBBV. Dat Marie Jungius en Van der Hucht-Kerkhoven naar buiten traden door zich als leidsvrouwen te presenteren wordt althans begrijpelijker wanneer we weten dat de vrouwelijke gids in de anti-vivisectie-romans een sleutelfiguur was. Met andere woorden de analyse van romans, gedichten en korte verhalen geeft inzicht in de wijze waarop vrouwen en het denken over vrouwelijkheid de anti-vivisectionistische politieke stijl mede vormgaven.

Over die politieke stijl werd duidelijk dat fictie als een wapen in de strijd tegen vivisectie werd ingezet. De anti-vivisectionisten deden dit in een tijd waarin, zoals ondermeer door Mary Poovey is beschreven, de roman ook meer in het algemeen als strijdmiddel in opkomst was. ${ }^{128}$ Rond 1900 werden veel tendensromans geschreven, romans waarin de beschrijving en oplossing van maatschappelijke vraagstukken centraal stonden. Dit type romans werd vaak geassocieerd met vrouwen. Dat ook de anti-vivisectionisten zich van dit strijdmiddel bedienden, maakt de contemporaine kritiek dat anti-vivisectie een vrouwenzaak was, begrijpelijker. In het volgende hoofdstuk zal echter duidelijk worden dat het niet alleen vrouwen waren die de kracht van de verbeelding exploreerden. 


\section{Fantasie als voertuig en obstakel 1903: Cursus over Vivisectie}

In de winter van 1902/1903 gaf Felix Ortt voor de 'afdeeling Amsterdam' van de NBBV een aantal lessen over de bestrijding van dierproeven. Zijn Cursus over vivisectiel was bedoeld om de leden van de NBBV te leren zich met 'waardigheid', 'waarachtigheid', 'zelfvertrouwen' en 'bedachtzaamheid' tegen 'de aanvallen van de voorstanders van vivisectie' te verdedigen. De vivisectie moest 'met kracht van argumenten' en op 'wetenschappelijke wijze' bestreden worden. Dit hield volgens Ortt in dat bij de beschrijving van vivisecties in de door de NBBV uitgegeven geschriften, uitsluitend uit medisch-wetenschappelijke tijdschriften werd geciteerd en steeds een degelijke bronvermelding werd gegeven. Indien men zich aan deze richtlijnen hield konden de anti-vivisectionisten nooit van overdrijving of onwetenschappelijkheid beticht worden. Zij haalden immers uitsluitend woorden van de medici zelf aan.

Volgens Ortt hadden de anti-vivisectionisten dit alles, vooral in de eerste jaren van het bestaan van de NBBV, ten onrechte achterwege gelaten. Vivisectie-bestrijders waren vaak niet goed geïnformeerd, te emotioneel en 'onhoffelijk'. Daar zij zich door fantasie en verbeelding lieten leiden, hadden zij de vivisectoren ten onrechte als gewetenloze monsters afgeschilderd. Hierdoor was het anti-vivisectionisme naar het oordeel van Ortt veel schade berokkend. ${ }^{2}$

Ortt sprak uit ondervinding. In een van zijn eerste anti-vivisectie-brochures, Is de vivisectie in

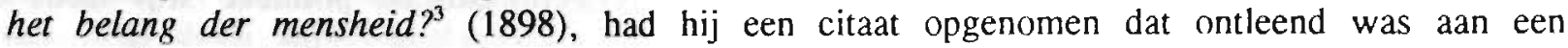
verzameling aanhalingen die door een bekende Engelse anti-vivisectionist was bewerkt. Ortt had de passage overgenomen zonder deze zelf in het British Medical Journal op te hebben gezocht. Na publicatie volgde direct een aanval van de redactie van het Nederlandsch Tijdschrift voor Geneeskunde. Het stuk zou volkomen uit zijn verband zijn gerukt. Tot zijn schrik werd Ortt, net een jaar voorzitter van de NBBV, beschuldigd van tendentieus citeren. Bij bestudering van de oorspronkelijke tekst bleken zijn tegenstanders gelijk te hebben. ${ }^{4}$ Ortt zag zich genoodzaakt om zijn ongelijk te bekennen en de passage uit alle brochures te laten schrappen. Deze blamerende gebeurtenis maakte hem zeer alert en deed hem beseffen dat de strijd tegen vivisectie alleen kon worden gevoerd door feiten boven tafel te halen. Bewijzen moesten worden geleverd, statistieken geproduceerd en in plaats van emotionele statements dienden logische redeneringen te worden gepresenteerd. Van dit alles probeerde Ortt de NBBV te voorzien. Na het herstel van zijn fout ging hij prat op zijn betrouwbaarheid, de nauwkeurige wijze waarop hij de bronnen die hij aanhaalde, natrok en de manier waarop de door hem gebezigde begrippen minutieus werden omschreven, zodat iedere twijfel over de betekenis ervan werd uitgesloten.

Het is dan ook niet verwonderlijk dat hij zich zeer voldaan voelde toen R.P. van Calcar, medisch hoogleraar, voorstander van vivisectie en lid van de Commissie inzake Vivisectie, hem tijdens de hoorzitting van 1908 het volgende compliment maakte over het door hem vervaardigde en door de NBBV uitgegeven werk Verdediging van Ons Standpunt', een bewerking van zijn Cursus over vivisectie:

1. Felix Ort, Cursus over Vivisectie (z.p. 1903).

2. Alle in deze alinea gebezigde citaten zijn te vinden in Ort. Cursus, 4-6.

3. Felix Ort, Is de vivisectie in het belang der menscheid ('s-Gravenhage 1898)

4. Ort beweerde in de brochure dat proeven op mensen door gezaghebbende medici werden gerechtvaardigd. Hij haalde de redevoering van de Engelse chirurg John Lister aan. Lister zou voor een internationaal medisch congres in Berlijn gezegd hebben: 'Ik heb het niet gewaagd om het experiment op grote schal te maken, hoewel ik dit lang in overweging nam. Het is een ernstige zaak om op levende lichamen onzer medemenschen te experimenteeren maar ik geloof dat de tijd nu aangebroken is waarop het beproefd mag worden'. Toen Ortt het oorspronkelijke cital in het British Medical Journal (16 augustus 1890) 379, opzocht. bleek het dat het Lister ging om het verschil tussen aseptische en antiseptische wondbehandeling. Hij vroeg zich af of hij zijn patiënten met de aseptische wondbehandeling moest gaan behandelen omdat dit door velen werd aanbevolen. Van verschrikkelijke proeven op mensen was geen sprake.

5. Felix Ort, Verdediging van ons standpunt door Felix Orll (z.p. 1905). 
'Ik heb Uw boek met belangstelling gelezen. Eenige beginselen der serum-therapie zijn daarin zoo helder uiteengezet, als menig medicus niet zou vermogen. ${ }^{6}$

De hoogleraar voegde hier aan toe dat Ortt beter op de hoogte was van de immuniteitsleer dan vele medici. Deze opmerking deed Ortts medestanders veel plezier. De lof van een medisch geschoolde tegenstrever beschouwden zij als een eerbetoon aan de eerlijke, op feiten gebaseerde strijdwijze die in de Cursus over vivisectie uit de doeken was gedaan. Voortaan werd de wijze van vivisectie-bestrijding die door Ortt werd voorgestaan door de NBBV als standaard genomen. Ortts lessen zouden tot 1927 toe, telkens in geactualiseerde en uitgebreide herdruk, worden gepubliceerd. ${ }^{7}$ Op deze wijze drukte hij zijn stempel op de strijdwijze van de NBBV.

Wanneer nogmaals naar Ortts lessen wordt gekeken dan valt op dat hij in zijn Cursus over vivisectie het emotionele, fantastische element in de strijd tegen vivisectie dat, zoals in het vorige hoofdstuk uiteen werd gezet, in het anti-vivisectionisme van vrouwen zo belangrijk was, regelrecht afwees. Dit is opmerkelijk aangezien Ortt met Naar het groote licht zelf een belangrijke antivivisectie-roman had geschreven. Even merkwaardig is het dat zijn kritiek op de vivisectiebestrijders van het eerste uur, waaronder Van Manen-Thesing, Van der Hucht-Kerkhoven, Roorda van Eysinga en Hugenholtz, sterke overeenkomsten vertoont met de argumentatie waarmee de contemporaine kritiek de anti-vivisectionisten veroordeelde. Zeker door de verwijzing naar het 'onhoffelijk gedrag', de 'waardigheid' en de 'bedaardheid' lijkt het erop alsof Ortt van mening was dat een aantal van zijn collega-anti-vivisectionisten zich te slap en onmannelijk opstelden. Hoe het ook zij, het is duidelijk dat Ortt de wijze waarop het vivisectie-vraagstuk tot dan toe zichtbaar was gemaakt, wilde veranderen en dat hij zich verzette tegen een strijdwijze die vooral door vrouwen werd gehanteerd en met vrouwen werd geassocieerd. De vraag komt dan ook op of zijn streven gevolgen had voor de politieke stijl van de anti-vivisectionisten en in het bijzonder voor de rol die vrouwen daarin in speelden. Wat gebeurde er binnen het Nederlandse anti-vivisectionisme met fictie en fantasie? Hoe verging het de vrouwen die zich van deze strijdmiddelen bedienden? En wat gebeurde er met de idee van de vrouw als gids en ideale strijdster tegen het kwaad, dat mede in anti-vivisectie-romans was vormgegeven? Om deze vragen te kunnen beantwoorden wordt in dit hoofdstuk over de verbeelding van het vivisectie-vraagstuk allereerst gekeken naar de opvattingen die er binnen de NBBV over de werking van fictie bestonden. Daarna wordt aangegeven of, en zo ja in welk opzicht, Ortts 'wetenschappelijke' en 'waardige' beeld van de vivisectie, de vivisector en het proefdier verschilde van de emotionele beschrijvingen die hij door middel van zijn cursus probeerde te bestrijden.

\section{De verbeelding als brug}

In het vorige hoofdstuk werd beschreven dat Ernst Grysanovski, de beschermeling van MarieEspérance von Schwartz, de roman Gemma vooral geschikt achtte om tot 'het hart' van vrouwen te spreken en hoe hij met zijn eigen wetenschappelijk gefundeerd en filosofisch essay vooral 'het hoofd' wilde bereiken van ac'ademici en mesici. Jaren voordat Ortt zich over de kwestie uitsprak, werd de meer emotionele vivisectie-bestrijding en de daarbij behorende anti-vivisectie-fictie dus met vrouwen geassocieerd en onderscheiden van een meer wetenschappelijke benadering. Anders dan voor Ortt was de fantasie naar het oordeel van Grysanovski zeker niet de grillige, gevaarlijke of minderwaardige zijde van de strijd die ook hij op zijn manier wilde voeren. De verbeelding was in zijn visie eerder complementair aan een meer wetenschappelijke benadering.

Ortt dacht daar dus anders over. Daarbij mag niet uit het oog worden verloren dat de door hem aanbevolen 'wetenschappelijke vivisectie-bestrijding', in het bijzonder zijn voorkeur voor het citeren uit medische geschriften, niet zo nieuw en zo typerend voor het Nederlandse antivivisectionisme was als hij deed voorkomen. Jungius was eveneens op het idee gekomen en ook zij was niet de eerste. Het gebruik van citaten uit medisch-wetenschappelijke werken maakt al

6. Rappon Commissie inzake Vivisectie (z.p. 1909) bijlage II, 47

7. Felix Ortt, Ons Standpunt Verdedigd door Felix Ort (Haarlem 1920). Idem. (Haarlem 1927). 
vanaf het begin van de geschiedenis van de binnen- en buitenlandse anti-vivisectie-beweging deel uit van de strijd tegen dierproeven. Zelfs in romans werd vaak op deze manier gewerkt. Illustratief zijn Anna en Gemma waarin met annotatie en al citaten werden gegeven die zo afkomstig leken te zijn uit werkelijk bestaande fysiologische geschriften.

Achter dit gebruik van dergelijke passages ging een bepaalde gedachte over de kracht van wetenschappelijke teksten schuil. Neem de belevenissen van Gemma. Zij wordt geconfronteerd met een tekst van de fysioloog Dr. Béclard, een medisch-fysiologisch rapport waarin proeven op levende dieren gedetailleerd en afstandelijk worden beschreven:

' $\mathrm{Bij}$ de hond kan men bijv. het afvoerkanaal der oorspeekselklieren onder de kauwspier blootleggen; men snijdt het kanaal bij A door, brengt in het gedeelte dat naar de klier is toegekeerd een zilveren sonde en bevestigt aan het einde van deze laatste een klein caoutchouc zakje dat de uitvloeiende stoffen moet opvangen. Wil men een fistel vormen bij het afvoerkanaal der onderkaakspieren (Ductus Whartonianus), dan snijdt men dit kanaal bij punt $\mathrm{R}$ door en handelt verder als hierboven."

En even later:

'Wanneer men een nuchter paard door een wond in de slokdarm een ons alcoholisch extract van braknoot of een drachme zwavelzure strychnine in de maag spuit, sterft het dier binnen een kwartier onder de ware strychnine-stuiptrekkingen. ${ }^{8}$

Gemma is geschokt door het opgetekende lichamelijke leed. Zij komt direct daarop tot het besef dat de wereld waarover zij leest deel uitmaakt van de wereld waarin zij zichzelf bevindt en besluit haar leven in dienst te stellen van de strijd tegen vivisectie.

De tekst die Gemma leest oefent dus invloed uit op haar denken, voelen en handelen. Gemma's lezing van de studie van Dr. Béclard past daarmee in een traditie die volgens Thomas W. Laqueur haar oorsprong vond in de achttiende eeuw. ${ }^{9}$ In die periode zou een nieuw soort vertellingen zijn ontstaan die door Laqueur worden aangeduid als humanitarian narratives. ${ }^{10}$ Het ging daarbij om teksten waarin aan de hand van een beschrijving van een dood of door pijn geteisterd lichaam verslag werd gedaan van het lijden van gewone mensen. Daarbij werd een zo sterk mogelijk reality effect nagestreefd. Om dit te bewerkstelligen richtten de auteurs ervan zich -volgens Laqueur als onmiskenbare kinderen van de wetenschappelijke revolutie- vooral op de gedetailleerde beschrijving van observaties. $\mathrm{Zij}$ boden het publiek een overvloed aan feiten in de hoop het ervan te doordringen dat hier niets meer of minder dan een nauwkeurig verslag van de werkelijkheid werd gegeven.

Op deze wijze probeerden de auteurs bij de lezers medelijden of in ieder geval een gevoel van betrokkenheid bij het beschreven leed op te roepen. Maar dit was niet hun enige oogmerk. Het was tevens de bedoeling dat het publiek door het lezen van de tekst uiteindelijk tot de overtuiging kwam dat het leed deel uitmaakte van en in causaal verband stond met de eigen realiteit. "De lezer moest zich deel voelen van de beschreven gebeurtenissen en ervan overtuigd raken dat hij deze zou kunnen beïnvloeden. Uiteindelijk was het de bedoeling dat hij werd overgehaald om door middel van een in de tekst aangedragen strategie daadwerkelijk tegen het beschreven leed in actie te komen:

Ameliorative action is represented as possible, effective and therefore morally imperative. Someone or something did something that caused pain, suffering or death, and that could under certain circumstances, have been avoided or mitigated. $|\ldots|$ the humanitarian narrative describes particular suffering and offers a model for the precise social action. ${ }^{12}$

8. Citaten afkomstig uit: Elpis Melena, Gemma, 58.

9. T.W. Laqueur. 'Bodies, details and the humanitarian narrative' in: Lynn Hunt cd., The New Cullural History (Berkely/ Los Angeles/ Londen 1989) 176-204. aldaar 177.

10. Ibidem.

11. Ibidem.

12. Ibidem, 178. 
Laqueur rekent verschillende soorten teksten tot de humanitarian narratives. Eén daarvan, de roman, wordt door hem omschreven als "the most self-conscious ${ }^{\prime 13}$ daar de auteurs van dit soort teksten zich het duidelijkst bewust waren van de kracht van de door hen gekozen literaire strategieën. Zij waren er op uit om met behulp van de beschrijving van het lijdende lichaam medelijden op te roepen en zodoende tot actie aan te sporen. Non-fictionele teksten, zoals de wetenschappelijke teksten waar Ortt gebruik van maakte en de door Gemma gelezen tekst van Dr. Béclard, waren in dit opzicht minder zelfbewust. Zij hadden meestal niet tot doel om medelijden op te roepen maar konden desondanks eenzelfde effect teweegbrengen wanneer zij werden gebruikt om tot actie aan te zetten. Laqueur ziet een parallel tussen romans en medische verslagen:

'In both novels and medical reports, the reader is asked to sympathize with, to feel vicariously through the body of the patient/protagonist.' 14

Ook al was de verhandeling van Dr. Béclard beslist niet met dit oogmerk geschreven, de werking die er vanuit ging was voldoende om bij Gemma bepaalde gevoelens op te wekken en haar tot actie aan te zetten. Het lichaam (in dit geval dat van een hond en dat van een paard) blijkt een doeltreffende brug tussen de tekst en het gemoed van de lezeres en is, in Laqueurs woorden, een effectief imaginative vehicle. ${ }^{\text {is }}$

Voor Gemma mocht het lezen van een wetenschappelijke tekst dan voldoende zijn om antivivisectionist te worden, voor de lezers die Von Schwartz wilde bereiken was dat waarschijnlijk niet zo. Von Schwartz moet beseft hebben dat medelijden met dieren beslist nog niet zo vanzelfsprekend was als het meevoelen met mensen. Haar publiek zou zich zeker niet zonder meer met het lijden van een dier vereenzelvigen. De door haar bewonderde Beecher Stowe had met eenzelfde probleem gekampt. In een tijd waarin zwarten niet of nauwelijks als volwaardige mensen werden gezien wilde zij haar publiek ervan doordringen dat zwarten geen vreemde exotische wezens waren die zich, zoals eeuwenlang was aangenomen, in het ontwikkelingsstadium tussen dier en mens bevonden. De schrijfster van Uncle Tom's Cabin loste dit probleem op door de slaven in het verhaal twee in de westerse wereld zeer bekende en gewaardeerde eigenschappen toe te kennen. In haar roman kreeg hun christelijk geloof en hun sterke familieband een zwaar accent. Dit alles diende, volgens Sternberger, om: 'den Lesern, den Weißen in aller Welt zu demonstrieren: solche Menschen gibt es unter Sklaven !'16 Laqueur is het met hem eens:

'I do not want to claim that [humanitarian] narratives of the sort I have just described are the only means of arousing compassion or action. In Harriet Beecher Stowe's Uncle Tom's Cabin. for example, the breakup of the slave family, far more than the slave's lacerated back, is the imaginative vehicle for abolitionist sentiment. ${ }^{17}$

Dit gaat ook op voor Gemma. In deze roman zijn het Gemma's vroomheid en weerloosheid die een brug vormen tussen het proefdier waar de roman voor opkomt en de lezer die tot actie moet worden aangezet. Om de overeenkomsten tussen Gemma en het weerloze aan vivisectie onderworpen dier te laten zien, wordt het proefdier geïndividualiseerd en gepsychologiseerd. Zo wordt Gemma's hond Roy beschreven als een individu met een naam en specifieke karaktereigenschappen:

'Roy [... had zich gedurende de vijf levensjaren, welke hij thans telde, flink ontwikkeld. Hoewel Dr. Farnham niets dan schoppen en scheldwoorden voor den trouwen hond over had.

13. Zie over de overeenkomsten tussen (medisch-) wetenschappelijke teksten en fictie in de achttiende en negentiende ecuw: Ludmilla Jordanova ed., Languages of nature. Critical essays on science and literature (Londen 1986). En Gillian Beer. Darwin's Plots. Evolutionary narrative in Darwin, George Elliol and nineteenth century fiction (Londen 1983).

14. Laqueur, 'Bodies', 183.

15. Laqueur, 'Bodies', passim.

16. Sternberger, Panorama, 66.

17. Laqueur, 'Bodies', 179. 
zoo betoonde het verstandige dier hem toch bij elke gelegenheid den eerbied die hij aan den heer des huizes verschuldigd was. ${ }^{18}$

De vermenselijking van Roy en de weerloosheid van Gemma boden het publiek de mogelijkheid om zich met het dier te identificeren. Zo fungeerde Gemma voor de lezers als gids in de hel der onschuldigen. Zoals ze zelf eens door de schok van het lezen van het geschrift van Béclard die onbekende wereld werd ingeslingerd, zo werden ook de lezers van de roman daarin binnengeleid.

Het thema van een reis door de hel der onschuldigen en de gids die de lezer het daar aanwezige kwaad van de vivisectie laat zien, stond niet alleen in anti-vivisectie-romans centraal maar ook in andere anti-vivisectionistische geschriften. ${ }^{19}$ Een goed voorbeeld is de in het Nederlands onder de titel Wetenschappelijk onderzoek aan de binnenzijde bekeken verschenen, oorspronkelijk Engelse brochure van Stephen Smith, uitgegeven door de NBBV. ${ }^{20}$ Zoals Von Schwartz haar lezers trakteerde op een passage uit het geschrift van Dr. Béclard, zo neemt Smith zijn lezers mee naar in werkelijkheid bestaande laboratoria en instellingen. Dat hij zichzelf als een gids beschouwt, blijkt uit de volgende passage:

'Wie nog nooit te voren een dronken man zag, is geschokt en ontzet door dit gezicht. Juist zoo is het met de verhouding van den man der wetenschap en den leek ten opzichte van proeven op levende dieren. Een gewoon mensch zou huiveren bij de gedachte een physiologisch instituut binnen te gaan [...] hij is er niet aan gewend [...]. Laat mij mijn lezers in het physiologisch instituut binnenleiden. ${ }^{21}$

Smith neemt de lezers bij de hand en beschrijft uitgebreid de wijze waarop het instituut er aan de binnenzijde uitziet. Hij opent deuren en vertelt wat daar achter te zien is, verhaalt over de mensen die hij op zijn weg tegenkomt, hoe zij eruit zien en hoe zij spreken. Ook de vivisecties die hij aanschouwt, worden gedetailleerd weergegeven. Smith geeft, alsof hij zelf een wetenschappelijk verslag geeft, precies aan wat gebeurde, wat hij daar als toeschouwer bij voelde, wat de reacties van de andere aanwezigen waren en hoe lang de proef duurde. Zijn brochure bevat ook illustraties van opengesneden kikvorsen, honden, en konijnen. Het zijn gekleurde pentekeningen die de indruk wekken zo uit een fysiologisch studieboek te zijn overgenomen. Smith geeft een ooggetuigeverslag maar heeft aan hetgeen hij aanschouwt niet genoeg. Hij neemt zijn toevlucht tot de verbeelding en vermengt zijn verslag met fictieve dialogen:

'vrager: Is het goed om een roodgloeiend stuk metaal op de huid van een kind te brengen zonder het gevoelloos te maken?

chirurg: (met spottende glimlach) de pijn heeft niets te beduiden. Alleen een vrouw of een ziekelijke humanitariër zou die vraag ter sprake kunnen brengen.

vrager: nu, hier is zoo'n cauterisatie-apparaat. [...] Laat mij het een seconde op uw vel houden.

chirurg:(haastig met veranderde gezichtsuitdrukking): neen, volstrekt niet.

vrager: maar ik meende dat u zeide dat het niets te beduiden had?

chirurg: Als u het goed vindt.... zouden we niet liever over wat anders praten?'22

Evenals dit bij Grysanovski en Von Schwartz het geval was, lag aan Smiths vermenging van een wetenschappelijk verslag met fictie, een bepaalde visie op de interactie tussen publiek en tekst ten grondslag. Smith is daar heel duidelijk over. Het zo nauwkeurig mogelijk weergeven van hetgeen er gebeurt, is noodzakelijk opdat de lezers zich een 'zelfstandig oordeel vormen'. ${ }^{23}$ Dit is zonder

18. Elpis Melena. Gemma, 19-20.

19. Het in de inleiding genoemde gedicht Vivisectie (1870) is daar een goed voorbeeld van. Hetzelfde geldt voor het in het vorige hoofdstuk genoemde Verborgene Gräuel van Hermann Stenz. 20. Stephen Smith. Wetenschappelijk onderzoek aan de binnenzijde bekeken (z.p. 1902). Een veraling van Scientific
research: a view from within.

21. Smith. Wetenschappelijk onderzoek, 10.

22. Ibidem. 56

23. Ibidem, 10. 
fantasie en emotie niet mogelijk. 'Zonder verbeeldingskracht, zonder scherp getekende sympathieën, zonder gemoedsgesteldheid vatbaar voor ontroering en zonder een aandoening in het temperament' wordt men niet door het vivisectie-vraagstuk aangegrepen. ${ }^{24}$

Verbeeldingskracht en emotionaliteit waren daarom onmisbare eigenschappen voor iedere vivisectie-bestrijder. Smith schaamde er zich dan ook niet voor dat hij deze kwaliteiten in sterke mate bezat en wond er geen doekjes om dat hij in zijn brochure gebruik maakte van de verbeelding. ${ }^{25}$ Hetzelfde geldt voor Jungius, Hugenholtz en Van der Hucht-Kerkhoven. Jungius, schrijfster van sprookjes en gedichten, was ervan overtuigd dat fantasie en werkelijkheid met elkaar samenhingen, zoals zij ook meende dat intuïtie en wetenschap al jaren dezelfde waarheid openbaarden. Zij zette haar betogen kracht bij door naar fictie te verwijzen. Zo vergeleek zij in één van haar lezingen de wonderlijke, betoverende gebeurtenissen in de verhalen van Duizend en één nacht met de nieuwste technologieën in de moderne samenleving. Als in de oude sprookjes ging tegenwoordig met één druk op de knop 'als bij toverslag' het licht aan of werden voorwerpen in beweging gebracht.

Voor Hugenholtz bestond er eveneens geen scherpe grens tussen fictie en werkelijkheid. In allebei werd naar zijn mening de waarheid geopenbaard. In één van zijn brochures ${ }^{26}$ gaat hij daarom uitgebreid in op de gebeurtenissen die in de Engelse anti-vivisectie roman St. Bernards van Edward Berdoe werden beschreven. Berdoes roman handelt over een jonge idealistische dokter die door het aanschouwen en verrichten van vivisecties zodanig wordt aangetast dat hij op het laatst geen onderscheid meer maakt tussen proefdieren en patiënten. Van een goed mens verandert hij langzaam maar zeker in een meedogenloze vivisector. Hugenholtz was ervan overtuigd dat Berdoe's roman een exacte weergave van de werkelijkheid gaf. Hij ried een ieder aan het boek te lezen en op deze wijze te weten te komen wat de gevolgen van vivisectie konden zijn.

Van der Hucht-Kerkhoven makkte een sterker onderscheid tussen fictie en werkelijkheid dan Jungius en Hugenholtz. Zij geloofde, evenals Von Schwartz, in de kracht van fictie en hechtte er veel waarde aan. Anders dan de schrijfster van Gemma was zij tegelijkertijd zeer verontrust over de invloed van fictie op de samenleving. Van afbeeldingen en teksten kon naar haar mening zo'n grote kracht uitgaan dat ze individuen konden beïnvloeden en beschadigen. In Anna gebeurt dat bijvoorbeeld met Anna's nichtjes die opgroeien in een omgeving waarin veel realistische kunst te zien is. Zo hangt boven de schoorsteen een dronkemanstoneeltje. Geen wonder, zo wordt in de roman gesuggereerd, dat Anna's nichtjes geen smaak hebben, slechts geïnteresseerd zijn in materiële zaken en hun haar in lichtzinnige krulletjes op het voorhoofd dragen.

Zoals een schilder door hetgeen hij vervaardigde zijn omgeving kon beïnvloeden zo had ook de schrijver volgens Van der Hucht-Kerkhoven een macht waarvan men

"bijna huivert als men bedenkt hoe die [...] vaak misbruikt wordt. Een lichtzinnig neergeschreven woord kan als een vonk zijn die in het buskruit wordt geworpen. Ach, dat tallooze schrijvers onzer dagen daarom bedenken mochten hoe groot de verantwoordelijkheid is die op hen rust $[\ldots]$ Waar wij in het leven platheid, ruwheid en alledaagsheid ontmoeten, wenden wij ons met afkeer af, waarom dan laten wij die toe in onze literatuur. ${ }^{27}$

Met deze laatste opmerking plaatste Van der Hucht zich midden in een discussie over de naturalistische en idealistische roman die rond 1880, dus een paar jaar voor de publicatie van Anna, in Nederland actueel was geworden. In deze periode werd, zoals onder meer wordt beschreven door Ton Anbeek, het idealistisch proza onder vuur genomen door een aantal veelal

24. Ibidem, 35-36

25. Ibidem, passim

26. Hugenholtz, Vivisecrie-vraagstuk, 28-29.

27. Daal. Anna. voorrede (geen blz. nrs.). 
naturalistische schrijvers. ${ }^{28}$ Marcellus Emants, Frans Netscher en Lodewijk van Deyssel namen, om met eerstgenoemde te spreken, stelling tegen: Gefabriekte verhaaltjes met interessante intriges, poëtisch-optimistische aflopen en helden, wier aderen met deugd in plaats van bloed zijn gevuld'. ${ }^{29}$

Met onder meer Toergenjev en Zola als voorbeeld zetten de naturalisten zich af tegen de onwetenschappelijkheid van het metafysisch mensbeeld en de moralistische bondschappen die de idealistische schrijvers in hun werk centraal stelden. Zij waren van mening dat kunst en natuurwetenschap met elkaar verzoend moesten worden. Volgens hen zou het zelfs niet langer om de tweedeling literatuur en wetenschap moeten gaan maar om literatuur als wetenschap. Bij dit oogmerk speelde de metafoor van de snijkamer een belangrijke, programmatische rol, zo stelt Maarten van Buuren.

'De [naturalistische] schrijver is een man van de wetenschap, een positivist die analyses uitvoert en de resultaten daarvan vastlegt in een verslag. Zijn roman is het proces-verbaal van een ontleding. Hij zal de sociale werkelijkheid van zijn meest ontluisterende kant laten zien, van de corruptie, en deze zedelijke verwording in de bovenlagen van de samenleving, tot de armoede, het alcoholisme en de prostitutie in de achterbuurten. Hij doet zijn werk en public. Zijn snijwerk heeft een didactisch doel. De roman is een anatomische les, een demonstratie. Het Franse woord voor snijkamer is niet toevallig 'amphithéatre'. Hij voert zijn demonstratie uit op een lijk. ${ }^{30}$

Wellicht meer nog dan de snijkamer van de anatoom nam de naturalist en hieraan besteedt Van Buuren geen aandacht- het laboratorium tot voorbeeld. Het was Zola die zich in Le roman expérimental $^{\beta 1}$ de Franse fysioloog Claude Bernard ten voorbeeld stelde door te beweren dat men in diens Introduction a l'étude de la medicine experimental slechts het woord 'medicus' hoefde te vervangen door 'romanschrijver' om de theorie van de proefondervindelijke roman te verkrijgen. Men ziet het zo, stelde ook Frans Netscher, één van Zola's meest serieuze Nederlandse navolgers, in 1885 :

'De weg dien de naturalist gevolgd heeft, is even degelijk geleerd en logisch juist als die welken den physioloog zou inslaan ten dienst der vivisectie. Hun manier van werken verschilt in geen enkel opzicht alleen neemt de physioloog proeven op een hond, kikvorsch enz. en de naturalist op het psychologisch leven van de menschen. ${ }^{32}$

Alleen al Zola's keuze voor Bernard als voorbeeld is een plausibele verklaring voor Van der Huchts afkeer van de naturalistische literatuur. Voor de anti-vivisectionisten was Claude Bernard een van de meest beruchte vivisectoren. Zijn Introduction en zijn Leçons hadden onder hen voor veel commotie gezorgd. Reeds in 1879 wijdde Androcles een artikel aan deze werken. De anonieme auteur constateerde tot zijn afschuw dat Bernard 'nauwkeurig en tot in de kleinste bijzonderheden' verslag deed van

'den langzamen marteldood [...] van 17 honden en 22 katten, in de hel van zijne vinding leen oven| gebakken en gebraden. Van bedwelming zijner dieren was nooit sprake. [... menigmaal wierp hij kleine honden in kokend water, om waarnemingen omtrent hun sterven te doen. ${ }^{33}$

Behalve door zijn proeven, of de proeven die aan hem werden toegeschreven, was Bernard zowel beroemd als berucht geworden door zijn vaak met bijbelse metaforen doorspekte publicaties en uitspraken. Zijn opmerking dat de fysiologie Gud overbodig zou maken was voor velen uitermate

28. Ton Anbeek. De naluralistische roman in Nederland (Amsterdam 1982), Zie 0wk: Ton Anbeek cn J.J. Kloek, Van idealisme naar naturalisme' in: De negentiende eeuw 5 (1981) 3-30.

29. Anbeek, Naturalistische. 76. 30. Maarten van Buuren, 'De anatomische les" Artsen in de literatuur rond de eeuwwisseling'. Feil \& Fictie 1 (voorjaar
1993) 40-52, aldaar 40 .

31. Emile Zola, De experimentele roman (1880). Ver. L.Wesseling.

32. Zoals geciteerd door Anbeek, Naturalistische, 27.

33. Onbekend, 'Vivisectie', Androcles (1897) 53-56, aldaar 54 
prikkelend. Bernard was een figuur die sterk tot de verbeelding sprak. Dit gold niet alleen voor de vivisectie-bestrijders. Ook een schrijver als Dostojevski was onder de indruk. In De gebroeders Karamazov spreekt Dimitri Karamazov vol bewondering over de fysioloog hoewel hij het 'sneu voor God' vindt. ${ }^{34}$ De Franse realist Léon l'Hermitte vervaardigde juist als blijk van appreciatie voor de overwinning van de wetenschap op de Almachtige een schilderij waarop te zien is hoe Bernard, zoals Eduward de Goncourt het uitdrukte, als een 'apostel van de wetenschap' ${ }^{\text {'35, }}$ omringd door zijn leerlingen, een vivisectie verricht.

Bernard was kortom de schrik van vele gelovigen en de held van het realisme en het naturalisme. Afgezien daarvan had Van der Hucht-Kerkhoven nog een reden om zich met Anna in de discussie over romankunst te mengen. Zij kwam in het geweer tegen het deterministisch mensbeeld van Zola, zijn inspirator Taine en hun navolgers die meenden dat het menselijk karakter vrijwel geheel door erfelijkheid en milieu of, preciezer, door race, moment et milieu werd bepaald. ${ }^{36}$ Evenals de experimenteel fysioloog die de verschijnselen van het leven bestudeerde om er macht over te krijgen, onderzochten zij de samenleving met de bedoeling deze te beïnvloeden. Van de roman, de uitkomst van dit wetenschappelijk experiment of sociologie pratique, konden bestuurders en wetgevers gebruik maken ter verbetering van de maatschappij. Deze politieke pretenties van de naturalisten dreigden de invloed van de naturwetenschappelijk georiënteerde medische wetenschap op de samenleving te vergroten. Van der Hucht moet gevreesd hebben dat in een dergelijke samenleving geen plaats zou zijn voor de idee van een zedelijke evolutie.

Tegenover de naturalistische opvattingen stelde zij haar eigen visie op de rol van de roman in de samenleving. Volgens haar diende een roman om er innerlijk rijker van te worden:

'rijker aan kennis of rijker aan liefde; ons verstand en ons hart moeten door onze lectuur ontwikkeld en veredeld worden. Een boek moet eene krachtige voedzame opwekkende verfrisschende spijze zijn voor onze ziel, [...] moet ons hooger en verder brengen, dichter bij het ideaal dat elk zedelijk mensch zich voorstelt. De roman is het eigenlijk veld waar een gezond idealisme gezaaid moet worden. Men mag de werkelijkheid niet vergeten om zich in idealen te verliezen maar het ideale moet de werkelijkheid veredelen, doordringen, idealiseren. ${ }^{37}$

Anna, maar ook Naar het groote licht, wordt mede vanwege juist deze gedachte door hedendaagse recensenten doorgaans tot de idealistische tendensroman gerekend. Jacqueline Bel beschrijft hue Lodewijk van Deyssel en Netscher rond 1897 een ontwakend gemeenschapsgevoel in kunst en literatuur signaleren. Het motto l'art pour l'art van de beweging van Tachtig leek voorbij, 'het getal van artiest-democraten, auteurs van geëngageerde romans ${ }^{.3 \times}$ toe te nemen. Bel constateert in deze periode:

'een preoccupatie met actuele maatschappelijke problemen. Zij [de schrijvers van romans] houden zich minder afzijdig dan voorheen en kiezen partij $[\ldots]$. In veel romans $[\ldots]$ vallen echo's te beluisteren van de meest uiteenlopende kwesties; socialisme, feminisme, anarchisme, maar ook kwesties als vrije liefde, vegetarisme, anti-vivisectie en de blauwe knoop. ${ }^{39}$

Romans waarin dergelijke actuele politiek-maatschappelijke kwesties aan de orde werden gesteld worden door Bel aangeduid als actualiteitsromans. Maar indien het verhaal vrijwel geheel ondergeschikt is gemaakt aan het uitdragen van een gedachte of idee noemt zij ze tendensromans.

34. F.M. Dostojevski, De gehroeders Karamazov (UtrechuAntwerpen 1981) 582.

35. Linda Nochlin, Realism (Londen 1990) 44 en 92

36. H. Taine. History of English literature (eerste druk 1863 Londen 1907). Zie ook: D. G. Charlton, Positivist thought in France during the Second Empire (Oxford 1959). Zie ook L M. Larkin. Man and sociery in Nineteenth Century Realism. Determinism and literature (Londen 1977).

37. Marie Daal, Anna. voorrede (geen blz. nrs.)

38. Jacqueline Bel. De Nederlandse literatuur in het fin de siècle. Een receptie historisch overzicht van het proza tussen 1885 en 1900 (Amsterdam 1993) 151

39. Bel, Nederlandse literaluur. 315 
Kenmerkend voor deze romans is, aldus Bel, dat zij in de regel een vooruitstrevend of in ieder geval niet gangbaar standpunt verdedigen en geschreven zijn volgens de 'afgesleten conventies van het oudere idealistisch proza' ${ }^{40}$ Ook tendensromans kennen net als dit soort proza vaak een gecompliceerde verhaallijn. De meestal goede afloop van deze boeken wordt bijvoorbeeld niet zelden door middel van toeval, misverstand of een deus ex machina opgelost. Verschillend van het oudere idealistisch proza zijn volgens Bel de 'nieuw mystieke geluiden' in de verhalen en vooral ook de vaak religieuze proporties die de ideële gevoelens van de progressieve romanhelden zouden hebben aangenomen. ${ }^{41}$

Bels definitie is, zoals de meeste definities van literatuurwetenschappers die een onderscheid maken tussen idealistische en naturalistische romans, te strikt. Anna is bijvoorbeeld een tendensroman, maar bevat onmiskenbaar ook naturalistische elementen. Het verhaal is, evenals Gemma, doorspekt met fel-realistische beschrijvingen van dierenmishandeling en vivisectie. In deze boeken zijn realisme en idealisme dus met elkaar vermengd. Beide romans kunnen dan ook beter gerekend worden tot de geïdealiseerde realistische romans, een door Anbeek onderscheiden 'compromisvorm tussen idealisme en naturalisme'.$^{42}$ Een schrijver van dergelijke proza beschreef wel

'walgelijkheden als die maar geadeld [werden] door een kiese toon en een verheven moraal.

Met andere woorden: een zeker realisme, maar binnen een idealistisch kader. ${ }^{, 43}$

De door Ortt met emotionaliteit en 'onwaardigheid' geassocieerde anti-vivisectionistische romans en andere geschriften waren dus met realistische beschrijvingen doorspekt. Omgekeerd ontkwam Ortt zelf, zoals in de volgende paragraaf zal blijken, niet aan het fantastische element in de strijd tegen vivisectie.

\section{Pijn en verbeelding}

Hoezeer hij zich ook tegen deze zijde van het vivisectie-bestrijding verzette, Ortts geschriften waren met fictie en fantasie doordrongen en beïnvloed door de Engelse anti-vivisectionistische verbeelding. Een goed voorbeeld is uitgerekend zijn Cursus over vivisectie. Ortt zet in dit geschrift de door hem voorgestane wetenschappelijke, niet-sensationele benadering van het vivisectie-vraagstuk uiteen aan de hand van het werk van Frances Power Cobbe. Cobbe schuwde de verbeelding niet. Dit blijkt al uit de titel van haar studie The Nine Circles, or the torture of the innocent, een verwijzing naar Dante's Hel. In haar werk besprak Cobbe verschillende soorten vivisecties die zij aanduidde met de termen martelingen, folteringen, gruwelijkheden en gruwelen. Ortt distantieert zich niet van de in dit geschrift gebezigde terminologie. Integendeel, hij neemt Cobbe's termen letterlijk over en beschrijft een hel in plaats van een laboratorium. Op deze wijze schildert hij zijn medisch-wetenschappelijke tegenstanders als duivels af. De toon is zo gezet. Ook Ortt heeft de verbeelding nodig om zijn boodschap over te brengen, al volgt bij hem een 'wetenschappelijke verantwoording' door middel van citaten.

Anti-vivisectionisme en verbeelding zijn, zo blijkt, onvermijdelijk met elkaar verbonden. Hoe anders dan met de hulp van fantasie kunnen gevoelens en gedachten van dieren worden weergegeven, kan gediscussieerd worden over een onzichtbaar fenomeen als pijn? Brian Harrison is ervan overtuigd dat het gevoel voor dieren en de zwakkeren in de samenleving zoals dat in de negentiende eeuw opkwam, voor een belangrijk deel werd vormgegeven door 'literair sentiment' ${ }^{44}$ Door middel van fictie werd geprobeerd medelijden op te wekken voor de lijdenden en gepijnigden. Dat pijn en lijden in de periode rond 1900 zeker tot de verbeelding van velen spraken, is de stelling van historicus James Turner. Hij zet uiteen hoe in de negentiende eeuw de houding ten opzichte van pijn gekenmerkt werd door enerzijds angst en anderzijds een interesse die niet zelden grensde

40. Ibidem.

41. Citaten zijn te vinden in: Bel, Nederlandse literatuur, 315-316.

42. Bel, Nederlandse literatuur, 76.

43. Ibidem.

44. Harrison, Peacable, 275. 
aan fascinatie. De gedachte aan de vivisector, die schijnbaar zonder terughoudendheid, en volgens velen zelfs met lust, pijn toebracht aan weerloze en onschuldige wezens, stimuleerde de angstgevoelens en de fantasie. Iedere vivisectie was bovendien een confrontatie tussen de hooggestemde idee van een morele evolutie en de schaduwzijde van de mens. Velen voelden volgens Turner dat zich in de wetenschap, de vivisector, de samenleving, maar toch vooral in de eigen geest, een beest bevond dat altijd dreigde aan de oppervlakte te komen. De vivisectie toonde de pijn en het lijden die het gevolg zouden zijn van die overwinning van lust en agressie op de reine, hogere kant van de mens. ${ }^{45}$

Ook de geschriften van de Nederlandse anti-vivisectionisten resoneerden dergelijke gevoelens. Een goed voorbeeld zijn de essays van Hugenholtz en Roorda van Eysinga die de vivisectie associeerden met een duister verleden en het overgeleverde 'duivelsche in de mens'. Vivisectie was volgens hen een atavisme dat zo snel mogelijk overwonnen diende te worden. Tegelijkertijd werden proeven op levende dieren juist voorgesteld als exponent van de beweging van l'art pour l'art met de vivisector als moraalloze kunstenaar die zijn proeven slechts neemt 'om de kunst' en die zich als een 'zo veel te beter kunstenaar' beschouwt, naarmate hij zich minder laat binden door ouderwetse overwegingen. En passant werd zo dus ook verwezen naar de eerder genoemde discussie over de moderne romankunst en de kracht van de verbeelding. Meestal werd de vivisectie tegelijkertijd geassocieerd met moderniteit en primitiviteit. Roorda van Eysinga stelde de levensbeschouwing van de vivisectoren bijvoorbeeld gelijk aan het naturalisme, een filosofie die naar zijn mening het beste vergeleken kon worden met oude 'heidense natuurdiensten' die meer begaan waren met de verwoestende, dan met de 'weldadige werkingen' van het 'wezen der natuur'. ${ }^{46}$

Ter illustratie van een dergelijk naturalisme verwees Roorda van Eysinga naar de evolutionistische en positivistische opvattingen over wetenschap die één van de eerste uitgesproken tegenstanders van de Nederlandse anti-vivisectionisten, Pieter Harting, inmiddels negentien jaar eerder in zijn Album der Natuur als volgt had geformuleerd:

'Wij kunnen den wil van God alleen uit de schepping leeren kennen, en wel verre dat deze ons een toneel van vrede, liefde, en geluk aanbiedt, zijn het land en de zee veeleer een groot slachtveld, waarop alleen het recht des sterksten geldt en leed en pijn de regel, vrede en geluk uitzonderingen zijn. Het verhinderen van pijn ligt zoo weinig in het plan des Scheppers, dat geen kind geboren wordt, zonder aan zijne moeder pijnen, vaak veel erger dan eenig dier bij een vivisectie ondervindt, te kosten. ${ }^{.47}$

Anders dan Harting wilde Roorda van Eysinga niet aanvaarden dat kennis over lichaam en natuur slechts door het toebrengen van pijn en leed kon worden verworven. Hij wilde niet aanvaarden dat de schepper de wereld als verwoestend, gewelddadig en vol van pijn had bedoeld. In dit opzicht leek hij op Cobbe. Naar aanleiding van haar opvattingen over dit onderwerp stelt Turner:

'The anti-vivisectionist [...] clung to a benevolent God en denied a world that operated on the principle of pain. ${ }^{48}$

Een ieder die er anders over dacht was volgens de anti-vivisectionisten een materialist, een atheïst, een monster of een duivel en opereerde aan de donkere kant van het menselijk bestaan.

De belangrijkste vertegenwoordiger van die gevaarlijke zijde van de mens was in de ogen van de Nederlandse anti-vivisectionisten de Italiaanse fysioloog Paolo Mantegazza die op z'n minst even gefascineerd was door het verschijnsel pijn als zijn tegenstanders. Door middel van een tormentatore, een pijniger, had Mantegazza het fenomeen pijn bij dieren onderzocht. Hij deed verslag van zijn bevindingen in zijn studies La Fisiologia del Dolore en Dell Influenza del Dolore

\footnotetext{
45. Turner, Reckoning, 102

46. S.F.W. Ruorda van Eysinga, Vivisectie e'n hooger onderwijs. Open brief aan Dirk Beerends ('s-Gravenhage 1893) 30 .

47. Ibidem, 32

48. Turner, Reckoning, 102
} 
sulla Respirazione. ${ }^{49}$ In deze werken beschreef hij onder meer hoe hij onverdoofde dieren spijkers in de poten sloeg, hoe hij hun huidplooien beklemde en lichaamsdelen verbrandde. Daarbij tekende hij nauwkeurig aan om welke gradatie van pijn het ging: 'folterende pijnen', 'de vreselijkste pijnen', 'de allervreselijkste pijnen', 'de allergruwelijkste', 'de allerwreedste' en 'de grootste pijn die een dier kon verdragen'. Zelfs Ortt, die toch meende dat men vivisectoren niet als monsters diende af te schilderen, was er stellig van overtuigd dat Mantegazza een monster en een sadist was. Alle anti-vivisectionisten, zowel in Nederland als daarbuiten, waren die mening toegedaan.

Zelf besefte Mantegazza dit maar al te goed. In een nawoord refereerde hij aan de beschuldigingen van de vivisectie-bestrijders:

'Ik die van toen af pijn langs experimenteelen weg begon te bestuderen, gevoelde behoefte om mij tegen de beschuldigingen van wreedheid te verdedigen. [... sommige van die barmhartige uitingen van teederheid voor dieren gelijken veel op arcadische gedichten, vol gemelijke gemaaktheid en sentimentaliteit.' ${ }^{\text {so }}$

Mantegazza signaleert in de hierboven aangehaalde passage uit Atlas van de pijn het fictionele element in de anti-vivisectionistische geschriften. Hij ziet hoe het wordt ingezet en keurt het af. Toch kon ook hij niet zonder de verbeelding wanneer hij over pijn sprak. De studie Physiologie der Pijn bestond voor een belangrijk deel uit een analyse van de wijze waarop in de loop der eeuwen het fenomeen pijn in de kunst was verbeeld en een uitgebreide beschouwing over de eisen waaraan schilderijen naar zijn oordeel dienden te voldoen:

'Ook bij de voorstellingen van de smart in de kunst moeten wij ons ten doel stellen voor alles aan tweeërlei roeping te voldoen; wij moeten onzen smaak ontwikkelen en idealiseeren. [...] De uitdrukking van de smart in de kunst moet medelijden opwekken; zij mag ons doen huilen, maar zij moet ons niet doen afschrikken.'st

Evenals Van der Hucht-Kerkhoven was Mantegazza van mening dat van schilderijen een grote invloed uit kon gaan. Gezien de nauwe band die er tussen de positivistische wetenschappelijke traditie en de realistische kunst bestond, was hij, opmerkelijk genoeg, niet erg te spreken over het realisme:

'Niet alle pijnlijke uitdrukkingen zijn schoon, er bestaan veeleer leelijke, zeer leelijke, weerzinwekkende. Het moderne realisme is werkelijk niets anders dan eene aesthetische ziekte, die onze hartstochten door middel van gruwelijke voorstellingen wil gaande maken, enkel omdat ze waar zijn. [... $]^{\text {s2 }}$

Ook Mantegazza vreesde dus de kracht van de verbeelding en liet haar tegelijkertijd toe in zijn beschouwingen over de pijn. Hetzelfde geldt, zoals gezegd, voor Ortt.

Nergens wordt dit duidelijker dan in zijn polemiek met $\checkmark$. van Rijnberk dic een groot bewonderaar van Mantegazza was. Van Rijnberk was er volgens Ortt de oorzaak van dat de discussie over het fenomeen pijn door filosofische drogredeneringen werd vertroebeld. Hij doelde in het bijzonder op de uitlating van Van Rijnberk in het Nederlandsch Tijdschrift voor Geneeskunde dat pijn een subjectief verschijnsel was. Men kon volgens de fysioloog nooit met zekerheid zeggen of een ander pijn had; een bewijs was niet te leveren. Mensen konden elkaar misleiden door bijvoorbeeld een gepijnigd gezicht te trekken of het uit te schreeuwen zonder werkelijk pijn te voelen. Wel kon het als stelregel worden genomen dat het pijngevoel afhing van iemands geestelijke vermogens. Van Rijnberk meende dat hoe groter het intellect van een wezen was, hoe groter de pijnvatbaarheid. Waar het de pijnervaring van dieren betrof, was het volgens de

49. Lang voordat dit werk in het Nederlands was vertaald waren de anti-vivisectionisten op de hoogte van de inhoud C.Stams haalt het werk in zijn brochures aan. In 1908 werd de Nederlandsc vertaling gepubliceerd. P.Mantegazza Physiologie der pijn (Amsterdam 1908).

50. Mantegazza, Pijn, 424.

51. Ibidem, 406.

52. Ibidem, 406 . 
Amsterdamse hoogleraar duidelijk. Daar zij geen intellect bezaten,was er geen dringende reden om aan te nemen dat het janken van een geslagen hond een uiting van bewuste pijn of lijden was.

Ortt gaf toe dat het onmogelijk was om het bewijs te leveren dat dieren op dezelfde wijze pijn voelden als mensen. Maar, zo voegde hij er aan toe, het kon volgens Van Rijnberks eigen redenering niet bewezen worden dat de hooggeleerde zelf pijn leed als hij bijvoorbeeld zonder verdoving werd geopereerd. Ortt verwees in dit verband naar een passage uit Van Eedens toneelstuk De Broeders ${ }^{53}$ waarin Ahasverus, de tot eeuwig wandelen gedoemde Jond, zichzelf tegenkomt. Wat zou er met Van Rijnberk gebeuren als hij zichzelf zou ontmoeten en in zijn eigen handen vallen? Van Rijnberk I zou hem ongenadig pijnigen terwijl Van Rijnberk II alles zou doen om hem duidelijk te maken dat hij pijn leed. Van Rijnberk I zou zich daar niets van aantrekken en zichzelf niet willen geloven:

'v. R. I ..... krimpt en schreeuwt van pijn

v. R. II .... houdt tegen de omstanders een wetenschappelijk betoog, dat het achtereind van een worm ook krimpt zonder pijn te hebben en een geslagen hond ook janken kan, zonder dat het bewezen is dat hij pijn lijdt .....

Id. I smeekt nog wanhopiger om morfine

Id. II. Gaat onverstoorbaar voort $[\ldots]^{, 54}$

Zo maakte Ortt gebruik van fantasie en fictie om zijn standpunt kracht bij te zetten. Zoals hij door de vergelijking van het laboratorium met 'de hel der onschuldigen' de vivisector afschilderde als een duivel, zo schildert hij Van Rijnberk hier af als een door Christus gestrafte Jood. De wetenschappelijke benadering van Ortt was niet losgekoppeld van emoties en fantasie, kon zonder in feite niet bestaan. De vraag komt dan ook op of, en op welke wijze zijn beeld van de vivisectie verschilde van de emotionele, en wellicht ook door hem meer met het vrouwelijke geassocieerde. beschrijvingen die hij door middel van zijn cursus zei te bestrijden.

\section{Menselijke dieren}

Vrijwel ieder anti-vivisectie-geschrift werd ingeleid met een definitie van vivisectie. Deze omschrijvingen konden wat betreft toonzetting en inhoud ten zeerste van elkaar verschillen. Zij hadden echter met elkaar gemeen dat telkens beklemtoond werd dat vivisectie meer was dan alleen het snijden in het levende. Zo schreef Hugenholtz in zijn brochure Het vivisectie-vraagstuk bijvoorbeeld:

'Gij zoudt u echter een onjuist en onvolledig denkbeeld van de vivisectie vormen, indien Gij meendet, dat zij alleen in het stuksnijden, en insnijden in levende dieren, dus alleen in bloedige proeven bestond. ${ }^{\text {ss }}$

Niet zelden werden lange lijsten vervaardigd van verrichtingen die eveneens onder de noemer vivisectie konden worden gebracht. Hugenholtz sprak van honden die tussen allerlei schroeven werden geklemd, op de martelbank werden vastgespijkerd en vervolgens levend opengesneden, doorstoken, gebraden, de ogen uitgestoken, en in kokend of bevriezend water geworpen. Ja, zo vervolgde hij,

'men bourt hen gaten in den kop, om met een roodgloeiend ijzeren staafje de hersens uit de branden of door kokend water uit te spoelen. Men zaagt hun levend de beenderen door, laat ze doodhongeren, vult de maag op kunstmatige wijze met kokend water, en de aders met zand, geeft hun braakmiddel in, na vooraf den bek met gips opgesneden te hebben, men neemt het ruggemerg weg, galvaniseert doorgesneden zenuwen, ja! Wie weet, aan welke duivelsche geraftineerde martelingen men de dieren nog meer onderwerpt. [...] Men laat de dieren ook

53. Frederik van Eeden, De Broeders. Tragedie wan het rechl, eerste druk 1894 (Leiden 1983).

54. Felix Ort. Meening over pijngevoel van prof. van Rijnherk en weerlegging daarvan (z.p. 1918) 3.

55. Hugenholtz, Vivisectie-vraagsık, 9 
levend verbranden, verschroeien, bevriezen, verhongeren, verdorsten, men dient hun vergif toe, onderwerpt ze aan electrische prikkelingen, maakt ze kunstmatig ziek enz. ${ }^{\text {"56 }}$

Jungius trakteerde haar gehoor op de Nationale Tentoonstelling van Vrouwenarbeid op eenzelfde soort combinatie van definitie en opsomming:

'De wijze van experimenteeren, waarbij men levende wezens snijdt, doorpriemt, volduwt met

buizen, kranen en allerlei meters, de huid aftrekt, lardeert met metalen voorwerpen, over- en doorgiet met kokende vloeistoffen, volpropt met chemische preparaten en producten, vernist, in brand steekt, ontwricht, uiteenrukt, uitrekt, trepaneert, besmet met allerlei ziektekiemen en andere vuile stoffen, platdrukt, uithongert, waarbij men hun nagels uittrekt, de oogen uitsteekt, de ooren afrukt, de tong uitscheurt, de half voldragen jongen uit het lichaam snijdt, allerlei zenuwen blootlegt en electriceert $[\ldots]^{57}$

Ortt gaf eveneens een lange lijst van handelingen die hij tot de vivisectie rekende. Hij zou Ortt niet zijn geweest als hij niet op de een of andere wijze ordening in die chaos van termen en begrippen aanbracht. Hij rangschikte de door hem onderscheiden soorten dierproeven aan de hand van Cobbe's negen kringen:

'Eerste kring: verminken (alsmede verbrijzelen van ledematen).

Tweede kring: kunstmatig ziek maken (o.a. door inenting of inspuiting van vergiften, of door slaan op den schedel).

Derde kring: vergiftigen (met allerlei soorten vergiften, ook met bedorven voedsel).

Vierde kring: verstikking (ook door langzaam verdrinken en door den mond met gips dicht te pleisteren).

Vijfde kring: verbranden en bevriezen (van de huid, ook door gesmolten lood of kokend water in de maag te gieten).

Zesde kring: verhongeren en dorst [doen] lijden.

Zevende kring: villen en vernissen, de huid van levende dieren stroopen, de huid

bedekken met ondoordringbare stoffen.

Achtste kring: diverse martelingen, zooals: dieren aan elkaar doen groeien; ledematen in gedwongen stand binden; verstoppen van natuurlijke openingen; doen rondtollen van levende dieren; verstijven; pogingen om door hevige martelingen zelfmoord op te wekken; enz. .

Negende kring: proeven op zedelijk gebied, met name: beproeven hoe aanhankelijk een hond is voor zijn baas en voor zijn jongen.'sk

In de meeste gevallen werd bij dergelijke opsommingen vermeld dat de proeven verricht werden door fysiologen ten behoeve van de wetenschap. Zo ook in de definitie die de NBBV hanteerde en die op de voorkant van iedere aflevering van het Orgaan werd afgedrukt:

'Wat de vivisectie eigenlijk is'? Vivisectie beteekent: Snijden in een levend wezen. Meer in het bizonder verstaat men daaronder: alle wetenschappelijke proefnemingen op levende dieren, welke pijn of nadeel veroorzaken en die niet het welzijn van het voorwerp dier proefnemingen ten doel hebben.'

Jungius voegde daaraan toe dat het te verwachten nut van de vivisecties zeer twijfelachtig was. Ortt stelde zich ook op dit standpunt al zag hij zich gedwongen toe te geven dat vivisectie in een beperkt aantal gevallen nuttig kon zijn. Hij verschilde in dit opzicht van de oprichters van de NBBV. Zo luidde het leidend beginsel van de bond dat de vivisectie vanuit praktisch oogpunt gevaarlijk was. Ortt vond dit te ver gaan. In 1909 stelde hij voor om juist die passage te schrappen. Het bestuur had grote problemen met dit voorstel maar presidente Groshans was het ermee eens. De strijd zou moeilijker maar eerlijker worden daar de vivisectie nu geheel vanuit een zedelijk standpunt zou moeten worden verworpen. 
Tegelijkertijd begreep Groshans dat dit al vele jaren de belangrijkste strategie van de Nederlandse anti-vivisectionisten was. ${ }^{59}$ Zelfs de weinige anti-vivisectionistische artsen die de NBBV tot haar leden rekende, hielden zich eerder met deze zijde van het vraagstuk bezig dan met de medisch-wetenschappelijke kant. Dat gold voor Van Rees, maar ook voor de oud-inspecteur en officier van gezondheid in Nederlands-Indië, G. Luchtmans die in Pro en Contra vivisectie. Een kritiek opmerkte:

'Neen, het vivisectie-vraagstuk is geen vraagstuk van physiologen en vakgeleerden, maar een

algemeen vraagstuk met ethisch-philosophischen ondergrond, dat ieder weldenkend mensch

kan en mag beoordelen. ${ }^{60}$

Om welk ethisch-filosofisch vraagstuk ging het volgens de Nederlandse anti-vivisectionisten eigenlijk? Het ging om een strijd tussen idealisme en materialisme stelde Roorda van Eysinga in Vivisectie en hooger onderwijs. ${ }^{\circ 1}$

Het debat over vivisectie was een strijd tussen twee wereldbeschouwingen, zo meende ook Luchtmans. Het ging volgens hem om twee stromingen waarvan 'de eene ons noodwendig leidt naar barbaarschheid en verwildering, en de andere naar ware beschaving, hogere ethische en aesthetische ontwikkeling'. De eerste, 'barbaarsche' wereldbeschouwing was die van de 'Jacobs'. Deze lieden die veruit in de meerderheid waren, eigenden zich, evenals de gelijknamige Bijbelse figuur, toe wat niet voor hen bestemd was. In het geval van de vivisectoren ging het om dieren. Als vertegenwoordigers van de 'Cartesisch-Leibnitz-Wolffsche wijsbegeerte' veronderstelden zij ten onrechte een scherpe grens tussen mens en dier. ${ }^{62}$

Luchtmans beriep zich op Darwin om aan te tonen dat het eten van of, zoals hij later suggereerde, het snijden in een dier in wezen gelijk stond aan het verslinden of verminken van een mens. Hij betwistte de grens tussen mens en dier door, net als Jungius, naar de evolutieleer te verwijzen. Hugenholtz deed dat juist niet. Hij verafschuwde de idee dat mensen en dieren aan elkaar gelijkgesteld werden en beschouwde de opvattingen van Darwin als een groot gevaar. Waren deze niet een vrijbrief voor de vivisectoren om zich, vermomd als huisdokter en gedreven door een tomeloze wetenschappelijke nieuwsgierigheid, aan zieke, hulpbehoevende familieleden en andere geliefden te vergrijpen? Werd de mens op deze wijze niet een ideaal proefdier? Deze angst voor de kennelijk steeds vager wordende grens tussen mens en dier verwoordde Hugenholtz in Patrimonium, de periodiek van de in 1877 opgerichte protestants-christelijke arbeidsbeweging. Een zekere heer $\mathrm{H}$. was hem voorgegaan. Deze, niet nader te identificeren, auteur uitte zich als volgt:

'Doch boven het stuitende tegen alle $[\ldots]$ menschelijk medegevoel, dat de vivisectie als zoodanig heeft, - is er nog een andere factor in heel deze proefneming op levende dieren, waarvoor de oogen onzer medechristenen wel geopend mogen worden. Die andere factor schuilt in de algeheele gelijkstelling van den mensch aan het dier, door den gruwel der vivisectie. Wat wil de moderne wetenschap anders dan ons te verstaan geven: de mensch is een hoogontwikkeld dier?'6.3

In 'Het vivisectie-vraagstuk' sloot Hugenholtz zich bij $\mathbf{H}$. aan. De voorstanders van vivisectie waren er naar zijn mening op uit om de zedelijkheid terug te brengen tot het peil van het oorspronkelijke instinct, op het peil van het zuiver dierlijk bestaan dat, aldus de anti-vivisectionist. louter bestond uit een 'egoïstische gerichtheid op het behoud des levens tot elken prijs'. ${ }^{\text {'N }} \mathrm{De}$ vivisectie verlaagde de mens tot een redeloos dier.

59. 'Verslag van de Algemeene Vergadering gehouden op vrijdag 7 mei 1909 in hotel de Witte Brug te 's-Gravenhage', Orgaan $S(1909)$ 1-19, aldaar 5

60. G.Luchtmans, Pro en contra vivisectie. Een kritiek (Den Haag 1906) 8.

61. Roorda van Eysinga. Vivisectie, 7

62. Luchtmans, Pro en contra, 6

63. Zoals geciteerd in Hugenholtz, Vivisectie-vraagstuk, 33 .

64. Ibidem. 
De weerzin tegen de gelijkstelling van mensen en dieren is op het eerste gezicht paradoxaal aangezien in de anti-vivisectionistische fictie (maar ook in andere geschriften) niet zelden de individualisering en vermenselijking van het dier centraal stond. Ook Hugenholtz sprak in 'Het vivisectie-vraagstuk' over de hond die 'door zijne zenuwgevoeligheid en zielsvermogens reeds, zooveel menschelijks heeft'. ${ }^{6}$ Daaraan voegde hij toe dat het dier 'het zinnebeeld van trouw' was. Zoals gezien werd bij de bespreking van Gemma, waren er meer anti-vivisectionisten die ten behoeve van hun strijd juist het accent legden op de gelijkstelling tussen dieren en mensen. Zulke vergelijkingen vormen in de anti-vivisectionistische literatuur een bijna eindeloze reeks. Zo omhelsden de Engelse strijders tegen vivisectie de schilderijen van Edwin Landseer die portretten van honden maakte. Volgens French vielen met name zijn Old Shepperd's Chief Mourner, waarop te zien is hoe een hond op het graf van zijn baas rouwt, en een tekening van een hond die gezellig een glas bier drinkt en een pijpje rookt, bijzonder in de smaak. De Duitse anti-vivisectionist Von Weber gebruikte versies van Landseers werk in zijn brochure Die Folterkammern der Wissenschaft (1879). ${ }^{6}$ Dit werk zou door de NVBD in 1883 in vertaling worden uitgegeven en de discussies over vivisectie in het Nederlandse parlement aanwakkeren.

Kortom, de anti-vivisectionisten ageerden niet zozeer tegen de gedachte dat dieren menselijke trekken konden hebben. Het was immers geen probleem om het bestaan van zedelijk hoogstaande geïndividualiseerde dieren, waarvan Gemma's hondje Roy een sprekend voorbeeld is, in te passen in de idealistische idee van een door God gewenste, voortschrijdende zedelijke vooruitgang. De omgekeerde consequentie van de gelijkschakeling van mens en dier, de aanvaarding dat in ieder mens iets dierlijks school, strookte daarentegen niet met de idee van een morele evolutie. Het dierlijke in de mens verwees naar seksuele driften, onzedelijkheid, agressie, kortom naar de lage en slechte kant van de mens, zoals de door Van der Hucht verafschuwde Zola deze in La Bête Humaine tot in de meest afschrikwekkende details had beschreven.

\section{Het beest in de mens}

De anti-vivisectionisten schuwden de beschrijving van de beestachtige zijde van de menselijke natuur evenmin. Medici die proeven op levende dieren verrichtten, werden afgeschilderd als mannen die zich door hun lusten en niet door de rede lieten leiden. Niet alleen werd deze zinnelijkheid geassocieerd met verkrachting en geweld. Het ging, zo suggereerden de antivivisectionisten, om onmatigheid in het algemeen, zoals drankgebruik, het gebruik van verdovende middelen, mateloze carrière-drang en nieuwsgierigheid. Dr. Farnham, Gemma's vader, wordt beschreven als een agressieve dronkaard, een echtbreker en de verantwoordelijke voor de verdwijning van zijn zoon en de vroege dood van zijn vrouw en dochter. Dr. Oldenburg uit $D e$ familie van Westvoorne is dit alles niet, maar hij wordt wel neergezet als een zeer ambitieus man met een tomeloze drang tot weten. Onder het vernis van zijn goede voorkomen is hij, zoals Frits van Queen Mab leert, een afschuwelijk monster. Ook in hem leefde dus het beest.

Het waren evenwel niet uitsluitend de, met Ortts woord, emotionele vivisectie-bestrijders die de vivisectoren op een dergelijke manier typeerden. Ortt zelf kenschetste dokter Willem Dam uit Naar het groote licht als een onmatig mens wiens gebrek aan moraal zich van kwaad tot erger ontwikkelt. Eerst raakt hij besmet met een geslachtsziekte, vervolgens wordt hij een dronkaard, schuldig aan de dood van een ander, en tot slot een opiumsnuiver. Het verschil met de wijze waarop Elpis Melena en Van der Hucht-Kerkhoven de vivisector afschilderden is dat Ortt van Willem Dam een tragische figuur maakt. Hij heeft steun en medelijden nodig en kan er weinig aan doen dat hij zo is als hij is. Zo brengt Ortt Willems onzedelijke levenswandel onder meer in verhand met de invloed die de arts op jonge leeftijd onderging door een al te intensieve omgang met de lagere klassen van de samenleving. Willem ging om met de ruwe zoontjes van de slager en

65. Ibidem.

66. Ernst von Weber, Die Follerkammern der Wissenschaft. Eine Sammlung von Tatsachen für das Laienpublikum (Berlijn en Leipzig 1879) 
aanschouwde met hen, vaak voor zijn plezier, het slachten van een os. Als in een variant op het verhaal van Hogarth over Tom Nero, is alleen al de aanblik van een dergelijk onzedelijk tafereel voldoende om de zwakke Willem tot iemand te maken die verdriet en destructie zaait.

Hiermee bouwde Ortt voort op een thema dat ook in veel vroege anti-vivisectie-geschriften naar voren kwam. Het ging om de invloed van het aanschouwen van ruwe praktijken (en in het bijzonder van vivisectie) op studenten, jongemannen die voorbestemd waren om later een belangrijke positie in de samenleving te vervullen. Illustratief in dit opzicht zijn de opvattingen van Roorda van Eysinga en Hugenholtz die van mening waren dat door het 'plegen' van vivisectie de onzedelijkheid van de proefnemer naar boven kwam. Deze zou als een 'gif, gevaarlijker dan de bacillen die doodelijke ziekte kweeken', doorgegeven worden aan de aanwezige studenten. Zo werden onbevangen mensen telkens blootgesteld aan de 'verpeste atmosfeer' van de laboratoria. Hugenholtz en Stams zagen voor zich hoe jonge mannen zich daar dagelijks met 'lange halzen vergaapten' aan de wijze waarop de 'hartklop sneller gaat, hoe het angstige hart van een weerloos gemarteld dier zich schokkend uitzet en dan plotseling weer inkrimpt. ${ }^{67}$ Het is alsof de antivivisectionist van mening is dat alleen al het aanschouwen van de fysiologische processen gelijk staat aan het verwerven van verboden kennis, aan het verliezen van onschuld en maagdelijkheid.

Niet alleen anti-vivisectionisten worstelden met dergelijke gevoelens wanneer het ging om het aanschouwen van lijdende of dode lichamen. Marjan Schwegman beschrijft in haar studie over Maria Montessori ${ }^{68}$ hoe geschokt deze was toen zij als medicijnenstudent de botten en het vlees van een dood mens aanschouwde. Een ander voorbeeld is Frederik van Eeden die, eveneens als medicijnenstudent, in de snijkamer het naakte lichaam van een vrouw zag liggen. De betovering was, zo voelde hij het, verbroken. Het menselijk bestaan en het wezen van de vrouw waren teruggebracht tot het lichamelijke, het vlees, het dierlijke. ${ }^{69}$ Ook wanneer het om levende wezens ging, zoals het geval is bij het aanschouwen van een vivisectie, was het alsof het niet juist was om slechts het puur lichamelijke waar te nemen. Typerend voor dergelijke gevoelens is de gêne van Hans Castorp, de hoofdpersoon uit Der Zauberberg van Thomas Mann wanneer de jongeman met behulp van een röntgen-apparaat in het lichaam van zijn neef Jonathan kijkt. Hij vraagt zich dan af of het wel toegestaan is dat een mens op deze wijze een blik in het graf werpt.

De anti-vivisectionisten waren ervan overtuigd dat dit, althans waar het de vivisectie betrof, niet toegestaan was. Studenten zouden al doende ten prooi vallen aan een fascinatie voor het lichamelijke en het snijden. Hun dorst naar kennis zou zo groot worden dat het lijden van het dier eraan ondergeschikt zou worden. Niet zelden werden de vermeende gevoelens van de studenten in bedekte termen gelijkgesteld aan interesse voor seksualiteit, prostitutiebezoek en aan onverschilligheden over het oplopen van geslachtsziekten. Verwijzend naar uitspraken van de Duitse anatowm E. Strauss Durkheim meende Hugenholtz hijvoorbeeld dat dweepzucht van studenten wanneer zij een vivisectie bijwoonden gekarakteriseerd kon worden als een hesmettelijke ziekte. Het was volgens hem niet verwonderlijk dat er sprake was van 'eene epidemie van zedelijke verwildering der geneeskunde-studeerenden'. ${ }^{70}$ Medicijnenstudenten dreigden af te glijden tot het niveau van het gewone volk en de publieke vrouwen en vormden op deze wijze een bedreiging voor de samenleving en het gezinsleven. Wanneer deze lieden eenmaal zelf medicus en wetenschapper waren, zouden zij zich, zo vreesde de predikant, niet alleen dan dieren maar ook aan mensen vergrijpen. Luchtmans was het daar mee eens. Ook hij associeerde de werkzaamheden van de vivisectoren met het bloedige en vleselijke:

'De bloedverwantschap tusschen den vleescheter of kreofaag en den menscheneter of anthropofaag is een zeer reeele en kan door niemand geloochend worden, die in den geest van het Darwinisme is doorgedrongen; de vleescheter en de menscheneter, de slager van beroep en

67. Hugenholtz, Vivisectie-vraagstuk. 15.

68. Marjan Schwegman, Maria Montessori 1870-1952. Kind van haar tijd, vroum van de wereld (Amsterdam 1999).

69. Fontijn, Tweespalt $1901,116$.

70. Hugenholtz, Vivisectie-vraagstuk, 35 . 
de amateur-slager zijn takken van denzelfden bloeddorstigen stam. De kannibalen zijn de snode ooms van de vrome vleescheter, beiden weinig eerbiedwaardige afstammelingen van gemeenschappelijke voorouders, die in gebreke zijn gehleven met de ware beschaving mee te gaan. ${ }^{71}$

Hugenholtz vergeleek de vivisectoren eveneens met slachters die zich dagelijks naar plaatsen begaven die dampten van het bloed en waarvan de muren bedekt waren met bloedspatten. Zij waren niet veel anders dan deze lieden die zich na hun slachtarbeid overgaven aan drank en andere onzedelijke gebruiken. ${ }^{72}$ Wie kende niet de verhalen over de ellendige toestanden in de wijken waar zich een slachthuis bevond, zoals het Londense Whitechapel waar niet voor niets een beruchte moordenaar had rondgewaard. Was het zo verwonderlijk, zo vroeg Hugenholtz zich af, dat velen nog altijd vermoedden dat The Ripper een vivisector was? ${ }^{73}$

De vivisector werd met andere woorden geassocieerd met moord, lust, bloed en monsterachtigheid. De anti-vivisectionisten namen wat dit betreft, ondanks hun kritiek op het naturalisme, nauwelijks een blad voor de mond. Zoals Ortt uitgebreid de slachting van een os beschreef, zo liet Van der Hucht-Kerkhoven niet na om de zedeloosheid en beestachtigheid van de lagere klassen breed uit te meten. ${ }^{74}$ In Anna gebeurt dat in brief-vorm. De roman bevat de correspondentie tussen Meta van Warnsveldt aan haar broer. In één van haar brieven vertelt Meta over haar reis door Zuid-Europa en haar verblijf in het Franse Menton. Daar is haar vooral opgevallen dat de mensen er met hun mooie figuren, elastische tred en donkere interessante gezichten weliswaar bekoorlijk, schilderachtig en poëtisch uitzien, maar dat zij geen veredelende invloed hebben ondergaan van de alom tegenwoordige schone natuur van hun leefomgeving. Integendeel. Het ogenschijnlijk zo lieflijke plaatsje kent een schaduwzijde. De bevolking huist in donkere, vuile holen en de zedelijke onvolmaaktheid is overal zichtbaar. Met name de mishandeling van dieren schokt de vrouw. Zij voelt zich omringd door 'lieden verre heneeden het edele dier'. ${ }^{75}$

Ook in eigen land bleken dergelijke mensen te wonen. Meta's broer, de arts en anti-vivisectionist Willem van Warnsveldt wijst daarop tijdens een lezing over dierenhescherming en de bestrijding van vivisectie. Met name in de Amsterdamse achterbuurten zou volgens zijn waarneming een onzedelijk soort beestachtigen leven:

'Ik kan u verzekeren dat ik er [de Amsterdamse achterbuurten] nooit kom zonder dat eene huivering mij overvalt bij het zien van zooveel laagheid, gemeenheid, verdorvenheid. Dat zijn ook menschen die daar wonen, die kijvende, vloekende tierende wezens; die afschuwelijke vrouwen, die verwaarloosde kinderen met bleeke gezichtjes en holle oogen die zich rond wentelen in 't slijk; die dronken mannen waarvan elk woord een vloek is. Eene door uiterlijk en zedelijke onreinheid verpeste atmosfeer heerscht daar in die straten en woningen waar armoede en ellende u tegengrijnzen. Niet zozeer de stoffelijke armoede, dan wel de armoede van den geest die gezonken is tot de diepste verdorvenheid. ${ }^{76}$

Zowel in Meta's woorden als in die van haar broer weerklinken een angst voor en een afschuw van het beestachtige proletariaat dat zich hij het minste of geringste aan gewelddadigheden zou overgeven:

71. Luchtmans, Hooger onderwijs, 2.

72. Zie over de vergelijking tussen medici en slachters ook Fontijn, Tweespall 1901, 116. 'Te midden van de onverschillige en zakelijke studenten die er als slagersjongens uitzagen, zag hij [Van Eeden] hoe de liefde en de waardigheid van de dood kapotgemaakı werd"

73. Hugenholtz, Historische kritiek, 2.

74. Zie Orvar Löfgren 'our friends in nature; class and animal symbolism' Ethnos 50 (1985) 184-213. vergl.: Ed Block, 'James Sully, evolutionist psychology, and late victorian gothic fiction', Victorian Studies: a quarterly journal of the lumanities, arts and sciences 25 (1982) 443-467.

75. Daal, Anna, 98.

76. Daal, Anna, 241. 
'De menschen die daar wonen zijn bijna geen menschen meer en bij de eerste gelegenheid die zich daar voordoet, bij een opstand b.v. of zelfs reeds bij eene kermis worden zij duivelsch in menschengedaante. ${ }^{77}$

De angst en fascinatie voor het duivelse en beestachtige in de massa, volgens Daniel Pick een onderdeel van het debat over degeneratie, werd in de negentiende eeuw door velen gedeeld. ${ }^{78}$ Het beest was ook buiten het verzet tegen vivisectie een wijdverbreid symbool voor het opdringerige proletariaat. Illustratief is de parabel over de bevrijding van het gekooide beest die Frederik van Eeden twee jaar na de publicatie van Anna in zijn dagboek neerschreef. De parabel handelt over een rijke man die een buitengewoon sterk beest bezit. Hij laat het monster voor zich werken en heeft daar veel profijt van. Tegelijkertijd is hij angstig voor de kracht waarover het beschikt. Daarom houdt hij het beest gevangen in een kooi. In die gevangenschap groeit de kracht van het wezen en neemt zijn intelligentie toe. De man weet niet wat hij met deze situatie aanmoet. Wanneer wijze mannen, waaronder een dichter, een zoölong en een wijsgeer, hem met betrekking tot dit probleem van advies dienen, slaat hij hun raad in de wind. Uiteindelijk breekt het beest, gesard en verhongerd uit zijn kooi om iedereen te verslinden. Van Eedens parabel die volgens Fontijn waarschijnlijk geschreven is naar aanleiding van een aantal relletjes in Amsterdam en andere steden in Nederland wordt in Tweespalt geïnterpreteerd als een beschrijving van het zich roerende proletariaat dat na gevangen te zijn geweest door het kapitalisme uitbreekt en met geweld overwint. $^{79}$

Buiten Nederland beheersten de angst en interesse voor het wezen van de massa wellicht nog duidelijker de wetenschappelijke en maatschappelijke discussies over actuele vraagstukken. In hetzelfde Menton als waar Meta van Warnsveldt vol afschuw over schreef werkte Taine, inspirator van Zola en exponent van de Franse positivistische traditie, vol ijver aan zijn geschiedenis van de Franse Revolutie, bij uitstek een periode waarin de massa van zich had laten spreken. Taine's beeld van die geschiedenis wordt door Jaap van Ginneken als volgt getypeerd:

' $[$...] his [Taines] view fit in well with the dominant ideas about mob behaviour. It corresponded closely to descriptions by French novelists like Dumas, Flaubert, Hugo, and British novelists like Brontë, Dickens, Eliot, Scott: most of which he probably read. If their fictional prose was partly based on documentary evidence, however, his own 'scientific' account was in turn partly based on literary license. ${ }^{80}$

Zoals de positivistische Mantegazza en zijn tegenstanders niet over het fenomeen pijn konden spreken zonder de verbeelding te hulp te roepen, zo werd ook Taine's wetenschappelijke beeld van de massa dus door fictie beïnvloed. Het beest in de mens sprak tot de verbeelding en kon wellicht niet zonder hulp van de fantasie beschreven en deel van de maatschappelijke discussie worden. Pick wijst dan ook op de 'fictions of degeneration', de vels Engelse Victoriaanse romans waarin het onderwerp werd besproken. De boeken gaven vorm aan het debat over degeneratie. De anti-vivisectionistische geschriften, ook de Nederlandse, echoden op hun beurt de beelden die in die romans werden geschetst. ${ }^{81}$

De fantasieën en het onbehagen van de anti-vivisectionisten over de massa waren overigens niet zelden vermengd met een romantisch beeld van de schoonheid en de eenvoud van de leden van de lagere klassen. De passage uit Meta's reisverslag is daar een voorbeeld van; zij doet onder meer denken aan de ambivalentie die schuil ging in de bewondering van de symbolistische schilders Wally Moes en Jan Veth in de jaren 1891-1893 voor de katholieke boerenmeisjes van Huizen. Bij deze vrouwen zou naar verluidde door jarenlange inteelt nog Spaans bloed door de aderen stromen. Men veronderstelde dat daarom onder hen zeer 'onhollandschen typen', 'brunettes

77. Ibidem.

78. Zie: Daniel Pick, Faces of degeneration. A European disorder c. 1848-1918 (Cambridge 1989).

79. Fontijn. Tweespalt 1901, $274 \mathrm{ev}$.

80. Jaap van Ginneken, Crowds, psychology \& politics, 187!-1899 (Cambridge 1992) 21.

81. Pick, Degeneration, $155 \mathrm{cv}$ 
met donkere als gepenseelde wenkbrauwen, een romeinschen neus en bloedrood zwellende lippen' gevonden werden. Op de schilderijen van Veth werden de Huizer vrouwen afgebeeld als madonna's, als symbool voor maagdelijke reinheid. Ook Richard Roland Holst meende dat het voorkomen van deze meisjes puurheid, onschuld en tedere schoonheid belichaamde. ${ }^{82}$ Maar hoe groot ook deze symboolwaarde van hun uiterlijk, innerlijk deugden de vrouwen volgens Moes in het geheel niet. Lien Heyting beschrijft hoe deze schilder zijn donkere schoonheden karakteriseerde als 'lastige portretten'. Medelijden met hun armoede verdienden ze naar zijn mening niet. ${ }^{83}$

De discrepantie tussen uiterlijke en innerlijke kwaliteiten is een thema in de anti-vivisectionistische romans. Ook dit past in het bredere debat over degeneratie. Zelfs de positivisten gingen er, zoals Pick laat zien, paradoxaal genoeg niet vanuit dat degeneratie als verschijnsel door de bestudering van de fysiek waarneembare werkelijkheid volledig te kennen was. 'It never lost its mystique and mystery, the sense of fundamental invisibility ${ }^{84}$, stelt hij. De anti-vivisectionistische preoccupatie met het zichtbaar maken van het kwaad hing nauw samen met dit facet van de discussie over degeneratie. Niet voor niets werd steeds beklemtoond dat er achter de schermen moest worden gekeken, dat het vernis van de zogenaamde beschaafde medici moest worden weggeschrapt of dat diep in de ziel van de vivisector moest worden getuurd. Alleen op die manier kon aan een breder publiek zichtbaar worden gemaakt wat alleen een enkeling wist of vermoedde. Hugenholtz' drang om alles wat hij in een Duits tijdschrift over vivisectie te weten was gekomen aan de onwetende Nederlandse bevolking over te brengen is daar een voorbeeld van. Zijn poging om het onzichtbare gevaar zichtbaar te maken, leidde uiteindelijk tot de oprichting van de NBBV. Ook de inleiding van Von Webers brochure Die Folterkammern der Wissenschaft verwees naar gevaren die aan het grote publiek zichtbaar moesten worden getoond. Von Weber sprak over intellectuele chaos en morele losbandigheid die hij, als ware hij een voorloper van Max Nordau, overal om zich heen meende te zien. ${ }^{85}$

Het ging Von Weber in het bijzonder om het dreigende verval van de hoogopgeleide medici, om het gevaar dat zij achter de gesloten deuren van het laboratorium in wezen eenzelfde soort ruwheid en beestachtigheid vertoonden als de lagere sociale klassen. Illustratief zijn de tekeningen die in het werk waren opgenomen. In het bijzonder de afbeelding waarop te zien is hoe studenten met munten in de hand staan te praten met een hoogleraar die op het punt staat een vivisectie te verrichten. ${ }^{86}$ De man heeft veel weg van een slager. Hij is dik, ziet er volks uit en heeft een wit slagersschort voor. Het proefdier dat hij voor zich op tafel heeft, zit geheel in de traditie van de 'vermenselijkte' dierenportretten ${ }^{87}$ van Landseer, met zijn poten als in een gebed gevouwen. Smekend kijkt het op naar de man. Gegrepen door de aanblik van het dier proberen de studenten de hond vrij te kopen. De medicus is, zo suggereert de plaat, onverbiddelijk. De hond zal in de folterkamers der wetenschap aan zijn eind komen. De tekening in Von Webers brochure laat zien dat de medicus niet veel anders is dan de beestachtige massa, dan de in de geschriften van Luchtmans en Hugenholtz genoemde slachters, kannibalen en kreofagen.

Het was precies die overeenkomst die de anti-vivisectionisten grote zorgen baarde. Dat het beest in de mens vooral onder de leden van de lagere sociale klassen de overhand had, was volgens de anti-vivisectionisten afschrikwekkend maar in ieder geval verklaarbaar en in overeenstemming te brengen met de idee van een zedelijke evolutie. Van de vivisectoren kon dit niet gezegd worden. Zij behoorden tot de geleerden, mensen die een universitaire opleiding achter de rug hadden, tot een stand die zich voorstond op haar beschaving. Het was een teken aan de wand

82. Citaten afkomstig uit Heyting. De wereld, 33-34

83. Heyting. De wereld, 36.

84. Pick, Degeneration, 215.

85. Von Weber. Folterkammem, 1-6.

86. Von Weber, Folterkammem, 56. 87. Zie over deze traditie: William Shupbach, 'A select iconography of Animal Experiment' in: Rupke, Vivisection,
340-360. 
dat juist deze mensen die het motto noblesse oblige hoog in het vaandel dienden te hebben, het op moreel gebied zo lieten afweten. Daarmee werd het leven van alledag op een ernstige wijze bedreigd. Dierproeven hingen volgens Ortt samen met andere 'maatschappelijke verkeerdheden', 'zooals alle zonden samenhangen en 't niet mogelijk zal blijken een enkele te doen verdwijnen zonder het geheele zedelijke peil der menschheid te verheffen's8.

Het was deze visie op de aard van de vivisectie en de verwantschap van deze praktijk met andere vormen van maatschappelijk kwaad die zowel in de door Ortt bestreden, fantasierijke antivivisectie brochures als in zijn eigen geschriften telkens weer uiteen werd gezet. Ortt en de andere anti-vivisectionisten verschilden dan ook niet zozeer wat betreft het beeld dat zij van de vivisectie schetsten. Alleen hun visie op de functie van fictie en fantasie verschilde. Ortt probeerde de rol van de verbeelding uit te bannen met zijn wetenschappelijke benadering van het vraagstuk. Hoewel hij zelf zijn standpunten over vivisectie niet geheel zonder verbeelding voor het voetlicht kon brengen vertegenwoordigde hij met zijn benadering een algemene kentering in de benadering van het anti-vivisectionisme. Voordat Ortt in 1898 tot voorzitter van de NBBV werd gekozen werd er in de anti-vivisectionistische geschriften geen strenge scheiding tussen fantasie en werkelijkheid gemaakt. Van der Hucht-Kerkhoven en Jungius waren immers van mening dat fictie een facet van de werkelijkheid liet zien, dat zij de werkelijkheid achter het fysiek waarneembare kon openbaren. Deze opvatting raakte mede door Ortts wetenschappelijke benadering op de achtergrond.

\section{Van voertuig tot obstakel}

Voor een belangrijk deel steunde het werk van de Nederlandse anti-vivisectionisten op de verbeelding die in het Engelse en Duitse debat over medisch-wetenschappelijke proeven op levende dieren vorm had gekregen. Dit was met name voor en vlak na de oprichting van de NBBV het geval. Hugenholtz verwees naar de romans van Edward Berdoe, de brochure van Smith werd vertaald, Von Webers tekeningen werden gretig overgenomen en Cobbe's Nine Circles werden een begrip. Ook werd een belangrijk strijdmiddel van de buitenlandse anti-vivisectionisten overgenomen: de anti-vivisectie-roman. Afbeeldingen en romans verdwenen rond 1900 als strijdmiddelen. Ortt had daar een aandeel in. Hij was tegen brochures met afbeeldingen van vivisecties omdat deze naar zijn oordeel te veel gericht waren op sensatie. Over tekeningen van honden in het genre van Lanseer sprak hij niet maar deze waren vrijwel geheel afwezig in de Nederlandse anti-vivisectionistische geschriften. Opmerkelijk is de parallel met de Nederlandse vrouwenkiesrecht-beweging uit deze periode. Marianne van der Klein constateert dat die beweging niet zo goed raad wist met afbeeldingen. De beweging was, zo laat zij zien, veel 'minder alert op visuele heeldvorming' dan de Engelse suffragettes die voor het vervaardigen van propaganda over een eigen atelier en kunstenaressen beschikten. Zij noemt dit een 'gemiste kans' voor de Nederlandse kiesrechtstrijdsters. ${ }^{89}$

Een echte verklaring voor dit verschil in beeldcultuur heeft Van der Klein echter niet. Wellicht had Nederland in vergelijking tot Engeland een minder beeldgerichte sensatiepers en lag het daarom voor verenigingen en bonden minder voor de hand om dat strijdmiddel te kiezen? Voor de anti-vivisectionistische aarzeling om afbeeldingen te gebruiken is eveneens moeilijk een verklaring te vinden. Op Ortts opmerking over de sensatie die het beeld ten onrechte zou opwekken na. spraken de vivisectie-bestrijders niet over hun terughoudendheid op dit gebied. Zou het magere gebruik van afbeeldingen misschien verklaard kunnen worden uit de streng protestantse achtergrond of sobere christen-anarchistische levenshouding van een aantal voorlieden van de beweging? Uitgesloten is dat niet, maar in die richting zijn geen duidelijke aanwijzingen.

88. Felix Ort, De vivisectie ('s-Gravenhage 1903) 7.

89. Marianne van der Klein. 'Engelse suffragettes in een Nederlandse vrouwenrubriek. Ecn confrontatic in prenten' in Mineke Bosch et al ed., Op het strijdtoneel van de politiek. twaalfde Jaarboek voor Vrouwengeschiedenis (Nijmegen 1992) 49-70, aldaar 53 . 
Over de romans als strijdmiddel sprak Ortt zich, anders dan over afbeeldingen, niet expliciet uit maar het was duidelijk dat hij ze niet onder de wetenschappelijke manier van vivisectiebestrijding rekende. Na 1897 werden in Nederland geen anti-vivisectie-romans meer gepubliceerd. Daarmee verdween een volgens Mary Poovey bij uitstek negentiende-eeuws vrouwelijk strijdmiddel van het anti-vivisectionistische toneel. ${ }^{90}$ Hetzelfde geldt voor de 'bezielende' redes die Jungius zo belangrijk vond. $\mathrm{Zij}$ verdwenen onder Ortts voorzitterschap vrijwel geheel. Ortt kon, zoals de naturalistische schrijver Arnold Aletrino dit naar aanleiding van een lezing van Ortt voor de Reinleven Beweging constateerde, niet goed in het openbaar spreken en organiseerde zo min mogelijk optredens. ${ }^{91}$ Hij beschouwde lezingen en emotionele geschriften waarschijnlijk als obstakels. $\mathrm{Zij}$ weerhielden hem ervan om zich als erudiete leek -Ortt had een exacte achtergrond en interesseerde zich ten zeerste voor medisch-wetenschappelijke vraagstukken- op basis van gelijkheid in het maatschappelijke debat over vivisectie te mengen.

Met het terugdringen van de roman en de lezing als politieke wapens werden de vrouwelijke leiders van de NBBV langzaam maar zeker minder zichtbaar in het openbare debat over vivisectie. Jungius, Van der Hucht-Kerkhoven en zelfs Groshans die vanaf 1910 tot in de jaren dertig de presidente van de bond zou zijn, speelden na 1900 in de discussie over vivisectie nauwelijks meer een rol. Natuurlijk, de eerste twee vrouwen trokken zich na de eeuwwisseling terug en ontvielen de NBBV door ziekte en dood. Dat neemt niet weg dat ook het eens zo belangrijke beeld van de vrouw als gids naar het goede en hogere met het verdwijnen van de anti-vivisectie-romans ver op de achtergrond raakte. De vrouwelijke gids werd verdrongen door de mannelijke christusfiguur die daarvoor als het ware in een symbiose met de leidsvrouwen een rol in de discussie over vivisectie en in de politieke stijl van de anti-vivisectionisten had gespeeld.

Het waren echter niet alleen de vrouwen en hun strijdwijze die voor een deel van het toneel verdwenen. In het voorgaande werd duidelijk dat ook mannelijke anti-vivisectionisten zoals Hugenholtz, Roorda van Eysinga, Luchtmans, Von Weber en Smith zich van fictie en fantasie bedienden om hun standpunten voor het voetlicht te brengen. Mede doordat Ortt zijn strenge, wetenschappelijke vivisectie-bestrijding doorvoerde en -ook al ontkwam ook hij niet aan het gebruik van de verbeelding- daar gedeeltelijk in slaagde, verdwenen deze emotionele, wellicht meer Engels georiënteerde geschriften waarin vaak heel persoonlijke visies op de geschiedenis en het verloop van de strijd tegen vivisectie naar voren werden gebracht. Die visies werden evenals de figuur van de vrouwelijke gids naar het hogere en naar superieure, geoorloofde kennis ondergeschikt gemaakt aan en voor een deel vervangen door een specifieke visie op de navolging van Christus. Hoe dit alles verliep en op welke wijze de Nederlandse vivisectie-bestrijding door deze verandering werd beïnvloed wordt beschreven in het volgende hoofdstuk dat gaat over de relatie tussen religiositeit en de ontwikkeling van de politieke stijl van de anti-vivisectionisten.

90. Poovey, Uneven, 89.

91. Kees Joosse, Amold Aletrino: pessimist met perspectief (Amsterdam 1986) 411 


\section{De man van het licht als reisgezel 1908: Optreden voor de hoorzitting van de Commissie inzake Vivisectie}

Felix Ortt zou een op basis van vivisectie ontwikkeld geneesmiddel weigeren, ook al zou hij als gevolg daarvan doodgaan. Hoe ver strekte een dergelijk principe zich uit? Om dat te weten te komen vroeg de Commissie inzake Vivisectie tijdens de hoorzitting van 10 juni 1908 aan Ortt wat hij zou doen als niet hij, maar zijn kind als gevolg van zijn anti-vivisectionistische principes zou sterven. 'Felix Ortt antwoordde dat het leven van zijn kind, hoe moeilijk dit voor hem persoonlijk ook zou zijn, opgeofferd moest worden aan het hogere principe van het anti-vivisectionisme:

'[...] de eerste christenen moedigden hunne kinderen tot daden van geloof aan met het folteren, dat daarvan het gevolg zou zijn, voor oogen. Dat noemen wij nou mooi of heroïek omdat het martelaars waren voor hetzelfde geloof dat wij nu belijden. Maar, waar het mijn ethisch geloof geldt, zou men een soortgelijke daad ten opzichte der vivisectie-quaestie fanatiek of misdadig noemen, hoewel in de grond het geval hetzelfde is. Ik zou ook zoo behooren te doen als die martelaars deden.'"

Tijdens de hoorzitting had Ortt al eerder een vergelijking tussen de anti-vivisectionisten en de eerste christenen gemaakt. Laatstgenoemden zouden hebben geweigerd om het voorgeschreven saluut aan de Romeinse keizerbeelden te geven. Zij hadden zich verzet tegen een veel sterkere en ongelovige meerderheid en waren bereid geweest om de uiterste consequentie van hun verzet te aanvaarden. Anti-vivisectionisten bevonden zich, zo suggereerde Ortt, in eenzelfde situatie. Zij vormden net zo goed een minderheid in een ongelovige samenleving en waren omringd door machtige tegenstanders.

Ortt vergeleek de anti-vivisectionisten met gelovigen, de strijd tegen vivisectie met een geloof. Hij was niet de enige, noch de eerste vivisectie-bestrijder die dat deed. In 1893 had Roorda van Eysinga de strijd tussen anti-vivisectionisten en vivisectoren al eens aangeduid als een 'geloofsstrijd' die de 'strijd tusschen Joden en Christenen, tusschen Roomschen en Protestanten, tussen Orthodoxen en Modernen' ${ }^{3}$ onbeduidend maakte. Hugenholtz meende dat het ging om een strijd die met de 'Almachtige aan onze zijde'4 werd gevoerd. In zijn visie moesten de anti-vivisectionisten het opnemen tegen gevaarlijke afgodsdienaren die hij, alsof hij op de kansel stond, streng en verwijtend toesprak:

'Gij [de vivisectoren] toch zaait het onkruid in de harten. Gij geeft steenen in plaats van brood. Waar het zaad niet deugt, deugt ook de oogst niet. Klaagt dus voor alle dingen u zelve aan. [...] Voor den afgod eener z.g. wetenschap bouwt Gij kostbare tempels, terwijl Gij dezen

1. Rapport Commissie inzake Vivisectie ('s-Gravenhage 1909) 45. De vraag die aan Ortt door het lid van de Commissie inzake Vivisectie. Mr. Snouck Hurgronje, werd voorgelegd luidde als volgt: 'Wat U zelf betreft, zoudi U eene serumbehandeling dus uit principieele grunden afwijzen, maar hoe bij een derde, bijv. wanneer uw kind leed aan miltvuur of diptherie ?'. Door deze vraag te stellen confronteerde de Commissie inzake Vivisectie Ort mel cen dilemma dat vanaf het begin van het bestaan van de anti-vivisectie-beweging door de contemporaine kritiek naar voren werd gehaald. De eerder genoemde Van Einthoven sprak zoals bleek over het afwegen van het leven van een paar konjinen tegen dat van een kind. Ook vandaag de dag. dat wil zeggen tegen het einde van de twintigste eeuw, wordt aan anti-vivisectionisten vaak een dergelijk dilemma voorgelegd: waarvoor kiest u, uw kind of uw hond? Vergl. Smit, Dierproeven, 105. Smit noemt de kind of hond afweging het 'emotionele dilemma'. Als voorbeeld van hedendaags gebruik van de vraag: 'U offert liever een mens dan een dier' noemt hij de hoogleraar De Wied die in De Telegraaf van 23 november 1985 stelt: 'Ik vind het vreemd als mensen in tranen uitbarsten als er een zielig poliokindje uit een ander land op de iv getoond wordt en tegelijkertijd schreeuwen om het afschaffen van dierproeven'.

2. Rapport Commissie inzake Vivisectie. 45. Zie voor een analyse van Ortts antwoord ook Smit, Dierproeven. 90. Volgens Smit maakt Ort gebruik van een vergelijking en meent hij daarmee ten onrechte dat hij zijn gelijk kan halen. Het heeft volgens Smit niets te maken met argumenteren of logisch redeneren. Het gebruik van vergelijkingen berust naar zijn mening op twijfelachtige gevoelens van herkenning. Ik ben van mening dat Smit door deze 'technische analyse' van Ortts argumenten geen recht doet aan het feit dat deze religieus geïnsireerd zijn en dat dit vanuit het oogpunt van de geschiedschrijver interessant is.

3. Roorda van Eysinga. Vivisectie. 2.

4. Hugenholtz. Vivisectie-vraagstuk. 41 
Moloch tallooze levende dieren ten offer brengt. ls het dan zoo ongeloofelijk dat er ook nog menschenoffers gebracht worden, wanneer de cultus van dezen afgod steeds fanatieker wordt? ${ }^{5}$

Hugo Nolthenius, van 1902 tot 1910 voorzitter van de NBBV, noemde het anti-vivisectionisme een 'Heilige Strijd' en elders zelfs een 'Heilige Oorlog'. Andere anti-vivisectionisten trokken een parallel met een kruistocht, een vergelijking die aan het eind van de negentiende eeuw in navolging van Josephine Butler ook in de anti-prostitutie-beweging werd gebezigd.

De retoriek van de anti-vivisectionisten duidt erop dat religie en religiositeit op de een of andere manier deel uitmaakten van de strijd tegen vivisectie, van de manier waarop het vraagstuk zichtbaar werd gemaakt. Maar hoe precies? Hoe verhield Ortts navolging van Christus zich bijvoorbeeld tot de religiositeit van andere anti-vivisectionisten, zoals de oprichters van de bond (waarvan er twee predikant waren) en de belangrijkste vrouwelijke vivisectie-bestrijders? Valt er een ontwikkeling waar te nemen in de manier waarop religiositeit een rol speelde in de bestrijding van vivisectie? Als de religieuze retoriek aan verandering onderhevig was dan zal dat invloed gehad hebben op de wijze waarop de vivisectie zichtbaar werd gemaakt en daardoor op de politieke stijl. Hetzelfde zou kunnen gelden voor een eventuele verandering van de door de antivivisectionisten gevolgde 'gids naar het hogere'. De keuze voor het volgen van de (mannelijke) figuur van Christus in plaats van een religieuze heldin als Jeanne d'Arc of een leidsvrouw als Queen Mab heeft mogelijk invloed gehad op de verhouding tussen mannen en vrouwen en het denken over mannelijkheid en vrouwelijkheid binnen de beweging. Deze kwesties staan centraal in dit hoofdstuk over anti-vivisectionisme en religiositeit.

\section{Het offer en de kruisiging}

In de weinig omvangrijke historiografie van het Nederlandse anti-vivisectionisme wordt ontkend dat er een sterk verband bestond tussen anti-vivisectionisme en religiositeit. Naar het oordeel van Davids waren godsdienstige argumenten zowel voor dierenbeschermers als voor anti-vivisectionisten nauwelijks van belang. Op het eerste gezicht lijkt hij het bij het rechte eind te hebben. Neem de reactie van de anti-vivisectionist C. Stams toen de redactie van het Utrechtse orthodoxprotestantse tijdschrift De Oranjevaan in 1894 beweerde dat de NBBV: 'onder den schijn van de dieren te beschermen' het christelijk geloof verwoestte en 'de geesten op de doolpaden van de heidensche volken van den ouden en nieuwe tijd' voerde. 'Onze bond als zoodanig [...] verdedigt noch bestrijdt het christelijke geloof', antwoordde Stams. ' En de vrijdenker J.G. ten Bokkel die in De Dageraad beweerde dat het merendeels 'geloovige christenen, de zoogenaamde kerkelijke partijen' waren die 'zich zoo tegen vivisectie kanten', repliceerde Stams als volgt:

'Ik vind het daar duidelijk genoeg gezegd, let wel door den president van den Nederlandschen

Bond tot Bestrijding der Vivisectie [Hugenholtz], dat de anti-vivisectiezaai geen gelootszaak is' ${ }^{8}$

Tegen Davids beweringen lijkt kortom niet al te veel te kunnen worden ingebracht. Behalve dan het volgende. Zowel Stams als Hugenholtz keerden zich af van de voorstelling dat de NBBV en het anti-vivisectionisme uitgingen van een bepaalde kerkelijke dogmatische geloofsleer maar ontkenden niet dat het anti-vivisectionisme religieus geïnspireerd was.

Ook in de geschiedschrijving van het negentiende- en vroeg-twintigste-eeuwse Engelse antivivisectionisme is slechts sporadisch aandacht besteed aan de religieuze component van de strijd tegen vivisectie. De studie van de medisch-historicus Lloyd Stevenson vormt hierop een uitzondering. Stevenson spreekt althans over een 'religieus gevoel' dat 'in Great Britain had permeated the

5. Ibidem. 34 .

6. Onder het verslag over 1896 van Roorda van Eysinga stond bovendien: 'Overtuigd dat wij zijn, dat wij eene heilige zaak voor hebben en dragen de leuze in onze banier GOD MET ONS'. Roorda, Hooger onderwijs, 19.

7. C. Stams, Tegen vivisectie (Rotterdam 1895) 19

8. Ibidem. 
whole issue of animal experimentation'. ${ }^{9}$ Dat een dergelijk gevoel zou hebben bestaan meent hij af te kunnen leiden uit de naar zijn mening opmerkelijke woordkeus van de negentiende-eeuwse Engelse vivisectoren en hun tegenstanders. Zo zouden de eerstgenoemden bij het beschrijven van een vivisectie vrijwel uitsluitend het woord 'offeren' bezigen:

'When a French or German physiologist has destroyed an animal, he says simply that he has killed it, whereas his English [...] counterpart almost always says that he has sacrificed the animal. ${ }^{10}$

Even opmerkelijk acht Stevenson de geschriften van de Engelse anti-vivisectionisten waarin vrijwel altijd gerefereerd werd aan het 'kruisigen' of de 'kruisiging' van een proefdier:

'In writing of this sort, an animal is seldom said to have been tied or secured to an operation table: almost always it is described as having been 'crucified', often of course, with the [...] specification that its extremities have been nailed in place. "11

Stevenson wijst op de religieuze retoriek in de Engelse discussie over vivisectie en ziet deze als een belangrijke aanwijzing voor het bestaan van een religieus gevoel, een religieus element in de strijd tegen dierproeven. Hij heeft daarin gelijk maar zijn stelling dat alleen Engelse antivivisectionisten zich van een dergelijk taalgebruik bedienden, kan geen stand houden. Nederlandse vivisectie bestrijders deden dat net zo goed. In de eerste door de NBBV uitgegeven brochure, Zullen wij nog langer lijdelijk blijven tegenover de gruwelen der vivisectie? (1890), bijvoorbeeld wordt het volgens Stevenson zo karakteristieke woord 'offeren' eveneens veelvuldig gebruikt. ${ }^{12}$ Gedeeltelijk laat zich dit verklaren uit het frequent citeren uit Engelse fysiologische- en antivivisectionistische geschriften. ${ }^{13}$ Toch kan niet onopgemerkt blijven dat de auteur zelf, ook buiten de citaten om, met enige regelmaat over het 'offeren' van dieren spreekt en het proefdier gelijk stelt aan een martelaar. Het proefdier was in de gedachtengang van de anti-vivisectionisten een offer voor de wetenschap en voor de mensheid. Door het martelen van het proefdier, zo werd in de anti-vivisectie-geschriften gesuggereerd, werd een oplossing gezocht voor de ziekten en kwalen die het gevolg waren van de zondige levenswijze van de moderne mens. Het proefdier werd opgeofferd om de benodigde kennis te verkrijgen maar, zo meenden de vivisectie-bestrijders, het offer was altijd te groot. Zij verwezen in dit verband onder meer naar Lied van schijn en wezen (1895) van Frederik van Eeden. Een strofe uit dit gedicht luidde:

'Met liefde slechts kan heilig weten stijgen,

met het bloed van een dier is te duur gekocht

een paradijs van kennis'

De NBBV koos deze passage als motto. Tot 1910 werd dit motto boven elke aflevering van het Orgaan afgedrukt.

Door hun leven te laten en pijn te lijden brachten dieren volgens de anti-vivisectionisten dus een offer voor kennis die de mensheid wilde bezitten om daarmee gezondheid en welzijn te verwerven. Daarmee was het dier letterlijk een slachtoffer, zoals eerder duidelijk werd uit de verbinding die werd gemaakt tussen vivisectie en het slachten van dieren. Doordat het proefdier als offer werd gezien kreeg het, net zoals dit volgens René Girard in werkelijke offer-rituelen

9. Lloyd Stevenson. 'Religinus elements in the background of the British anti-vivisection movement', Yale Journal of Biology' and Medicine' 29 (1956) 125.

10. Stevenson, 'Religious', 125

11. Ibidem

12. NBBV, Zullen wij nog langer lijdelijk blijven legenover de gruwelen der vivisectie? Vraag aan het Nederlandsche Volk door de redactie van Androcles, maandblad aan de belangen van dieren gewijd ('s-Gravenhage 1890). Ook verschenen onder de titel: De vivisectie, de heginselen, waardoor zij wordt gedreven, en de weg om haar te bestrijden ('s-Gravenhage 1890).

13. Een dankbare bron om citaten aan te ontlenen was het werk van de oprichter van de Victoria Street Society. George Hoggan. Deze marine-officier was na zijn pensionering medicijnen gaan studeren. Als 'a sort of pastime' liep hij stage in de laboratoria van Claude Bernard. Na zijn terugkomst stortle Hoggan zich met overgave in de discussie over vivisectie die toen in de Britse pers werd gevoerd. Zijn brief in The Morning Post van 2 februari 1875 maakte veel indruk op de publieke opinie. 
geschiedt, een sacrale status. ${ }^{14}$ Tegelijkertijd kreeg het een menselijke status. Als dit ergens duidelijk wordt dan is het wel in de anti-vivisectie-roman, Eli, waar zijt gij!' van Jo ZeegersClaessen, een roman die in de jaren dertig met enthousiasme door de NBBV werd besproken. Het verhaal handelt over Eli, de mens die telkens wedergeboren wordt. In zijn vele levens wordt de held Eli geconfronteerd met de vele gezichten van het menselijk kwaad. Eén daarvan is de vivisector die Eli's reisgezel, een trouw hondje, naar zijn laboratorium ontvoert. Als Eli deze 'hel der onschuldigen' betreedt, ziet hij het dier vastgebonden op een tafel liggen:

'Daar lag zijn kleine vriend [...] zijn stembanden doorgesneden, opdat hij niemand zou kunnen hinderen met de kreten van pijn, die anders noodwendig zijn keeltje zouden ontsnappen, de buik opengereten, want de professor was juist bezig den studenten uit te leggen, waar en hoe... Eli zag de oogen van zijn vriend op hem gericht. De angst en de smart doorboorden zijn hart. Dat waren de oogen van Christus, toen hij gekruisigd werd.'

Het proefdier is het ultieme heilige slachtoffer geworden. Nergens in de anti-vivisectie-geschriften werd dit zo duidelijk uitgesproken als in deze roman. Dat neemt niet weg dat de vivisectiebestrijders wel verbanden legden tussen de positivistische wetenschap, de vivisectie, het wezen van het kwaad en de kruisiging van Christus. Dit laat zich het beste illustreren aan de hand van de parabel De ziel der wijze (1898) van Felix Ortt ${ }^{16}$.

\section{De ziel der wijze}

De ziel der wijze speelt zich af in een ver verleden dat door Ortt wordt aangeduid als 'overoude' tijden. Toen leefde er 'in 't Oosten' een tevreden en ijverig volk van eenvoudige en onontwikkelde mensen in een onschadelijke zelfzucht. Op een dag kwam een Wijze in hun midden wonen. Hij hielp hen met hun werk en gaf troost bij ziekte en raad en steun als er problemen waren. De Wijze zag dat de meeste mensen van het volk liefdeloos waren en leerde hen, zoals Ortt het uitdrukte, 'van God' en van liefde:

'Hij leerde hun dat liefhebben was: zichzelf vergeten en zich te plaatsen in de toestand van een ander en die aan te doen, wat men zichzelf zou wensen. ${ }^{17}$

Opdat het volk niet zou vergeten wat het had geleerd, nam hij een scherpe doorn. Daarmee grifte hij lettertekens, figuren en afbeeldingen op een stuk boomschors. Bij elk teken vertelde hij een verhaal zodat men zich deze woorden zou herinneren wanneer men naar de afbeeldingen keek. Niet lang daarna verdween de Wijze. Het volk zocht hem overal maar vond hem nergens. Hoewel het volk aanvankelijk zeer verdrietig was, troostte het zich met de gedachte dat het geleerd had wat liefde was. De mensen leefden voort zoals de Wijze het hun had geleerd.

$\mathrm{Na}$ een lange tijd, vele geslachten later, werd het vredige volk aangevallen door een ruw, woest en vijandig volk uit de bergen. Allen die zich verweerden werden gedood, de overigen werden tot slaaf gemaakt. Ondanks het gemak waarmee zij het vredige volk hadden overwonnen, vreesden de ruwe overweldigers dat zij hun heerschappij spoedig zouden verliezen omdat zij in de minderheid waren. Eén van de oudsten uit hun midden stelde daarom voor om de in de bergen woonachtige en alom gevreesde tovenaar om raad te vragen. Een delegatie werd uitgezonden. Deze voerde tien vrouwen van het overwonnen volk mee als voedsel voor de draak die de tovenaar bewaakte. Na enige dagen kwamen de gezanten terug, zonder de vrouwen maar met de raad van de tovenaar. Het enige wat zij bij zich hadden was de spreuk: 'kennis is macht'.

Nadat de overweldigers diep over deze spreuk hadden nagedacht, besloten zij kennis te verzamelen over alles wat zij om zich heen zagen:

14. René Girard, La violence el le sacré (Parijs 1994) 7. Girard verwijst in verband met de heiligheid van het ofrer of slachtoffer naar de studie van H. Huber en M. Mauss. 'Essai sur la nature el la fonction du sacrifice' in: M.Mauss, Oevres I (Parijs 1968) 110-126.

15. Zeegers-Claessen. Eli, 48-49.

16. Felix Oru, 'De ziel der Wijze (een gelijkenis)' in: Mensch en Dier. Beschouwingen en schetsen door Felax Orll (Soest 1948, eerste druk 1916). De ziel der wijze werd voor het eerst gepubliceerd in 1898 in Androctes.

17. Orlt. 'Wijze', 21. 
'Zij bestudeerden de eigenschappen van zijde en staal, en van andere delfstoffen: zij vonden middelen om de bestanddelen te onderscheiden, waaruit deze bestonden. En later, toen zij bemerkten dat velen van hen ziek werden door' $t$ gemakkelijk overdadig leven in de vlakte, maakten zij afkooksels van planten en probeerden daarmede de zieken te genezen: en vervolgens namen zij dieren en svervoederden die, tot deze ook ziek werden, en trachtten dan te onderzoeken waar de ziekte schuilde, en ze sneden het zieke orgaan weg, of wiesen het met een prikkelend afkooksel. of besmeerden het met zware vergiften, en keken of het dier dan beter werd. ${ }^{\text {i8 }}$

De heersers werden ondanks deze kennis steeds zwakker, nietiger en ziekelijker. Zij benijdden het slavenvolk dat matig en vredig leefde, hard werkte en gezond en sterk was gebleven, terwijl het toch geen kennis en geen macht bezat. De geleerden van het heersersvolk namen een aantal van de slaven en martelden hen. 'Waarom verzamelen jullie geen kennis?' vroegen zij de gepijnigden. Het antwoord luidde: 'wij hebben niet geleerd dat kennis geluk brengt. Alleen liefde brengt geluk.' De slaven vertelden het verhaal van de wijze en de boomschors.

Niet lang daarna werd het stuk boomschors door de nieuwsgierige overweldigers gevonden en na vele martelingen vertelde het overwonnen volk dat in de boomschors nog altijd de ziel van de wijze woonde. De overheersers werden aanvankelijk kwaad omdat het verhaal hun zeer ongeloofwaardig voorkwam. Uiteindelijk besloten zij de boomschors toch aan een onderzoek te onderwerpen. Zij verkeerden in de overtuiging dat het geheim van de schors door middel van wetenschap achterhaald en verklaard kon worden:

'Ze begonnen het stuk schors te wegen. en ' $t$ volume te bepalen en het soortelijk gewicht, en 't opslorpingsvermogen voor water, de suortelijke warmte, het geleidingsvermogen voor electriciteit, de doorschijnendheid van fijne schilfers, de elasticiteit, het draagvermogen $|\ldots|$ maar alles was gelijk aan dat van gewone boomschors. [...] Toen begonnen zij de groeven der lettertekens te onderzoeken, deze werden gemeten. de diepte van elke haal en insnijding, men liet ze vollopen met donker vocht en drukte ze af. $[\ldots]$ de statistici $[\ldots]$ gingen meten met fijne werktuigen de lengte van alle halen naar boven, en groeven naar beneden, naar rechts en naar links, en tellen alle mensen en dierentiguren, en rangschikken in groepen van alle lettertekens [...] Maar de ziel werd niet gevonden. ${ }^{, i 9}$

De geleerden besloten vervolgens om de schors in een retort te vervluchtigen en te onderzoeken of, in het op deze wijze ontstane gas, de ziel van de wijze te vinden was. Het slavenvolk klaagde en jammerde en smeekte de heersers om de schors te sparen. Tevergeefs. De schors werd verbrand maar men vond niets. De geleerden verklaarden dat afdoende was bewezen dat de ziel nooit had bestaan. Het slavenvolk huilde om het verlies van zijn schat, maar de ziel van de Wijze ging van de schors in hun harten over. ${ }^{20}$

In de parabel van de ziel der Wijze trok Ortt een parallel tussen de vernietiging van de schors (met daarin de ziel van een op Christus gelijkende figuur door de positivistische wetenschappers) en de kruisiging. Het hezielde, heilige stuk schors werd opgeofferd aan de dorst naar kennis en de zunden van het barbaarse volk. Evenals de vivisectoren pijnigden en vernietigden zij hun onderzoeksobject in de hoop dat zij op deze wijze de genezing van hun moderne kwalen zouden vinden.

\section{Ibidem. 23}

19. Ibidem. 25.

20. Dit einde van Orts parabel doet denken aan de kruisiging van Christus die wordt beschreven in Ben Hur: $a$ lale of the time of our Lord van Lew Wallace. In dit boek uil 18,80 wordt de kruisiging uitdrukkelijk beschreven als een daad van de Rumeinse overheid tegen de eerste Christenen. Wallace beschrijf hoe na de dood van Christus de geest van deze zoon van God de eerste Christenen aanraakt. Het is niet ondenkhaar dat Ont door dit verhaal geinspireerd was. De Nederlandse vertaling van het populaire boek was vier jaar voor de parabel verschenen en Ont voelde zich, zoals bleek uit zijn optreden voor de Commissie inzake Vivisectie, ten zeerste aangetrokken tot de vergelijking tussen moderne ethische kwesties en het geloof van de ecrste christenen ten tijde van de Romeinse onderdrukking. 
Ortt onderscheidde in zijn gelijkenis twee manieren van kennis verwerven, een geoorloofde en een ongeoorloofde. In de parabel van de ziel der Wijze wordt het slavenvolk, na aanvankelijk onwetend te zijn, 'wetend' doordat het leert om zich met anderen te identificeren of, zoals Ortt het samenvatte, te leren de naaste lief te hebben. Het volk verwerft kennis door hetgeen waarover men iets wilde weten lief te hebben. De barbaarse overweldigers worden daarentegen 'wetend' op de manier zoals dit door de positivistische wetenschap werd nagestreefd, zonder identificatie met of gevoel ten opzichte van het onderzoeksobject. Bovendien, en dit is minstens zo belangrijk in Ortts typering van deze overheersers, hechten zij slechts waarde aan het zintuiglijk waarneembare.

In Ortts gelijkenis gaat het om het probleem dat door Roger Shattuck wordt aangeduid als 'Knowlegde Double-Bound':

'Both common sense and the history of philosophy recognize two kinds, two tendencies of knowledge. Or we may stand outside, observe, anatomize, analyze, and ponder the thing known in order to attain objective knowledge. Subjective or empathic knowledge causes us to lose a judicious perspective on the object; objective knowledge, in seeking to maintain that perspective, loses the bond of sympathy. We cannot know something by both means at the same time. To attempt to reconcile the two or to alternate between them leads to great mental stress.' 21

In de parabel stelt Ortt de 'empathische kennis' van de navolgers van Christus boven de positivistische, 'observerende kennis' van zijn kruisigers. Toch klinkt in zijn beschrijving een ambivalentie door. De uiterste consequentie van de niet agressieve, gevoelige manier van kennis verwerven was passiviteit, het wachten tot wijsheid uit liefde werd ontvangen of door liefde werd doorvoeld. Dit door geloof en gevoel verkregen 'weten' bleek gevaarlijk te zijn voor degene die het bezat. Het slavenvolk uit de parabel was naïef en kwetsbaar. Het kon zomaar overvallen worden door gewelddadige barbaarse buitenstaanders. Het bereikte op deze manier niets, althans op de korte termijn en gedurende het aardse leven niet, en het ging aan het eigen gelijk ten onder. Zie hier het dilemma van de expressieve politiek en de navolging van Christus in een notedop.

Geen wonder dat juist Ortt worstelde met dit probleem van kwetshaarheid, met de vraag op welke wijze men zich als volk, groep of individu tot het kwaad diende te verhouden. In verband met deze kwesties verdiepte hij zich in theorieën over de aard en oorsprong van het kwaad, over de plaats van het kwaad in de morele evolutie en over het verschil in 'zedelijk peil' tussen individuen en volkeren onderling. Verschillende gangbare evolutionistische en antropologische theorieën waren voor hem belangrijk. Zo moet hij bij het schrijven van zijn gelijkenis gedacht hebben aan de theorie van de door hem zeer bewonderde achttiende-eeuwse biolong George Louis Buffon, die stelde dat in het Oosten, en meer in het bijzonder in India, de eerste mensen als een liefdevol, wijs en gelukkig volk hadden geleefd. Buffon was ervan overtuigd dat het volk op een zeker moment door een ruw en woest bergvolk was aangevallen en dat het kwaad zich op deze wijze over de wereld had verspreid. ${ }^{22}$

Minstens zo zeer als tot de theorie van Buffon voelde Ortt zich aangetrokken tot het werk van Edward Burnett Tylor. ${ }^{23}$ Deze antropoloog ging er vanuit dat er één evolutionair proces was waarin alle bestaande culturen zich van een primitieve vorm naar de hoogste beschaving ontwikkelden. Ortt gaf aan deze opvatting een eigen draai door Tylors inzichten,gecombineerd met de denkbeelden van Wallace en Darwin, te presenteren als een bewijs voor het bestaan van een

21. Roger Shattuck. Forbidden knowledge. From Prometheus to pornography (New York 1996) 332

22. Leon Poliakov, De Arische Mythe (Amsterdam 1979). Zie ook: Wolf Lepenies, Auloren und Wissenschafller im 18. Jahrhundert: Buffon, Winckelmann, George Forster, Erasmus Darwin (München 1988) John Herbert Eddy jr., Buffon, organic change and the races of man (Michigan 1980).

23. Zie over hem in de eerste plaats het werk van zijn criticus Franz Boas. 'The History of Antropology' (1904) in: George W. Socking jr. ed., A Franz Boas Reader. The Shaping of American Anthropology 1883-1911 (Chicago/Londen 1974) 23-36. Zie ook: Edward B. Tylor, Primitive Culture; Researches into the development of mythology, philosophy, religion, language, art, and custom (Londen 1920, oorspronkelijke versie 1858). Zie ook: Joan Leopold, Culture and evolutionary perspective: E.B. Tylor and the making of primitive culture (Berlijn 1980) 
morele evolutie. 'Negers en andere natuurvolkeren' waren, zo concludeerde Ortt, 'jonge zielen' die zich in een vroeger stadium van de morele evolutie bevonden en nog niet doordrongen waren van de eenheid van al het levende. Zij hadden geen medelijden met andere wezens, bekommerden zich slechts om het eigen heil of dat van directe verwanten en hadden er geen moeite mee om anderen kwaad te berokkenen. Om die reden maakten zij zich schuldig aan de jacht, dierenkwelling en geweld. In de loop der tijden zou dit veranderen.

Tekenend voor zijn eclectische benadering en wellicht ook tekenend voor zijn verwarring over de vraag naar de oorsprong van het kwaad en de aard van culturele verschillen, is dat Ortt in zijn denken, en bij het schrijven van zijn parabel, behalve door de evolutionaire antropologie sterk werd beïnvloed door Herders Ideen zu einer Philosophie der Geschichte der Menschkeit. Evenals Herder nam Ortt aan dat oosterse volkeren anders dan 'negers, indianen en eskimo's' van nature 'volgzaam, kinderlijk, vredelievend, passief en devoot' ${ }^{24}$ waren. Die mening zag hij bevestigd in het werk van $\mathrm{H}$. Fielding, de Engelse schrijver en reiziger die in hetzelfde jaar als waarin Ortt zijn gelijkenis schreef furore maakte met de bestseller The soul of a people. ${ }^{25}$ In dit boek beschreef Fielding zijn jarenlange verblijf onder de boeddhisten in Burma. Ortt werkte aan een vertaling van Fieldings verslag en was er zeer van onder de indruk. Vooral de religiositeit van de Burmezen sprak hem aan. In het voorwoord bij De ziel van een volk. Het boeddhisme als volksgeloof in Burma, dat in 1900 werd gepubliceerd stelde hij: 'Ja, voorzeker zullen die Boeddhisten ons Christenen voorgaan in het Koninkrijk Gods'. ${ }^{26}$ Ortt betreurde het dat de zogenaamd beschaafde christenen de cultuur van de Burmezen kapot hadden gemaakt door het onschuldige en vredelievende volk te confronteren met geldjagend kapitalisme, brutaal geweld, kerks vormgeloof en dierenmishandeling. De reine levenswijze, de wijsheid en het natuurlijke leefgebied van dit volk was ernstige schade toegebracht door oproer, brandstichting, plundering en 'wit gepleisterde graven vol dondsbeenderen'.?7 De christenen stonden daarom gelijk aan de Farizeërs in de tijd van Jezus.

Zowel in dit voorwoord hij Fieldings boek als in De Ziel der wijze beschrijft Ortt 'het kwaad' als een invasie van een volk dat in de geest van Christus leeft door een vreemde, barbaarse cultuur. Dit thema keert ook terug in zijn roman Felicia, een boek van vervulling over de opkomst en ondergang van een groep navolgers van Christus die zich op de Nederlandse heide in een kolonie vestigde en daar volgens het Liefdebeginsel van Jezus in vreedzaamheid probeerde te leven. $^{28}$ Op een dag wordt de kolonie bezocht door de vieze, brutale joodse zwerver, Mozes Augurk. De ongenode gast vraagt de kolonisten om onderdak en werk. Hoewel de meeste kolonisten ernstig twijfelen aan de goede bedoelingen van de jood zijn zij van mening dat hij een kans moet krijgen. Mozes Augurk krijgt een baantje als letterzetter in de drukkerij die de kolonie rijk is.

De nieuwe kolonist werkt hard en introduceert een aantal neefjes en kennissen in de kolonie die hem bij het letterzetten hehulpzaam zijn. Uiteindelijk komt hij onverwachts met zijn vriendin Rebecca aanzetten. Haar achternaam 'Konijn' verwijst naar de bedreigende mate waarin het aantal verwanten van de letterzetter toeneemt. Zo vervullen Mozes en zijn kornuiten langzaam maar zeker de rol van overweldigers of, om in Ortts woorden te spreken, zij zijn een ware invasie. De neefjes verpesten de frisse geur van de kolonie met hun sigarettenwalm, hun vrienden maken de dekens vies en vuil. De kolonievrouwen kunnen daardoor de was, werk dat hen zeer zwaar valt, niet meer bijbenen. Het lukt hen met andere woorden niet om zich tegen de toenemende

24. Citaat ontleend aan Ian Buruma, 'De boom van Herder' in: De boom van Herder. Van der Leeuw Lezing, De Volkskrant (Amsterdam 1993) 12-20. 16.

25. H. Fielding, The soul of a people (Londen 1898).

26. H.Fielding, De ziel van een volk. Boeddhisme als volksgeloof in Burma. Vertaling Felix Orn ('s-Gravenhage 1900). woord vooraf". (geen blz. irs.).

27. Fielding. 'woord vooraf'.

28. Felix Ortt. Felicia, een boek van vervulling ('s-Gravenhage 1905). De roman maakte deel uit van een trilogie waartoe ook Heidekind (Blaricum 1904) en Felicia, een hoek van roeping ('s-Gravenhage 1905) behoorden. 
onzuivere, onreine elementen te verweren. Hierdoor ontstaat irritatie tussen de kolonisten onderling. Deze onderlinge verdeeldheid draagt er toe bij dat Mozes Augurk betrekkelijk gemakkelijk, volgens de kolonisten door een echte 'fieltenstreek', de kolonie volledig in zijn greep krijgt. De eenheid van de oorspronkelijke bewoners is gebroken en uiteindelijk wordt de kolonie door brand verwoest.

Het slavenvolk uit De ziel der wijze, het 'eerste volk' uit de theorie van Buffon, de Burmezen uit Fieldings verslag, de kolonisten uit Felicia en de 'eerste christenen' waar Ortt tijdens de hoorzitting van de Commissie inzake Vivisectie aan refereerde, hebben met elkaar gemeen dat zij in de geest van Christus leven en in ethisch opzicht een elite vormen. Zij staan symbool voor het goede, voor de eenheid van al het levende en voor liefde. De overweldigers van deze navolgers van Christus hebben met elkaar gemeen dat zij tweespalt zaaien, fragmentatie en chaus veroorzaken. Zij zijn materialistisch, gewelddadig en onzedelijk en worden op de een of andere wijze met joden vergeleken. In De ziel der Wijze omdat zij in feite de kruisiging van de op Christus gelijkende figuur uitvoeren en in het voorwoord bij De ziel van een volk omdat zij farizeërs worden genoemd. In Felicia, een boek van vervulling wordt de gemeenschap van de navolgers van Christus door een joodse invasie verstoord en vernietigd, 'gekruisigd' zou men kunnen zeggen.

Wanneer met het bovenstaande in gedachten de eerder aangehaalde passage uit Eli, waar zij gij? (waarin de ogen van een proefdier met die van Christus aan het kruis werden vergeleken) en ook Ortts vergelijking tussen Van Rijnberk en Ahasvarus de wandelende Jood, in herinnering worden gehaald dan wordt duidelijk dat de vivisector inderdaad gelijk gesteld werd aan de kruisiger, de beul van Christus. De kruisiging werd op haar beurt weer beschouwd als de afwijzing van een in praktijk gebracht liefdesbeginsel, als een belemmering van de zedelijke evolutie en een knieval voor chaos en geweld. Op deze wijze, en op dit niveau van gedachten en associaties vloeiden de figuur van de vivisector en de figuur van de jood ineen. Beiden representeerden, geheel conform de wijze waarop in die periode in brede kring over joden werd gedacht, het wezen van het kwaad: materialisme, positivisme, sociale onrust, chaos en de ontkenning van het bestaan van een schepper. ${ }^{29}$

Kan op basis van deze keten van associaties gesteld worden dat de religieuze component of zijde van het anti-vivisectionisme in wezen antisemitisch was'? Die vraag kan niet zonder meer bevestigend beantwoord worden. Over de Zwisterse anti-vivisectie-beweging schrijft de medischhistoricus Rudolf Neff:

'Die Frage nach der Verbindung zwischen Antisemitismus und Antivivisektionsbewegung läßt sich nich so einfach beantworten. An der Existenz einer solchen is jedoch nicht zu zweifeln. ${ }^{30}$

Volgens Neff waren anti-vivisectionisme en antisemitisme in Zwitserland met elkaar verstrengeld en wel door de sympathie van veel vivisectie-hestrijders voor de strijd tegen het 'kosher slachten'. Toen in 1905 in Zürich het 'ritueel slachten' door middel van een referendum werd verboden, meenden de anti-vivisectionisten in dit kanton bijvoorbeeld dat de aan deze kwestie verwante strijd tegen dierproeven eveneens langs deze weg kon en zou worden beslecht. Ook in Duitsland was de strijd tegen ritueel slachten nauw met het anti-vivisectionisme verhonden. Het belangrijkste antivivisectionistische periodiek, Thier- und Menschenfreund voerde een fanatieke strijd voor de afschaffing van kosher slachten. Het aantal artikelen over dit onderwerp oversteeg soms zelfs de hoeveelheid artikelen over de bestrijding van vivisectie. ${ }^{3}$ Met name Hermann Stenz, de aan het tijdschrift verbonden schrijver die zo'n indruk op Hugenholtz had gemaakt, stond als een fervent abolitionist van kosher slachten bekend. Behalve in de strijd tegen het slachten kwamen antivivisectionisme en antisemitisme in Duitsland samen in de Bayreuther Blätter. Deze fungeerden als spreekbuis voor Bernhard Förster (broer van de in Nederland door Suze Groshans zeer bewonder-

29. Zie hierover bijvoorbeeld : George L. Mosse, The Culture of Western Europe (Boulder en Londen 1988 ) 52.

30. Neff, Schweiz, 44.

31. Ibidem, 22. 
de anti-vivisectionist Paul Förster) die er in 1880 zijn aan de Reichstag gerichte antisemitische petitie in publiceerde. Twee jaar later volgden een aantal anti-vivisectionistische artikelen van zijn hand. Wagner zelf publiceerde na lezing van Von Webers Die Folterkammern der Wissenschaft een open brief tegen vivisectie in zijn tijdschrift. ${ }^{32}$

De Engelse anti-vivisectionisten schrokken er, zoals French laat zien, niet voor terug om veelvuldig uit Duitse anti-vivisectie-geschriften te citeren. $\mathrm{Zij}$ trakteerden hun publiek aldus op vlammende verhandelingen over de schadelijke invloed van 'Judaism and Materialism'. Dit zou met name het geval zijn geweest toen de organisatie van de Humane Jews of England niet bereid bleek om adhesie te betuigen aan de Victoria Street Society. De daarop volgende antisemitische tendens in de geschriften van de anti-vivisectionisten bleef niet onopgemerkt. De door French aangehaalde contemporaine publicist Morris Rubens concludeerde bijvoorbeeld verontwaardigd dat Cobbe en de anti-vivisectionistische arts Lawson Tait met het antisemitisme als wapen, de vouruitgang van de wetenschap probeerden tegen te gaan.

In Nederland lag de zaak bepaald anders. De Nederlandse anti-vivisectionisten maakten zich niet druk over kosher slachten. Dierenbeschermers hadden doorgaans meer belangstelling. De NBBV citeerde wel uit Thier- und Menschenfreund en uit het werk van Lawson Tait, zij het niet uit de antisemitische artikelen. De negatieve voorstellingen van joden bleven beperkt tot het niveau van associaties die nauw samenhingen met de religieuze retoriek waarmee het vivisectie-vraagstuk werd verbeeld, met voorstellingen van het kwaad, het offer en de kruisiging van Christus. Het is dan ook moeilijk te bepalen wat het negatieve beeld van joden in de hierboven beschreven associatie-keten zegt over de religieuze zijde van het protest tegen vivisectie. Het was er een onderdeel van, maar het is niet eenvoudig om uit te maken hoe substantieel het voor de Nederlandse anti-vivisectionisten was.

Toch kan niet zonder meer akkoord kan worden gegaan met French' opvatting dat antisemitisme niets verduidelijkt over de religieuze kant van het anti-vivisectionisme omdat het niet zou gaan om 'bonafide theologische issues' maar om 'the particular mentality of certain spokesmen for the movement'. ${ }^{33}$ Juist in een expressieve politieke beweging, waarin het uitdragen van morele en religieuze opvattingen een centrale plaats innam en het stellen van een persoonlijk voorbeeld zeer belangrijk was, zijn persoonsgebonden opvattingen belangrijk. Ook Turner is van mening dat de bestudering van biografische gegevens en van de levensbeschouwelijke opvattingen van toonaangevende figuren binnen de anti-vivisectie-beweging inzicht geeft in de relatie tussen religiositeit en anti-vivisectie. ${ }^{34}$ In ieder geval hadden, zoals in het volgende deel van dit hoofdstuk zal blijken, Ortts persoonlijke opvattingen over en ervaringen met de navolging van Christus een duidelijke invloed op de ontwikkeling van de politieke stijl van de NBBV.

\section{De navolging van Christus}

In de rede 'Waarom werd ik anti-vivisectionist?' stelt Felix Ortt zijn beslissing om lid te worden van de NBBV voor als een bekering. En wel één die sterke overeenkomsten vertoont met de manier waarop Marie Loving uit Naar het groote licht haar vriend Frits van Beers van het kwaad van de vivisectie wist te overtuigen (zie hoofdstuk 3). Marie stelde dat Christus nooit een vivisectie zou verrichten. Ortt beschreef zijn beslissing om anti-vivisectionist te worden als volgt:

' $\mathrm{k}$ was dierenvriend, maar ik voelde het klemmende in de redenering van hen, die menen uit ethisch oogpunt toch soms dierproeven te moeten nemen. Hoewel het lijden dat daarbij gewoonlijk plaatsvindt, mij vol sympathie voor de anti-vivisectionistische idee deed stemmen, meende ik om die reden toch geen lid van een anti-vivisectie-vereniging te kunnen worden.

32. Zie hierover: Baron von Wolzogen, Richard Wagner en de wereld der dieren, bijdrage tot eene levensgeschiedenis (Amsterdam 1890). Dit werd vrij vertald door Hugo Nolthenius die Ort in 1905 als voorzitter van de NBBV opvolgde. Nolthenius droeg het werk op aan de Nederlandse dirigent en Wagner-liefhebber Henri Viotta.

33. French, Antivivisection, 348.

34. Turner, Reckoning, 209 
Maar op een avond kwam plotseling een gedachte bij me op en wel deze: zou Jezus, om welke reden ook, ooit vivisectie kunnen plegen? En met die vraag was meteen het antwoord gegeven en de volgende morgen meldde ik mijn toetreding tot de anti-vivisectie beweging. ${ }^{35}$

Ortt was ervan overtuigd dat het voorbeeld van Christus gevolgd diende te worden. Andere toonaangevende anti-vivisectionisten, Jungius en Van Rees bijvoorbeeld, waren dezelfde mening toegedaan. Niet voor niets werd bij de dood van Van der Hucht-Kerkhoven in het Orgaan nadrukkelijk vermeld dat Thomas a Kempis' Imitatio Christi ${ }^{37}$ haar lievelingsboek was geweest. Ook het door Jungius geschreven sprookje 'Onze lieve Heiland van de doornen kroon' illustreert het belang dat aan de navolging van Christus werd gehecht. ${ }^{38}$

\section{Onze lieve Heiland van de doornen kroon}

'Onze lieve Heiland van de doornen kroon' handelt over een land dat eens weelderig en vruchtbaar was, maar zich nu met schrale, kale vlakten uitstrekte. Ergens op die droge grond stond een heuvel met de 'Kapel voor Onze Lieve Heiland'. Niemand ging er ooit heen. Van haar glorie restte slechts een oude sage dat de Heiland, die in de nis van de kapel stond, eens een wonder zou verrichten. Hij zou de dorre velden herscheppen tot de feestelijk wuivende bossen van weleer. De mensen hadden zelf al geprobeerd om het land weer vruchtbaar te maken maar zij hadden die strijd uiteindelijk opgegeven. Één man was stug door blijven gaan. Op een dag ging hij naar de kapel om te bidden dat zijn arbeid eens vruchten af zou werpen. Toen hij vertrok was het al nacht. Hij beschouwde dit als een teken dat hij voortaan in het donker moest werken, zodat niemand hem zou zien of storen. En zo gebeurde het. Iedere nacht werkte de man totdat er grote druppels bloed uit zijn handen en druppels zweet van zijn lichaam in de omgewoelde aarde vielen. Zijn lichaamsvocht maakte de bodem ongemerkt vruchthaar. Overdag zagen de mensen dat het land 's nachts bebouwd werd. Zij trokken naar de kapel om voor de Heiland te bidden maar zij kregen geen reactie. De Heiland keek teer en geduldig voor zich uit en de mensen vertrokken weer. Na vele jaren had de zwoegende man zijn nachtelijke arbeid voltooid. Hij ging opnieuw naar de kapel om daar dagen en nachten achter elkaar te bidden. In die tijd maakten de elfen het land groen. De man huilde van dankbaarheid en het volk was blij. Toen geschiedde een wonder. De handen van de Heiland bewogen zich en legden zijn doornen kroon op het hoofd van de biddende man. De doornen verwondden hem en verdrietig vroeg de man: 'Waarom aldus'? Is dit het wonder uwer genade? Ik wacht het loon uwer liefde' ${ }^{39}$. Er kwam geen antwoord. Alleen de doornen prikten dieper in zijn vlees. Treurig verliet de man de kapel. Tijden lang zwierf hij rond en elke dag groeide de pijn. Op een ochtend knielde hij wanhopig neer en smeekte hij om verlossing. Weer geschiedde een wonder. De doornen takken veranderden in bloemen van licht. De man vond berusting en vrede, Hij keerde terug onder de mensen en troostte hen die bedroefd waren en in nood.

Jungius beschreef in haar sprookje hoe ver een navolger van Christus moest gaan met het brengen van persoonlijke offers. Zoals Ortt zich voor de Commissie inzake Vivisectie bereid verklaarde om het leven van zijn kind aan zijn principes op te offeren, zo stelde Jungius dat men bereid moest zijn om zijn hele leven lang en hard te werken zonder daarvoor een beloning of erkenning te krijgen. Evenals de op Christus gelijkende figuur moest de anti-vivisectionist het ultieme offer brengen en uit liefde en medelijden voor anderen zijn leven geven.

35. Felix Ort. Waarom werd ik anti-vivisectionist (z.p. z.j.). De lezing heeft geen pagina-nummers. Een getypte versie van deze lezing is aanwezig in het archief van de Anti-Vivisectie Stichting te Den Haag.

36. 'In memoriam mevrouw C. Van der Hucht-Kerkhoven overleden te Amsterdam 25 december 1915', Orgaan van den Nederlandschen Bond tot Bestrijding der Vivisectie 13 (1916) $21 \mathrm{ev}$

37. Thomas a Kempis, De navolging van Christus (Amsterdam 1973).

38. Marie Jungius, 'Onze lieve heiland van de doornen kroon' in: Verzen en sprookjes van Marie. Jungius (tweede druk z.p. 1928) 89-95. De eerste druk van Jungius sprookjes verscheen in 1899.

39. Ibidem, 92 . 
De voorstelling van de figuur van Christus die door de Nederlandse anti-vivisectionisten werd gegeven paste in een bredere traditie. Hans Hinterhaüser betoogt in zijn studie dat de Europese literatuur in de periode 1880-1914 doorspekt was met op Christus gelijkende of naar de figuur van Christus verwijzende personages. Gedacht kan bijvoorbeeld worden aan De ldioot van Dostojevski maar ook aan Der Heiland der Tiere van Emil von Schoenaich-Carolath. ${ }^{40}$

In romans en verhalen werden zogenaamde dubhelgangers van Christus ten tonele gevoerd. $\mathrm{Zij}$ werden voorgesteld als apostels, droumbeelden of als dwaas en tegelijkertijd als de personificatie van medelijden, liefde, deemoed, zelfopoffering en vergevingsgezindheid. Een belangrijk verschil met de beschrijvingen van de historische figuur van Christus door Ernest Renan en D.F. Strauss was dat Christus in de dubbelgangers-literatuur werd afgeschilderd als een idealist die zich inzette voor maatschappelijke en sociale hervormingen. Soms werd hij beschreven als een Don Quichot die, onbegrepen door de buitenwereld, werk verrichtte. De door Jungius beschreven ploeterende landarbeider is daarvan een voorbeeld.

De op Christus gelijkende figuren werden in de dubbelgangersliteratuur steeds met twee door Hinterhaüser als volgt omschreven vragen verbonden:

'Wie würde man sich zu Christus verhalten wann mann heute 'plötzlich' seine ansichtig würde? oder; was würde Christus zur heutigen Gesellschaft sagen wann er plötzlich zurrückkehrte?'. ${ }^{41}$

Het waren deze twee vragen die ook Ortt bezighielden. Marie Dam uit Naar het groote licht stelde de eerste vraag aan Frits van Beers, Ortt stelde de vraag aan zichzelf zoals uit de beschrijving van zijn 'bekering' tot het anti-vivisectionisme blijkt. Anders dan de meeste door Hinterhaüser aangehaalde auteurs, meende Ortt dat hij Christus' voorbeeld niet alleen in verhalen maar ook in het dagelijkse leven moest worden nagevolgd. Er moest niet alleen maar over dubbelgangers van Christus verteld worden. Het ging er om dat men er zelf een werd. Maar hoe? De Nederlandse anti-vivisectionisten kozen verschillende wegen.

\section{Zielereizen}

Hoe werd men aan Christus gelijk? In Het Tweede Leven (1916) beschrijft Pieter Pijl hoe hij dit ideaal bereikte door een 'geestelijke kruisdood' te sterven. Zijn verhaal volgt het patroon van de heldenreis. Pijl beschrijft hoe hij een onbekend gebied betrad. Hij drong door tot het diepste van zijn innerlijk, de 'wereld van het Naamelooze' of in andere woorden 'de substantie, het eeuwige, God, Tao, het Eene, de Al-Eenheid'42. Daar aangekomen moest hij een 'verschrikkelijke inwijding' ondergaan. Hij voelde een 'afgrijselijk schok' die alleen een held, iemand die zo sterk was 'als een rots', kon verdragen. De inwijding die Pijl doormaakte was de dood, maar ook de hongste zaligheid want het was de verlossingsdood die hem voorgoed bevrijdde uit de "ban der begoochelin's'. Pijl werd naar zijn zeggen gekruisigd en kwam tot het inzicht dat de gehele kosmos gekruisigd en daardoor verlost en bevrijd was.

Anders dan Pieter Pijl vindt Frits van Beers uit Naar het groote licht na zijn lichamelijke dood een antwoord op de vraag hoe Christus gevolgd dient te worden. Ortt beschrijft hoe deze romanheld na zijn door Marie Loving bewerkstelligde bekering tot het anti-vivisectionisme steeds meer gevoel krijgt voor het leed van armen en gebrekkigen. Uiteindelijk besluit hij zijn betrekking als ingenieur op te geven om zich samen met Marie geheel aan het helpen van deze mensen te

40. Hans Hinterhäuser. Fin de siècle (München 1977). Zie met name het eerste hoofdstuk over 'Doppelgänger Christi' Zie ook: Hans Hinterhäuser. 'Die Christus Gestalt im Roman der Fin de Siècle', Archiv für das Studium der neueren Sprachen und Literaturen 113 (1962) 1-21. Gustav Pfanmüller, Jesus im Urteil der Jahrhunderte (Berlijn 1939), M. Spanjaard-Levy, De gestalte van Christus in Nederlandse dichtkunst (Groningen 1952), H. Weijtens, Christus onze ijdgenoot. Een vergelijkende literatuurstudie over het motief van de wederkerende Christus in de laatste halve eetuw (Roermond/Maaseik z.j.). Heinrich Wemel, Jesus in neunzehnten Jahrhundert (Tübingen 1907). Zie over de navolging van Christus door Frederik van Eeden: Fontijn. Tweespalt 1901

41. Hinterhaüser, Fin de siècle, 14

42. Pijl. Tweede, 240. 
wijden. Met zijn 'zusterziel' vestigt hij zich in een klein hofje midden in de armste buurt van de stad. Vanuit deze plek proberen zij een ieder die dat nodig heeft met geld, goederen of anderszins te helpen. Uiteindelijk zijn zij even arm als de omwonenden en wordt het harde bestaan hun fataal. Frits en Marie raken lichamelijk verzwakt en worden ernstig ziek door de belabberde hygiënische omstandigheden in het stadsdeel. Volkomen berooid en onder het lijden van de vreselijkste pijnen sterven zij in elkaars armen. Na hun dood wacht hun een aangename verrassing. Marie's moeder verwelkomt hen in het hiernamaals. $\mathrm{Zij}$ is de leidsvrouw die hen naar Christus zal brengen. Haar volgend stijgen zij hoog boven het armzalige huisje, het hofje, de arme buurt en de stad uit. Maar terwijl zij naar de hemelzon stijgen, realiseren de zielen van Frits en Marie zich plotseling dat Christus daar hoog boven de wereld niet te vinden is:

'Christus is waar armen zijn en lijdenden, waar zielen zijn, roepende om verlossing, struikelend en vallend op den zwaren, moeilijken aardschen levensweg. En zij wilden Hem zoeken, dáár. En zij daalden neer, neer ... tot de aarde nabij kwam en de stad met de vele fabrieken, de ellendige sloppen en stegen en krotten... Maar was dat dezelfde stad waar zij op aarde die lange jaren geweest waren? Was dat hun hofje, waar zij zoolang gewoond hadden? Want uit die stad en uit dat hofje kwam hun tegen een licht, zoo warm, zoo rein, zoo koesterend en stralend van hooge, heerlijke, heilige Liefde, dat zij moesten afwenden het oog en het bedekken met de vleugelen der Ziel... Zij hadden gevonden het Groote Licht. ${ }^{\text {,43 }}$

\section{Ortt en het tolstojanisme}

In Naar het groote licht verbindt Ortt het navolgen en het vinden van Christus met de pogingen van individuen om de oplossing te vinden voor de nijpende sociale ellende van hun tijd. In de periode waarin Ortt de lotgevallen van Frits van Beers aan het papier toevertrouwde, worstelde in Leiden een groep studenten met hetzelfde probleem. Zij wilden in de wereld staan en zich wijden aan een praktische oplossing voor het sociale vraagstuk. Alleen op die manier konden, in hun ogen, het modernisme en het christendom in overeenstemming worden gebracht met de moderne cultuur. ${ }^{44} \mathrm{Zij}$ raakten geïnspireerd door Tolstoj, de 'profeet van Jasnaja Poljana' zoals Romein hem aanduidt. ${ }^{45}$ Deze Russische literator stelde dat het christendom vervormd was tot een dogmatisch stelsel waarin de praktijk van naastenliefde geen rol meer speelde. Tolstoj creëerde een eigen christendom, gezuiverd van alle metafysische en niet-ethische elementen. Hij baseerde zich daarvoor op de geboden van Christus' Bergrede omdat daarin volgens hem het beginsel der Liefde het duidelijkste uiteen werd gezet. Geweldloosheid en soberheid waren de kern van het leven dat daarbij hoorde.

Zoals Tolstoj dit in Rusland poogde, zo probeerden de jonge Leidse studenten het Liefdebeginsel in Nederland in praktijk te brengen. Onder meer door steun aan tal van sociaal geëngageerde initiatieven waaronder de geheelonthouding. Een aantal van hen zou zich uiteindelijk van Tolstoj afkeren en socialist worden. Anderen werden 'christen-anarchist' en sloten zich aan bij de groep die zich vormde rond Ds. J.K. van der Veer, de eerste Nederlandse dienstweigeraar die zich op de opvattingen van Tolstoj beriep. Tot deze groep, die al spoedig bekend zou komen te staan als de Vredebeweging, behoorden ook Hugenholtz, Van der Hucht-Kerkhoven, Felix Ortt en diens vrienden Lodewijk van Mierop en Daniël de Clercq. Zij richtten een eigen drukkerij en het tijdschrift Vrede op. Het doel hiervan was door middel van de verspreiding van weerloosheidstheorieën, waaronder met name die van Tolstoj, te ageren tegen de dienstplicht. Hoewel de leden van de Vredebeweging doorgaans als 'tolstojanen' werden aangeduid prefereerden zij zelf de term 'Christen-anarchisten'. Zij waren, zo redeneerden zij, geen volgelingen van Tolstoj maar navolgers van Christus. De toevoeging 'anarchist' verwees naar hun opzet niet de wetten van de

44. Zie hierover: K.H. Roessingh, Het modernisme in Nederland (Haarlem 1922) 6. Ook Boersen, De kolonie, 28-29 Rudolf Jans, Tolstoj in Nederland (Bussum 1952). Zie ouk Barkas. Hel groene geloof.

45. Romein. Breukvlak. 646. 
staat, maar die van het eigen geweten te volgen. Naar dergelijke opvattingen verwijst ook Romein die stelt dat de petites religions doorgaans anarchistisch waren.

De leden van de Vredebeweging pleitten voor een leven op basis van het Liefdebeginsel. Dit zou in de praktijk onder meer moeten inhouden dat geen misbruik mocht worden gemaakt van hetgeen werd aangeduid als 'economische toestanden van de kapitalistische maatschappij'. De christen-anarchisten wilden geen gebruik maken van afgedwongen arbeid van anderen. Zolang het niet mogelijk was dit streven in praktijk te brengen diende een christen-anarchist meer arbeid aan de samenleving te geven dan hij ervan nam. Bovendien diende iedere weelde, zich uitend in roken, drinken, visites maken, dure kleding dragen en onnodige reizen maken, achterwege te blijven. Ook het eten van vlees, het toepassen van vivisectie en het vervullen van leidende functies in militaire en overheidsdiensten verwierpen zij omdat die zaken in strijd waren met het aan Christus ontleende Liefdebeginsel. Uit zo'n christen-anarchistische overtuiging gaf Ortt zijn betrekking op als ingenieur van Rijkswaterstaat. Ortt had Van der Hucht-Kerkhoven, die vanaf dat moment voorlopig als zijn financier en beschermvrouwe fungeerde, voor het eerst ontmoet toen hij in 1887, als eenentwintig-jarige in dienst trad als adjudant van de inspecteur van de Rijkswaterstaat in Den Haag. Bij Van der Hucht-Kerkhoven makte hij kennis met een geheel andere wereldbeschouwing en levenswijze dan waar hij vertrouwd mee was. Vooral op het gebied van het geloof huldigden de meeste leden van Van der Huchts kring een geheel andere visie dan hij van huis uit gewend was.

Ortt was in 1866 geboren als Louis Felix Ortt, het vierde kind van Leontine de Raikem en Jhr.Ir. Jacob Ortt. Hij groeide op in Haarlem alwaar, zoals Jan Fontijn vermeldt, de Ortts bekend stonden als "echte aristocraten" ${ }^{46}$. Zijn vader maakte carrière in dienst van Rijkswaterstaat en bracht het tot hoofdingenieur van Noord-Holland. Het was, zo blijkt uit zijn dagboeken, een sobere, strenge, ambitieuze maar lichamelijk zwakke man die godsdienst en plichtsbesef hoog in het vaandel had staan. Het plichtsbesef vertaalde zich in drie duidelijk regels: een Ortt ging naar de H.B.S. en niet naar het Gymnasium, een Ortt bleef op school nooit zitten, en een Ortt werd officier maar liever nog, zoals vader, ingenieur. ${ }^{47}$ Als een overkoepelende leefregel gold nog dat eenvoudige: het door God gewilde lot diende aanvaard te worden en, zoals Jacob Ortt zijn kinderen voorhield in een brief die pas na zijn dood geopend mocht worden, men had de opdracht om Jezus na te volgen. ${ }^{48}$

Deze laatste stellingen werden onderstreept door een godsdienstige opvoeding. Joan, Willem, Henriëtte, Felix en Steffan, gingen zondags trouw naar de kerk. De preken van de door vader Ortt zeer gerespecteerde ethisch-irenische dominee Andries Bronsveld werden bovendien in familiekring besproken. ${ }^{49}$ Daarnaast kregen de kinderen Ortt godsdienstles van dominee T.H. Looman die tevens onderwijs had gegeven aan de zoon van Isaac Da Costa. Over zijn religieuze vorming schreef Ortt in 1911:

'Opgevoed in orthodox-protestantse richting, zoowel in den huiselijken kringen als door opzettelijk godsdienst onderwijs, was ik geworden tot iemand die de waarheden van zijn godsdienst, de leerstellingen van zijn geloof gaarne aanvaardde en deze ook verstandelijk wist te verdedigen. , 50

Over de vraag in hoeverre de godsdienstigheid van vader en moeder Ortt als orthodox-protestants kan worden aangeduid, valt te twisten. Jacob Ortt had een brede belangstelling voor protestantse stromingen. Hij bezocht de Waalse Kerk, af en toe de Lutherse Kerk, en was geìnteresseerd in het Réveil en de ethisch-irenische richting. Felix Ortt beschouwde het dan ook niet als een radicale breuk met zijn verleden toen hij van 1890 tot 1894 kerkvoogd werd van de Nederlandse

\footnotetext{
46. Fontijn, Tweespalt 1901, 90.

47. Mundelinge mededeling Nanda Niermans-Ort, duchter van Felix Ort.

48. Helty Kock, Felix Ortt. Leven van een christen-anarchist. Ongepubliceerde doctoraal-scriptie (Amsterdam 1986) 5.

49. Zie over Bronsveld: L.S. Sultorp. Dr. A.W. Bronsveld. Zijn visie op een halve eeuw (Assen 1966$) 7$.

50. Felix Ort. 'Mijn getuigenis betreffende het spiritisme (191l)' in: Van en over Felix Orll 36-38, aldaar 36.
} 
Hervormde Kerk te Brielle. Orthodox-Protestants is voor Ortts godsdienstige achtergrond dus wellicht een wat misleidende term. Felix Ortt was gevormd door een streng godsdienstige opvoeding maar, zoals hij het in dezelfde terugblik uit 1911 formuleerde:

'Toch was er, ondanks mijn belangstelling voor godsdienstige en kerkelijke zaken in mijn christendom iets onvolledigs, arms en kouds. ${ }^{51}$

Wat dit betreft, was hij aan het eind van de negentiende en het begin van de twintigste eeuw niet uitzonderlijk. Veel mensen verloren in die tijd hun geloof, keerden zich af van de kerkelijke richting waarin zij opgevoed waren of 'rouwden', zoals Ilse Bulhof het uitdrukt, om de dood van God. ${ }^{52}$ Geen wonder dat de pragmatische filosoof William James zich interesseerde voor de vele verschillende individuele geloofsbelevingen die uit de geschiedenis bekend waren en deze optekende en analyseerde in zijn Varieties of religious experiences. ${ }^{53}$ Maar meer mensen dan alleen deze bekende denker waren met het fenomeen bezig, in gedachten en in hun dagelijks leven. In het proces waarin velen zich van het geloof afkeerden leken zij zich des te meer bewust van de betekenis van godsdienst als zingevend kader in het leven. ${ }^{54}$ Het was dan ook zeker niet zo dat de religiositeit verdween.

In ieder geval kon Ortt rekenen op veel begrip vonr de twijfels over het geloof die hij blijkens zijn terugblik uit 1911 moet hebben gevoeld. Vooral in de Haagse kring van Van der HuchtKerkhoven. Daar voerde Ortt vele gesprekken met Ds. S.F.W. Roorda van Eysinga, een bevlogen man met een bewogen tijd achter zich, niet in de laatste plaats door de wijze waarop hij zich gedurende zijn leven tot het geloof had verhouden. In de voor het protestantisme zeer woelige jaren vijftig had Roorda van Eysinga in Utrecht theologie gestudeerd. ${ }^{55} \mathrm{Na}$ zijn afstuderen in 1862 werd hij predikant in het dorpje Grevenbicht. In deze protestantse 'enclave' in het nagenoeg homogeen katholieke Limburg benutte hij zijn vrije tijd om aan zijn dissertatie De zelfopenbaring Gods in de menschelijken geest te werken. Roorda was op dat moment een vurig aanhanger van Jan Hendrik Scholten (1811-1885) die, evenals Cornelis Opzoomer, wel wordt beschouwd als vader van de oud-moderne protestantse theologie. ${ }^{36}$

Scholten stond bekend als de man van de rede. Hij was van mening dat, zoals hij het in de eerste druk van zijn hoofdwerk De leer der Hervormde Kerk (1859) beschreef, in de theologie of de leer van God geen andere methode dan de empirische gekend kon worden:

'is er kennis van God mogelijk, zij moet verkregen worden uit de empirische kennis der feiten, die de natuurkunde, geschiedenis en psychologie constateren, en niet a priori, evenmin door kerkelijke traditie als op grond van dusgenaamde idea innatae of aangeboren begrippen.[...] De fout der Hervormers bestond in het a priori vaststellen der oneindigheid of souvereiniteit van God.....57

Roorda was volledig door Scholtens opvattingen gegrepen en de wetenschap dat zijn promotor N.C. Kist deze groot-inquisiteur van het modernisme had uitgeku<en als lezer van de dissertatie moet hem zeker hebben aangestaan. Het was dan ook een deceptie, zo beschrijft Roorda in een

\section{Ort, 'Getuigenis', 36.}

52. Ilse N. Bulhof. 'De psychoanalyse als rouwarbeid over de dood van God', Nederlands Theologisch Tijdschrift 39 (1985) 214-230, aldaar 214.

53. William James. The varielies of religious experience's. A study in human nature (eerste druk 1902, (Toronto 1985). 54. Zie over de drang om een zingevend kader te formuleren en metafysische standpunten te geven: W. E. Houghton, The Victorian frame of mind, 1831-1879 (New Haven 1957) 104. Roy F. Baumeister, Meanings of life (New York/Londen 1991) $29 \mathrm{ev}$.

55. Het levensverhaal over Roorda is ontleend aan Derk Jansen, Op zoek naar nieuwe zekerheid. Negentiende-eeuwst protestanten en het spiritisme (Groningen 1994) I0I-104 en aan W.C. van Maanen, 'pleitbezorgers van het spiritisme', Vaderlandsche lelleroefeningen voor 1874114 (1874) 1-31.

56. K.H. Roessingh, Het modernisme in Nederland (Haarlem 1922) 22. 57. Geciteerd door G.J. Hoenderdaal, 'Het modernisme in Leiden' in: W. Otterspeer, De universiteil herleefi (Leiden
1984) 10-25, aldaar 15 . 
brief aan de literator H.J. Schimmel, toen de door hem zo bewonderde theoloog zijn proefschrift meedogenloos afwees ${ }^{58}$ :

'Toen ik hem [Scholten] die [de zelfopenbaring Gods] als mijne dissertatie aanbood [...] verguisde en vertrapte hij ze. ${ }^{59}$

Ook andere teleurstellingen bleven Roorda in Grevenbicht niet bespaard. Zo werd zijn broer Sicco, werkzaam als ingenieur tweede klasse in Nederlands-Indië, uit de kolonie verbannen vanwege zijn felle kritiek op het koloniale bewind die hij onder meer verwoord had in zijn artikel 'Solo en de resident van Nieuwenhuizen' in De Javabode van 25 juni 1864. Teleurgesteld en berooid omdat zijn pensioenrecht hem met de verbanning was ontnomen zou Sicco een periode bij zijn broer en diens vrouw komen wonen. Tekenend voor de stemming van Sicco op dat moment is hetgeen hij zijn correspondentie-vriend Multatuli toevertrouwde: 'De Hollanders haten mij, daarop ben ik trotsch [...] maar tegen hongerlijden ben ik niet bestand' ${ }^{\circ}$.

Sytze Roorda van Eysinga had op dat moment zo zijn eigen problemen. ${ }^{61}$ Ook hij voelde zich uit- en buitengesloten door de gemeenschap waarin hij leefde. Het leven en leiden van een protestantse minderheid in een Roomse omgeving viel hem zeer zwaar. Voor hem was Grevenbicht het symbool van 'het protestantisme in diaspora', een kleine gemeente omringd door katholieken 'worstelend met Rome'62. Roorda was daar, zoals hij het in een terugblik zou omschrijven 'sentinelle perdue' op 'een protestantsche buitenpost'. Aanvankelijk probeerde hij er nog wat van te maken. Roorda bedacht een plan om de strijd tegen de boze katholieke buitenwereld te kunnen blijven voeren. Hij zag de oplossing in het oprichten van een landbouwschool die de voor zijn gemeente noodzakelijk geachte welvaart zou brengen. Maar dit initiatief kreeg tot zijn teleurstelling noch van het orthodoxe, noch van het moderne deel van zijn geloofsgenoten gehoor. ${ }^{63}$

Kortom, in zijn Limburgse periode leerde Roorda wat het betekende om wat betreft opvattingen en interesse geen aansluiting te vinden bij de eigen samenleving of het eigen milieu. Dit zou het leidmotief van zijn leven worden. Zijn opvattingen brachten hem, zoals hij het zelfs eens formuleerde, 'meer en meer in strijd met zijn volk en tijd, maakten de afstand steeds groter'. Voor velen in zijn omgeving zal het toch als een verrassing zijn gekomen toen hij ervoor koos om zijn isolement te vergroten door in 1868 zijn ambt van predikant neer te leggen. Naar het scheen, leek hij vastbesloten zichzelf voortaan door het uitdragen van zijn overtuiging vrijwillig tot doelwit van spot te maken:

'Voormalige vrienden treden hem tegemoet met de eenvoudige verklaring "gij zijt gek, mijn waarde", maar grooter geesten hebben wel hun leven gewijd aan de verkondiging van wat der wereld dwaasheid scheen ! Zal hij dan terugdeinzen voor den spot eener onkundige meenigte? ${ }^{\text {65 }}$

Poorda had zich tot het spiritisme 'bekeerd'. Hij stond naar zijn «cggen in contact met leidsgeesten, overleden geestelijken uit lang vervlogen tijden, zoals de eerbiedwaardige Melanchton, Anselmus en Parker van Canterbury. In opdracht van laatstgenoemde verhuisde hij uiteindelijk

58. Scholten had volgens Ruessingh de gave um mensen 'onder de betoovering van zijn weten' te brengen. Roorda van Eysinga zal dus als velen werkelijk gegrepen zijn geweest door de man en zijn opvattingen. Roessingh beschrijft Scholten als cen bijzonder fel en fanatiek iemand. Zijn kritick op Roorda zal weinig zachtzinnig zijn geweest. K.H. Roessingh. Het modermisme in Nederland (Haarlem 1922). Zie over Scholten ook: J. Vree, De Groninger godgeleerden. De oorsprong en de eerste periode van hun optreden (1820-1843) (Kampen 1984)

59. Geciteerd door Jansen, Op zoek, 101. Zie ook: Derk Jansen, 'Lich op H.J. Schimmel. Het spiritisme als levenshouding', De negentiende eeuw 9 (1985) 207-220

60. Briefwisseling Multaluli en S.E.W. Roorda van Eysinga (z.p. 1967) 23

61. Sytze is S.F.W. Roorda van Eysinga.

62. Znals geciteerd door Jansen, 'Licht op', 209.

63. Jansen, Op zoek, 101-104.

64. Brief van Roorda van Eysinga aan H.J. Schimmel (ca. 1889)

65. Van Manen, 'pleitbezorgers', 1 
naar de Haagse Laan van Meerdervoort om aldaar een pastorie ter verspreiding van het spiritisme op te richten en zich geheel aan zijn nieuwe geloof te wijden. Bij de oprichting van de NBBV in 1890 meende hij daarin een manier gevonden te hebben om 'spiritisme en action' te laten zien. In de beginperiode van de bond zette hij zich persoonlijk in om leden te winnen. Aangezien hij al jaren bekend stond als een 'profeet' die zich bediende van 'aangrijpende en bezielende taal', als een man die 'den geesel zwaaide ter tuchtiging van vriend en vijand' en 'boeide, ook waar hij [...] overdreef en de werkelijkheid aan zijn idealen ten offer bracht ${ }^{\prime 66}$ kan aangenomen worden dat hij dit met verve heeft gedaan. Hij verzamelde veel verschillende mensen om zich heen. Van deze leden van de NBBV kan, voor zover dat is na te gaan, worden aangenomen dat zij evenals Hugenholtz, Van der Hucht-Kerkhoven, Jungius, Roorda van Eysinga zelf en Ortt van protestantse huize waren. Onder hen bevonden zich ook tien predikanten en enkele studenten theologie.

Drie jaar voor de oprichting van de NBBV had Roorda van Eysinga met minstens zo veel enthousiasme uitvoerig met Ortt over het spiritisme van gedachten gewisseld. Hij gaf hem een boek over het onderwerp en vertelde hem over zijn ervaringen. Ortt moest er niet veel van hebben. Het contact met Roorda verwaterde bovendien al snel omdat Ortt werd overgeplaatst naar Maarssen om daar aan de aanleg van het Merwedekanaal te werken. Over die periode in Maarssen is niet al te veel bekend, behalve dan dat Ortt daar tijdens zijn werk ernstig ziek werd. Welke ziekte het was is niet geheel duidelijk, maar naar wordt aangenomen leed Ortt aan malaria.

$\mathrm{Na}$ een moeizaam herstel werkte Ortt vier jaar als arrondissements-ingenieur te Brielle. Aldaar ontmoette hij Anna Petronella Gelderman, dochter van de idealistische dichteres Marie Boddaert $^{67}$ en telg van een rijke adellijke familie. Aan de dichteres zou hij later Naar het groote licht opdragen. Ortt verloofde zich met Annie, een volgens de overlevering zeer kinderlijke en nerveuze vrouw die zelfs vaak voor Ortts dochter werd aangezien. In 1892 trouwden zij in het mondaine Montreux waar zij enige tijd verbleven. Vrijwel onmiddellijk na thuiskomst kreeg Ortt weer last van koortsaanvallen. Hij verliet zijn huis om enige tijd door te brengen in een kuuroord. Aldaar maakte hij kennis met de basisprincipes van de natuurgeneeswijze. Ortt raakte erdoor gegrepen, verdiepte zich in literatuur over dit onderwerp en besloot een streng vegetarisch dieet te volgen. Hoewel dit alles hem in het geheel niet genas -hij raakte zelfs zwaar ondervoed door een sapkuur- bleef hij zijn vertrouwen in de natuurgeneeskunde behouden. Zijn leven lang zou hij geen vlees meer eten.

Zo kwam het dat Ortt toen hij zich in 1894 weer in Den Haag vestigde, veel meer bekend was met de opvattingen die gangbaar waren in de humanitaire kring van Roorda van Eysinga en Van der Hucht-Kerkhoven. Het is dan ook niet onbegrijpelijk dat hij opnieuw aansluiting bij hen zocht. Wellicht gebeurde dit ook op aanraden van zijn schoonmoeder. Boddaert kende Van der HuchtKerkhoven goed en was enige tijd medewerkster van Androcles geweest. Hoe het ook zij, zeker is dat Ortts balangstelling voor het humanitair-idealisme in zijn tweede Haagse periode in een stroomversnelling kwam. Ondanks zijn zich steeds duidelijker manifesterende interesse voor natuurgeneeswijze, vegetarisme, en de opvattingen van Tolstoj wees niets er op, zo stelt Rudolf Jans, dat uit de jongeman ooit iets anders zou groeien dan een verdienstelijk ambtenaar. ${ }^{68}$

Vijf jaar later zou Ortt evenwel ontslag nemen uit zijn functie bij Rijkswaterstaat omdat hij een leidinggevende carrière in overheidsdienst niet meer met zijn christen-anarchistische opvattingen in overeenstemming kon brengen. Voor Ortt stond zijn betrekking gelijk aan een militaire functie. Op zichzelf was dit niet verwonderlijk. Van oudsher waren ingenieurs militair geschoold. Ortts vader en oom waren daar voorbeelden van. Ingenieurs werkten in staatsdienst in een strenge, van het leger afgeleide hiërarchie. Daarbij kwam nog dat het beroep zeker bij Rijkswaterstaat geassocieerd werd met de verdediging van het land tegen het water. Illustratief in dit opzicht zijn

66. Ibidem, 2.

67. Zie over haar: Marlijne Hemelaar, Een leven zonder eind. Met hel oog op Marie Boddaert (1844-1914) ongepubli-
ceerde doctoraalscriptic (Leiden 1991). 68. Rudolf Jans, Tolstoj in Nederland (Bussum 1952) 65 
de dagboeken die Ortts vader over zijn werkzaamheden bijhield. Deze hebben iets van een logboek waarin een strenge legerkapitein verantwoording aflegt over het verloop van de strijd. ${ }^{69}$ Het weigeren van een promotie en het ontslag nemen uit de overheidsdienst stond voor de tolstojaan Ortt dus in meer dan één opzicht gelijk aan het dienstweigeren van Van der Veer.

Met zijn 'dienstweigering' en zijn toetreding tot de christen-anarchistische Vredebeweging brak Ortt met de strenge traditie van zijn familie. Hij koos voor een leven dat geheel anders was dan zijn vader bij zijn leven wenselijk had geacht. Tegelijkertijd bleef hij in zeker opzicht voldoen aan de wensen van zijn strenge vader. Had deze niet de opdracht meegegeven om Jezus na te volgen? Dat was, zoals Hetty Kock ${ }^{70}$ terecht heeft opgemerkt, precies wat Ortt zijn leven lang nastreefde, al was het dan op een geheel andere manier dan zijn vader ooit voor mogelijk had gehouden. Ortt was met zijn tolstojanisme een navolger van Christus en dit droeg hij uit waar hij maar kon.

\section{Anti-vivisectionisme en christen-anarchisme}

Hugenholtz, Van der Hucht-Kerkhoven en Felix Ortt waren er als leden van de Vredebeweging van overtuigd dat medisch-wetenschappelijke proeven op levende dieren niet met het Liefdebeginsel en Tolstojs opvattingen verenigbaar waren. Een klein probleem was dat Tolstoj zich wel tegen de jacht en het eten van vlees had uitgesproken, maar verzuimd had iets over vivisectie te zeggen. Maar, zo stelde de anti-vivisectionist J. Westendorp bij de dood van de Rus in 1911 in het Orgaan, een:

'denker die zoo heeft gevoeld wat een Maeterlinck heeft uitgedrukt in La vie des abeilles en $L$ ' intelligence des fleurs kan nooit anders dan een tegenstander der wrede dierproeven geweest zijn. ${ }^{.11}$

Vervolgens wist Westendorp, waarschijnlijk tot zijn opluchting, de toch wel vervelende kwestie van Tolstojs zwijgen over dierproeven als volgt op te lossen. Tolstoj zou tijdens zijn leven zijn stem tegen vivisectie verheven hebben en wel in een brief van 23 april 1909 gericht aan het Londense anti-vivisectie tijdschrift The Abolitionist. Daarin zou de grote man hebben geschreven:

' $\mathrm{kk}$ herinner mij niet, tegen de vivisectie iets te hebben geschreven; zoveel te meer verheug ik

mij, dat mij thans de gelegenheid wordt geboden, mijne sterke afkeuring over de vivisectie uit te drukken, die ik als wreed en als niet noodzakelijk beschouw. ${ }^{12}$

Enthousiast besloot Westendorp zijn opstel met de uitroep:

'Het zou ook onmogelijk geweest zijn, zich een man als Tolstoy als vivisector te denken, evenals men zich bijvoorbeeld Jezus van Nazareth niet als vivisector of als jager voorstellen kan. ${ }^{73}$

Anti-vivisectionisme was dus een manier om zowel Christus als Tolstoj na te volgen. Maar het was nog niet zo eenvoudig om de leden van de NBBV duidelijk te maken hoe zij dit moesten doen en hoever zij moesten gaan.

Ortt stelde in zijn artikelen voor de anti-vivisectie-beweging dat hij niet verwachtte dat ieder lid van de NBBV evenals hijzelf in staat zou zijn om zijn leven of dat van zijn kinderen aan de goede zaak op te offeren. Of men in staat was om een dergelijke beslissing te nemen hing volgens hem af van het zedelijk peil en het geweten van de betrokkene. Wel vond Ortt het noodzakelijk dat alle leden van de bond zich een consequente levenshouding aanmaten. Alleen zo kon de antivivisectionistische boodschap worden uitgedragen. Wat verstond Ortt onder een consequente manier van leven? Welnu, hij vond het noodzakelijk dat anti-vivisectionisten geen vlees aten (vanwege de 'slachtgruwelen' en omdat vleeseten een luxe was), dat zij geheelonthouders waren

69. Het dagboek van vader Ort bevindt zich in het Uirechts stadsarchief familiearchieven signatuur 122.

70. Kock, Christen-anarchist, 76.

71. J. Westendorp, 'Tolstoy over vivisectie', Orgaan 7 (1911) 67-69, aldaar 68.

72. Westendorp, "Tolstuy", 68

73. Ihidem, 69. 
(omdat drank met name in arme gezinnen veel leed teweeg bracht) en zich verder, evenals de christen-anarchisten, van iedere luxe onthielden. Evenals Christus zouden zij op deze wijze tonen dat zij bereid waren om 'alles [te] beschermen wat verdrukt wordt en bescherming nodig heeft ${ }^{74}$. Alleen door liefde voor al wat lijdt en verdrukt werd, kon aan de samenleving duidelijk worden gemaakt dat het de anti-vivisectionisten 'heilige ernst" was. Het ontbreken van een dergelijke consequente levenswijze zou daarentegen aan vriend en vijand duidelijk maken dat dierenbescherming en anti-vivisectionisme slechts gelijk stonden aan 'ziekelijke egoïste voorliefde voor een bepaalde klasse van wezens, naast misdadige onverschilligheid tegenover andere klassen van wezens. ${ }^{75}$ Een ieder die hier anders over dacht was, wat Ortt betreft, niet welkom hinnen de NBBV, omdat hij de tegenstanders in de kaart speelde.

Ortts denkbeelden over de navolging van Christus werden niet door iedereen in de bond gedeeld. De 'oude garde', waaronder de leden van de Vredebeweging, hadden er geen problemen mee maar hun rol begon zo langzamerhand kleiner te worden. Zij waren nog slechts op de achtergrond actief in de anti-vivisectie-beweging. De nieuwe leiders waren Ortt (van 1898 tot 1902 voorzitter en tot 1910 vice-voorzitter van de NBBV) en Hugo Nolthenius (van 1909 voorzitter en vanaf 1905 redacteur van het Orgaan). Nolthenius, leraar klassieke talen en Wagnerfanaat, vond Ortts opvattingen gevaarlijk en elitair. Hij was van mening dat een ieder die goede bedoelingen had aan de strijd tegen vivisectie mocht deelnemen. Niemand mocht met een hooghartig non tali auxilio verstoten worden. Niet consequent levende leden konden er niets aan doen dat zij niet in staat waren om zich aan de 'macht van sleur en conventie ${ }^{76}$ te onttrekken. Dat kon pas met veel moed worden bereikt. Met andere woorden, de navolging van de ideale maatschappijhervormende Don Quichot-achtige Christus was voor de meesten wat te veel gevraagd. Nolthenius stelde: "wij hebben geen recht zulke opofferingen van anderen te vragen'."7

Het was niet de eerste keer dat de voorzitter en de vice-voorzitter van de NBBV recht tegenover elkaar stonden. Het was Ortt die in 1902 het voorzitterschap van de bond had neergelegd omdat hij het niet eens was met een voorstel van Nolthenius dat tijdens een Algemene Ledenvergadering was aangenomen. Nolthenius wilde door middel van een adres aan de regering vragen om een wettelijke beperking van dierproeven. Hij streefde er naar zijn zeggen naar om zonder het 'beginsel der afschaffing 'te verlaten, toch op de korte termijn resultaat te behalen. Dit druiste recht tegen Ortts opvattingen in. Ortt was een volbloed abolitionist. Hij vond dat de enige juiste bestrijding van vivisectie was compromisloos te streven naar uitroeiing ervan.

Ortts abolitionisme was anders dan dat van abolitionistische Engelse anti-vivisectionisten. In Engeland wilden deze afschaffers alleen genoegen nemen met een wettelijk verbod van vivisectie. Zij stonden vijandig tegenover de 'restrictionisten' die dit doel stap voor stap wilden bereiken of zelfs tevreden waren met een gedeeltelijke beperking van de vivisectie als einddoel. Ortt die, zoals gezegd, als anarchist geen heil zag in wettelijke verboden verstond onder het abolitionisme het streven naar een totale omwenteling van de publieke opinie door zelf het goede voorbeeld te geven, met andere woorden, door het eigen offervaardige en aan de navolging van Christus gewijde leven als belichaming van het anti-vivisectionistisch ideaal te presenteren. Vandaar zijn nadruk op de noodzaak van een consequente levenshouding. Evenals de Engelse abolitionisten moest Ortt niet veel van restrictionisten hebben. Nolthenius' voorstel om een adres aan de regering te sturen beschouwde hij als een tegemoetkoming aan de gevestigde orde. Hij liet het weliswaar niet aankomen op een scheuring van de Nederlandse anti-vivisectie-beweging, zoals in de Engelse anti-vivisectie-beweging en de in 1898 opgerichte Wereldbond tegen Vivisectie (die

74. Zie hierover ook de bij Drukkerij Vrede uitgegeven bundel van Lodewijk van Mierop. Dwepers ! Een beschouwing over Tolstoy en zijn geestverwanten ('s-Gravenhage 1901). Ook: Felix Ortl. Hel beginsel der Liefde ('s-Gravenhage 1898). Felix Ort. Denkbeelden van een christen-anarchisi ('s-Gravenhage 1900). 75. Felix Ort, Dieren en menschenbescheming. (z.p. 1905). Ook gepubliceerd in Felix Ort. Mens en dier,
heschouwingen en schetsen (Soest 1948) 47-51, aldaar 49 .

76. Hugo Nolthenius, 'het beginsel van dierenbescherming', Orgaan 2 (1905) 133-135, aldaar 134

77. Nolthenius, 'Beginsel', 134. 
door conflicten tussen bestrijders en beperkers had plaatsgevonden). Maar door het voorzitterschap neer te leggen gaf Ortt wel een statement af. De NBBV dreigde volgens hem de verkeerde kant op te gaan. ${ }^{78}$

Behalve van het hoofdbestuur van de NBBV kenden Nolthenius en Ortt elkaar uit de in 1894 opgerichte Nederlandsche Vegetariërs Bond (NVB). Evenals Van der Hucht-Kerkhoven waren zij nauw bij deze organisatie betrokken. Zo was Ortt in 1897 gedurende een jaar voorzitter van de NVB, was hij hoofd van het Vegetarisch Inlichtingen Bureau en vanaf 1908 tevens de enige redacteur van het periodiek van de NVB, de Vegetarische Bode. Ook binnen de NVB kwamen Nolthenius en Ortt meerdere malen met elkaar in botsing. Ook dan ging het om de vraag of men consequent diende te leven. Samen met Ir. Daniël de Clercq ${ }^{79}$, een lid van de Vredebeweging, had Ortt ervoor geijverd om de statuten van de NVB te wijzigen. Volgens beide heren diende daarin niet alleen te staan dat de leden zich van het eten van voedsel afkomstig van het gedode dier moesten onthouden. Zij zagen er tevens graag een aantal verwijzingen naar het principe van 'sociale betrokkenheid' in opgenomen. Bovendien stelden zij in 1900 voor om de NVB te laten opgaan in een grote Humanitariërs Bond. ${ }^{80}$ De op te richten bond zou verschillende aan elkaar verwante idealen na moeten streven. Ortt en De Clercq dachten onder meer aan anti-vivisectie, vegetarisme, geheelonthouding en rein-leven.

Geheel conform het eerder beschreven ideaal van de eenheid van al het levende en in overeenstemming met het streven naar harmonie dat volgens Remieg Aerts zo kenmerkend was voor de cultuur van het Nederlandse fin de siècle, verlangden zij ook naar de eenheid van het humanitair streven ${ }^{81}$ Beide voorstellen -waarin de opvattingen die Ortt vijf jaar later in het Orgaan uiteen zou zetten al duidelijk te herkennen zijn- werden afgewezen. Niet in de laatste plaats door toedoen van Nolthenius. Ortt concludeerde hieruit dat de tijd niet rijp was voor een bundeling van humanitaire krachten. De Clercq was zeer teleurgesteld. Als pleister op de wonde werd wel een clausule aan de statuten toegevoegd dat alcoholgebruik onverenigbaar werd geacht met het vegetarisme. ${ }^{82}$

Nolthenius vervulde vaker op vergelijkbare wijze de rol van practische, op compromissen gerichte strijder tegen het in zijn ogen wereldvreemde christen-anarchistische idealisme van Ortt. Waar mogelijk bestreed Nolthenius de opvattingen, maar ook de persoon van Ortt. Toen laatstgenoemde op de Algemeene Ledenvergadering zijn visie op de strijd tegen vivisectie ten beste gaf, werden zijn woorden door Nolthenius spottend samengevat als de 'bekende lyrische ontboezemingen van den heer Ortt'. ${ }^{83}$ Ook placht de leraar klassieke talen er indirect aan te refereren dat Ortt slechts H.B.S. als opleiding en de Polytechnische School in Delft had genoten. Werkelijke beschaving kon volgens hem slechts verkregen worden door een Gymnasium-

78. Het was deze visie die Ort nogmaals onderstreepte door in 1910 , toen de dierenbeschermer De Klerck voorstelde om meer samen te werken met het puur restrictionistische Comité tot beperking der vivisectie, uit hel hoofdbestuur te treden. Hij was alleen nog bereid om de functie van hibliothecaris van Van der Hucht-Kerkhoven over te nemen.

79. Zie over hem: Caljé, 'De jongens' in: Corps

80. Vergl. H.M. van Nes, De nieuwe mystiek (Rotterdam 1901). Van Nes rekent onder de nieuw mystieke gevoelens onder meer een 'cultus der humaniteit'.

81. Aerts, 'Op zoek', $91 \mathrm{ev}$

82. Zoals in de studie van Röling valt te lezen versterkte Nolthenius zijn invloed binnen de NVB in 1906. Dit hing samen met het feit dat deze bond een omvangrijke erfenis (vegewezen kreeg (het ging om 70.000 gulden) van een rijke heer die door cen vegetarisch dieet tijdens het lijden aan een ongeneselijk ziekte verlichting had gevonden. Nolthenius en zijn vrouw namen zitting in een special opgerichte erfenis-commissie. Deze had tot doel te onderzoeken hoe het geld het best kon worden gebrukt en hoe de statuten zo konden worden gewijzigd dat het geld kon worden geaceepteerd. De commissie Nolthenius diende hiervoor een ontwerp in dat geheel uitging van een beperkt begrip van vegetarisme en zonder anti-alcohol clausule. Dit was voor Ortt en De Clercq onaanvaardbaar. De laatste trad om die reden in 1907 af.

83. Hugo Nolthenius, 'verslag van de achiste jaarvergadering', Orgaan 1 (1905) 117-129, aldaar 128. 
opleiding. ${ }^{84}$ Het fanatiekst trok Nolthenius van leer tegen Ortts standpunt over het 'Liefdebeginsel':

'Ja, we weten het wel, dat er harmonie moet en zal bestaan in al onze daden, wanneer de grondtoon zuiver is die der liefde, maar we mogen niet vergeten dat diezelfde liefde leidt tot wijsheid, tot ontwikkeling van inzicht en intelligentie. Want de toestand van de geheele wereld en de daardoor bepaalde, daar vanaf hangende maatschappij, plaatst ons met onzen wil tot daden van liefde elk oogenblik voor een dilemma, waaruit enkel die liefde ons niet redden kan. Dit is het eigenlijke, dat den idealist onpractisch maakt en hem directe waarde door het heil van anderen ontneemt. Dan kan het wel weer ideaal heeten tijden lang groote hoeveelheden levensheil op te offeren, om voor later den gewenschten toestand te bereiken, maar dit lijkt -en volkomen terecht- hoogst gevaarlijk spel. ${ }^{85}$

Nolthenius had het tijdstip (1905) van zijn aanval op Ortt binnen de NBBV en op De Clercq binnen de NVB slim gekozen. Hij formuleerde zijn kritiek op een moment waarop de humanitairidealistische beweging in een grote crisis of, zoals dit ook wel wordt aangeduid, 'een rouwstemming' verkeerde. Eén reden oorzaak daarvan was dat de Blaricumse christen-anarchistische Kolonie der Internationale Broederschap, een project waarbij Ortt, Van Rees en De Clercq nauw betrokken waren, op een mislukking was uitgelopen.

De Kolonie der Internationale Broederschap werd opgericht op initiatief van de Vredebeweging. ${ }^{86}$ Het was de bedoeling dat op een gekocht stuk grond op de heide door een groep geestverwanten het Liefdebeginsel in praktijk zou worden gebracht. In 1900 was het zo ver. Zesentwintig christen-anarchisten vestigden zich op de Blaricumse heide. Zij werden vanaf de oprichting met tal van praktische belemmeringen geconfronteerd. De grond die was aangekocht bleek niet geschikt voor de landbouw die de kolonie zelfvoorzienend moest maken. Bovendien wisten de meeste kolonisten niets van akkerbouw af. Voor de meesten was de lichamelijke landarbeid die zij in hun vroegere leven niet gewend waren veel te zwaar. Dit alles leidde er toe dat de kolonisten mensen moesten aantrekken die wel over de nodige expertise en kracht beschikten. Het toelatingsbeleid werd aldus versoepeld. Ook mensen zonder een christen-anarchistische overtuiging traden toe.

Dit alles zorgde voor interne spanningen. Geleidelijk aan werden de christen-anarchistische principes losgelaten. Dit proces was in volle gang toen Ortt zich, samen met zijn vriend Lodewijk van Mierop, in 1902 in de kolonie vestigde om daar de drukkerij Vrede voort te zetten. Daar maakten zij mee dat de gemeenschap van kolonisten uiteen viel. De drukkerij Vrede kwam bijvoorbeeld los te staan van de zogenaamde tuinbouw groep. Bestuurlijk en financieel vormden zij geen eenheid meer. Spoedig daarna volgde in 1903 een gewelddadige confrontatie met de autochtone bevolking, de katholieke boeren van Blaricum en de orthodox-protestantse vissers van Huizen. $\mathrm{Zij}$ hadden de kolonisten al die jaren met wantrouwen en ergernis bezien. Nu de christenanarchisten zich solidair hadden verklaard met de grote spoorwegstaking tegen de 'worgwetten' van Abraham Kuyper en zij er door de bevolking van verdacht werden mee te hebben gedaan aan het vernielen van de Gooise trambaan, togen de Blaricummers en Huizenaars in het donker tezamen naar de kolonie om deze met stenen de bekogelen. Een aantal kolonisten raakte in paniek en wilde zichzelf verdedigen. De wiskundige Van Mierop, voorman van de rein-leven beweging, weigerde om van zijn plaats te gaan. Hij zat bij het raam te lezen en bleef dat ondanks alle consternatie doen. Toen een steen de ruit verbrijzelde en Van Mierops olielampje omver wierp, ontstond er brand. Het houten koloniehuis, de spil van de christen-anarchistische gemeenschap,

84. Hugo Nolthenius, 'Verslag van de achtste jaarvergadering', Orgaan 1 (1905) 101-104, aldaar 103. Zie ook: H Nolthenus, 'Gezaghebbend', Orgaan 1 (1904) 9-11, aldaar 10

85. Hugo Nolthenius, 'Het beginsel der dierenbescherming', Orgaan 1 (1905) 133-135, aldaar 134.

86. Zie hierover Becker en Frieswijk. Bedrijven, ook Boersen, De kolonie en het verslag van Herniëue Hendriks in De Telegraaf. Henriētte Hendriks, Een week in de kolonie der Intemationale Broederschap te Blaricum (Amsterdam 1901). Zie ook: Guido van Suchtelen, 'Quia Absurdum of de huttebouwers', Mededelingen van het Frederik van Eeden Genootschap (1982) 18-21 en Nico van Suchtelen. Quia Absurdum (z.j. 1903) 
werd verwoest. Na deze ramp was het uiteenvallen van de kolonie een feit. Het christenanarchistisch gedachtengoed van geweldloosheid werd losgelaten, velen vertrokken. $\mathrm{Zij}$ die bleven, gingen op commerciële basis verder. Waar de meeste kolonisten zich terugtrokken uit de humanitair-idealistische wereld, bleef Ortt echter, als een van de weinigen, de navolging van Christus en het Liefdebeginsel propageren. Zo ook binnen de anti-vivisectie-beweging.

\section{De navolging van Christus en de politieke stijl van de NBBV}

In het licht van de hierboven beschreven gebeurtenissen mag het duidelijk zijn dat Nolthenius' kritiek op onpraktisch idealisme en op het Liefdebeginsel meer was dan het gemopper van een verbolgen voorzitter. Het betrof een regelrecht offensief tegen een strijdwijze, een politieke stijl waarbinnen de navolging van Christus centraal stond en waar Ortt de belangrijkste exponent van was. Wat hield, behalve de hierboven besproken poging om een consequente levenswijze volgens het Liefdebeginsel uit te dragen en in praktijk te brengen, die navolging van Christus, eigenlijk in? Welke opvattingen over politiek lagen aan het christen-anarchistische anti-vivisectionisme ten grondslag? Hoe diende de ideale, religieus geïnspireerde strijder tegen het kwaad zich tot zijn volk, de staat, het rechtswezen en de parlementaire politiek te verhouden? Het antwoord op die vraag is te vinden in de geschriften waarin de vivisectie, behalve aan verschillende vormen van onmatigheid, aan oorlog en militarisme werd gekoppeld.

Vivisectie en oorlog: in de roman De familie van Westvoorne zijn dat volgens de antimilitarist Frits van Westvoorne en de fee Queen Mab de twee meest afschrikwekkende verschijnselen van de negentiende eeuw. Volgens de Vredebeweging en de anti-vivisectionisten stonden ze niet los van elkaar. De verbondenheid tussen militarisme en dierproeven bestond naar het oordeel van de NBBV op verschillende niveau's. De relatie tussen beide kwam bijvoorbeeld aan het licht op het gebied van de methoden en technieken van oorlogvoering. Uit alarmerende berichten in de kranten werd het rond 1900 steeds duidelijker dat dierproeven gebruikt werden om de doeltreffendheid van allerlei wapens te testen. Het ontging de anti-vivisectionisten bijvoorbeeld niet dat in $\mathrm{Het}$ Vaderland van 16 maart 1910 werd beschreven hoe aan boord van het Franse oorlogsschip Jena 'de uitwerking der moderne projectielen' op honden werd getest. De honden zouden dag in dag uit zijn beschoten totdat zij uiteindelijk 'zenuwziek' waren geworden. Twee van de ongelukkige dieren hadden volgens het bericht zelfmoord gepleegd door in zee te springen en vervolgens geen poging te doen om te zwemmen.

Ortt wees, eveneens in 1910, op een in de Nieuwe Rotterdamsche Courant genoemde proef van de Münchense hoogleraar J. Fessler die de uitwerking van de model-S-kogel had bestudeerd op uit ziekenhuizen afkomstige lijken en op levende paarden. Het krantebericht meldde dat achtentwintigduizend geweerschoten waren gelost en vierhonderd verschillende wonden bestudeerd. ${ }^{87}$ Mede naar aanleiding van dergelijke voorbeelden besloc: het hoofdbestuur van de NBBV na het uitbreken van de Eerste Wereldoorlog dat de bond zich zou aansluiten bij de Nederlandse Anti-Oorlogsraad. In het Orgaan werden de anti-vivisectionisten aangespoord om de betreffende organisatie ook op persoonlijke titel te steunen. ${ }^{88}$

$\mathrm{Na}$ de Eerste Wereldoorlog waren veel anti-vivisectionisten ervan overtuigd dat die oorlog nooit zo gevoerd had kunnen worden als hij gevoerd was, zonder een gedegen voorbereiding door middel van vivisectie. Het ging daarbij met name om het gebruik van nieuwe wapens als gifgassen. Ortt wees in dit verband op een verslag in het Nederlandsch Tijdschrift voor Geneeskunde van 1915 waarin vermeld werd dat konijnen gedwongen werden om chloor en broomgas in

87. Zie hierover: Ort, Ons sundpunt. 221

88. Zie hicrover: '1 januari 1915', Orgaun 11 (1915) 13-14. In dit artikel word gesteld dat de anti-vivisectionisten zich niet door de oorlog moeten laten ontmoedigen. Daar lezingen en dergelijke in verband met de oorlog enig uitstel behoeven wordt de leden aangeraden om zich meer op algemeen humanitair werk te richten. Het steunen van lichamen en groepen die het oorlogsleed heipen verzachten. De oproep van de Nederlandsche Anti-Oorlogsraad volgde op deze boodschap. 
te ademen om op deze wijze een effectieve behandeling van gifgas-slachtoffers te kunnen vinden. ${ }^{89}$ Behalve een dergelijk direct verband tussen vivisectie en oorlog beschreven de antivivisectionisten ook op een ander niveau een relatie tussen beide verschijnselen. De samenhang tussen medische wetenschap, vivisectie en militarisme toonde, met name in de ogen van Van der Hucht-Kerkhoven en Ortt, aan dat het staatsverband waarbinnen het individu leefde niet deugde. Het maakte duidelijk dat de staat door middel van wetten en regelingen juist de slechte, lage, egoïstische zijde van het individu stimuleerde en zijn goede eigenschappen onderdrukte en zelfs bestrafte. Niet voor niets was de hoofdpersoon van De familie van Westvoorne een antimilitarist die voor deze overtuiging op alle mogelijke wijzen sociaal wordt gesanctioneerd. Het hoger inzicht dat hij als beloning voor deze maatschappelijke verbanning verkrijgt, bestaat er onder andere uit dat hij, door toedoen van Queen Mab niet alleen het wezen van de vivisectie aanschouwt maar ook dat van de oorlog.

Frits ziet hoe een vorst een oorlogsverklaring ondertekent terwijl hij even daarvoor geschokt de taferelen op het slachtveld aan zich voorbij zag trekken. Het staatsverband brengt zelfs in deze edele koning de slechte, gemene en gewelddadige kant naar boven. Hij raakt als individu zijn controle kwijt en wordt als het ware ingelijfd door het sterkere verband van staat en conventie.

Ortt was het met Van der Hucht-Kerkhoven eens. In 1915 stelde hij in zijn essay De volksziel en de staatsziel dat de staat vergelijkbaar was met een mierenkolonie. De mierenkolonie bestond, zo schreef Ortt, uit individuele mieren die ieder op zichzelf weer uit miljoenen cellen waren samengesteld. ${ }^{90}$ De cellen waren op hun beurt weer 'begaafd' met een eigen 'ordenend-principe', een eigen ziel. Het betrof hier zielen van een lagere orde. Zij waren dienstbaar aan een hoger ordeningsprincipe, in dit geval het individuele insekt. De mieren, zielen van de tweede, hogere orde, vormden op hun beurt met elkaar een mierenkolonie, een hogere ziel van de derde orde, waaraan iedere mier dienstbaar was. Bij de mensen was het volgens Ortt precies zo. De ziel van de staat torende hoog en machtig uit boven de ziel van een verzameling mensen:

'De staatsziel is principieel iets anders dan de individuele menschenziel; even principieel iets anders als de menschenziel anders is dan de ziel van een onzer hersen- of lever- of spiercellen. De staatsziel heeft haar eigen geestelijk scheppingsideaal waarnaar zij streeft; evenals de ziel van het eikeltje als geestelijk scheppingsideaal den eikeboom heeft die zij door haar ordenend vermogen tracht te verwezenlijken. De staatsziel volbrengt haar plannen, haar roeping in het Groote Evolutieplan haar aangewezen, onbekommerd om het wel of wee der ondergeschikte zielen, die zij slechts kent als materiaal wat zij ordenen moet tot bereiking van eigen doel, naar de ontplooiing van eigen individualiteit: de staat. ${ }^{91}$

Burgers moesten als zielen van een lagere orde op straffe van uitstoting meewerken aan dit doel. Bezien van hun standpunt handelde de staat niet zelden zelfzuchtig, immoreel en geheel in strijd met de 'christcnmoraal'. De staat doodde, bedroog, loog, huichelde en stal om zichzelf tegenover andere staten te handhaven. Dat de staat zich op deze wijze gedroeg was volgens Ortt geen wonder. De staatsziel handelde in wezen niet anders dan ieder andere 'jonge ziel':

'Een wilde, - uit ras-oogpunt een jonge menschen-ziel, - is uiteraard zelfzuchtig. Een kind uit individueel oogpunt een jonge menschenziel, - is ook zelfzuchtig: die zelfzucht vermindert vaak naarmate de ziel ouder en geestelijk rijper wordt. Een staat -een jonge ziel der derde orde,- is derhalve ook krachtens zijn jeugd en wezen, zelfzuchtig. Want hoe jong zijn niet, met den maatstaf der beschavingsgeschiedenis gemeten, de machtige, toonaangevende Staten onzer twintigste eeuw?'

Het individu kon door dit op overleving gerichte gedrag sterk in verwarring raken. Zoals de vorst uit De familie van Westvoorne achtte het individu bepaalde daden vanuit zijn eigen moraal

89. Ort, 'Ons standpunt', NTVG (1915) I no. 24, $2091 \mathrm{cn} \mathrm{no.} \mathrm{3,} 603$.

90. Felix Ort De Volksziel en de staatsziel (z.p. 1915) 12. Zie ook: Van en over Felix Orll 109-113

91. Ort, Volksziel, 12.

92. Ibidem. 
verkeerd terwijl hij leerde om deze als deugdelijk en plichtsgetrouw te betitelen wanneer hij in dienst van de staat handelde. Een duidelijk geval van een dubbele moraal, zo meende Ortt. Zoals de mens er niet was voor het geluk van zijn levercellen, zo was de staat niet uit op het geluk van individuen. ${ }^{93}$

Anders dan de cellen in organen of de mierenziel was de mens volgens Ortt een zeer hoog ontwikkelde ziel, verder ontwikkeld dan de staat. De mens had veel meer besef van de universele en goddelijke moraal en had de drang om deze uit te leven als een 'zelfbewust moraal werktuig'. Het was uiteindelijk dit verlangen naar verbetering dat het individu kon inzetten om de staatsziel op indirecte wijze te corrigeren. Door goed te doen zou het zedelijk niveau van de staat uiteindelijk toenemen. Het individu diende zich evenwel te realiseren dat de consequente levenshouding die daarvoor nodig was tot conflicten zou leiden. De morele mens moest erop voorbereid zijn dat hij, evenals Frits van Westvoorne uit Van der Huchts roman en Frits van Beers uit Naar het groote licht, zou worden uitgestoten en wellicht zelfs verpletterd.

De 'ballingschap' van het individu op grond van morele en religieuze overtuiging maakte deel uit van de wijze waarop de offervaardigheid van de ideale strijder tegen het kwaad en daarmee de ideale anti-vivisectionist werd beschreven. Voorbeelden zijn de gevangenisstraf die Van Rees kreeg opgelegd in verband met de ondertekening van het dienstweigeraars-manifest, Ortts beslissing om zijn dienst bij de Waterstaat neer te leggen, maar evengoed Roorda van Eysinga's geografische, religieuze en sociaal-maatschappelijke ballingschap. Opmerkelijk in dit verband is dat in door vrouwen vervaardigde anti-vivisectionistische beschouwingen en romans, waarin ook de positie van vrouwen aan de orde werd gesteld, de heldin beschreven werd als iemand aan wie het, door het brengen van vele offers, gelukte om in het sociale verband van de samenleving te worden opgenomen. Anna is daarvan een voorbeeld. Een ander voorbeeld is Jungius' opmerking dat de daden en opvattingen van het individu niets waard zijn indien deze niet zijn ingebed in de samenleving. ${ }^{95}$ Het is niet verwonderlijk dat dit verschil tussen door vrouwen en door mannen gecreëerde helden bestaat. Voor Nieuwe Vrouwen waren juist de participatie aan het maatschappelijke leven, kiesrecht, arbeid of, in algemenere termen, burgerschap uitermate belangrijk.

Het vrouwelijke beeld van de held is dan ook meer gecentreerd rond pogingen om binnen het staatsbestel op de een of andere wijze een stem te kunnen laten horen en invloed uit te oefenen. Het mannelijke beeld van de held draait juist om het afkeren van of verlaten van de staat. Dit verschil tussen de mannelijke en vrouwelijke held lag ook besloten in de keuze voor de gids naar het hogere. Ortt volgde een Don Quichot-achtige, anarchistische Jezus. De Jeanne d'Arc waar Jungius zich door liet inspireren bezit deze kenmerken ook, maar in deze figuur ligt toch iets besloten dat niet is terug te vinden in de Christus-figuur. Jeanne d'Arc koos ervoor om zich in mannen-kleding te hullen, een gevechtstenue verwijzend naar een uitsluitend door mannen sedomineerde hiërarchie. Zij vocht ten hehoeve van haar land en vorst en trad daarom niet geheel buiten de samenleving waartoe zij behoorde. Juist deze combinatie van religiositeit, het offer en wat zij zagen als de binding met de natie moet voor Marie Jungius, Van der Hucht-Kerkhoven en Suze Groshans aantrekkelijk en belangrijk zijn geweest. Voor hun heldinnen was binnen de NBBV evenwel steeds minder ruimte. De vrouwelijke gidsen naar het hogere, het meisje, de zuster, de moeder, de etherische leidsvrouw, werden langzaam maar zeker verdrongen door de christenanarchistische, Tolstojaanse figuur van Jezus.

Dat was in Engeland anders. In de historiografie over het Engelse protest tegen vivisectie wordt nauwelijks gerept over een verband tussen de beweging rond Tolstoj (die in Nederland aanzienlijk groter en invloedrijker was) en het protest tegen vivisectie. Wel bestonden in Engeland sterke banden en sympathieën tussen de anti-prostitutie en de anti-vivisectie-beweging. In beide waren vrouwen gezichtsbepalend. $\mathrm{Zij}$ duidden hun strijd expliciet aan als een zaak van vrouwen.

93. Ibidem, 13.

94. Ibidem, 15.

95. Jungius, De vivise'tic', 12 
Dit verklaart wellicht waardoor in Engeland meer werd gedaan om wettelijke verboden te bewerkstelligen en de parlementaire politiek te beïnvloeden. Ook al toonden de voorvrouwen van de Engelse anti-vivisectie-beweging zich nog zo bezorgd over de invloed van het openbare leven op de deugden van de vrouw, uiteindelijk waren zij toch niet al te afkerig van de 'harde zijde' van de politiek.

In zekere zin is de term expressieve politiek dan ook veel meer van toepassing op het Nederlandse anti-vivisectionisme dat jaren lang, zo niet bepaald, dan toch sterk beïnvloed werd door de persoon en opvattingen van Felix Ortt. Door de sterke band met het door hem gepropageerde christen-anarchisme werd het nastreven van parlementaire invloed binnen de NBBV lange tijd beschouwd als een weinig verheven streven. De feministische opvattingen over deze kwestie, het verlangen naar burgerschap en de mogelijkheden die het anti-vivisectionisme eventueel zou kunnen bieden om invloed op het parlement uit te oefenen, werden vanaf 1898 steeds duidelijker door deze opvattingen overschaduwd. Deze verschuiving wordt duidelijk wanneer De familie van Westwoorne en de roman van Ortt, Felicia, een boek van roeping worden vergeleken. Waar in 1891 Queen Mab enthousiast aan Frits van Westvoorne duidelijk maakt dat vrouwen die wilden stemmen dat in de toekomst zouden mogen doen, wordt de vrouwelijke hoofdpersoon van Ortts roman uit 1905 juist zeer streng gestraft wanneer zij zich inlaat met de parlementaire politiek.

Felicia is maatschappelijk werkster en zeer actief in de Rein Leven beweging. Zij is tegen prostitutie maar niet uitsluitend omdat zij feministisch is. Het was het levensverhaal van de door haar beminde jonge ingenieur Enno Bergsma dat haar ogen voor dit maatschappelijk kwaad opende. Toen Enno en Felicia elkaar ontmoetten, merkten zij beiden dat zij voor elkaar geboren waren. Maar naarmate hun liefde groeide, viel het Felicia steeds meer op dat Enno haar nooit zoende en eigenlijk ieder lichamelijk contact zoveel mogelijk vermeed. Op een dag blijkt waarom. Enno vertelt haar hoe hij in zijn studententijd door zijn vrienden dronken werd gevoerd en naar een bordeel werd meegenomen. Hem werd verteld dat daar een meisje tegen haar zin werd vastgehouden. Bergsma, een rijke jongeman, kon haar redden door haar geld te laten verdienen. Meegesleurd in een roes van drank had hij gedaan wat zij van hem verlangden. Niet lang na deze nachtelijke escapade was hij er achter gekomen dat hij een geslachtsziekte had opgelopen. Weliswaar was hij lang voor zijn ontmoeting met Felicia genezen verklaard maar er is toch geen volledige zekerheid over de eventuele gevolgen voor zijn toekomstige vrouw en nageslacht. Korte tijd nadat hij dit verhaal aan Felicia heeft verteld vertrekt Enno, zonder afscheid te nemen, naar Amerika. Vanuit dat land stuurt hij haar af en toe trosstrijke boveken over spirituele onderwerpen. Felicia betreurt zijn vlucht. Zij was bereid geweest tot het sluiten van een platonisch huwelijk en had hem willen helpen om zijn maatschappelijke idealen te verwezenlijken. Na jaren ontmoet zij een andere man, een SDAP-er die sympathie koestert voor haar opvattingen over sociale wantoestandcn en haar strijd tegen cu prostitutie. Felicia trouwt met hem.

Felicia's echtgenoot is van mening dat hun idealen het beste kunnen worden verwezenlijkt wanneer hij parlementslid is. Zo werkt Felicia bijna dag en nacht om hem te steunen. Zij houdt zijn administratie bij, helpt hem met het schrijven van lezingen, formuleert standpunten, voedt en kleedt hem. Dit alles werpt vruchten af. De partij ziet steeds meer in Felicia's man. Naar men vermoedt, kan hij veel politiek gewin behalen. Felicia is blij en heeft haar echtgenoot nog meer goed nieuws te vertellen. Ze is in blijde verwachting. De SDAP-er is van mening dat dit niet zo goed uitkomt maar alles blijft voor de wind gaan totdat, tegen het einde van de zwangerschap en op het hoogtepunt van de verkiezingsstrijd, Felicia ernstig ziek wordt. Vrijwel ogenblikkelijk ontpopt haar man zich als een keiharde politicus die op niets anders dan stemmen en macht uit is. Hij laat Felicia zonder scrupules alleen op haar ziekbed achter. Als het kind geboren wordt, is hij niet aanwezig en als de baby uiteindelijk sterft toont hij zich onverschillig. Felicia begrijpt nu dat de dood van haar dochter en de mislukking van haar huwelijk een juiste straf zijn voor het verraad aan de idealen en de liefde die zij eens met haar jonge ingenieur deelde. Vertwijfeld stelt ze zichzelf de vraag hoe ze die ooit had kunnen verloochenen voor de opvattingen en de liefde van een materialistische politicus. Op dit toppunt van wanhoop keert haar vroegere geliefde gelouterd 
en genezen terug. Felicia scheidt van haar SDAP-er, wordt sociaal uitgestoten en volgt Enno naar een door hem gestichte christen-anarchistische kolonie. Daar wordt zij, evenals Anna, voor haar strijd beloond met de geboorte van een gezonde zoon.

De reden waarom Felicia deze beloning krijgt, is evenwel anders dan bij de hoofdpersoon uit Van der Huchts roman. Anna heeft zich door haar strijd als vrouw een plaats verworven in de samenleving. $\mathrm{Zij}$ is deel van een organisatie die zich inzet voor arbeidende en studerende vrouwen op weg naar zelfstandigheid, ze werkt samen met mannen en vrouwen in de openbare sfeer. Voor haar huwelijk deed Felicia dit alles ook als lid van de Rein Leven Beweging en als maatschappelijk werkster. Ze gaat in Ortts ogen evenwel te ver door zich in te laten met de parlementaire politiek en een politieke partij. Als straf wordt haar het moederschap ontnomen. Pas wanneer zij zich afkeert van de 'materialistische' politiek en zich zoveel mogelijk van de staat afwendt door tot een christen-anarchistische kolonie toe te treden, wordt haar verraad opgeheven en haar strijd beloond. Felicia volgt aldus het patroon van de anti-vivisectionistische heldenreis omdat zij door te scheiden en ongehuwd met Enno samen te wonen alle conventies verwerpt. Maar van haar wordt misschien wel een groter offer gevraagd dan van de mannelijke helden. Zij moet immers iets opgeven dat zij als vrouw niet eens echt kan bezitten: parlementaire invloed. Binnen de NBBV vroeg Ortt door zijn typisch anti-parlementair abolitionistisch standpunt in combinatie met zijn religieus anarchisme en de navolging van Christus, eenzelfde offer van de binnen de beweging werkzame vrouwen. Het op het eerste gezicht 'ongeseksueerde' ideaal van de navolging van Christus had op deze manier door Ortts invulling consequenties voor de strijdwijze van de antivivisectionisten.

\section{De overwinning van het christen-anarchisme}

'Wat is het hele leven van elk wezen, van het slechts met de microscoop waar te nemen wezen af tot het hoogst georganiseerde toe, wat is het anders dan een strijd om het bestaan? En zou dat ooit veranderen? Immers, neen: het is de natuur, het wezen van het leven, dat die strijd bestaat; met zijn einde zal het leven zelf ophouden. Geen sterveling dus is het beschoren daarin verandering te brengen. ${ }^{\prime 26}$

Als voorzitter van de NBBV zette Nolthenius zich af tegen de naar zijn oordeel passieve, onpraktische strijdwijze van Felix Ortt. Tegelijkertijd bekritiseerde hij de binnen de NBBV dominante idee van een morele evolutie die nauw met Ortts politieke stijl en de navolging van Christus verbonden was. In tegenstelling tot andere vivisectie-bestrijders geloofde Nolthenius niet dat de humanitaire idealen ooit, ook niet in de verre toekomst geheel gerealiseerd zouden worden. Gedreven door ergernis over Ortts idealisme kwam hij in 1905 openlijk voor deze mening uit. Zijn vrijwel geheel in positivistische termen geformuleerde kritiek op een optimistisch geloof in de toekomst, zou in de beginjaren van de bond -de jaren 1890-1900- ondenkbaar zijn geweest. In deze periode werd, zoals in het vorige hoofdstuk is beschreven, de strijd tegen vivisectie juist voorgesteld als een beweging tegen een strikt natuurwetenschappelijke en darwinistische benadering van het leven. Men verzette zich tegen de idee dat de schepping geen zedelijk doel had, niet door een zedelijke macht werd geleid en tegen de opvatting dat er geen eeuwige zedelijke richtsnoeren gevolgd dienden te worden. Het anti-vivisectionisme werd daarbij niet zelden umschreven als een religieuze tegenkracht, een struming die zich teweer stelde tegen het denken in termen van strijd en doelloosheid. De NBBV streed, zoals Hugenholtz het formuleerde, tegen een heidense of atheïsrische filosotie die het bestaan van God en zedelijkheid ontkende.

Dat Nolthenius het principe van de strijd centraal stelde in zijn kritiek op de onpraktische strijdwijze van Ortt en dat hij, als alternatief voor de abolitionistische benadering, voorstelde een adres naar de regering te sturen, doet vermoeden dat de voorzitter van de NBBV ernstig van plan was om het anti-vivisectionisme een andere koers te doen in slaan. Hij wilde de politieke stijl van de beweging veranderen en deze minder laten beheersen door het christen-anarchisme. Erg 
daadkrachtig of, wellicht beter gezegd, bedreven, was hij niet. Nolthenius maakte een cruciale fout waardoor de NBBV de door hem gewenste ommezwaai niet meer kon maken. Dit alles speelde zich af in 1907. In dat jaar verzocht de Commissie inzake Vivisectie de NBBV of zij een representant naar de hoorzitting wilde afvaardigen om aldaar de visie van de bond op het vivisectie-vraagstuk weer te geven. Bij monde van Nolthenius koos de bond ervoor om niet op de uitnodiging in te gaan. In een brief gedateerd 23 juli 1907 antwoordde de voorzitter van de NBBV dat zij geen leden in haar midden had met "practische persoonlijke ervaring aangaande de beoefening van vivisectie's? . Nolthenius veronderstelde voorts dat een getuigenis van een afgevaardigde van de bond voor de Commissie van minder belang zou zijn.

De Commissie inzake Vivisectie die er erg op gebrand was om niet alleen bekende voorstanders, maar ook toonaangevende tegenstanders van vivisectie te horen, nodigde daarom Ortt uit om zijn visie op het vraagstuk te geven. Dat de leden van de commissie voor vice-voorzitter Ortt kozen, lag voor de hand. Nolthenius had geweigerd en bovendien was Ortt de bekendste en belangrijkste Nederlandse anti-vivisectionist. Hij produceerde vrijwel alle anti-vivisectie-geschriften die de NBBV na 1900 uitgaf en was om die reden woor de publieke opinie het gezicht van het protest tegen vivisectie, zeker nu de 'oude garde' - Hugenholtz, Roorda van Eysinga, Jungius en Van der Hucht-Kerkhoven- was uitgespeeld.

Ortt accepteerde de uitnodiging van de Commissie inzake Vivisectie maar liet van te voren schriftelijk weten dat hij niet als vice-voorzitter van de NBBV maar a titre personelle zou spreken. Hij moet verondersteld hebben dat Nolthenius niet zou instemmen met hetgeen hij tijdens de hoorzitting zou verklaren. Niet ten onrechte, want Ortt stak aldaar zijn keuze voor de navolging van Christus niet onder stoelen of banken. Vanuit zijn positie binnen de NBBV beschouwd was Ortts brief een meesterzet. Met zijn acceptatie van de uitnodiging bracht hij Nolthenius in grote verlegenheid. De overige bestuursleden, waaronder Jungius" vriendin Suze Groshans, gingen namelijk zo ver om er bij de voorzitter op aan te dringen om de Commissie inzake Vivisectie het volgende verzoek te doen:

'Nu echter de heer F.L. Ortt -onze vice-president- op uwe uitnoodiging voor uwe Commissie verschenen is, en deze getuige gemeend heeft te moeten verklaren dat zijn getuigenis slechts hemzelven en niet den Bond gold [...], en daar ons Hoofdbestuur met de door den heer Ortt gegeven antwoorden in beginsel en in hoofdzaken geheel instemt, meenen wij Uwe Commissie te kunnen verzoeken het getuigenis niet alleen als een persoonlijk getuigenis van den heer Ortt, doch tevens als dat van onzen Bond te willen beschouwen, omdat het onzen Bond niet onverschillig kan zijn ook voor Uwe Commissie vertegenwoordigd te zijn.'

Zo werden de religieuze opvattingen van Ortt tıch het officiële standpunt van de bond. Nolthenius kwam deze nederlaag niet te boven. In 1909, rond de tijd waarin het Rapport van de Commissie inzake Vivisectie openbaar werd gemaakt, bedankte hij als voorzitter, als secretaris en als redacteur van het Orgaan. Hij verklaarde het gevoel te hebben in zijn overtuigingen niet genneg gesteund te worden door de overige hoofdbestuursleden. Suze Groshans nam het presidentschap van Nolthenius over, Ortt bleef tot 1910 vice-president van de NBBV.

$\mathrm{Na}$ het vertrek van Nolthenius bleven het door deze voorzitter zo gehekelde idealisme en het daarbij behorende geloof in de compromisloze, opofferingsgezinde navolging van Christus nauw met het Nederlandse anti-vivisectionisme verhonden. Dit kwam zeker niet uitsluitend door toeduen van Ortt. Ook andere, nieuwe gezichten in de beweging zagen een innige relatie tussen religiositeit en de strijd tegen vivisectie. Maar was het dezelfde soort verbondenheid? In zeker opzicht wel, zo blijkt uit het artikel 'Wreedheid' van Ds C.A. Cramer. In 'Wreedheid' wordt de vivisectie gelijkgesteld aan de vernietiging van en het zich vergrijpen aan Gods schepping. ${ }^{98}$ Cramers stelling is dat deze daad van geweld gelijk staat aan de verwoesting van het eigen innerlijk. Hij 97. Brief van het hoofdbestuur aan de Cornmissie inzake vivisectie te 's-Gravenhage. De brief werd afgedrukt in
Orgaan 6 (1909) 75-76.

98. C.A. Cramer. 'Wreedheid', Orgaan 16 (1920) 3-6 
expliciteerde hiermee een angst die in andere, vroegere anti-vivisectie-geschriften met een verwijzing naar God of Christus meer impliciet bleef: de angst voor de verbreking van de eenheid, het contact van het individu met het hogere en de vrees dat wreedheid en egoïsme de weg naar goddelijke vervolmaking zouden belemmeren. Eerder werd beschreven dat Jungius reeds in haar lezing van 1898 aannemelijk probeerde te maken dat de vivisectie zo'n obstakel in de menselijke ontwikkelingsgang was.

\section{Ontwikkeling van de expressieve politiek: religie}

Het Nederlandse anti-vivisectionisme had, anders dan Davids in zijn studies suggereert, een sterk religieuze component. Het betreft hier evenwel geen kerkelijke religiositeit maar eerder, zoals Stevenson het uitdrukt, een religieus gevoel dat het vivisectie-vraagstuk doordrong. Dit gevoel was gecentreerd rond een keten van associaties die de vivisectie, de kruisiging, de angst voor chaos, fragmentatie, het kwaad, atheïsme, darwinisme en het materialisme met elkaar verbond. Het zijn deze associaties die, veel meer nog dan de door Stevenson en French geanalyseerde kerkelijke achtergrond van de leden en de voorlieden van de anti-vivisectie beweging, de kern zijn van de religieuze component van het verzet tegen vivisectie in Nederland.

De hierboven bedoelde religieuze retoriek die in anti-vivisectie-brochures werd gebezigd en de verwijzingen naar religiositeit in anti-vivisectie-romans en korte verhalen waren, zoals bleek, niet zelden gekoppeld aan verhandelingen over het wezen van het kwaad en een daarmee verbonden onderscheid tussen geoorloofde en ongeoorloofde manieren om kennis te verwerven. $\mathrm{Bij}$ het zichtbaar maken van het kwaad (en daarmee van het goed en het hogere) werd gebruik gemaakt van voorstellingen van sociale klassen, sekse en racialiteit. Een goed voorbeeld is de parabel van De ziel der Wijze. Geseksueerd is de passage waarin de overweldigers de vrouwen van het vredelievende volk opofferen om de spreuk van de tovenaar te bemachtigen. De vrouwen van het overwonnen volk worden opgeofferd aan een verkeerd soort kennis en vloeien daarmee, zoals Gemma, ineen met proefdieren die, althans in de denkwereld van de anti-vivisectionisten, als offer aan de wetenschap een zelfde lot ondergingen. Wat betreft de verbeelding van racialiteit waarmee de religieuze zijde van het anti-vivisectionisme werd gearticuleerd, kan gedacht worden aan het onderscheid tussen oosterse en andere volkeren. Oosterse volkeren werden doorgaans afgeschilderd als religieus en vergeleken met christen-anarchisten. Afrikanen en Indianen werden daarentegen juist als agressief en wreed en dierlijk neergezet. Joden werden geassocieerd met overweldiging, invasie, fragmentatie, materialisme, de kruisiging en daardoor tevens met vivisectie.

Op grond van het voorgaande verdient de opvatting van French dat de studie van de relatie tussen antisemitisme en anti-vivisectionisme weinig of niets duidelijk maakt over de relatie tussen religiositeit en de strijd tegen vivisectie, genuanceerd te worden. In ieder geval gaan zijn bevindingen niet op voor de Nederlandse situatie. Hetzelfde geldt voor French' opmerking dat religiositeit geen rol van betekenis speelde op het niveau van de door de beweging gevoerde politiek. In Nederland was dit zeker wel het geval. Met name de idee van de navolging van Christus, de compromisloze maatschappijhervormer, zorgde voor grote spanningen binnen de NBBV. Tegelijkertijd vormde de navolging van Christus een onmisbaar element van de expressieve politiek van voorlieden als Ortt, Jungius en Van der Hucht-Kerkhoven. Het optreden van Ortt voor de Commissie inzake Vivisectie is daarvan een voorbeeld.

Opvallend aan de 'religieuze richtingenstrijd' zoals het conflict tussen Ortt en Nolthenius wellicht kan worden aangeduid, is overigens dat de vrouwelijke voorlieden van de NBBV daarhij nauwelijks een rol lijken te spelen. De strijd lijkt vooral te worden gevoerd door de twee heren. Dit is evenwel maar gedeeltelijk waar. Niet vergeten mag worden dat Van der Hucht-Kerkhoven Ortt en zijn compaan binnen de vegetarische beweging Daniel de Clercq zowel financieel als moreel ondersteunde. Wellicht heeft hij deze dan ook in haar naam gevoerd. Ook het belang dat werd gehecht aan de vrouwelijke gids naar het hogere maakte deel uit van de anti-vivisectionistische religiositeit. Dit alles kan echter niet verhullen dat er een duidelijke spanning was tussen het 
denken over sekse en de religieuze zijde van de expressieve politiek van de anti-vivisectionisten. De vrouwelijke gidsen naar het hogere legden het af tegen de mannelijke, tolstojaanse figuur van Christus. Zij verdwenen na 1900 samen met Jungius, Van der Hucht-Kerkhoven en de antivivisectie roman als strijdmiddel, uit de discussie over vivisectie.

Die discussie over vivisectie nam dan ook een andere vorm aan. Zij werd uitsluitend gevoerd vanuit de idee van de navolging van Christus. Tegelijkertijd werd een door Ortt voorgestane 'wetenschappelijke', niet emotionele strijd gevoerd. Deze ontwikkeling gecombineerd met de antivivisectionistische preoccupatie met 'weten' en het onderscheid tussen geoorloofde en verboden manieren van kennis verwerven, doet vermoeden dat de religiositeit van de vivisectie-bestrijders zich op een gecompliceerde wijze verhield tot de moderne wetenschap. Gecompliceerd in die zin dat niet zonder meer, zoals French en Turner wel doen, kan worden aangenomen dat de antivivisectionisten door hun religiositeit ondubbelzinnig anti-wetenschappelijk, anti-technologisch en anti-modern waren. Mogelijk draaide het verzet tegen vivisectie in Nederland niet zozeer om de strijd tussen wetenschap en religie maar bestond zij eerder uit een poging om deze fenomenen met elkaar te verenigen en heeft juist die inzet de politieke stijl van de beweging en de daaraan gekoppelde discussie over vivisectie sterk beïnvloed. 


\section{Wetenschap als wegwijzer 1917 : Inleiding tot het pneumat-energetisch monisme}

In 1917 publiceerde Felix Ortt zijn wereldbeschouwelijke studie Inleiding tot het pneumatenergetisch monisme ${ }^{1}$, een samenvoeging van de artikelen die hij vanaf 1910 in het Theologisch Tijdschrift aan zijn monistische filosofie had gewijd. Het boek, waarvan Ortt meende dat het zijn belangrijkste werk was, droeg als ondertitel Een beschouwing over God, de wereld, het leven, mens en maatschappij, van het standpunt der natuurwetenschap. Met name het laatste deel van deze toevoeging intrigeert: Ortt was kennelijk van mening dat hij vanuit de exacte, positieve wetenschappen redeneerde. Hij beschouwde de moderne wetenschap dus niet als vijandig aan zijn morele en religieuze overtuigingen, maar probeerde zijn ethische standpunten en zijn geloof juist met behulp van wetenschappelijke inzichten kracht bij te zetten en tot uitdrukking te brengen. Dit is interessant omdat de beweging tegen dierproeven in de historiografie doorgaans wordt beschreven tegen de achtergrond van de zogenaamde Victoriaanse strijd tussen wetenschap en geloof. Waarom dit wordt gedaan, wordt door de desbetreffende historici nauwelijks geëxpliciteerd, zo evident is het voor hen dat deze context de juiste is. Alleen omdat de vivisectiebestrijders zich verzetten tegen een aantal belangrijke representanten van de positieve, experimentele fysiologie worden zij afgeschilderd als vertegenwoordigers van 'het geloven'.

Op die benadering valt wel wat af te dingen. Veel (wetenschaps)historici vragen zich tegenwoordig af of er ooit wel zoiets als een strijd tussen wetenschap en geloof heeft bestaan. Ook is het de vraag of het wel mogelijk is om over de wetenschap en het geloof te spreken. Maar bovenal kan in twijfel worden getrokken of uit het ganghare perspectief op de vivisectie-bestrijding wel genoeg recht wordt gedaan aan de complexiteit van het denken over wetenschap en geloof in de negentiende en vroeg-twintigste eeuw. Is het wel zo dat wetenschap en geloof altijd zo scherp te scheiden waren? ${ }^{2}$

In de historiografie van het anti-vivisectionisme is er in ieder geval onvoldoende oog voor dat. zoals Romein ook aangeeft, velen rond 1900 niet zozeer de behoefte voelden om weten en geloven strikt van elkaar te (onder)scheiden maar juist om wetenschap en geloof met elkaar te verenigen. ${ }^{3}$ Veel mensen verloren in de loop van de negentiende eeuw hun kerkelijk geloof en zij probeerden niet zelden met behulp van de wetenschap een nieuw geloof te verwerven. Ortts Inleiding tot het pneumat-energetisch monisme is daar een voorbeeld van, zo meende ook een recensent van de Nieuwe Rotterdamsche Courant. De criticus beoordeelde het boek weliswaar negatief maar onderkende tegelijkertijd dat Ortt door middel van zijn studie probeerde te bereiken wat door veel van zijn tijdgenoten werd nagestreefd: 'Als geenszins op zichzelf staand verschijnsel des tijds heeft dit merkwaardige syncretisme ontegenzeggelijk waarde'.

Was, zoals in de historiografie wordt gesuggereerd, dit 'merkwaardig syncretisme', deze nieuwe religiositeit, per definitie anti-wetenschappelijk en anti-modern? Men kan zich afvragen of dergelijke kwalificaties een goed uitgangspunt vormen voor een beter begrip van de toenmalige relatie tussen wetenschap en geloof. Met de termen anti-wetenschappelijk en anti-modern gaat men voorbij aan de flexibiliteit en creativiteit die ongetwijfeld nodig waren om 'weten en geloven' met

\footnotetext{
1. Felix Ort, Inleiding lot he! pneumat-energetisch monisme. Een beschoiming over God, de wereld, het leven, mens en maatschappij, van het standpunt der natuurwetenschap ('s-Gravenhage 1917, derde druk 1950).

2. Klaas van Berkel, 'Ter inleiding. Trots, overmued en onbehagen. Discussies over naturwetenschap en levensbeschouwing rond 1900', Groniek (1984) 8-14. Zie ook: James R. Moore. 'Speaking of science and religion then and now' in: History of science; an annual review of literature, research and teaching 30 (1992) 311-323. Zie ook Peter Derkx. 'Wetenschap en godsdienst: vroeger en nu'. Rekenschap 44 (1997) 191-199.

3. Romein. Breukvlak. $643 \mathrm{ev}$. Vergl. W. Balke. 'Allard Pierson in de klem tussen geloof en wetenschap', De negentiende eeuw 21 (1997) $51-82$.

4. Nieuwe Rotterdamsche Couran 13 juni, 1917. Ook geciteerd door: André van Raaij, 'Felix Orts pneumatenergetisch monisme. Een filosofie van hel christen-anarchisme". Geschiedenis van de wijsbegeerte in Nederland. Documentatieblad werkgroep Sassen 8 (1997) 93-102, aldaar 110
} 
elkaar te verenigen en om belangrijke aspecten van het moderne leven in de eigen wereldbeschouwing te integreren. Wordt dit alles wel bij de beschouwing van het anti-vivisectionisme en de kleine geloven betrokken dan wordt het duidelijk dat dergelijke stromingen zich niet zonder meer van de moderniteit afkeerden. De stelling dat zij er mede vorm aan gaven, verdient dan ook nader onderzoek. Dat hun pogingen om wetenschap en geloof te verenigen vanuit natuurwetenschappelijk oogpunt de toets der kritiek niet kunnen doorstaan is daarbij niet relevant.

In de historiografie vormt de studie van Turner een uitzondering. Deze auteur kenschetst het anti-vivisectionisme weliswaar als anti-wetenschappelijk, maar besteedt toch ook enige aandacht aan de complexiteit van die houding ten opzichte van de wetenschap. Turner doet dit door de persoonlijke belevenissen van Frances Power Cobbe te belichten. Hij laat zien hoe haar verhouding tot wetenschap en geloof zich heeft ontwikkeld en hoe haar wereldbeschouwing en antivivisectionisme in de loop van dit proces vorm hebben gekregen. Anders dan French is Turner ervan overtuigd dat persoonlijke ervaringen belangrijk zijn om het anti-vivisectionisme te begrijpen.

Turner schetst hoe Cobbe als jong meisje vooral belast was met de zorg voor haar invalide moeder en haar vrije tijd meestal in eenzaamheid doorbracht met lezen. Zo kwam zij al op zeer jonge leeftijd in aanraking met wetenschappelijke theorieën. Deze strookten op z'n zachtst gezegd niet met het strenge maar blijmoedige evangelicalism waarin zij werd opgevoed en droegen er toe bij dat Cobbe rond haar twintigste langzaam in agnosticisme verviel. Bij een 'mogelijke God' kon zij niet de geborgenheid en bescherming vinden waar zij behoefte aan had. De frictie tussen dit verlangen en haar tanend geloof werd na de dood van haar ouders steeds groter. Jarenlang ging Cobbe door een zware geloofscrisis. Na deze periode in de 'deserts of doubt' vond zij uiteindelijk met veel moeite een nieuwe levensbeschouwing in een combinatie van gedeelten van de filosofie van Kant, de opvattingen die Theodore Parker in zijn Discourse on religion ontvouwde, en het geloof in de absolute goedheid van God. Cobbe's God was, zoals Turner het schrijft, een Victoriaan. Net als zijzelf verafschuwde hij boven alles pijn en wreedheid. Cobbe verdedigde haar nieuwe geloof met hand en tand tegen alles wat het zou kunnen aantasten. Ze wantrouwde de wetenschap die eens de twijfel in haar leven had gebracht. Ondertussen maakte zij carrière. Rond haar dertigste was ze een niet onverdienstelijk schrijfster van reisverhalen en essays. Ze had contacten met vele Engelse cultuurdragers onder wie Charles Darwin en was als onderwijzeres verbonden aan een armenschool. In die vruchtbare periode van haar leven vol van maatschappelijke activiteiten verstuikte ze haar enkel. De volgende vier jaar kon zij, naar haar zeggen als gevolg van een medische fout, nauwelijks lopen. In deze periode van invaliditeit veranderde haar argwanende houding ten opzichte van de geneeskunde in een regelrechte haat tegen de medische wetenschap die, zo meende zij, ook haar moeder had laten lijden. Op dit punt in haar leven aangeland was Cobbe, volgens Turner, 'vatbaar' voor het anti-vivisectionisme:

'Wary of science, hostile to the pretentions of medicine, and clinging to a faith that required

God to damn pain, miss Cobbe easily caught the anti-vivisectionist fever. Her skilled pen and contacts among the influential inevitably made her a prime agent for its spread.'

Cobbe's persoonlijke religieuze ervaringen worden door Turner verbonden met de Victoriaanse cultuur waarin, zoals ook wordt beschreven door Peter Gay, zowel angst als fascinatie voor pijn, wreedheid en agressie centraal stonden. ${ }^{6}$ Tegelijkertijd verbindt Turner die ervaringen met de manier waarop Cobbe als voorvrouw van het Engelse anti-vivisectionisme vorm gaf aan de discussie over vivisectie. Haar religious experience, om met de titel van William James' wereldberoemde studie te spreken, was volgens Turner dus representatief voor de manier waarop de meeste anti-vivisectionisten zich tot wetenschap en geloof zouden hebben verhouden.

Wat Turner niet ziet, is dat Cobbe's (zelf gestileerde) biografie de structuur heeft die volgens Campbell kenmerkend is voor de heldenreis. De heldin Cobbe moest een reis door een donker

5. Het verhaal over Cobbe is ontleend aan Turner, Reckoning. 70 ev. Het citaat is te vinden op 123

6. Zie Peter Gay, Cultivation. 
gehied maken, de 'deserts of doubt', om uiteindelijk gelouterd en als overwinnaar uit de strijd te komen. Haar levensverhaal lijkt op dat van Gemma. Evenals deze romanheldin werd Cobbe in haar jeugd aan huis gekluisterd en in die schijnbaar veilige omgeving geconfronteerd met indringende en wellicht daarom verboden wetenschappelijke kennis. Uiteindelijk zou deze schok bepalend zijn voor de beslissingen die zij in haar leven zou nemen.

De vraag of alles zich werkelijk op deze manier in Cobbes leven heeft afgespeeld is niet belangrijk. Waar het om gaat, is hoe Cobbe haar levensverhaal vertelde en hoe haar biografie ook door anderen is vormgegeven. Het verhaal over haar leven deelt iets mee over de manier waarop zij zich tot wetenschap en religie verhield, over de relatie die zij en anderen zagen tussen haar eigen levensverhaal en het anti-vivisectionisme. Haar biografie vertelt, zo zou wellicht gesteld kunnen worden, hoe de anti-vivisectionisten geacht werden zich tot wetenschap en geloof te verhouden. In de expressieve politiek draait het immers om het uitdragen van morele en religieuze opvattingen en om het geven van het goede voorbeeld. Cobbe belichaamde de idealen van de beweging waarvan zij de leider was. Hoe zat dat eigenlijk bij Ortt? Wat valt er uit het verhaal over zijn leven en uit zijn levensbeschouwelijk werk Inleiding tot het pneumat-energetisch monisme op te maken over de relatie tussen wetenschap, religiositeit en de politieke stijl van de Nederlandse vivisectie-bestrijders?

\section{De 'twijfel-chaos'}

Doordat ego-documenten zoals brieven en dagboeken van Ortt niet beschikbaar zijn, is het niet mogelijk om via dergelijke bronnen meer te weten te komen over de verhouding tussen wetenschap en geloof in zijn leven. ${ }^{7}$ Wel beschikbaar zijn Ortts romans, essays en zijn Inleiding tot het pneumat-energetisch monisme. Als uit deze diversiteit aan teksten iets duidelijk wordt dan is het wel dat de verhouding tussen wetenschap en geloof een belangrijke thematiek in dit oeuvre vormt.

Voor de hoofdpersoon van de roman Naar het groote licht, Frits van Beers, zijn wetenschap en geloof wezenlijke referentiepunten. Dit blijkt uit de wijze waarop hij zich tot het echtpaar Marie en Willem Dam verhoudt. Marie Dam, zijn zusterziel, staat zowel symbool voor het gevoel als voor het geloof. Willem Dam is een joviale arts die er een wetenschappelijk-materialistische levensbeschouwing op na houdt en aan het gevoelsgeloof van zijn vrouw geen boodschap heeft. Frits van Beers beziet bewonderend en niet zonder verbazing Maries onconventionele, ondogmatische geloof dat hij vanuit zijn eigen orthodoxe geloofsovertuiging behoort af te keuren. Tegelijkertijd deelt hij haar mans enthousiasme voor de wetenschap al maakt hij zich op hetzelfde moment bezorgd over diens ongeloof.

Wanneer tot Frits' ontzetting blijkt dat het huwelijk van zijn vrienden een grote disharmonie vertoont, raakt hij volkomen in de war. Het is alsof het conflict tussen Marie en Willem hem doet buseffen dat ook in zijn innerlijk wetenschap en gevoel, of preciezer, wetenschap en geloof niet met elkaar overeenstemmen. Voor het eerst in zijn leven ziet hij zijn eigen orthodoxe geloof in het licht van de wetenschap en twijfelt hij aan de authenticiteit van de Bijbel als Gods woord. In bijbelse wonderen kan hij niet langer geloven:

'Verbeeld je dat God in de natuurwetten zou gaan ingrijpen [...] dat was immers een bakersprookje; daar geloofde geen verstandig mens in die de natuurwetenschappen had bestudeerd. ${ }^{8}$

In die natururwetenschappen had Frits zich inderdaad verdiept. Evenals Felix Ortt doorliep hij eerst een HBS-opleiding en vervolgens een ingenieurs-studie. Toch was het niet uitsluitend de wetenschap die er toe leidde dat Ortts romanheld zijn geloof verloor. Een tweede belangrijke oorzaak is Frits van Beers' eerste persoonlijke confrontatie met het kwaad. Tot zijn verbijstering ziet hij zijn vriend Willem Dam aan een alcoholverslaving ten onder gaan. De medicus maakt in

7. Met dit probleem kample ook Hetly Kock. Christen-anarchist. Zij interviewde daarom de dochter van Felix Ort. Nanda Niermans-Ort. Ook ik heh Nanda Niermans-Ort en haar man Jan Niermans geïnterviewd.

8. Ort, Gronte licht. 172 
benevelde toestand tijdens een operatie een cruciale fout waardoor een straatarm oud vrouwtje het leven laat. Het drama heeft tot gevolg dat dokter Dam vrijwel al zijn patiënten verliest en door zijn collega's wordt uitgestoten als een paria. De enige uitweg die hem rest, is de aanvaarding van een betrekking als vivisector in Nederlandsch-Indië bij het Instituut Pasteur. ${ }^{9}$ Marie Dam blijft achter, tevergeefs wachtend op de terugkeer en rehabilitatie van een volledig genezen echtgenoot die zich op dat moment in 'de Oost' overgeeft aan opium-schuiverij en ellendig sterft.

Al deze gebeurtenissen maken op Frits van Beers grote indruk, te meer daar zijn vriend hem aanwijst als de oorzaak van zijn alcoholisme. Het was immers Frits, zo redeneert Willem meedogenloos, die hem gedurende hun studietijd Toddy had leren drinken. Had hij daarmee zijn zwakkere broeder niet in verleiding gebracht? Was hij daarom niet evengoed de oorzaak van de ondergang van zijn vriend, het ongeluk van zijn vrouw en de dood van het oudje? Na deze ernstige beschuldiging wordt Frits direct geheelonthouder. Hoe meer hij zich deze levenswijze eigen maakt des te meer worden zijn ogen geopend voor de sociale ellende die overal, maar vooral onder arme mensen, door alcohol wordt veroorzaakt. In dit proces valt hem op een dag onverwacht de volgende gedachte binnen:

'Hoe is "t mogelijk dat God den alcohol in de wereld heeft gebracht? Hij wist toch dat zooveelen van zijn schepselen er door ongelukkig zouden worden! Was dat niet hen opzettelijk eeuwig rampzalig maken.' ${ }^{10}$

Frits van Beers zag zich met andere woorden voor het 'vraagstuk der theodicee' geplaatst. Een probleem waarvoor hij tot zijn schrik geen oplossing kon vinden.

De oorzaken van Frits van Beers' geloofscrisis, de natuurwetenschappelijke kennis en de sociale kwestie, zijn precies de problemen die met name het Nederlandse protestantisme in de negentiende eeuw in beroering brachten. Het orthodox-protestantisme kwam vanaf 1850 onder grote druk te staan door de opkomst van het natuurwetenschappelijke denken dat, zoals K.H. Roessingh het uitdrukt, 'als een magische betoovering de 'moderne mensch' had gevangen'. Illustratief zijn de bijnamen van Cornelis Opzoomer die bekend stond als de eerste Nederlandse 'moderne mensch" en als de "apostel des ongeloofs'." Opzoomers denkbeelden waren sterk door de natuurwetenschappen beïnvloed. Hij ontwikkelde een monistische religie waarin de eenheid van het goddelijke en het menselijke centraal stond. Het idee van het goddelijke ingrijpen en het gebed tot een persoonlijke God liet hij om die reden los. In Ortts roman zag Frits van Beers zich genoodzaakt om hetzelfde te doen. Geïnspireerd door het hegelianisme verklaarde Opzoomer tevens dat het christendom slechts een schakel was in de ontwikkeling van de mensheid. Door de godsdienst op deze wijze te historiseren verwierp hij het bestaande beeld van het onovertrefbare christendom. Daarmee werd hij één van de vaders van het Nederlandse modernisme dat christendom en moderne cultuur met elkaar probeerde te verenigen en daarbij de autonomie van de menselijke geest centraal stelde. ${ }^{12}$

Het in het vorige hoofdstuk besproken initiatief van de Leidse theologen en de groep rond Van der Veer zijn voorbeelden van de wijze waarop deze pogingen gestalte kregen en illustreert de wereld waartoe Ortt zich aangetrokken voelde toen hij Naar het groote licht schreef. Het gaat wellicht te ver te veronderstellen dat Ortt in deze periode, evenals zijn romanheld, hulpeloos rondliep met de brokstukken van zijn orthodoxie. Maar het is zeker niet uit te sluiten dat hij zich vanaf het einde van de jaren tachtig voor de steeds dringender vraag gesteld zag of, en op welke manier, het geloof waarmee hij was opgevoed voor hem nog betekenis had. Een andere vraag die op dat moment in zijn persoonlijk leven moet hebben gespeeld en die, naar kan worden aangeno-

9. Zie over dit instituut: A. De Knecht-van Eekelen, 'Tropische geneeskunde in Nederland en koloniale geneeskunde in Nederland-Indië', Tijdschrifi voor geschiedenis 105 (1991) 407-428.

10. Ort, Groote licht, 63-64.

11. K.H. Roessingh, Het modernisme in Nederland (Haarlem 1922) 6. Zie ook: Oene Noordenbos, Hel atheïsme in Nederland in de negentiende eeuw. Een kritisch overzicht (Bussum 1961).

12. Roessingh. Modernisme. 22. 
men, nauw samenhing met zijn vragen over het geloof en zijn verhouding tot de wetenschap, was de vraag of de ingenieursloopbaan waar hij, zoals zijn familie het zich althans voorstelde, voor was bestemd, wel overeenkwam met hetgeen hijzelf wilde. Volgens Ortts dochter, Nanda Niermans-Ortt, koesterde haar vader als leerling van de Haarlemse H.B.S. in stilte de wens om evenals zijn buurjongen, Frederik van Eeden, medicijnen te studeren. Mogelijk bewonderde hij de oudere Van Eeden, misschien hield zijn interesse voor de geneeskunde ook verband met de ziekte van zijn vader. Deze leed al jaren aan een zeer pijnlijke reumatische kwaal.

De jonge Louis Ortt, zoals Felix toen nog genoemd werd, wist evenwel dat hij voor een medicijnen-studie geen toestemming zou krijgen. Zijn vader had immers nooit enige twijfel laten bestaan over het beroep dat zijn zoons dienden uit te oefenen. Ortt zou dit thema later verwerken in het korte verhaal Sint Nicolaasavond over een zoon van een niet rijke adellijke familie die, zijn hartewens volgend, medicijnen gaat studeren terwijl dit door zijn ouders streng wordt afgekeurd omdat het te duur en te burgerlijk is. ${ }^{13}$ De student uit het verhaal volgt zijn hart, maar Ortt zelf zag daar kennelijk geen mogelijkheden toe. Daar in het gezin Ortt -om met Romeins ironische verwijzing naar Freud te spreken- de vader nog altijd het Über-ich van zijn zoon was, ${ }^{14}$ bestond er in de gedachten van de jonge Louis waarschijnlijk geen andere mogelijkheid dan zich te schikken naar zijn vaders wensen.

In het vorige hoofdstuk werd beschreven dat Ortt na de ontmoeting met Roorda van Eysinga en de kring van Van der Hucht-Kerkhoven en na een langdurige ziekte uiteindelijk ontslag nam uit de overheidsdienst om als christen-anarchist een humanitaire loopbaan aan te vangen. Precies zo vergaat het zijn romanheld Frits van Beers wiens lotgevallen in het jaar van Ortts ontslag werden opgetekend. Ook deze romanheld geeft zijn betrekking als ingenieur op. Voordat hij dat doet valt hij ten prooi aan twijfels:

'Ik denk aan niets anders, onder mijn werk door en in mijn vrije oogenblikken, "s avonds voor ik ga slapen en 's morgens als ik wakker word. [...] Ik heb over alle godsdiensten verhandelingen gelezen en de voornaamste werken van de grootste wijsgeren. [...] Ik wist dat ik geen rust zou hebben voor ik zag wat de waarheid was, voor ik vrede had met mijzelf. Ik heb erom gebeden, om licht en geloof, om een aanwijzing in die twijfel-chaos en nu ben ik op, ik kan niet meer [...].'

Frits van Beers krijgt hoge koorts en ligt weken lang ijlend op bed geteisterd door monsterlijke droombeelden.

Naar analogie van wat hierboven over het levensverhaal van Cobbe is opgemaakt is het niet belangrijk of Frits' koortsaanvallen vergeleken kunnen worden met de periode van Ortts malariaaanvallen, of Ortt met andere woorden evenals Frits van Beers een geloofscrisis heeft doorgemaakt. Waar het om gaat is dat de worsteling met het geloof en de confrontatie tussen geloven en weten deel uitmaakte van de wijze waarop de anti-vivisectionistische leiders hun eigen leven mede met behulp van fictie beschreven en in verband brachten met de strijd die zij voerden. In het autobiografisch heldenverhaal is de vertwijfeling die ontstaat door de confrontatie van wetenschap en geloof een belangrijke fase. Deze moest doorlopen worden om uiteindelijk geheel in evenwicht de strijd tegen het kwaad aan te vatten, een ethische levenswijze te kiezen en een ware en harmonieuze wereldbeschouwing uit te dragen. Zeker is in ieder geval dat Ortt zich jaren heeft beziggehouden met het bezweren van de door hem aan Frits van Beers toegeschreven 'twijfelchaos'. Zijn vele pogingen daartoe resulteerden uiteindelijk in de Inleiding tot het pneumatenergetisch monisme.

13. Ort. 'Sint Nicolaasavond' in: Van Asselt, Mens en dier, 26-36.

14. Jan Romein. 'De vereenzaming van de mens'. Proeve ener theorie van geestelijke crises (1946)' in: Jan Romein. Historische lijnen en patronen. Een keuze uit essays (Amsterdam 1976) 215-244, aldaar 234. 


\section{De waarheidszoeker}

'Langs welken weg mogen wij hopen vastheid te bereiken, de Waarheid te benaderen'15, vroeg Ortt zich af in Inleiding tot het pneumat-energetisch monisme. Ook al werd dit werk twintig jaar na Naar het groote licht gepubliceerd en al gebruikt Ortt in dit wijsgerig werk geen romanpersonage, in wezen handelt deze beschouwing nog altijd over 'een Frits van Beers'. In zijn Inleiding schrijft hij aanvankelijk meer in het algemeen over mensen die geen bevrediging vonden bij bestaande godsdienstige dogma's en filosofische stelsels:

'Wanneer zij gingen zoeken buiten de grenzen van het dogma waarin zij waren groot gebracht

[...] werden de veelheid van meeningen en onderlinge tegenspraak daarvan verbijsterend.

Waar kan de denkende mensch vastheid vinden in dien warrel van beschouwingen, meeningen, geloofsbelijdenissen? Want vastheid voelt hij als voorwaarde voor zielsvrede en geluk. '16

Uiteindelijk laat Ortt zich als het ware 'betrappen' door over te gaan op de eerste persoon enkelvoud:

'Ik [voel] den drang naar Waarheid, ook in het bereiken van een zoo zuiver mogelijk Godsbegrip [...] van een godsbesef dat zo mogelijk aansluit aan mijn inductieve en intuitieve weten. [...] Zoo mij dit gelukt ben ik daarmede bewaard voor innerlijke conflicten, tegenstrijdigheden en twijfelingen, die onvermijdelijk deel zijn van hen die nog strijd zien.' ${ }^{77}$

Van het boek waarin hij dit schreef, moest een helende kracht uitgaan die dergelijke innerlijke conflicten kon voorkomen. Ortt streefde er naar te bewijzen dat het mogelijk was de waarheid te vinden zonder met het geloof of met de wetenschap in conflict te raken. Volgens Ortt verdroegen wetenschap en religie elkaar, omdat zowel de positivistische wetenschap als het intuïtieve geloof eenzelfde soort waarheid openbaarden.

Dit nam niet weg dat de waarheidszoeker - en dat was volgens Ortt in feite ieder individu- op zijn zoektocht naar de waarheid het beste kon uitgaan van de natuurwetenschappen. In die sfeer heerste in ieder geval een eenstemmigheid die de waarheidszoeker de mogelijkheid bood om uiteindelijk met vaste grond onder de voeten zijn intuïtie 'aan te raken'. Indien de zoektocht naar de waarheid vanuit de intuïtie zou worden begonnen ontstonden er problemen. Iedere zekerheid van de inductieve wetenschap ontbrak dan en iedere 'twijfelschok' zou dan al snel noodlottig zijn omdat de intuïtie niet zuiver genoeg was om dwalingen te voorkomen. De waarheidszoeker kon zijn reis het beste aanvangen als in een 'ballon captif'. Ortt trok de vergelijking met een luchtballon, stevig verankerd aan de grond (de natuurwetenschappelijke basis en de empirie), maar hoog boven de wereld (in de 'ijle' sfeer van de intuïtie). Zo verkreeg hij het beste overzicht zonder zich mee te laten voeren door zijn gevoel of door de fantasie.

Om die reden ging Ortt in het eerste deel van Inleiding tot het pneumat-energetisch monisme uit van de natuurwetenschappen. Daarbij stelde hij de eerste Hoofdwet der Thermodynamica centraal. Volgens deze 'wet van het behoud van energie' is, zo gaf Ortt aan, het wereldgebeuren aan energie gebonden. Alles wat geschiedt, kan daarom als omzetting van energie worden beschouwd. Vervolgens beriep Ortt zich op het onderzoek van Boltzmann en Van der Waals waaruit gebleken was dat er continu een degradatie en vervlakking van energie plaatsvindt. Minder waarschijnlijke 'energie-toestanden' zouden altijd overgaan in meer waarschijnlijke. De eerste soort wordt gekenmerkt door orde en regelmaat terwijl de laatste juist bepaald wordt door het ontbreken daarvan. In verband met deze natuurkundige kwestie formuleerde Ortt de volgende vraag: als alles volgens de eerste Hoofdwet der thermodynamica kan worden beschouwd als energie en energieomzetting, hoe kan het dan dat in de oneindige loop der tijd niet de meest waarschijnlijke toestand van maximale ordeloosheid is ontstaan?

15. Ort. Inleiding tot. $\mathrm{l}$.

16. Ibidem.

17. Ibidem, 114. 
'Vanaf het electron af door het atoom, de molecuul, de cel, het organisme heen tot de maatschappij en de staat vertount zich immers een raadselachtige, uiterst onwaarschijnlijke ordening.' 18

Dit alles zou volgens Ortt alleen worden verklaard door tezamen met de wereldenergie het bestaan van een ordenend beginsel aan te nemen waarmee de energie 'begaafd' is. Door dit ordenend beginsel als entelechie aan te duiden, plaatst hij zich in de vitalistische traditie. Het door Ortt gebezigde begrip was afkomstig van Aristoteles. Deze verwierp een mechanistische verklaring van het leven door in zijn beschouwing over levensverschijnselen een aparte vormende levenskracht aan te nemen die hij de naam entelechia (iets dat een doel in zichzelf draagt) gaf. Ortts tijdgenoot, de bioloog Hans Driesch (1867-1941) was van mening dat in het leven een autonome factor werkzaam was die, los van de fysica en chemie, haar werking deed gelden in individuele levensvormen. ${ }^{19} \mathrm{Om}$ deze factor te benoemen gebruikte hij eveneens het begrip entelechie. Ortt beroept zich in zijn Inleiding tot het pneumat-energetisch monisme op Driesch. Hij besteedt veel aandacht aan de denkbeelden van de filosoof en dit is, zoals ook G. Heymans in een recensie van het werk heeft opgemerkt, zeer eigenaardig, daar Ortt zich slechts partieel met diens filosofie kon vereenzelvigen. ${ }^{20}$ Het neo-vitalisme van Driesch ging namelijk uit van een zeer scherpe grens tussen de anorganische natuur en het leven en juist dit aspect paste in het geheel niet in Ortts denkwijze. Voor Ortt bestond er slechts een gradueel verschil tussen de werking van de entelechie in moleculen en die in organismen. Wilde hij Driesch' redenering consequent volgen, dan was hij dus gedwongen om dit monistisch beginsel los te laten. Zijn wereldentelechie zou dan gedegradeerd worden tot slechts één van de vele natuurkrachten die niet in maar naast de energie bestaat. Een dergelijk dualisme (eigenlijk ieder denkbaar dualisme) harmonieerde op z'n zachtst gezegd niet met de door Ortt gevoelde drang tot vereniging. Dualisme strookte niet met zijn 'monistische waarheidsintuïtie'. Zo kon het gebeuren dat hij, ondanks zijn talloze verwijzingen naar Driesch, uiteindelijk in tegenstelling tot deze denker uitging van een wereld bestaande uit een Al-eenheid van energie begaafd met entelechie: het pneumat-energetisch monisme.

Het was deze Al-Eenheid die Ortt aanduidde als 'God'. Maar, zo haastte hij zich te vermelden, deze gelijkstelling maakte het pneumat-energetisch monisme beslist niet tot een pantheïstisch stelsel. Met deze stellige verklaring zette hij zich- zoals Hugenholtz dit vóór hem op een geheel andere wijze had gedaan- nadrukkelijk af tegen het monisme van Ernst Haeckel en diens credo: 'Alles ist Natur, Natur ist Alles'. Ortt stelde zich op het standpunt dat het wezen van God (de AlMacht en Al-eenheid geleid door de Al-Wil) zich buiten tijd en ruimte bevond, en eeuwig en universeel was. In Ortts pneumat-energetisch monisme was de natuur slechts de Al-Openbaring van het Al-Wezen, iets van 'lagere orde' waarin Gods wil, het ordenend vermogen, werd onthuld.

Alleen met een dergelijke voorstelling was volgens Ortt de weg geopend naar een werkelijke verstandhouding tussen wetenschap en geloof. Dat nam niet weg dat de wanhopige en door twijfelchaos bedreigde, op Frits van Beers gelijkende. waarheidszoeker nog twee wezenlijke problemen restten. Ten eerste was het niet zo eenvoudig om het bestaan van een Al-Eenheid met de zintuiglijk waarneembare feiten te rijmen. Het heelal openbaarde zich immers niet als eenheid maar als een oneindige veelheid. Met andere woorden, wat was het 'dat de eenheid van de entelechische energie tot splitsing heeft gebracht, tot een samenstel van moleculen, individuen en individuele intelligenties gelijk ons de wereld kennen doet? ${ }^{21}$

De eenvoudigste oplossing was de voorstelling van een naast God bestaande eenheidverbrekende Satan. Maar ook deze dualistische verklaring beantwoordde niet aan Ortts monistische

\section{Ibidem, 160.}

19. Zie over de ontwikkeling van het vitalisme in de negentiende eeuw: E. Benton, 'Vitalism in nineteenth-century scientific thought: A typolugy and reassesment'. Studies in History and Philosophy of Science 5 (1974) 17-48.

20. G. Heymans, 'Pneumat-energetisch monisme'. Tijdschrift wor Wijshegeerte (juli 1919). Herdrukt als aanhangsel in Inleiding tol, 159-165

21. Ort. Inleiding $10 t, 70$ 
waarheidsintuïtie. Wel achtte Ortt het mogelijk om Satan voor te stellen als een passieve kracht, als de duivel die stond voor de afwezigheid van ordening, voor de chaos. In het verlengde van deze oplossing stelde Ortt het 'wereldgebeuren' vour als 'het proces van een Zich-BewustWording der Al-Eenheid' en de tijd als 'de maat voor de passieve weerstand van de chaos tegen het ordeningsproces of de Al-Wil'. De Al-Wil zou in de loop der tijden telkens meer gescheiden elementen (energie-complexen) tot eenheden hebben geordend. Daardoor was, zo veronderstelde Ortt, uiteindelijk ook het leven, waarin verschillende ordenende beginsels samenwerkten, ontstaan. Het 'entelechie-complex' dat op deze wijze werd gevormd stond in het pneumat-energetisch monisme gelijk aan de ziel die uiteindelijk een dusdanige identiteit kon krijgen dat zij zich van haar eigen eenheid en ordenend vermogen bewust werd. Er was dan sprake van intelligentie.

Met deze uiteenzetting had Ortt de eerste moeilijkheid van de waarheidszoeker opgelost. Het tweede probleem dat hem restte, was evenwel essentiëler en verbonden met het eerder door hem geformuleerde godsbegrip: aan de Al-Eenheid kon geen persoonlijkheid worden toegeschreven. Het was niet de 'persoonlijke God, naar wiens gemeenschap de gelovige smacht, tot Wien hij bidt, aan Wiens leiding hij zich vol vertrouwen onderwerpt. ${ }^{22}$ Het pneumat-energetisch monisme handelde weliswaar over een wetenschappelijke aanwijzing voor het bestaan van God maar hielp de zoekende ziel daarmee niet veel verder. Die verlangde immers, zoals Frits van Beers en Frances Power Cobbe op het hoogtepunt van hun geloofscrisis, naar

'de intuïtieve verzekerdheid van een persoonlijke band met de Oppermacht [...] dien hij met volkomen eerbied en liefde kan aanhangen en van Wiens vaderlijke gezindheid hij overtuigd kan zijn. ${ }^{23}$

Als om tegemoet te komen aan deze diep gevoelde behoefte verklaarde Ortt dat bepaalde zeer sterke ordeningsprincipes, zoals mensenzielen, na de dood bleven voortbestaan. Zij konden zich samenvoegen met andere ordeningsprincipes ten einde een nog sterkere ziel te vormen en na de dood, als krachtiger persoonlijkheden (zoals Frits van Beers en Marie Loving) onder de mensen terugkeren. Uiteindelijk zou ook deze wedergeboorte eindigen. De vergevorderde ziel zou dan alleen als geest blijven voortbestaan. Met name deze aan het spiritisme ontleende gedachte was de sleutel tot de oplossing van het probleem dat Frits van Beers voelde wanneer hij aan de oude onbereikbare 'God der Modernen' dacht. Want hoewel het onmogelijk was om met de Al-Eenheid in contact te treden, was het wel denkbaar om tot deze geesten te bidden. Zij stonden dicht bij de mens en luisterden naar hem. Van hun liefde kon hij zich verzekerd achten. Op deze wijze kregen het spiritisme, de reïncarnatie-leer als ook de katholieke heiligenverering, de navolging van Christus en de Chinese aanbidding van voorouders een plaats in Ortts pneumat-energetisch monisme. Het probleem dat bleef bestaan was dat de geesten evenals de god der Modernen niet bij machte waren om op verzoek van het individu de natuurwetten te doorbreken.

Voor hen die leefden volgens de op basis van het pneumat-energetisch monisme ontwikkelde zedenleer was dit volgens Ortt niet langer een treurig gegeven. Zij begrepen immers dat de mens zelf een actief deel van God was en een dergelijk inzicht zou uiteindelijk meer bevrediging schenken dan het supranaturalisme ooit zou doen. Het uitgangspunt van de ethiek van het pneumat-energetisch monisme was de eerder genoemde Al-Wil (God) die gelijk stond aan de Liefde. Zoals het licht in de duisternis breidde God zich uit in de chaos. Op die manier was de emanatie van goddelijke liefde ook werkzaam in alle mensen. Daarmee kwam Ortt op een voor hem zeer wezenlijke "wetenschappelijke" verklaring van het zedelijk verschil tussen individuen. De werkzaamheid van God was nog niet in ieder individu in gelijke mate aanwezig. Het was daarom de 'heilige' taak van alle mensen om de uitbreiding van God mogelijk te maken en Hem ook in anderen werkzaam te doen zijn:

'Ja, het is onze plicht, het moet onze plicht zijn als deelen der Al-Eenheid, als vonken der Alentelechie, als dragers der Al-Energie, om aan haar worsteling met het Niet deel te hebben:

22. Ibidem, 67.

23. Ibidem. 
om te bevorderen al wat ordening is, om ordening te scheppen waar zij niet bestaat en hare vernietiging tegen te houden waar die dreigt, om de bestaande ordening aan te passen tot grooter harmonische eenheden. ${ }^{24}$

Zo dienden alle eenheidsverstorende zaken nagelaten te worden:

'[...] leven onbekommerd om het heil van anderen, belemmeren van het menswaardig bestaan van medemensen [...] elke onheilige daad die strekt tot de ordening in ons zelf te verstoren en elke nalatigheid om het ordenend vermogen in ons zelf aan te wakkeren, neerzitting in luiheid, in traagheid van handen en geest, in plaats van in onze geest meerdere orde te brengen en zijn orde-scheppend vermogen te versterken, verwaarloozing van het lichaam waardoor wanorde, ziekte en dood in de wonderschone lichaamsorganisatie wordt gebracht. ${ }^{25}$

De combinatie van deze levenshouding (die sterke overeenkomsten vertoont met het christenanarchisme en de anti-vivisectionistische politiek) moest de waarheidszoeker voorgoed van al zijn twijfels verlossen. Voortaan, zo is de strekking van de conclusie van Ortts Inleiding tot het pneumat-energetisch monisme, kon hij met een rustig gemoed bidden. Het individu had de waarheid gevonden. Hij wist zich onsterfelijk en kende zijn plichten.

Het pneumat-energetisch monisme stond niet op zichzelf. Met zijn keuze voor een monistische wijsbegeerte plaatste Ortt zich in de traditie van het laat-negentiende-eeuwse verzet tegen de volgens sommigen halfslachtige opvattingen van de moderne theologen. De modernen hadden de consequenties van het door hen zelf ontwikkelde monisme niet willen aanvaarden. ${ }^{26} \mathrm{Zij}$ hadden weliswaar het supranaturalisme verworpen maar bleven beweren dat het christelijke geloof in God ook na de opkomst van de natuurwetenschappen bestaansgrond hield. Dit alles ging vooral Ernst Haeckel, een belangrijke inspirator van Ortt, niet ver genoeg. Hij was uit op de totale vernietiging van het christendom.

Hoewel Ortt daar anders over dacht en zich veel verzoenender zou opstellen ten opzichte van de christelijke leer, was hij ten zeerste gegrepen door Haeckels opvattingen en diens levensverhaal. Verwonderlijk is dat niet. Evenals Ortt en zijn romanheld Frits van Beers had Haeckel het protestantse geloof van zijn jeugd verloren. Kenmerkend voor de eeuw van de natuurwetenschappen, zoals de negentiende eeuw ook wel wordt aangeduid, zou de crisis in het geloofsleven van de denker hebben plaatsgevonden tijdens zijn studie natuurkunde. Net als de hoofdpersoon uit Naar het groote licht, bemerkte Haeckel als student dat hij het christendom op geen enkele wijze in overeenstemming kon brengen met de wetenschappelijke inzichten die hij bestudeerde. De genadeslag voor Haeckels geloof was spoedig een feit toen hij, inmiddels werkzaam als medicus, geconfronteerd werd met hetgeen hij aanduidde als de wreedheid van het leven. De jonge Haeckel zag zich evenals Frits van Beers voor het vraagstuk der theodicee gep! ?atst.

Voor Haeckel was, zo luidt de stelling van Daniel Gasman, het monisme uiteindelijk de aangewezen manier om de tegenstrijdigheden die hij op zijn levensweg was tegengekomen met elkaar te verenigen, om tegemoet te komen aan het 'folterend verlangen om een enkele, eenvoudige wet te formuleren die de werking van het universum zou verklaren' en aldus twijfelbrengende anomalieën uit te sluiten. ${ }^{27}$

Of Haeckel nu werkelijk zo'n veilige haven voor zoekende zielen als hijzelf had gevonden is de vraag. In zijn tijd stond het monisme evenzeer onder druk als het protestantisme niet lang

\footnotetext{
24. Ibidem, 139

25. Ibidem.

26. Jost Hermand, Grüne Ulopien in Deutschland. Zur geschichte des ölologischen Bewußtsein (Frankfurt am Main 1991). Zie ook: Claudia Bibo. Naturalismus als Weltanschauung ? Biologischen, theosophische und deutsch-völkische Bildlichkeil in der von Fidus illustrierten Lyriek (1893-1902) Mil einem Anhang: Organisarionen der Deutschgläubigen Bew'egung(Frankfur am Main/ Berlin 1995)

27. Daniel Gasman. The scientific origins of national socialism: social Darwinism in Ernst Haeckel and the German Monist League (Londen 1971). Het citaat 'folterend verlangen...' is afkomstig uit E.H. Kossmann, De lage landen 1780-1980. Twee eeuwen Nederland en België Deel I (Amsterdam 1986) 44
} 
daarvoor. De reden daarvoor was dat de meeste monisten zich op een materialistisch standpunt hadden gesteld. Monisme en materialisme hadden zij als het ware aan elkaar geklonken. Toen het rond 1890 zelfs voor de meest verstokte materialist steeds moeilijker werd om vol te houden dat alle levensverschijnselen vanuit de materie konden worden verklaard leek het monisme ten dode opgeschreven.

De redding kwam van Wilhelm Ostwald, geestverwant van Haeckel en één van Ortts belangrijkste inspirators. Door in plaats van de materie, het begrip energie als uitgangspunt van zijn denken te nemen en alle wereldverschijnselen te benaderen als 'energie' en 'energieomzetting', makkte hij het mogelijk om het op de natuurwetenschappen gebaseerde monisme te behouden. Hij speelde daarmee in op de opvattingen van zijn leermeester Ernest Solvay, de Belgische liberaal die er ondermeer vanuit ging dat een zo efficiënt mogelijke omzetting van energie (en daaruit voortvloeiende de verhoging van de produktie) uiteindelijk tot de oplossing van de sociale kwestie zou kunnen leiden.

In deze wereld van in termen van energie denkende monisten, kan ook Ortt geplaatst worden. De voorman van de Nederlandse anti-vivisectionisten voelde zich zowel aangetrokken tot de opvattingen van Solvay, als tot de deels liberale, deels nationalistische culturele kring waar de Belgische monisten deel vanuit maakten. Bij interesse alleen bleef het overigens niet. Ortt trad in contact met de Vlaamse nationalisten Jef Hinderdael en Lodewijk de Raet (een leerling van Solvay) en de reformpedagoog Edward Peeters. ${ }^{28}$ Hij verdiepte zich in de strijd voor culturele zelfstandigheid van de Vlamingen en het zogenaamde nationaliteitenprobleem van België. In deze kwestie zag hij een bewijs voor zijn stelling dat staat en volk conflicterende zielen van verschillende orde waren. Die opvatting, waarmee hij, zoals Willem Otterspeer laat zien, onder meer reageerde op het werk van de Nederlandse filosoof Bolland, in de Inleiding tot het pneumatenergetisch monisme een prominente plaats in. ${ }^{29}$

Behalve door de Vlaamse nationalisten en monisten was Ortts pneumat-energetisch monisme sterk beïnvloed door het psychisch-monisme van de Groningse psycholoog Heymans. Ortt was bijzonder ingenomen met de recensie van deze gerenommeerde wetenschapper in het Tijdschrift voor Wijsbegeerte. Dat hij de bespreking als een teken van erkenning door de wetenschappelijke wereld beschouwde, betekent overigens niet dat Heymans onverdeeld enthousiast was over Ortts monisme. In zijn artikel stak hij niet onder stoelen of banken dat de verdediging van het neovitalisme een inconsequentie in Ortts betoog vormde. Daar stond tegenover dat Heymans Ortts werk zonder ironie typeerde als een 'ernstig doordacht [...]metaphysisch systeem' dat vee] aanrakingspunten vertoonde met zijn eigen psychisch monisme. In die lof lag wellicht ook het grootste venijn. De psychisch monist identificeerde Ortts monisme in wezen als een overbodig stelsel, als een variant op zijn eigen monistisch denken. Hij dekte deze kritiek toe door de hoop uit de spreken dat

'de heer Ortt de mogelijkheid, ons beider opvattingen met elkander te verbinden, in overweging zal willen nemen. Wat evenwel ook de uitslag dezer overweging moge zijn, in elk geval kan (en zal, voor zoover ik er iets aan kan doen) het psychisch monisme dankbaar gebruik maken van verscheidene gezichtspunten, waartoe het hier besproken boek den weg heeft gewezen. ${ }^{30}$

Behalve de directe invloed van de verschillende hierboven genoemde monisten was Ortts wereldbeschouwing een niet onlogisch vervolg op de oud-moderne protestantse theologie. De eerder genoemde Scholten en Opzoomer gingen, hoezeer zij verder onk van elkaar verschilden en met elkaar in discussie traden, evenals Ortt uit van de empirisch waarneembare openbaring en ontdekten daarin doelmatigheid, innerlijke doelstreving, vooruitgang en eenheid. Hoewel er meer

28. Pecters publiceerde in België een boek over Felix Ortt: E.D.D.Y. (pseudoniem voor Edward Pecters), Een triptiek van Felix Ortt: e'ene studie (Oostende 1907).

29. Willem Outerspeer, Bolland, een biografie (Amsterdam 1995)

30. G.Heymans, 'Pneumat-energetisch monisme', 165. 
is dat Ortt van beide modernisten scheidde kan Opzoomers opvatting dat naast de zinnelijke gewaarwording, het innerlijk geviel als een tweede bron van kennis onderscheiden kon worden, zonder veel moeite worden teruggevonden in Ortts metafoor van de waarheidszoeker in de ballon captif.

Een andere opvallende overeenkomst tussen de wereldbeschouwingen van Opzoomer, Scholten en Ortt is dat alle drie het bestaan van een vrije wil uitsloten. Critici van Scholten zagen in dit aspect van zijn denken een rest van de orthodox-protestantse opvoeding uit zijn jeugd. Het is niet ondenkbaar dat deze opmerking -de mogelijk boosaardige bedoelingen van degenen die haar makkten ten spijt- ook op Ortt van toepassing kan worden geacht. Ook hij lijkt immers grote waarde te hechten aan de idee van voorbeschikking. Zijn eerder besproken optreden voor de Commissie inzake Vivisectie en de nadruk die hij in zijn geschriften legde op de verschillen tussen het zedelijk en moreel peil van individuen, lijken althans sterk op een eigentijdse 'vertaling' van de predestinatie-gedachte. Hoe het ook zij, zeker is dat Ortts levensbeschouwing resulteerde in een, om met de woorden van Anton Constandse te spreken, zeker 'aristocratisch individualisme'. ${ }^{31}$ De daden, opvattingen en ontwikkelingen van een individu, bijvoorbeeld zijn strijd tegen de vivisectie, werden door Ortt opgevat als een vaststaand onderdeel van het Grote Doel van de Al-Macht. Zo is, juist door naar Ortts opvattingen over wetenschap te kijken, een deel van de oorsprong en achtergrond van de religieuze component van de anti-vivisectionistische expressieve politiek getraceerd.

Overigens is aristocratisch individualisme ook aan te treffen bij Pieter Pijl en meer in het bijzonder in het eerder genoemde Het Tweede Leven dat een jaar voor Inleiding tot het pneumatenergetisch monisme werd gepubliceerd. In dit geschrift wordt meer dan eens een duidelijk onderscheid gemaakt tussen gewone mensen die in de waarnemingswereld gevangen zijn en zij die, zoals Pijl, begiftigd zijn met een hoger inzicht en daardoor kennis hebben van Het Tweede Leven. Opzoomer en Scholten zijn op het eerste gezicht wat minder voor de hand liggende inspiratiebronnen voor Pijl, temeer aangezien deze anti-vivisectionist het bestaan van de vrije wil niet uitsloot. Wat hij wel met de modernen en Ortt deelde, was een grote belangstelling voor het leven en de werken van Spinoza. ${ }^{32}$ Terwijl Ortts pneumat-energetisch monisme door zijn bewonderaars wel als een neo-spinozistische leer werd betiteld, verwijst Pijl direct naar Spinoza's substantie wanneer hij een synoniem probeert te vinden voor de door hem beschreven Goddelijke wereld van het Nameloze (Ortts Al-eenheid).

Ook de belangstelling van Pijl en Ortt voor Spinoza makkte deel uit van een bredere culturele stroming die in Nederland haar aanvang nam in de tweede helft van de negentiende eeuw. Of beide anti-vivisectionisten recht deden aan de opvattingen van de grote denker is niet zozeer aan de orde. Zoals Kossmann terecht heeft opgemerkt was het Johannes van Vloten, de man achter de negentiende-eeuwse Spinoza-revival, die de wijsgeer afschilderde als een rationalistische materialistische atheïst, een beschrijving die meer recht deed aan Van Vloten zelf dan aan Spinoza. Voor Van Vloten was Spinoza de blijde boodschapper van de mondige mensheid. Voor de Tachtiger Herman Gorter was hij de oplossing voor de eenzaamheid die hij als dichter voelde na zijn allerindividueelste expressie van de allerindividueelste emotie. Gorter zou gevoeld hebben dat de tot God geworden dichter de mensheid niets meer te melden had en vervolgens in Spinoza zijn gevlucht. Diens wiskundige methode gaf zekerheid. Gezien zijn achtergrond moet juist dit exacte van Spinoza ook voor Ortt zeer belangrijk zijn geweest. Spinoza legde door zijn pantheïsme en mystiek een relatie tussen 'het grote verband' en het individu dat daarin een zinrijke plaats had. Het moeten ook deze aspecten van Spinoza's denken zijn geweest die voor Ortt en Pijl van belang waren. Beide anti-vivisectionisten beschreven religiositeit als iets zeer persoonlijks en authentieks. Tegelijkertijd beklemtoonden zij met behulp van hun aristocratisch individualisme, de cultivering van het individuele offer en een beroep op de positieve wetenschap, het belang van een vastom-

31. A.L. Constandse, 'Herman Goner en Spinoza' in: Acht over Gorter (Amsterdam 1978) 213-252.

32. Kossmann, De lage landen, 175 
lijnde plaats in de eenheid van al het zichtbare en onzichtbare en de daaruit voortkomende relatie met het hogere.

Zeker is dat Ortt één van de velen was die in de periode rond de eeuwwisseling een poging deed om, zoals Aerts het met betrekking tot Heymans psychisch monisme formuleerde, 'wetenschappelijk door te dringen tot het schijnbaar ongrijpbare ${ }^{\text {33 }}$. Typisch voor de Nederlandse culturele stijl van deze periode was dat dit zoeken naar 'eenheid, binding, universaliteit' en 'het opheffen van tegenstellingen in een hoger allesverheffend verband'. Meer dan in het buitenland draaide het in Nederland om verzoening van uitersten en niet om het aanzetten van scherpe contrasten.

Van deze stelling is Ortts monisme in ieder geval een toepasselijke illustratie. Anders dan Haeckel toont Ortt zich niet zozeer een verbeten strijder. Hij gaf uitdrukkelijk aan met zijn werk naar verzoening te streven en noemde zijn pneumat-energetisch monisme om die reden de 'filosofie der verdraagzaamheid'. Als om daarbij nogmaals te onderstrepen dat het hem in het geheel niet te doen was om de vernietiging van het christelijk geloof eindigde Ortt zijn boek met een kolomsgewijze opsomming van de overeenkomsten tussen zijn pneumat-energetisch monisme en de christelijke leer. Hij trok een parallel tussen 'de Al-Eenheid' en 'God, onze Vader in de Hemelen'. De 'zich als een met de Al-Entelechie bewuste entelechie van de mens' kon wat Ortt betreft gelijk worden gesteld met de 'inwonende Christus' ${ }^{34}$ Op deze wijze behield Ortt de voor hem essentiële kanten van het christendom en benadrukte hij eens te meer dat voelen en weten, religie en wetenschap niet alleen samen konden gaan, maar zelfs uiteindelijk niet zonder elkaar konden bestaan.

\section{Evenwichtige mannen, gefragmenteerde vrouwen}

De rond 'geloven' en 'weten' gecentreerde crisis en de overwinning op de grote vertwijfeling maakten deel uit van het verhaal waarin de levensloop van de 'held' of 'leider' van de antivivisectie-beweging aan het publiek, de achterban en de tegenstrevers werd gepresenteerd. Typerend voor de manier waarop Ortt zichzelf beschreef en anderen hem beschreven is het accent op de innerlijke vrede, het evenwicht en de zekerheid die hij na de strijd tussen weten en geloven had verworven. Dat evenwicht werd in de aan hem gewijde levens- en karakterschetsen zowel gelijkgesteld aan 'wetenschappelijkheid' als aan 'kinderlijkheid'. Zo prees de spiritist J. Kakebeeke Ortts 'heldere, door en door wetenschappelijke betoogtrant' die gepaard ging aan een 'rustige houding tegenover andersdenkenden (...)'. De antroposofe Tine Kaayk schreef in 1946:

'wat mij bij mijn persoonlijk contact met Ortt steeds weer opvalt, is zijn kinderlijkheid, misschien vreemd gezegd van iemand, die ongeveer even oud is als mijn grootvader. Doch zoals een kind oorspronkelijk argeloos en vol vertrouwen in 't leven staat - o wee wanneer dit vertrouwen te spoedig beschaamd wordt en het kind dus een gelukkige, zonnige jeugd moet missen - zo staat Ortt steeds weer vol vertrouwen ten opzichte van de medemens. Zeker zal ook hij dikwijls in dit vertrouwen beschaamd zijn en daarvan verdriet hebben gehad, doch even zeker is dat door dit grote vertrouwen in de ander, dikwijls in die ander het beste wat in hem was, wakker werd gemaakt en op deze wijze is het goede in de wereld toegenomen, het geluk vermeerderd. ${ }^{35}$

Aan dergelijke karakteriseringen werd doorgaans toegevoegd dat Ortt zijn idealen uitdroeg door ernaar te leven, door ze als het ware te belichamen. Daarbij werden niet zelden, zoals in de volgende beschouwing van kinderboeken-schrijfster Christine Doorman, zijn voorbeeldfunctie, opofferingsgezindheid en geloof aangehaald: 
'Ik heb aan Felix Ortt zoo heel veel te danken, zijn eenvoud is mij een weldadig voorbeeld.

Zijn godsdienstzin is van het echte soort: niets voor zich zelf, alles voor de medemensch. Hij dient in waarheid God. Hij bezit de hoogere Wijsheid, die stabiel troont boven de wisselingen, die meer is dan intellectueel weten en waarin het Eeuwige vervat is. ${ }^{36}$

Jacob van Rees' leven werd op vergelijkbare wijze als dat van Ortt beschreven. Zijn strijd zou hebben bestaan uit het trotseren van de publieke opinie en de gangbare cultuur onder medici en, niet te vergeten, de tien dagen die hij in hechtenis doorbracht vanwege de ondertekening van het Dienstweigeraarsmanifest. Van Rees' overwinning van twijfel en chaos werd getypeerd als het 'aan den kinderkens gelijk' zijn:

'Welke een fijne geest, zeldzaam samenstel van hooge eruditie, grooten eenvoud, volstrekte zuiverheid en warm idealisme (...) En wat een durf om, in strijd met alle conventie, in alle omstandigheden zichzelf te geven, zooals hij was. (...hij heeft...) vele anderen gesterkt. Wie heeft, als hij, het beste van zijn jeugd zoo levend gehouden, heel het lange moeilijke leven door?'37

Ook Marie Jungius werd tegelijkertijd als kinderlijk en wetenschappelijk gekenschetst. ${ }^{38}$ Toch is er een opvallend verschil tussen de manier waarop over het leven van Jungius werd geschreven en de wijze waarop het leven van Ortt en Van Rees werd getypeerd. Bij de laatstgenoemden werd het accent gelegd op de stabiliteit van hun evenwichtige geestesgesteldheid. De 'zielerust' van de mannelijke anti-vivisectionisten werd voorgesteld als een gesteldheid die door een persoonlijke strijd verworven was en daarom als onverwoestbaar.

De evenwichtige staat van Jungius werd daarentegen voorgesteld als een gesteldheid die, aangezien zij eens in crisis had verkeerd, op ieder moment door allerlei krachten doorbroken en aangetast kon worden. Bovendien werd Jungius gezien als iemand die tenauwernood aan een ellendig lot was ontsnapt, niet als iemand die zich eraan had ontworsteld. In de Hollandsche Revue werd bijvoorbeeld geschreven dat Jungius' talent en belangstelling voor het exacte, voor de positieve vakken, haar geluk en de redding voor haar zieleleven waren geweest. De natuurkunde had haar behoed voor een te grote overgave aan religiositeit en gevoel en zou haar bewaard hebben voor ontaarding in 'afstotelijke vrouwelijke sentimentaliteit, ziekelijke weekheid en onpraktische huilerigheid' 39

Eens, zo wordt in het artikel vermeld, had Jungius in een dergelijke 'roezemoes van kinderlijke overgevoeligheid, vrouwelijke impulsiviteit, en onpraktische boosheid'verkeerd. Een spoor van dit onevenwichtig verleden was volgens de Hollandsche Revue terug te vinden in de aanhef van een harer gedichtjes ${ }^{40}$ :

'Een roer- en zeilloos wrak

zoo dreef ik rond

ik dwaalde en zocht

of ik geen ankergrond

geen strand kon vinden

geschut voor winden

vertwijfeling riep en strekte de armen uit

klagend met groot geluid

maar alles sliep-

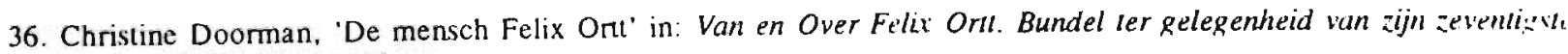
verjaardag (1936) 10-11, aldaar 11

37. Arriēns, Felix Orll, voorrede.

38. In 1900 werd in de Hollandsche Revwe' gesproken van een sterke vrouw, een activiste een 'wiskundige kıp' dic honoris causa tot ingenieur kon worden uitgeroepen.

39. Onbekend (mogelijk Netscher), 'Karakterschets', Hollandsche Revue (1900) 827.

40. Ibidem, 828 
Gelukkig, zo stelt de Hollandsche Revue ${ }^{41}$, had het 'gevaarlijk wrak' van Jungius' gevoel een anker gevonden in de wetenschap van anderen. In haar werk werden niet de namen van profeten en apostelen, maar vooral die van beroemde geleerden als Darwin, Mayer, Dow en Keppler aangehaald.

Alleen dit wetenschappelijk gefundeerde werk en niet Jungius' emotionele poëzie verdiende daarom de aandacht. Haar lyrische gedichten lieten teveel van haar onevenwichtige periode zien en hadden om die reden volgens de Hollandsche Revue beter nooit geschreven kunnen worden. De sprookjes van Jungius konden in het desbetreffende commentaar nog wel genade vinden omdat Jungius zich daar in ieder geval een 'ziel in evenwicht tussen Voelen en Weten' toonde.

In Leven en Werken wordt Marie Jungius anders gekenschetst. Waar in de Hollandsche Revue slechts gezocht werd naar en waardering werd uitgesproken voor de strijdbare, positivistische zijde van Jungius, probeert de schrijfster van dit artikel, Ida Heijermans, aan te tonen dat Jungius uiteindelijk tenonder was gegaan aan de 'desavouering' van haar gevoel. ${ }^{42}$ Jungius, de 'profetes' en navolgster van Jeanne d'Arc zou pleitbezorgster van een radicaal 'onnatuurlijk', tot wegsterven gedoemd feminisme zijn geweest. ${ }^{43}$ Door haar strijd tegen de andere sekse zou zij haar gevoelige vrouwelijke natuur hebben verloochend. Dat zij haar blonde haar afknipte was volgens de schrijfster bijvoorbeeld een miskenning van haar diepste wezen: het zijn van een liefhebbende vrouw. ${ }^{44}$

Deze essentie van Jungius' vrouwelijkheid meende Heijermans juist in de door de Hollandsche Revue verworpen poëzie te vinden, niet in haar sprookjes. Deze lijkt Heijermans te pretentieus te vinden, meer een mantel waarin zij zich in het openbare leven hulde dan een neerslag van het diepste wezen van de schrijfster. Jungius gedichten waren dat wel:

'Zij is er niet meer de strijdster, die zocht en streefde naar kracht. Zij is er de jonge vrouw, die liefde en sympathie verlangt en jubelt als zij die vindt. ${ }^{.45}$

Heijermans makkte uit de verzen op dat Jungius alleen gelukkig kon zijn 'in liefde en sympathie in vereering voor een ander'.46 Maar zij had haar geluk gezocht op een plaats waar het niet te vinden was, in zware arbeid en maatschappelijke strijd. Zo was Jungius uiteindelijk door deze zelf gekozen confrontatie met de harde wereld op fatale wijze 'gewond geraakt'. ${ }^{77}$ De eerste regels van Jungius' gedicht De sympathie konden volgens Heijermans dan ook als de zwanezang van de strijdster-dichteres worden beschouwd:

'O stil diephlauwe nacht leg zacht uw liefde

om de gewonde teere bloem, [...]'

41. 'Karakterschets', 825

42. Iua Heijermans, 'Marie Jungius' in: Leven en Werken (1916) 46. Henriette Goudsmit meende op haar beurt dat Jungius ten onder was gegaan aan 'de onevenredigheid tusschen kunnen en willen, en een taak die haar lichamelijke en geestelijke krachten te hoven ging!'.

43. Ibidem.

44. Ida Heijennans, 'Jungius', 46.

45. Ibidem. 51 .

46. Ibidem.

47. De verschillende commentatoren refereren aan de volgende werken van Marie Jungius: Vivisectie in Nederland (Den Haag 1895). Een wourd over de voorgenume'n Nationale Tentoonstelling van Vrouwenarbeid (Den Haag 1897), het reeds genoumde: De vivisectie is een kwilad en moel daarom uit de samenleving verdwijnen ('s-Gravenhage 1898), De Nederlandsche Kinderhond en de eenheid van alle humanitaire sireven. Toespraak op hel congres voor 'maatschappelijk werk' van de Nationale' Tenlomstelling visn Vrow'tenarheid (Amsterdam 1899). Verzen (2.p. 1899). Sprookjes van Leven (L.p. 1899), Over de unbegrensdheid van ons meegevoel. Rede uilgesproken te Rotlerdam, 's-Gravenhage en Nijmegen
(Soest 1900). 
Zowel in de beschouwing in de Hollandsche Revue, als ook door Heijermans wordt juist de problematische zijde van het door Jungius gevonden evenwicht tussen wetenschap en geloof, voelen en weten, beklemtoond. In beide publicaties valt Marie Jungius uiteen in een goed, ordelijk en wetenschappelijk persoon en een onberekenbare, gevaarlijke vrouw. In de presentatie van haar openbare leven wordt zij als vrouw als het ware gefragmenteerd. Heijermans laat Jungius' vrouwelijkheid door het openbare leven in stukken slaan en op jammerlijke wijze in de verdrukking komen. Waar in de Hollandsche Revue Jungius' evenwicht met de ondergang juist door haar vrouwelijkheid wordt bedreigd, denkt Heijermans dat eerder het gebrek aan ruimte voor de door haar eveneens met vrouwelijkheid geassocieerde fantasie en gevoel de oorzaak van Jungius ondergang is geweest. Jungius wordt dus in tweeën gesplitst, in een goed deel en een gevaarlijk destructief deel. Ook bij Heijermans is uiteindelijk de emotionele zijde, de verbeelding en de fantasie van Jungius gevaarlijk, al wordt bij haar juist de inperking ervan als schadelijk aangeduid. ${ }^{48}$

Ortt en Van Rees blijven in tegenstelling tot Jungius 'heel' wanneer er over hen wordt geschreven. Kennelijk gaat het hier om een verschil tussen de representatie van mannelijke en vrouwelijke helden of leiders. Waarom zou anders alleen Jungius worden gesplitst? Ortt en zij leken toch in zoveel opzichten op frappante wijze -zowel wat betreft levensloop als wat betreft anti-vivisectionisme- op elkaar? Waar Jungius zich Jeanne d'Arc en Christus tot voorbeeld stelde, volgde Ortt Christus en Tolstoj. Alletwee hadden zij een streng protestantse achtergrond. Waar Jungius volgens velen honoris causa tot ingenieur diende te worden uitgeroepen, was Ortt civiel ingenieur. Beiden hadden een grote belangstelling voor wiskunde. Beiden schreven proza en poëzie.

Terwijl Jungius haar carrière als onderwijzeres opgaf om zich aan het humanitair-idealisme te wijden $^{49}$, deed Ortt hetzelfde met zijn loopbaan bij Rijkswaterstaat. Hij zou zich in zijn humanitaire leven uiteindelijk als onderwijzer ontpoppen. Zowel Jungius als Ortt noemden zich feminist en traden in dienst van Van der Hucht-Kerkhoven. Ook de wereldbeschouwing van Jungius en Ortt vertoont op veel punten een grote overeenkomst. De zoektocht naar evenwicht, de eenheid van weten en geloven, voelen en denken, de verhouding tussen strijd en liefde alsmede de nadruk op het brengen van offers stonden erin centraal.

Niet alleen Ortt, ook Jungius probeerde de vivisectie te bestrijden door vooral de medische wetenschappers en vivisectoren zelf aan het woord te laten. Ook zij confronteerde haar publiek in haar geschriften met citaten uit medisch-wetenschappelijke tijdschriften. Ortts claim dat deze methode zijn eigen vinding was, is niet juist. Jungius en hij hebben op hetzelfde moment voor een dergelijke methode gekozen. Eerstgenoemde publiceerde zelfs nog vóór Ortt het eerste volgens deze methode vervaardigde overzicht van vivisectie in Nederland. Oıtt heeft dit werk uiteindelijk voortgezet, maar Jungius was wat dit betreft in Nederland een pionier.

Dat was zij, zoals gezegd, ook met haar lezing voor de Nationale Tentoonstelling van Vrouwenarbeid, het eerste openbare optreden van de bond. En daarmee wordt meteen een kwaliteit van Jungius naar voren gehaald die Ortt niet bezat. Waar eerstgenoemde tijdens een lezing haar gehoor kon boeien, meevoeren en opwekken tot daden, was Ortt niet goed als spreker in het openbaar. Lezingen waren onder zijn leiderschap geen belangrijk middel om leden voor de NBBV te werven. Wanneer ze plaatsvonden was dit slechts voor eigen, reeds overtuigd publiek.

\footnotetext{
48. Jungius zelf hield zich tijdens haar leven met deze problematiek van fragmentatie bezig. Dit blijkt wel uit haar in het eerste hoofdstuk aangehaalde en door Groshans gememoreerde uitspraak dat de Nieuwe Vrouw er naar moest streven een geheel mens te worden. Zij was dat kennelijk voorheen niet.

49. Jungius was bestuurslid van de NBBV. $Z_{i j}$ was tevens, zoals Myriam. Everard heeft laten zien, lid van hel oprichtingsbureau van de NVB. werkte mee aan het in 1869 opgerichte Androcles. Was van 1901-1908 directrice van het National Bureau voor Vrouwenarbeid. Ze was vice-presidente van de Commissie van voorbereiding van de Nationale Tentoonstellling van Vrouwenarbeid. Jungius was betrokken bij de oprichting van de Nationale Vrouwenraad en Ridder in de Orde van Oranje Nassau.
} 
Alleen Jungius durfde het aan om niet alleen voor eigen parochie, maar ook voor nog niet bekeerd publiek te preken.

Hoe het ook zij, ondanks de vele overeenkomsten tussen Ortt en Jungius, gebeurt er met het levensverhaal van laatstgenoemde uiteindelijk dus iets anders. Zij blijft een gevaarlijk onberekenbaar deel houden, ondanks haar wetenschappelijkheid. En aangezien er hier gesuggereerd wordt dat dit met haar vrouw zijn te maken heef, is het intrigerend dat Ortt de strijd tegen vivisectie op eenzelfde wijze benaderde, namelijk door deze eveneens op te delen in een betrouwbaar, wetenschappelijk deel en een grillig en emotioneel deel. Dat emotionaliteit deel uitmaakte van de nieuwe openbaarheid in de Nederlandse politiek zoals De Haan en Te Velde stellen, betekende dus niet automatisch dat vrouwen gemakkelijker tot die openbaarheid werden toegelaten. Waar gevoel voor mannen als een kwaliteit werd beschouwd, werd het wanneer vrouwen gevoel toonden als een zwaktebod en een gevaar gezien.

\section{Besluit}

In Op het breukvlak van twee eeuwen stelt Jan Romein dat het kenmerkende van veel kleine geloven was dat zij het geloven door weten wilden vervangen. Als voorbeeld noemt hij het spiritisme dat zich met het occulte bezighield en zich daarbij beriep op wetenschappelijk onderzoek. ${ }^{\text {so }}$ Het anti-vivisectionisme heeft zeker ook zo'n wetenschappelijk georiënteerde, positieve zijde. Al was het maar omdat een aantal toonaangevende anti-vivisectionisten, Roorda van Eysinga, Ortt en later Pieter Pijl een meer dan oppervlakkige belangstelling hadden voor het spiritisme. Eerstgenoemde was zelfs van mening dat het anti-vivisectionisme bij uitstek een beweging was om, zoals hij het aan de literator H.J Schimmel schreef, te laten zien wat nu precies het spiritisme en action inhield, namelijk de strijd tegen atheïsme en materialisme en voor zedelijkheid, het geloof in het bovenzinnelijke en idealisme. Het ging volgens Roorda om een strijd tussen goed en kwaad, tussen het dierlijke en het zedelijke in de mens die al vanaf de oudheid werd gevoerd.

Meer nog dan Roorda hechtte Ortt behalve aan deze ethische zijde van het spiritisme veel waarde aan de wetenschappelijke kant van het spiritisme. Voor hem was het essentieel dat de spiritistische experimenten door gerenommeerde wetenschappers werden uitgevoerd en opgetekend. Dit was ook de reden waarom hij het spiritisme niet en de theosofie uiteindelijk wel verwierp. De laatste levensbeschouwing trachtte eveneens om wetenschap en geloof met elkaar te verenigen, maar maakte daarbij veel minder gebruik van het experiment. Dat bevredigde Ortt niet. En dit is interessant in het licht van French' visie dat de anti-vivisectionisten anti-wetenschappelijk waren. Voor Ortt gaat dat duidelijk niet op. Hij was niet tegen de wetenschap, niet tegen het experiment; hij was alleen tegen experimenten op levende dieren. Deze stonden voor hem gelijk aan destructie, chaos en uiteindelijk aan het passieve kwaad dat de ontwikkeling van de mensheid belemmerde.

Dat een levend wezen tot object werd gereduceerd, dat het pijn werd aangedaan en dat het experiment werd verricht zonder dat de vivisector zich met het proefdier identificeerde, maakten de vivisectie voor hem tot een uitwas van de wetenschap. Medisch-wetenschappelijke proeven op levende dieren stonden voor hem symbool voor een wetenschap die haar maatschappelijke verantwoordelijkheid als werkzaam deel van de Al-Eenheid, niet wenste te aanvaarden. Dat hij het vivisectie-vraagstuk op deze wijze uiteindelijk uitdrukkelijk als een ethisch vraagstuk benaderde, kan niet zonder meer, zoals French met betrekking tot het Engelse anti-vivisectionisme suggereert, worden afgedaan als een handige manier om ingewikkelde medische discussies te vermijden. Indien gekeken wordt naar de wijze waarop Ortt medische kennis vergaarde, kan zeker niet gezegd worden dat hij een discussie over medische zaken uit de weg wilde gaan. Een morele discussie was volgens hem minstens zo ingewikkeld. Niet voor niets stelde hij in zijn cursus

50. Romein, Breukvlak. Zie ook: A.M. Lauret, 'Tafeitje dans je ?’. Zeeuws Tijdschrifi 4 (1978) 118-123. Van de7.lfde auteur: 'Van Desimetrie via hypnose tol psychotherapie', Zeeuws Tijdschrift 6 (1977) 171-179. 
strenge richtlijnen op voor hen die een dergelijk debat wilden voeren. Op deze wijze maakte hij het anti-vivisectionisme uiteindelijk toch, meer dan dit voorheen het geval was, tot een exclusieve levenshouding die slechts door enkelen op een juiste wijze kon worden uitgedragen.

Maar probeerde Ortt aldoende geloven door weten te vervangen? In zekere zin wel. Hij droeg, zoals bleek, bewijzen aan voor het bestaan van een Al-macht, van geesten en andere bovenzinnelijke zaken. Illustratief is in dit opzicht niet alleen zijn Inleiding tot het pneumat-energetisch monisme, maar tevens de anekdote dat Ortt eens een dominee uit het Gooi op een papiertje heeft voorgerekend dat de Heilige Geest bestond. Maar of hij ook in zijn strijd tegen vivisectie het geloven geheel door weten probeerde te vervangen is maar de vraag. Op het eerste gezicht lijkt dit wel op te gaan omdat hij een wetenschappelijke bestrijding van vivisectie voorstond. Aan de andere kant mag daarbij niet uit het oog worden verloren dat Ortt zich duidelijk presenteerde als een navolger van Christus. De figuur van Christus die hem voor ogen stond werd door hem op geen enkele wijze wetenschappelijk benaderd. Dit voorbeeld stond voor hem vast en bleef naast de wetenschappelijke blik op het vraagstuk een essentieel deel van zijn anti-vivisectionisme uitmaken. De wijze waarop hij zich de figuur van Christus voorstelde stond voor hem niet gelijk aan de verbeelding die hij probeerde in te tomen en te bestrijden. 


\section{De hel in kaart gebracht Anti-vivisectionisten, hun tegenstanders en het parlement}

De meeste anti-vivisectionisten beschouwden de vivisectie als deel van een keten van verschillende soorten maatschappelijk kwaad. Al dan niet met behulp van fictie koppelden zij het vraagstuk aan de sociale kwestie, drankzucht en andere vormen van onmatigheid. Naar gelang van de persoonlijke preoccupaties van de anti-vivisectionist, werd een van deze problemen meer belicht. Voor alle anti-vivisectionisten geldt dat zij van mening waren dat medisch-wetenschappelijke proeven op levende dieren onaanvaardbaar waren vanwege de pijn en het lijden dat de dieren werd aangedaan. In hun werelbeschouwing stond de angst voor de onbeheersbare zijde van de mens centraal. De medische wetenschap werd gezien als een kracht door middel waarvan de donkere kant van de mensheid zowel kon worden opgewekt als bestreden.

Anders dan in de historiografie van het anti-vivisectionisme wordt beweerd, gaat dit alles voor een belangrijk deel ook op voor de medisch-wetenschappelijke voorstanders van vivisectie. Hoewel zij van mening waren dat de vivisectie aanvaardbaar was omdat deze onderzoeksmethode uiteindelijk zou leiden tot een vermindering van de pijn en het lijden van mensen vonden zij tegelijkertijd dat de wetenschap een kracht was die zowel ten goede als ten kwade kon worden aangewend. Naar hun mening was de wetenschap niet geheel beheersbaar. De parlementariërs waren eenzelfde mening toegedaan. Hun voorstelling van de vivisectie en de wetenschap verschilde, ongeacht of zij zich nu voor of tegen proeven op levende dieren uitspraken, nauwelijks van het door de anti-vivisectionisten geschetste beeld. Ook indien de voor- en tegenstanders van vivisectie als representanten van politieke bewegingen worden benaderd, blijkt dat hun politieke stijl veel overeenkomstiger is dan men op grond van de door French gehanteerde dichotomie en het winnaars- en verliezers perspectief van de historiografie zou denken. Om dit duidelijk te maken zal in dit hoofdstuk aandacht worden besteed aan de wijze waarop het vraagstuk rond de eeuwwisseling buiten de anti-vivisectie-beweging, te weten door de tegenstanders van vivisectie en in het parlement, werd besproken, beoordeeld en verbeeld.

\section{Die Folterkammern der Wissenschaft}

In 1879 werd Die Folterkammern der Wissenschaft gepubliceerd. De brochure, uitgegeven met een opmerkelijke fel gele kaft, bestaat uit een groot aantal citaten uit medisch-wetenschappelijke tijdschriften en elf pentekeningen. De afbeeldingen tonen ondermeer jongelieden waarvan er een aantal pijp of sigaar roken. Gefascineerd slaan zij de verrichtingen gade van een wat oudere man, hun leermeester. Deze bewerkt een op een tafel vastgebonden of anderszins gefixeerd dier met een arsenaal aan messen, tangen, zaagjes en priemen. Geen van de mannen uit het publiek lijkt zich om het gekwelde dier te bekommeren. Dat wordt althans gesuggereerd door het bordje: 'Kein rauchen erlaubt da es die Thiere belästigen könnte!'dat aan de wand van de folterkamer hangt, en door de glimlach die om de mond van een aantal aanwezigen speelt. De pijn en wanhoop van het dier lijken hun niet te deren maar hun zelfs te bekoren.

De combinatie van citaten en beelden in Die Folterkammern der Wissenschaft maakte indruk Anders dan Grysanovski boekte Von Weber met zijn publicatie groot succes. Een meerderheid van de Dresdener Dierenbeschermingsbeweging waarvan hij vice-president was, schaarde zich naar aanleiding van dit geschrift achter zijn denkbeelden en verklaarde zich anti-vivisectionist. Belangrijker nog was het, zo stellen Tröhler en Maehle terecht, dat Die Folterkammern der Wissenschaft de aandacht trok van Richard Wagner en diens echtgenote. Zij nodigden Von Weber na een uitgebreide correspondentie uit in Bayreuth.

De ontmoeting van de anti-vivisectionist en de componist resulteerde in een publicatie van een brief van Von Weber in de Bayreuther Blätter. Tweeduizend door Wagner gefinancierde 
overdrukjes van de tekst werden door de Dresdener dierenbescherming gedistribueerd. En daarbij bleef het niet, zoals uit het volgende overzicht van Tröhler en Maehle blijkt:

'In October 1879, Wagner wrote about the vivisection question to his Royal friend, King

Louis II of Bavaria. Later that. month Von Weber informed him that the conservative party might support the movement. From then on Wagner, his family and, after his death in 1883, his circle, publicly supported the 'cause' for decades to come using the Bayreuther Blätter.'2

Die Folterkammern der Wissenschaft zou uiteindelijk ook het debat over vivisectie in Nederland beïnvloeden. Het werk van de anti-vivisectionisten rond de eeuwwisseling sloot althans nauw aan bij de visie die in dit geschrift voor het voetlicht werd gebracht. Bepaalde trekken van de gestalte van de vivisectie in Von Webers brochures, de jongemannen, de vivisector, de harteloze baas die zijn hond verkoopt en, niet te vergeten, de gepsychologiseerde en geïndividualiseerde dieren, zijn ook terug te vinden in de rond 1890 uitgegeven anti-vivisectie-brochures van de NBBV. Ook in deze geschriften werd gesuggereerd dat het aanschouwen van vivisectie een slechte invloed had op studenten, werd een relatie gelegd tussen de wreedheid van de vivisectoren en de opvattingen van de lagere klassen.

Die Folterkammern der Wissenschaft was echter meer dan een inspiratiebron voor het georganiseerd verzet tegen vivisectie in Nederland. De vertaling van de brochure die de dierenbescherming in 1880 had uitgebracht en aan alle kamerleden verzonden, zou tevens een rol spelen in de discussie over vivisectie zoals deze in het Nederlandse parlement werd gevoerd. In de jaren 1880-1883 werd De folterkamers der wetenschap, zoals de Nederlandse titel luidde, zelfs expliciet in de kamerdebatten genoemd, telkens in verband met de totstandkoming van het Wetboek van Strafrecht.

De vraag die in de beraadslagingen over het Wetboek van strafrecht een rol speelde, was of de vivisectie strafbaar was onder artikel 254 of artikel 455, waarin respectievelijk de mishandeling van een dier en het nodeloos pijnlijk belasten of vervoeren van dieren, strafbaar werd gesteld. In beide artikelen werd dierenmishandeling onder de misdaden tegen de zeden geplaatst. Hieraan lag de gedachte ten grondslag dat het aanschouwen van dierenmishandeling een slechte invloed had op de mens en zou leiden tot misdaden tussen mensen onderling. ${ }^{3}$

De liberale minister Modderman wilde de artikelen echter niet alleen voor dierenmishandeling in het openbaar laten gelden, maar ook voor het maltraiteren van dieren dat niet direct voor de samenleving zichtbaar was. Dit stuitte onder meer op tegenstand van het katholieke kamerlid C.J.A. Heydenrijck die meende dat door bestraffing van niet-openbare dierenmishandeling, het dier een zeker recht werd toegekend. Dit was niet alleen voor hem onaanvaardbaar, maar ook voor de liberale leden van de Commissie van Rapporteurs. Toch werd het wetsvoorstel van minister Modderman met één stem meerderheid aangenomen. De regering stelde voorop dat de artikelen niet bedoeld waren om de vivisectie onmogelijk te maken. In de Memorie van Toelichting werd gesteld dat bij de mishandeling van het dier sprake moest zijn van een opzettelijk wrede gerichtheid op het teweegbrengen van leed: 'Wanneer de smart van het dier niet doel maar middel is voor een rationeel doel, dan is het artikel niet van toepassing. De physiologische proeven, het snijden van dieren en in het algemeen elke handeling, die een rechtmatige geoorloofde oorzaak heeft, waarbij het toegebragt leed slechts middel is, valt buiten het voorschrift. ${ }^{\circ 4}$ In feite werd de vivisectie dus buiten de artikelen gehouden. Artikel 254 kon volgens de regering zonodig wel gebruikt worden tegen mogelijke excessen van vivisectie.

2. Maehle en Tröhler, 'Germany', 61

3. Tot 1886, bij de uitgave van het Welboek van Strafregt werden dieren, volgens het geldend recht gelijkgesteld aan roerende goederen. Er waren alleen verordeningen op gemeentelijk niveau ter regulering van het gedrag van de mens ten opzichte van dieren en een landelijke hondsdotheidswel. Hicrin werd gesteld dat katten en honden niet mishandeld mochten worden, umdat men dan door bijvoorbeeld een beet zelf besmet kon raken.

4. Zie Dyserinck, Vivisectie. 6-7. Handelingen der Staten Generaal II 1880-1881 3 november II 232-237. aldaar 236. 
Over de vraag of er dergelijk excessen bestonden kon geen kamerlid een zinnige uitspraak doen. In de loop van de beraadslagingen werd steeds duidelijker dat niemand ook maar iets afwist van de aard en omvang van vivisectie in Nederland. Men beschikte slechts over een beperkt aantal bronnen. De belangrijkste was Die Folterkammern der Wissenschaft'. De eerste die in het Nederlandse parlement aan Von Webers brochure refereerde, was de anti-revolutionair A.F. de Savornin Lohman. Hij was lid van de Commissie der Rapporteurs die net een amendement had ingediend om de artikelen 254 en 455 af te zwakken. Aanvankelijk was De Savornin Lohman het daar mee eens geweest. Maar zo stelde hij aan het begin van de beraadslagingen, het 'boekje van Von Weber' had hem 'de lust ontnomen tegen de bepaling door de regering voorgesteld, op te komen'. De daarin beschreven vivisecties werden niet in het openbaar verricht, maar waren dermate schokkend dat hij weinig meer voelde voor een beperking van de voorgestelde artikelen. En meer nog, De folterkamers der wetenschap had hem eraan doen twijfelen of het wel juist was om de wetten der natuur te onderzoeken indien dit alleen mogelijk was door middel van martelingen. ${ }^{6}$

De Savornin Lohman verklaarde dat hij er door Von Weber van overtuigd was geraakt dat hij, indien hij ziek werd, niet genezen wilde worden wanneer dit betekende dat zijn geneesheer daarvoor uren en dagen lang de beschreven folteringen moest verrichten. Von Webers werk had hem in ieder geval duidelijk gemaakt dat hetgeen in Duitsland geschiedde dermate schandelijk en barbaars was, dat de staat er hard tegen op moest treden. De martelingen waren het soort zonde dat te vuur en te zwaard bestreden diende te worden, zoals eens de onnatuurlijke ontucht afkomstig van heidense volken uitgeroeid had moeten worden. Dieren moesten tegen de wetenschap beschermd worden opdat de studerende kinderen niet tot barbaren werden gemaakt.

Dit alles betekende overigens niet dat De Savornin Lohman zich tegen de wetenschap of zelfs de vivisectie keerde. Hij geloofde niet dat Nederlandse wetenschappers zich op vergelijkbare wijze gedroegen. Maar daar Nederlanders nog al eens geneigd waren iets over te nemen van hun buurland zou het zeker geen kwaad kunnen indien bij monde van het artikel duidelijk gesteld zou worden:

'Indien gij dezelfde noodelooze proeven neemt, waardoor gij dieren onnodig martelt, dan is dat mishandeling en zulks dulden wij niet."7

Heydenrijck was het daar niet mee eens en verklaarde dat De Savornin Lohman het belangrijke beginsel van de openbaarheid van dierenmishandeling alleen maar liet varen omdat hij zich had laten imponeren door lezing van de in 'hooggekleurden omslag' aangeboden brochure van Von Weber.

De Savornin Lohman was evenwel niet het enige kamerlid dat naar De folterkamers der wetenschap verwees. Afgevaardigde F. de Casembroot stelde bijvoorbeeld dat Von Webers brochure hem tot het inzicht had laten komen dat de Duitse voorstanders van vivisectie doctrinairen waren. Wat dit inhield had Nederland naar zijn mening aan den lijve ondervonden:

'Hebben wij in de geschiedenis van ons lieve Vaderland ook geen doctrinairen gehad? Hebben wij niet gezien dat Israelieten, Protestanten en Katholieken elkaar de grootste folteringen deden ondergaan, elkaar levendig te verbranden. Men dacht den Heere God te dienen, door menschen die niet precies hetzelfde geloof hadden levendig te verbranden. De doctrinairen der wetenschap hebben daarvoor zulk eene groote liefde, dat alle mogelijke gevoel in hun binnenste wordt gestikt. De wetenschap eischt, zeggen zij, dat wij moeten weten, in hoeveel seconden een dier doodbloedt; wanneer het bijvoorbeeld een poot wordt afgesneden of een oug

5. Ernst von Weber, Die Folterkammem der Wissenschaft. Eine Sammlung von Tatsachen für das Laienpublikum (Berlijn en Leipzig 1879).

6. Handelingen (1880-81) 3 november II 232-237. De Savornin Lohman was lid van de NBBV.

7. Ibidem, 232. 
wordt uitgestoken, voor hen houdt alle gevoel op, is alle gevoel belachelijk, want de mensch en de wetenschap worden gediend.'8

De Savornin Lohman wilde een aparte wettelijke regulering van vivisectie. Hij stemde daarom tegen het amendement.

Dat deed ook het lid van de Commissie van Rapporteurs H.A.A. des Amorie van der Hoeven en wederom werd aan De folterkamers der wetenschap gerefereerd. Lohman was volgens de spreker te ver gegaan toen hij beweerde dat hij de 'zoo vreeselijke martelingen in het door hem bedoelde werkje' niet wilde toelaten' zelfs indien daardoor belangrijke wetenschappelijke resultaten zouden worden verkregen. Ook was hij te ver gegaan door te stellen dat hij liever aan een kwaal zou blijven lijden of zelfs zou willen sterven als dergelijke proeven noodzakelijk waren voor zijn genezing. Des Amorie van der Hoeven meende dat martelingen wel degelijk geoorloofd waren mits deze niet door onbevoegden werden uitgevoerd. Een wet als de Engelse Cruelty to Animals Act zou dat kunnen voorkomen. ${ }^{?}$

In 1883 liet Des Amorie van der Hoeven wederom van zich horen bij de Algemeene Beraadslaging over hoofdstuk vier van het Wetboek van Strafregt. ${ }^{10}$ Hij sprak nogmaals de hoop uit dat de minister De folterkamers der wetenschap niet terzijde zou leggen."

De afgevaardigde C.A. Rombach stelde daarop dat een uitbreiding van artikel 254 alleen gerechtvaardigd was indien bewezen werd dat de door Von Weber beschreven martelingen ook in Nederland plaatsvonden:

'Hebben bij ons zulke vivisectie-misgrepen plaats gehad, men wijze ze mij aan, ik ken ze niet. ${ }^{12}$

En daarmee legde dit kamerlid de vinger op de zere plek. Er was nog altijd nauwelijks iets bekend over vivisectie in Nederland. De brochure van Von Weber handelde alleen over in het buitenland verrichte proeven. Voor het advies dat de minister in 1883 aan de afdeling natuurkunde van de KNAW had gevraagd gold dat niet, maar het rapport speelde in de beraadslagingen nauwelijks een rol. De brochure van Von Weber maakte bij een aantal kamerleden een veel grotere indruk. Wellicht hangt dit samen met het feit dat het KNAW-rapport de vivisectie zelf niet zichtbaar maakte. Het stuk voorzag niet in gegevens over de aard en omvang van vivisectie in Nederland, maar stelde daarentegen vooral de common sense van de medische wetenschappers centraal. Dit maakte dat de vivisectie als praktijk, als het ware gedragen door de beelden die Von Weber opriep, haar geheimzinnige en dreigende gedaante behield. De folterkamers der wetenschap prikkelde de verbeelding en maakte juist de bedaarde redelijkheid van de medische wetenschappers verdacht. In anti-revolutionaire kringen leek dit alles het sterkst te leven. Men vroeg zich af of vivisectie niet een teken was dat de wetenschap een te prominente plaats in de samenleving innam, of dat haar soevereiniteit niet gevaarlijker was dan voorheen werd aangenomen.

Tegenover deze groeiende verontrusting stond evenwel dat de vivisectie vijftien jaar lang niet in de kamer werd besproken. Pas in de jaren na de officiële goedkeuring van de statuten van de NBBV in 1897 zou het onderwerp wederom op de agenda verschijnen. Andermaal werd het parlement geconfronteerd met het feit dat nog altijd nauwelijks iets over vivisectie in Nederland bekend was en opnieuw waren het met name anti-revolutionairen die de discussie een richting gaven en om opheldering vroegen.

\footnotetext{
8. Ibidem, 33.

9. Ibidem. 234.

10. Handelingen II (1882-1883) 7 december, 590.

11. Handelingen II 1882-1883, 590.

12 Handelingen II (1882-1883) $7 \mathrm{dec}, 593$.
} 


\section{Vivisectie en de soevereine wetenschap}

'Mijnheer de Voorzitter ! Ik meen werkelijk dan ik van een kentering in den gedachtengang mag spreken, als ik met aandacht lees de Ministeriële beschikking van 3 sept. 1903, zooals ons die in 5 artikelen, in de Memorie van Antwoord is medegedeeld. Tot op heden verkeerden we aangaande dit onderwerp, naar het mij voorkomt, in Regeerings- en in wetgevende kringen, onder een zekere hypnose, te ernstiger en te intenser van vorm, aangezien hier de wetenschap zelf, hypnotiste was. [...] En in deze hypnotische clairvoyance, werd de zaak der vivisectie [...] steeds bezien, zoodat de tegenstanders dier leer, in hun zoo dringende betoogen, zoo weinig gehoor vonden. Maar, Mijnheer de Voorzitter, voor den machtig helderen geest van dezen Minister bleek eindelijk toch die bekoring te zwak: de ban is gebroken, het volle licht brak door [...].'13

Deze enthousiaste woorden sprak het anti-revolutionaire kamerlid M.A. Brants (tevens zoöloog) naar aanleiding van een vijftal voorschriften die minister Abraham Kuyper bij ministeriële beschikking had vastgesteld. De voorschriften waren bedoeld als richtlijn voor proeven op levende dieren. Volgens de beschikking mochten vivisecties uitsluitend plaatshebben wanneer zij voor wetenschappelijk onderzoek of onderwijs onmisbaar waren en alleen uitgevoerd werden door hoogleraren, lectoren of docenten en, onder verantwoordelijkheid van een hoogleraar, door doctorandi, artsen en assistenten. De proeven dienden, indien mogelijk, op lagere diersoorten te worden verricht. Er moest in principe een verdoving worden gebruikt, tenzij de operatie door een hoogleraar of lector werd verricht en het wetenschappelijk doel zonder verdoving niet te bereiken was. Voorts stelde de minister dat de dieren onmiddellijk na de proefneming moesten worden afgemaakt, tenzij hen geen ernstig letsel was aangedaan en het zeker was dat zij geen pijn zouden lijden.

De richtlijnen waren opgesteld nadat er vragen waren gerezen naar aanleiding van het adres dat de NBBV bij monde van Hugo Nolthenius in 1902 had ingediend. Nolthenius had in het voor Ortt zo teleurstellende antwoord van minister H. Goeman Borgesius uit 1901 aanleiding gezien om een rekest te schrijven. Nolthenius legde hierin de nadruk op de in zijn ogen uitgebreide omvang van de vivisectie in Nederland. Proeven op levende dieren zouden niet uitsluitend worden verricht door hoogleraren of gepromoveerden aan de faculteiten der geneeskunde, wis- en natuurkunde en de veeartsenijschool, maar uitgevoerd worden ten behoeve van het lager, middelbaar en voorbereidend wetenschappelijk onderwijs. De vivisectie zou tevens bedreven worden door onwetenschappelijke lieden, zonder wetenschappelijk doel. Zij zou met 'noodelooze kwellingen' verricht worden. Dit alles was een ernstig vergrijp tegen de zeden dat evenals dierenmishandeling strafbaar moest worden gesteld. Nolthenius stelde, geheel in de lijn van het door Ortt zo verfoeide restrictionisme, voor om met een regulering te beginnen. Wel beklemtoonde hij dat het doel van de NBBV was de vivisectie totaal af te schaffen omdat het aanschouwen of verrichten van vivisectie verhardend zou werken. ${ }^{14}$

Kuyper speelde met zijn richtlijnen in op vrijwel alles wat in het rekest werd aangevoerd. Maar, zoals het kamerlid De Ridder reeds voor de formulering en bekendmaking van de voorschriften teleurgesteld opmerkte, de minister was niet van zins om wettelijke maatregelen te nemen. Het ging slechts om een administratief voorschrift en er zou geen rechtsgrond zijn om overtreding te vervolgen. Ook controle op de navolging ontbrak. Op dit aspect van Kuypers maatregelen richtte ook Brants zijn pijlen. Na zijn opmerking dat de hypnose door de minister doorbroken was vroeg hij zich af waarom Kuyper toch de soevereine rechten van de wetenschap om vivisectie uit te oefenen erkende. Was het niet beter geweest indien het wettelijk toegestaan

\section{Handelingen II (1903-1904) 12 dec. $864-866$, aldaar 865}

14. Handelingen II (1902-1903), 12 dec., 555-557: over de beraadshagingen van Kuyper over het adres van Nolthenius. Het adres is te vinden in: Verslag betreffende de verrichtingen van den Nederlandschen Bond tot bestrijding der Vivisectic over het 6e vereenigingsjaar 1902-1903'. Verslag van de zesde jaarvergadering van den NBBV (1903) 4-21. aldaar $7 \mathrm{ev}$. Zie ook: Dyserinck, Vivisectie, 28-31 en Ort. Ons Standpunt. De Ridder besprak het adres : Handelingen II (1902-1903), 12 dec., 555-557, aldaar 555 
zou worden om onder bepaalde voorwaarden proeven op levende dieren te verrichten? In ieder geval zou dan duidelijk zijn dat van een aan de wetenschap inherent recht om dieren te kwellen geen sprake was. ${ }^{15}$

Dit zou, aldus Brants, ook voor de wetenschap zelf een betere situatie zijn. Pathologen en fysiologen zouden beseffen dat het dier meer was dan een agglomeratie van cellen ten dienste van hun 'nieuwsgierig scalpel'. Bovendien -en dit was voor het eerst dat iemand dit op deze wijze inbracht- zou een wettelijke regulering van vivisectie dienen als broodnodige bescherming van de zwakken, de armen en de kleine man die met medici in aanraking kwamen. Zolang de vivisectie niet door de wet werd beperkt, zouden met name deze mensen zich onveilig voelen en zelfs daadwerkelijk gevaar lopen. Zo heschouwd was de vivisectie volgens Brants een 'schrijnende volksnood'. ${ }^{16}$

Het was immers bekend, zo veronderstelde de spreker, dat proeven op dieren voor het onderzoek naar sommige ziekten niet meer voldoende waren. Buitenlandse wetenschappers gingen ervan uit dat ook proeven op mensen noodzakelijk waren. Wat was er zo bijzonder aan de Nederlandse wetenschappers dat deze niet tot diezelfde conclusie zouden komen? Hadden zij niet dezelfde aspiraties en vragen als hun collega's in andere landen? Er mocht daarom eenvoudigweg niet lijdzaam afgewacht worden tot in Nederland hetzelfde zou geschieden als in Rusland waarover in Die Deutsche Medicinische Wochenschrift, Archiv für Gynäkologie en Archiv für Dermatologie und Syphilis het volgende werd geschreven:

'In verschillende klinieken in het buitenland werden allerlei besmettelijke ziekten ontelbare malen op menschen geeënt. Nu eens waren het kinderen, dan 'jonge meisjes', dan ouden van dagen, soms bijna stervenden, op wie geëxperimenteerd werd. Ja, de schrikkelijk onreine en geheele geslachten verontreinigende syphillis zoude geeënt zijn op kinderen en reine maagden enz.' 17

Het onderscheid tussen 'Menschen und Meerschweinschen' leek niet langer te bestaan. Iets dergelijks mocht de Nederlandse wetenschappers niet overkomen. En hoewel de afgevaardigde zich uiteindelijk niet kon indenken dat er op dit moment in Nederland misstanden waren aan te wijzen, meende hij dat een wettelijke regulering ook door medici verwelkomd zou worden. De wet zou als wegbereidster tot verhoging van het zedelijk bewustzijn van jongeren fungeren, zou de hoge aspiraties van wetenschappers versterken en de aloude roem van Nederlandse medici bevestigen. $^{18}$

Kuypers opvattingen over vivisectie waren, blijkens het antwoord aan Brants, niet eenduidig. Enerzijds ging hij uit van de soevereiniteit van de universiteit en de daar beoefende wetenschap. De wetenschap was volgens Kuyper evenals de andere 'soevereine kringen', het gezin, de staat en de natuur, in Gods schepping tot ontwikkeling gebracht en daarom uitgerust met een eigen bevoegdheids -en verantwoordelijksheids-structuur. Zich beroepend op die soevereiniteit in eigen kring, meende Kuyper dat de staat juist zoveel mogelijk de publieke voorwaarden moest scheppen voor de vrije ontplooiing van de wetenschap. De wetenschap moest op haar eigen terrein vrij zijn en een verbod of regulering van vivisectie zou inbreuk op dit recht maken. Tegen deze achtergrond is het begrijpelijk dat hij uitsluitend voorschriften uitvaardigde. ${ }^{19}$

Toch sloot Kuyper niet uit dat wetenschappers de vivisectie op een onjuiste wijze waardeerden. $\mathrm{Zij}$ waren immers, als iedereen, zondige stervelingen en liepen daarom het gevaar dat hun liefde voor de wereld werd getemperd. De wetenschap kon op deze wijze van haar object

\footnotetext{
15. Handelingen II (1902-1903) 559.

16. Handelingen II (1903-1904) 12 dec.. 871 .

17. Ibidem.

18. Ibidern.

19. Zie hierover: C. Augustijn e.a. (ed.) Abraham Kuyper: zijn volksdeel, zijn invloed (Delft 1987) Dick van Lente, Techniek en ideologie. Opvattingen over de maatschappelijke betekenis van technische vernieuwingen in Nederland 1850-1920 (Groningen 1988) 59.
} 
vervreemd raakten. Het inzicht in de samenhang van alle fenomenen zou dan verdwijnen en een algemene desintegratie van kennis plaatsvinden. De staat mocht daar-ook door het formuleren van een verbodswet- iets tegen doen en voorkomen dat andere kringen op negatieve wijze werden beïnvloed.

Maar hoezeer hij ook tegen vivisectie was, Kuyper maakte van deze uitweg geen gebruik. Dit lijkt- blijkens zijn ironische opmerkingen in de kamer-gedeeltelijk samen te hangen met zijn aversie tegen anti-vivisectionisten:

'Ik heb dikwijls de gelegenheid gehad met mannelijke en vrouwelijke apostelen van die richting te spreken en ik moet zeggen dat ik mij wel eens heb afgevraagd of het al te zeer zich bezighouden met de liefde voor de dieren langzamerhand het effect kan hebben dat men min of meer iets overneemt van de voorwerpen van zijn liefde. Ik zeg dit niet in het minst met het oog op de geachte afgevaardigde. Maar ik heb eens een dierenminnares omtrent dit onderwerp de vraag gedaan: Als gij nu eens alleen langs een water liept, waarin gij plotseling ontwaardet een kind en een kat, beiden in gevaar om te verdrinken, waarnaar zoudt gij dan het eerst grijpen om te redden? Waarop metterdaad geantwoord werd: ik zou toch nog aarzelen. Nu zal men toch toestemmen dat, wanneer ik dergelijke excessen bemerk, het toch niet op mijn weg ligt, althans niet als minister, daarmee mede te gaan. Ik wens ook in deze een gematigd en gezond standpunt in te nemen. ${ }^{20}$

Dit alles nam niet weg dat Kuyper, zoals hij zelf ook aan de kamer mededeelde, al sinds jaar en dag lid was van de NBBV. Zijn naam prijkte op dezelfde ledenlijst als die waar bijvoorbeeld ook een aantal prominente leden van de door hem zo zeer verfoeide Reinleven-beweging op te vinden waren. Vivisectie was voor hem niet zomaar een onderwerp, maar een praktijk waarvan de ontwikkelingen wel degelijk nauwlettend in de gaten moesten worden gehouden. Hij stond er dan ook op dat iedere afgevaardigde die weet had van Nederlandse excessen op het gebied van medisch-wetenschappelijke experimenten, hem deze met naam en toenaam zou noemen. Hetzij door middel van een 'onderhandsche meededeeling', hetzij tijdens een debat. Alleen op deze wijze konden misbruiken worden voorkomen. Een wet was daarvoor, zo meende hij, minder geschikt. In Engeland had de Cruelty to Animals Act naar Kuypers inzicht nauwelijks resultaat gehad. ${ }^{21}$

Bovendien zou het volgens Kuyper buitengewoon moeilijk zijn om ten behoeve van de formulering van een wet het object van de vivisectie vast te stellen, en aan te geven aan wie precies de bevoegdheid om proeven op levende dieren te verrichten gegeven kon worden. Kuyper worstelde met de idee dat een wettelijke regulering van vivisectie in feite zou leiden tot een acceptatie van de opvatting dat de medische wetenschap zich op experimenten op levende dieren kon en diende te baseren. Hij vreesde de aanvaarding van de bewering dat kennis over het lichaam van dieren zou leiden tot kennis over de mens.

Dit was een probleem voor Kuyper omdat hij er ondanks zijn opvattingen dat er soevereine kringen waren van overtuigd was dat, zoals medisch-historicus G.A. Lindeboom ook aangeeft, het object van de medische wetenschap zeer strikt bepaald diende te worden.22 In zijn Encyclopaedie der Heilige Godgeleerdheid (1894) stelde Kuyper vast dat dit object uitsluitend het menselijk lichaam diende te zijn :

'[...] het object van onderzoek voor deze [medische] faculteit [is] het soma van den mens, of beter nog de mens naar zijn somatische zijde [...]. ${ }^{23}$

Wanneer er dieren bij het onderzoek werden betrokken was dit voor hem in feite een ongewenste uitbreiding van dit object. Zo stelt hij:

20. Handelingen II, (1903-1904) 12 dec., 869.

21. Ibidem.

22. G.A. Lindeboom, Kuyper over de geneeskunde (Kampen 1955).

23. A. Kuyper. Encyclopaedie der heilige' Godgeleerdheid. Deel twee. Algemeen deel (Kampen 1894) 147. 
'Reeds hierom dient geprotesteerd te worden tegen de poging, om het soma van het dier bij deze faculteit op te nemen, en evenzo tegen de te hoog gaande verwachtingen, en daarom tegen de te ver gaande exploiten, van de vivisectie gewaarschuwd. ${ }^{24}$

Het Darwinisme mocht er niet toe leiden dat mensen en dieren aan elkaar gelijk werden gesteld, ook niet in somatisch opzicht.

Deze strenge opvatting over de begrenzing van het object van de medische wetenschap deed Kuyper dus afzien van een wettelijke regulering. Een aantal antirevolutionairen zoals Brants, de Ridder en Van Idsinga vonden dit teleurstellend en interpreteerden Kuypers beslissing vooral als een al te grote eerbied voor de soevereiniteit van de wetenschap. Kuyper was evenwel niet van zins om een uitgebreide discussie over soevereiniteit aan te gaan en gooide het over een andere boeg. Hij wilde naar zijn zeggen beslist niet loochenen dat er zeer ernstige, 'gewetenlooze mishruiken' op medisch terrein waren voorgekomen. Er waren in het buitenland inderdaad proeven op zieken verricht en dit was ontegenzeggelijk het gevolg van de invloed van vivisectie op het gevoel en de moraal van de proefnemer:

'Ik ontken niet, dat dit in verband staat met de vivisectie, dat dit al te sterk botvieren aan de kerving in het levende die degenen, die dit doet, min of meer ongevoelig maakt, diens teer en fijn gevoel min of meer afstompt, dat het veel verkeeren in bloedende gesneden organismen dikwijls verkeerd werkt. Men ziet het in het gewone leven, hoe zij die op een abattoir hun hoofdverblijf vinden, door dat kerven in het dier zekere mindere fijnheid hebben in de waardeering van hetgeen op die organismen moet toegepast worden. ${ }^{25}$

Met deze constatering kwam Kuyper wederom uit op de kwestie die al sinds de jaren tachtig speelde. Er was nog altijd niets bekend over de aard en omvang van vivisectie in Nederland, eventuele misbruiken konden niet worden aangepakt zonder bewijzen. De suggestie wekken dat proeven op levende dieren ook in Nederland hadden geleid of zouden leiden tot proeven op mensen was iets anders dan het aanreiken van concrete gegevens. Maar de suggestie van Brants om een enquête over het onderwerp te houden ging hem net een stap te ver. De uitkomst van een dergelijk onderzoek liet zich volgens de minister wel raden. Medische wetenschappers zouden niet het achterste van hun tong laten zien wanneer hun naar eventuele misstanden werd gevraagd. Daarmee was voor Kuyper de kous af. ${ }^{26}$ De anti-revolutionairen zouden nog vier jaar moeten wachten tot de liberale Minister Rink in 1907 uiteindelijk de Commissie inzake Vivisectie instelde.

\section{De Commissie inzake vivisectie}

De Commissie inzake Vivisectie was ingesteld naar Engels voorbeeld. De Royal Commission on Vivisection had in Engeland een zeer omvangrijke enquête gehouden. Gerenommeerde voor- en tegenstanders van vivisectie werden tijdens een door deze commissie ingestelde hoorzitting ondervraagd over hun mening over medisch-wetenschappelijke proeven op levende dieren. Meer dan vijfduizend vragen waren gesteld en sommige antworden hadden voor veel opschudding gezorgd. De hier volgende dialoog tussen de in Londen werkzame maar uit Wenen afkomstige Dr. Emmanuel Klein en de voorzitter van de commissie had zowel in het kamp van anti-vivisectionisten als aan de zijde van de voorstanders van vivisectie de meeste commotie tot gevolg gehad:

Chairman : Then for your own purposes you disregard entirely the suffering of the animal on performing a painful experiment?

Klein: I do.' ${ }^{\prime 7}$

$\mathrm{Vol}$ ongeloof en tevens razend over het ondoordachte optreden van Klein had T.H. Huxley, een voorstander van vivisectie en een fier verdediger van de wetenschappelijke vrijheid, onmiddellijk

\section{Ibidem}

25. Handelingen II (1903-1904), $12 \mathrm{dec} ., 871$

26. Ibidem.

27. Westacot, Century, 61-63. 
naar Darwin geschreven dat zich tijdens de hoorzitting een uitermate vervelend voorval had voorgedaan. ${ }^{28}$

De affaire Klein en de brief aan Darwin zouden nog doorklinken in de vragen die gesteld werden tijdens de tweede enquête van de Royal Commission on Vivisection die in 1906 -hetzelfde jaar als waarin Rink in Nederland toestemde om de Commissie inzake Vivisectie in te stellenwerd gehouden en tijdens welke meer dan twintigduizend vragen werden gesteld en beantwoord. Tijdens de hoorzittingen in Engeland deden zich vele heftige woordenwisselingen met geschreeuw en boe-geroep voor. ${ }^{29}$

Dergelijke sensationele taferelen zouden zich tijdens de Nederlandse hoorzitting van de Commissie inzake Vivisectie niet voordoen. De Commissie leefde voor de Nederlandse pers en publieke opinie niet zo. Zij was, wat betreft werkwijze en doelstellingen, ook niet zo ambitieus van opzet. Daar kwam nog bij dat de anti-vivisectionisten aan de hoorzittingen van de Commissie inzake Vivisectie niet al te veel aandacht schonken. De NBBV was immers bijna verscheurd geraakt door het conflict tussen Nolthenius en Ortt en het gegeven dat laatstgenoemde aanvankelijk op persoonlijke titel sprak, maakte de hoorzitting voor de vivisectie-bestrijders eerder tot een pijnlijke dan een triomfantelijke of verheugende gebeurtenis. Dit gold niet voor het eerder genoemde Comité tot Beperking der Vivisectie dat naarstig had gelobbyed voor de instelling van de Commissie inzake Vivisectie.

Het Comité tot beperking der vivisectie was in 1906 opgericht door, zoals Felix Ortt het enigszins zuur formuleerde, 'eenige invloedrijke staatslieden' die vooral aandrongen op een wettelijke regulering van vivisectie. ${ }^{30}$ De meest invloedrijke van hen was Jhr. Mr. W.F. Rochussen, de oud-Minister van Buitenlandse Zaken en oud-lid van de Raad van State. Hij zou door het Comité afgevaardigd worden naar de hoorzitting van de Commissie inzake Vivisectie om aldaar met groot ontzag en welwillendheid te worden aangehoord. Voordat het zo ver was profileerde het Comité zich in 1906 door middel van de publicatie van een aantal brochures waarin vooral benadrukt werd dat de nieuwe organisatie gericht was op verzoening van de strijdende partijen, op compromissen en op redelijke en vooral praktische oplossingen. Waar de discussie over vivisectie tot nu toe vol verbittering en zonder respect voor de verschillende standpunten was gevoerd zou het Comité er naar haar zeggen toe bijdragen dat de gulden regel dat de waarheid in het midden lag, weer zou worden gehanteerd. Het Comité tot beperking der vivisectie ontleende zijn bestaansgrond dus aan de discussie over vivisectie zoals die vooral in de eerste zes jaar van de twintigste eeuw was gevoerd. Hoe was het met die discussie verder gegaan na de aanvaringen tussen de NBBV, Harting en Beerends?

\section{Pro en contra vivisectie 1900-1906}

$\mathrm{Na}$ de aanvaringen tussen de NBBV en (in de jaren '70-'80) Harting en, in 1898 Beerends, was de discussie tussen anti- en pro-vivisectionisten regelmatig opgelaaid. In 1900 en 1903 werd door middel van ingezonden brieven in De Telegraaf ${ }^{\prime}$ een fel debat over vivisectie gevoerd waarvan, zo blijkt uit de handelingen der Tweede Kamer, vooral de anti-revolutionairen met belangstelling kennis hadden genomen. In 1905 had het vivisectie-vraagstuk bredere bekendheid gekregen toen

\footnotetext{
28. Stephen Coleridge, The Royal Commission on Vivisection (Londen 1907) 184-185.

29. Ibidem. De anti-vivisectionist Stephen Coleridge stelde tijdens de hoorzitting aan de orde dat Klein na invoering van de Cruelty to Animals Act en zelfs anno 1906 nog altijd een licentie had om proeven op dieren te nemen. Coleridge wilde de brief van Huxley ter tafel brengen om aan te geven dat de zaak Klein in 1875 niet alleen door antivivisectionisten hoog was opgenomen. De voorzitter weigerde hier loestemming voor te geven en een langdurige woordenwisseling ontstond. Deze draaide erop uit dat Coleridge zijn brief weer mee naar huis kon nemen.

30. Onder hen de oud-Commissaris van de Koningin en President van de Raad van Adel, A. Baron Schimmelpenninck van der Oye van Nijenbeek, de Commissaris van de Koningin van Gelderland, Mr. J.H.M. Baron Mollerus van Westkerke, de rechter in de Arrondissements-rechtbank te 'S-Gravenhage, Jhr. Mr. Rh. Feith, de burgemeester van Driebergen, G.D.C. D' Aumale Baron van Hardenbroek tot Hardenbroek, de redacteur van de Nieuwe Rotterdamsche Courant, Mr. A. Meyroos, de arts Dr. C.L. Rümke, P.A. J. Baron Smeth van Alphen en Mr. A.G. Vreede.
}

31. Zie voor een bundeling van deze artikelen Felix Ori, De vivisectie van verschillende zijden heschouwd (z.p. 1903). 
een deel van de serie brochures Pro en Contra vraagstukken van algemeen belang aan het onderwerp werd gewijd. De arts H.J.L. Struijcken had het pro-gedeelte op zich genomen. Het contra-gedeelte was van de hand van Ortt. ${ }^{32}$ In 1906 was tenslotte, even voor de oprichting van het Comité tot beperking der vivisectie en aan de vooravond van de instelling van de Commissie inzake Vivisectie, een hevige (door middel van brochures gevoerde) woordenwisseling ontstaan tussen anti-vivisectionisten en de medisch hoogleraren R.P. van Calcar en H. Burger. ${ }^{33}$

Waren de debatten zo onverzoenlijk en gericht op het beledigen van de tegenstander in plaats van op een redelijke oplossing? Zeker is dat de strijdende partijen elkaar van onredelijkheid beschuldigden. Met name de pro-vivisectionistische zijde had sterk het idee dat de persoon van de vivisector en daarmee die van de medische wetenschapper werd belasterd. Zo noemde Struijcken de anti-vivisectionistische opvatting dat proeven op levende dieren 'hard' of 'onverschillig' voor de dood of de pijn van anderen zouden maken, een 'monsterachtige beschuldiging'. Wanneer men, zo redeneerde hij, dagelijks de wreedheid van de natuur om zich heen kon zien: 'hoe de kat speelt met de muis, hoe de sperwer een duif vervolgt, hoe de ovievaar een levende kikvorsch vervoert enz. enz. ' dan was het uitermate kwaadwillend wanneer men uitgerekend vivisectoren die met hun werk het verlichten van menselijk lijden voor hadden, wreed noemde.

Van kwaadwillendheid beschuldigde ook Van Calcar zijn tegenstrevers. In zijn geschrift analyseerde de hoogleraar een drietal anti-vivisectionistische publicaties die hij kenmerkend vond voor de strijdwijze van de Nederlandse anti-vivisectionisten: De Folterkamers der Wetenschap van Von Weber, Pro en Contra proeven op levende dieren van G. Luchtmans en Medische wetenschap en vivisectie van Ortt. Van deze drie brochures achtte Van Calcar die van Von Weber ontoelaatbaar omdat medici in dit geschrift naar zijn mening werden afgebeeld en beschreven als gedegenereerde boeven. De toon die in De Folterkamers der Wetenschap werd gebezigd was volgens Van Calcar het tegenovergestelde van de toon waarvan een welopgevoede, beschaafde vrouw zich bediende wanneer zij gedwongen was om met iemand over een uiterst onkies onderwerp te spreken. In Von Webers brochure werd, zo merkte Van Calcar verontwaardigd op, niet gesproken over het aanleggen van een maagfistel bij de hond maar over 'een gezonde. liefst gestolen, trouwe hond, [die] uit een donker, vunzig hok naar de experimenteerkamer [wordt] gesleurd'. ${ }^{34}$ Ook de tekeningen waren naar Van Calcars mening uiterst tendentieus.

De geschriften van Ortt en Luchtmans waren weliswaar niet van dergelijke illustraties voorzien maar waren naar de mening van Van Calcar op zodanige wijze geschreven dat iemand die 'begaafd [was] met slechts een luttele hoeveelheid verbeeldingskracht' zich weinig hoefde in te spannen om zich 'tooneelen voor oogen te tooveren gelijk aan of erger dan het zoojuist beschrevene'. Met name de verwijzing naar The Nine circles of the Hell of the innocent deed Van Calcar naar zijn zeggen twijfelen aan het ethisch gevoel van Ortt. Een beschaafd mens zou volgens Van Calcar geen woorden als verminken of een uitdrukking als 'het lardeeren van de voeten met spijkers' in de mond nemen. De anti-vivisectionisten wilden op deze manier in twijfel trekken dat de vivisector een mens was. Zo was Ortt volgens Van Calcar zelf de veroorzaker van pijn. Het ging hier niet om lichamelijke pijn maar om een andere vorm van pijn, een kwetsing die voor een ethisch hoogstaand mens veel heviger was.

Van Calcar draaide op deze wijze de rollen om. Door Ortt van het pijnigen van anderen te beschuldigen protesteerde hij tegen de wijze waarop de anti-vivisectionisten zich in de loop der jaren het ethisch standpunt hadden toegeëigend. Zijn collega Struijcken had dit in 1898 al eens eerder gedaan. Samen met de arts J. Bartolotti Rijnders had hij in de brochure getiteld Vivisectie is in het belang der Menschheid een hilarische persiflage van de, naar zijn mening, onterechte

32. Struycken en Oru, Pro en Contra vraagstukken van algemeen belang: De vivisectie (z.p. 1906).

33. R.P. van Calear. De vivisectie. Naar aanleiding van het adres van den Bond tot Bestrijding der Vivisectie in Nederland aan Z.E. de Minister van Binnenlandsche Zaken (Amsterdam 1906)

34. Van Culcar, De vivisectie, 10 . 
anti-vivisectionistische claim op medelijden en gevoel geschreven, daarbij en passant ook het taalgebruik van Ortt op de korrel nemend:

'[...] Wij gelooven, dat de hoogste deugd is Liefde. Wij gelooven, dat het wenschelijk ware, dat in het geheele rijk der Natuur die Liefde heerschte als hoogste deugd; maar wij weten, dat zij als zoodanig alleen voorkomt bij den mensch, en in al hare volkomenheid alleen bij den mensch op zijn meest beschaafden, meest ontwikkelden trap [...] Wij gelooven dat al zijn de middelen ter verkrijging van wetenschappelijke kennis aan de eene zijde van gezondheid en levensgeluk aan de andere zijde voor den leek ook soms onbegrijpelijk, dat zij toch alle reden van bestaan hebben als zij geheel berusten op de toepassing van het Beginsel der Naastenliefde. Dit geloof - dat zoo diep in ons geweten gevolgd wordt, dat het voor ons tot zekerheid is geworden, is het, dat ons van de vivisectie, met de meest mogelijke omzichtigheid en zachtheid verricht, nog meer nut doet verwachten, dan zij tot nu toe reeds gegeven heeft, -tot vermeerdering onzer kennis, tot vooruitgang der Wetenschap, tot genezing van ziekte, tot bevordering van veler gezondheid en veler levens geluk -uit Liefde tot den Naaste. [... $]^{335}$

Van Calcar en Struijcken deelden met de andere pro-vivisectionistische betrokkenen bij de verschillende debatten de opvatting dat de persoon van de medicus tevens belasterd werd door het verspreiden van onjuiste gegevens over de werking van sera en vaccins, over het verloop van ziekten en kwalen en over bepaalde geneesmethoden. Een goed voorbeeld was volgens Van Calcar het werk van Dr. G. Luchtmans. Deze medicus had in zijn brochure pro en contra een aantal uitspraken gedaan die naar het oordeel van Van Calcar bewezen dat deze oud-gediende niet meer op de hoogte was van de stand van zijn vak. De foutieve uitspraken die hij deed over bijvoorbeeld de besmetting en verspreiding van tetanus werden door hem overgoten met een sausje van onzinnige darwinistische ethiek. Dit alles zou lachwekkend zijn en niet de moeite van het bespreken waard, ware het niet dat de medische wetenschap ten overstaan van de geïnteresseerde leek op slimme wijze verdacht werd gemaakt. Bovendien dreigde het parlement door dergelijke geschriften te worden beïnvloed. Het was daarom een buitengewoon belangrijke taak voor medici om de anti-vivisectionistische redeneringen in een helder licht te plaatsen.

Van Calcar had de analyse van de geschriften van Von Weber, Ortt en Luchtmans naar zijn zeggen gemaakt om daarmee tevens te voorzien in een soort richtlijn voor collega's die zich ook aangesproken voelden om de strijd tegen de anti-vivisectie-beweging aan te gaan. Een dergelijke handleiding was noodzakelijk, zo meende Van Calcar, want in het verleden was die strijd nog al eens op verkeerde wijze aangevat. Onlangs nog had collega $\mathrm{H}$. Burger olie op het vuur gegooid door de anti-vivisectionisten het volgende toe te voegen: 'Wat baet $\epsilon$ kaers of bril/ Als den uijl niet sien en wil !'. Burger had een aantal statistieken aangehaald en dit was naar de mening van Van Calcar eveneens een veel gemaakte fout van de bestrijders van de anti-vivisectie-beweging. Met cijfers en algemeenheden kon men de geïnteresseerde leek niet bereiken. Er zat niets anders op Jan het publiek mee te nemen naar 'ziekbed en laboratorium' om aldaar 'argumenten tegenover argumenten te stellen'. ${ }^{36}$

Van Calcar was met dit betoog niet het laatste woord gegund. Niet lang na de publicatie van zijn geschrift antwoordde Ortt met zijn brochure De aanval van twee hoogleeraren op de Nederlandsche Bond tot Bestrijding der Vivisectic waarin hij zowel Burger als Van Calcar van repliek diende. ${ }^{37}$ Volgens het Comité tot beperking der vivisectie stond ook deze brochure vol met verdachtmakingen en beschuldigingen. Ortts woorden vormden voor het Comité mede de aanleiding om het vivisectie-vraagstuk op een andere manier aan de orde te stellen.

\footnotetext{
35. J. Bartoloui Rijnders en H.l.J. Struijcken. Vivisectie is in het helang der menschheid! Een enkel woord lol heorrdeling der brochure uilgegeven door den NBBV (Breda 1898) 1-2.

36. Van Calcar, De vivisectie. 35-36. 37. Felix Ort, De aanval van mee hoogleeraren op den Nederlandschen Bond tot Bestrijding der Vivisectie beantwoord
(Utrecht 1906). Special uilgegeven als Orkaan 3 (1906).
} 


\section{Het Comité}

Om zichzelf als redelijk en verzoenend te presenteren nam het Comité allereerst afstand van de radicale strijdwijze van de NBBV. Het Comité meende dit onder meer te kunnen bereiken door het tot in detail beschrijven van experimenten op levende dieren achterwege te laten. Zo langzamerhand kon er vanuit worden gegaan, zo werd in de eerste brochure Beperking van Vivisectie van de organisaties gesteld, dat het 'afschuwelijke' van de vivisectie bekend was. ${ }^{38}$ Alleen indien dit voor de discussie absoluut noodzakelijk was zou er over worden gerept. Toch konden de gedetailleerde beschrijvingen van dierproeven door de 'beperkers' kennelijk niet gemist worden bij het zichtbaar maken van het vivisectie-vraagstuk. In de tweede brochure van het Comité, Vivisectie is zij te rechtvaardigen ? $^{39}$ een uit het Engels vertaald geschrift van de antivivisectionistische medicus Charles Bell Taylor, werd althans toegegeven dat het toch nodig was om de dingen bij hun naam te noemen. Alleen zo werd het mogelijk gemaakt om zich te verplaatsen in de 'onbeschrijfelijke smarten der gebezigde dieren!' en zou het duidelijk worden dat het aandringen op verzachting van het dierenleed en beperking van vivisectie geen 'sentimentaliteit' was maar juist een streven dat 'grond vindt in een gezond medelijden met zulke smarten!' ${ }^{40}$

Dit onderscheid tussen ongezonde overgevoeligheid en gezond medeleven speelde in de wijze waarop het Comité zich tegen de NBBV afzette een uitermate belangrijke rol. Dat geldt met name voor de geschriften van de feministe Welmoed Wijnaendts Francken-Dyserinck, een van de belangrijkste woordvoersters van het Comité. Waar het Dyserinck om ging was aan te tonen dat de eventuele toetreding van vrouwen tot het Comité niet hoefde te betekenen dat deze organisatie zou overslaan naar een sentimentele benadering van het vraagstuk en 'gefühlsduselei'. De emotionaliteit van vrouwen zou juist zorgdragen voor een beter begrip voor het vraagstuk, zoals ook beroemde schrijvers als Frederik van Eeden de kwestie met behulp van het gevoel en niet met behulp van het verstand hadden weten te doorgronden. ${ }^{41}$

Tegelijkertijd was Dyserinck bijzonder beducht voor juist die emotionele zijde van de vrouw. Als voorvechtster van vrouwenkiesrecht wilde zij laten zien dat vrouwen heel wel in staat waren om tot redelijke en praktische oplossingen te komen en koele en objectieve oordelen te vellen. Zelf probeerde ze het goede voorbeeld te geven door zeer grondig onderzoek te verrichten naar de parlementaire discussies die over vivisectie waren gevoerd. In Vivisectie in het Nederlandsch Parlement, de derde door het Comité uitgegeven brochure, becommentarieert zij de debatten steeds op de toon van een redelijke, op compromissen gerichte vrouw van de wereld. Het was die toon die zij ook graag zou willen aantreffen in de bijdragen van vrouwen die zich achter het standpunt van het Comité schaarden. ${ }^{42}$

Uit haar beschouwingen blijkt dat zij eigenlijk in bedekte termen wilde aangeven dat de strijdwijze van de NBBV te weinig ruimte gaf voor de initiatieven van vrouwen. Hun redelijkheid en politieke ambities kregen geen kans in een door Ortt en andere onverzoenlijken gedomineerd debat waarin religiositeit en verwijzingen naar radicale levenswijzen als het vegetarisme de boventoon voerden. Dyserinck wilde met andere woorden aangeven dat vrouwen veel beter af waren, meer ruimte kregen en beter begeleid werden, wanneer zij zich afkeerden van de NBBV en zich bij het veel redelijker en zeker niet religieuze Comité voegden. Binnen de organisatie heerste geen oud-liberaal of christelijk-historisch conservatisme ten opzichte van vrouwen, ook al deed de ledenlijst dit wellicht vermoeden. Had niet Van Rochussen er expliciet op gewezen zeer welwillend tegenover de medewerking van vrouwen te staan?

38. Beperking der vivisectie. No 1. der brochures uitgegeven door het Comité tot beperking der vivisectie. ('sGravenhage 1907).

39. Charles Bell Taylor, Vivisectie is zij te rechtvaardigen? Uitgave van de London and provincial anti-vivisection socicty vertaald door G.E. Ridder Huyssen van Kattendijke. No.2 der brochures uitgegeven door het Comité tot beperking der vivisectie ('s-Gravenhage 1908)

40. Ibidem, voorwoord

41. Welmoed Wijnaendts Francken-Dyserinck, 'Het juiste standpunt', De Telegraaf 24 november 1906.

42. Dyserinck, Vivisectie, voorrede. 
Kortom, Dyserinck wenste vurig dat zich een schare van redelijke, bekwame en praktische vrouwen bij het Comité zou voegen, vrouwen die zouden bewijzen dat zij zich in de juiste omgeving niet zouden laten verleiden tot overdrijving en polariserende emotionaliteit. Zij zal zich er dan ook zonder meer over hebben verheugd dat een aantal vrouwen zich inderdaad geroepen voelde om in het openbaar steun te betuigen aan het Comité. De dames namen het op zich om in Den Haag een tentoonstelling over vivisectie te organiseren en op deze wijze geld in te zamelen ten behoeve van de 'beperkers'. Dat de vrouwen geen lid waren van de NBBV leek een bevestiging van Dyserincks vermoeden dat die bond met haar zogenaamde 'hogere gevoelens' niet genoeg ruimte gaf aan meer praktisch ingestelde vrouwen.

Hoe teleurstellend moet het voor haar zijn geweest toen zij de uitnodiging voor de tentoonstelling ontving die de ijverige dames aan journalisten, politici en schrijvers hadden gestuurd. De invitatie was opgesierd met een in de ogen van velen, niet in de laatste plaats die van Dyserinck, uitermate sentimentele afbeelding van een hond. Het ging om de eerder beschreven tekening uit het puur anti-vivisectionistische Die Folterkammern der Wissenschaft waarop benevens een 'biddende' hond een aantal jongemannen met geld in de hand en de man met het witte slagersschort te zien waren. Alleen het bijschrift verschilde van de gangbare anti-vivisectionistische versie:

'Het proef dier -een hondje- angstig geworden door de dreigende toebereidselen, ging opzitten en bedelde beurtelings bij elk der aanwezigen, om zijn leven. De studenten, geroerd door dit pathetische beroep op hun hulp, probeerden het arme schepsel te redden en boden aan het te kopen, of wat ook te doen om het te bevrijden. Maar vergeefs, het werd gruwelijk gemarteld en bij de volgende les opnieuw gebruikt voor herhaling van de proef waarbij het stierf. ${ }^{, 43}$

Wijnaendts Francken-Dyserinck die in De Telegraaf verslag uitbracht over de tentoonstelling, probeerde het naar haar oordeel overdreven beroep op het gevoel dat uit de tekening sprak, nog enigszins te rechtvaardigen. De 'klif der overdrijving' was dan niet omzeild, door de illustratie werd volgens Dyserinck wel degelijk een zeer wezenlijk probleem aan de orde gesteld. Het getekende dier was zonder twijfel in aanraking geweest met een huisgezin. Geen hond ging immers vanzelf 'mooi zitten' en de studenten wisten dat ook. Omdat zij op deze wijze herinnerd waren aan lief en leed dat zij eens met hun eigen huisdier hadden gedeeld, was het betreffende hondje voor hen meer dan een proefdier dat ten behoeve van de wetenschap geofferd diende te worden. Hun leraar had daar rekening mee moeten houden en een ander dier moeten gebruiken. Op deze wijze had hij minder schade toegebracht aan het gemoed van de jongelui. Op dit soort fouten van de kant van medici mochten de 'beperkers' en hun sympathisanten zeker wijzen. Zij moesten zich daarbij, zo waarschuwde Dyserinck, evenwel niet bedienen van anti-vivisectionistische methoden. Daar Dyserinck het initiatief van de dames om begrijpelijke redenen niet wilde torpederen, haastte zij zich om vervolgens vol lof over het georganiseerde evenement te spreken. Zo zou de tentoonstelling recht doen aan het feit dat de verontrusting over vivisectie in veel bredere kringen dan alleen de strikt anti-vivisectionistische beweging leefde. ${ }^{44}$

Alsof men op deze woorden had gewacht werden de organisatie van de tentoonstelling en de oprichting van het Comité in de meeste dagbladen juichend begroet. Gesproken werd over verzoening, compromissen, praktische regulering, het betreden van een gulden middenweg en een goed alternatief voor de onverzoenlijke standpunten van pro- en anti-vivisectionisten. Volgens een aantal commentatoren zou het Comité de kwestie tot een goede oplossing brengen zonder de wetenschap in haar groei en werk te belemmeren. ${ }^{45}$ Of deze hoop gegrond of ijdel was moest toen nog blijken. Wat echter wel snel duidelijk werd was dat het Comité in ieder geval wist te bewerkstelligen dat ook een aantal mensen buiten de NBBV en Ortt om zich over de vivisectiekwestie uitsprak.

43. Dyserinck, 'Standpunt', De Telegraaf 24 november 1906

44. Ibidem.

45. Zie voor een overzicht Cornité broch. 1, 9-14 
De schrijver Marcellus Emants verklaarde zich in Het Vaderland een voorstander van een wettelijke beperking van vivisectie en verwees in dit stuk naar de tentoonstelling over vivisectie. $\mathrm{Hij}$ ried een ieder aan om een voorbeeld te nemen aan menig 'krantenman' en politicus die daar zijn licht over de kwestie had opgestoken. ${ }^{46}$ Niet minder enthousiast was de Vlaamse literator Cyrille Buysse die ten behoeve van het Comité het korte verhaal Canule schreef. Het relaas handelde over de lotgevallen van een huishondje, Canule genaamd, dat zijn naam eer aandoet omdat het telkens met giftige stoffen wordt geïnjecteerd door de heer des huizes en zijn medischwetenschappelijke vrienden. Buysse beschrijft hoe het hondje telkens bijna sterft en dan na veel lijden weer herstelt om vervolgens weer te worden vergiftigd. Vele malen zien de kinderen van het gezin de 'sterre-oogen' van Canule, uitdoven en weer gaan stralen. Zij verbazen zich over het lijden dat hun kleine vriend op initiatief van hun vader wordt aangedaan. Als de ogen van Canule voor de allerlaatste keer uitdoven weten zij dat zij deze aanblik hun leven lang met zich mee zullen dragen. ${ }^{47}$

Net als bij de tentoonstelling het geval was wordt ook door Emants en het verhaal van Buysse duidelijk dat er wel degelijk een aantal duidelijke overeenkomsten bestonden tussen de geschriften van de NBBV en die van het Comité. Zeker, Emants verschilde van de anti-vivisectionisten omdat hij als echte naturalist te kennen gaf dat de medische wetenschap slechts een schijnwetenschap zou zijn als zij zich niet op proeven, op onderzoekingen, kortom op het experiment, zou baseren. Hij noemde de vivisectie bovendien een 'noodzakelijk kwaad', een aanduiding die voor de leden van de NBBV taboe was. ${ }^{48}$ Maar evenals de anti-vivisectionisten koppelde Emants het vraagstuk aan het geloof in morele vooruitgang en sprak hij over 'nodelooze martelingen', 'gruwelen' en 'offers'. Buysses verhaal is zelfs in het geheel niet te onderscheiden van de traditie van binnenlandse en buitenlandse anti-vivisectie-fictie. In Canule wordt het kwaad zichtbaar gemaakt door het in de privé-sfeer te plaatsen. De vivisectie wordt verricht op een geïndividualiseerd en gepsychologiseerd dier en de suggestie wordt gewekt dat de medicus-vader en zijn collega's zich evengoed aan de toch al voor hun leven getekende kinderen had kunnen vergrijpen.

Het was kortom, nog niet zo eenvoudig om een alternatief te vinden voor de anti-vivisectionistische politieke stijl. De reden daarvoor was dat er nog steeds nauwelijks iets concreets over vivisectie bekend was. Een andere, dat wil zeggen minder emotionele en meer redelijke manier om het vraagstuk te benaderen was, zo suggereerde het Comité in een adres aan minister Rink. alleen mogelijk indien de waarheid boven tafel kwam:

'In steeds groter wordende kringen van ons volk is een gevoel van onrust ontstaan over den omvang, dien men meent dat de vivisectie in Nederland heeft genomen. Dit gevoelen berust bij de volslagen afwezigheid van volledige gegevens, weliswaar op losse berichten en verspreide mededeelingen in medische en anti-vivisectionistische geschriften: maar hetgeen dienaangaande bekend is geworden heeft niettemin bij zeer velen, ook bij ondergeteekenden, de overtuiging doen ontstaan dat een vermindering van het dierenlijden en een beperking van het aantal proeven mogelijk en zeer gewenscht zoude zijn. Om in deze [...] belangrijke aangelegenheid evenwel een beslist en juist omschreven antwoord te kunnen geven, zou de feitelijke toestand inzake de vivisectie in ons land eerst in zijn geheelen omvang moeten worden vastgesteld, iets wat alleen zou kunnen geschieden, indien het Uw Excellentie zou mogen behagen, daarnaar een volledig onderzoek te willen instellen." ${ }^{49}$

Het Comité beschouwde het als een grote triomf toen de Commissie inzake Vivisectie inderdaad mede door Rink werd ingesteld om de volgende vragen beantwoorden: 'le Welke proefnemingen op of met levende dieren, aangeduid onder den algemeenen naam van vivisectie, worden in Nederland ondernomen of toegepast (waar?, door wie? en met welk doel? )?, 2e Welke proefne-

46. Marcellus Emants, Beperking der Vivisectie, 50. (overgenomen uit Het Vaderland).

47. Wat is uwe mening over vivisectie? antwoord van :Cyrille Buysse, Canule (1907).

48. De reden daarvoor was dat de prostitutie eveneens als een 'noodzakelijk kwaad' werd aangeduid.

49. Dyserinck, Vivisectie, 82-83. 
mingen moeten geheel verboden worden?, 3e Aan welke beperkende voorwaarden behooren de toegelaten proefnemingen te worden onderworpen?, 4e Op welke wijze ware de nakoming dier voorwaarden het best te verzekeren?'so

Gerustgesteld door de gedachte dat Rochussen als onder-voorzitter van het Comité tijdens de hoorzitting zijn redelijke standpunt uiteen zou zetten, stelde Wijnaendts Francken-Dyserinck lang voor de publicatie van het rapport van de Commissie inzake Vivisectie, dat het vivisectievraagstuk spoedig voor lange tijd zou zijn afgedaan.

\section{De leden van de commissie}

Minister Rink kon bij de installatie van de Commissie inzake Vivisectie niet aanwezig zijn. De honneurs werden daarom waargenomen door de voorzitter van de commissie, Van Idsinga. 'Geen slechte ruil' zo memoreerde de toenmalige Leidse hoogleraar R.P. Van Calcar jaren later in zijn Collegeherinneringen ${ }^{31}$ dit optreden van het toen als 'wild' en intelligent bekend staande kamerlid. Van Idsinga had een korte toespraak gehouden waarvan de laatste zin luidde: 'Wij dienen elkaar te leren begrijpen en waarderen'52. Of hij bij het uitspreken van zijn woorden in het bijzonder naar Van Calcar heeft gekeken en of dit verklaart waarom Van Calcar zich deze woorden nog zo goed herinnerde, is niet bekend.

Wel kan worden aangenomen dat Van Idsinga met zijn slotwoorden refereerde aan de wellicht het beste als 'ontvlambaar' aan te duiden samenstelling van de Commissie. Van Idsinga zelf en het kamerlid Brants waren de enige anti-revolutionairen en tegenstanders van vivisectie in het gezelschap. Zij waren bovendien, samen met de Haagse jurist W.J. Snouck Hurgronje, de enige 'leken'. De rest van de Commissie bestond uit medici en niet de minst invloedrijke: behalve Van Calcar was daar Dr. J. Poels, directeur van de Rotterdamse Rijksseruminrichting, de Utrechtse hoogleraar C.H.H. Spronck en de Haagse arts Rümke.

Alleen van de laatste was bekend dat hij lid was van het Comité tot beperking der vivisectie. Van de anderen wist Van Idsinga dat zij of wel in een felle polemiek met de anti-vivisectionisten verwikkeld waren, dan wel regelmatig doelwit van de pijlen van de NBBV waren geweest. Bovendien ging Van Idsinga er waarschijnlijk vanuit dat met name Poels zo zijn bedenkingen zou kunnen hebben tegen een anti-revolutionair als voorzitter. Het is niet ondenkbaar dat Poels Van Idsinga en ook Brants associeerde met de strijd van de anti-revolutionaire voormannen Abraham Kuyper en (de later christelijk-historische) De Savornin Lohman tegen respectievelijk de indirecte vaccinatiedwang en de 'vaccine-vereering'. ${ }^{53}$ Een pikant gegeven, niet alleen vanwege Poels' hetrekking tot het seruminstituut, maar tevens omdat vragen over de bereiding en toepassing van sera en vaccins in de loop der jaren steeds duidelijker met de vivisectie-kwestie verweven waren geraakt.

Voor de oprichting van de NBBV en in de eerste jaren van het bestaan van de bond was het vivisectie-vraagstuk ook al aan de vaccinatie-kwestie gekoppeld. In anti-vivisectionistische geschriften werden inentingen als vivisectie op mensen aangemerkt. Gewezen werd op de gevaren van vaccinatie en de overbodigheid ervan. Met name de methode Pasteur tegen hondsdolheid werd fel aangevallen. De eerder genoemde dierenbeschermer Salomon had in 1881 de toon gezet door te suggereren dat sinds Pasteur zijn werkzaamheden had aangevangen, er in Frankrijk heel wat meer hondjes dol waren geworden dan tevoren. Ook Ortt had zich in 1903 in zijn Cursus over Vivisectic fel tegen Pasteur uitgesproken. Anders dan men doorgaans suggereerde was de Fransman volgens Ortt geen weldoener der mensheid. In de 'les' ervoor had Ortt even fanatiek de serumtherapie als een 'omweg' voor en niet een verworvenheid van de geneeskunde aangeduid.

50. Hundelingen (1905-1906) Il 13 dec. 632-655. Zie ook: Rapport Commissie inzake Vivisectie (1909).

51. R.P. van Calcar, Collegeherinneringen (Rollerdam 1936) voorwoord.

52. Ihidem.

53. Zic hicrover: Vaccine-Vereering. Mei een brief 1 i.tn Jhr. Mr. A.F. de Savornin Lohman ('s-Gravenhage 1892). 
Het verband tussen anti-vaccinatie en anti-vivisectie dat in vivisectie-bestrijders als Ortt was verenigd, werd voor het eerst expliciet aan het parlement voorgelegd in het rekest dat de NBBV (zeer tegen de zin van Ortt) nog voor de instelling van de Commissie inzake Vivisectie in 1906 bij minister Rink indiende. In dit schrijven vroeg Nolthenius niet alleen om een verbod van vivisectie ten behoeve van universitair en overig onderwijs, een verbod van prijsvragen die voor de beantwoording proeven op levende dieren vereisten, het intrekken van 'rijksgelden' die de vivisectie op enigerlei wijze ten goede kwamen, maar tevens om het instellen van leerstoelen 'physische therapie' die -en deze toevoeging is veelzeggend- 'anders dan de heerschende serumtherapie, op vivisectie berust'.

Nolthenius ging met andere woorden zo ver om het bestaan van vivisectie in verband te brengen met het gebruik van sera en vaccins in plaats van, zoals voorheen het geval was, de serumtherapie uitsluitend als onderdeel van de vivisectie voor te stellen. Deze ontwikkeling van de anti-vivisectionistische voorstelling van experimenten op dieren als 'snijden en pijnigen' naar vivisectie als 'prikken en injecteren' ontging ook de critici van de beweging niet. Van Calcar refereerde eraan in zijn eerder genoemde brochure De vivisectie. Hij zag in de uitspraken over sera -en vaccins een slinkse poging van anti-vivisectionisten om hun zogenaamd ethisch standpunt te verlaten en een pseudo-ethisch standpunt in te nemen. Zonder dat het publiek dit besefte, brachten zij de nodige onzin over vaktechnische zaken te berde, waar alleen een medicus, een wetenschapper, een zinnig woord over kon spreken.

Van Idsinga sprak dus niet zonder reden over het belang van begrip en respect toen hij de eerste zitting van de Commissie inzake Vivisectie opende. Hij wist dat het niet eenvoudig zou zijn om als één man de vragen van de minister te beantwoorden en de genodigden tijdens de hoorzitting te woord te staan. Van Calcar en Poels meenden na afloop van alle werkzaamheden dat de samenwerking tussen de zo verschillende commissie-leden wonderlijk goed was verlopen. Slechts één maal was het tot een uitbarsting gekomen. De voorzitter zelf was, zo blijkt uit de volgende door Van Calcar opgetekende anekdote, uit zijn slof geschoten toen hij met de overige commissieleden te gast was op een hoorcollege van Poels:

'Stel b.v. eens, zoo doceerde Poels, dat de antivivisectionisten à tort et à travers [...] gedaan weten te krijgen dat de vaccinatie tegen pokken wordt afgeschaft. Wij weten toch, dat de immuniteit der massa zich slechts enkele jaren na de vaccinatie kan handhaven en dat de overige preventieve maatregelen tegen de ziekte veel minder efficiënt zijn, dan die tegen verschillende andere infectieziekten [...]. Het slot dezer uiteenzetting werd gevormd door een advies aan onzen voorzitter. Het luidde ongeveer: Brengt $u$ dat alles eens in de Kamer ter sprake. Toen kwam voor het eerst Van Idsinga los, zooals wij hem slechts zelden hebben gehoord: "Ik zal aan die augusterij niet doen, het gevolg kent u even goed als ik, de zaak heeft reeds de volle belangstelling van een bewindsman, of hij is er reeds over in bespreking met een college of met personen, die er even weinig van begrijpen als hij zelf", .4

\section{De hoorzitting}

De leden van de commissie mogen dan wat betreft hun achtergrond en opvattingen ten zeerste van elkaar hebben verschild, voor de mensen die zij tijdens de hoorzitting inderdaad vrij eensgezind ondervroegen gold dat wellicht nog in sterkere mate. Maar hoe verschillend ook, allen benaderden het vivisectie-vraagstuk als een kwestie die nauw verbonden was met vragen over nut, zedelijkheid en bovenal de persoon of het karakter van de proefnemer en over de aard van het lijden van het proefdier. Zowel voor-als tegenstanders van vivisectie deelden een manier van denken die sterke overeenkomsten vertoonde met de beelden die afkomstig leken te zijn uit, of in ieder geval nauw verwant waren aan, de anti-vivisectie-fictie en de tekeningen zoals deze bijvoorbeeld in $D e$ Folterkamers der Wetenschap te vinden waren.

Typerend is de volgende passage uit het verhoor van de eerder genoemde Rochussen: 
'[...] Persoonlijk zou het mij veel waard zijn, als honden en paarden werden vrijgesteld [van vivisectie], mijn persoonlijk gevoel doet mij aldus voor de huisdieren pleiten; vooral bij honden toch treedt het zieleleven sterk op den voorgrond. Het is een vaak waargenomen feit, dat een hond als hij uit den kelder wordt gehaald, waar hij geruimen tijd opgesloten was geweest, het stellige voorgevoel en het bewustzijn heeft van wat in de snijkamer met hem staat te gebeuren; dat verhoogt zijn lijden. ${ }^{55}$

De kelder waar Rochussen aan refereert is afkomstig uit de anti-vivisectie fictie, voor het 'vaak waargenomen feit' waarover hij spreekt geldt dit net zo goed. De leden van de Commissie inzake Vivisectie, ook de vivisectoren onder hen, lijken dit niet te bemerken. Zij spreken het bestaan van 'een kelder' niet tegen, ook voor hen lijkt deze fictieve ruimte uit de Hel der onschuldigen, deze echo van de anti-vivisectionistische geschriften, reëel te zijn. Ook het profiel van de vivisector dat door de verschillende genodigden werd geschetst, is nauw verwant, en op sommige momenten zelfs identiek, aan het beeld dat in de anti-vivisectie fictie werd gegeven. De homeopathisch arts Wouters, Felix Ortt en de Haagse arts Van Lissa stelden dat de vivisectie bij de proefnemers en hun publiek de eerbied voor het leven en de liefde voor het dier aantastte en 'verhardend' werkte op zijn 'zedelijk gehalte'. Daartoe droeg naar de mening van de eerstgenoemde bij, dat hoogleraren en hun assistenten vaak het verkeerde voorbeeld gaven. Zij sprongen ruw met het proefdier om en dit werkte zonder meer 'verlagend' op de studenten.

De arts en literator Arnold Aletrino stelde het wat radicaler. Hij was eenvoudigweg van mening dat een 'fijn georganiseerd mensch' geen vivisecties verrichtte. Wouters was het met hem eens en zette zijn mening kracht bij met de beschrijving van een proef die hij zelf had bijgewoond en die op hem, als fijngevoelig mens een 'diep ontroerende' indruk had gemaakt:

'Ik zag een konijn, waaraan naar ik meen ook de hartwerking naast die van den ureter werd gedemonstreerd. Het dier was niet gedurende de geheele proef genarcotiseerd; het schreeuwde van smart. Aldus heeft een diepe inprenting in het geheugen plaats door de ijzingwekkendheid'. ${ }^{56}$

Het uitvoeren van vivisecties stond volgens Aletrino gelijk aan een gebrek aan ethisch gevoel, en een teken van grofheid en hardheid. Medici waren volgens de literator bij uitstek een grof soort mensen. Dit kon men constateren wanneer men naar het meubilair en de versiering van hun huizen keek en naar wat men aan boeken las en vooral niet las. Het was een treurige zaak dat de medicijnenstudie die toch al 'verhardde' nog eens extra werd 'verruwd' door de demonstratie van vivisecties.

De Nieuwediepse officier van gezondheid W.A. Stark was zelfs van mening dat de vivisectie 'wreed maakte'. Yan Rees was het daar niet mee eens: 'ik geloof eirgenlijk niet aan meerdere wreedheid bij vivisectie, het proefdier toch is voor den proefnemer geheel object. Hij abstraheert zich volkomen van het begrip smart.' De hoogleraar psychiatrie Bouman gaf toe dat hij zelf door het verrichten van vivisectie meer gehard was geraakt tegen het veroorzaken van pijn:

'in het begin is leed veroorzaken iets onaangenaams maar opereeren op kadavers was mij eerst ook onaangenaam; aan beide went men; het binden en narcotiseeren doet onaangenaam aan, maar de tiende keer veel minder dan de eerste. 's7

De meeste genodigden waren, evenals Van Rees, van mening dat dit proces van afstand nemen noodzakelijk was. Indien de vivisector geen afstand nam van het leed en de gevoelens van het proefdier dan zou hij, zo meende Ortt, een pure wreedaard zijn die voor zijn genoegen proeven nam. Identificatie was dus, met andere woorden, niet goed mogelijk. Aan de andere kant waren 'hardheid' en 'gevoelloosheid' in de ogen van de meeste genodigden juist alarmerende tekens. Hoewel zij dit niet expliciteerden, leek deze gevoelsmatige verwijdering van het onderzoeks-object

55. Bijlage II 'Verslag van de verhooren der voor de zitling verschenen personen', Rapport der Commissie inzake Vivisectie (1909) 1-52, antw. op vraag 408, 50.

56. Ibidem. antw. op vraag 39, 4.

57. Ibidem. antw. op vraag 276. 34 . 
voor hen gelijk te staan aan het loslaten van een algemeen geldende moraal ten gunste van een onberekenbare hogere autoriteit die op de proefnemer inwerkte. Een autoriteit die de persoon van de vivisector tot slaaf maakte van een 'nieuwsgierig scalpel', die in het parlement door sommige anti-revolutionairen met de term soevereine wetenschap werd aangeduid en in de anti-vivisectionistische geschriften omschreven werd als lust, roes of afgoderij.

Het lijkt er op alsof vrijwel iedere spreker min of meer rekening hield met deze donkere, onberekenbare zijde van de wetenschap, en naar oplossingen zocht om deze te bedwingen en in goede banen te leiden. Aletrino meende dat dit vooral mogelijk zou zijn indien de medici een voorbeeld aan Darwin zouden nemen en niet direct beroemd wilden worden. Na dertig jaar observatie van regenwormen zouden zij er uiteindelijk ook komen. Geduld en zorgvuldigheid waren, hoewel niet op de wijze waarop Aletrino deze beschreef, ook volgens W.C. Schimmel, leraar aan de Rijks Veeartsenijschool te Utrecht, de beste preventie tegen misstanden. Onder de 'jongelui' aan wie hij doceerde, noch onder zijn collega veeartsen kwam enige ruwheid voor. Dit kwam omdat de operaties dagen van de voren werden voorbereid om deze zo goed en zo snel mogelijk te laten verlopen. Het waren juist de leken die er, volgens Schimmel, 'zonder voorbereiding maar op in sneden'.

De Utrechtse arts G.W. Zadelhoff meende eveneens dat de wetenschap in goede banen kon worden geleid indien de vivisectie slechts aan een selecte groep zou worden toegestaan. Hij dacht daarbij niet uitsluitend in termen van het door Schimmel gehanteerde onderscheid tussen deskundigen en leken. Zadelhoff was van mening dat ook onder de eerstgenoemde groep hoge en lage naturen te vinden waren en was er een voorstander van dat alleen de 'hoogstaanden' die bereid waren om een 'betrouwbaarheidseed' af te leggen, de bevoegdheid mochten hebben om dieren te 'offeren'. Het was de beschaving en het zedelijk peil van de persoon waar het volgens deze arts op aan kwam.

Van Rees was het in zekere zin met hem eens. Volgens hem was het belangrijk dat de individuele medicus zich bewust was van de ethische, zedelijke zijde van zijn handelingen, van de grote politieke en maatschappelijke verantwoordelijkheden die aan zijn werk verbonden waren. De wetenschap kon veel schade aanrichten als dit besef op het niveau van de individuele medicus niet aanwezig was. Dit kon volgens Van Rees uitermate goed geïllustreerd worden aan de hand van de toepassing van sera en vaccins. Deze stelde de geneesheer in staat om zwakke individuen met een ongezonde en dus moreel laakbare levenswijze te genezen van of te beschermen tegen ziekten waaraan zij anders zouden zijn bezweken. De zwakkeren in de samenleving werden op deze wijze in staat gesteld om hun gebrekkig weerstandsvermogen door te geven aan het nageslacht met een algemene ontaarding van het ras tot gevolg.

Van Rees pleitte ervoor dat de 'rasquestie' zou meewegen in de beslissingen van medici. In plaats van proefnemer en toediener van vaccins, diende de geneesheer voor de samenleving een gids te zijn voor een gezonde en morele levenswijze. ${ }^{58}$ Door persoonlijk het goede voorbeeld te geven, door het propageren van een vleesloos dieet, geheelonthouding, door niet te roken en te wijzen op de voordelen van het rein-leven, kon hij er toe bijdragen dat veel ziekten werden voorkomen. Het ras zou op deze wijze sterker worden en de opoffering van dieren om een zondige levenswijze in stand te houden zou overbodig worden. Dat de meeste medici dit alles niet inzagen weet Van Rees aan hun 'vivisectorische opleiding'. Hoe kon het anders verklaard worden, zo vroeg hij zich af, dat een man als collega Cornelis Pekelharing voorzitter was van de 'Volksbond tegen Drankmisbruik' maar tegelijkertijd volkomen vreemd stond tegenover 'De ethische beteekenis van de persoonlijke algeheele onthouding van alcoholische dranken tegenover de zwakkeren individuen [... [? ${ }^{59}$

Naar aanleiding van deze uiteenzetting vroeg de Commissie inzake Vivisectie of Van Rees, met zijn begaanheid met de kwaliteit van het ras en het belang dat hij hechtte aan de voorbeeld-

58. Jan Nourdman. Om de kwaliteit vin hel nageslachi. Eugenetica in Nederland 1900-1950 (Nijmegen 1989 ) 187.

59. Rapport antw. op vragen $186-189,24-25$ 
functie, zo ver zou willen gaan dat hij zelf van het gebruik van op vivisectie gebaseerde geneesmiddelen zou willen afzien, zelfs indien dit zijn leven zou kosten. Van Rees verklaarde dat hij, evenals Felix Ortt, bereid was om te sterven. Hij wist evenwel niet zeker of hij niet zou aarzelen indien het om zijn eigen nageslacht ging:

'Doch voor het geval dat ik ooit, wat ik vurig hoop dat mij gespaard zal blijven, voor de moeilijkheid kwam te staan, dat een medicus, die mijn vertrouwen bezat, voor kind of kleinkind in hoogste gevaar als eenig redmiddel serum-injectie voorschreef, acht ik het voorbarig nu in alle veiligheid uit te maken, dat ik dan in mijn groot streven naar redding niet de zwakheid hebben zou, hem deze injectie te laten uitvoeren. Doch ik zou het ook dan verkeerd blijven achten en alleen uit zwakheid aanvaard. ${ }^{60}$

Ook Aletrino verklaarde zich evenals Van Rees en Ortt bereid om te sterven in plaats van te genezen door proeven op levende dieren. De laatste stap, de acceptatie van het offer van geliefden kon hij naar eigen zeggen eenvoudigweg niet zetten:

'Wanneer ik ziek zou zijn, en men zou mij zeggen, dat ik alleen te redden zou zijn, wanneer op eenige tientallen dieren vivisectie zou worden gedaan, zou ik antwoorden: Laat mij maar doodgaan. Zoo prettig vind ik het niet, en zooveel waard acht ik me ook niet. Maar wanneer mijn vrouw of een vriend, van wien ik veel houd, alleen gered kon worden door het opofferen van honderden dieren en die beslissing aan mij stond, dan zou ik niet weten, of ik niet zou zeggen: Offer die dieren maar op. Zelfs zou ik niet weten, of $i k$, wanneer onder diezelfde omstandigheden menschen zouden moeten worden opgeofferd, ik ook dan niet toestemming zou geven. ${ }^{61}$

Van Rees, Ortt en Aletrino gingen er met andere woorden vanuit dat de donkere, onberekenbare zijde van de wetenschap juist door de angsten van het individu, het belang dat het aan zijn eigen leven en vooral aan dat van zijn geliefden hechtte, werd gestimuleerd en legden de schuld dus uiteindelijk niet uitsluitend bij de vivisectoren.

De gevoelens die Van Rees en Ortt min of meer als schadelijke zelfzuchtigheid definieerden, vormden voor de voorstanders van vivisectie die door de Commissie inzake Vivisectie werden gehoord -de Utrechtse hoogleraar Hendrik Zwaardemaker, de Amsterdamse hoogleraar neuropathologie en psychiatrie C. Winkler, de directeur van het Amsterdamse gemeentelijk abattoir, D. van der Sluys en de eerder genoemde W.C. Schimmel- juist een belangrijke legitimering voor medisch-wetenschappelijke experimenten op levende dieren. Een en ander blijkt uit het verhoor van Zwaardemaker. Deze hoogleraar noemde de vivisectie een 'volkomen zedelijk en door de humaniteit voorgeschreven wijze van onderzoek' en onderbouwde deze stelling als volgt:

'Staat het vast dat de mensch recht heeft om te leven, dan is het ook geoorloofd alle middelen, die godsdienst en wijsbegeerte toelaten, toe te passen. Een verbod van vivisectie zou de geneeskunde onbeweeglijk vast leggen en de leden der maatschappij zouden in aantal verminderen, de gezondheidstoestand zou afnemen en dan zou men van zelf van dit dwaalbegrip terugkomen. [...] ik raadpleegde mijn theologische en filosofische ambtgenooten, waarbij mij bleek dat geen enkel gecodificeerde, goed uitgedachte godsdienst of wijsbegeerte vivisectie verbiedt. Het lot van de menschheid is slecht; wat wij daaraan kunnen doen, mogen wij niet nalaten. ${ }^{62}$

Toen de Commissie in zake vivisectie tijdens het interview met Aletrino deze kwestie ter tafel bracht gaf de literator te kennen dat hij dergelijke verwijzingen naar de mensheid niet vertrouwde:

'[...] de menschheid, de menschheid ! Vooral wanneer dat gezegd wordt met ten hemel geslagen oogen en een zalvende stem. Natuurlijk, wie voor de menschheid voelt, staat hooger.

60. Rapport. antw. op vragen 186-189, 24-25.

61. Rapport, antwoord op vragen 128 en $129,15$.

62. Rapport, antw. op vraag $103,10$. 
Jammer, dat ik niet veel van dat voelen voor die menschheid geloof. De Menschheid is in dat verband een frase. ${ }^{63}$

Van Calcar nam met dit antwoord geen genoegen. Medelijden met de mensheid bestond onder medici wel degelijk. De geïnterviewde was immers zelf arts en kende toch de gevoelens van de geneesheer aan het ziekbed van een patient met een bloedspuwing. Aletrino kende die gewaarwording naar zijn zeggen inderdaad, maar stelde dat het hier beslist niet om medelijden met de mensheid ging. Wat Van Calcar beschreef was eerder een vorm van identité personelle. Omdat de medicus zijn patient persoonlijk kende, identificeerde hij zich met hem en voelde hij medelijden. Met de menschheid kon hij zoiets niet doen. De identité sociale was veel oppervlakkiger, en zeker geen reden om vivisecties te verrichten. ${ }^{64}$

Winkler was het daar niet mee eens. Een en ander blijkt wel uit het diens geïrriteerde antwoord op de vraag van het commissie-lid Brants of de mens het recht had om over het dier te beschikken:

'Mag ik dit met een wedervraag beantwoorden? Wie geeft $U$ het recht de vivisectie te bestrijden, als het vast staat, dat menschen van die bestrijding de slachtoffers zijn? Als voorbeeld noem ik het diphterie-serum, door vivisectie gevonden. Zonder dierexperiment zou ook de hersenchirurgie onmogelijk zijn, die toch ook hare resultaten heeft gegeven.

Heeft $U$ het recht aldus menschen te doen verliezen om dieren te beschermen?'05

Toch onderkende ook de fanatieke Winkler het bestaan van een gevaarlijke zijde van de wetenschap. Waar de op beperking van vivisectie gerichte en anti-vivisectionistische genodigden de vivisectie als een materialisering van deze onberekenbare kant beschouwden, meende Winkler juist dat experimenten op dieren preventief werkten tegen een ontsporing van de wetenschap: 'Hoe hard het klinke, ben ik overtuigd van de waarheid der stelling: de voortschrijdende wetenschap gaat over stapels lijken'. Er waren volgens de spreker vele nodeloze operaties op mensen verricht alvorens er één slaagde. Zonder vivisectie zouden proeven op mensen naar zijn mening enorm toenemen.

Het kostte Winkler overigens moeite om deze door hem zelf gekenschetste zijde van de wetenschap onder ogen te zien, want toen Brants hem vroeg of de medische wetenschap 'verhoogd' zou worden indien proeven op mensen verboden werden, antwoordde de hoogleraar met de wedervraag of deze dan voorkwamen. Brants, kennelijk opgewarmd door de snauwerige antwoorden van de genodigde, overhandigde hem daarop prompt een artikel van Ortt dat twee maanden voor het verhoor in Orgaan ${ }^{66}$ was gepubliceerd en een aantal citaten uit medischwetenschappelijke tijdschriften bevatte die wezen op experimenten op mensen. Enigszins uit het veld geslagen antwoordde Winkler dat hij over de genoemde gevallen zo snel niet kon oordelen. Hij was wel bereid om ten overstaan van de commissie te erkennen dat experimenten op mensen zonder meer misdadig waren. Deze mening waren vrijwel alle genodigden toegedaan. Alleen Van Rees leek te aarzelen:

'Indien iemand voor vivisectie een kind opeischte dan voelt een ieder, dat dat zedelijk ongeoorloofd zou zijn. Ik vraag nu, waarom dan ook niet ten opzichte van een hoogstaand dier, een volwassen hond hijv. die misschien meer pijn gevoelt dan een zeer klein kind. Stel dat ouders zulk een kind afstonden, dan zouden tegen zulk een bedrijf de tegenwoordige vivisectoren zelf opkomen. Is het met dieren dan anders, die door overmacht worden gebruikt. ${ }^{67}$ En met deze vraag stipte Van Rees een tweetal kwesties aan die door alle verhoren heen speelde: had de mens het recht om het dier voor experimenten te gebruiken en welke rol speelde de

63. Ibidem, antwoord op vragen $137.138,16-17$.

64. Ibidem.

65. Ibidem, antwoord op vraag 166, 20.

66. Ortt. 'Vivisectie op menschen', Orgaan 4 (1908) 43

67. Verslag, 23. 


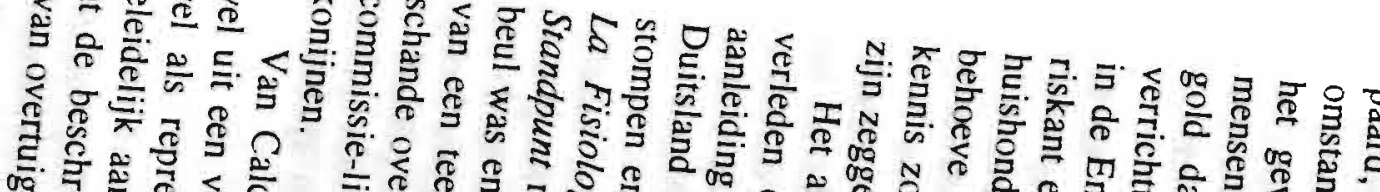

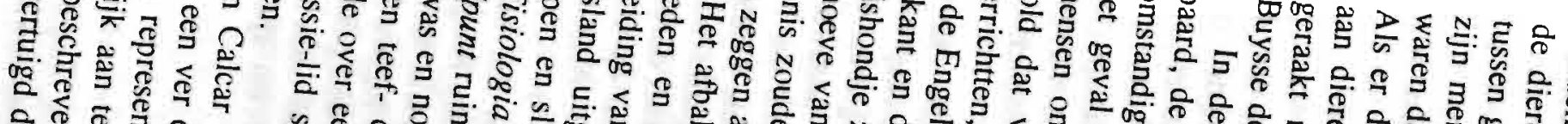

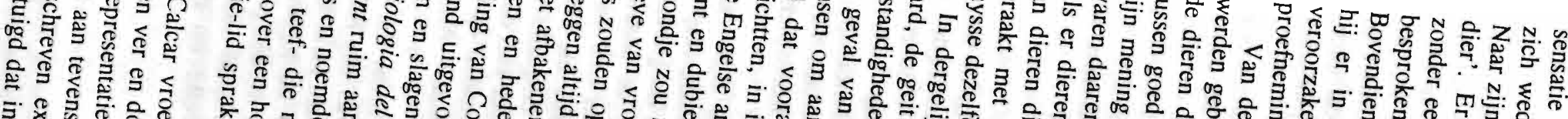

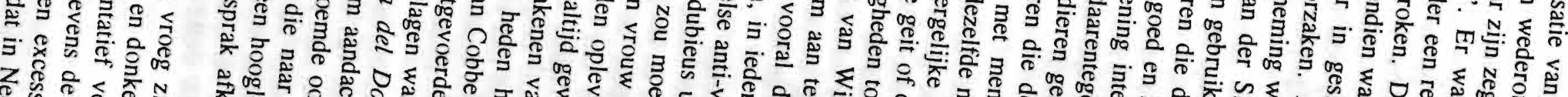

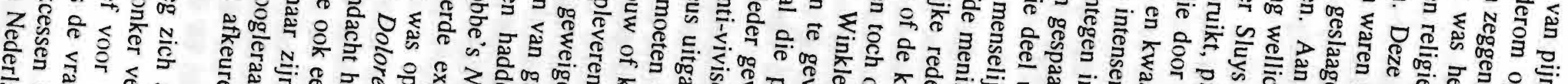

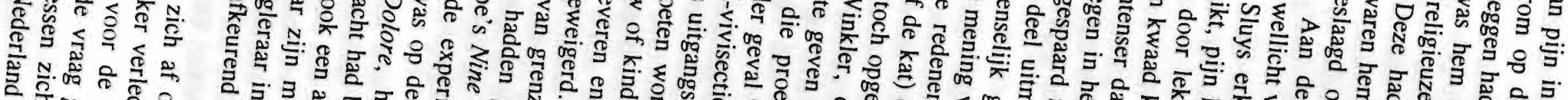

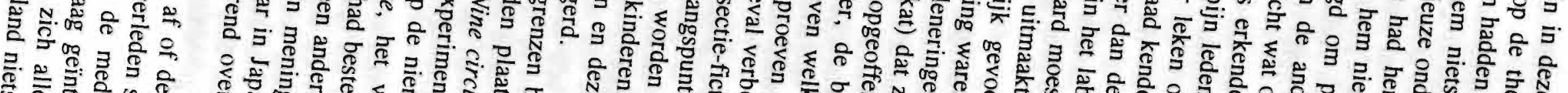

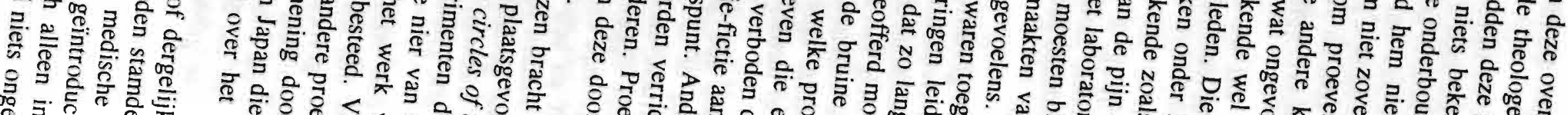

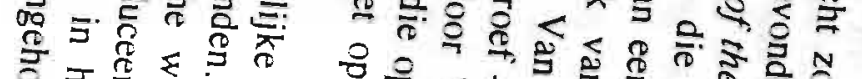
후웜

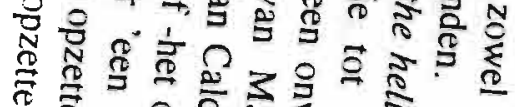

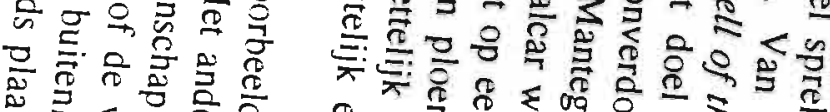

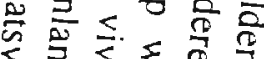

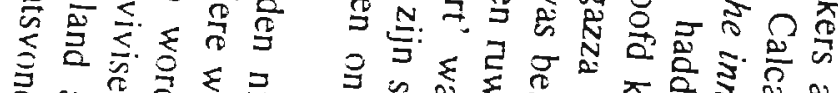

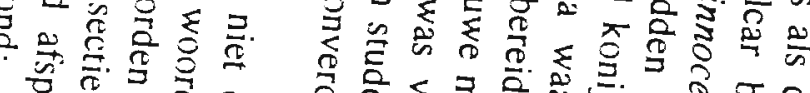

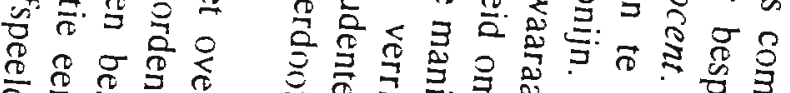

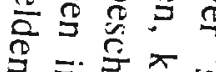

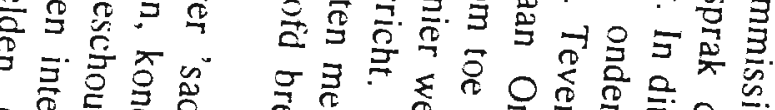

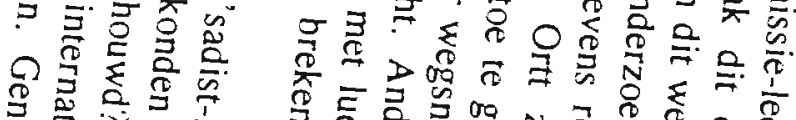

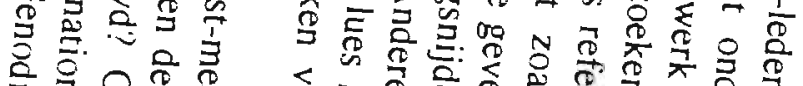

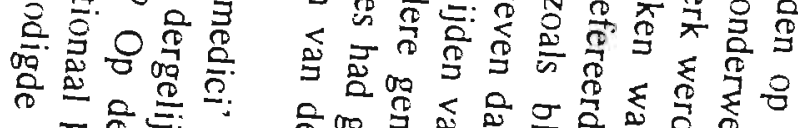

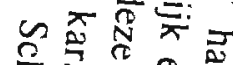

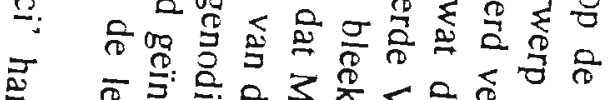

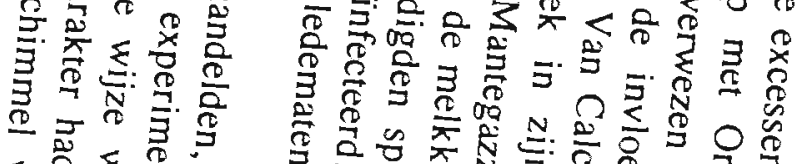

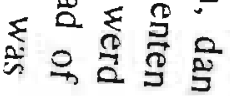

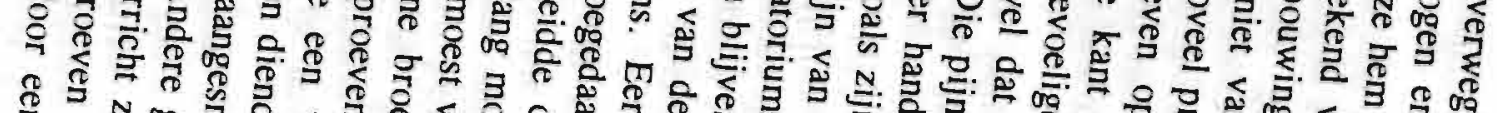

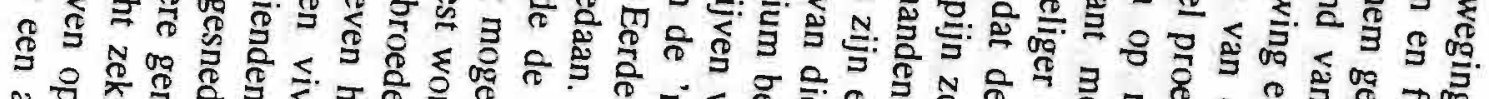

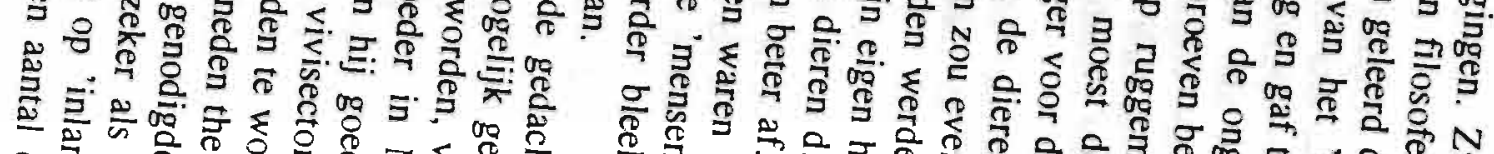

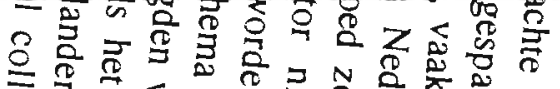

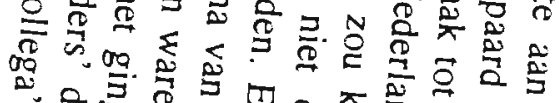

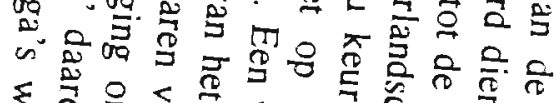

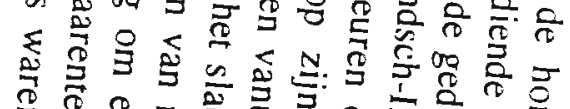

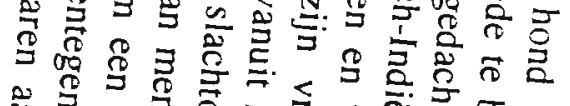

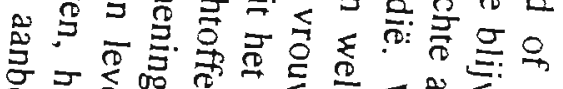

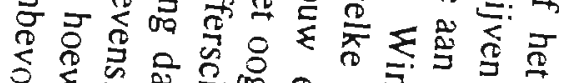

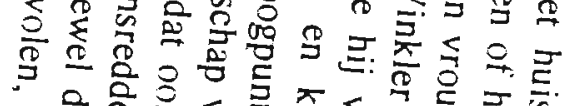

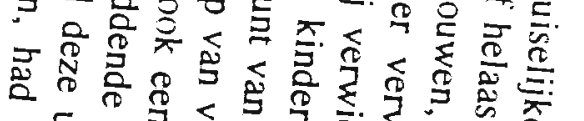

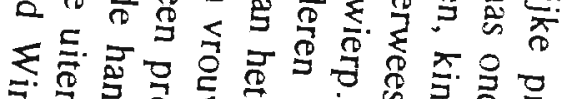

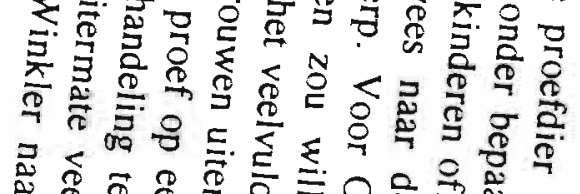

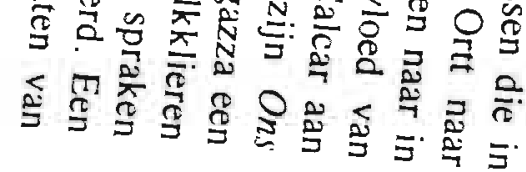

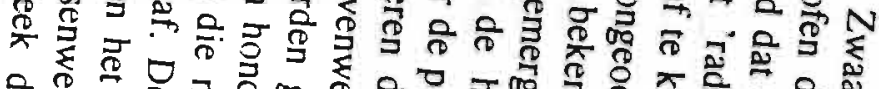

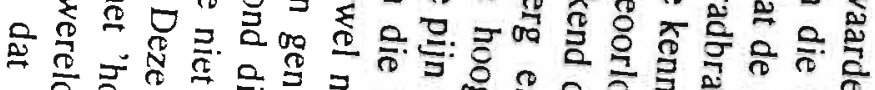

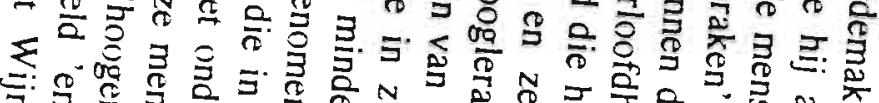

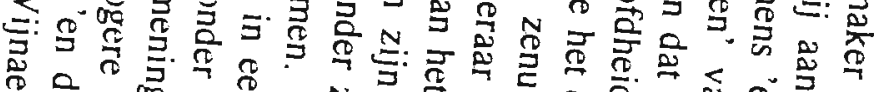

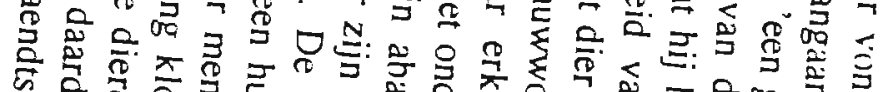

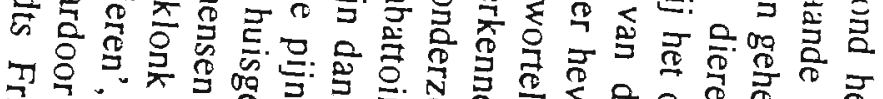

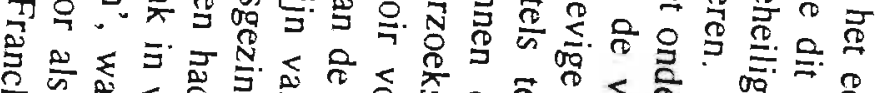

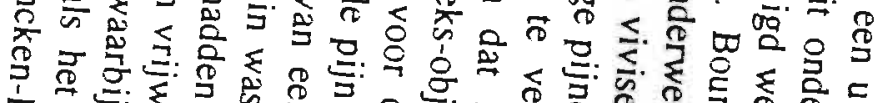

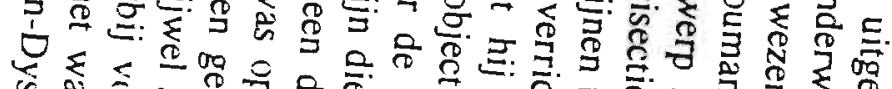

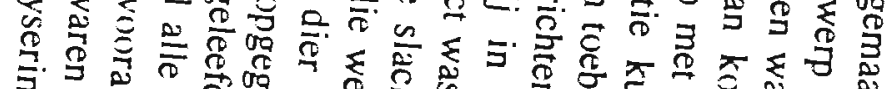

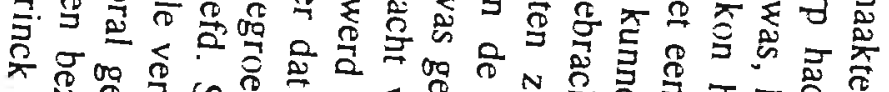

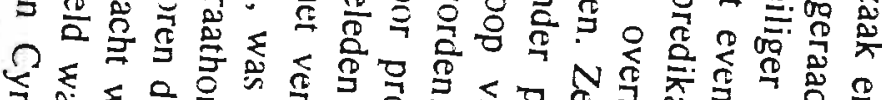

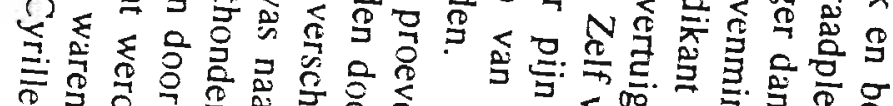

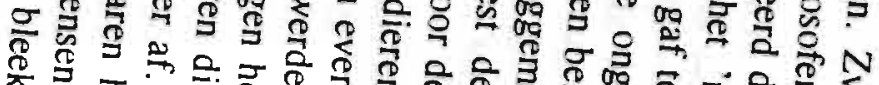

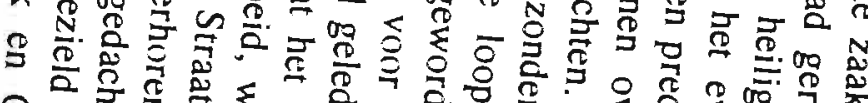


'Neen, nooit. Mogelijk denkt $U$ aan de legende dat aan de veeartsenijschool jarenlang een schaap werd gehouden waarbij men telkens een been brak teneinde dit door de jongelui te

doen zetten. Dat is een leugen; hoe men aan zoo iets is gekomen, begrijp ik niet. ${ }^{68}$

Ortt stelde zich wat dit punt betreft op een standpunt dat ook in het parlement door de antirevolutionaire kamerleden naar voren was gebracht. Wellicht waren excessen in Nederland tot nu toe minder voorgekomen dan in het buitenland maar er was niets dat garandeerde dat de wetenschap niet ook aan haar Nederlandse dienaren dezelfde vragen zou stellen. De vivisectie was een internationaal verschijnsel. Dit bleek wel uit de experimenten die waren verricht door twee Utrechtse hoogleraren die konijnen in heet water hadden ondergedompeld om hun op deze wijze brandwonden toe te brengen. De meeste genodigden, zo ook bijvoorbeeld de anti-vivisectionist Van Rees, plaatsten de onberekenbare, gevaarlijke zijde van de wetenschap evenwel toch vooral in het buitenland, waar deze dreigde uit te groeien tot een gevaar voor het nabije Nederland.

\section{Het rapport}

De Commissie inzake vivisectie bracht zo goed en zo kwaad als het ging -soms stuitten zij op instituten of personen die geen medewerking aan de door de Commissie georganiseerde enquête wilden verlenen- in kaart hoeveel medisch-wetenschappelijke proeven op levende dieren er in de periode september 1907-september 1908 in Nederland waren verricht, waar dit geschiedde, met welke doel en door wie. Ongeveer duizend vivisecties werden gemeld. Een groot deel was verricht op konijnen, cavia's, honden, paarden en kikvorsen in ziekenhuizen, krankzinnigeninrichtingen, sanatoria, keuringsdiensten van handelswaren en levensmiddelen, in abattoirs, in apotheken en laboratoria voor chemisch en bacteriologisch onderzoek, in chemische, farmaceutische, serotherapeutische inrichtingen of fabrieken, aan universiteiten, een enkele H.B.S., aan de Rijks Veeartsenijschool en aan de Universiteiten.

Ook inventariseerde zij door middel van een enquête onder alle Nederlandse artsen hoe medici over het nut van vivisectie voor het onderwijs dachten. Daaruit kwam naar voren dat vijfenvijftig procent van de ondervraagde artsen van mening was dat de proeven op levende dieren voor het beschreven doel nuttig tot zeer nuttig waren. De rest van de ondervraagden achtte de vivisectie voor het onderwijs soms nuttig, dan wel niet nuttig, overbodig, twijfelachtig, of liet de vraag onbeantwoord.

Tijdens haar onderzoek werd de commissie er door verschillende personen op geattendeerd dat er misbruiken en misstanden tijdens medisch-wetenschappelijke experimenten op dieren hadden plaatsgevonden. De commissie zelf signaleerde dat de proeven van Dr. H. Couvée onnodig pijnlijk waren. De betreffende medicus makkte in zijn in 1902 verdedigde proefschrift melding van proeven op meer dan vijftig konijnen waarvan zonder dat zij verdoofd waren de nieren waren geëxstirpeerd. Vervolgens had de promovendus de konijnen laten doodhongeren tot zij na honderd uur 'ten gronde gingen'. De commissie sprak haar verwondering uit over het feit dat Couvée in zijn dissertatie niet vermeldde waarom hij verdoving of een gedeeltelijke anesthesie achterwege had gelaten en vroeg zich af of hij zich daarvoor bij de verdediging van zijn proefschrift had moeten verantwoorden. Van de andere misbruiken die de commissie op het spoor was gekomen werden geen details gegeven. Het was, zo werd in het rapport gesteld, niet het oogmerk van de commissie om deze 'wreedheden' die in het verleden hadden plaatsgevonden en waar dus niets meer aan te doen was, aan de kaak te stellen. Het ging haar uitsluitend om het bevorderen van doelmatige maatregelen om zulke gevallen in de toekomst zoveel mogelijk te voorkomen.

In het rapport werd vervolgens het standpunt van de commissie tegenover vivisectie in het algemeen uiteengezet. Alle leden van de commissie erkenden, sommigen na enige aarzeling, dat de wetenschap niet buiten de wetten der moraliteit en zedelijke opvattingen der maatschappij mocht treden. De wetenschap was bovendien 'uit haren aard' niet vrij om zonder enige bemoeienis van de overheid de middelen te kiezen die zij voor het verkrijgen van kennis nodig achtte. Het 
uitgangspunt van de soevereiniteit van de wetenschap werd aldus verworpen. Haar vrijheden en daarmee de vivisectie vormden, zo concludeerde de commissie, een zedelijk vraagstuk.

Hoe belangrijk de kwestie van de zedelijkheid voor de Commissie was, blijkt uit de wijze waarop zij de standpunten die in de loop van de hoorzitting naar voren waren gebracht, samenvatte. Tijdens de verhoren waren, zo stelt het rapport, vijf meningen over de zedelijkheid van medisch-wetenschappelijke experimenten op dieren naar voren gebracht. In vier van deze vijf werd ervan uitgegaan dat de vivisectie vanuit een zedelijk oogpunt niet te rechtvaardigen was. Alleen de vraag of er om die reden een wettelijk verbod of een regulering van vivisectie noodzakelijk was, werd op verschillende wijzen beantwoord. De commissie stelde zich op geen van de vijf standpunten maar formuleerde een eigen zesde mening:

'De commissie acht vivisectie wegens haar onmiskenbaar gebleken, groot nut voor de menschheid in het algemeen en voor de lijdende menschheid in het bijzonder een uit zedelijk oogpunt geoorloofd middel ter bevordering van wetenschappelijke kennis en ter opleiding van aanstaande genees- of veeartsenijkundigen. ${ }^{69}$

De gehele moderne medische wetenschap was op vivisectie gebaseerd en het zou volgens de commissie dan ook onjuist zijn om deze te verbieden, ook wanneer het pijnlijke en bloedige proeven op levende dieren betrof. Een kleine minderheid van de commissie (waarschijnlijk Brants en Van Idsinga) was van mening dat de vivisectie niet zedelijk geoorloofd was en stelde dat deze onderzoeksmethode even veel afkeuring verdiende als het gebruik van de pijnbank om achter de waarheid te komen tijdens een rechtszaak. Deze commissieleden moesten evenwel erkennen dat hun mening niet door brede lagen van de bevolking werd gedeeld en dat vele achtenswaardige personen een andere mening toe waren gedaan.

Alle leden van de commissie waren het er mee eens dat bloedige en pijnlijke experimenten en het daarmee gepaard gaande lijden van de dieren zoveel mogelijk beperkt dienden te worden. Wettelijke regelingen die dit zouden bevorderen, verdienden volgens de commissie daarom aanbeveling. De voorkeur ging uit naar een door Rochussen voorgestelde speciale wet door middel waarvan werd vastgesteld waaraan alle proeven dienden te voldoen. Daarbij zou allereerst worden bepaald dat vivisectie niet uitsluitend betekende 'het snijden in levende organismen'. De term omvatte tevens verbrandingsproeven of het breken van beenderen als mede injecties van vergiften of ziektestoffen, het inwendig of uitwendig toedienen van voor het proefdier meer of minder schadelijke stoffen. De definitie van vivisectie die naar het oordeel van de commissie diende te worden gehanteerd was:

'Het gebruiken van een levend dier als proefmiddel voor eenig onderzoek of als hulpmiddel

bij het onderwijs of voor medische of veterinaire doeleinden op eene wijze waardoor men het dier verwondt of het in eenig ander opzicht doet of kan doen lijden. ${ }^{70}$

De commissie was van mening dat het verrichten van vivisectie aan een vergunning en het aanschouwen van dierproeven aan een leeftijdsgrens gebonden moest zijn. Op deze wijze zou steeds tot uitdrukking worden gebracht dat de vivisectie een 'te betreuren noodwendigheid' was.

Een verbod op het gebruik van bepaalde dieren werd afgeraden, maar de commissie zag graag dat huisdieren, dat wil zeggen dieren die in 'dagelijksch verkeer' met mensen waren geweest, door een speciale wettelijke regeling beschermd werden. Apen dienden vanwege hun gelijkenis met de mens zo min mogelijk gebruikt te worden, ongewervelde dieren verdienden de voorkeur boven gewervelde dieren. Narcose of plaatselijke anesthesie moesten steeds en in voldoende mate aangewend worden, tenzij deze het dier meer zouden doen lijden dan de verrichting zelf, of wanneer zij het doel der vivisectie zouden verijdelen. De dieren dienden na de proefnemingen nog onder narcose te worden afgemaakt tenzij zij geen functiestoornis zouden vertonen en het zeker was dat zij geen pijn leden.

69. 'Standpunt der Commissie tegenover vivisectie in het algumeen' in: Rapport (1909) 14-18, aldaar 15.

70. Ibidem, 17. 
Het naleven van de wet zou volgens de commissie bevorderd kunnen worden door een registratie van alle vergunninghouders en de lokaliteiten waar vivisectie werd verricht en door strenge straffen in te stellen voor de personen die zich niet aan de regels hielden. Overtreding van de wet diende te worden bestraft zoals was vastgesteld in artikel 254 en zou moeten leiden tot het intrekken van de vergunning. Een inspecteur die een groot dierenvriend en iemand met kennis van vivisectie moest zijn, zou moeten worden aangesteld om ter plekke controles uit te kunnen oefenen en alle informatie te vragen die hij nodig achtte. De inspecteur zou de bevoegdheid moeten hebben om zelfstandig vergunningen in te trekken. Hij zou verslag moeten doen aan de minister, het openbaar ministerie en aan een speciaal in te stellen Commissie van onderzoek en advies die beslissingen nam over de uit te vaardigen vergunningen en die de registratie van deze op zich zou nemen. Iedere proefnemer zou jaarlijks opgave moeten doen van de verrichte vivisecties en bovendien beval de commissie aan om een jaarlijks rapport te publiceren met daarin een opgave van alle verleende vergunningen, alle verrichte vivisecties en alle geregistreerde lokaties. Ten slotte stelde de commissie dat de aandacht van de ministers tevens uit zou moeten uitgaan naar de omstandigheid dat in Nederlandsch-Indië eveneens vivisectie werden verricht en dat gelijksoortige maatregelen als aanbevolen ook voor de koloniën dienden te worden vastgesteld.

\section{Besluit}

Zowel de vivisectie-bestrijders als hun medisch-wetenschappelijke tegenstanders etaleerden hun hoge morele opvattingen door zich te beroepen op hun individuele relatie met het hogere. Ortt beriep zich op Christus en de eerste christenen, Van Rees op de zuivere christelijke leer van Tolstoj. Zwaardemaker droeg er zorg voor goed uit te laten komen dat zijn opvattingen op een canon van theologische en filosofische denkbeelden steunden. Bouman benadrukte dat hij bij een geestelijke om raad had gevraagd. Het beroep op emotionaliteit, op gevoelens en liefde was geen van de bovengenoemden vreemd.

De in het perspectief van winnaars en verliezers zo sterk van elkaar onderscheiden soorten politiek deelden een sterke afkeer van een wettelijke regulering van het vivisectie-vraagstuk. De inhoud van hun politieke standpunt kwam vooral overeen op het punt waar de beknotting van de handelingen van het individu ter sprake kwam. Door beide groepen werd gewezen op het belang van het individuele karakter, het geweten en de daaraan gekoppelde verantwoordelijkheid van de betreffende persoon. Uiteindelijk was deze gerichtheid op het individu op sommige momenten bij de medische wetenschappers zelfs nog sterker aanwezig dan bij de anti-vivisectionisten. Waar Ortt reeds in 1907 te kennen gaf dat hij zich wellicht op een te anarchistisch standpunt had gesteld en moest erkennen dat wetten nuttig konden zijn om moreel achterlijken tot verbetering aan te sporen $^{71}$, stelden de meeste medici dat alleen al de vraag naar een wettelijke beperking als een wantrouwen ten opzichte van de persoon van de medicus kon worden beschouwd.

Als reactie op het gesignaleerde wantrouwen etaleerden de wetenschappers zich als hardwerkende, zich voor de mensheid opofferende mannen, die juist oordeelden over de noodzaak van de uit te voeren experimenten en het toe te brengen leed aan het proefdier. De anti-vivisectionisten presenteerden zich op vergelijkbare wijze. Tegenover het beeld van de medicus stelden zij hun eigen bereidheid om te sterven, een zekere verachting van het aardse leven en hun persoonlijke relatie met het hogere of met een hoogstaande levensbeschouwing.

Voor de politieke stijl van zowel de pro-vivisectionisten als de anti-vivisectionisten gold dat deze, juist door het beroep op mannelijke offervaardigheid, als het ware vrouwen uitsloot. In het door beide groepen voor het voetlicht gebrachte wereldbeeld was voor vrouwen slechts de rol weggelegd van slachtoffer of passief object van onderzoek of redding. Tot enige weerstand werden zij niet in staat geacht, net zo min als er aan hen enige beslissingsbevoegdheid werd toegekend. Mannen als Ortt, Aletrino en Van Rees, maar ouk hun medische tegenstrevers schetsten hoe zij aan het ziekbed van vrouwen of kinderen zittend, beslisten welk offer gebracht zou worden en

71. Felix Ont, Vivisectie-bestrijding (z.p. 1907) 3. 
door wie. In hun voorstelling zijn zij het die voor de moeder beslissen of haar kind al dan niet een vaccinatie krijgt, zijn het mannen die uitmaken of er al dan niet dieren worden opgeofferd om het leven van de vrouw of kind te redden. De vrouw is in deze manier van denken evenals het proefdier volkomen handelingsonbekwaam. Haar positie is gelijk aan die van een getrouwde vrouw, en het is dan ook alsof pro- en anti-vivisectionisten een collectief huwelijk met haar zijn aangegaan om des te duidelijker de mannelijke opofferingsgezindheid en zedelijke kwaliteiten te doen uitkomen.

Alleen Winkler geeft een op het eerste gezicht ander beeld van vrouwen. Hij beschrijft hoe zijn eigen vrouw zeer handig is in het verwijderen van het gehoor bij duiven. Dit doet hij evenwel niet om de aandacht op haar kundigheid te vestigen, maar om aan te tonen dat de anti-vivisectionistische gedachte van medelijden met al het levende niet vol te houden is. Het vernietigen en pijnigen van andere wezens was inherent aan het menselijk bestaan en dit werd geïllustreerd door de handelingen van de verder zo zachtaardige mevrouw Winkler.

Met deze opmerking plaatste Winkler zich in de traditie van de negentiende-eeuwse positivistische medici. Dezen, zoals de eerder genoemde fysioloog Paolo Mantegazza, benadrukten vooral de verwoestingen die de mens alleen al door te leven, te eten en te bewegen zou aanrichten. Niet voor niets was het motto van Fysiologia del Dolore: 'Homo natus de muliere brevi vivens repletur multis miseriis'. ${ }^{72}$ Ook Van Calcar wees in zijn brochure De vivisectie op juist deze zijde van het menselijk bestaan. Naar zijn mening was het onzinnig om de opvattingen van Darwin over de verwantschap van dieren en mensen als uitgangspunt voor ethische beschouwingen te nemen zoals Luchtmans in zijn geschrift Pro en Contra proeven op levende dieren had gedaan. Wanneer men zo ver ging ieder leed dat dieren werd aangedaan te betreuren, kon men eenvoudigweg niet leven. Men zou ten ondergaan aan de gevoelens van de zogenaamd verwante mossel of de vlo. Toch speelde Darwin ook in het denken van de voorstanders van vivisectie een uitermate belangrijke rol. Zij beriepen zich op de strijd tussen al het levende en op de lichamelijke overeenkomsten tussen mensen en dieren. $\mathrm{Zij}$ vonden in verwijzingen naar Darwin een legitimatie voor proeven op levende dieren, net zoals de anti-vivisectionisten daar een reden voor de strijd tegen vivisectie in vonden.

Deze dubbelzinnigheid lag overigens ook in de persoon en het denken van Darwin zelf besloten. Darwin was een groot voorstander van wetenschappelijke vrijheid en daarom een tegenstander van een wettelijke regulering van vivisectie, of liever gezegd een opponent van de Engelse anti-vivisectie-beweging. Tegelijkertijd had hij een grote afschuw van pijn en het lijden van dieren in het bijzonder. Vivisecties had hij daarom nooit willen verrichten of aanschouwen. Een dergelijke paradoxale houding was ook te vinden in het werk en de personen van Emants en Buysse. Als pur sang naturalisten waren zij literaire navolgers van Claude Bernard, de beroemde en beruchte Franse vivisector. Tegelijkertijd zagen zij de vivisectie graag aan banden gelegd en zo veel mogelijk beperkt.

Zelfs Bernard, die evenals Mantegazza door de anti-vivisectionisten als een duivel werd afgeschilderd, was in zekere zin verwant aan zijn tegenstrevers. Zijn werk was doorspekt met bijbelse metaforen en verwijzingen naar de uiterste consequenties van zijn eigen levensbeschouwingen, van de experimentele wetenschap. Dit had hij met de Nederlandse anti- en pro-vivisectionisten gemeen. Ook zij gingen uit van extremen, van uitersten, en verkenden op deze wijze de grenzen van het schijnbaar onbeheershaar autonoom fenomeen: de wetenschap.

72. De mens uit een vrouw geboren en slechts korte tijd levend, lijdt overstelpend veel smart (Giobbe). Mantegazza verdedigde zich in zijn werk tegen de anti-vivisectionistische beschuldigingen: 'lk, die van toen af pijn langs experimenteelen weg begon te bestuderen, gevoelde behoefte om mij tegen de beschuldiging van wreedheid te verdedigen en ik schreef: Sommige van die barmhartige uitingen van teederheid voor dieren gelijken veel op arcadische gedichten. vol gemelijke gemaaktheid en sentimentaliteit; het zijn volstrekt geen moreele problemen, omdat ook zelfs het fijnste meisje, dat niet zien kan dat men een kip den hals omdraait, welke zij toch met smaak eet, toch een arme vloo, die in haar lief velletje bijt, wreedaardig doodknijpt (Mantegazza. Fysiologie 424). Interessant is dat Mantegazza de nadruk legt op de fictionele zijde van de anti-vivisectie geschriften. 
Alleen wanneer de situatie in Nederland ter sprake kwam, werd een poging gedian om nan deze denkwijze afstand te nemen. De uiterste consequenties waren, $z_{0}$ meenden allen, in Nederland nog niet getrokken. Nederland was een eiland in een wereld die reetis diloor thet Itwagall van de extremen was overspoeld. Tegelijkertijd werd gewezen op de zedelijke acthterstanilspositie van Nederland. De medici beklemtoonden vooral het feit dat Nederland im stekensthapretlijk opzicht achterop dreigde te raken en presenteerden dit probleem als eten ldoweestie die raaum samenhing met beschaving.

In zekere zin kan dan ook gesteld worden dat zowel anti-vivisectionistehals prowwiwisectionisten dragers waren van een beschavingsoffensief dat, zoals Davids opmerkt met betretkking tot dide dierenbescherming, gericht was op de eigen klasse en bedoeld was om de elite in thet louitenlandite tonen dat Nederland tot de zedelijke naties gerekend kon worden. In ieder ggeval haan dde sicherpe scheiding die door De Rooy wordt aangebracht tussen bewegingen die geticht, wareen ogp eeen collectieve verbetering van de samenleving en de kleine geloven die dit williden Heereiken dopor middel van individuele hervormingen, voor wat betreft de anti- en pro-vivisectionisstenrodiet wwordeten gehandhaafd. Beide groepen lieten zich, anders dan door French' dichotomie een thet diaarnee verbonden winnaars- en verliezers perspectief, niet zelden leiden door ehroties, wetheetiding een

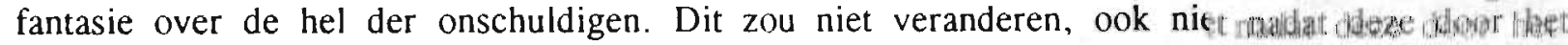
rapport van de Commissie inzake Vivisectie officieel in kaart was gebracht. 


\section{Besluit en aankomst in een nieuwe tijd}

\section{8: Een nieuw begin}

In de zomer van 1928 kijkt Suze Groshans terug op de geschiedenis van de Nederlandse vivisectie-bestrijding waarvan zij op dat moment al meer dan dertig jaar deel uitmaakt. Het waren, zo concludeert zij, jaren van 'zware arbeid'. Het gemis aan 'direct waarneembaar resultaat' van de gevoerde strijd had menig strijder tegen dierproeven, zijzelf niet in de laatste plaats, wel eens terneer geslagen. Steeds hadden echter het 'diepe geloof aan [het] ethisch fundament dat niet falen kan', en 'het geloof dat elke humanitaire beweging langzaam groeien moet' haar voor ontmoediging behoed. En niet zonder reden. Een goed voorbeeld was volgens Groshans de vredesheweging. Voor de oorlog zo bloeiend, leek al het werk van deze tak van het humanitair-idealisme na 1914-1918 'verloren' en 'vergeefs'. Toch was uit de puinhopen een 'nieuw en krachtiger' leven opgekomen, een meer 'daadwerkelijke beweging' ontstaan.

Ditzelfde proces voltrok zich volgens Groshans ook binnen de Nederlandse anti-vivisectiebeweging. Deze verjongde en vernieuwde zich doordat de anti-vivisectionisten zich niet langer uitsluitend richtten op de bestrijding van medisch-wetenschappelijke proeven op levende dieren, maar tevens werkten aan de opbouw van een vivisectie-vrije geneeskunde:

'Het spreekt vanzelf dat daarbij niets verloren mag gaan van ons onophoudelijke getuigenis, onze geloofsbelijdenis, ons zedelijk protest ! Maar naast en met dit onverzettelijk beginsel groeit een toenemend inzicht in de noodzaak van constructief werken.'

De overdenkingen van Suze Groshans zijn met het oog op de geschiedenis van de expressieve politiek van de Nederlandse anti-vivisectionisten om verschillende redenen interessant. Niet in de laatste plaats omdat Groshans in haar bespiegeling in feite een haarscherpe omschrijving geeft van deze bijzondere politieke stijl. Zij spreekt over een 'geloofsbelijdenis', een 'getuigenis van een zedelijk of ethisch standpunt' en geeft aan dat deze niet leiden tot een zichtbaar rendement op de korte termijn.

Tegelijkertijd - en dit is van belang in verband met de vraag of de kleine geloven en de antivivisectionistische politiek in het bijzonder, een ontwikkeling doormaakten- geeft zij aan dat de tijd heeft geleerd dat deze politieke stijl niet langer op zichzelf dient te staan. Getuigen en belijden was niet meer voldoende. Het was voortaan noodzakelijk om ook te streven naar een sneller te realiseren resultaat. Tenslotte springt ook de vergelijking tussen de anti-vivisectie-beweging en de vredesbeweging in het oog. Groshans stelt, in tegenstelling tot hetgeen in de historiografie doorgaans wordt aangegeven, dat het idealisme na de Eerste Wereldoorlog een nieuw begin makkte en steiker werd dan ooit tevoren. Had de presidente van de NBBV gelijk? Was de politieke stijl van de anti-vivisectionisten na de Eerste Wereldoorlog an het veranderen? Was de beweging krachtiger geworden?

\section{De anti-vivisectie-beweging gedurende het Interbellum}

Het uitbreken van de Eerste Wereldoorlog was voor de Nederlandse humanitair-idealisten een grote schok. Het kwaad leek overal om zich heen te grijpen en de goedwillenden restte niets anders dan machteloos toe te kijken. Ortts opvatting dat de staat egoïstisch en onderwerpend was, is illustratief voor deze stemming. Maar ook los van dit wereldgebeuren was de periode 19141918 en het decennium dat daarop volgde, er voor de vivisectie-bestrijding een van neergang en verliezen. Het Comité tot Beperking der Vivisectie ging in 1915 ter ziele. Het ledental van de NBBV daalde, waar het altijd rond de duizend had geslingerd, tot zeshonderd. Mogelijk waren veel anti-vivisectionisten teleurgesteld geraakt door het uitblijven van een wettelijke regulering.

1. Suze Groshans, 'Officieele mededeelingen Ned. Bond tot Bestrijding der vivisectie', Uitkomst 1 (1928) 182-185. aldaar 184. 
Wellicht hing de tanende belangstelling van de eigen achterban ook samen met een 'vergrijzing' van de bond en haar voorlieden.

De NBBV leek stervende. Mevrouw Van der Hucht-Kerkhoven was tijdens de oorlog overleden. Het zozeer met haar verbonden Androcles 'ontsliep' in 1919. Bovendien werden vanaf 1918 de afleveringen van het Orgaan niet zelden aangevangen met een overlijdensbericht van zeer actieve (hoofdbestuurs-)leden. Dezen waren weliswaar voor de gedachtenvorming over vivisectie niet zo belangrijk geweest -die rol was al die jaren toch vooral weggelegd voor Ortt, Luchtmans, Jungius en de andere in de voorgaande hoofdstukken genoemde anti-vivisectionisten- maar zij hadden wel altijd veel werk verzet om de bond draaiende te houden, de zaken financieel te regelen, propaganda-materiaal te verspreiden, de leden bij elkaar te houden en te informeren. De overleden sympathisanten waren vaak ook in de dierenbeschermingswereld bekende gezichten geweest en hadden niet zelden hun kennissen tot lid van de beweging weten te maken. De NBBV moest het steeds meer zonder deze met de bond vergroeide personen zien te stellen. ${ }^{2}$

Behalve het dramatisch teruglopende ledental en het 'afsterven' van kopstukken was er nog een reden voor bezorgdheid. Het was Ortt die wat dit betreft de alarmklok luidde. Na lezing van een Engelse anti-vivisectie brochure had hij tot zijn schrik moeten concluderen dat de antivivisectie-beweging ook in het buitenland tot stilstand was gekomen. Het geschrift was naar zijn mening aardig, maar het bevatte drogredeneringen en was meer geestig dan juist. Dat het niet geschikt was voor vertaling verbaasde Ortt niet. Wat hem zorgen baarde was dat het werk evengoed een aantal jaren geleden geschreven had kunnen zijn. Het anti-vivisectionisme was volgens Ortt nodig aan een nieuwe impuls toe, maar deze bleef door de oorlog uit.

De NBBV liet het er niet bij zitten. In de periode van neergang voltrokken zich in de wijze waarop men zich aan het publiek en de achterban presenteerde, een aantal veranderingen. Zo ging de bond er voor het eerst toe over om met enige regelmaat illustraties bij haar artikelen in het Orgaan te plaatsen. Aanvankelijk betrof het, alsof in de tijd van crisis de rijke geschiedenis en traditie van de beweging benadrukt moesten worden, vooral portretten van negentiende-eeuwse anti-vivisectionisten die als 'Pioniers in den strijd tegen vivisectie' werden aangeduid. Deze beeltenissen werden vergezeld van korte 'hagiografische' schetsen waarin de opofferingsgezindheid van de betreffende vivisectie-bestrijder werd beklemtoond.

Zo werd Anna Kingsford (1846-1888), de Engelse anti-vivisectioniste die getracht had om door middel van magische krachten Claude Bernard, Paul Bert en Louis Pasteur te doden, beschreven als een heldin en een heilige. De wijze waarop zij werd getypeerd doet denken aan de manier waarop eens de kwaliteiten van Marie Jungius waren beschreven, namelijk als een mooie, jonge en fragiele vrouw met een helder verstand die zich volledig inzette voor haar idealen. Vermeld werd dat Kingsford in Frankrijk, het bolwerk van de experimentele fysiologie, medicijnen was gaan studeren om vervolgens als arts de strijd tegen vivisectie aan te binden. Aan dit harde werken, de eenzaamheid en het onbegrip dat zij op haar weg had gevonden en het grote zielelijden dat zij had moeten ondergaan was haar zwakke gestel uiteindelijk ten onder gegaan.

Nog belangrijker dan de verdienste van Anna Kingsford voor de Engelse bestrijding van vivisectie was dat zij een bekende was geweest van mevrouw Van der Hucht. Hetzelfde gold voor Ernst von Weber wiens biografie als tweede in deze serie van pioniers verscheen. Von Weber werd neergezet als een kunstenaar en een humanitariër in de ruimste zin van het woord. Beklemtoond werd zijn zachtmoedigheid, zijn rusteloos en toegewijd arbeiden voor de goede zaak. Ook werd geschetst hoe hij door veel van zijn tijdgenoten voor dit alles was beloond met laster en vervolging. Met name de kritische reacties op Die Folterkammern der Wissenschaft werden als zodanig voorgesteld.

2. Onder wie het hoofdbestuurslid de Rotterdamse predikant Dr. H.T. Oberman, de hoofdbestuursleden J. Th. Noordijk, Johanna W. Tadema, de tekenaar Willem van den Heuvel, S.B. Criellaer en de voorzitter van de Commissie inzake Vivisectie Mr. J.W. H. M. van Idsinga. Th. P. Almelrood en de onvolprezen 2. Van Rees. 
In de serie van pioniers werden tevens portretten en biografieën gepubliceerd van Oberman, Westendorp, Noordijk, Van Idsinga, Tadema, De Klerck en Criellaert. Zij werden geprezen om hun niet aflatende inzet en dienstbaarheid aan de beweging. Over De Klerck werd gemeld dat hij zich als voorzitter van de dierenbescherming niet met de doelstellingen van de NBBV kon verenigen, maar dat hij als persoon de bond een warm hart toedroeg. Waar voorheen juist geen scheiding werd gemaakt tussen het persoonlijke en het openbare, geschiedde dit nu wel. Ook werd meer waardering uitgesproken voor de verbeelding. Criellaert, een bekend tekenaar van paarden, werd afgeschilderd als een groot voorstander van de wijze waarop de Engelse en Duitse antivivisectionisten propaganda hadden gemaakt door middel van 'gruwelboekjes' en eclatante voorbeelden van experimenten. Hij had het volgens de NBBV altijd betreurd dat de bond haar strijd, mede door de tegenstand van Ortt, niet op dezelfde wijze aanpakte. ${ }^{3}$

Deze opmerking duidt erop dat de NBBV, wellicht door wanhoop over de zich steeds duidelijker openbarende neergang van de beweging, meer openstond voor andere visies op de vivisectie-bestrijding dan voorheen. Vanaf 1915 ruimde de redactie van het Orgaan, zij het aarzelend, steeds meer plaats in voor een aspect van de vivisectie-bestrijding waar Ortt voor had gewaarschuwd: fantasie. De bond streefde daarbij wel naar een eigen weg, die van de buitenlandse strijdwijze verschilde. Evenals dit het geval was geweest bij de serie artikelen over de pioniers, zocht en vond zij die in haar eigen geschiedenis. Gedichten in de trant van het decennia geleden geschreven Vivisectie werden wederom gepubliceerd. Oude anti-vivisectie-romans als Anna, De familie van Westvoorne en Naar het groote licht werden herontdekt en, wellicht nadrukkelijker dan ooit tevoren, ter lezing aanbevolen. ${ }^{4}$ Zorgvuldig bewaarde oude exemplaren van de eerste twee romans werden te koop of te leen aangeboden, de roman van Ortt beleefde in 1918 zelfs een herdruk.

Een ander aanknopingspunt in de geschiedenis van de bond vond het hoofdbestuur van de NBBV in de relatie met de dierenbescherming, een beweging waar Van der Hucht-Kerkhoven en Groshans altijd grote sympathie voor hadden gekoesterd en waarmee ze nauwe contacten hadden onderhouden. Vanaf 1898, toen de nadruk in de strijd tegen vivisectie vooral had gelegen op een christen-anarchistische, compromisloze benadering van het vivisectie-vraagstuk, waren de dierenbeschermers voorgesteld als halfslachtigen en conservatieven. Nu Ortt in het hoofdbestuur het veld had geruimd om plaats te maken voor een aantal anti-vivisectionistische dierenbeschermers en de NBBV zulke grote verliezen leed, benadrukte de bond maar al te graag dat zij deel uitmaakte van de bredere dierenbeschermingsbeweging. Op de achterkant van het Orgaan werden zelfs advertenties van de Nederlandsche Vereeniging tot bescherming van Dieren afgedrukt.

Illustratief voor deze hernieuwde belangstelling voor de schijnbaar vergeten zijde van de antivivisectie-beweging is de aandacht die de NBBV toonde voor de benefiet-tentoonstelling 'Dier en kunst' die door twee dierenbeschermsters was georganiseerd. De bond roemde het initiatief en ging uitgebreid in op de getoonde achttiende-eeuwse en nog veel oudere kunstvoorwerpen met afbeeldingen van dieren. In het Orgaan werd niet alleen de schoonheid en de exclusiviteit van de kunstwerken geroemd maar tevens voorzichtig gesuggereerd dat uit de afbeeldingen kon worden opgemaakt dat zich gedurende de negentiende eeuw een evolutie had voltrokken:

'Zou men niet zeggen bij het aanschouwen van honden op oude schilderijen dat zij er minder verstandig uitzien dan nu, de katten minder gracieus, de paarden woester [...] Indien de menschheid vooruitgegaan is, waarom zou het dierenrijk dan stil zijn blijven staan ? [... $\left.\right|^{5}$

Een wilde speculatie, zo meende ook de auteur van het artikel, de jurist F. Witteman. Maar zijn opmerking was weer een teken dat Ortts woord niet langer wet was binnen de gelederen der antivivisectionisten. Laatstgenoemde had vóór de oorlog meerdere malen beklemtoond dat de morele

3. Suze Groshans, 'In memoriam S.B. Criellaer'. Orgaan 13 (1918) 33-34.

4. 'Verslag van de 18 de Algemeene Vergadering gehouden op zaterdag 12 juni 1915 in "Pulchri Studio Den Haag', Orgaan 11 (1915) 61-70, aldaar 62.

5. F. Wittemans, 'Tentoonstelling dier en kunst', Orgaan 13 (1917) 44-46, aldaar 45. 
evolutie waar hij vanuit ging, niet inhield dat een mus uiteindelijk meer menselijke, verstandelijke eigenschappen zou vertonen naarmate het evolutie-proces voortschreed.

Ortt was niet van zins om de veranderingen binnen de NBBV zonder een vorm van protest te laten plaatsvinden. Op verschillende manieren probeerde hij opnieuw zijn gezag als vader van de beweging en beschermeling van wijlen mevrouw Van der Hucht te doen gelden. Hij ging daarbij aanvankelijk omzichtiger te werk dan rond 1905 het geval was geweest. Zo probeerde Ortt in 1916 met zijn nieuwe brochure Wetenschappelijke Dierenmarteling te voldoen aan de wens die op de jaarvergadering van 1915 was uitgesproken, dat er een aan de eisen des tijds aangepast 'gruwelboekje' zou moeten worden gepubliceerd. ${ }^{6}$ Het geschrift was bedoeld, zo stelde het bestuur van de NBBV, als compromis tussen dit laatste vooral in het buitenland gangbare genre en Ortts 'beproefde opvattingen omtrent feitenmateriaal'? Het uiteindelijke resultaat was evenwel meer een krachtig pleidooi voor de evenwichtige strijdwijze die de auteur voorstond. Brochures als Die Folterkammern der Wissenschaft en The Nine Circles of the Hell of the innocent werden in het boekje afgedaan als uitingen van een strijdwijze die vooral in het buitenland haar nut had gehad, maar die als een gepasseerd station diende te worden beschouwd.

In aansluiting op deze weliswaar verhulde, maar evengoed duidelijke kritiek op de weg die de NBBV nu insloeg, veroordeelde Ortt tevens de toenadering tot de dierenbeschermers. Hij deed dit evenwel niet in het Orgaan maar -en dit was wellicht een meesterzet- in het tijdschrift De dierenvriend, het orgaan van de dierenbeschermers zelf. Ortt wekte met zijn bijdrage aan het blad de suggestie dat hij achter de toenaderingspogingen van de bond stond, maar maakte tegelijkertijd aan de dierenbeschermingswereld duidelijk dat hij nog altijd een echte abolitionist was. ${ }^{8}$ Maar waar Ortt voorheen met een dergelijk sandpunt het verlangen naar een toenadering tot de dierenbeschermers en een meer sensationele griezelpropaganda, zoals Criellaert deze voor zich zag, wel zo ongeveer het zwijgen op zou hebben weten te leggen, bleef de NBBV zich aangetrokken voelen tot de NVBD en tot een meer 'fantastische' benadering van het vivisectie-vraagstuk.

Het leek alsof de NBBV in de jaren na de Eerste Wereldoorlog een weg insloeg die rond 1898 vroegtijdig was verlaten maar die in de gedachten van een aantal anti-vivisectionisten wel degelijk als mogelijke route was blijven bestaan. Zelfs Ortt was onder de indruk geweest van bepaalde schilderijen en tekeningen met het vivisectie-vraagstuk als onderwerp. Dit bleek reeds bij het overlijden van de Duitse schilder Gabriel von Max in 1916. Het Orgaan publiceerde ter nagedachtenis een aantal overdenkingen van Ortt naar aanleiding van Max' schilderij Der Vivisektor (1883). ${ }^{10}$ Felix Ortt en de redactie van Orgaan waren in 1915 diep getroffen door de 'edele,

6. Felix Oru, Wetenschappelijke dierenmarteling (Utrecht 1916)

7. 'Jaarverslag over 1916', Orguan 13 (1917) 38-43, aldaar 38.

8. Hij richue zich direct tegen de bekende dierenbeschermster Camo die een on vangrijk interview met Dr. Ariëns Kappers, directeur van het Nederlandsch Instituut voor Hersenonderzoek, had gehouden en aan de weergave daarvan enige beschouwingen had vastgeknoopt. In haar artikel pleitte Carno evenals Ariëns Kappers voor een wettelijke regulering van vivisectie door middel van een vergunningenstelsel naar Engels voorbeeld. Ortt gaf in niet mis te verstane woorden te kennen dat de dierenbeschermster het vraagstuk op een verkeerde wijze benaderde. Een wettelijke regulering zou geen werkelijke oplossing bieden. In de eerste plaats werden de vivisectoren in Engeland alleen beoordeeld op hun bekwaamheid en niet op hun 'humaniteit'. Bovendien meende Ort dat de vivisectie nog altijd diende te worden bestreden door het bewerken van de publieke opinie. Alleen op die manier kon het medisch-wetenschappelijke stelsel waarin de vivisectie centraal stond en dat uitging van de ondergeschiktheid van het leven en het lijden van het proefdier aan het lijden van de mens, omver worden geworpen.

10. Waarvan een in 1886 vervaardigde gravure was afgedrukt. Van Der Vivisektor is de volgende beschrijving uit de iconografische studie van William Schupbach de meest accurate schriftelijke weergave : '[...] on the left, an elderly grey-bearded physiologist which embodies the foreign notion of a German professor in the 1880 's. He sits, with scalpel posited at a well-constructed vivisection tabel equipped with bolts, bars and rings. The table is probably copied from an illustration in some anti-vivisection tract which had lifted it in turn from a physiological textbook. Behind him arises a female figure dressed in red en white robes: her vaguely Early christian appearance proclaims her an allegory or personification of virue- pity, humanity, conscience, etc. She holds a bleeding puppy which she has rescued from a physiological experiment and with her left hand holds up a balance in which one pan, inscribed 'Kain'. contains a indistinct object which turns out to be a human brain crowned with golden bay-leaves. It is outweighed by the other pan which contains a golden hean smouldering with the fire of love' 
sobere wijze' waarop de schilder het 'tendentieuze onderwerp' had vereeuwigd. Met name het feit dat de vivisector zelf niet als wreedaard werd verbeeld maar als 'iemand in spanning en twijfel' maakte dat het werk geheel in het straatje van Ortt paste. Geen sensationele, beledigende afbeelding, maar een menselijk beeld van de proefnemer. ${ }^{11}$

Juist het overlijden van Gabriel von Max vormde de aanleiding om op zoek te gaan naar afbeeldingen die in het verleden de strijd tegen vivisectie hadden ondersteund en dit opnieuw zouden kunnen doen. Ook zocht men meer hedendaagse kunstenaars die in het onderwerp geïnteresseerd waren. Op de vleugels van deze belangstelling voor dit kunstzinnige aspect van de meer oncontroleerbare zijde van het verzet tegen vivisectie leek ook de aandacht voor de rol van de vrouw in het anti-vivisectionisme steeds meer terug te komen. Zij was te zien als leidsvrouwe op schilderijen en afbeeldingen die de NBBV na decennia soms letterlijk van zolder haalde. Leidsvrouwen werden tevens getoond op kunstwerken die de NBBV liet vervaardigen door aan de beweging verbonden schilders als Max Nauta en de kunstenares Adri Pieck. Ook zag men haar op afbeeldingen die, noodgedwongen door het toch beperkte binnenlandse aanbod, gretig werden overgenomen uit buitenlandse anti-vivisectie organen. Een goed voorbeeld is de in Orgaan van mei 1916 gepubliceerde afbeelding van Justitia ontleend aan een tijdschrift van Zweedse vivisectiebestrijders. Op de plaat draagt de godin van de gerechtigheid een weegschaal met in de ene schaal een aantal dieren die tezamen de 88,634 proefdieren die in dat jaar in Engeland aan vivisectie waren onderworpen, voorstelden. Uit de andere schaal, duidelijk lichter van gewicht dan de schaal met de geofferde dieren, rijst slechts een zwart vraagteken op.

De hernieuwde interesse voor de relatie tussen vrouwen en de strijd tegen vivisectie bleef niet tot dit soort afbeeldingen beperkt. De invoering van het kiesrecht voor vrouwen (passief 1917 en actief 1919) was voor een aantal anti-vivisectionisten aanleiding om op de bijzondere kwaliteiten en gebreken van vrouwen te wijzen. Ditmaal bleven de aan dit onderwerp gewijde beschouwingen niet beperkt tot verwijzingen in fictie. In Orgaan verschenen regelmatig artikelen die aan de rol van de vrouw in de landelijke politiek en in de humanitaire en/of anti-vivisectie-beweging waren gewijd.

Het gebreken van vrouwen bestond, zo werd in dergelijke artikelen geheel in het straatje van de inmiddels lang vergeten liberaal Beerends gesteld, vooral uit sentimentaliteit. Vrouwen waren volgens de feministe Kooy-van Zeggelen ${ }^{12}$ dikwijls geneigd om zich op overdreven wijze bezig te houden met schoothondjes. Zij droegen de diertjes bij zich en lieten zich door hen zoenen. Dergelijke uitwassen mochten niet gelijk worden gesteld aan de oprechte verontwaardiging over dierenleed die veel vrouwen voelden. Het was daarom een taak voor vrouwen om het onderscheid tussen die legitieme gevoelens en de eerder beschreven overgevoeligheid telkens te benadrukken.

Nog meer in de lijn van Beerends commentaar op de anti-vivisectionisten was het artikel Vrouwenkiesrecht en humaniteit dat in april 1918 in Orgaan werd gepubliceerd. In deze bijdrage werd er met klem op gewezen dat vrouwen zich door 'de nieuwe wegen' die zij insloegen en 'de nieuwe machtssfeer' waarin zij traden, niet moesten laten verleiden om hun natuurlijke aanleg te verloochenen. De vrouw bezat in de eerste plaats moederlijke krachten. Het waren deze kwaliteiten en geen andere die zij door haar intrede in het openbare leven aan de maatschappij zou moeten schenken. Vrouwen die dat niet deden, en dus op verkeerde gronden een bijdrage aan de politiek wilden leveren, waren volgens de onbekende auteur gevaarlijk en afschrikwekkend. Zij werden vergeleken met de vrouwelijke vivisector die als een van de meest droevige verschijnselen van de moderne tijd kon worden aangemerkt. ${ }^{13}$

De meeste artikelen die in Orgaan aan het onderwerp werden gewijd leken vooral te zijn gepubliceerd om nog eens kort en bondig aan te geven wat er in de openbaarheid en de politiek nu

11. 'Bij de plaat'. Orgaan 12 (1916) 42-45.

12. $\mathrm{Zij}$ deed deze uitspraak in de Hollandsche Lelie. In Orgaan (13) 1917, 52 ev, werden haar woorden met instemming geciteerd.

13. 'V rouwenkiesrecht en humaniteit', Orgaan 14 (1918) 23-24. 
precies wel en niet van vrouwen werd verwacht. In 1916 wees Groshans op de bijzondere roeping van de vrouw om in de 'opvoeding van haar gezin en van de staat' vooral aandacht te besteden aan de ontwikkeling van het gemoedsleven, de vorming van het karakter en de hervorming van de samenleving en de zorg voor zwakkeren zoals prostituées, dieren en armen. Het verslag van de afgevaardigde in de Vrouwenraad van 1918 was waar het gaat om een dergelijke verwijzing naar de moederlijke kwaliteiten van de vrouw uitdrukkelijker. Gesteld werd dat vrouwen hun moederlijke zorg uitsluitend dienden in te zetten om het recht van de zwaksten te doen zegevieren over het recht van de sterksten.

De anti-vivisectionist J. Engelen ging in 1919 nog een stap verder. Bijna dreigend stelde hij dat Orgaan zeker de plaats en januari 1919 beslist het tijdstip was om de verwachting uit de spreken dat:

'[...] de leidsters van de Nederlandsche vrouwen, die straks van haar nieuwe recht gebruik

zullen gaan maken niet [...] [zouden] vergeten te wijzen op de plichten tegenover het zwakke,

welke dat recht dien vrouwen naar haren aard dan oplegt. ${ }^{14}$

Door middel van een tweetal uit Engeland overgenomen artikelen ${ }^{15}$ over vrouwenkiesrecht werden vrouwen er bovendien aan herinnerd dat zij bij het stemmen en bij het denken over politiek de volgende stelregel voor ogen dienden te houden: 'What is morally wrong can never be politically right'. Dergelijke uit bezorgdheid voortgekomen raadgevingen brachten de vrouw terug op het anti-vivisectionistisch toneel. Aldaar werd zij met argusogen gadegeslagen. Daar kwam nog bij dat haar positie buitengewoon wankel was. De autoriteit van de moeder van de beweging. Suze Groshans, werd althans niet langer door iedereen zonder meer geaccepteerd en gerespecteerd zoals uit de volgende verwikkelingen in de jaren dertig zal blijken.

\section{De splitsing en de oprichting van de SAVB}

Niet zonder reden zag de inmiddels achtenzestig-jarige Suze Groshans de toekomst van de antivivisectie-beweging in 1928 met vertrouwen tegemoet. De NBBV ontworstelde zich langzaam maar zeker aan de zware crisis waarin zij na de Eerste Wereldoorlog was komen te verkeren. Het ledental steeg weer tot (iets onder) voor-oorlogse omvang en in Nederlands-Indië groeide de NIBBV, de met de bond sympathiserende koloniale 'zuster'-vereniging, gestaag. Belangrijker nog dan dit alles was dat de constructieve vivisectie-bestrijding waarover Groshans sprak, daadwerkelijk gestalte leek te krijgen door de op initiatief van Ortt tot stand gebrachte samenwerking met de Nederlandsche Vereeniging voor Natuurgeneeswijze (NVV). De NBBV stond niet langer alleen, maar zou met deze in 1926 opgerichte organisatie, waarin de bekende natuurarts en naturist Yge Hettema actief was, de strijd tegen vivisectie aanbinden en tevens een vivisectie-vrije geneeskunde propageren. Deze samenwerking met geestverwanten werd door Ortt en Groshans aangemerkt als een welkom antwoord op de nieuwe tijd. Niet voor niets kozen zij in overleg met Hettema 'Uitkomst' als naam voor het orgaan dat NVV en NBBV gezamenlijk zouden uitgeven en bekostigen:

'Uitkomst voor de in den greep der vivisectie geklemde dierenwereld geeft de vivisectievrije geneeskunst.

Onze Titel

Als onzen titel hebben wij gekozen het hoopvolle devies 'Uitkomst.' [...] de natuurlijke leefen geneeswijze [is] beter [...। dan de richting die de officieele geneeskunde thans volgt, daarvan zijn wij op goede gronden overtuigd. Die overtuiging wenschen wij mede te deelen, eerst in dit orgaan, en later, zoodra mogelijk, te demonstreeren door en in natuurgeneesinrichtingen. Hierin zien wij een uitkomst voor de dierenwereld, die door de miljoenen slachtoffers welke de vivisectie

14. J. Engelen. 'Vrouw en kiesrecht'. Orgaan 14 (1919) 63-65, aldaar 63.

15. Eén artikel was afkomstig was uit de Animal Guardian van 1919. Het andere artikel was een weergave van een door de 'predikanie' Maud Royden gehouden lezing voor het achtste Internationale Congres voor Vrouwenkiesrecht te Genève (1921). 
jaarlijks eischt en ieder jaar in meerdere mate dreigt te eischen, als onder een banvloek ligt; en tevens ook in het verschiet een uitkomst voor de naar verlossing snakkende lijdende menschheid. En hierom geven we ons Tijdschrift dezen hoopvollen titel. Moge het daarin liggend getuigenis, dat wij de uitkomst zien, aan onze kleine groep de moed geven, die tot uiteindelijke zegepraal leidt. ${ }^{16}$

Wat de schrijver van deze hoopvolle woorden niet kon vermoeden was dat een aantal nieuwkomers binnen de bond, waaronder de arts Pieter Pijl en diens echtgenote N. Pijl-Muller, een ware opstand tegen het hoofdbestuur van de NBBV en presidente Suze Groshans in het bijzonder aan het voorbereiden waren. De commissie van tien, zoals de groep zichzelf aanduidde was van mening dat Groshans de bond had laten inslapen. De samenwerking met de NVV had naar de mening van Pijl niet het gewenste resultaat. Nieuwe krachten waren, zo meenden de arts en de zijnen, noodzakelijk om nieuw leven in de strijd tegen vivisectie te blazen.

Evenals Ortt was Pijl een bekende in de Haagse wereld van humanitair-idealisten. Met name onder spiritisten had hij veel bewonderaars omdat het verhaal ging dat hij het als medicus in 1927 publiekelijk had opgenomen voor een vrouw die krankzinnig zou zijn verklaard omdat zij met geesten communiceerde. De anti-vivisectionistische arts Lize Deutmann beschreef in haar boek Een pleidooi voor natuur en menschelijkheid hoe de echtgenoot van de mediamieke vrouw gebruik zou hebben gemaakt van de heersende vooroordelen over het spiritisme om haar in een inrichting te laten opsluiten en op welke wijze Pijl dezelfde vrouw gezond had verklaard. ${ }^{17}$

Groshans kende Pijl al van voor het incident rond de krankzinnig verklaarde vrouw omdat hij op haar verzoek in Orgaan een recensie had geschreven over Ortts Ons Standpunt. Die lovende bespreking en het feit dat hij arts was en zich dienstbaar probeerde te maken voor de NBBV, moeten de presidente hebben doen besluiten om Pijl ergens rond 1924 te laten toetreden tot het hoofdbestuur. Na enkele maanden zag zij zich evenwel genoodzaakt hem te verzoeken weer af te treden. Om onduidelijke redenen weigerde Pijl akkoord te gaan met het tekenen van enkele formulieren die waarschijnlijk verband hielden met het vruchtgebruik van de eerder genoemde erfenis Coster van Voorhout-Hamm.

Pijl trad af en Groshans beschouwde de zaak als afgedaan. Een misvatting, zoals zou blijken. Met de heimelijk rond hem geformeerde commissie van tien formuleerde Pijl in alle stilte een aantal grieven jegens het hoofdbestuur van de NBBV en het functioneren van Groshans in het hijzonder. Op 21 juni 1930 barstte de bom. Tijdens een algemene ledenvergadering gaf Pijl te kennen dat hij een aantal ernstige problemen aan de orde wenste te stellen. Hij kreeg het woord en hield dit volgens de overlevering zo lang dat de zaal rumoerig werd, hem uitfloot en met boegeroep het spreken onmogelijk maakte. Pijl toog huiswaarts maar gaf zich niet gewonnen. Tezamen met de commissie schreef hij een aan alle leden gerichte brief waarin de (veertien) kritiekpunten die hij aan de orde had willen stellen, breed werden uitgemeten.

De belangrijkste grieven waren dat Groshans in vertrouwen tegen Pijls echtgenote gezegd zou hebben dat zij liever een bond zonder leden had en er helemaal niet blij mee was dat het ledental sinds 1925 van 600 naar 850 was gestegen. Voorts beschuldigde de commissie van tien de NBBV van gesjoemel met geld. Ortt zou ten onrechte voor zijn werk betaald worden en de dame die de contributie regelde zou meer onkostenvergoeding krijgen dan zij aan gelden inde. Ook meenden Pijl en zijn groep dat de NBBV geen enkele baat had bij de samenwerking met de NVV. Uitkomst zou slechts aan de natuurgeneeswijze zijn gewijd en nauwelijks ruimte bieden aan het thema van de anti-vivisectie.

Dergelijke beschuldigingen kon het hoofdbestuur niet over zijn kant laten gaan. Op 27 augustus 1930 luidde het de noodklok in een aan alle leden gericht schrijven. Hoe zeer de leiding van de NBBV zich bedreigd maar vooral beledigd voelde blijkt uit de volgende passages:

16. Deze tekst werd op iedere aflevering van Orgaan afgedrukt

17. Lize Deutmann, Een pleidooi voor natuur en menschelijkheid (Middelburg 1935) $26 \mathrm{ev}$ 
'Dat wij thans een beroep op uw medewerking doen, heeft een [...] oorzaak die veel ernstiger gevolgen kan hebben, dan een financieele moeilijkheid, en die het werk dat de Bond gedurende meer dan dertig jaar, de laatste twintig jaren onder voorzitterschap van Suze Groshans, heeft verricht en waarbij hoofdzakelijk de inzichten van Felix Ortt werden gevolgd, wat betreft de degelijkheid, wetenschappelijkheid en objectiviteit, dreigt te vernietigen. Een groep leden is bezig op hoogst onorganisatorische destructieve wijze te ageeren tegen de leiding van den Bond $[\ldots]^{18}$

De NBBV zou zeker niet onbeschadigd uit de strijd komen. Pieter Pijl richtte in 1931 een organisatie ter bestrijding van vivisectie op: de Stichting Anti-Vivisectie Bond (SAVB). Problematisch voor de NBBV was dat hij een even select als kapitaalkrachtig deel van de leden mee wist te krijgen en dat hij zich meester maakte van de bezittingen van de bond. De NBBV bleef in verbijstering achter. Een crisis van een dergelijke omvang had zich in haar geschiedenis nog niet voorgedaan. ${ }^{19}$

Niet lang na deze gebeurtenissen trad Groshans af. Ortt kon als 'buitenlid' niet anders dan toekijken. Toen na de afsplitsing van de 'Pijl-groep' bleek dat het nieuwe hoofdbestuur van de NBBV onenigheid kreeg met de NVV, keerde Ortt zich lange tijd van de anti-vivisectie-beweging af. Pijl ging het in tegenstelling tot deze oude garde in allerlei opzichten voor de wind. In de periode 1931-1941 wist hij, charismatisch als hij was, in totaal zo'n 4000 leden en donateurs voor kortere of langere tijd aan zich te binden. Deze werden van de activiteiten, opvattingen en de in verbazend korte tijd tot stand gebrachte internationale contacten van de nieuwe stichting op de hoogte gebracht door het orgaan Meededeelingen dat om de drie en later om de twee maanden werd gepubliceerd en uiteindelijk zelfs op een eigen luxueuze drukpers vervaardigd.

Waarom zeggen de splitsing van de NBBV en de ruzies die daaraan vooraf gingen, meer over geschiedenis van de vivisectie-bestrijding in Nederland dan op het eerste gezicht lijkt? Hoewel het ging om een botsing van persoonlijkheden die in ieder verband kan voorkomen ging het ook om de botsing van generaties. De NBBV bevond zich in een impasse. De bond had het niet aangedurfd om werkelijk nieuwe wegen in te slaan. Bovendien leken door de samenwerking met de NVV (waar Ortt in het hoofdbestuur zat) alle belangrijke elementen van de expressieve politiek te verdwijnen. Zo werd het vivisectie-vraagstuk in Uitkomst slechts bij uitzondering als religieuze, persoonlijke kwestie benaderd.

Anders dan rond 1900, baarde de NBBV eind jaren twintig en in de jaren dertig nauwelijks meer opzien. Rond 1917 waren er nog felle polemieken geweest met Van Rijnberk. Maar zelfs deze fysioloog, die altijd in was voor een goed gevecht, voelde zich eind jaren twintig niet langer geprikkeld door de anti-vivisectionistische geschriften. Over Ons Standpunt schreef hij, met een irone die zijn teleurstelling over het verlies van zijn 'sparringpartner' niet kon verhullen:

'De beroepsbestrijder der vivisectie, de heer Felix Ortt heeft weer een kloek boekdeel van 393 bladzijden geschreven. 'Ons Standpunt' is de titel ervan. De algemeene indruk, dien ik bij het doorbladeren van dit boek heb gekregen, is die van matheid. Het mist hier noode den haatdragenden toon, de belachelijke overdrijvingen, de heftige aantijgingen, de kwaadaardige verdachtmakingen, waarmede 's heeren Ortts vroegere geschriften zoo aangenaam gekruid

\section{NBBV, Aan onzé leden ('s-Gravenhage 1928)}

19. De geruchten die Pijl in de wereld had gebracht moesten worden bestreden. leden moesten worden teruggewonnen en nieuwe sympathisanten gevonden. Ook moesten er rechiszaken worden aangespannen. De NBBV eiste dat de SAVB haar naam zou wijzigen en in ieder geval het woordje 'bond' zou schrappen omdat het verwarring schiep en verwisseling van beide organisaties in de hand werkte. Ook probeerde de NBBV via een kort geding haar bezittingen terug te vorderen. Een andere rechtszaak werd na het overlijden van Pijl gevoerd tegen een lid van de stichting die in naam van de SAVB -die inderdaad haar naam had moeten veranderen in Anti-Vivisectie Stichting (AVS)- een open brief aan de leden van de NBBV had geschreven. Daarin stelde de vrouw dat de NBBV een propaganda-film had laten vervaardigen en daarvoor zonder scrupules een onnodige proef op een levend dier had laten verrichten. De NBBV eiste rectificatie en een schadevergoeding. Steeds won de NBBV het kort geding. Maar met die juridische genoegdoening was haar crisis nog niet bedwongen. 
waren, en die hen tot lecture amusante van een bijzonderen soort stempelden. Hij is bezadigd geworden, en daardoor vervelend, tot onleesbaar toe. ${ }^{20}$

Na deze opmerking bleef het opvallend stil. In de jaren twintig vond nog een aanvaring plaats met professor F.J.J. Buytendijk maar daarbij bleef het. Van een maatschappelijke discussie over vivisectie, opgewekt door middel van brochures en artikelen in kranten en tijdschriften, was geen sprake meer. Ook in het parlement leefde de kwestie niet langer. Het leek alsof alleen in Nederlandsch Indië nog werkelijk een vivisectie-vraagstuk bestond. In de kolonie bloeide de NIBBV met een eigen, dik en professioneel vervaardigd orgaan.

Tegen de achtergrond van de hierboven geschetste eerdere neergang van de bond moet het voor Pijl onbegrijpelijk zijn geweest dat Groshans zich ontevreden toonde over het toenemende ledental. De presidente was, geheel conform de wijze waarop rond 1900 werd gedacht, van mening dat de bond beter weinig, maar actieve, consequent levende en getuigende leden kon hebben dan 850 onbekenden die slechts hun contributie in de kas stortten. Pijl was juist een voorstander van zoveel mogelijk leden die financiële en morele steun konden geven aan een actief en deskundig bestuur.

Actief vond hij de leden het hoofdbestuur van de NBBV bepaald niet. Aan hun manier van leven kon hij niets bijzonders opmerken, hij zag er geen getuigenis in van een bijzonder ethisch standpunt of een diep geloof. Met de geschiedenis van de NBBV voelde hij zich niet verbonden, kon hij zich ook niet verbonden voelen. De expressieve politiek die door Groshans, Jungius en Ortt al die jaren was bedreven, stamde uit de tijd dat Pijl nog een kind was. Zijn manier van denken over strijd en politiek waren eenvoudigweg niet zo sterk verbonden met het christenanarchisme dat eens zo belangrijk was geweest. Daarbij kwam nog dat toen Pijl de manier van werken van Groshans en de anderen onder de loep nam, deze zoals gezegd nu niet bepaald in volle glorie was. Met zijn SAVB probeerde hij daar een andere strijdwijze tegenover te stellen.

Van Rijnberk, inmiddels meer dan een decennium de bekendste tegenstrever van de bond, merkte deze verandering op. In 1931 schreef hij:

'De laatste jaren is het aantal personen, gekant tegen proeven op dieren, misschien niet toegenomen, maar wel is de manier waarin tegen deze methode van onderzoek stemming gemaakt wordt, op betreurenswaardige wijze erop achteruit gegaan. Met Jhr. Ortt heb ik vaak de pen gekruist en zijn denkbeelden bestreden. Zijn geschriften muntten niet altijd uit door juistheid van inzicht en soms waren zijn beweringen tastbaar onjuist, zijn aanklachten onbillijk. Maar zijn drijfveeren schenen altijd zuiver, zijn overtuiging oprecht. Zijn geschriften waren steeds met de allergrootste vlijt samengesteld, vormden telkens een eerlijke poging tot bewijslevering en critiek. De toon er van was gewoonlijk die van een beschaafd man jegens andersdenkenden. '21

Van Rijnberks opmerking roept de vraag op of het anti-vivisectionisme van Pijl werkelijk zoveel verschilde van de strijd tegen vivisectie zoals die in de jaren twintig en rond 1900 werd gevoerd? In het volgende gedeelte zal deze vraag beantwoord worden aan de hand van een terugblik op de in deze studie gemaakte reis door de hel der onschuldigen.

\section{De expressieve politiek: aandachtspunten en ontwikkeling 1890-1940}

In de inleiding van deze dissertatie werd onder meer verwezen naar historicus Richard French die het Engelse anti-vivisectionisme karakteriseerde als een beweging met een expressieve politieke stijl die vooral door vrouwen werd vormgegeven en ten zeerste verschilde van de politiek van medische wetenschappers en parlementariërs. In deze studie werd gesteld dat de Nederlandse antivivisectie-beweging eveneens een expressieve politieke stijl kende. Het uitdragen van een hoge morele en religieuze levenshouding was ten nauwste verstrengeld met de verschillende manieren

20. G. van Rijnberk. De vivisectie-bestrijding (z.p. 1929) 2

21. Van Rijnberk, 'Anti-vivisectie'. NTVG 76 (1931) 278 
waarop de anti-vivisectionisten de vivisectie zichthaar probeerden te maken en als maatschappelijk kwaad trachtten te ontmaskeren en tentoon te stellen.

Er werd vanuit gegaan dat juist de studie naar deze verbeelding van het vivisectie-vraagstuk zou leiden tot inzicht in de wijze waarop vrouwen, religiositeit, wetenschap, verbeelding en het denken over andere bewegingen en de parlementaire politiek een rol speelden in de expressieve politiek van de Nederlandse anti-vivisectionisten. Daarbij werd evenwel opgemerkt dat het onderzoek naar het Nederlandse anti-vivisectionisme niet uitsluitend gericht moest zijn op de eigenheid van de door deze beweging gehanteerde politieke stijl. Juist het signaleren van de overeenkomsten tussen de expressieve politiek en de wijze waarop het vivisectie-vraagstuk door de voorstanders van vivisectie en de parlementaire politici werd benaderd moest leiden tot een minder statisch, minder karikaturaal beeld van het verzet tegen medisch-wetenschappelijke proeven op levende dieren. De reis door de hel der onschuldigen zou op deze wijze een alternatief bieden voor het denken in termen van winnaars en verliezers dat ten grondslag ligt aan de historiografie van de petites religions en het anti-vivisectionisme.

De reis ving aan in 1898 op de Nationale Tentoonstelling van Vrouwenarbeid alwaar Marie Jungius haar rede hield. Naar aanleiding van deze gebeurtenis werd duidelijk dat hetgeen in de historiografie over de participatie van vrouwen en het denken over vrouwelijkheid (en mannelijkheid) in de anti-vivisectie-beweging naar voren wordt gebracht, niet zonder meer toepasbaar is op de Nederlandse situatie. De Nederlandse anti-vivisectie-beweging was niet expliciet op vrouwen gericht. Haar strijd tegen de vivisectie was noch een dekmantel voor een strijd tegen de onderdrukking van de vrouw, noch werd zij door vrouwen gedomineerd. Wel waren vrouwen met name voor de oprichting van de NBBV en in de beginjaren van deze bond, de jaren 1890-1900 van grote betekenis. Financieel was de beweging lange tijd van hen afhankelijk. In organisatorisch opzicht was dat niet minder het geval, terwijl ook de wereldbeschouwing van de anti-vivisectionisten door vrouwen, in het bijzonder Van der Hucht-Kerkhoven, Jungius en Suze Groshans, ontwikkeld werd en onder woorden gebracht.

Van nog grotere betekenis bleek evenwel het denken over vrouwen en vrouwelijkheid zoals dit in het genre van de anti-vivisectie-roman te vinden was. De vrouw werd voorgesteld als gids naar een morele levenshouding die inzicht zou geven in het bestaan van een hogere wereld, zou leiden tot geoorloofde kennis die zich achter het fysiek waarneembare zou bevinden en op de een of andere wijze in relatie stond met het goddelijke. Conform de in de negentiende en begin-twintigste eeuw gebruikelijke literaire verbeelding van vrouwelijkheid werden deze leidsvrouwen voorgesteld als maagd, als moeder of als etherische lichtgestalte zonder sekse, maar met een vrouwelijke inborst. De maagd, zoals Gemma of de stervende zusjes die zowel in Naar het groote licht als Het Tweede Leven werden beschreven, verwees naar opofferingsgezindheid, naar het sterven voor de zonden van de wereld, naar de kruisiging en naar een leven hiernamaals, alwaar men voor de eigen daden verantwoording diende af te leggen. Het moederschap verwees naar de eenheid van al het levende en naar de bijzondere kwaliteiten die de vrou $:$ in het openbare leven tentoon zou kunnen spreiden als moeder van de mensheid en als vertegenwoordigster van de moraal.

De periode tussen kinderlijke maagdelijkheid en moederschap werd in de anti-vivisectieromans, maar ook in andere geschriften over het vivisectie-vraagstuk, voorgesteld als een gevaarlijke fase in het bestaan van de vrouw. In dit stadium had de vrouw haar bestemming nog niet gevonden. Juist omdat haar positie in de samenleving onduidelijk was liep zij het risico belaagd te worden en haar bijzondere kwaliteiten te verliezen of ten kwade te ontwikkelen. Uit de aldus beschreven onzekere en riskante periode in het bestaan van vrouwen werd de Nieuwe Vrouw geboren. Deze wist haar weg in de samenleving te vinden, verankerde haar positie in de maatschappij en vond manieren om haar idealen te formuleren en uit te dragen.

De identiteit van de Nieuwe Vrouw stond dus niet los van de oudere literaire modellen van moeder, madad of zuster. Zij leek slechts door middel van deze voorstellingen tot stand te komen en invloed te kunnen uitoefenen. Niet voor niets trad Van der Hucht-Kerkhoven naar buiten als wijze. oude, maar vooral moederlijke beschermvrouwe. Jungius verwees door haar voorbeeld 
Jeanne d'Arc zowel naar strijdbare maagdelijkheid als naar kinderlijke onschuld en benadrukte op deze wijze haar offervaardige levensbeschouwing. Groshans schreef in de jaren na het overlijden van Jungius waar zij maar kon over de wereldbeschouwing en levenswijze van de haar ontvallen vriendin. Haar jarenlange presidentschap over de NBBV leek soms geheel in naam en geest van Jungius te worden gevoerd. Door deze constante getuigenis van de opvattingen van een overleden vrouw leek Groshans een zusterziel, die de afstand tussen de wereld der levenden en het hiernamaals leek te kunnen verkleinen.

Opgemerkt dient te worden dat het optreden van de hierboven genoemde vrouwen niet uitsluitend gekenmerkt werd door de zelfverzekerdheid die in de historiografie doorgaans aan de New Woman wordt toegeschreven. In anti-vivisectie-romans en andere geschriften werd juist niet alleen gewezen op de kwaliteiten en mogelijkheden van vrouwen, maar tevens op hun gebreken en de gevaren die zij in zich droegen. Moederschap zou, zo meenden de vrouwen zelf, leiden tot overdreven emotionaliteit en egoïstische liefde. De energie van vrouwen kon onder bepaalde omstandigheden een gevaarlijke uitweg vinden. Vrouwen zouden bovendien het gevaar lopen hun eigenheid te verliezen. $\mathrm{Zij}$ werden beschreven als individuen die zich nogal eens door de verbeelding lieten meeslepen. Aangenomen werd dat dergelijke gevaarlijke eigenschappen door een offervaardige levenshouding uiteindelijk konden worden omgezet in kwaliteiten die de samenleving en de mensheid ten goede kwamen. Daar stond weer tegenover dat de daarvoor gevraagde offers zo zwaar waren dat deze slechts door buitengewoon goede vrouwen volbracht konden worden.

De idee dat vrouwen een onberekenhare emotionele zijde bezaten, leek altijd mee te spelen in de wijze waarop belangrijke vivisectie-bestrijdsters als Marie Jungius, Van der Hucht of Kingsford door hun medestrijders (of deze nu uit de vrouwenbeweging of uit de anti-vivisectie-beweging afkomstig waren) werden beschreven. Ortt kenschetste de door hem geconstateerde onberekenbare zijde van de strijd tegen vivisectie in feite als vrouwelijk. Hij waarschuwde voor fantasie, emotionaliteit, onwetenschappelijkheid en het beledigen van de persoon van de medische wetenschapper. Bovendien situeerde hij deze 'tekortkomingen' expliciet in de jaren rond 1890, de periode dus waarin vrouwen en het denken over de positie van de vrouw een veel nadrukkelijker invloed op de strijd tegen vivisectie hadden dan in de jaren na 1898. Met andere woorden, het lijkt alsof Ortt evenals de contemporaine critici van de beweging de oncontroleerbare en de naar zijn mening te bestrijden zijde van het anti-vivisectionisme met vrouwelijkheid associeerde.

Dit alles is des te opmerkelijker indien in herinnering wordt gehaald dat de vrouwelijke gids naar het hogere, zoals deze in de anti-vivisectie-romans werd beschreven, na 1898 steeds meer verdween uit de wereldbeschouwing van de vivisectie-bestrijders. Zij maakte plaats voor de offervaardige en idealistische figuur van Christus. Dat ook romans, gedichien en afbeeldingen door Ortts en Nolthenius steeds duidelijker uit de strijd tegen vivisectie werden geweerd, wijst op een verschuiving in de expressieve politiek. Deze voltrok zich ten koste van een vrouwelijke of met vrouwen geassocieerde inbreng (het houden van lezingen, het gebruik van fictie en de idee van leidsvrouwen) en ten gunste van een op het eerste gezicht ongeseksueerd idee van religieus geïnspireerde offervaardigheid, die vooral door middel van geschriften werd uitgedragen.

De christen-anarchistische figuur van Jezus leek te staan voor 'gender overstijgende' ideeën als liefde en het volgen van de stem van het eigen geweten. De vrouwen binnen de bond voelden zich evenzeer aangetrokken tot deze Christus-figuur die zij associeerden met een volkomen overgave aan de strijd, met arbeiden voor de goede zaak en liefde voor al het levende. Ook Felix Ortt benadrukte deze kwaliteiten wanneer hij de navolging van Christus belichtte. In zijn beschrijving lag de klemtoon evenwel op de anarchistische zijde van de Christus-figuur. Ook omschreef hij de consequente levenshouding die van de navolgers van deze Jezus werd verwacht, veel preciezer en eenduidiger dan voorheen was geschied.

Daarbij gaf hij geen speciale aandacht aan de specifieke problemen waarop vrouwen zouden stuiten indien zij een dergelijke levenswijze aannamen. In zijn anti-vivisectie-geschriften en tijdens vergaderingen met de leden en het bestuur van de NBBV wijdde hij geen woorden aan de 
bijzondere positie van vrouwen in de samenleving. Het feit dat vrouwen actief, noch passief stemrecht hadden stelde hij voor als een bron van verleiding (het verhaal over Felicia's huwelijk met een SDAP-er) en niet als een ongelijkheid die maakte dat de (uitgangs-)situatie van vrouwen anders was dan die van mannen. Dat een vrouw na het sluiten van een huwelijk voor de wet in feite handelingsonbekwaam werd verklaard, was voor Ortt eerder een reden om het huwelijk als instituut te verwerpen en ervoor te pleiten dat vrouwen zo dapper zouden zijn om niet te trouwen dan te stellen dat een wetswijziging noodzakelijk was.

Ortts offervaardigheid impliceerde met andere woorden dat men zich van de samenleving, de wet en de parlementaire politiek afkeerde. De offervaardigheid die door vrouwen werd beschreven stond in dienst van de maatschappij. Vrouwen probeerden juist aan te tonen op welke wijze zij hun bijzondere kwaliteiten konden aanwenden voor een verbetering van de bestaande samenleving. Daarbij moet overigens direct worden opgemerkt dat deze scheidslijn niet doorlaatbaar was. De opvattingen over mannelijke en vrouwelijke offervaardigheid waren vloeiend en niet zo strikt aan sekse gebonden. Het meer en meer verdwijnen van de vrouwelijke gids naar het hogere ten gunste van de christen-anarchistische navolging van een Don Quichote-achtige Jezus is in dit boek vooral beschreven om aan te tonen dat zich in de expressieve politiek van de anti-vivisectionisten verschuivingen voordeden die alleen zichtbaar kunnen worden gemaakt indien de anti-vivisectiefictie bij het onderzoek wordt betrokken.

Het gaat om een subtiele ontwikkeling, wellicht bij oppervlakkige beschouwing zelfs futiel. Toch hebben deze de expressieve politiek van de Nederlandse anti-vivisectionisten wat betreft de inbreng en de invloed van vrouwen, en wat betreft de houding tegenover wetgeving en de parlementaire politiek, een eigen karakter gegeven. Anders dan in Engeland werd de rol van vrouwen binnen de strijd tegen vivisectie steeds meer beperkt tot die van organisator. Vrouwen werden secretaris, geldschieter of zoals Groshans presidente. Hun inbreng in de wijze waarop de vivisectie zichtbaar werd gemaakt, verminderde aanmerkelijk na de instorting van Marie Jungius.

Met het verdwijnen van de vrouwen naar de achtergrond van de NBBV veranderde ook het accent van de contemporaine kritiek op de anti-vivisectionisten. In de periode voor 1898 werd vooral de vrouwelijkheid of verwijfdheid van de vivisectie-bestrijders beklemtoond. Dit bleef ook in latere kritiek het geval. Maar in dergelijke commentaren veranderden vrouwen steeds meer van handelende personen (die weliswaar belachelijk en sentimenteel waren), in passieve objecten die door sluwe charlatans werden misleid en daardoor hun werkelijke dienstbare bestemming in het leven verloochenden.

Deze verschuiving in het denken over vrouwen binnen de expressieve politiek van de antivivisectionisten loopt als het ware parallel aan een omslag in het denken over de relatie tussen Darwin en religiositeit. Voor de oprichting van de NBBV en in de beginjaren van deze bond werd Darwin voornamelijk beschreven als een afschrikwekkende vertegenwoordiger van een door en door materialistische wereldbeschouwing. In deze visie stond de gelijkschakeling van mens en dier die Darwin tot stand zou hebben gebracht ten dienste van een schaamteloze ontkenning van de menselijke rede, het bestaan van een universele moraal en het bestaan van een goddelijke macht. Onder invloed van Hugenholtz, maar vooral Jungius en Ortt, veranderde deze receptie in een juichend onthaal. Darwin veranderde van een incarnatie van de anti-christ in een beminnenswaardig persoon die wetenschappelijk had aangetoond dat gevoelens van medeleven een teken van ware beschaving waren.

Juist in de periode dat de acceptatie van de verwantschap van de mens met het dier gemeengoed werd onder de anti-vivisectionisten, werden vrouwen voorgesteld als passieve wezens die de inzet werden van een discussie over (mannelijke) offervaardigheid en religiositeit. Voor dieren gold dit in nog sterkere mate. Evenals vrouwen werden zij in de discussie over vivisectie langzaam maar zeker naar de achtergrond gedrongen.

In Ortts Naar het groote licht speelt het dier bijvoorbeeld lang niet zo'n belangrijke rol meer als in de beginjaren van het georganiseerd verzet tegen vivisectie. Er zijn geen dieren die, zoals het hondje Roy van Gemma, de hoofdpersoon op zijn weg door het leven begeleiden. Het verhaal 
van Ortt is een relaas over mensen waarin de liefde voor dieren in zekere zin zelfs ter discussie wordt gesteld. De plaats van dieren was in de anti-vivisectionistische wereldbeschouwing problematisch was geworden. Dat wordt nog duidelijker indien gekeken wordt naar de geschriften waarin Ortt het vivisectie-vraagstuk op een meer wetenschappelijke manier benadert. In dergelijke studies was geen ruimte voor het geïndividualiseerde en gepsychologiseerde dier. Aandacht voor fantasieën over de menselijke eigenschappen en gevoelens van dieren leek steeds meer tot het verleden te behoren.

Tegelijkertijd bleven fantasie, emotionaliteit en fictie een onontbeerlijk wapen in de strijd tegen vivisectie, bijvoorbeeld voor het beschrijven van zulke ongrijpbare en onzichtbare verschijnselen als de 'pijn' en het 'lijden' van dieren. Vrouwen, dieren, emotionaliteit en fantasie verdwenen nooit geheel van het anti-vivisectionistische toneel. $\mathrm{Zij}$ waren hoe dan ook nodig voor het zichtbaar maken van het vivisectie-vraagstuk en beleefden gedurende het Interbellum bovendien een come back. Maar waar rond 1900 in het anti-vivisectionisme een diversiteit aan vrouwenrollen en feminiene kwaliteiten scheen te bestaan -de strijdbare maagd, de aan christus gelijke maagd, de onderdrukte echtgenote uit de buitenlandse anti-vivisectie-romans, de zusterlijke maagd, de etherische leidsvrouw, de zelfhewuste nieuwe vrouw en de moeder- leek het denken over vrouwen in de jaren twintig slechts gecentreerd rond het begrip moederschap. Iedere vrouw, om het even welke burgerlijke of maatschappelijke staat zij had, was in potentie moeder en leek volgens de anti-vivisectionisten uitsluitend op grond van die specifieke seksegebonden kwaliteit gerechtigd om zich in het openbare, politieke leven te storten. Zij het niet zonder een vaderlijk en soms moederlijk advies van de oudere anti-vivisectionisten die haar toetreden tot de wereld van mannen met bezorgdheid gadesloegen. Gedurende de jaren dertig werd in de anti-vivisectionistische geschriften van zowel de NBBV als de SAVB opvallend weinig over de kwaliteiten of gebreken van vrouwen geschreven. Het woord werd vrijwel nooit speciaal tot hen gericht. Waar dit wel gebeurde werden vrouwen evenals in de jaren twintig vooral aangesproken op het moederschap. ${ }^{22}$ Zelden of nooit werd zij, zoals rond 1900 gebruikelijk was, als (potentieel) slachtoffer van de vivisector beschreven.

Ook de student verdween als slachtoffer uit de anti-vivisectie geschriften. Waar hij in de brochures van de NBBV regelmatig werd genoemd in verband met de schadelijke verruwing die hij door het aanschouwen van vivisectie zou ondergaan, wijdde de SAVB nauwelijks een woord aan hem. Wanneer dit wel geschiedde werd vrijwel nooit de tragiek van dit proces benadrukt, maar vooral de slechtheid van de betreffende student.

Vrouwen en studenten die in de anti-vivisectie-geschriften van rond de eeuwwisseling belangrijk waren geweest, maakten plaats voor de massa, de arbeider of gewone man en zijn kinderen. De wijze waarop de massa werd beschreven verschilde eveneens sterk van de manier waarop dit drie decennia eerder geschiedde. Toen klonk in de beschouwingen duidelijk een grote angst door voor diezelfde armen en arbeiders. Zij werden gezien als onbeschaafd en beestachtig, en beschreven als griezelige mensen die moreel nog nauwelijks geëvolueerd was (en daarom aan een kind of wilde gelijk) en de donkere zijde van de natuur in zich droegen. Voor de vorm werden enkele pogingen ondernomen om dergelijke lieden voor de goede zaak te winnen door speciaal op hen gerichte literatuur te schrijven, maar die projecten, waarvan Ortt de spil was, werden spoedig afgeblazen.

In de jaren dertig bekeek Pijl de arbeider noch met weerzin, noch met angst. Wel zag hij overeenkomsten tussen de gewone man, het kind en het dier, maar uitsluitend omdat zij in zijn visie allen slachtoffer waren van de manipulatieve krachten van het 'grootkapitaal' en haar dienaren. Deze complot-theorie zou in de jaren dertig steeds luider in de anti-vivisectionistische

22. Een uitzondering vormde de folder Met bont getooide vrotwen laat u intichten! die los bij de afleveringen van Mededeelingen werd gepubliceerd en waarin een beroep op vrouwen werd gedaan om hun ijdelheid te laten varen en de bonthandel een halt toe te roepen. Daamaast werden vrouwen in de pers genoemd in verband met vivisectie op kinderen en wederom uitsluitend aangesproken op hun moederschap. 
geschriften van de SAVB doorklinken. ${ }^{23}$ Met name bij monde van Pijl, die bijwoorbeeld een direct verband zag tussen manipulatie door het kapitalisme, vivisectie en een mogelijk op handen zijnde tweede gifgas-oorlog. Eerder werd duidelijk dat voor, tijdens en vlak na de Eerste Wereldoorlog eveneens een verband werd gelegd tussen oorlog, geld en vivisectie. De tendens van die artikelen was echter anders. Rond 1915 werd geld door de anti-vivisectionisten vooral geassocieerd met de hang naar status van individuele wetenschappers. Deze lieten zich in deze voorstelling als het ware tot persoonlijke zonden verleiden (het verrichten van dierproeven) en werkten zo zonder te weten wat zij aanrichtten, mee aan de voorbereiding van een oorlog.

In de jaren dertig wezen Pijl en zijn stichting veel explicieter op het bestaan van een onontwarbare kluwen van belangen van medici, producenten van geneesmiddelen, politici en het grote publiek. Daarbij werd veel minder aandacht besteed aan de persoonlijkheid van de individuele vivisector en veel uitdrukkelijker gesproken over het wezen en de kracht van het grootkapitaal. Waar rond 1900 vooral de voorstelling van 'offers op het altaar van de wetenschap' gangbaar was, werd in deze periode door de anti-vivisectionisten juist aan het kapitalistische systeem zelf een autonome, manipulerende kracht toegekend. In dertig jaar was de wetenschap in de anti-vivisectie geschriften als het ware getransformeerd van een onberekenbare, veeleisende, machtige, geldgod met de vivisectoren als dienaren, tot een onmondige slaaf van de Mammon zelf.

Deze verandering in de verbeelding van zowel het kwaad (van wetenschap naar grootkapitaal) als de slachtoffers (van onschuldige vrouwen en kinderen en afschrikwekkende armen naar de gewone man, de arbeider en zijn kind) hing ten nauwste samen met denkbeelden van de SAVB over de wijze waarop de strijd tegen vivisectie diende te worden gevoerd. Deze opvattingen verschilden van de noties die hierover binnen de anti-vivisectie-beweging van rond de eeuwwisseling bestonden. Daar Pijl geen angst voelde voor een eventueel in opstand komend proletariaat, hij hen niet als vertegenwoordigers van het beestachtige in de mens beschouwde maar juist als gewone, hardwerkende stervelingen die bescherming nodig hadden, had hij er geen bezwaar tegen om hen in zijn beweging op te nemen. Sterker nog, Pijl zag het liefst dat de SAVB tot een massabeweging zou uitgroeien. De strijd tegen vivisectie moest op allerlei niveaus worden gevoerd en de steun van zoveel mogelijk mensen was daarbij noodzakelijk.

Op allerlei manieren werd zoveel mogelijk ruchtbaarheid aan het bestaan van de stichting gegeven. Op treinstations werd de reclameplaat van de stichting neergehangen: een tekening met daarop een donkere hand die onder dwang van de greep van een witte hand een scalpel laat vallen. Onder dit tafereel een cavia, een hond en twee apen, het 'anti-vivisectie-kruis' (een kruis met drie dwarsbalken, en het onderschrift: BEVRIJDT HEN van de VIVISECTIE! Propaganda voor de stichting maakte Pijl ook door er zorg voor te dragen dat de SAVB op iedere beurs, tentoonstelling of bazar van belang met een stand en een overvloed aan zelf gedrukt reclame-materiaal vertegenwoordigd was. Een aantal keren lukte het de anti-vivisectionisten om in dit verband genoemd te worden in het film-journaal dat ook de trots van de SAVB toonde, de speciale antivivisectie-automobiel waarmee het land voor propaganda werd doorkruist. Daarnaast onderhield Pijl contacten met de pers, met name Het Vaderland en de Haagsche Post.

Journalisten werden uitdrukkelijk uitgenodigd en onthaald bij gelegenheden als de oprichting van de stichting, de opening van het speciale in Den Haag gevestigde Anti-Vivisectie Gebouw dat uit donaties was bekostigd, en bij lustra en lezingen. Tijdens dergelijke gelegenheden konden de

23. Die tendens was overigens al te bespeuren in 1928 in Vitkomst: "Want aan velen schijnt de vivisectie-bestrijding haast een hoopelooze onderneming. waar wij tegenover ons hebben: de massa der geleerden en der medici; het groote publiek dat niet zelf denkt, maar zich blindelings onderwerpt aan al wie het genezing van kwalen en verlenging van leven voorspiegelt; de Regeering. die aan den leiband loopt der officieele adviseurs en die niets durft doen dat met de met de vooroordeelen van het groote publiek in strijd is, en het enome kapitaal, dat rechtstreeks of zijdelings de vivisectie steunt. Daartegenover een kleine groep, zonder aanzien of gezag. die: regenover die geweldige macht van traditie, van schoolsche wetenschap, sleur, eigenbelang en grootkapitaal alleen maar stelt het vaste geloof in de zegepraal van liefde en mededoogen $|\ldots|$ '. 
genodigden kennisnemen van de standpunten van de stichting en zich verwonderen over de vele contacten waar Pijl zich op kon beroepen. Opzien baarde onder meer dat de ledenvergadering van 1931 door Z.K.H. Prins Hendrik werd bezocht. Nauwelijks minder opmerkelijk waren de contacten van de SAVB met Henriëtte Roland Holst en internationale beroemdheden als Dr. Max Herzog zu Sachsen ${ }^{34}$, Dr. Johannes Ude uit Graz, de Italiaanse arts B. Ciaburri en niet te vergeten Mahatma Ghandi. Wie niet naar Den Haag kon komen werd in de gelegenheid gesteld om dichter in de buurt van de eigen woonplaats een door de SAVB georganiseerde bijeenkomst bij te wonen. De binnenlandse en buitenlandse sprekers ondersteunden hun verhaal met geavanceerde 'lichtbeelden' die de vivisectie ten overstaan van het publiek zichtbaar maakten. ${ }^{25}$

Een groter contrast tussen zich met de modernste middelen profilerende SAVB de nogal in zichzelf gekeerde en door crises aangetaste NBBV, was nauwelijks denkbaar. Dit contrast kwam niet alleen tot uitdrukking in de propaganda, maar ook in de visie op de maatschappelijke plaats van de strijder tegen vivisectie. In de voorgaande hoofdstukken bleek dat de anti-vivisectionisten vanaf 1890 (en vanaf 1898 in toenemende mate door de invloed van Ortt) liever geen toenadering zochten tot de parlementaire politiek. Parlementaire politiek werd gezien als een verschijnsel van voorbijgaande aard, ondergeschikt aan of slechts een noodzakelijk stadium in het proces van morele evolutie dat zich volgens de wetten van een Al-macht voltrok. Het streven naar invloed in de landelijke politiek werd beschouwd als enigszins vulgair, omdat dit al snel kon uitmonden in compromissen en aanvaarding van het kwalijke en misleidende begrip 'noodzakelijk kwaad'.

Pijl versmaadde daarentegen de steun en het geld van halfslachtigen meestal niet en beschouwde het streven naar invloed, macht en het invoeren van een wettelijke regulering van vivisectie niet als een zonde. Zelf was hij zeer geïnteresseerd in de juridische aspecten van het vivisectievraagstuk, hetgeen werd onderstreept door de oprichting van een juridische commissie binnen de SAVB. Daarin nam een aantal gerenommeerde juristen zitting die alle rechtskundige en vaak ook rechtshistorische kanten van de kwestie bestudeerden. Het bleef niet bij onderzoek alleen. Gesteund door zijn adviseurs waagde Pijl het om een tweetal medici voor het Medisch Tuchtcollege te dagen en hen te beschuldigen van proeven op kinderen.

Ook aan de reactie van Pijls tegenstrevers is te zien dat zich een verandering had voltrokken. Ook zij benaderden de kwestie veel meer als een formele en minder als een persoonsgebonden strijd. Pijl werd met gelijke wapens bestreden en zelf voor de tuchtcommissie gedaagd. Hij zou de medische beroepsgroep hebben belasterd. De commissie verklaarde zich voor beide zaken niet ontvankelijk en dat hinderde geen van de betrokken partijen. De SAVB was tevreden, omdat de naam van haar stichter voorgoed was gevestigd.

Die naamsbekendheid was voor Pijl niet voldoende. HIj had een beweging voor ogen met een brede uitstraling. De leden van de SAVB, waaronder opvallend veel juristen en ingenieurs, moedigde hij aan om waar mogelijk hun invloed te doen gelden. Uitdrukkelijk werd vermeld dat het daarbij niet in de eerste plaats ging om het getuigen in eigen kring, zoals de NBBV vooral voor ogen had gestaan, maar juist om het verwerven van gezag in officiële organen:

'Gij allen, die belang stelt in Humaniteit en Humanitaire Wetgeving, en daarom ook belangstelling hebt voor Het Anti-vivisectie-vraagstuk, bevordert de practische uitvoering van dit alles door -waar Gij kunt- in Regeeringslichamen als Eerste en Tweede Kamer, Provinciale Staten, Gemeenteraden, Overheidscommissies, Gezondheidsraden, enzoovoort, te doen

\footnotetext{
24. Zie over hem: Iso Baumer, Max von Sachsen. Priester und professor. Seine Täligkeil in Freiburg/Schweiz, Lemherg und Köln (Freiburg 1990).

25. Een indruk van de afbeeldingen die ter gelegenheid van de lezingen getoond werden geeft het volgende overzicht dat werd afgedrukt bij een schriftelijke weergave van de lezing die Pieter Pijl tussen 16 en 24 maar 1932 op een aantal plaatsen in Nederland hield : 'Wij zullen thans een en ander projecteeren om met voorbeelden het $U$ gezegde te verduidelijken: GEPROJECTEERD WERD: I: Hond met doorgesneden stembanden (Moritz Schifn 2: Kat op de vivisectie-tafel gebonden. 3: Schijnvoering van Pawlow. 4: Zwangere kat met buikvenster. 5: Electrisch gedreven trommel voor vermoeienisproeven. 6: Uitgeteerde slachtoffer met totale blindheid intentingsproeven. 7: Door curare verlamde kikvorsch, opgespeld. 8: Afgesneden hondekop. 9: Hel ontwaken van de afgesneden hondekop. 10: De doodstrijd van de afgesneden hondekop. 11: Aap met teerkanker uit het Ned. Tijdschrift voor Geneeskunde."
} 
opnemen humanitair ingestelde menschen, die werkelijke dierenbeschermers en anti-vivisectionisten tevens zijn!'

Om de leden van de Stichting te helpen zich aan anderen als anti-vivisectionist en voorstander van een humanitaire vivisectie-vrije geneeskunde kenbaar te maken, werden insignes met daarop het teken van de SAVB (het eerder genoemde anti-vivisectie kruis of een zilveren hondje met de initialen van de bond) beschikbaar gesteld.

Het zou een misvatting zijn om het verschil tussen de strijdwijze van de SAVB en die van de NBBV van rond 1900 te duiden als een verschil tussen actieve en passieve strijd, tussen een moderne, rationele politiek en een expressieve politiek. Daarmee zou het verschil tussen beide periodes en organisaties te veel in het schema van winnaars en verliezers worden geplaatst. Het onderscheid tussen beide soorten anti-vivisectionisme is eerder dat de SAVB in de samenleving wilde staan. Als kind van de jaren dertig beschouwde deze organisatie de samenleving en de politieke constellatie als een onontkoombaar gegeven. Ortt wilde juist dat de anti-vivisectionisten van de NBBV zich door hun manier van leven enigszins buiten de maatschappij plaatsten. De NBBV verwees niet naar relaties met politieke partijen, naar een plaats in de samenleving of naar een geloofsrichting. Zij beklemtoonden hun persoonlijke relatie tot de samenleving, de wet en een universele moraal.

Hun medisch-wetenschappelijke tegenstanders deden hetzelfde. Bovendien deelden voorstanders en tegenstanders van vivisectie rond de eeuwwisseling eenzelfde soort beeld over de plaats die Nederland internationaal gezien innam. Hoewel beide groepen een ander antwoord gaven op de vraag of het afschaffen dan wel beperken van vivisectie schadelijke gevolgen had voor die internationale reputatie en zo ja, of dat erg was, leken zij er allebei uit te gaan dat Nederland in de wereld een bijzondere positie innam. De Nederlandse natie werd door beide groepen beschreven als een enclave in een zich snel moderniserende wereld, een eiland dat wel bedreigd werd maar toch nog zodanig afgeschermd kon worden dat de bevolking de ruimte en de tijd had om te beslissen of zij bepaalde, elders reeds gangbare gebruiken en opvattingen, wilde overnemen.

Nederland was in de ogen van Pijl daarentegen veel meer een land als alle anderen, dat wil zeggen, opgenomen in een kapitalistisch wereldsysteem, waarin niet afzonderlijke landen maar organisaties als The Rockefeller Foundation en de farmaceutische industrie in belangrijke mate de dienst uitmaakten. Hij ging er niet vanuit dat Nederland kwalijke invloeden buiten zou kunnen sluiten. Voor hem was het anti-vivisectionisme dan ook, meer dan voor Ortt en de zijnen, een internationale stroming, een wereldwijd verzet tegen de beheersing van de medische wetenschap door het kapitaal.

Voor die strijd tegen het kapitalisme was meer nodig dan alleen een zuivere individuele levenswijze. Met spanning werd daarom uitgezien naar eventuele oplossingen die krachtige figuren als Hitler en Mussolini voor het vivisectie-vraagstuk zouden aandragen. Alleen dictators zouden het wellicht tegen de samenspannende krachten kunnen opnemen. Niet zonder enthousiasme werd in Meededeelingen van september 1933 het volgende bericht uit Het Vaderland geciteerd:

Door een verordening van den Pruisischen minister is van gisteren af de vivisectie op alle soorten dieren voor het gehele Pruisische grondgebied verboden. De premier heeft den betrokken ministeries verzocht hem onmiddellijk een betreffend wetsontwerp voor te leggen. In afwachting van de uitvaardiging van de wet zullen alle personen die, ondanks het verbod vivisectie toelaten, zelf verrichten of mogelijk maken naar een concentratiekamp gebracht worden. 26

Een andere belangrijke kracht tegen het kapitalisme was volgens de SAVB de oosterse wijsheid. De figuur van de oosterse wijze zou binnen de SAVB een belangrijke plaats innemen en voorgesteld worden als navolgenswaardige figuur. Met name Mahatma Ghandi, het voormalig hootd van de theosofische Orde van de Ster in het Oosten Krisjnamurti, de in India tegen het religieus slachten van geiten strijdende Ram Chandra en de soefist Inyat Kahn werd de betekenis

26. Het Vaderland 17 augustus. 
toegeschreven die rond 1900 aan Tolstoj was toebedeeld. ${ }^{27}$ Gesteld kan worden dat in de op zich zo verschillende politieke stijl van de organisatie van Pijl toch de navolging van Christus (nu in de persoon van de oosterse wijze) en daarmee het patroon van de heldenreis belangrijke onderdelen bleven van het verzet tegen vivisectie. In dit opzicht bleef het anti-vivisectionisme een expressieve politiek.

\section{De Tweede Wereldoorlog}

Het anti-vivisectionistische idealisme was niet stuk geslagen op de harde werkelijkheid van de Eerste Wereldoorlog. Ook het uitbreken van de Tweede Wereldoorlog betekende niet, zoals in de historiografie wel is gesuggereerd, het absolute einde van het geloof in de morele vooruitgang van de mensheid en de mogelijkheid om een betere wereld tot stand te brengen. De oorlog werd in de kring van anti-vivisectionisten niet als doelloos ervaren maar als een mogelijkheid om voor altijd met het kwade af te rekenen en ruimte te geven aan het goede. Soms werd de Tweede Wereldoorlog voorgesteld als een noodzakelijk stadium in de morele evolutie. Illustratief is de bijdrage van Henriëtte Roland Holst-Van der Schalk voor het Jubileum-nummer van Meededeelingen in februari 1941:

'[...] In vreugde herdenken wij, en wenden ons voorwaarts in vertrouwen. Wij weten dat krachten van liefde en deernis ook nu aan het werk zijn, dat de verbondenheid groeit tusschen menschen onderling, tusschen menschen en dieren. Wij weten dat de orkaan van verschrikking die over de wereld vaart, veel zal vernietigen wat ons lief was maar ook veel wat wij verfoeien en waartegen ons streven zich keert. Het wangeloof aan een materialistisch-gerichte pseudo-wetenschap krijgt een doodelijken knauw, de beate verafgoding van de 'wonderen der techniek' maakt plaats voor afgrijzen. Het tijdperk van valsche 'beschaving; en valsch gerichte wetenschap, gaat ten einde - en daarmee de gedrochtelijke instelling der vivisectie. In de gereinigde atmosfeer zullen de stemmen van Boeddha, Plato en Christus helderder klinken dan in eeuwen. ${ }^{28}$

Het commentaar van de redactie van Meededeelingen in januari 1942 ademde eenzelfde geest:

'Kerstmis 1941! De geheele wereld in oorlogsbrand! Kunnen we daarbij nog hoop hebben op betere tijden ? Ja, dat kunnen we, ondanks alles. Maar dan moesten we beseffen dat in de natuur niets zinloos geschiedt. Laat ons dan vertrouwen, dat uit deze wereld van smart een betere geboren zal worden, waarin een werkelijke vrede zal heerschen en een samenleving zal ontstaan waarin de ongeschreven heilige wetten van mensch en dier nageleefd zullen worden. Zoo gaan wij dan het nieuwe jaar in met ongeschokt vertrouwen op de toekomst. Het Bestuur wenst alle leden een gelukkig jaar 1942. ${ }^{29}$

Het vertrouwen in de toekomst ingegeven door het feit dat zowel de SAVB als de NBBV in de eerste jaren van de oorlog gewoon door konden werken. De organen van beide organisaties bleven op regelmatige basis uitkomen. Als we de redactionele commentaren van Meededeelingen mogen geloven, waren veel leden in deze periode zelfs geneigd om de bond met extra donaties van soms een paar honderd gulden te steunen.

De anti-vivisectie-beweging kon bovendien rekenen op de sympathie van een aantal vooraanstaande nationaal-socialisten. Op de ledenlijst van de SAVB (sinds 1939 Anti-Vivisectie Stichting AVS) waren de namen te vinden van Ir. Anton Mussert en M.M. Rost van Tonningen. Het is niet ondenkbaar dat Pijl tijdens zijn leven in deze kringen goodwill had gekweekt door zijn contacten met Duitse anti-vivisectionisten (en natuurgeneeskundigen) en de door Mussolini zeer bewonderde Italiaanse arts Ciaburri. De NSB-ers zullen zich ook aangetrokken hebben gevoeld door Pijls talent

27. Citaten uit het werk van deze grootheden alsmede de meest uiteenlopende verwijzingen naar de Mahabarata en Indiase verellingen complementeerden dit beeld van Indiase en oosterse wijzen

28. 'Henriëtle Roland-Holst', Meededeelingen Lustrumnummer 10 (1941) 26-27, aldaar 27. Zie ook: Henriëtte Roland Holst-Van der Schalk, 'Vivisectic en levensbeschouwing', Meededeelingen Lustrumnummer 15 (1946) 32-33

29. 'Bij hel nieuwe jaar', Meededeelingen 11 (1942) 1 
om van de meest moderne propagandamiddelen gebruik te maken, een zo groot mogelijk aantal mensen te mobiliseren en veel geld los te krijgen. Van de NBBV zijn uit de periode van vlak voor de Tweede Wereldoorlog geen ledenlijsten beschikbaar. Een vergelijking op dit punt is dus niet mogelijk. Het is echter niet al te waarschijnlijk dat de elitaire maar veel minder kapitaalkrachtige en invloedrijke NBBV aantrekkelijk was voor de aanhangers van de NSB. Dit betekent niet dat de bond geheel vrij was van nationaal-socialistische sympathieën. Via Yge Hettema -volgens de overlevering een groot bewonderaar van Hitler en Oostfrontstrijder- was de NBBV gelieerd aan groepen die waren voortgekomen uit de Nederlandse beweging rond de vrije lichaamskultuur. In Nederland interesseerde een deel van deze beweging zich tijdens het Interbellum voor riten die de superioriteit, schoonheid en gezondheid van het arische ras vierden.

Ook al raakte het anti-vivisectionisme en het humanitair-idealisme waarmee deze beweging verwant was niet dodelijk gewond door de oorlog, toch dringt zich de vraag op of deze stroming, zoals Wolfgang Krabbe en Dolf Sternberger suggereren, mogelijk geruisloos in het nationaalsocialisme is opgegaan? Deze vraag kan, althans voor wat betreft Nederland, niet bevestigend beantwoord worden. Toch wijst een aantal gebeurtenissen uit de geschiedenis van de beweging bij oppervlakkige beschouwing op een symbiose tussen het verzet tegen vivisectie, de daarmee verbonden beelden van goed en kwaad, en nationaal-socialistische sympathieën. In de eerste plaats is daar de tekst die in 1942 in Meededeelingen werd afgedrukt:

'Het bestuur herinnert aan de verordening van de Duitsche Overheid waarbij het aan Joden verboden is lid te zijn van vereenigingen of stichtingen met een niet-economisch doel. Het bestuur beschikt niet over gegevens en neemt aan, dat zij, die om die reden hun lidmaatschap moeten beëindigen, zulks aan het bestuur kenbaar maken.'

De NBBV liet dergelijke mededelingen achterwege. Toch voerde deze bond in 1942 samen met 'aartsvijand' AVS en de dierenbescherming overleg met de Duitse Oberregierungsrat Dr. Pschorr, de 'gevolmachtigde' voor veterinaire aangelegenheden van de Rijkscommissaris voor het bezette Nederlandse gebied. Na een voordracht van Hugo van Poelgeest, de vice-voorzitter van de NVBD, hield Pschorr een lezing over de uitgangspunten van de moderne dierenbescherming. Hij benadrukte de dierenliefde die de Germaansche volken al eeuwenlang voelden. De NBBV was tevreden over de woorden van de Oberregierungsrat.

'Het spreekt vanzelf, dat wij met groote voldoening vernomen hebben, dat de totstandkoming van een wettelijke regeling in het belang van het dier in de naaste toekomst mag worden tegemoet gezien, en dat wij met groote belangstelling hebben geluisterd naar de uiteenzettingen van Dr. Pschorr, uit wiens sympathieke beschouwingen bleek, dat hier inderdaad een oprecht dierenvriend het woord voerde. ${ }^{30}$

De positieve woorden van de NBBV komen in een ander licht te staan wanneer duidelijk wordt dat deze op exact dezelfde wijze werden gepubliceerd in Meededeelingen. Het is met het oog hierop niet ondenkbaar dat de anti-vivisectionisten gedurende het overleg met Pschorr voor de keuze zijn gesteld om in welwillende en duidelijk geregisseerde toon verslag te doen van Duitse bemoeienis met dierenbescherming en anti-vivisectionisme of wellicht een verbod van de beweging. De AVS en de NBBV kozen voor het eerste. In 1943 stopten beide bewegingen echter toch met de uitgave van hun respectievelijke organen.

Van een geruisloos overgaan van het anti-vivisectionisme en het humanitair-idealisme in het nationaal-socialisme is met andere woorden geen sprake, al waren er sympathieën in die richting en publiceerden beide organisaties in oorlogstijd opvallend veel artikelen die uit Duitse tijdschriften afkomstig waren. Wel kan gesteld worden dat het anti-vivisectionisme op of wellicht over de rand van collaboratie verkeerde. Wanneer dit gegeven wordt gecombineerd met het feit dat er rond 1900 sprake was van een koppeling van het beeld van de duivelse vivisector aan het beeld van de jood als vertegenwoordiger van het materialisme en de moordenaars van Christus, is het dan niet meer dan juist te veronderstellen dat Sternberger het bij het rechte eind had toen hij stelde

30. Ibidem. 
dat het negentiende-eeuwse anti-vivisectionisme en humanitair-idealisme vanaf het begin een donkere en gevaarlijke beweging was?

In de inleiding werd er uitdrukkelijk voor gekozen om deze opvatting niet als uitgangspunt voor deze studie te nemen. Terugkijkend op de reis door de hel der onschuldigen blijkt dit ondanks het hierboven beschrevene een juiste keuze te zijn geweest. De verbeelding van de antivivisectionisten kwam voort uit en speelde in op beelden, angsten en fantasieën die zij deelden met hun tijdgenoten. Het beeld van de jood als vertegenwoordiger van het kwaad was er een van, het beeld van de vrouw als onberekenbaar of als moeder een ander. De beweging om die reden vanaf het prilste begin als antisemitisch en gevaarlijk bestempelen is, althans waar het de Nederlandse anti-vivisectionisten betreft, even onzinnig als haar als seksistisch of racistisch bestempelen. Naar hedendaagse maatstaven was de beweging dit alles inderdaad. Hetzelfde kan evenwel over de Europese samenleving van die tijd gezegd worden.

De sympathie voor het nationaal-socialisme die zich rond 1940 manifesteerde, is dan ook slechts gedeeltelijk een voortbouwen op de verbeelding van de periode rond 1900. Zij lijkt eerder het resultaat van een verschuiving in het denken over slachtoffers en helden, over wetenschap en, zeker niet onbelangrijk, politiek en samenleving. Sternberger ziet een groot gevaar in de wijze waarop de negentiende-eeuwse anti-vivisectionisten en idealisten door middel van fictie en een daarin uiteengezet polariserend en esthetiserend beeld van goed en kwaad inspeelden op de gevoelens van de burgerij. Het is de vraag of niet ook het verdwijnen van deze 'oude beelden', de conventies over goed en kwaad met een eigen gedaante maar ook eigen grenzen, niet meer ruimte gaf aan sympathie voor de dynamiek van het nationaal-socialisme en fascisme.

\section{Beschavingsoffensief en individuele hervorming}

Dit boek stelde zich niet alleen ten doel om de strijd tegen vivisectie op een andere dan met het doorgaans in de historiografie gebezigde winnaars- en verliezersperspectief te benaderen. Het was tevens de bedoeling kanttekeningen te plaatsen bij de opvatting dat de politieke stijl van de antivivisectionisten lijnrecht tegenover de politieke stijl van de voorstanders van dierproeven stond. Ook werd bestreden dat het humanitair-idealisme haarscherp te onderscheiden valt van bewegingen of organisaties die compromissen nastreefden of een burgerlijk beschavingsoffensief inzetten.

$\mathrm{Nu}$ de reis door de hel der onschuldigen ten einde loopt is duidelijk geworden dat pro- en antivivisectionisten niet zelden uitgingen van dezelfde opvattingen over wetenschap en politiek. De poging om, in het geval van de medici, de eigen beroepsgroep of, in het geval van de antivivisectionisten, de eigen klasse te beschaven, makkte zeker deel uit van de door hen gevoerde strijd. Maar de benaming beschavingsoffensief is niet goed bruikbaar. Wanneer die term wordt gehanteerd blijven te veel aspecten van de expressieve politiek van de anti-vivisectionisten buiten beschouwing.

Te stellen dat het binnen de anti-vivisectie-beweging draaide om de hervorming van het individu is op zichzelf juist, maar ook hier geldt dat een dergelijke kwalificatie voorbijgaat aan de veelzijdigheid van de anti-vivisectionistische expressieve politiek. Bovendien suggereert een dergelijke omschrijving dat het alleen de humanitair-idealisten waren die zo'n waarde aan het individu hechtten, terwijl de liberale voorstanders van vivisectie en een aantal liberale en confessionele kamerleden hetzelfde deden. Dat geldt ook voor het uitdragen van een morele levenshouding, het benadrukken van de relatie met een hogere macht en het gebruik van de verbeelding. Deze kenmerken van de expressieve politiek van de anti-vivisectionisten vindt men ook bij de andere betrokkenen in het debat over vivisectie. Wellicht wijst dit erop dat de Nederlandse politiek rond 1900 expressiever was dan tot nu toe is aangenomen. 


\section{Epiloog}

Meteen na de oorlog hervatten de NBBV en de AVS hun strijd tegen de vivisectie. In het lustrumnummer van 1946 bracht de AVS hulde aan Felix Ortt, de nestor van de beweging en werd een aanleiding gevonden om de strijd met hernieuwde kracht te voeren:

'Bij de berechtiging der oorlogsmisdadigers in Neurenberg is gebleken aan welke gruwelijke vivisectie-proeven de gevangenen en geinterneerden in Duitschland werden blootgesteld. Ook dit moet voor ons een aanleiding zijn onze actie met alle krachten voort te zetten, opdat aan dergelijke gruwelen voor goed een einde kome !'

Vandaag de dag bestaan de NBBV en de AVS nog altijd. Beide stichtingen zijn in Den Haag gevestigd in hemelsbreed zeer dicht bij elkaar gelegen panden. Lange tijd, tot in de jaren tachtig waren beide organisaties niet 'on speaking terms'. In de jaren negentig was er sprake van enige toenadering maar de relaties bleven problematisch. Een fusie van beide organisaties mislukte jammerlijk. Anno 1999, meer dan honderd jaar na de oprichting van de NBBV, kan gezegd worden dat de strijdwijze van de beweging veranderd is. Christus wordt niet langer nagevolgd en de vrouwen binnen de beweging (die nog altijd meer dan de helft van de leden uitmaken) hoeven geen maagdelijke, zusterlijke of moederlijke heldinnen te zijn om in het openbaar te treden.

De foto van Felix Ortt die jarenlang aan de muur hing, is verdwenen. Waar de afbeelding gebleven is weet niemand. Wie zou hij ook tot voorbeeld moeten dienen? De hardwerkende en zonder twijfel idealistische medewerkers van AVS en NBBV bedrijven geen expressieve politiek." In plaats daarvan is men in een geduchte concurrentiestrijd verwikkeld met 'grote jongens' als Greenpeace, NOVIB en andere organisaties. Ergens in de tijd, waarschijnlijk in de jaren vijftig en zestig, moet het anti-vivisectionisme veranderd zijn in de instrumentele beweging van vandaag.

1. J.J. Theling. 'Vijftien jaren van strijd tegen de vivisectic'. Meededeelingen Lustrum-Nummer 15 (1946) 3-4, aldaar 4

2. Zie ook: Amanda Kluveld 'Anti-vivisectionisten en het verleden. Peter Singers 'Animal Liberation' bezien in het licht van het honderd-jarig bestaan van de NBBV'ID. faculteitsblad Cultuurwetenschappen 3 (1996) 5. 


\section{Lijst van geraadpleegd materiaal}

\section{ARCHIEVEN}

Archief Nederlandse Dierenbescherming, Den Haag

Archief Nederlandse Bond tot Bestrijding der Vivisectie, Den Haag

Archief Anti-Vivisectie Stichting, Den Haag

Archief Hugo van Poelgeest, ARA, Den Haag

\section{PERIODIEKEN}

Androcles, maandschrift aan de belangen van dieren gewijd, 1869-1904.

Orgaan van den NBBV, 1904-1928.

Uitkomst, Orgaan van den NBBV, 1929-1943.

De Geillustreerde Dierenvriend, orgaan van den NBBV, 1933-1939.

De Dierenvriend, orgaan van den NBBV, 1940-1942.

Meededeelingen, orgaan van de SAVB, 1931-1950.

\section{ROMANS/KORTE VERHALEN/GEDICHTEN}

Anoniem, De Vivisectie (gedicht) (1871).

Adams, Richard, The Plague Dogs (novel) (Londen 1977).

Aesculapius Scalpel, Dying Scientifically. A key to St. Bernard's (Londen 1888).

Beecher Stowe, Harriet, Uncle Tom's Cabin, or life among the lowly (Boston 1852).

Beecher Stowe, Harriet, De hut van oom Tom. Een verhaal uit het slavenleven in Noord-Amerika

(Amsterdam 1991).

Berdoe, Edward, St. Bernard. The romance of a medical student (Londen 1877).

Blankenaar, J., Vivisectie (gedicht) (1891).

Buysse, Cyrille, Canule (z.p. 1907).

Collins, Wilkie, Heart and Science (z.p. 1883).

Daal, Marie (pseudoniem voor C.J. van der Hucht-Kerkhoven) Anna ('s-Gravenhage 1880).

Daal, Marie, De familie van Westvoorne deel I ('s-Gravenhage 1891).

Daal, Marie, De familie van Westvoorne deel 2 ('s-Gravenhage 1891).

Dostojevski, F. M., De gebroeders Karamazov (Utrecht/Antwerpen 1981).

Eeden, Frederik van, De Broeders. Tragedie van het recht. Eerste druk 1894 (Leiden 1983).

Eeden, Frederik van, Het lied van schijn en wezen. Uitgegeven, ingeleid en toegelicht door H.W. van Tricht. Tweede herziene druk. Eerste druk Zwolle 1954 (Den Haag 1981).

Eeden, Frederik van, De kleine Johannes Eerste druk 1887 (Amsterdam 1991).

Elpis Melena, (pseudoniem voor M.E. von Schwartz), Gemma, oder Tugend und Laster (München 1877).

Elpis Melena, Gemma, naar het Duitsch ('s-Gravenhage 1891).

Fiore della Neve (pseudoniem voor M.G.L. van Loghem), Victor (Amsterdam 1886).

George, Elisabeth, Playing for the ashes (Toronto 1994).

Goekoop-de Jong van Beek en Donk, Cécile, Hilda van Suylenburg eerste druk 1897 (Amsterdam 1984).

Grand, Sarah, The Beth book: being the study of Elisabeth Caldwell Maclure, a woman of genius (Londen 1889).

Haasse, Hella, Heren van de thee (Amsterdam 1992).

Jungius, Marie, Sprookjes van leven (z.p. 1899).

Jungius, Marie, Verzen en sprookjes van Marie Jungius (Huis ter Heide 1928).

Kingsford, Anna, Het land aan genezijde van de zon ('s-Gravenhage 1895).

Macdonalds, George, Paul Faber, surgeon (z.p. 1871).

Mann, Thomas, Der Zauberberg (Berlijn 1991).

Ortt, Felix, Naar het groote licht (Amersfoort 1897). 
Ortt, Felix, Heidekind (Blaricum 1904).

Ortt, Felix, Felicia. Het boek van roeping (Den Haag 1905).

Ortt, Felix, Felicia. Het boek van vervulling (Den Haag 1905).

Powys, John Cowper, Jobber Skald (Londen 1935).

Sanders van Loo, A., Kleine Lichten (z.p. 1901).

Shaw, George Bernard, The Doctor's dilemma (Londen 1922).

Shaw, George Bernard, The adventures of the Black girl in search for God (Londen 1944).

Twain, Mark, The horse's tale and the dog's tale (New York 1906).

Twain, Mark, De geschiedenis van een paard, gevolgd door de geschiedenis van een hond ('sGravenhage 1915).

Vestdijk, Simon, De vrije vogel en zijn kooien. De geschiedenis van een domicilie. Anton Wachter roman 6. Eerste druk 1958 (Rotterdam 1982).

White, Patrick, The vivisector (Londen 1970).

Wolkers, Jan, Serpentina's petticoat (Amsterdam 1961).

Zeegers-Claessen, Jo, Eli, waar zijt Gij? De mensch, de maatschappij en haar toekomst (Deventer 1937).

\section{PUBLICATIES FELIX ORTT}

Een veilige buitenduinsche haven voor Scheveningen (z.p. 1895).

Het Vegetarisme als bondgenoot (Amsterdam 1896).

Verslag van de eerste jaarvergadering NBBV (z.p. 1897).

Het Beginsel der Liefde (Haarlem 1898).

Is de vivisectie in het belang der menschheid? (1898).

Liefde en huwelijk (Den Haag 1898).

Het spiritisme (z.p. 1899).

Open brief aan de presidente v.d. Nederl. Vrouwenbond ter Internationale ontwapening (Amsterdam 1899).

Denkbeelden van een Christen-Anarchist (Den Haag 1900).

Onnodige gruwelen in voedsel mode en sport (z.p. 1900).

De vivisectie van verschillende zijden beschouwd (z.p. 1901).

Betrekkelijke machteloosheid der regeering inzake vivisectie-bestrijding (z.p. 1901).

Brieven over gezondheid (Blaricum 1902).

Medische wetenschap en vivisectie ('s-Gravenhage 1903).

Cursus over vivisectie ('s-Gravenhage 1903).

Practisch socialisme (Amer-foort 1903).

Het streven der Christen-Anarchisten (Amersfoort 1903).

Rein Leven en Geheelonthouding (Amersfoort 1903).

Over de beteekenis van vivisectie in Nederland (z.p. 1904).

Van de planeet Mars (Amersfoort 1904).

Brieven aan 'n vriendinnetje over religieuze begrippen (z.p. 1904).

Eerste Vredebundel (Amersfoort 1904).

Pro en contra vivisectie (z.p. 1905).

Troost voor stervenden (Rotterdam 1906).

Nieuwere beschouwingen over voeding (Den Haag 1906).

De aanval van twee hoogleeraren op de NBBV beantwoord (z.p. 1907).

Apen en menschen ('s-Gravenhage 1907).

Verdediging van ons standpunt (z.p. 1907).

De vivisectie-bestrijding (z.p. 1907).

De Rein Leven Beweging (z.p. 1908).

Over een gevaarlijke gewoonte (Den Haag 1908).

Brieven over Godsgeloof (Blaricum 1909). 
Pro en contra: Tweeërlei moraal (Baarn 1909).

Over god en het schepsel Gods (Zwolle 1910).

Prof. Zwaardemaker over vivisectie (Amsterdam 1910).

Overzicht van het vivisectie-vraagstuk (Amsterdam 1910).

Drankzucht en hoe die tegen te gaan (z.p. 1911).

Natuurgeneeswijze en schoolgeneeskunde (z.p. 1912).

Vivisectie op kinderen (Oostende 1912).

De vivisectiestrijd (z.j. 1913).

Het peil van ons rechtswezen (Rotterdam 1916).

De invloed van den oorlog op de ethiek (Purmerend 1916).

Inleiding tot het pneumat-energetisch monisme ('s-Gravenhage 1917).

Wetenschappelijke dierenmarteling (Utrecht 1916).

Mensch en dier (Laren 1917).

Meening over pijngevoel van Prof. van Rijnberk en weerlegging daarvan (z.p. 1918).

Prof. Van Rijnberk over de anti-vivisectiebeweging (Haarlem 1918).

Vertellingen uit den Bijbel voor de kleintjes (Maassluis 1918).

Staat en volk (Blaricum 1920).

Het Rooken (Amsterdam 1920).

Ons Standpunt verdedigd (z.p. 1920).

Over kunst en schoonheid (Blaricum 1921).

Hoe staan de vivisectie-bestrijders tegen de serum- en vaccintherapie? (Soest 1926).

Ons Standpunt verdedigd door Felix Ortt (Haarlem 1927).

Waarom werd ik anti-vivisectionist (z.p. z.j.).

Annie Ruys en Felix Ortt, De strijd tegen vivisectie (Haarlem 1941).

\section{PUBLICATIES VAN ANTI-VIVISECTIONISTEN/PUBLICATIES VOOR, TEGEN EN OVER VIVISECTIE TOT 1945:}

Balt, Murk, Uw persoonlijk belang (Ede 1910).

Bartolotti Rijnders, J. En H.I.J. Struijken, Vivisectie is in het belang der menschheid! Een enkel woord tot beoordeeling der brochure uitgegeven door den NBBV (Breda 1898).

Blaubeen, Martin, Vivisectie (z.p. 1921).

Beddow Bayly, M., Vivisection in the light of philosophy and modern science (z.p. 1930).

Beddow Bayly, M., From Koch to Calmette (z.p. z.j.).

Bayly, R., Vivisection, Its past, present and future (Londen 1937).

Beerends, Dirk, Is de vivisectie onzedelijk? Open brief aan Androcles, met aanteekeningen door Dirk Beerends (Amsterdam 1892).

Bell Taylor, Charles, Vivisectie is zij te rechtvaardigen? Uitgave van de Londen en provincial anti-vivisection society vertaald door G.E. Ridder Huyssen van Kattendijke ('s-Gravenhage 1908).

Bouvé, M.J., Welke zijn de ethische en medische gronden voor de bestrijding der vivisectie (Katwijk aan Zee 1939).

Brink, N.E.M. ten, Een valsch gevoel der harten in mensch -en dierenbescherming van onzen tijd (z.p. 1883).

Calcar, R.P., De vivisectie. Naar aanleiding van het adres van den NBBV in Nederland aan Z.E. de minister van Binnenlandsche Zaken (Amsterdam 1906).

Cobbe, Frances Power, The nine circles of the Hell of the Innocent (z.p. 1892).

Cobbe, Frances Power, The nine circles (z.p. 1893).

Commissie inzake Vivisectie, Rapport der Commissie inzake Vivisectie ('s-Gravenhage 1909).

Coleridge, Stephen, The Royal Commission on Vivisection (Londen 1907). 
Deutmann, L., Mystiek en officieele wetenschap. Tevens critiek op Van Rijnberks Hedenkdaagsch Mirakelgeloof ('s-Gravenhage 1915).

Deutmann, Lize, Het zijn maar prikjes (Den Haag 1941).

Dyerinck, A.G., S. Groshans en S.C. van Leersum, Is onze rijpere jeugd in wezen anders dan vroeger? ('s-Gravenhage 1923).

Doorman, Christine, 'De mensch Felix Ortt' in: A. Arriëns, ed. Van en Over Felix Ortt. Bundel ter gelegenheid van zijn zeventigste verjaardag (z.p. 1936) 10-11.

Ebeling, A.J.J., Bewijst elkander schuldige eer. Open brief aan den heer Dirk Beerends (Amsterdam 1893).

E.D.D.Y. (pseudoniem voor Edward Peeters) Een triptiek van Felix Ortt (Oostende 1907).

Eerdmans, A.J.A.F., De wetenschap tegenover hondsdolheid, en de Buissonmethode ter genezing van hondsdolheid. Lezing den 18 en augustus gehouden in de loge Sint Jan te Bandoeng (Bandoeng 1927).

Elpis Melena, Dr. E.F.G. Grysanovski. Mitteilungen aus seinem Leben und seinen Briefen (Hannover 1890).

Emants, Marcellus, Beperking der vivisectie (z.p. 1906).

Esculaap (pseudoniem voor Lize Deutmann), Jenner en de vaccinatie (z.p. 1939).

Groshans, Suze, De taak van de vrouw bij de gemoedsontwikkeling ('s-Gravenhage 1914).

Harting, Pieter, 'Vivisectiën', Album der Natuur 5 (1874) 65-70.

Harting, Pieter, 'Philothérie of philantropie', Album der Natuur 12 (1881) 131-142.

Harting, Pieter, 'Eene psychologische studie naar aanleiding van een hangend vraagstuk', Album der Natuur 15 (1884) 161-184.

Hucht, J.C., In Memoriam Lord Shaftesbury (z.p. 1891).

Hugenholtz, J.B.Th., Open brief aan Dr. W. Koster ('s-Gravenhage 1891).

Hugenholtz, J.B. Th. , Het vivisectie-vraagstuk. Rede gehouden in Patrimonium te Amsterdam en Utrecht (Utrecht 1892).

Hugenholtz, J.B., De vivisectie in het Licht der Moraal en der Historische Kritiek (Edam, z.j.).

Huber, Johannes, Der Tierschutzgedanke in philosophisch-geschichtlicher Betrachtung (Basel 1927).

HVBD, Een paar bedenkingen naar aanleiding van het conflict ontstaan tusschen Prof. Harting en de Vereeniging tot Bescherming van Dieren te 's-Gravenhage betrekkelijk vivisectie, opgedragen aan de abonnee's van het Album der Natuur ('s-Gravenhave 1874).

Iatros (pseudoniem voor E. Grysanovski), Die Vivisektion. Ihr wissenshaftlichen Wert und ihre ethische Berechtigung (Leipzig 1877).

Jelgersma, G., Leerboek der functionele neurosen (Amsterdam 1897).

Jungius, Marie, De vivisectie in Nederland (Den Haag 1895).

Jungius, Marie, Een woord over de voorgenomen Nationale Tentoonstelling van Vrouwenarbeid (Den Haag 1897).

Jungius, Marie, De vivisectie is een kwaad en moet daarom uit de samenleving verdwijnen ("sGravenhage 1898).

Jungius, Marie, De Nederlandsche Kinderbond en de eenheid van alle humanitaire streven. Toespraak op het congres voor maatschappelijk werk van de Nationale Tentoonstelling van Vrouwenarbeid (Amsterdam 1899).

Jungius, Marie, Over de onbegrensdheid van ons meegevoel. Rede uitgesproken te Rotterdam, 'sGravenhage en Nijmegen (Suest 1900)

Kaayk, Tine, 'Felix Ortt' in: NVB, Leven en laten leven 1894-1944. Uitgave van de Nederlandsche Vegetariërs Bond ter gelegenheid van het vijftig-jarig bestaan. Opgedragen aan Suze Groshans en Felix Ortt (z.p. 1944) 18-22.

Kingsford, Anna, Pasteur, zijne methode en hare resultaten. Voordracht gehouden te Hampstead 13 mei 1886. Vrij uit het Engelsch vertaald en van een naschrift voorzien, door J.C. van der Hucht (z.p. 1887). 
Kingsford, Anna, Onwetenschappelijke wetenschap. Vrij uit het Engelsch vertaald door J.C. van der Hucht (z.p. 1891).

Kingsford, Anna, De perfecte voeding (z.p. 1894).

Kist-Van Rhijn, C., Het vivisectie-vraagstuk. Schets van het ontstaan, de wordingsgeschiedenis der anti-vivisectiebewegingen en de resultaten die in de laatste 50 jaren zijn bereikt (z.p.1926).

KNAW, 'Verslag van het antwoord aan de minister van Binnenlandsche Zaken te geven op vier vragen betrekkelijk vivisectie', Verslagen en meededeelingen der Koninklijke Academie van Wetenschappen afdeeling natuurkunde (1883) 414-423.

Luchtmans, G., Een blik in de geneeskunde der toekomst ("s-Gravenhage 1899).

Luchtmans, G., Schoolgeneeskunde en volksgezondheid ('s-Gravenhage 1900).

Luchtmans, G., Pro en contra vivisectie. Een kritiek (Den Haag 1906).

Luitjes, T., Theorie en praktijk van binnenlandsche kolonisatie (Bussum 1902).

Mantegazza, P., Physiologie der pijn (Amsterdam 1908).

Metzger, D., La Vivisection, ses dangers et ses crimes. Ouvrage couronné par la Soc. Française contre la Vivisection (z.p. 1891).

Metzger, D., De Vivisectie, hare gevaren en hare gruwelen (z.p. 1893).

Mierop, Lodewijk van, Dwepers ! Een beschouwing over Tolstoy en zijn geestverwanten ('sGravenhage 1901).

National Anti-vivisection Society. The Royal Commission on vivisection. Evidence by the honbl. Stephen Coleridge (Londen 1907).

NBBV, Zullen wij nog langer lijdelijk blijven tegenover de gruwelen der vivisectie? Vraag aan het Nederlandsche Volk door de redactie van Androcles, maandblad aan de belangen van dieren gewijd ("s-Gravenhage 1890).

NBBV, De vivisectie, de beginselen, waardoor zij wordt gedreven, en de weg om haar te bestrijden ('s-Gravenhage 1890).

Nieuwe Dordtsche dierenbescherming en vivisectie-bestrijding, Vivisectie is een door de wet beschermde en met belasting van het volk betaalde misdaad. De grootste schandvlek onzer kultuur (Dordrecht 1916).

NIVB, Pasteur faalde volkomen! (Bandoeng 1941).

NVB, Leven en laten leven 1894-1944. Uitgave van de Nederlandsche Vegetariërs Bond ter gelegenheid van het vijftig-jarig bestaan. Opgedragen aan Suze Groshans en Felix Ortt (z.p. 1944).

NVBD, Onnoodige gruwelen in voedsel, mode en sport door Eenige leden der NVBD ('s-Gravenhage 1916).

Oberman, H. T., Vivisectie (z.p. 1912).

Oosterhuis, R.A.B. en B.C.J. Lievegoed ed., Paracelsus herdacht 1493-1541 (Den Haag 1941)

Pekelharing, C.A., 'Wettelijke regeling der vivisectie', De Gids: Nieuwe Vaderlandsche Letteroefeningen 27 (1909) 328-355.

Pijl, Pieter, Warum Vivisektionsfreie Heilkunst? Ongepubliceerde lezing voor het Internationalen Kongress für Homoöpathie und andere biologische Heilmethoden (1931).

Pijl, Pieter, Vivisectie-vrije geneeskunst ('s-Gravenhage 1939).

Pyl, Piet (pseudoniem voor Pieter Pijl) Het Tweede Leven (Amsterdam 1916).

Redactie NTVG, 'Redactioneel commentaar: Prof van Rees en de vivisectie', Weekblad van het NTVG (1898) 753.

Rees, J. van, Over de luchtademing van de Caricus Moenas (Utrecht 1878).

Römer, L.W., De Anti-Vivisectie-Bond. Voordracht gehouden 12 dec. 1898 in de Vereeniging Maarten Luther (z.p. 1898).

Roorda van Eysinga, Vivisectie en hooger onderwijs. Open brief aan Dirk Beerends ('s-Gravenhage 1893).

Roorda van Eysinga-Romein, Kort verlag over 1996 (Scheveningen 1897).

Rijnberk, G. van, Voor en tegen proeven op levende dieren (Haarlem 1917). 
Rijnberk, G. Van, Leidraad voor het physiologisch practicum. Bloed, hart, bloedsomloop, ademhaling, spijsvertering, centraal zenuwstelsel, zintuigen. Tweede deel (Haarlem 1917).

Salomon, H.I.V.E., Hoe mensch- en dierenbescherming van onzen tijd aanleiding geeft tot vorming van verkeerde denkbeelden, zelfs bij geestelijken. Antwoord aan N.E.M. ten Brink (z.p. 1883).

Salomon, H.I.V.E., Open brief aan de Minister van Justitie (z.p. 1886).

Salt, Henry S., Het Humanitarianisme (z.p. z.j.).

Salt, Henry S., De Rechten der Dieren, beschouwd in verband met den socialen vooruitgang. Naar het Engelsch door S. Groshans (z.p. 1897).

SAVB, Welke practische waarde heeft de ontdekking van de tuberkel-bacil door Robert Koch en diens uitvinding van het tuberculine? (Den Haag 1939).

Smith, Stephen, Wetenschappelijk onderzoek aan de binnenzijde bekeken (z.p. 1902).

Smith, Stephen, Scientific research: a view from within (z.p. 1902).

Stams, C., Tegen vivisectie. Vermeerderd met een gedicht van J. Blankenaar (Rotterdam 1895).

Stenz, Hermann, Verborgene Gräuel. Tatsachen und Vernunftgründe gegen die Vivisektion gesammelt von Hermann Stenz. Internat. Verein. zur Bekämpfung der Wissenschaftl. Thierfolter (Dresden 1889).

Tait, Lawson, Wetenschappelijk getuigenis tegen de vivisectic (Den Haag 1898).

Wijnaendts Francken-Dyserinck, W., Het vivisectie-vraagstuk in het Nederlandsche parlement ( $\mathrm{s}$ Gravenhage 1903).

Witsen, Hendrik M., Rechtskundige beschouwingen over vivisectie (Amsterdam 1880).

Wolzogen, Hans von, Richard Wagner en de wereld der dieren, bijdrage tot eene levensgeschiedenis. Vertaald door Hugo Nolthenius (Amsterdam 1890).

Weber, Ernst, von, Die Folterkammern der Wissenschaft. Eine Sammlung von Tatsachen für dus Laienpublikum (Berlijn/Leipzig 1897).

\section{OVERIGE LITERATUUR}

Abrams, M.H., Natural supernaturalism. Tradition and Revolution in Romantic Literature (New York 1973).

Aerts, Mieke, 'Gewoon hetzelfde of gewoon anders? Een feministisch dilemma', Te Elfder Ure. Dilemma's van het feminisme 39 (Nijmegen 1986) 4-13.

Aerts, Remieg, 'Bevoegde autoriteiten. Burgerlijke intellectuelen in de negentiende eeuw', De negentiende eeuw: documentatieblad Werkgroep 19 e eeuw 22 (1988) 72-95.

Aerts, Remieg, 'Op zoek naar een Nederlands fin de siècle', De Gids 156 (1993) 91-102.

Alexandrescu, Sorin, ed., Richard Rorty (Kampen 1995).

Anbeek, Ton en J.J. Kloek, 'Van idealisme naar naturalisme', De negentiende eeuw 5 (1981) 330.

Anbeek, Ton, De naturalistische roman in Nederland (Amsterdam 1982).

Anbeek, Ton, 'Het boek van een generatie. < <Quia absurdum $>>$ of de vreugden van de literatuurschrijver', Literatuur: Tijdschrift over Nederlandse letterkunde 3 (1986) 10-14.

Ariëns, Hans, Laurens Berentsen en Frank Hermans, Religieus Anarchisme in Nederland tussen 1918 en 1940. In het rijk der vrede (Zwolle 1984).

Armstrong, Nancy, Desire and domestic fiction. A political history of the novel (New York 1987).

Arriëns, A., J. Henri Ledeboer en P. v.d. Meulen, Prof. Dr. J. Van Rees dankbaar herdacht (Assen 1929).

Arriëns, A. ed., Van en Over Felix Ortt. Bundel ter gelegenheid van zijn zeventigste verjaardag (z.p. 1936).

Augustijn, C. e.a ed., Abraham Kuyper: zijn volksdeel, zijn invloed (Delft 1987).

Balke, W., 'Allard Pierson in de klem tussen geloof en wetenschap', De negentiende eeuw 21 (1997) 51-82. 
Banks, Olive, Faces of feminism. A study of feminism as a social movement (Oxford 1981).

Barkas, Janet, The vegetable passion. A history of the vegetarian State of Mind (Londen 1975).

Baumeister, Roy, Meanings of life (New York/Londen 1991).

Baumer, Iso, Max von Sachsen. Priester und Professor. Seine Tätigkeit in Freiburg/Schweiz, Lemberg und Köln (Freiburg 1990).

Becker, Frans en Johan Frieswijk, Bedrijven in eigen beheer. Kolonies en produktieve associaties in Nederland tussen 1901 en 1985. Met bijdragen van J.M. Welker en F.J.M. van Puijenbroek (Nijmegen 1976).

Beer, Gillian, 'Plot and the analogy with science in later nineteenth-century novelists', Comparative criticism: a yearbook (Cambridge 1980) 131-149.

Beer, Gillian, Darwin's plots. Evolutionary narrative in Darwin. George Elliot and nineteenth century fiction (Londen 1983).

Belzen, Jaap van, 'Psychologisering van de theologie? De receptie van de godsdienstpsychologie aan theologische faculteiten', Tijdschrift voor psychologie en maatschappij 13 (1992) 259-275.

Benton, E., 'Vitalism in nineteenth-century scientific thought: A typology and reassesment', Studies in History and Philosophy of Science 5 (1974) 17-48.

Bergkamp, L., Het proefdier mens. De normering en regulering van medische experimenten op mensen (Alphen aan de Rijn 1988).

Berkel, Klaas van, 'Ter inleiding. Trots, overmoed en onbehagen. Discussies over natuurwetenschap en levensbeschouwing rond 1900', Groniek. Wetenschap en wereldbeeld rond 1900 (1984) 8-14.

Berkel, Klaas van, In het voetspoor van Stevin. Geschiedenis van de natuurwetenschap in Nederland 1580-1940 (Meppel/Amsterdam 1985).

Beukers, H., 'Een nieuwe werkplaats in de geneeskunde; de opkomst van laboratoria in de geneeskundige faculteiten', Tijdschrift voor de Geschiedenis der geneeskunde, natuurwetenschappen, wiskunde en Techniek 9 (1986) 226-279.

Bel, Jacqueline, De Nederlandse literatuur in het fin de siècle. Een receptie historisch overzicht van het proza tussen 1885 en 1900 (Amsterdam 1993).

Bibo, Claudia, Naturalismus als Weltanschauung? Biologische, theosophische und deutschvölkische Bildlichkeit in der von Fidus Illustrierten Lyriek 1893-1902 (Berlijn 1995).

Blaas, P. B.M., 'Het paradigma van de eeuwwende', in: Jaarboek van de Maatschappij der Nederlandse Letterkunde te Leiden 1992-1993 (Leiden 1994) 43-55.

Block, Ed, 'James Sully, evolutionist psychology, and late Victorian gothic fiction', Victorian Studies: a quarterly journal of the humanities, arts and sciences 25 (1982) 443-467.

Boas, Franz, 'The history of Antropology' in: George W. Socking jr. ed., A Franz Boas Reader. The shaping of American Anthropology 1883-1911 (Chicago/Londen 1974) 23-36.

Boersen, Maria W.L., De kolonie der Internationale Broederschap te Blaricum (Blaricum z.j.).

Bois, Jules, Les petites religions de Paris (Parijs 1894).

Boon, Dirk, Nederlands dierenrecht (Arnhem 1983).

Braun, Marianne, De prijs van de liefde. De eerste feministische golf, het huwelijksrecht en de vaderlandse geschiedenis (Amsterdam 1992).

Briefwisseling Multatuli en S.E.W. Roorda van Eysinga (z.p. 1967).

Brill, Paul, ed., Opmaat van een nieuwe ceuw. Hoofdstukken uit het Nederlandse fin de siècle (Amsterdam 1995).

Bromader, L., 'Vivisektionsdebatten I Sverige unde 1880-talet', Lychnos (1969-70) 249-291 .

Bronfen, Elisabeth, Over her dead body. Death, femininity and the aesthetic (Manchester 1992).

Bulhof, Ilse N. 'De psychoanalyse als rouwarbeid over de dood van God', Nederlands Theologisch Tijdschrift, 39 (1985) 214-230.

Buettinger, Craig, 'Antivivisection and the charge of zoophil-psychosis in the early twentieth century', The historian 55 (1993) 277-288. 
Buettinger, Craig, 'Women and antivivisection in late Nineteenth-Century America', Journal of social history 30 (1997) 857-872.

Buruma, Ian, De boom van Herder (Amsterdam 1993).

Butler, J., 'The force of fantasy: Feminism, Mapplethorpe, and Discursive Excess', Differences: A Journal of Feminist Cultural Studies 2 (1990) 105-125.

Buuren, Maarten van, 'Een barst waardoor het kwaad de ziel binnendringt. Hysterie en literatuur in de 19e eeuw', De Revisor 6 (1991) 30-48.

Buuren, Maarten van, 'De anatomische les. Artsen in de literatuur rond de eeuwwisseling', Feit en Fictie 1 (1993) 40-52.

Buys Ballot, C.H.D., 'Levenbericht van Pieter Harting', Levensberichten van de Maatschappij der Nederlandsche Letterkunde te Leiden (1886-187) 147-175.

Calcar, R.P. van, Collegeherinneringen (Rotterdam 1936).

Caljé, P.A.J., 'De jongens van weleer' in: Het corps als koninkrijk (Delft 1998) 84-314.

Campbell, Joseph, A hero with a thousand faces (Princeton 1949).

Canetti, Elias, Masse und Macht (Londen 1960).

Chantepie de la Saussaye, P.D., Geestelijke stroomingen (Haarlem 1914).

Charlton, D.G., Positivist thought in France during the Second Empire (Oxford 1959).

Coffeng, Liesbeth, 'Het Album der natuur. Popularisering van de natuurwetenschap in een tijdschrift uit de eerste helft van de negentiende eeuw', Groniek 27 (1994) 52-66.

Constandse, A.L, 'Herman Gorter over Spinoza' in: Acht over Gorter (Amsterdam 1978) 213252.

Cott, Nancy F., 'Feminist theory and feminist movement: The past before us' in: Julliet Michell en Ann Oackley, ed., What's feminism? (New York 1986).

Daalen, Rineke van en Marijke Gijswijt-Hofstra, Gezond en wel. Vrouwen en de zorg voor gezondheid in de twintigste eeuw (Amsterdam 1998).

Dam, Martine van, Liefde voor al wat leeft. Geschiedenis en aspecten van het vegetarisme (Amsterdam 1981).

Davids, C.A., 'Aristocraten en juristen, financiers en feministen. Het beschavingsoffensief van de dierenbeschermers in Nederland voor de eerste wereldoorlog', Volkskundig Bulletin 13 (1987) 157-159.

Davids, Karel, Dieren en Nederlanders. Zeven ceuwen licf en leed (Utrecht 1989).

Dekker, G., Die invloed van Keats en Shelley in Nederland gedurende die negentiende eeu (Groningen/Den Haag 1926).

Derkx, Peter, 'Wetenschap en godsdienst: vroeger en nu', Rekenschap 44 (1997) 191-199.

Dijkstra, Bram. Idols of perversity. Fantasies of feminine evil in Fin-de-siècle Culture (New York/Oxtord 1988).

Dongen, H. van en J.L.F. Gerding, PSI in wetenschap en wijsbegeerte. Geschiedenis van het parapsychologisch onderzoek in Nederland (Deventer 1983).

Draaisma, Douwe, Een laboratorium voor de ziel: Gerard Heymans en het begin van de Experimentele psychologie (Groningen 1992).

Drenth, Annemieke, 'Over dienende liefde en zorgende macht. Sekse en sekseverhoudingen in historisch perspectief', Tijdschrift voor Vrouwenstudies 18 (1997) 322-336.

Eddy, John Herbert jr., Buffon, organic change and the races of man (Michigan 1980).

Einthoven, Willem, Rectoraatsrede (Leiden 1906).

Ekstein. M. Rites of spring. The great War and the British modern age (New York/ Londen 1989).

Elston, Mary Ann, 'Women and antivivisection in Victorian England, 1870-1890' in: Rupke, N.A., ed., Vivisection in historical perspective (Londen/New York 1987) 259-294.

Elliot, Paul, 'vivisection and the Emergence of Experimental Physiologie in Nineteenth Century France' in: Rupke, N.A., ed., Vivisection in historical perspective (Londen/New York 1987) 48-77. 
Estés, Clarissa Pinkola, Women who run with the wolves. Myths and stories of the Wild Woman archetype (New York 1992).

Everard, Myriam, 'Het burgerlijk feminisme van de eerste golf: Annette Versluys Poelman en haar kring' in: Jeske Reys, e.a. ed., De eerste feministische golf. Zesde jaarboek voor vrouwengeschiedenis (Amsterdam 1985) 106-137.

Fielding, H. The soul of a people (Londen 1898).

Fielding, H. De ziel van een volk. Boeddhisme als volksgeloof in Burma. Vertaling Felix Ortt ('sGravenhage 1900).

Fontijn, Jan, Leven in extase. Opstellen over mystiek en muziek, literatuur en decadentie rond 1900 (Amsterdam 1983).

Fontijn, Jan, 'Een wereldse mysticus. Over Maeterlinck en zijn invloed in Nederland rond 1900', De Tweede Ronde 5 (1984) 74-78.

Fontijn, Jan, Tweespalt. het leven van Frederik van Eeden tot 1901. (Amsterdam 1990).

Frecot, Janos, 'Die Lebensreformbewegung' in: Klaus Vondung ed., Das Wilhelminische Bildungsbürgertum. Zur Sozialgeschichte seiner Ideeen (Göttingen 1976) 138-152.

French, Richard D., Antivivisection and medical science in Victorian Society (Princeton, Londen 1975)

Friedrich, C.F. en Benno Reifenberg, Sprache und Politick (Heidelberg 1968).

Frieswijk, Tjalling H., In het voetspoor van Edward Bellamy. De ontwikkeling van de Internationale vereniging Bellamy gedurende het Interbellum. Een voorlopig onderzoeksverslag (Groningen 1987).

Frost, William, 'Marginal religion, marginal women', Reviews in American History 25 (1997) 213-219.

Gasman, Daniel, The Scientific Origins of Sational Socialism: Social Darwinism in Ernst Haeckel and the German Monist League (Londen 1971).

Gay, Peter, The Bourgeois Experience. Victoria to Freud Volume 1. Education of the Senses (New York/Oxford 1984).

Gay, Peter, The Bourgeois Experience. Victoria to Freud. Volume II. The tender Passion (New York/Oxford 1986).

Gay, Peter, The Bourgeois Experience. Victoria to Freud. Volume III. Cultivation of the hatered (New York 1995).

Gibbels, Mario, 'Daniel Dunglas Home en het begin van de tafelklopperij', De negentiende eeuw: documentatieblad Werkgroep 19 e eeuw 21 (1997) 127-144.

Gijsbertsen, Gerrie, Hermine. Discoursanalyse van de Domestieke roman. Ongepubliceerde doctoraalscriptie (Amsterdam 1998).

Gijswijt-Hofstra, Marijke, Vragen bij een onttoverde wereld. oratie (Amsterdam 1997).

Ginneken, Jaap van, Crowds, psychology and politics, 1871-1899 (Cambridge 1992).

Girard, René, La violence et le sacré (Parijs 1994).

Godschalkx, Simone, De invloed van de theosofie op de Nederlandse letterkunde tussen 1880 en 1930 (Leuven 1982).

Goodfield-Toulmin, June, 'Some aspects of English physiology: 1780-1840', Journal of the History of biology 2 (1969) 283-320.

Goudsmit, Jaap, Anderhalve eeuw dokteren aan de arts. Geschiedenis van de medische opleiding in Nederland (Amsterdam 1978).

Grever, Maria en Berteke Waaldijk, Feministische openbaarheid. De Nationale Tentoonstelling van Vrouwenarbeid in 1898 (Amsterdam 1998).

Groot. Annemiek de,' De lust tot last. De rein leven beweging als pioniers in de strijd om de nieuwe mens‘, Groniek. Einde van een utopie? (1993) 55-64.

Gross, Michael, "A lessened locus of feelings?: A transformation of French physiology in Early Nineteenth Century', Journal of the history of biology 12 (1979) 231-271

Gulden. W.I.I. van der, Dierproeven, geen vivisectie. Oratie (Nijmgen 1988). 
Haan, Francisca de en Romke van der Heide, 'Vrouwen-vereenigingen, Dames-Comité's en feministen. De zorg van vrouwen voor vrouwelijke gevangenen in de negentiende eeuw', Tijdschrift voor sociale geschiedenis 23 (1997) 278-311.

Haan, Francisca de, 'Kiesrecht, het einde van het feminisme', Tijdschrift voor vrouwenstudies 18 (1997) 74-76.

Haan, Ido de en Henk te Velde 'Vormen van politiek. Veranderingen van de openbaarheid in Nederland 1848-1900', BMGN 111 (1996) 167-200.

Halsema, J.D. van, 'Christusvoorstellingen in de Nederlandse poëzie 1880-1893', Molaer 92 (1983) $16-21$ en 93 (1984) 4-8.

Hamilton, Susan, 'Pets and scientific subjects: Constructions of the Animal Body in Victorian anti-vivisection periodicals' in: Purdy, Anthony, ed., Literature and the body (Atlanta 1993) 77-94.

Hampson, Judith, 'Animal welfare - a century of conflict', New Scientist 8 (1979) 280-282.

Hampson, Judith, 'Legislation: A practical solution to the vivisection dilemma?' in: Rupke, N.A., ed., Vivisection in historical perspective (Londen/New York 1987) 314-339.

Harmsen, Ger, Blauwe en rode jeugd. Een bijdrage tot de geschiedenis van de jongelieden geheelonthoudersbond van oprichting tot opheffing (1912-1950) eerste druk 1961 (Nijmegen 1975).

Harrison, Brian, Peacable Kingdom: stability and change in Modern Brittain (Oxford 1982).

Harting, Pieter, Mijne herinneringen (Amsterdam 1961).

Harwood, Dix, Love for animals and how it developed in Great Brittain (New York 1928).

Haskell, Thomas L., 'Capitalism and the Origins of Humanitarian Sensibility', American Historical Review 90 (1985) 339-361, 547-566.

Hemelaar, Marlijne, Een leven zonder eind. Met het oog op Marie Boddaert 1844-1914. Ongepubliceerde doctoraalscriptie (Leiden 1991).

Hendriks, Henriëtte, Een week in de kolonie der Internationale Broederschap te Blaricum (Amsterdam 1901).

Henkels, H., ed., Otto en Adya van Rees: leven en werk tot 1934 (Utrecht/Den Haag 1975).

Hermand, Jost, Grüne Utopien in Deutschland. Zur geschichte des ökologischen Bewußtsein (Frankfurt am Main 1991).

Heymans, G., 'Pneumat-energetisch monisme' in: Felix Ortt, Inleiding tot het pneumat-energetisch monisme (Haarlem 1917) 159-165.

Heyting, Lien, De wereld in een dorp. Schilders, schrijvers en wereldverbeteraars in Laren en Blaricum (Amsterdam 1994).

Hinterhaüser, Hans, 'Die Christusgestalt im Roman der "Fin de siècle", Archiv für das Studium der neueren Spachen und Literaturen 113 (1962).

Hinterhaüser, Hans, Fin de siècle (München 1977).

Hirsch, Marianne, The mother/daughter plot. Narrative, psychoanalysis, feminism (Bloomington/ Indianapolis 1989).

Hollis, Patricia, ed., Pressure from without in early Victorian England (Londen 1974).

Honegger, C., Frauen und medizinische Duetungsmacht im 19. Jahrhundert' in: A. Labisch, ed.. Medizinische Deutungsmacht im sozialen Wandel (Bonn 1989) 181-194.

Howe, J., 'Foxhunting as ritual', American ethnologist: Journal of the American Anthropological Association, 7 (1981) 278-301.

Hottois, G. , M. van den Bossche en M. Weyemberg, ed., Richard Rorty. Ironie, politiek en postmodernisme (Antwerpen/Baarn 1994).

Houghton, W.E.. The Victorian frame of mind, 1830-1879 (New Haven 1957).

Hulst, J.W. van der, 'De spanning tussen orthodoxie en modernisme in de negentiende eeuw', Kerkblaadje 74 (1981) 90-96.

Hunt, Lynn, ed., The New Cultural History (Berkeley/Los Angeles/Londen 1989).

Jaffé, Aniela. Anna Kingsford. Religiöser Wahn und Magie (Bonn 1980). 
Jans, Rudolf, Tolstoj in Nederland (Bussum 1952).

Jansen, D., 'Het spiritistisch genootschap Oromase 's-Gravenhage, 1859-1860,1869-1879', De negentiende eeuw 6 (1982) 159-172.

Jansen, D., ' Licht op H.J. Schimmel. Het spiritisme als levenshouding', De negentiende eeuw 9 (1985) 207-220.

Jansen, Derk, Op zoek naar nieuwe zekerheid. Negentiende-eeuwse protestanten en het spiritisme (Groningen 1994).

Jansz, Ulla, Denken over sekse in de eerste feministische golf (Amsterdam 1990).

Jansz, Ulla, 'Sociale kwestie en sekse in de politieke geschiedenis. De arbeidswet van 1889' in: Marjan Schwegman et al ed., Op het strijdtoneel van de politiek. Twaalfde jaarboek voor vrouwengeschiedenis (Nijmegen 1992) 70-91.

James, William, The varieties of religious experience. A study of human nature. Eerste druk 1902. (Toronto 1985).

James, J., 'Jacohus van Rees (1854-1928) een vreemde eend in de universitaire bijt', NTVG 140 (1996) 2554-2559.

Jeffeys, Sheila, The spinster and her enemies. Feminism and sexuality 1880-1930 (Londen 1985).

Jonkman, H.F.. 'Pieter Harting' in: Mannen van beteekenis in onze dagen (Haarlem 1886) 319 366.

Joosse, Kees, Arnold Aletrino. Pessimist met perspectief (Amsterdam 1986).

Jordanova, Ludmilla, ed., Languages of nature. Critical essays on science and literature (Londen 1986).

Kean, Hilda, 'The feminist and socialist response to vivisection', History Workshop Journal 40 (1995) 16-38.

Kempis, Thomas a, De navolging van Christus (Amsterdam 1973).

Klein, Marianne van der, 'Engelse suffragettes in een Nederlandse vrouwenrubriek. Een confrontatie in prenten' in: Marjan Schwegman et al ed., Op het strijdtoneel van de politiek.Twaalfde jaarboek voor vrouwengeschiedenis (Nijmegen 1992) 49-70.

Kluveld, Amanda, 'Anti-vivisectionisten en het verleden. Peter Singers 'Animal Liberation' bezien in het licht van het honderd-jarig bestaan van de NBBV', ID, faculteitsblad Orakel studievereniging Faculteit Cultuurwetenschappen 3 (1996) 5.

Kluveld, Amanda, 'Antivivisectionisme en feminisme. De strijd van Marie Jungius tegen een kwaad dat uit de samenleving moet verdwijnen' in: Daalen, Rineke van en Marijke GijswijtHofstra ed., Gezond en wel. Vrouwen en de zorg voor gezondheid in de twintigste eeuw (Amsterdam 1998) 141-154.

Knecht-van Eekelen, A., 'Tropische geneeskunde in Nederland en koloniale geneeskunde in Nederlands-Indië', Tijdschrift voor geschiedenis 105 (1991) 407-is.

Kock, Hetty, Felix Ortt. Leven van een christen-anarchist. Ongepubliceerde doctoraalscriptie geschiedenis Universiteit van Amsterdam (Amsterdam 1986).

Kossmann, E.H., De lage landen 1780-1980. Twee eeuwen Nederland en België Deel I (Amsterdam 1986).

Kossmann, E.H., 'Romeins breukvlak en de Nederlandse geschiedenis', BMGN 100 (1991) 625 640.

Krabbe, W.R., Gesellschaftsveränderung durch Lebensreform. Strukturmerkmale einer sozialreformerischen Bewegung in Deutschland der Industrialisierungsperiode (Göttingen 1974).

Krabbe, W.R., Die Weltanschauung der deutsche Lebensreformbewegung ist der Nationalsozialismus. Zur Gleichschaltung einiger Alternativströmung im Dritten Reich' in: Archiv für Kulturgeschichte (Keulen-Wenen 1989) 413-461.

Kruithof, Bernard en Ernst Mulder, 'Natuurlijk, dus christelijk. Nederlandse gereformeerden en de reformpedagogiek', Comenius 52 (1991) 142-154.

Kuyper, A, Evolutie (Amsterdam/Pretoria 1899).

Labrie, A., Het verlangen naar zuiverheid. Een essay over Duitsland. Oratie (Maastricht 1993). 
Lansbury, Coral, The old brown dog. Women, workers and vivisection in Edwardian England (Wisconsin 1983).

Laqueur, T. W., 'Bodies, details and the humanitarian narrative' in: Lynn Hunt, ed., The New Cultural History (Berkeley/Los Angeles/Londen 1989).

Larkin, Maurice, Man and society in nineteenth century realism (Londen/Basingstoke 1980).

Lauret, A.M., 'Tafeltje dans je? Dr. A.W. van Renterghem en het spiritisme', Zeeuw tijdschrift (1978) 171-179.

Lente, Dick van, Techniek en ideologie. Opvattingen over de maatschappelijke betekenis van technische vernieuwingen in Nederland 1850-1920 (Groningen 1988).

Leopold, Joan, Culture and evolutionary perspective: E.B. Tylor and the making of primitive culture (Berlijn 1980).

Lepenies, Wolf, Autoren und Wissenschaftler im 18. Jahrhundert: Lime, Buffon, Winckelmann, George Forster, Erasmus Darwin (München 1988).

Linde, Irene van der, De naakte waarheid. Levenshervormingsbewegingen in Duitsland 1890-1918 (ongepubliceerde scriptie Universiteit van Amsterdam 1990).

Lindeboom, G., Geschiedenis van de medische wetenschap in Nederland (Bussum 1972).

Lindeboom, G., 'Dog and frog. Physiological experiments at Leiden University during the seventeenth century' in: Th.H. Lunsingh Scheurleer en G.H.M. Posthumus Meyjes ed., Leiden University in the seventeenth century. An exchange of learning (Leiden 1975) 279-293.

Lindeboom, J., Het protestantisme in de 19e eeuw (Delft, z.p.).

Lintsen, Harry, Ingenieurs in Nederland in de negentiende eeuw: een streven naar erkenning en macht ('s-Gravenhage 1981).

Lötgren, O., 'Our friends in nature; class and animal symbolism', Ethnos 50 (1985) 184-213.

Lunsingh Scheurleer, Th. H. en G.H.M. Posthumus Meyjes, ed., Leiden University in the seventeenth century. An exchange of learning (Leiden 1975) 279-293.

Maanen, W.C. van, 'Pleitbezorgers van het spiritisme', Vaderlandsche Letteroefeningen voor 1874,114 (1874) 1-31.

Maanen, C.M.J. van, 'Het psychisch monisme van Fechner-Heymans', Theosophia: Maandblad gewijd aan broederschap en aan de studie van godsdienst, wijsbegeerte, wetenschap en occultisme 26 (1918) 18-24, 40-45.

Macdonald-Ross G., 'Science and philosophy' in: R.C. Olby et al ed., Companion to the History of modern science (Londen/New York 1990) 799-815.

Mack, Godelieve, 'Henriëtte Ortt, Frederik van Eedens Beatrice', MFVEG 1967, 16-27.

Maehle, A.H. en U. Tröhler, 'Animal experiments from antiquity to the end of the eighteenth century: attitudes and arguments' in: Rupke, N.A., ed., Vivisection in historical perspective (Londen/New York 1987).

Manuel, Diana, 'Marshall Hall (1790-18570: Vivisection and the development of experimental Physiology' in: Rupke, N.A., ed., Vivisection in historical perspective (Londen/New York 1987) 74-104.

Margadant-Van Arcken, M.J.A., Dierenjuf. Natuureducatie en de relatie tussen jonge kinderen en dieren (Utrecht 1990).

Martelaere, Patricia de, 'Wie goed doet, goed ontmoet: ironische bemerkingen bij Rorty's idyllisch liberalisme' in: Alexandrescu, Sorin, ed., Richard Rorty (Kampen 1995) 115-127.

Mathijsen,A.H.H.M., 'De oefenoperaties aan de Rijksveeartsenijschool als doelwit van de antivivisectie- beweging 1870-1880”, Argos speciale uitgave (1991) 62-84.

Mauss, M., Oeuvres I (Parijs 1968).

Meinel, Christoph, Karl Fricdich Zöllner und die Wissenschaftskultur der Gründerzeit. Eine Fallstudie zur Genese konservativer Zivilisationskritik (Berlijn 1991).

Mees, Leen, Één voor één. Korte geschiedenissen uit een lang leven (Driebergen/Rijsenburg 1988). 
Menninger, Karl, A., 'Totemic Aspects of Contemporary Attitudes Toward Animals' in: Wilbur, George en Muensterberger, Warner, Psychoanalysis and Culture. Essays in Honor of Géza Róheim (New York 1951).

Meyer, Bernard S. En T. Copplestone, ed., The history of art (Londen/New York 1985).

Meyers, Jan, Domela, een hemel op aarde (Amsterdam 1993).

Michell, Julliet en Ann Oackley, ed., What's feminism (New York 1986).

Middendorp, H.W., Prof. dr. A.P. Fokker, de vertegenwoordiger van de bacteriologie aan de Rijksuniversiteit Groningen. Open brief aan dezen (Groningen 1902).

Montijn, Ileen, 'Een beetje heilig. Vegetarisme als levenshouding', NRC 22 mei 1993.

Mooij, Annet, Geslachtsziekten en besmettingsangst: een historisch-sociologische studie, 18501990 (Amsterdam 1993).

Moore, James R., 'Speaking of science and religion then and now', History of science: an anual review of literature, research and teaching 30 (1992) 311-323.

Mosse, George L., The Culture of Western Europe. The Nineteenth and Twentieth Centuries (Boulder/Londen 1988).

Mosse, George L., 'Fin de siecle; challenge and response', BMGN 104 (1991) 573-580.

Mossink, Marijke, De levensbrengsters. Over vrouwen, vrede, feminisme en politiek in Nederland (Amsterdam 1995).

Neff, Rudolf, Der Streit um der Wissentschaflichen Tierversuch in der Schweiz des 19. Jahrhundert (Schwabe/Basel 1989).

Nes, A. van, De nieuwe mystiek (Rotterdam 1900).

Nochlin, Linda, Realism (Londen 1990).

Noordegraaf, Herman, Niet met de wapenen der barbaren. het christen-anarchisme van Bart de Ligt (Baarn 1994).

Noordenbos, Oene, Het Atheisme in Nederland in de Negentiende Eeuw. Een kritisch overzicht(Rotterdam 1931).

Noordman, Jan, Om de kwaliteit van het nageslacht. Eugenetica in Nederland 1900-1950 (Nijmegen 1989).

Noske, Barbara, Huilen met de wolven: een interdisciplinaire benadering van de mens-dier relatie (Amsterdam 1988).

Oefenmateriaal. 20 auteurs over vivisectie (Pijnacker 1975)

Offerhaus, M.C., Dierenmishandeling,. Het Ned. W.v.S. vergeleken met eenige buitenlandsche wetgevingen (z.p. 1892).

Otterspeer, Willem, De universiteit herleeft (Leiden 1984).

Otterspeer, Willem, Bolland, een biografie (Amsterdam 1995).

Parkin, Frarik, Middle Class Radicalism. The social bases of the Bristish campaign for nuclear disarmement (New York/Washington 1968).

Passmore, John 'The treatment of animals', Journal of the History of Ideas 36 (1975) 195-21

Pfanmüller, Richard, Jesus im Urteil der Jahrhunderte (Berlijn 1939).

Perdeck, A. , Nakend op de fiets (Den Haag 1967).

Pieterson, Maarten, ed., Het technisch labyrinth. Een maatschappijgeschiedenis van drie industriële revoluties (Amsterdam 1981).

Poliakov, Léon, De arische mythe (Amsterdam 1979).

Poovey, Marie, Uneven developments. The ideology work of gender in Mid-Victorian England (Chicago 1988)

Poortman, J.J., 'De loge post nubila lux', Theosofia (1937) 155-169.

Prochaska, F., Women and philanthropy in 19th century England (Oxford 1980).

Pruis, Marja, Wie is wie in Anton Wachter. Een kennismaking met de personages uit de romancyclus van Simon Vestdijk (Amsterdam 1994). 
Raaij, A. van, 'Felix Ortts pneumat-energetisch monisme. Een filosofie van het christen-anarchisme', Geschiedenis van de wijsbegeerte in Nederland. Documentatieblad werkgroep Sassen (1997) 93-102.

Reijerse, Amanda, Standpunten over vivisectie en anti-vivisectie 1870-1917. Ongepubliceerde doctoraalscriptie maatschappijgeschiedenis Erasmus Universiteit (Rotterdam 1992).

Reijnder, Karel, 'Staaltjes van traktie en attraktie', De Schans 12 (1981) 5-16.

Reys, Jeske e.a. ed., De eerste feministische golf. Zesde jaarboek voor vrouwengeschiedenis (Amsterdam 1985).

Richards, S., 'Vicarious suffering, necessary pain. Physiological method in late nineteenth-century Brittan' in: Rupke, N.A. , ed., Vivisection in historical perspective (Londen/New York 1987) 125-148.

Righart, Hans, Politicke cultuur. een omgevingsverkenning (Amsterdam 1989).

Rigter, R.B.M., Met raad en daad. De geschiedenis van de gezondheidsraad 1902-1985 (Rotterdam 1992).

Rijck, A.H. de, 125 dierenbescherming (Den Haag 1989).

Ritvo, Harriet, The animal estate. The English and other creatures in the Victorian Age (Londen 1987).

Röckelein, Hedwig, Charlotte Schoell-Glass en Marie E. Müller, Jeanne d'Arc, oder wie Geschichte eine Figur konstruiert (Bazel/Wenen 1996).

Roessingh, K.H., Het modernisme in Nederland (Haarlem 1922).

Röling, Hugo, De god'lijke stem van het medelijden. Vegetarisme in Nederland 1894-19/4. Werkschrift 4 uitgegeven door het Historisch Seminarium van de Universiteit van Amsterdam (Amsterdam 1972).

Röling, H. Q., De tragedie van het geslachtsleven: Dr. J. Rutgers (1850-1924) en de NieuwMalthusiaansche Bond (Amsterdam 1987).

Roll-Hansen, Nils, 'Critical theology: Immanuel Kant and Claude Bernard on physiology', ISIS 76 (1985) 49-70.

Romein, Jan, 'De vereenzaming van de mens. Proeve ener theorie van geestelijke crises' in: Jan

Romein, Historische lijnen en patronen. Een keuze uit essays (Amsterdam 1976) 215-244.

Romein, Jan, Historische lijnen en patronen. Een keuze uit essays (Amsterdam 1976)

Romein, Jan, Op het breukvlak van twee eeuwen. Tweede druk (Amsterdam 1976).

Rooy, Piet, de, 'Liefde en plichtsbesef. De kinderbescherming in Nederland rond 1900', Sociologisch Tijdschrift 13 (1987) 637-668.

Rooy, Piet de, 'Een hevig gewarrel. Humanitair idealisme en socialisme in Nederland rond de eeuwwisseling’, BMGN 104 (1991) 625-640.

Rooy, Piet de, Op zoek naar volmaakheid. H.M. Bernelot Moens en het mysterie van afkomst en toekomst (Houten 1991).

Rooy, Piet de, Een ideaal dat ons toelacht (Amsterdam 1994).

Rorty, Richard, Contingency, Irony and Solidarity (Cambridge 1989).

Rorty, Richard, 'Rechten van de mens, rationaliteit en sentimentaliteit' in: Hottois, G. , M. van den Bossche en M. Weyemberg, ed., Richard Rorty. Ironic, politick en postmodernisme (Antwerpen/Baarn 1994) vooraf.

Rupke, N.A. , ed., Vivisection in historical perspective (Londen/New York 1987).

Rupp, Leila J., 'Sexuality and politics in the Early Twentieth Century', Feminist studies 23 (1997) $577-606$.

Rüter, A.J.C., De spoorwegstakingen van 1903 Eerste druk 1935 (Nijmegen 1978).

Ryder, Richard D., Victims of science. The use of animals in research (Londen 1975).

Sassen, F.. Descartes (Den Haag 1963).

Sasz, Kathleen, Petishism. Petcults of the Western world (Londen 1968).

Schultz, Christoph, Ein Beitrag zur Vivisektionsfrage (z.p. 1881). 
Schwegman, Marjan, ed., Op het strijdtoneel van de politiek. Twaalfde jaarboek voor Vrouwengeschiedenis (1993).

Schwegman, Marjan, 'Ieder ding op zijn eigen plaats', Kennis en Methode: tijdschrift voor wetenschapsfilosofie en methodologie (1993) 12-29.

Schwegman, Marjan, 'Healing the gap between science and love. The religious experience of Marie Montessori. Paper presented at the project Varieties of Religious Experiences' ongepubliceerd (New Brunswick 1997).

Schwegman, Marjan, De prima donna. Over exemplarische vrouwenlevens. oratie (Utrecht 1998).

Schwegman, Marjan, Maria Montessori 1870-1952. Kind van haar tijd, Vrouw van de wereld (Amsterdam 1999).

Schorske, Carl, Fin de siècle Vienna. Politics and culture. (New York en Londen 1980).

Schouten, Rob, 'De student Vestdijk', AMC-magazine. Special: 325 jaar Academische Geneeskunde in Amsterdam 9 (1994) 106-111.

Scott, Joan Wallach, 'Deconstruction equality-versus-difference: or, the uses of poststructuralist theory for feminism', Feminist studies 14 (1988) 33-50.

Sevenhuijsen, Selma, De orde van het vaderschap (Amsterdam 1987).

Shattuck, Roger, Forbidden knowledge. From Prometheus to pornography (New York 1996).

Showalter, Elaine, The female malady. Women, madness and English culture, 1830-1980 (New York 1985).

Showalter, Elaine, Sexual anarchy. Gender, culture at the fin the siecle (Londen 1992).

Singer, Peter, Animal liberation. A new ethics for our treatment of animals (Londen 1975).

Singer, Peter, The animal liberation movement: it's philosophy, it's achievements, and its future (Nothingham 1985).

Smit, Cock, Dierproeven honderd jaar discussie (Kampen 1989).

Smit, Henk, Dierproeven in de moderne samenleving (Deventer 1978).

Socking, George W., jr. ed., A Franz Boas Reader. The shaping of American Anthropology 18831911 (Chicago/Londen 1974).

Sontag, Susan, Illness as methaphor (New York 1979).

Spanjaard-Levy, M., De gestalte van Christus in de Nederlandse dichtkunst (Groningen 1952).

Stanton, Theodor, ed., The woman question in Europe. A series of original essays with an introduction by Frances Power Cobbe (Londen 1884).

Stevenson, Lloyd, 'Religious elements in the background of the British anti-vivisection-movement', Yale Journal of Biology and Medicine 29 (1956) 125-145.

Sternberger, Dolf, Panorama oder Ansichten vom 19. Jahrhundert Eerste druk 1938 (Hamburg 1981).

Stryker Boudier, Henk, 'Notitie verschil tussen mens en dier. Correspondentie van F.J.J. Buytendijk met Max Scheler', Bijdragen, tijdschrift voor filosofie en theologie, 53 (1992) 312 322.

Stuart Hughes, H. Consciousness and the Society. The reorientation of European Social thought 1890-1930 (New York 1961).

Suchtelen, Guido 'Quia absurdum of De Huttenbouwers', MFVEG 1984 53-35.

Suchtelen, Nico, Quia absurdum (z.j. 1903).

Suttorp, L.S., Dr. A.W. Bronsveld. Zijn visie op een halve eeuw (Assen 1966).

Taine, Hypolyte, History of English literature. Eerste druk 1863 (Londen 1907).

Tansey, E.M., 'Protection against dog distemper and dogs protection bills; the medical research council and the anti-vivisection protest 1911-1933', Medical History 38 (1994) 1-26.

Theunissen, Bert, 'een warm hart en een koel hoofd. Pieter Harting over wetenschap, de natie en de voortuigang', BMGN 110 (1995) 473-498.

Thomas, Keith, Man and the natural world. Changing attitudes in England 1500-1800 (Londen/New York 1983). 
Tijn, Th. van, 'De Doleantie kwam niet alleen', Documentatieblad voor de Nederlandse kerkgeschiedenis van de negentiende eeuw 7 (1984) 41-46.

Todorov, Boris, 'Mystiek in het vrouwelijk', Kultuurleven 63 (1996) 54-61.

Tollebeek, Jo, 'Taine in tweevoud', Theoretische geschiedenis 24 (1997) 321-339.

Treub, Hector en C. Winkler, 'De vrouw en studie' in: Voordrachten en debatten gehouden in de vergaderingen van 3 maart en 10 november 1898 voor de Vereenigingen ter behartiging van de belangen der Vrouw' te Rotterdam (Haarlem 1898) 40-42.

Tröhler, U., 'Was ist neu? - Der medizinische Tierversuch im Meinungsstreit' in: Swiss Pharma:

Schweizerische Zeitschrift für die pharmazeutische Industrie, 6 (1985) 7-16.

Turner, James, Reckoning with the Beast, Animals, pain and humanity in the Victorian Mind (Baltimore 1990).

Turner, Kathleen, The history of hell (New York 1993).

Tussenbroek, Catharine van, Over het tekort aan levensenergie bij onze jonge vrouwen en meisjes. Rede uitgesproken op de Nationale Tentoonstelling van Vrouwenarbeid (z.p. 1898).

Tylor, Edward B., Primitive culture: researches into the development of mythology, philosophy, religion, language, art and custom. Oorspronkelijke versie 1858 (Londen 1920).

Van Rees Comité, Bestevaer Prof. Dr. J. van Rees herdacht. Uitgave ten bate van het Van Rees Comité tot stichting van de Van Rees-Aula en de geheelonthouding (z.p. z.j.)

Varekamp, P. Vóór of tegen de Dierproeven? (Zandvoort 1908).

Velde, Henk te, 'De vanzelfsprekendheden van de negentiende eeuw', De negentiende eeuw. documentatieblad Werkgroep 19e eeuw 22 (1988) 1-3.

Velde, Henk te, 'Viriliteit en opoffering. mannelijkheid in het Nederlandse politieke debat van het fin de siècle', Tijdschrift voor vrouwenstudies 56 (1993) 421-434.

Velde, Henk te, Gemeenschapszin en plichtsbesef; liberalisme en nationalisme in Nederland 18701918 (Groningen 1992).

Verhoog, H., 'Dier als meetlat. Dierproeven en proefdieren' in: M.B.H. Visser en F.J. Grommers, ed., Dier of ding. Objectivering van dieren (Wageningen 1988) 24-37.

Visser, Hans, Simon Vestdijk. Een schrijversleven (Utrecht 1087).

Visser, H., Brieven rond de Vestdijk-biografie (Amsterdam 1987).

Visser, M.B.H., en F.J. Grommers ed., Dier of ding. Objectivering van dieren (Wageningen 1988).

Vrankrijker, A.C.J. de, Onze anarchisten en utopisten rond 1900 (Bussem 1972).

Vree, J., De Groninger godgeleerden. De uorsprong en de eerste periode van hun optreden 18201843 (Kampen 1984).

Vries, Gerard de, 'Gevoelens van ironici' in: Alexandrescu, Sorin, ed., Richard Rorty (Kampen 1995) 128-142.

Vries, Petra de, Kuisheid vor mannen, vrijheid voor vrouwen: de regelementering en bestrijding van prostitutie in Nederland, 1850-1911 (Hilversum 1997).

Waart, A. de, Het levenswerk van Willem Einthoven 1860-1927. Uitgegeven ter gelegenheid van het honderdjarig bestaand der vereeniging Nederlandsch Tijdschrift vonr Geneeskunde (Haarlem 1957).

Walkowitz, Judith R., City of dreadfull delight. Narratives of sexual danger in Late-Victorian London (Londen 1992).

Walsem, G.C., Vivisectie (z.p. z.j.).

Warner, Marina, Alone of all her sex. The Myth and Cult of the Virgin Mary (Londen 1976).

Warner, Marina, Monuments and Maidens. The allegory of the female form (Londen 1985).

Warner, Marina, The absent mother, or women agains vinmen in the 'old wives' tail (Hilversum 1991).

Warner, Marina, Joan of Arc. The imago of female heroeism (Londen 1991).

Weber, Ruth, 'De medische wereld en de vrouw', De negentiende ceuw 6 (1982) 2-20. 
Weijtjens, H., Christus onze tijdgenoot. Een vergelijkende litteratuurstudie over het motief van den wederkerende Christus in de laatste halve eeuw (Roermond/Maaseik z.j.).

Wemel, Heinrich, Jesus in neunzehnten Jahrhundert (Tübingen 1907).

Weindling, P., 'Hygienepolitik als sozialintegrative Strategie im späten Deutschen Kaisserreich' in: A. Labisch ed., Medizinische Deutungsmacht im sozialen Wandel (Bonn 1989) 37-55.

Westacott, E., A century of vivisection and antivivisection (Essex 1956).

Wetering, Ineke van den, 'Dan ben je vrouw in dit land. Creools-Surinaamse vrouwen in Nederland' in: Daalen, Rineke van en Marijke Gijswijt-Hofstra ed., Gezond en wel. Vrouwen en de zorg voor gezondheid in de twintigste eeuw (Amsterdam 1998) 73-90.

Wijfjes, Huub, 'Niet drinken, niet roken en op tijd naar bed', De Volkskrant 25 februari 1995.

Withuis, Jolande, 'De dubbele bodems van vrouwelijke opoffering', De Gids 158 (1995) 340-353.

Withuis, Jolande, De jurk van de kosmonaute: over politiek, cultuur en psyche (Amsterdam 1995).

Zegger, R.E., 'Protecting animals in Paris: 1815-1870. The emperor Napoleon III was a leading patron of the French society for animal welfare', History Today 28 (1978) 105-122. 


\section{Summary}

\section{Journey through the Hell of the Innocent \\ The expressive politics of the Dutch anti-vivisectionists, 1890-1940.}

By the end of the nineteenth century a public controversy about medical experimentation on animals, a practice also known as vivisection, flare up in northern and western Europe. From the 1870's on in England, Germany, Scandinavia and the Netherlands, societies for the abolition of vivisection were founded. The members of this antivivisection movement declared medical experiments on animals to be morally wrong. A relatively large number of these members were women.

The anti-vivisection movement was opposed to a practice that was almost completely unknown at the time. Only a few people knew what vivisection was and even fewer people had actually seen or performed a vivisection. In other words experiments on animals were no part of daily life. They were not performed in public but performed in private laboratories and lecture-rooms. Therfore, as a member of a Dutch antivivisection society stated at the end of the nineteenth century, nowbody knew 'the hidden sins' of the vivisectors. This view was shared by many opponents of experiments on animals. They considered it to be an important task 'to open the eyes of the public'. 'The evil of vivisection' had to be shown to society. 'The Hell of the innocent' had to be exhibited. In their eagerness to acomplish this, the anti-vivisectionists did publish a lot: novels, articles, poems and pamphlets.

'Journey through the Hell of the Innocent' is a book about the Dutch anti-vivisection movement and its leaders (Felix Ortt, Marie Jungius, Pieter Pijl) in the period 1890-1940. It describes and analyses the way anti-vivisectionists have tried to visualise the vivisection in novels and other writings, and the way their imagination has influenced and shaped the public debate (newspaper articles, pamphlets of medical scientist on vivisection and the discussion on vivisection in parliament) about medical experiments on animals. In this book the various images of vivisection in the public debate will pass in revue like in a sightseeing tour: a journey through the Hell of the Innocent.

The title of this PhD-dissertation also refers to the way the anti-vivisectionists described their task. They considered themselves to be explorers of an unknown, dangerous and mysterious world. They described their endeavours like a heroic saga. In their view the ideal anti-vivisectionist was a man or a woman ready to make great sacrifices. They had tot be prepared to battle like a Don Quichote their whole life without any hope for tangible results and with only the mockery of their contemporaries as their reward. In this carefully self-designed profile of ideal warrior against vivisection, one can perceive an ambivalence. On the onc hand the anti-vivisectionists considered themselves to be herves with the right on their side, on the other hand they considerd themselves to be not understood by society. In this profile the anti-vivisectionist was winner and loser, hero and victim at the same time. Losing was part of being a winner and a hero.

For the contemporary opponents of the anti-vivisectionists, the movement against medical experiments on animals was a movement of losers and sentimental fools. The anti-vivisectionists didn't succeed in making vivisection disappear. This fact combined with the self-shaped profile and the image shaped by their opponents has influenced the modern historiography of antivivisectionism. Historians describe the anti-vivisectionists as anti-modern, anti-scientific, religious and sentimental and as irrational losers in a battle against modernity. The anti-vivisectionists share this fate with other humanitarian movements like those of vegetarians, teetotallers, spiritists and natural curers. Otten, in historiography the 'failure' of these movements is contrasted with the success, with the instrumentality and with the so called rationality of the scientific proponents of vivisection, of the socialist movement and of movements like the animal protection movement.

'Journey through the Hell of the Innocent' argues that this static and anachronistic approach of anti-vivisectionist politics is not tenable anymore. In stead of a perspective dominated by the idea 
of winning or losing, this study proposes a different approach. In this book the anti-vivisectionist movement is approached as a political movement with, to use a term of Frank Parkin and Richard French, an expressive political style. Anti-vivisectionists have tried to deal with modernity in a complex and often creative way. The same can be said of their opponents. 'Journey through the Hell of the Innocent' argues that the way the expression of a moral way of living and thinking for most anti-vivisectionists was more important than the legal regulation or abolition of vivisection. In other words, this study claims that the ways of thought of anti-vivisectionists about winning and losing, failure and succes, politics and engagement diverge from the modern views on these subjects. That quite a number of women (who as such were excluded from public life) joined and shaped the anti-vivisection movement emphasises that the expressive politics of the anti-vivisectionists are indeed more complex than is suggested by the more or less caricatural view of other historians.

In order to do credit to this complexity of the expressive politics and the public debate they shaped and were shaped in, the author of this book has chosen a broader approach of politics as a framework to analyse the vivisection controversy in the Netherlands. This broader approach offers a possibility to analyse and interpretate the motives and political style of movements which would otherwise -when viewed within a framework of a more classical approach of political history- be considered irrelevant and marginal. From this broader view on political history 'Journey through the Hell of the Innocent' fits into a lively modern debate on the boundaries of political history, on the cultural context of reform movements in the Dutch fin de siècle and the Interbellum. The book also contributes to the historiography on the two most important Dutch anti-vivisectionist societies: the Nederlandsche Bond tot Bestrijding der Vivisectie (NBBV, Dutch Society for the Abolition of Vivisection, founded in 1890) and the Anti Vivisectie Stichting (AVS, Anti Vivisection society, founded in 1931). 


\section{Personenregister}

\begin{tabular}{|c|c|}
\hline Aers, Remieg & $59,103,124$ \\
\hline Aletrino, Amold & $84.146-148.153$ \\
\hline Alkmaion van Kroton & 10 \\
\hline Anbeek, Ton & 69.72 \\
\hline Anselmus & 99 \\
\hline Aristoteles & 119 \\
\hline Augustinus & 8 \\
\hline Baehler, Louis & 18 \\
\hline Becker, F. & 18 \\
\hline Béclard, J. & $46,47,51,66-68$ \\
\hline Beerends, Dirk & $22-24,26,138,160$ \\
\hline Bel, Jacqueline & 71.72 \\
\hline Bell, Charles & 11.12 \\
\hline Berdoe, Edward & 69.83 \\
\hline Bernard, Claude & $11,70,154,157$ \\
\hline Bert, Paul & 157 \\
\hline Boddaert, Marie & 100 \\
\hline Boersen, M.W.J.L.M. & 18 \\
\hline Bokkel, J.G. ten & 86 \\
\hline Bolland, G.J.P.J. & 122 \\
\hline Boltzmann, L.E. & 118 \\
\hline Borgesius, H. Goeman & 134 \\
\hline Bouman, L. & 150,153 \\
\hline Brants, M.A. & $134,135,137,144,149,152$ \\
\hline Bronfen, Elisabeth & 50 \\
\hline Bronsveld, Andries & 97 \\
\hline Brontë. Charlotte & 81 \\
\hline Buffon, George Louis & 90 \\
\hline Bulhof, Ilse & 98 \\
\hline Burger, $\mathrm{H}$. & 139.140 \\
\hline Buss. G. & 56,57 \\
\hline Buuren, Maarten van & 70 \\
\hline Buysse, Cyrille & $143,150,154$ \\
\hline Buytendijk, F.J.J. & 164 \\
\hline Calcar, R.P. van & $\begin{array}{r}64,139,140,144,145 \\
149,150,154\end{array}$ \\
\hline Campbell, Joseph & 47.114 \\
\hline Casembroot, F. de & 132 \\
\hline Celsus & \\
\hline Chandra, Ram & 17 \\
\hline Ciaburri, B. & 170,172 \\
\hline Clercq. Daniël de & $96,103,104,111$ \\
\hline Cobbe. Frances Power & $9,34,35,38,40$ \\
\hline
\end{tabular}

$48,72,73,76,93,114,115,117$.

120. 150

Colam, John

40

123

Constandse, Anton

43,162

151

Couvée, $\mathrm{H}$.

41,42

110

158,159

Cramer, C.A.

Criellacr, S.B.

Daal, Marie

Zie: Hucht-Kerkhoven, C.C.A. van der

D'Arc, Jeanne

$60.62,86,107,126,127,166$

Da Costa, Isaac

Dante (Alighieri)
45,55
Darwin, Charles

$13,59,77,90,114,126$,

$138,154,167$

Davids, C.A.

Descartes, René

$30,41,86,111$

Deutmann, Lize

11

53,162

70,71

Deyssel, Lodewijk van

Domela Nieuwenhuis, Ferdinand

23

Doorman, Christine

Dostojerski. F.

Dumas, A.

Eeden. Prederik van

Einthoven, Willem

$59,75,79,81,87,117$

$24-26,44$

Eliot, George

Elpis Melena

Zic: Schwartz, Marie-Espérance von

Elston, Mary-Ann

Emants, Marcellus

20. 35,38

Engelen, J.

$70,143,154$

Everard, Myriam

161

Fessler, J.

33

Fielding, $\mathrm{H}$.

Flaubert, G.

Fontijn, Jan

91,92

$59,81,97$

Förster, Bernhard

Förster, Paul

French, Richard

$18-21,30,33-35,38,44$, $78,93,111,112,114,128,155,164$

Freud, Sigmund

117

Frieswijk, J

Galenus van Pergamon

Garibaldi, Guiseppe

Gasman, Daniel

Gay, Peter

Gelderman, Anna Petronella

18

10

43

121

114

100

Ghandi

170. 171

Ginneken, Jaap van 81

Girard, Rení $\quad 87$

Goekoop-de Jong van Beek en Donk, Cécile 43, 60

Goncourt, Edwarid de 71

Gorter, Herman

Graham, Leonard

Grand, Sarah

Groshans, Suze

Grysanovski, E.F.G.

Haan, Ido de

Haeckel, Emst

Hamilton, Susan

Harrison, Brian

Harting. Pieler

Harvey, William

Heijermans, Ida

123

37

37

$32,33,43,59,60,62,63$. $84,92,107,110,156,161-167$ $45,46,65,68,130$ 13. $15,29,128$ $119,121,122,124$

$20,34-36,38,45,48,51$ 72

$21-24,26,27,39,40,42,138$

10,11

$60,126,127$

Hendrik, Z.K.H. Prins 170

Herder, G. von

Hermitte, Léon I'

Hettema, Yge 91 71

161,173

Heydenrijck, C.J.A. 
Heymans, Gerard

$119,122,124$

18,82

Heyring, Lien

Hinderdael, Jef

122

95

57

171

133

$36,37,79$

\section{9}

Hoggan, George

Holst-van der Schalk, Henriētte Roland

170,172

43,45 ,

Hucht-Kerkhoven, C.C.A. van der $46,48,51,53,61-63,65,69-71$, $74,78,80,83,84,94,96-98,100$, $101,103,106,107,109-112,117$, $127,157,158,165,166$

Hugenholtz, J.B.Th. $39,42,43,65,69$, $73,75,77-80,82-84,86,96,100$, $101,110,119,167$

Hugo, Victor 81

Huxley, T.H.

13, 137

Idsinga, J.W.H.M. van

$14,137,144,145$. 152,158

James, William

98,114

100

60

Jans, Rudolf

Jungius, Marie

$9,32,33,44,58-63,65$. $69,76,77,83,84,94,95,100$, $107,110-112,125-128,157,164,165-167$

Kaayk, Tine

Kahn, Inyat

Kakeheeke, J.

124

Kant, I.

Kempis, Thomas a

Keppler, Joseph

Kingsford. Anna

Kist, N.C.

Klein, Emmanuel

Klein, Marianne van der

Klerck, R.A. de

Kock. Helly

Kooy-van Zeggelen, J.

Kossmann, E.H

Krabbe, Wolfgang

Krisjnamuri

Kuyper, Abraham

Landseer. Edwin

Lansbury, Coral

Laqueur, Thomas Walter

Lindeboom, G.A.

Lissa, $\mathrm{Ph}$. van

Lohman, A.F. de Savornin

Looman. T.H

Luchtmans, $G$.

Maehle. A.H

Magendie. François

Magnan. E.

Maitland, Edward

Manen, C. van

Manen-Thesing, M.J. van

171

124

114

94

126

$53,58,59,61,157,166$

98

137. 138

83

42,158

101

160

123

28,173

171

$23,104,134-137,144$

78,82

$20,35-38,45,48,50,51$

66.67

136

146

132. 133,144

97

$77,79.82,84.139,140$,

154. 157

131

II

40

$43,53,59,61$

$22,39.65$
Mann, Thomas

79

Mantegazza, Paulo

Marchéal. M.

Max, Gabriel von

$73,74,81,150,154$

Mayer, Johann Tobias

Melanchton

Mierop, Lodewijk van

Modderman, A.E.J.

Moes, Wally

Montessori, Maria

Montijn, I.

Mussert, Anton

Mussolini, Benito

Nauta, Max

Neff, Rudolf

Netscher, Frans

Niermans-Ort, Nanda

Nightingale, Florence

Nolthenius, Hugo

Noordijk, Th.

Nordau, Max

Oberman, H.T.

Opzoomer, Comslis

Ortt, Felix
Ort. Henriëtte

Ortt, Jacob

Ortt, Joan

Ort. Steffan

Ortt. Willem

Ostwald, Wilhelm

Otterspeer. Willem

Parker van Canterbury

Parker. Theodore

Parkin, Frank

Pasteur, Louis

Peeters, Edward

Pekelharing, Cornelis

Pick, Daniel

Pieck, Adri

Pijl, Pieter

Pijl-Muller, $\mathrm{N}$

Poelgeest, Hugo van

Poels, J.

Poovey, Mary

Prochaska, F.K.

Pschorr, W.

Rael, Lodewijk de

Raikem, Leontine de

Rees. Jacob van

Ridder, N. de
159,160

126

99

18, 96,104

131

81

79

17

172

171,172

160

92

70.71

117

24

$86,102-105,109-111$. $134,138,145,166$

158

82

158

$98,116,122,123$

14, 15, 17, 18, 26, 29, 32, 52 . $55,59,62,63,64,65,72,74-76$.

78-80, 83-86, 88-91, 93, 95-98.

100-104, 106-113,115,116. $117-125,127-129,134,138-141$.

$144,145,146,148,150,153$, $156-164,166-168,170,171,175$

97

97. 100,101

97

97

97

122

122

99

114

15,19

$116,144,157$

122

1.47

81,82

160

$43,52,54,59,62,95,123$. $128,162-164,168-172$

162

173

144,145

63,84

34

173

122

97

$14,15,17,18,25-27,32$, $60.77,94,104,107,125,127$.

$146-149,151,153$

134. 137 
Rijnberk, Gerard van

Rijnders, J. Bartolott

Rink, $S$.

Rochussen, W.F.

Roessingh, K.H.

Roland Holst, Richard

Röling, H.Q

Rombach, C.A.

Romein, J.M.

$17-19,21,28,31,96,113$.

Roorda van Eysinga, S.E.W.

Roorda van Eysinga, S.F.W.

$65,73,77,79,84,85,98-100$. $107,110,117,128$

Roorda van Eysinga-Romijn, M.A.

Rooy, Piet de

$17,18,28-30,155$

Rost vau Tonningen, M.M.

Rubens. Morris

Sachsen, Max Herzog zu

Salomon, H.L.V.E.

Schiff, Moritz

Schimmel. H.J.

Schimmel, W.C.

Schoenaich-Carolath, Emil von

Scholten, Jan Hendrik

Schwartz. Marie-Espérance von

Schwegman, Marjan

Scolt, Walter

Shatuck, Roger

Shelley, P.B.

Sluys, D. van der

Smith, Stephen

Snouck Hurgronje, W.J.

Solvay, Ernest

Sontag. Susan

Spinoza, B. de

Spronck, C.H.H.

Stams, C.

Stark, W.A.

Stenz. Hermann

Sternberger, Dolf

Sievenson, Lloyd

Stowe, Harrict Beecher

Strauss Durkheim, E.

Strauss, D.F.

Struijcken, H.J.L.

Stuan Hughes, $\mathrm{H}$.

Stuar, Mary

Sylvius, Franciscus

Tadema, J.W.

Taine, $\mathrm{H}$.

Tail, Lawson

Taylor, Charles Bell

Terullianus

Toergenjev. I.S

Tolstoj, L.

Trühler, U

Tumer, James
39.92

$20,50,51,67,173,174$

$86,87,111$ $45,50,67$

95

139, 140

31

44

11

158

71.81

93

141

$96,100,101,107,127,153,172$

131

$72.73,93,112,114$
79 117,128

99

$9,43,59$,

8,9 172

99,128

Tumer, Kathleen $\quad 47$

Tusschenbroek, Catharina van 60

Twain, Mark 61

Tylor, Edward Burnelt 90

Ude, Johannes 170

Veer, J.K. van der 96,116

Velde, Henk te $13,15,23,24,29,128$

Vesidijk, Simon 26, 27

Veth, Jan

Victoria, Koningin

Vloten, Johannes van

Waals, J.D.

Wagner, Richard

Wale, Jan de

Wallace, A.R.

Wamer, Marina

Weber, Ernst von

81

$13,40,47,57$

$93,102,130,131$

11

59.90

61

$78,82-84,93,130-133$,

$139,140,157$

101,158

Westendorp, J

Wijfjes, $\mathrm{H}$

Wijnaendts Francken-Dyserinck, Welmoed

Winkler, C

Wirtz, A.H.W.

$141,142,144,150$

$60,148-150,154$

Witteman, F.

$98,99,122,123$

$43,45-47$.

$50,65,67-69,78$

Wouters, J.T.

Zadelhoff, G.W

Zcegers-Claessen. Jo

Zola, E

Zwaardemaker, Hendrik

57,88

$70,71,78,81$

148,150 
